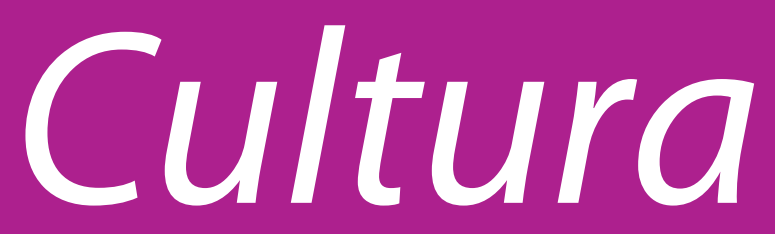

Revista de História e Teoria das Ideias

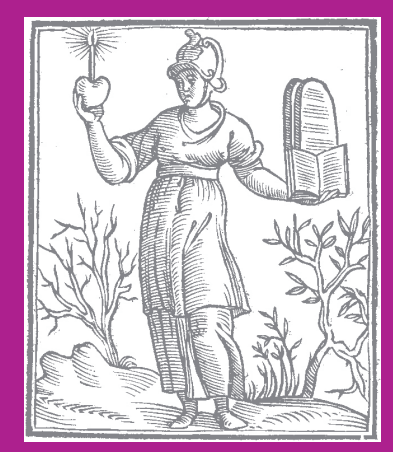

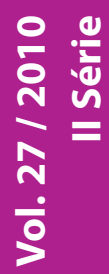

Helles che 


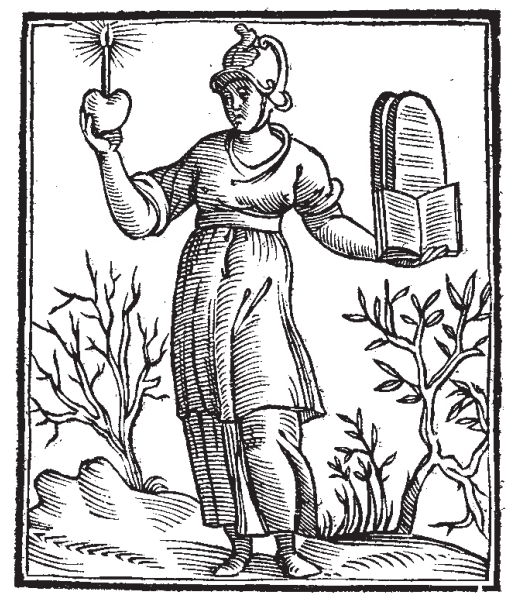

FEDE CATTOLICA

(Fé católica)

Mulher vestida de branco, com o elmo na cabeça, segurará uma candeia acesa e um coração na mão direita e a tábua da lei antiga junto com um livro aberto na esquerda. A Fé, como uma das virtudes teológicas, tem na cabeça o elmo para demonstrar que, para se ter a verdadeira fé, deve-se manter o engenho a salvo dos golpes das armas inimigas, que são a razão natural dos filósofos e as razões sofísticas dos hereges e dos maus cristãos, tendo a mente inflexível para a doutrina evangélica e para os mandamentos divinos, dizendo São Gregório na homilia 26 que: Fides non habet meritum, ubi humana ratio praebet experimentum.

O livro com as tábuas de Moisés é a junção dos testamentos, antigo e novo. O coração na mão com a candeia acesa mostra a iluminação da mente, nascida da Fé, que afugenta as trevas da infidelidade e da ignorância, dizendo Santo Agostinho sobre São João no cap. 9: Caecitas est infidelitas, \& illuminatio fides. 


\section{Cultura}

Revista de História e Teoria das Ideias 


\author{
Cultura - Revista de História e Teoria das Ideias \\ (II Série) vol. 27 - 2010 \\ Publicação semestral do Centro de História da Cultura \\ da Faculdade de Ciências Sociais e Humanas da Universidade Nova de Lisboa
}

Referenciada no catálogo LATINDEX - Sistemas de Informação Internacional de Revistas Científicas e no European Reference Index for the Humanities (ERIH) da European Science Foundation (ESF).

Publicação interdisciplinar fazendo convergir as perspectivas da história, da filosofia, do pensamento político e dos estudos literários. Trata ideias e práticas políticas, religiosas, científicas, económicas, sociais, estéticas e filosóficas, nas suas formas de expressão e difusão, com destaque para a ligação entre o espaço português e o espaço ibérico, brasileiro e ibero-americano.

Fundador: J. S. da Silva Dias

Director: José Esteves Pereira

Subdirector: Luís Manuel A. V. Bernardo

Coordenação editorial: Adelino Cardoso

Conselho de Redacção: Adelino Cardoso; Ana Maria Martinho; António Camões Gouveia; Cristina Montalvão Sarmento; Isabel Cluny; João Luís Lisboa; José Esteves Pereira; José Henrique Dias; Luís Crespo de Andrade; Luís Manuel A. V. Bernardo; Margarida Isaura Almeida Amoedo; Maria do Rosário Monteiro.

Comissão de acompanhamento científico: Armando Savignano (Univ. Trieste, Itália); Claude Gilbert Dubois (Univ. Bordéus, França); Luís de Oliveira Ramos (Univ. Porto); Norberto Cunha (Univ. Minho); Onésimo Teotónio de Almeida (Brown University, EUA); Roger Chartier (EHESS, Paris e Collège de France, França).

Referees deste número: António José de Almeida (O. P.); Artur Anselmo (FCSH-UNL); Fernando António Baptista Pereira (FBA-UL); Hugo Ferrão (FBA-UL); José Alberto Seabra Carvalho (MNAA); José Custódio Vieira da Silva (FCSH-UNL); José Meco (ESAD-FRESS); Manuel Joaquim Moreira da Rocha (FL-UP); Maria de Lurdes Cidrães (FL-UL); Nelson Correia Borges (FL-UC); Vítor Serrão (FL-UL); Vítor Teixeira (EA-UCP).

Direcção gráfica: Edições Húmus

Editor: Centro de História da Cultura da Universidade Nova de Lisboa / Edições Húmus

Depósito legal n.॰ 97341/96

ISSN: 0870-4546

Preço deste número: 16,80 euros

Assinatura: 26 euros

Correspondência relativa a colaboração de permutas e oferta de publicações deve ser dirigida a:

Centro de História da Cultura - UNL, Av. de Berna, 26 C - 1069-061 LISBOA

Fax: 217939228 E-mail: chc@fcsh.unl.pt

Para referência de números anteriores consultar: www.fcsh.unl.pt/chc

Publicação subsidiada ao abrigo do Financiamento Plurianual da FCT (Fundação para a Ciência e a Tecnologia). 


\section{Cultura}

Revista de História e Teoria das Ideias Vol. 27 - 2010 / II Série

Iconografia religiosa das invocações nacionais 



\section{Índice}

Imagens, devoções e o que podem representar

Devoções maiores e devoções menores na pintura mural portuguesa dos séculos XV e XVI Luís Urbano Afonso

Imagens da devoção nacional em retábulos do Baixo Tâmega e do Vale do Sousa

José Carlos Meneses Rodrigues

Variantes iconográficas nas representações antonianas

D. Carlos A. Moreira Azevedo

São Vasco Martins ou Frei Vasco Martins? A iconografia do fundador

dos Jerónimos portugueses, a propósito de uma pintura de Valdés Leal Joaquim Oliveira Caetano

Isabel de Aragão, rainha e santa de Portugal:

o seu jacente medieval como imagem excelsa de santidade

Joana Ramôa

A representação gravada da Rainha Santa Isabel: política e devoção

António Filipe Pimentel

Estilo e iconografia - As beatas de Portugal e a pintura romana

Nuno Saldanha

Relance sobre a iconografia da Padroeira de Aveiro: de 1470 (?) a 2008

Mons. João Gonçalves Gaspar

Quitéria, uma santa da Lusitânia nas terras de Entre-Douro-e-Minho

O martírio de Inácio de Azevedo e dos seus trinta e nove companheiros (1570) na hagiografia da Companhia de Jesus entre os séculos XVI e XIX

Maria Cristina Osswald 
A iconografia dos santos mártires de Lisboa em quatro pinturas do século XVI: linguagem e significados

Manuel Batoréo

Os santos mártires de Évora

Artur Goulart de Melo Borges

A invocação e o culto do Senhor Santo Cristo em Ponta Delgada - São Miguel Maria Fernanda Enes

Nossa Senhora de Brotas: um exemplo de regionalismo na iconografia mariana 227 Ana Paula Rebelo Correia

A iconografia da Senhora de Fátima:

da criação ex nihilo às composições plásticas dos artistas

Marco Daniel Duarte

Autores

Authors

Resumos e palavras-chave

Abstracts and keywords 


\section{Imagens, devoções e o que podem representar}

Em finais de Maio de 2008, o Sector dos Bens Culturais do Patriarcado de Lisboa, com o apoio do Centro de História da Cultura, da Universidade Católica Portuguesa e da Associação Portuguesa de Historiadores da Arte, organizou, coordenado pelo P. António Pedro Boto de Oliveira e por Sandra Costa Saldanha, o seu II Ciclo de Conferências com o tema "Iconografia religiosa das invocações nacionais".

A organização partia então da ideia de que pouca atenção era dedicada à questão da iconografia e da iconologia em Portugal. O trabalho feito sobre o tema tinha como dois principais motores o cuidado do património e a perspectiva da História da Arte, e entendia-se ser necessário integrar a reflexão crítica sobre as ideias e a cultura na história. Tratava-se de adoptar o olhar, que pode ser o do historiador da arte, como o do antropólogo ou do historiador cultural, que entende as imagens como expressão de ideias, de sentimentos, de gestos com sentido, até como tensão que testemunha e que provoca. Práticas de devoção ou invocação de exemplos de caridade, aproximação do belo representável ou imposição visual de episódios de martírio, ou da própria ideia de martírio, a mão do pintor e o olho do crente, por estes estudos passa a espiritualidade quotidiana, a paisagem visual de comunidades que tendemos a pensar próximas de nós. Os testemunhos materiais facilitam a ideia de proximidade. A continuidade das devoções também. Em contrapartida, a interpretação sugere diferenças que o tempo foi impondo e que só a reflexão permite entender.

A participação do $\mathrm{CHC}$ nesta iniciativa, incluindo a reunião do conjunto de textos que agora se apresentam, inscreve-se no cruzamento de diversos projectos que convergem no grande projecto. A linha de trabalho que dera acolhimento às conferências de 2008, expressamente dedicada ao estudo da iconografia, é simultaneamente mais vasta (porque não se restringe à iconografia e símbolos religiosos) e mais restrita (porque trabalha imagens impressas em livro). Simultaneamente, a parceria que volta a juntar o $\mathrm{CHC}$ a investigadores da Universidade Católica Portuguesa e da Universidade de Coimbra produz um seminário anual de História religiosa moderna que em 2011 tem por tema a "santidade."O que se representa, com os significados das imagens, nos seus contextos, está também nos sentidos das convergências da investigação actual em história cultural e das ideias.

A Direcção de Cultura 



\title{
Devoções maiores e devoções menores na pintura mural portuguesa dos séculos XV e XVI
}

\author{
Luís Urbano Afonso*
}

\section{Introdução}

Subsistem perto de cento e cinquenta monumentos em Portugal com pintura mural realizada entre os finais do século XV e os meados do século XVI. ${ }^{1}$ Por vicissitudes históricas diversas, a distribuição destes monumentos pelo território nacional é muito desigual, verificando-se uma concentração em templos rurais situados no território de Entre-Douro-e-Minho (c. 30\%), em Trás-os-Montes (c. 25\%) e na Beira Interior (c. 20\%) (Fig. 1). À excepção de Entre-Douroe-Minho, considerado um "alfobre de gente" desde a Idade Média, a maior parte destas pinturas preservou-se em regiões de fraca densidade populacional. Os edifícios que nos séculos XV e XVI receberam pintura mural conservaram-se mais ou menos incólumes em povoados de fraco crescimento demográfico e de recursos limitados, enquanto em meios mais dinâmicos os edifícios e as campanhas artísticas foram sendo sucessivamente ampliados ou substituídos.

A análise destas pinturas murais permite perceber quais as principais funções que desempenhavam, salientando-se, acima de tudo, os aspectos ligados à protecção do corpo

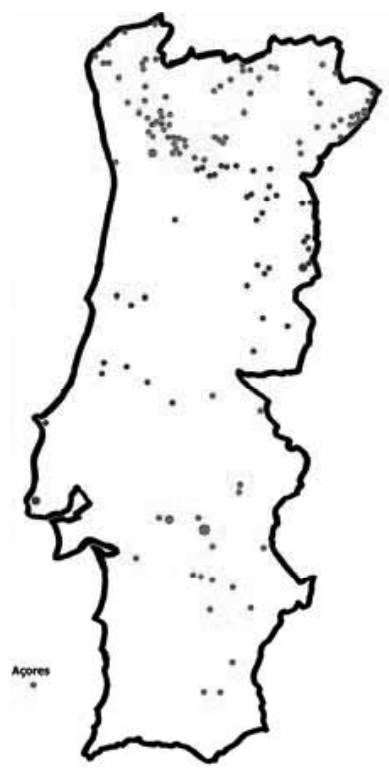

1. Distribuição nacional dos monumentos com pinturas murais (c.1400-c.1550)* e da alma dos fiéis (e respectivos familiares defuntos), os aspectos ligados ao prestígio dos detentores dos direitos de padroado e das próprias comunidades de fregueses e ainda os aspectos ligados à manifestação da autoridade reli-

* Faculdade de Letras/Universidade de Lisboa.

1 Sobre a literatura dedicada à pintura mural do período em causa, veja-se Luís U. Afonso, 2002. "A pintura mural dos séculos XV-XVI na historiografia da arte portuguesa: estado da questão", in Artis, n. 1, pp. 119-137. 
giosas seja a eclesiástica seja a monástica. ${ }^{2}$ Por sua vez, o estudo da iconografia destas pinturas permite identificar quais as principais devoções da população da época.

Em relação a este último aspecto, verifica-se que São Sebastião era o santo mais representado, seguido por Santo António (de Pádua), Santa Catarina, São Pedro, São Miguel, São João Baptista e São Tiago, ao mesmo tempo que ao nível das temáticas sacras apenas a Anunciação e o Calvário têm uma representatividade equiparável à dos santos mencionados. Também se verifica que, na maior parte dos casos, a preferência pelos santos referidos não estava dependente da invocação dos templos. Finalmente, nota-se uma nítida diferenciação entre as imagens sacras representadas na zona dos templos cujo cuidado pertencia aos fregueses, a nave, e a zona sob a responsabilidade dos padroeiros, a cabeceira.

O objectivo deste estudo consiste em sugerir explicações para a preeminência de determinadas figuras do hagiológio cristão na pintura mural da época, bem como para a ausência de outras cuja presença seria expectável. Pretende-se explicar, também, quais as razões que ditam a diferenciação entre a iconografia das cabeceiras e a iconografia das paredes da nave. $A$ análise conjugada destes dados permite trazer alguma luz sobre os motivos que justificam as principais devoções dos portugueses da época, sobretudo os que viviam em ambientes rurais.

\section{Devoções maiores}

No âmbito da nossa dissertação de doutoramento sobre a pintura mural dos séculos XV e $\mathrm{XVI}^{3}$, realizámos um estudo quantitativo que nos permitiu chegar aos dados apresentados no Quadro I. Este quadro identifica as figuras e os temas mais frequentes na pintura mural portuguesa e enumera as localidades onde se situam os monumentos com essas mesmas representações. Incluímos no quadro as figuras e temas que surgem, pelo menos, em sete ocasiões.

2 Luís U. Afonso, 2007."Protection, prestige and authority: on the functions of Portuguese mural paintings", in L. U. Afonso e V. Serrão (eds.), Out of the Stream: Studies in Medieval and Renaissance Mural Painting, Newcastle, Cambridge Scholars Publishing, pp.69-87.

3 Luís U. Afonso, 2006. A Pintura Mural Portuguesa entre o Gótico Internacional e o Fim do Renascimento. Formas, significados, funções, dissertação de Doutoramento em História da Arte apresentada à Universidade de Lisboa, 3 vols. 
Quadro I - Temas e figuras mais representados na pintura mural (c.1400-c.1550) ${ }^{4}$

\begin{tabular}{|c|c|c|}
\hline Tema & Locais & Total \\
\hline Anunciação & $\begin{array}{l}\text { Adeganha; Alfaiates I (?); Arnoso; Braga (?); Cimo de Vila; } \\
\text { Covas do Barroso; Covilhã; Duas Igrejas l; Ega; Ermelo; } \\
\text { Folhadela; Leiria; Lordelo (?); Marco de Canaveses; Meijinhos; } \\
\text { Outeiro Seco; Quintanilha; São Cucufate; São Martinho do } \\
\text { Peso (?); Serzedelo;Trancoso (x2); Valhelhas. }\end{array}$ & 23 \\
\hline Calvário & $\begin{array}{l}\text { Aivado; Amieira do Tejo; Ariola; Corvite; Duas Igrejas II; Idanha; } \\
\text { Leiria; Malhadas (?); Orca (?); Outeiro Seco; Sendim / Picote; } \\
\text { Tomar; Trancoso;Vile. }\end{array}$ & 14 \\
\hline Agonia no Horto & $\begin{array}{l}\text { Atouguia da Baleia; Ega; Marco de Canaveses (?); Outeiro Seco; } \\
\text { Tomar; Vila de São Sebastião; Vila Marim. }\end{array}$ & 7 \\
\hline Pentecostes & $\begin{array}{l}\text { Abrantes; Arcos de Valdevez; Arnoso (x2); Maçainhas; } \\
\text { Outeiro Seco; São Martinho do Peso (?). }\end{array}$ & 7 \\
\hline Santa Catarina & $\begin{array}{l}\text { Adeganha; Aivado; Algosinho; Cimo de Vila; Corvite; Gatão; } \\
\text { Idanha (?); Maçainhas; Martim Longo (?); Sanfins de Castanheira; } \\
\text { Santa Leocádia; Santo Isidoro; Serzedelo;Teixeira;Trevões; } \\
\text { Valadares. }\end{array}$ & 16 \\
\hline Santa Luzia & $\begin{array}{l}\text { Belmonte; Cárquere; Duas Igrejas I; Duas Igrejas II; Gatão; } \\
\text { Idanha (?); Larinho; Pias; São Pedro de Almuro. }\end{array}$ & 9 \\
\hline Santo Antão & $\begin{array}{l}\text { Chaviães; Corvite; Folhadela; Gondar; São Julião de } \\
\text { Montenegro; Marco de Canaveses; Serzedelo; Vila Marim. }\end{array}$ & 8 \\
\hline Santo António & $\begin{array}{l}\text { Adeganha; Aivado; Ariola; Belmonte; Cárquere; Chaviães; } \\
\text { Fonte Arcada (?); Gatão; Idanha (?); Numão (?); Outeiro Seco; } \\
\text { São Julião de Montenegro; São Pedro de Almuro (?); } \\
\text { Sapiãos (?); Serzedelo;Trancoso;Vilar; Vile (?). }\end{array}$ & 18 \\
\hline São Bartolomeu & $\begin{array}{l}\text { Adeganha; Algosinho; Chaviães; Folhadela; Idanha; } \\
\text { Martim Longo; Marvão; Pentieiros (?); Sarzeda. }\end{array}$ & 9 \\
\hline São Cristóvão & $\begin{array}{l}\text { Adeganha; Évora l; Gondar; Outeiro Seco; Santa Leocádia; } \\
\text { Serzedelo (?);Tomar. }\end{array}$ & 7 \\
\hline
\end{tabular}

4 Os locais mencionados neste quadro que aparecem seguidos por um ponto de interrogação dizem respeito a imagens onde o grau de certeza da identificação iconográfica não é absoluto. Os locais seguidos pela expressão" $x 2$ " indicam a existência de duas representações do mesmo tema/figura no mesmo edifício. Os locais seguidos por numeração romana dizem respeito a localidades onde existe mais de um edifício com pintura mural deste período. Para uma identificação completa das localidades e monumentos referidos, veja-se o corpus coligido em L. U. Afonso, 2006 (vol. II). 


\begin{tabular}{|c|c|c|}
\hline São Francisco & $\begin{array}{l}\text { Adeganha; Alfaiates I (?); Ervededo (?); Leiria; Mércoles (?); } \\
\text { Outeiro Seco; São Jordão; Serzedelo. }\end{array}$ & 8 \\
\hline São João Baptista & $\begin{array}{l}\text { Barcos; Belmonte (?); Fontelo; Gatão; Guimarães; Leiria; } \\
\text { Outeiro Seco; Porto; São Martinho do Peso;Tabuado. }\end{array}$ & 10 \\
\hline São Martinho & $\begin{array}{l}\text { Ervededo; Penacova; São Jordão (?); São Martinho de Mouros (?); } \\
\text { São Martinho do Peso; Sapiãos (?); Serzedelo (x2). }\end{array}$ & 8 \\
\hline São Miguel & $\begin{array}{l}\text { Azinhoso; Batalha; Leiria; Malhada Sorda; Santa Leocádia; } \\
\text { Santo Isidoro; São Jordão (?); São Martinho do Peso; Serzedelo; } \\
\text { Vila de São Sebastião; Vila Marim. }\end{array}$ & 11 \\
\hline São Paulo & $\begin{array}{l}\text { Batalha; Folhadela; Santa Leocádia; Sendim / Picote; } \\
\text { Souto de Lafões; Valadares; Vila Real; Vila Verde II. }\end{array}$ & 8 \\
\hline São Pedro & $\begin{array}{l}\text { Barcos; Belmonte; Casteição; Folhadela (x2); Leiria; } \\
\text { Montemor-o-Novo I; Santa Leocádia; Sintra II (?); } \\
\text { Souto de Lafões; Vila Real; Vila Verde II. }\end{array}$ & 12 \\
\hline São Sebastião & $\begin{array}{l}\text { Adeganha; Alvito; Arnoso; Arões; Bravães (x2); Castelo Bom; } \\
\text { Castro Vicente (x2); Cête I; Chaviães; Colmeal (x2); Corvite; } \\
\text { Évora III; Folhadela; Gatão; Idanha; Leiria; Lordelo; Marialva; } \\
\text { Santa Leocádia; Santo Aleixo; São Julião de Montenegro; } \\
\text { Serzedelo;Tresminas;Vila de São Sebastião;Vila Ruiva;Vile. }\end{array}$ & 29 \\
\hline São Tiago & $\begin{array}{l}\text { Adeganha; Aivado; Alvito; Belmonte; Ermelo; Folhadela; Joane; } \\
\text { Santo Isidoro; Tabuado; Valadares (?). }\end{array}$ & 10 \\
\hline Virgem com o Menino & $\begin{array}{l}\text { Aldeia Velha; Ariola; Arões; Barcos; Beja (?); Belmonte; Bravães; } \\
\text { Corvite; Lalim; Martim Longo; Porto; Santo Isidoro; Serzedelo. }\end{array}$ & 13 \\
\hline Virgem do Rosário & $\begin{array}{l}\text { Castelo Bom; Castelo Mendo; Joane; Sanjurge; } \\
\text { Sendim / Picote; Sernancelhe;Travanca II. }\end{array}$ & 7 \\
\hline
\end{tabular}

De uma maneira geral, estes dados permitem retirar quatro grandes conclusões. Em primeiro lugar, identifica-se uma nítida preferência por um reduzido leque de santos, de acordo com a seguinte ordem de importância: São Sebastião, Santo António, Santa Catarina, São Miguel, São Pedro, São João Baptista, São Tiago, Santa Luzia, São Bartolomeu, São Francisco, Santo Antão, São Martinho, São Paulo e São Cristóvão. Neste panorama importa sublinhar que as imagens de São Sebastião surgem, em média, num em cada cinco monumentos com pintura mural e que as imagens de Santo António surgem, em média, num em cada oito monumentos.

Em segundo lugar, importa sublinhar a clara predominância dos discursos visuais assentes em imagens de tipo “icónico”, em que um ou vários santos preenchem a parede sobre a mesa de altar. Estes santos são representados normalmente isolados e em posição fron- 
tal, quase sempre com os rostos a três quartos, hieráticos, e contra um fundo simples que acentua a sua presença, evitando a distracção do fiel com os fundos paisagísticos ou com os interiores perspectivados. Normalmente, estes santos não desempenham qualquer acção, a não ser segurarem os seus atributos específicos. Estas figuras são pintadas dentro de enquadramentos que visam mimetizar a pintura de cavalete, como se estivéssemos diante de um painel isolado ou de um tríptico. Entre as representações narrativas mais frequentes apenas contamos com quatro temas que podem assumir, ou não, um discurso narrativo. Referimo-nos à Anunciação (presente em 16,2\% dos monumentos com pintura mural dos séculos XV e XVI), ao Calvário (9,9\%), ao Pentecostes (5\%) e à Oração no Horto (5\%).

Em terceiro lugar, destacamos um aspecto decorrente da conclusão anterior, mas cuja percepção é algo difusa no Quadro I. Referimo-nos ao reduzido número de casos em que podemos falar de um discurso visual assente em estratégias narrativas, como sucede, por exemplo, na nave de Outeiro Seco ou na cabeceira de Santa Leocádia. De facto, o número de casos onde existem pelo menos duas composições que formam uma narrativa sequencial é muito reduzido, mais ainda quando se pretende falar da existência de um ciclo narrativo minimamente alargado. Ainda assim, para lá dos dois casos mencionados, e excluindo as situações em que existe uma mera oposição entre dois princípios contrários (por exemplo, Paraíso/Inferno), insuficiente para falarmos de uma narrativa, destaque-se o esforço em construir discursos narrativos nas pinturas de Adeganha, Bragança, Bravães, Covas do Barroso, Duas Igrejas I, Malhada Sorda, Meijinhos, Quintanilha, Sacaparte, Santa Leocádia, Santo Aleixo,Tomar, Trancoso, Valhelhas, Vila de São Sebastião e Vila Marim. Ou seja, apenas em dezoito dos cento e quarenta e dois monumentos estudados é possível identificar a presença de uma solução narrativa, o que equivale a $13 \%$ do total. Mesmo tendo em conta que este número é prejudicado pela destruição da maior parte das pinturas murais que não ficaram protegidas pelos retábulos em talha - e deve-se sublinhar que os ciclos narrativos ocupavam, preferencialmente, os panos laterais da ousia e da nave -, não nos parece que esta realidade pudesse ultrapassar os $15 \%-20 \%$ dos casos atendendo aos dados veiculados pelas visitações realizadas na época em questão. ${ }^{5}$

Por último, os dados recolhidos permitem concluir que não existe qualquer preferência pela representação de santos "nacionais". Com efeito, das entidades patentes no Quadro I, a única figura que nasceu ou viveu em território português foi Santo António, habitualmente representado de pé, descalço ou em sandálias, vestindo um hábito de cor cinza ou

5 Luís U.Afonso, 2005.“A pintura mural das igrejas das Ordens Militares, em torno de 1500.Primeiras impressões de uma abordagem iconográfica", in As Ordens Militares e as Ordens de Cavalaria na Construção do Mundo Ocidental. Actas do IV Encontro sobre Ordens Militares, Lisboa, Colibri-Câmara Municipal de Palmela, pp. 899-916. Veja-se também L. U. Afonso, 2006, vol. I, pp. 117-121. 
acastanhada cingido por um cordão de três nós. Normalmente, o santo segura numa mão um crucifixo (ou, raramente, um lírio) e na outra mão um livro aberto, sobre o qual, muitas vezes, está representado o Menino numa escala mais reduzida. Importa referir, porém, que o elevado número de representações deste santo não parece relacionar-se minimamente com a sua naturalidade. De facto, no único caso onde o nome do santo é seguido por um toponímico verifica-se que a cidade mencionada não é Lisboa (ou Coimbra), mas sim Pádua. ${ }^{6}$ Ou seja, pelo menos até meados do século XVI, fica a impressão de que a pintura mural portuguesa não participou em quaisquer processos de promoção e legitimação de santos regionais ou nacionais. Do mesmo modo, exceptuando o caso particular e sui generis do Apóstolo São Tiago, não se encontram nesta lista quaisquer figuras associadas à Península Ibérica. Referimo-nos, em concreto, aos vários santos mártires que deram origem a inúmeras paróquias do território português e cujas relíquias foram muito veneradas durante a Idade Média em santuários de alcance regional.

\section{Devoções menores}

A partir da mesma recolha utilizada para produzir o Quadro I, apresentamos no Quadro II as figuras e os temas que surgem representados apenas por uma vez entre os cento e quarenta e dois monumentos estudados. Naturalmente, em comparação com as figuras e os temas patentes no primeiro quadro, as figuras listadas neste segundo quadro terão sido objecto de uma menor devoção por parte da população portuguesa dos séculos XV e XVI.

\section{Quadro II - Figuras e temas representados uma só vez na pintura mural (c.1400-c.1550)}

\begin{tabular}{|l|l|}
\hline Tema & Locais \\
\hline Santa Eulália & Pentieiros (?) \\
\hline Santa Madalena & Marvão \\
\hline Santa Marta & Santa Leocádia \\
\hline Santa Odília (Otília) & Riba de Âncora \\
\hline Santo Aleixo & Santo Aleixo \\
\hline São Geraldo & Sapiãos \\
\hline Santo Isidoro & Santo isidoro \\
\hline
\end{tabular}

6 Referimo-nos à pintura existente na capela-mor da igreja de São Julião de Montenegro. A identificação do nome do santo através de uma inscrição surge nas igrejas de São Tiago de Adeganha (Torre de Moncorvo), Santa Cristina de Serzedelo (Guimarães) e igreja de Nossa Senhora da Guia em Vilar (Boticas). 


\begin{tabular}{|l|l|}
\hline São Jacinto & Covilhã \\
\hline São Jerónimo & Outeiro Seco \\
\hline São Leonardo & São Julião de Montenegro (?) \\
\hline São Lourenço & Castelo Bom \\
\hline São Lucas & Gondar \\
\hline São Pedro Mártir & Casteição \\
\hline São Plácido & Pombeiro \\
\hline São Telmo (Corpo Santo) & Geraz do Lima \\
\hline São Valério & Leiria \\
\hline São Vicente & Leiria \\
\hline
\end{tabular}

A primeira nota a destacar neste quadro diz respeito à presença de bastantes santos ibéricos, ou que passaram parte da respectiva vida na Península. É o caso de quatro mártires muito populares durante a Idade Média, a saber, Santa Eulália, São Lourenço, São Valério e São Vicente. É o caso, também, de três figuras ligadas à vida da Igreja peninsular, designadamente o arcebispo de Sevilha e Doutor da Igreja Santo Isidoro, o arcebispo de Braga São Geraldo (de origem francesa) e ainda o dominicano São [Pedro Gonçalves] Telmo, também conhecido como Corpo Santo, originário de Palência e muito activo na Galiza. No caso de São Geraldo, deve sublinhar-se, sem surpresa, que a presença do santo se integra na área de influência do arcebispado bracarense. No caso de São Telmo a sua representação ocorre num arcossólio de uma igreja do Alto Minho, uma área percorrida pelo santo, sendo de sublinhar que na mesma composição se encontra outro santo dominicano, São Gonçalo de Amarante, ${ }^{7}$ e um santo beneditino, São Mauro.

Outro ponto a destacar, relacionado com o anterior, é o reduzido número de representações de certas figuras listadas neste quadro em relação às quais seria expectável encontrarmos sinais de maior devoção. Referimo-nos, sobretudo, a São Vicente, São Jerónimo, São Lourenço e Santa Madalena. De facto, o primeiro destes santos tinha grande importância nas festividades religiosas nacionais. Durante os séculos XIV e XV, São Vicente alcançou mesmo uma enorme projecção na região de Lisboa, promovendo-se o culto das suas relíquias na catedral.Também surpreendente é o caso de São Jerónimo, uma figura fulcral para o movimento reformista monástico e eclesiástico dos séculos XV e XVI. Aparentemente, este Doutor da Igreja também não parece ter encontrado eco nas igrejas e ermidas das 
vilas e aldeias rurais que constituem o grosso da pintura mural remanescente. Finalmente, São Lourenço e Santa Madalena são dois santos relativamente populares, pelo que se esperaria maior número de representações para cada um deles. Com efeito, São Lourenço é padroeiro dos pobres e protector contra o fogo e os incêndios e quanto a Santa Madalena, para lá da sua recorrência nas imagens do Calvário e da proximidade a Cristo, importa salientar o seu papel como santa curadora, papel que Ihe granjearia muitos devotos.

\section{Topografia das representações}

Até aqui tomámos como certa a proposição de que o elevado número de representações de uma determinada figura sagrada era sinónimo de maior devoção a essa mesma figura. Porém, quando partimos para uma análise mais fina da realidade, nomeadamente ao nível da "topografia das representações", verificamos que esta associação não é tão linear como parece. Desde logo, importa sublinhar que no período em causa existia uma distinção entre o patrocínio dos padroeiros de um templo e o patrocínio da respectiva comunidade de fregueses. Esta diferença materializava-se, por exemplo, nas obrigações de manutenção e ornamentação de dois espaços muito distintos: a cabeceira do templo no caso dos padroeiros, e a nave no caso dos fregueses. Por isso, saber em que local de uma igreja se encontram pintadas as figuras sagradas do Quadro I permite-nos perceber qual o peso relativo dessas figuras para os detentores dos direitos de padroado e para a comunidade de fregueses, dados que nem sempre são coincidentes. A partir destes elementos ficamos a saber quais as figuras sagradas que estes dois actores veneravam de forma semelhante e quais aquelas que eram veneradas de forma diferenciada.

Vejamos, em primeiro lugar, os casos onde existem maiores desequilíbrios. Comecemos por abordar o caso das figuras que são mais representadas do lado dos fregueses e que por essa razão seriam objecto de devoção por maior número de pessoas. Entre estas figuras encontra-se São Sebastião (Fig. 2), esmagadoramente representado nas naves dos templos (83\%) e menos nas cabeceiras (17\%), e o Calvário (Fig. 3), numa relação 3/4 contra 1/4. ${ }^{8}$ Um caso muito interessante diz respeito à Agonia no Horto (Fig. 4), cujas representações se encontram apenas ao nível da nave. Regressando às imagens mais representadas no Quadro I, como São Sebastião, verificamos que quer Santo António (Fig. 5), quer Santa

8 A diferença que pode surgir entre os números patentes nos gráficos e os números patentes no Quadro I deve-se à impossibilidade de distribuir algumas representações numa destas duas categorias (capela-mor ou nave). As razões podem ser várias: edifício com um só volume; pinturas destacadas sem indicação de localização primitiva; tipologia arquitectónica impossível de confinar ao modelo proposto; etc. 


\section{Representações de São Sebastião}

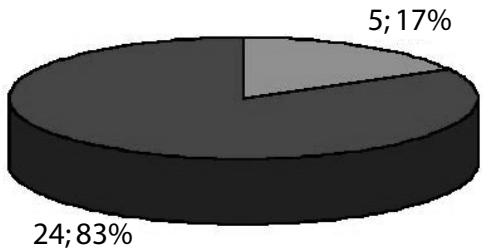

Cabeceira Nave

\section{Representações do Calvário}

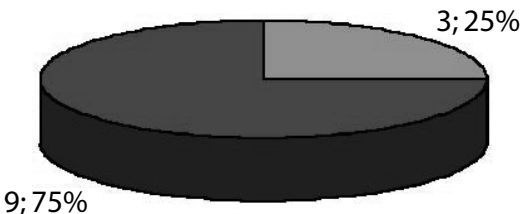

Cabeceira Nave

\section{Representações da Agonia no Horto}

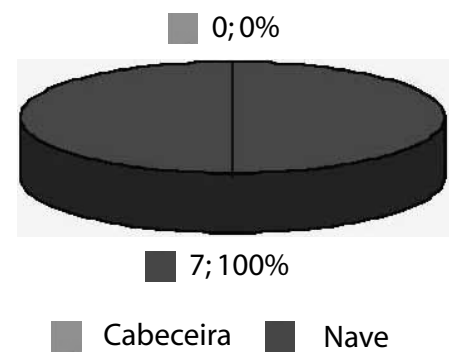




\section{Representações de Santo António}

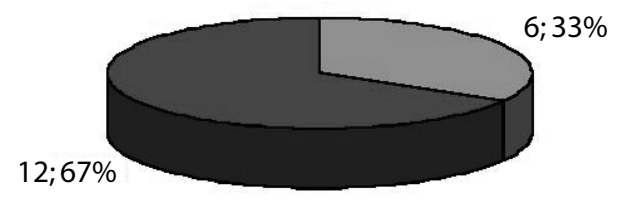

Cabeceira Nave

\section{Representações de Santa Catarina}

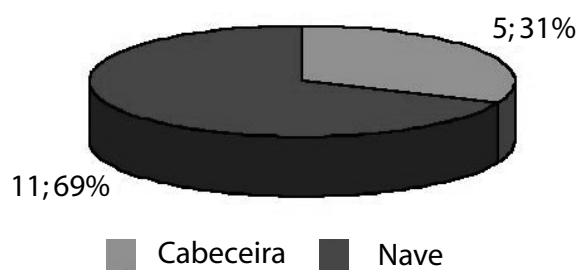

Catarina (Fig. 6) estão mais representados no espaço dos fregueses do que no espaço dos padroeiros, sensivelmente numa proporção de $2 / 3$ contra $1 / 3$.

Já em relação às figuras que estão mais representadas do lado dos padroeiros do que do lado dos fregueses, destacam-se os casos de São Pedro (Fig. 7) e de São Paulo (Fig. 8), normalmente representados em conjunto. No primeiro caso a percentagem é elevadíssima, $83 \%$ contra $17 \%$, mas o segundo caso é ainda mais impressionante na medida em que todas as representações de São Paulo se encontram unicamente ao nível da cabeceira dos templos. Também algo surpreendente é verificar que São Tiago (Fig.9) apenas surge representado, praticamente, ao nível das cabeceiras.

Antes de analisarmos as razões destas diferenças, importa destacar os casos em que os temas e as figuras estão distribuídos de forma equilibrada entre os dois espaços em questão. Por exemplo, o segundo tema/figura mais representado na pintura mural da época, a Anunciação, está distribuído de forma bastante harmoniosa, com dez representações na cabeceira (43\%) e treze na nave (57\%). São João Baptista tem idêntica distribuição, com cinco representações na cabeceira (56\%) e quatro na nave (44\%). O mesmo sucede com São Martinho, embora neste caso com maior presença na cabeceira (57\%), com quatro ocorrências, do que na nave (43\%), com três ocorrências. 


\section{Representações de São Pedro}

\section{$2 ; 17 \%$}

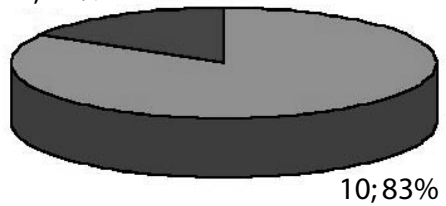

Cabeceira Nave

\section{Representações de São Paulo}

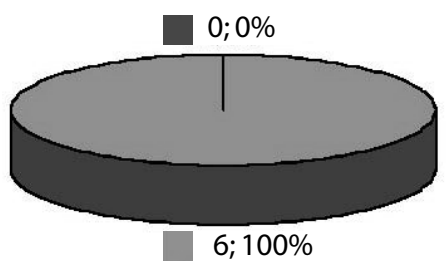

Cabeceira $\square$ Nave

\section{Representações de São Tiago}

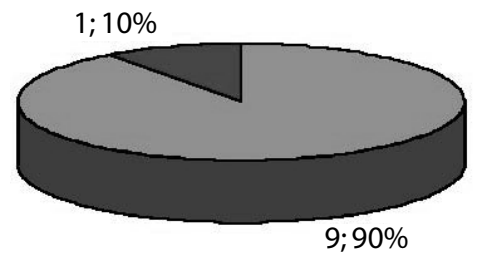

Cabeceira Nave

\section{Conclusão}

Conforme verificámos anteriormente, os elementos coligidos no Quadro / indicam quais as entidades sagradas e os temas religiosos mais populares ao nível da pintura mural dos séculos XV e XVI. O Quadro II, por seu lado, identifica as figuras que só por uma vez receberam a preferência dos encomendantes. $O$ estudo que realizámos, porém, permitiu concluir 
que a análise meramente quantitativa das representações iconográficas pode induzir os investigadores em erro, pois elas não espelham de forma plena as principais devoções da época. Com efeito, verificámos que existe um desfasamento entre aquilo que as pessoas comuns, os fregueses, mais valorizavam ao nível das entidades sagradas e aquilo que as elites detentoras dos direitos de padroado pretendiam sublinhar e promover. A diferença é visível na medida em que cada um destes grupos era responsável por espaços diferentes, respectivamente a nave e a cabeceira dos templos. Deste modo, em função das figuras e dos temas mais representados em cada um destes espaços ficamos a saber quais as entidades sagradas que cada grupo mais valorizava. Este ponto é importante porque entre os cinco temas e figuras mais representados apenas a Anunciação tem uma distribuição equilibrada entre os espaços da nave (fregueses) e da cabeceira (padroeiros).

Proporcionalmente, verificámos que as imagens mais comuns na cabeceira dizem respeito a São Pedro e São Paulo, seguramente duas entidades que reforçavam o poder e a autoridade dos padroeiros eclesiásticos dos templos, actuando em nome do Papa e dos fundadores da Igreja de Roma. Muitas vezes, aliás, estas imagens eram acompanhadas pelos brasões dos padroeiros que se associavam, assim, ao prestígio e autoridade dos dois santos. Outra imagem muito presente nas cabeceiras dos templos é São Tiago, mas neste caso a explicação encontra-se no facto de o Apóstolo ser orago de quase um terço dos templos onde surge pintado.

Quanto às imagens mais representadas ao nível da nave, torna-se evidente que o elevado número de imagens de São Sebastião, Santo António e Santa Catarina (de Alexandria) corresponde à grande popularidade destes três santos, fazendo deles o objecto de devoção mais universal no território português durante o período em questão. Como se sabe, o primeiro destes santos era venerado devido à protecção que oferecia aos fiéis contra os surtos de peste e as doenças (sendo secundado por Santo Antão, também representado de forma significativa na pintura mural). Santo António, por sua vez, era venerado sobretudo por ser um santo capaz de operar "milagres." Finalmente, no que diz respeito a Santa Catarina, julgamos que a sua elevada presença na pintura mural estava relacionada com o seu papel enquanto intercessora junto da Corte Celeste, denotando, por esta via, a preocupação dos fiéis com a salvação da alma.

Finalmente, quanto às figuras sub-representadas, algumas delas evocadas no Quadro I, parece-nos que são um subproduto dos esforços de concentração e uniformização religiosa iniciada nos séculos XI-XII com a Reforma Gregoriana. A prossecução desta política ao longo do tempo acabou por retirar peso aos santos locais e regionais, substituídos por santos "campeões", mais universais, aos quais era atribuída uma eficácia superior perante os pedidos e anseios dos devotos. 
Além disso, como na maior parte dos monumentos estudados existe uma significativa economia de meios, circunscrevendo a intervenção fresquista às paredes dos altares (limitando, deste modo, o número de figuras representadas), os recursos concentraram-se nos santos e nos temas que eram considerados mais úteis e eficazes. Deste modo, a concentração produziu-se num núcleo muito restrito de santos mártires (São Sebastião, Santa Catarina e São João Baptista) e de santos apóstolos (São Pedro, São Tiago e São Paulo). A única excepção neste grupo é a presença de Santo António, o mais "jovem" de todos os santos patentes no Quadro I.

* As localidades presentes no mapa da p. 7 são, por ordem alfabética, as seguintes: Abrantes, Adeganha, Aivado, Alcácer do Sal, Aldeia Velha, Alfaiates I, Alfaiates II, Algosinho, Alvito, Amieira do Tejo, Arcos de Valdevez, Ariola, Armamar, Arnoso, Arões, Atouguia da Baleia, Azinhoso, Barcos, Batalha, Beja, Belmonte, Braga, Bragança, Bravães, Calvos, Caminha, Cárquere, Casais da Abadia, Casteição, Castelo Bom, Castelo Mendo, Castro Roupal, Castro Vicente, Cête I, Cête II, Chaviães, Cimo de Vila de Castanheira, Coimbra, Colmeal, Corvite, Covas do Barroso, Covilhã, Duas Igrejas I, Duas Igrejas II, Ega, Ermelo, Ervededo, Escarigo, Estremoz, Évora I, Évora II, Évora III, Folhadela, Fonte Arcada, Fontelo, Freixo de Baixo, Gatão, Geraz do Lima, Gondar, Guimarães, Idanha-a-Velha, Ifanes, Joane, Lalim, Larinho, Leiria, Lordelo, Maçainhas, Malhada Sorda, Malhadas, Marco de Canaveses, Marialva, Marmelar, Martim Longo, Marvão, Meijinhos, Mércoles, Mértola, Mesão Frio, Midões, Monsaraz, Montemor-o-Novo I, Montemor-o-Novo II, Montemor-o-Velho, Mouçós, Negrelos, Numão, Orca, Outeiro Seco, Palaçoulo, Penacova, Pentieiros, Pias, Picote, Pombeiro, Porto, Quintanilha, Quintela de Lampaças, Reboreda, Riba de Âncora, Sacaparte, Sanfins de Castanheira, Sanfins de Ferreira, Sanjurge, Santa Cruz, Santa Leocádia, Santo Aleixo, Santo Isidoro, São Cucufate, São Jordão, São Julião de Montenegro, São Martinho de Mouros, São Martinho do Peso, São Pedro de Almuro, Sapiãos, Sarzeda, Sendim / Picote, Sernancelhe, Serzedelo, Sintra I, Sintra II, Souto de Lafões, Tabuado, Távora, Teixeira, Tomar, Trancoso, Travanca I, Travanca II, Tresminas, Trevões, Valadares, Valença, Valhelhas, Vila de São Sebastião, Vila Marim, Vila Real, Vila Ruiva, Vila Verde I, Vila Verde II, Vilar, Vile. 



\section{Imagens da devoção nacional em retábulos do Baixo Tâmega e do Vale do Sousa}

José Carlos Meneses Rodrigues*

\section{Introdução}

São de Portugal todos os santos que se ligaram a ele pelo nascimento, pela morte ou pela presença de relíquias. Acrescentam-se três novos critérios de apropriação de santos: o "nascimento espiritual" (baptismo), a dignidade (ter exercido uma função eclesiástica no território) e a habitação (Rosa, 2000, 339).

Consideram-se ainda as fronteiras históricas: os santos da antiga Lusitânia, os da Galiza (sujeita espiritualmente a Braga) e os de todas as conquistas ultramarinas portuguesas. Além dos santos canonizados, dos beatos e dos mártires, têm lugar as pessoas de esclarecida virtude, e acreditadas no céu com maravilhas, e as de conhecida e exemplar vida, dignas de se proporem para imitação (Rosa, 2000, 339), linhas assertivas igualmente seguidas por Neves (2006).

A nossa lista de catorze santos portugueses resulta do cruzamento das informações de Neves (2006, 259-262), Rosa (2000, 336-338) e Valadares (2001, 126): São Vicente, São Pantaleão, São Veríssimo, São Frutuoso, Santo Ovídio, Santa Iria, Santa Quitéria, Santa Comba, São Teotónio, Santo António, São Gonçalo, São João de Deus, São Francisco Xavier, Frei Gonçalo Dias de Amarante.

Seguimos a taxonomia de Neves $(2006,25)$ para abordar o quadro genérico da santidade em Portugal, para a qual apontamos ainda alguns elementos sobre a especificidade portuguesa (Daix, 231): i) grande época da santidade - fase do esforço da missionação pós-tridentina; ii) esmagadoramente do género masculino; iii) fora de Portugal; iv) preponderância de jesuítas, entre os beatos; $v$ ) depois de São João de Brito (+1693) não teria ocorrido qualquer beatificação de um português.

Depois de uma abordagem teórica sobre a hagiografia, a iconografia, ou seja, os percursos da santidade em Portugal, guardámos a última parte para tratar as especificidades no Baixo Tâmega e no Vale do Sousa (Amarante, Felgueiras, Marco de Canaveses e Penafiel).

* Associação Portuguesa de Historiadores da Arte. 


\section{Antes da nacionalidade: o tempo dos mártires e bispos}

São Vicente [Fig. 1], São Pantaleão, São Veríssimo [Fig. 3], São Frutuoso [Fig. 2], Santo Ovídio [Fig. 4], Santa Iria, Santa Quitéria [Fig.5] e Santa Comba

Alguns santos mais notáveis dos caminhos portugueses de Santiago coincidem com a lista que propomos para a nossa proposta de trabalho.

Na diversidade dos milagres (Marques, 2006, 260), é evidente a presença de casos de curas de possessões diabólicas, de acalmia de tempestades marítimas, salvamento de perigos de naufrágio, salvamento de torrentes fluviais, curas de doenças do foro neurológico, incluindo casos de loucura, de cegueira, surdez, paralisias, cancros, feridas crónicas, tumores cerebrais, ruptura da coluna, etc.

À construção de um espaço sagrado específico - Lisboa libertada pelos mártires para a recristianização -, irá colocar-se como pedra-de-toque o culto a São Vicente que, para além de ser um dos mais prestigiados mártires hispânicos, gozava de grande difusão europeia, em termos de culto (Rosa, 2000, 336).

Luís Kruz (citado por Rosa, 2000, 336) sinteza:

O corpo [de São Vicente] é recuperado em plena Reconquista. Tal como antes acontecera com S. Tiago, em relação à Galiza, também S. Vicente se exila por mar em terras cristãs. Foge do espaço profanado pelo Islão e restitui-se aos fiéis, oferecendo-lhes as suas relíquias, os
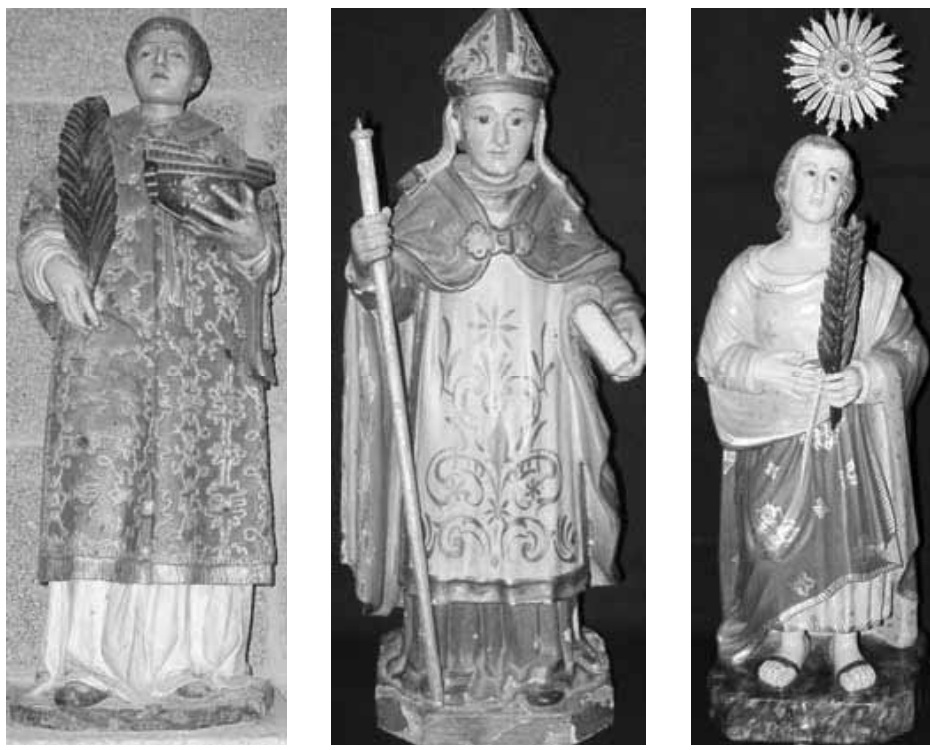

1. São Vicente

2. São Frutuoso

3. São Veríssimo 

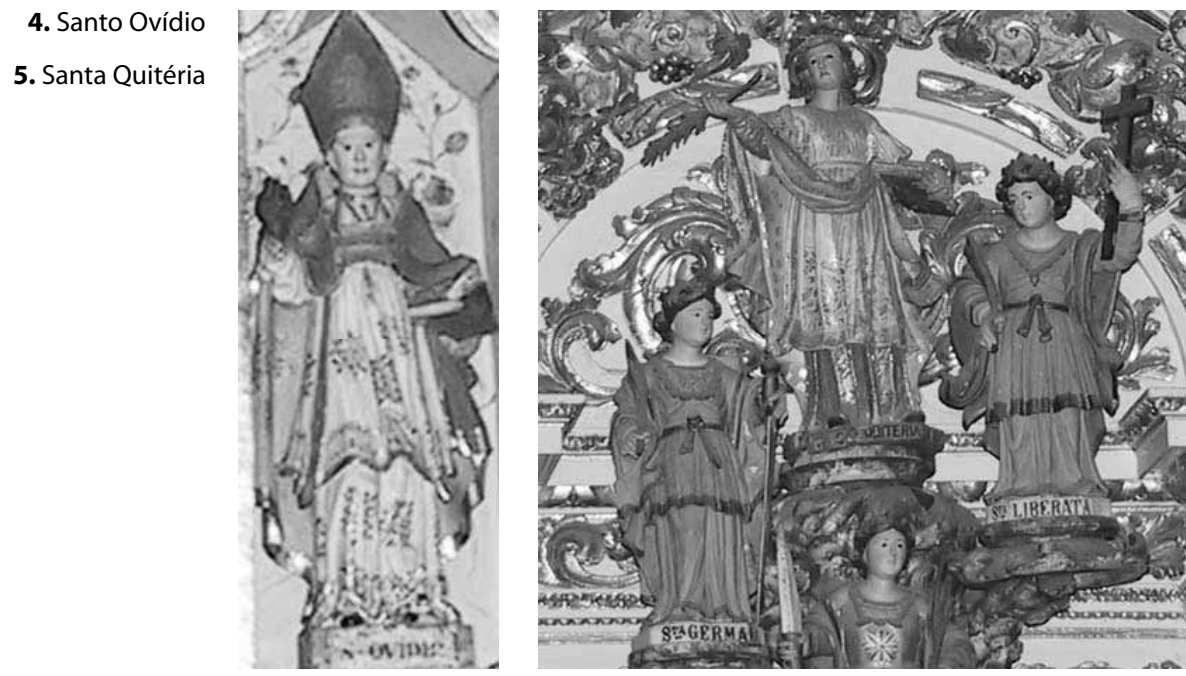

seus poderes taumatúrgicos. Percorrendo um itinerário marítimo inverso ao dos invasores da Cristandade, profetiza um retorno vitorioso, simbolizado pelo seu próprio nome.

São Vicente (Marques, 2006, 252-254), muito mais antigo do que São Frutuoso e São Geraldo, só passou a ser venerado, em Lisboa, depois de reconquistada, em 1147. Sabe-se que, de Valência, onde era cultuado, para o preservar da fúria devastadora de Abderramão, o seu corpo foi levado para o Cabo a que deu o seu nome, onde alguns cristãos lhe levantaram uma capela e continuaram a prestar-lhe culto.

A transferência das suas relíquias para Lisboa deve-se a D. Afonso Henriques, em 1173, tendo acabado por ficar à veneração dos fiéis na Sé. $O$ incremento do culto vicentino em Lisboa encontrou grande receptividade no povo de Lisboa e até em localidades muito afastadas, inclusive além-fronteiras, como a descrição de alguns milagres revela, tendo o sínodo de Lisboa de 1240 determinado que os párocos orientassem os fiéis a visitarem anualmente as relíquias de São Vicente, prestando-Ihes a honra e homenagem devidas (Idem, 253).

A casuística taumaturga tem referência explícita à cura de paralisias, cegueira, surdez, doenças neurológicas, libertação da pressão ou mesmo possessão diabólica e outros. Exemplos (Idem,253-254):i) o da cura de uma jovem em idade núbil, que ficou louca, tendo sido feitas veementes súplicas por ela a São Vicente, recuperando o juízo e a voz que tinha perdido; ii) uma criança de três anos deformada e sem fala foi curada de repente; iii) uma menina de oito anos possessa do demónio, levada ao túmulo de São Vicente pelos pais, é 
curada; iv) a cura do calceteiro coxo, que se arrastava apoiado sobre as mãos, e do cego que estava à porta da cidade, que dava para o Lumiar; $v$ ) espectacular é a cura do homem de Lugo, pai de um presbítero e um diácono que morreram queimados num incêndio; face a esta tragédia ficou transtornado e cego, mas, aconselhado a ir a Lisboa ao túmulo de São Vicente, ficou curado e recuperou a vista.

São Frutuoso, abade e bispo de Dume, arcebispo de Braga na sua última fase, falecido em 665 (provavelmente), destaca-se pela sua acção como fundador de elevado número de mosteiros (treze, onde se inclui o de Montélios, Braga), alvo e centro da devoção de fiéis, que, atraídos pela fama dos seus milagres, continuaram a acorrer a Montélios após a sua morte (Idem, 249-250).

Sintetizemos alguns milagres (Idem, 250): i) corça perseguida por caçadores e cães, protegida sob o seu hábito, ficando a dever-se-lhe o perdão e a saúde do jovem que matou a corça; ii) graça recebida durante uma travessia da Lusitânia para a Bética, libertando da morte por afogamento um jovem que conduzia o cavalo carregado com os seus códices; ambos arrastados por violento redemoinho, verificaram que os códices estavam secos; iii) barca salva de naufrágio iminente, atingida por violenta tempestade, conseguindo a suspensão das chuvas torrenciais.

Associado ao culto dos santos, encontra-se o das relíquias que o Concílio de Trento, na sessão XXV, de 3 de Dezembro de 1563, declarou solenemente dignas de serem veneradas, não se aceitando uma nova relíquia sem aprovação do bispo (Marques, 2000, 2, 359).

A abundância de relíquias em circulação e a sua apetência em tempos modernos percebem-se desmesuradas, o que faz duvidar a autenticidade de muitas na posse dos fiéis dos templos e oratórios privados. Perante a ganância e o lucro na sua aquisição, os menos escrupulosos aproveitavam-se, sem recuar perante o roubo, a falsificação e o comércio. Narram as crónicas que o crânio venerado em São Frutuoso foi roubado para a Galiza em 1540, mas a relíquia de tanta consolação para os fiéis voltaria milagrosamente ao seu lugar em Constantim de Panóias, onde passaria a ser guardada num nicho com grades douradas (Idem, 364).

São Pantaleão: médico e mártir do século III, de Nicomedia, as suas relíquias são trazidas, no século XV, para o Porto por cristãos arménios, fugidos dos conquistadores muçulmanos do sultão Maomet III, onde é elevado à condição de padroeiro da diocese, em condições semelhantes às de São Vicente. Perdido o rasto das suas relíquias, na Sé do Porto, em 1981 deixa de figurar como padroeiro da diocese (Neves, 2006, 63).

Como santo do Oriente, é apresentado no século IV, curando os doentes em nome de Cristo (Tavares, 2001, 118), não sendo nomeado em Daix (1996, 229-230). Socorremo-nos daqueles autores (Neves, 2006; Tavares, 2001; Daix, 2000; Rosa, 2000) para uma breve abordagem hagiográfica a outras figuras. 
São Veríssimo, Máxima e Júlia, leigos e mártires, com nascimento e morte em Lisboa, no século III, considerados os primeiros de Lisboa (Neves, 2006, 67-68). A actual igreja de Santos-o-Velho, Lisboa, reconstruída após o terramoto de 1755 , mantém a devoção no local dos três mártires, resumindo o culto aos irmãos a veneração a todos os mártires lisboetas das perseguições romanas.

Santo Ovídio, bispo de Braga, século I, cidadão romano de grande erudição; martirizado quando era bispo, com a probabilidade de sepultura na Sé de Braga. Santa Iria ou Irene, virgem e mártir; nasce e morre em Tomar, no século VIl; padroeira de Santarém e de Tomar.

Santa Quitéria, de Coimbra, irmã de Santa Vilgeforte, é decapitada pelo pai.

Santa Comba, virgem e mártir em Coimbra, sepultada no mosteiro de Santa Cruz de Coimbra. Refiram-se várias santas com o nome de Combas em Portugal (Alentejo, Coimbra, Dão, Trás-os-Montes); algumas são versões portuguesas de santas em Sens (França) e em Córdova (Espanha).

\section{Portugal nasceu e cresceu cristão (1143-1500)}

\section{São Teotónio [Fig. 6], Santo António [Fig. 7] e São Gonçalo [Fig. 8]}

Ao avanço da Reconquista e ao apoio ideológico de Santa Cruz de Coimbra, irá corresponder um dinamismo religioso muito específico. Feito de um entusiasmo evangelista, apropriação de cultos moçárabes e espírito de cruzada, tem a sua expressão hagiográfica nos textos do cenóbio crúzio coimbrão, em torno de figuras como São Teotónio, São Martinho de Soure, São Vicente, o cavaleiro Henrique (Rosa, 2000, 346).
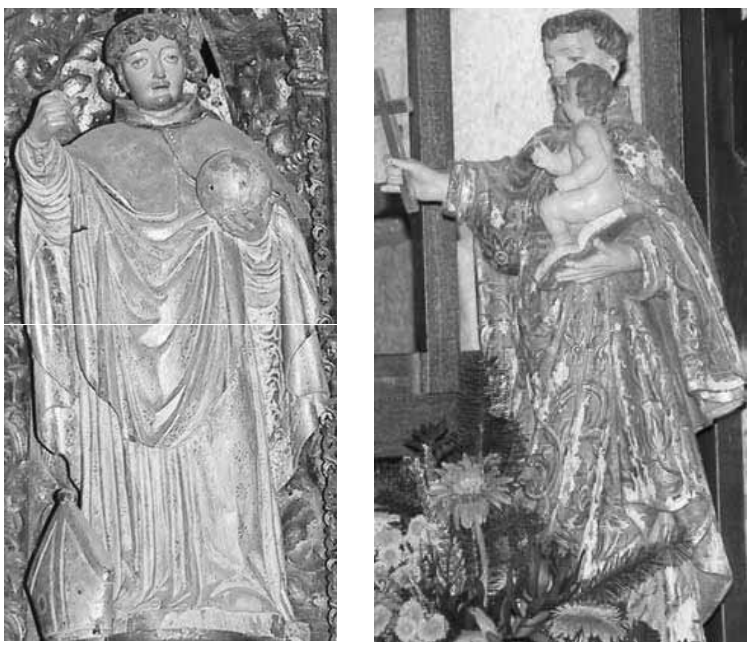

6. São Teotónio

7. Santo António 


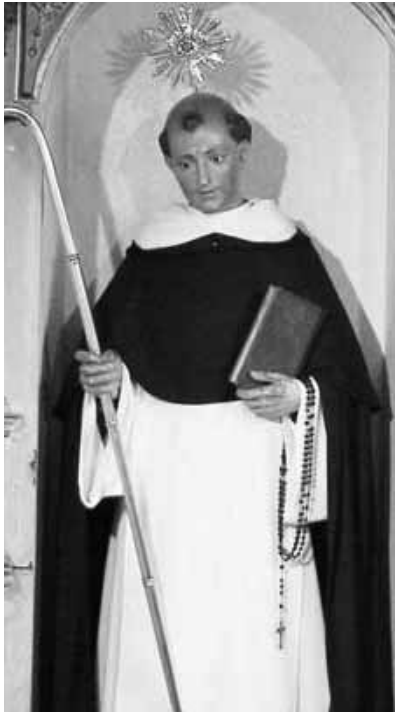

8. São Gonçalo

São Teotónio (Marques, 2006, 255-256), pertencendo aos santos de Coimbra, natural de Valença, é convidado a integrar os Cónegos Regrantes de Santa Cruz de Coimbra, de que foi o primeiro prior, abandonando, definitivamente, o projecto de regressar à Terra Santa e acabar os seus dias junto do Santo Sepulcro.

A sua vida é coroada com o dom dos milagres, especialmente a cura da possessão diabólica, curando o monge inglês Samuel, expressamente trazido ao mosteiro de Santa Cruz, o mesmo tendo feito com dois religiosos da sua comunidade, de que imperiosamente expulsou o demónio. Um recebimento festivo digno de menção foi o da relíquia de São Teotónio, natural de Ganfei, Valença, ida de Santa cruz de Coimbra, em 1643, para Viana do Minho, sendo esperada em Darque com grandes festas também de teor profano (Marques, 2000, 2, 359).

No segundo grande período medieval - identificação do País, entre nós --, as grandes figuras vão de Santo António aos membros das novas ordens, São Gonçalo de Amarante, entre outros, os leigos Isabel d'Aragão, Santa Joana... (Rosa, 2000, 346).

A determinação sinodal (Marques, 2000,637) de 1447: D. Luís Pires, arcebispo de Braga não esqueceu a representação das imagens, ao indicar a hierarquia, a roupagem e os símbolos, meios didácticos atendendo ao analfabetismo dos crentes.

Com as ordens mendicantes, São Domingos e São Gonçalo de Amarante, São Francisco de Assis e Santo António de Lisboa verão os seus cultos e imagens incrementados por dominicanos e franciscanos (Idem).

A cristianização das festas pagãs do solstício de Verão consagra a popularidade de São João, São Pedro e Santo António, o santo português de maior predilecção, advogado das coisas perdidas e protector dos gados para a gente do campo (Idem, 641-642).

O século XVIII (Azevedo, 2001,414) acentuou o gosto de temas místicos, de aparições e de visões, usados nos sermões e nas leituras espirituais, destacando-se Santo António de Lisboa, cuja iconografia se reflecte profundamente nos ciclos de azulejos (São Francisco de Guimarães) ou séries de 24 pinturas, como a da capela do santo no Convento da Madre de Deus (André Gonçalves, 17501760) ou da capela de Lagos.

Santo António é conhecido nas representações de cónego regrante de Santa Cruz e de franciscano. Aparece num exemplar único vestido de doutor coimbrão, numa escultura do século XVIII, da Venerável Ordem Terceira de São Francisco, Lamego (Idem, 414). 


\section{A evangelização das terras achadas (1500-1899)}

\section{São João de Deus e São Francisco Xavier}

O culto dos santos, na Idade Média, foi adquirindo um sólido fortalecimento na piedade cristã, alargando-se os oragos das freguesias em ombreio com Nossa Senhora. Mas a ignorância, a rudeza, a permanência de crenças pagãs e supersticiosas e a proliferação de representações iconográficas agravaram o desvirtuamento de um meio pedagógico para o pastoreio das almas.

A crítica erasmiana e a ruptura luterana reclamam o regresso ao purificador evangelismo primitivo. A presença esmagadora dos mártires São Paio, Santa Eulália, São Mamede, Santa Marinha, Santa Bárbara, Santa Luzia, São Vicente... deve juntar-se à dos apóstolos São Paulo, São Tiago e São Tomé (Marques, 2000, 636-637).

O combate ao profano e herético é visível nas Constituições de 1591 (Coimbra), onde o rigor censório vai repercutir-se sobre a herança iconográfica pela meia-idade e pelo renascimento. A arte medieval conhecera figuras desnudas - morte de Cristo e martírio de alguns santos: São Sebastião, São Vicente, Santa Eulália... (Idem, 640).

De fins do século XVI até inícios do século XVIII, tornam-se nítidos três grupos (Rosa, 2000, 346): i) os mártires da evangelização (Japão, Brasil, Achém... Gonçalo Garcia), em boa parte jesuítas; ii) as princesas-freiras (Teresa, Sancha, Mafalda, Joana); iii) e os grandes organizadores (Bartolomeu dos Mártires, João de Deus). São outras tantas características de base do cristianismo pós-Trento.

Uma tentativa hagiográfica cuidada para esta época (Idem, 334) pertence a Aires Gameiro e diz respeito a São João de Deus: Instável e Santo. Tentativa de Análise Psicológica (1978). Enquadra-se a conversão de João Cidade numa crise de vida, surgida aos quarenta anos na sequência de angústia e depressão.

De início, a crise é plena de aspectos destrutivos, levando ao internamento de João: a sua resolução é positiva, tomando a forma de conversão religiosa. A sua santidade resume-se assim: João de Deus tornou-se santo por ter conseguido harmonizar os seus impulsos e aspirações com uma grande dose de satisfação e motivações cristãs ao serviço dos homens que de ajuda precisavam (Gameiro, citado por Rosa, 2000, 334).

$\mathrm{Na}$ Idade Moderna, irrompe a imaginária de vulto, nos altares e nos retábulos de talha. Cristo, a Virgem e os oragos pontificam, seguindo as prescrições tridentinas.

Na piedade dos fiéis, continuam com lugar proeminente os fundadores das ordens religiosas e protectores contra as calamidades (peste, fome e guerra). $O$ povo reserva grande devoção a São Martinho, São Sebastião, São Tiago, São Bento, São Brás, São Francisco e São Vicente, entre outros (Marques, 2000, 641). 
O período da Restauração foi um momento crucial de uma nova mobilização dos santos do País em torno da defesa da independência (Rosa, 2000, 340).

Na prova do martírio, as missões além-mar tornaram-se no espaço ideal para as vocações juvenis. Os 39 companheiros do beato Inácio de Azevedo, mortos em 1570, nos mares das Canárias, às mãos de corsários franceses, navegavam para as missões do Brasil; São João de Brito (1647-1697), pajem de Afonso VI, vestiu a roupeta da Companhia de Jesus e partiu para o Malabar, em 1662 (Marques, 2000, 644).

A Companhia de Jesus, entregue ao ensino, à assistência e ao apostolado junto das elites sociais e poderes políticos, burguesia e povo, pregação e missionação, passou logo a contar com o santo fundador e São Francisco Xavier (1506-1552), o evangelizador do Oriente e considerado o segundo São Paulo; foram canonizados em 1662, pretexto para os apoteóticos festejos que os jesuítas de São Roque organizaram em Lisboa, em 1671 (Idem, 646).

A interferência espanhola (Rosa, 2000,346) é um fenómeno específico do quadro português, na diáspora dos impérios: a canonização da Rainha Santa, e a abertura de processos para Gregório Lopes, Gonçalo Dias de Amarante, António de São Pedro, todos com fama de santidade na América espanhola, em quadros de errância prévia.

No século XVIII pontificam as grandes figuras dos oratorianos: Bartolomeu Quental e José Vaz (Idem, 347); o perfil é o do organizador com forte pendor intelectual: as freiras místicas e profetisas Maria do Lado, Teresa da Anunciada, Maria Custódia do Santíssimo Sacramento. É um século que se caracteriza por um enorme número de confirmações de culto, com as ordens tradicionais a tentarem recuperar o prestígio.

Relativamente à iconografia dos santos, aparecem novas figuras, canonizadas dentro dos novos modelos a difundir (Teresa d'Ávila, Inácio de Loiola, São Francisco Xavier, São João Nepomuceno) (Azevedo, 2001,413).

Os jesuítas beneficiarão de um pintor próprio, Manuel Henriques (1618-1654), que passou a vida a encher os colégios onde viveu de painéis de figuração arcaica, relativos à vida de Santo Inácio, de São Francisco Xavier, de martírio de padres do Oriente (Idem).

O percurso iconográfico de São João de Brito $(/ d e m, 414)$ foi traçado por Costa Lima, que, de modo singelo, já tinha divulgado o conhecimento da iconografia assuncionista.

Os esquemas iconográficos dos séculos XVII e XVIII mantiveram-se durante o século XIX (Idem, 414-415). A crise oitocentista produziu painéis e multiplicou esculturas de santeiros, que raramente saem da vulgaridade. Episodicamente, pintores como Joaquim Rafael (1783-1864), José de Brito (1855-1933) e até Columbano (1855-1933), que pintou Aparição do Menino a Santo António (1898), intervieram com representações de inegável interesse iconográfico. 
O dealbar da I Guerra Mundial recentra na Europa as atenções, e a grande figura é o Santo Condestável. Com a excepção de São João de Brito, os santos do Império ficam ao cargo dos novos países, e não mais possessões portuguesas (Rosa, 2000, 347).

\section{Portugueses a caminho dos altares?}

\section{Frei Gonçalo Dias de Amarante [Fig. 9]}

Nasce na Folhada, Marco de Canaveses (1548); morre no Peru, 1618. Pouco conhecido na terra onde nasceu, é venerado nas terras que evangelizou.

A interferência espanhola (Rosa, 2000, 346), no século XVII, é um fenómeno específico do quadro português, na diáspora dos impérios: a canonização da Rainha Santa e a abertura de processos para Gregório Lopes, Gonçalo Dias de Amarante, António de São Pedro, todos com fama de santidade na América espanhola, em quadros de errância prévia.

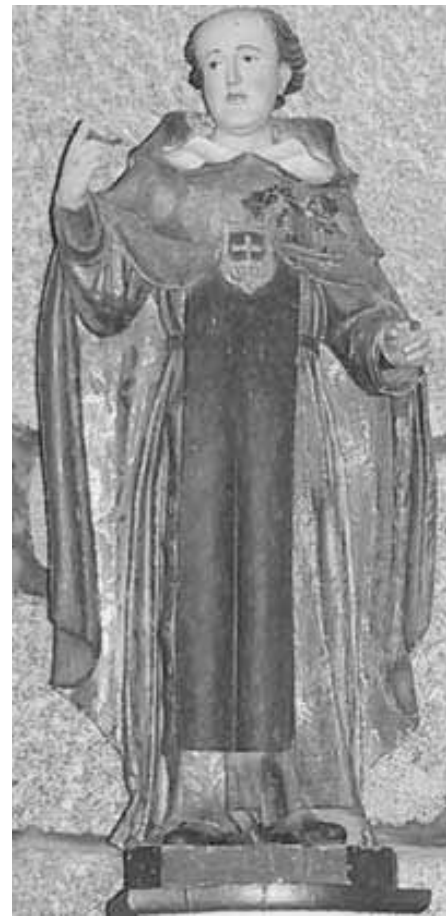

9. Frei Gonçalo Dias de Amarante

\section{Santos portugueses no Baixo Tâmega e no Vale do Sousa}

Não tivemos a preocupação de identificar as imagens actuais com as de 1726 e 1758, funcionando apenas os nomes como objectivo na busca de uma permanência devocional que se revê nos locais de origem (como oragos e invocações de altares) e na mobilidade interna dos templos. Restará tal identificação para outra investigação. O Quadro / não constitui um cenário exaustivo das informações de autores que têm trabalhado a área devocional; serve, igualmente, de guião para investigação ulterior. Os atributos e o calendário santoral espelham os contributos de várias épocas (inclusive o martirológio de 1590, de padres jesuítas, na qualidade de primeira sistematização nacional impressa). 


\section{Quadro 1 - Atributos dos santos no Baixo Tâmega e no Vale do Sousa}

\begin{tabular}{|c|c|c|}
\hline $\begin{array}{l}\text { Santos no Baixo } \\
\text { Tâmega e no } \\
\text { Vale do Sousa } \\
\text { (Rodrigues, 2004) }\end{array}$ & $\begin{array}{l}\text { Atributos } \\
\text { (Neves, 2006; Tavares, 2001; Daix, 2000) }\end{array}$ & $\begin{array}{l}\text { Calendário } \\
\text { Santoral } \\
\text { (Rosa, 2000; } \\
\text { Neves, 2006; } \\
\text { Tavares, 2001; } \\
\text { Croiset, 1923) }\end{array}$ \\
\hline António & $\begin{array}{l}\text { Burro ajoelhado diante da hóstia; chamas na } \\
\text { mão; crucifixo; livro; Menino Jesus em visão } \\
\text { mística; pão trazido por corvo; com um saco de } \\
\text { pão; Santo António dos Pobres representado } \\
\text { como crúzio (Caramos, Felgueiras; Vila Boa } \\
\text { do Bispo, Marco de Canaveses); ou como } \\
\text { menino de Coro (Sé do Porto).Variantes: diaba } \\
\text { (mulher sedutora); Menino Jesus num feixe de } \\
\text { luz; Menino Jesus sentado num livro; peixes } \\
\text { escutando o sermão; sineta; flor-de-lis. }\end{array}$ & 13 de Junho \\
\hline Comba & Crivada de setas. & 31 de Dezembro \\
\hline Francisco Xavier & $\begin{array}{l}\text { Coração inflamado trespassado com flechas; } \\
\text { crânio (penitência); crucifixo; índios; com uma } \\
\text { vieira (usada para baptizar os índios).Variantes: } \\
\text { crucifixo pressionado junto do coração; } \\
\text { caranguejo com crucifixo, aos pés. }\end{array}$ & 3 de Dezembro \\
\hline Frutuoso & Mitra e báculo. & 16 de Abril \\
\hline Gonçalo & $\begin{array}{l}\text { Hábito de dominicano; livro; báculo e maqueta } \\
\text { de ponte. }\end{array}$ & 10 de Janeiro \\
\hline $\begin{array}{l}\text { Gonçalo Dias de } \\
\text { Amarante }\end{array}$ & $\begin{array}{l}\text { Hábito da Ordem Real e Militar de Nossa } \\
\text { Senhora das Mercês da Redenção dos Cativos } \\
\text { ou, mais simplesmente, Ordem de Nossa } \\
\text { Senhora das Mercês. }\end{array}$ & ---- \\
\hline Iria ou Irene & $\begin{array}{l}\text { Boião de farmácia ou caixa de unguentos } \\
\text { (que curou as feridas a São Sebastião); cavalo } \\
\text { ditado; ramo de oliveira. }\end{array}$ & 20 de Outubro \\
\hline
\end{tabular}




\begin{tabular}{|c|c|c|}
\hline João de Deus & $\begin{array}{l}\text { Assistência e caridade; vestes de franciscano. } \\
\text { Corda de penitente; coroação de espinhos; } \\
\text { crucifixo; doentes a serem cuidados; granada } \\
\text { com cruz sobreposta; com um menino } \\
\text { moribundo nos braços. Variante: com pão nos } \\
\text { braços. }\end{array}$ & 8 de Março \\
\hline Ovídio & $\begin{array}{l}\text { Representado como Bispo, ou como clérigo } \\
\text { com barrete circular. Mão direita a apontar } \\
\text { para o ouvido. }\end{array}$ & 3 de Junho \\
\hline Pantaleão & $\begin{array}{l}\text { Despido, agarrado a um tronco de oliveira, com } \\
\text { as duas mãos, uma sobre a outra, pregadas ao } \\
\text { topo do crânio. Como médico: um cravo, alusão } \\
\text { ao suplício, uma espátula de medicina, uma } \\
\text { caixa de unguentos e uma pequena cruz. }\end{array}$ & 27 de Julho \\
\hline Quitéria & $\begin{array}{l}\text { Cabeça nas mãos; cão raivoso, aos pés, com } \\
\text { a língua de fora, ou um dragão encadeado (e } \\
\text { heresia).Também com livro e palma. }\end{array}$ & 22 de Maio \\
\hline Teotónio & $\begin{array}{l}\text { Abade, báculo e mitra aos pés (alusão à } \\
\text { renúncia do bispado de Viseu); um globo } \\
\text { celeste na mão. Representado como crúzio. }\end{array}$ & 18 de Fevereiro \\
\hline Veríssimo & Palma, resplendor. & $\begin{array}{l}1 \text { de Outubro } \\
\text { - Santos } \\
\text { Veríssimo, } \\
\text { Máxima e Júlia }\end{array}$ \\
\hline Vicente & $\begin{array}{l}\text { Jovem diácono ou “levita". Mó, grelha com } \\
\text { puas, instrumentos da sua tortura, um corvo, } \\
\text { um modelo de navio, um cacho de uvas; } \\
\text { ocasionalmente, uma tesoura de poda e um } \\
\text { podão, e mão sobre um pipo de vinho. }\end{array}$ & 22 de Janeiro \\
\hline
\end{tabular}

Os Gráficos 1-4 prestam melhor serviço de leitura no posicionamento da sub-região em apreço: 184 igrejas e capelas em Amarante (58), Felgueiras (31), Marco de Canaveses (45) e Penafiel (50). 
As referências encontradas em 1726 e 1758 - oragos, invocações e colocação retabular evidenciam Santo António [Fig.7] e São Gonçalo [Fig.8] (antes do padroado), Santa Quitéria [Fig. 5] e São Frutuoso [Fig. 2] (pré-nacionalidade) - visibilidade evidenciada no Gráfico 1.

Gráfico 1. Referências 1726-1758

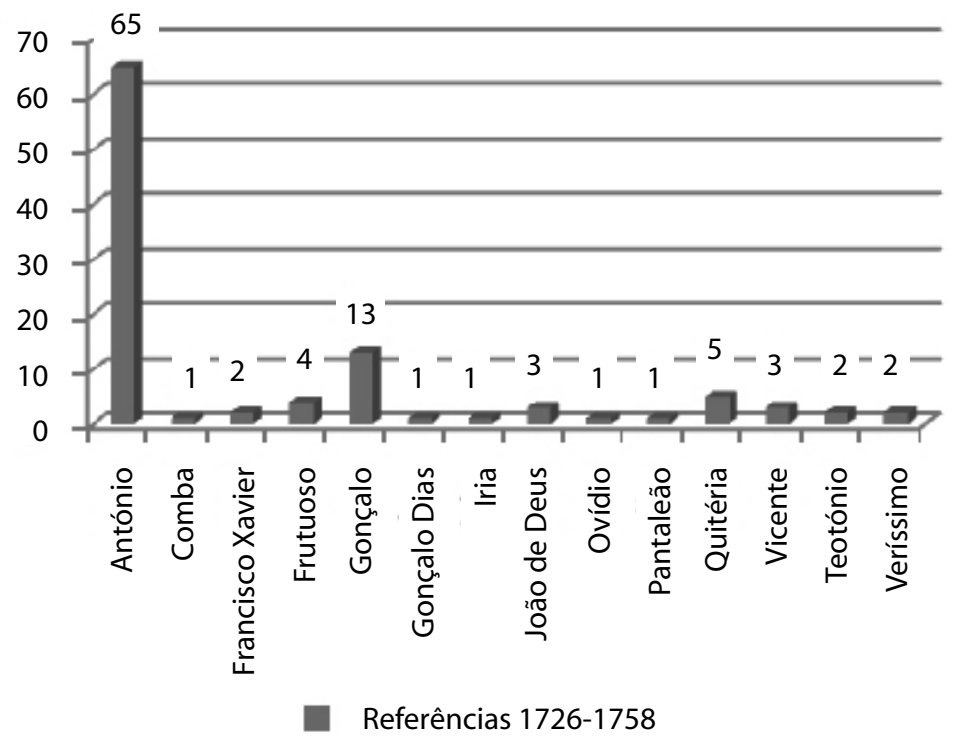

Nos oragos (Gráfico 2), mais um lugar destacado para Santo António nas capelas (6), seguindo-se São Vicente [Fig. 1] (3 - Pinheiro e Irivo, Penafiel; Sousa, Felgueiras; presentes no retábulo-mor, no lado do Evangelho, excepto em Sousa, colocado na capela-mor, sendo substituído por São Pedro); São Veríssimo [Fig. 3] (2 - São Veríssimo, Amarante (na sacristia) e Lagares, Felgueiras); a São Gonçalo, Amarante (capela-mor) e a Santa Comba, Regilde, Felgueiras (retábulo-mor), cabe uma presença a cada uma.

Três santos são da pré-nacionalidade (São Veríssimo, São Vicente e Santa Comba) e dois do período anterior ao padroado (Santo António e São Gonçalo). Nas invocações de altares, Santo António (22), São João de Deus e Santa Quitéria (dois cada), São Frutuoso e São Gonçalo (um cada) são os privilegiados.

A presença das imagens nos retábulos é assinalada no Gráfico 3: os retábulos colaterais são preferidos (54) aos retábulos-mores (28) e aos laterais (12). Reconhecemos a sua importância nestes espaços nobres do espaço sagrado mas, em posições secundárias, quer nos mores, quer nos colaterais, isto é, acompanhantes das invocações e dos oragos. 
Gráfico 2. Oragos e invocações

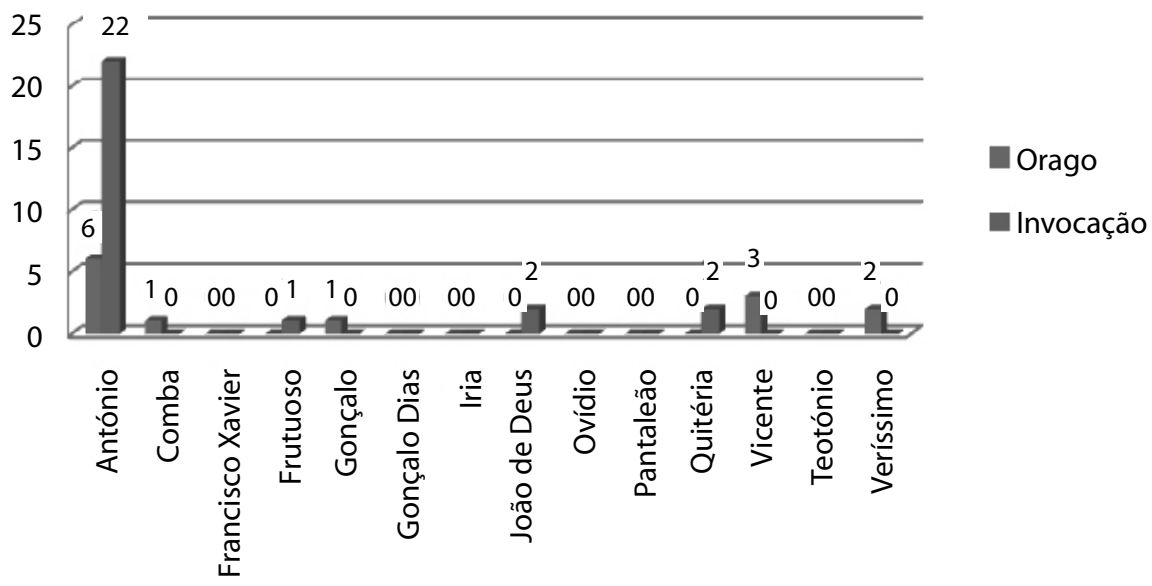

Gráfico 3. Frequência retabular

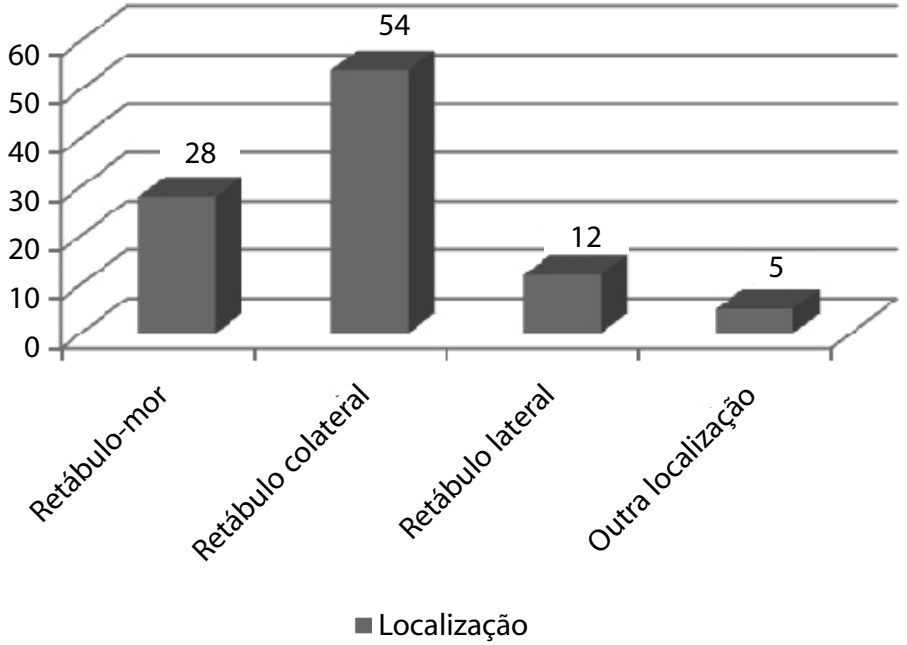




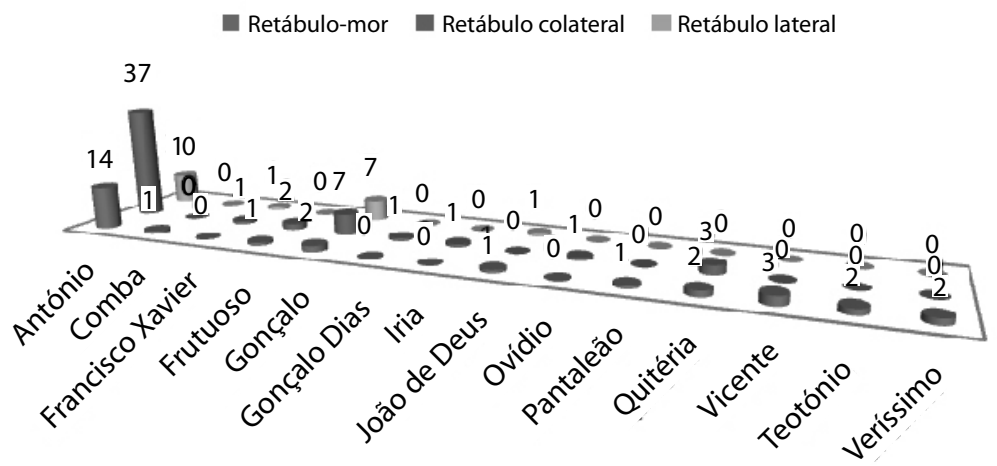

Santo António e São Gonçalo são os únicos que têm colocação nos retábulos-mores, nos colaterais e nos laterais (Gráfico 4). O primeiro nos colaterais (37), mores (14) e laterais (10); o segundo nos colaterais e laterais, em paridade (7), confirmando-se a predominância dos colaterais, já patente no Gráfico 3.

A variação dos restantes santos, nos mores (1-3), revê-se como oragos (Gráfico 2) e com colocação secundária - São Frutuoso, São João de Deus, São Pantaleão, Santa Quitéria e São Teotónio [Fig. 6].

\section{Conclusão}

No universo encontrado - São Vicente, São Pantaleão, São Veríssimo, São Frutuoso, Santo Ovídio, Santa Iria, Santa Quitéria e Santa Comba; São Teotónio, Santo António e São Gonçalo; São João de Deus e São Francisco Xavier; e São Gonçalo Dias, Santo António e São Gonçalo - são as figuras medievais predominantes enquanto a pré-nacionalidade se direcciona para São Vicente e São Veríssimo. Estamos numa área geográfica de talha e imaginária periféricas, onde os atributos com frequência se encontram incompletos ou adulterados pela repintura. As imagens existentes nos locais de origem (34) e a mobilidade interna nos templos (29) inscrevem-se num quadro positivo, já que o desaparecimento é inferior (26). A sua salvaguarda cabe aos investigadores, aos párocos, aos conservadores e restauradores, às instituições, aos cidadãos, na generalidade. Identificar as devoções nacionais tornava-se uma tarefa facilitada em termos quantitativos; a opção pelas portuguesas tornou-se numa motivação a consolidar posteriormente. 


\section{Bibliografia}

AZEVEDO, Carlos (2001), Iconografia Religiosa, in "Dicionário de História Religiosa de Portugal", Dir. de Carlos Azevedo, Rio de Mouro, C. de Leitores SA e Centro Estudos de História Religiosa da Universidade Católica Portuguesa, Apêndices, pp. 406-416.

DAIX, Georges (1996), Dicionário dos Santos do Calendário Romano e dos Beatos Portugueses, Lisboa, Terramar.

MARQUES, José (2006), Os Santos dos Caminhos Portugueses, in “Revista da Faculdade de Letras - HISTÓRIA", Porto, III Série, vol. 7, pp. 243-262.

MARQUES, João Francisco (2000), Oração e Devoções, in "História Religiosa de Portugal," Dir. de Carlos Azevedo, Rio de Mouro, Círculo de Leitores SA e Autores, vol. 2, pp. 636-650.

MARQUES, João Francisco (2000), Os Itinerários da Santidade: Milagres, relíquias e devoções, in "História Religiosa de Portugal", Dir. de Carlos Azevedo, Rio de Mouro, Círculo de Leitores SA e Autores, vol. 2, pp. 359-365.

NEVES, João César das (2006), Os Santos de Portugal, Estoril, Lucerna.

RODRIGUES, José Carlos Meneses (2004), Retábulos no Baixo Tâmega e no Vale do Sousa (Séculos XVII-XIX), Porto, FLUP, Dissertação de Doutoramento, vol. III (policopiado).

ROSA, Maria de Lurdes (2000), Hagiografia, in “Dicionário de História Religiosa de Portugal", Dir. de Carlos Azevedo, Rio de Mouro, Círculo de Leitores SA e Autores, pp. 326-359.

TAVARES, Jorge Campos (2001), Dicionário de Santos, 3. a edição, (s.l.), Lello Editores. 



\title{
Variantes iconográficas nas representações antonianas
}

\author{
D. Carlos A. Moreira Azevedo*
}

A quantidade de prodígios que Santo António executou já em vida atesta a fama e motiva o culto. Os milagres de Santo António situam-se em diferentes vertentes. Atribuem-se-lhe exorcismos, curas várias, ressurreições, levar uma criança a tomar a defesa da mãe... Os mais duradouros na fama assumiram, na arte, representações que os imortalizaram. Deixamos para outra ocasião o tratamento dos ciclos iconográficos antonianos como o famoso Sermão aos peixes, o Milagre eucarístico ou da mula, ou o episódio de Santo António a livrar o pai da forca. Grande parte destes episódios não resiste à crítica histórica moderna, porque a sua origem é tardia nas fontes. Aparecem pela primeira vez na legenda Rigaldina e particularmente no Liber miraculorum (c. 1370). Outros faltam nas biografias mais antigas ${ }^{1}$. A corrente do maravilhoso, a fabulação fantástica traçam, a seu modo, a real magia de uma vida, que saltou para o mito e alimenta com força expressiva as narrações, as pinturas, as esculturas. ${ }^{2}$

As primeiras imagens italianas, que datam do século XIII, mostram o santo sem atributos específicos. Começam os artistas a recorrer a atributos já comuns a outros santos, como o fogo e o bordão, que copiam de Santo Antão; o ramo de açucenas que retiram a São Bernardino de Siena, canonizado em 1450 . O seu primeiro atributo parece ser a cruz.É este

* Escola das Artes / Universidade Católica Portuguesa .

1 Quanto aos milagres realizados depois da morte, há um inquérito rigoroso do bispo de Pádua, promovido a pedido do Papa Gregório IX. No relatório apresentado ao Papa são elencadas dezanove curas: cinco de paralíticos, sete de cegos, três de surdos, dois epilépticos, três de corcundas, dois de altas febres, duas ressurreições. A Assídua considera que se registam apenas os mais conhecidos. Logo no dia da trasladação do corpo de Santo António muitos sentiram a cura das suas enfermidades.

2 Entre o ciclo mais completo talvez seja o de André Gonçalves, para o Convento da Madre de Deus, Capela de Santo António, década de 1750: S. António soluciona uma disputa; S. António cura o pé do rapaz arrependido; Milagre da mula; cena familiar com S. António; o parto milagroso; S. António ressuscita um morto; a conversão das meretrizes; Visão de S. António; Aparição do Menino Jesus a S. António; Ressurreição de um jovem numa carroça; Pregação de S. António aos peixes; S. António cura uma criança; S. António cura um possesso; S. António converte um burguês. No tecto: S. António em oração; S. António converte um cavaleiro; S. António em estudo; Aparição de S. Francisco a S. António; S. António recebe a bênção; Comunicação do Espírito a um frade; Pregação diante de um bispo; Pregação com aparição de S. Francisco; Transporte do corpo de S. António; S. António é arrebatado ao céu (Cf. MACHADO, José Alberto Gomes - André Gonçalves pintura do Barroco português. Lisboa: Ed. Estampa, 1995, pp. 223-225). 
percurso que vamos percorrer. Iniciemos pela figura e suas vestes, antes de avançarmos para a caracterização dos seus atributos.

\section{A figura de Santo António, suas vestes}

A esmagadora maioria das esculturas de temática antoniana apresenta o Santo como franciscano. São raras as imagens de Santo António revestido de Menino de Coro ou Cónego Regrante de Santo Agostinho.

\subsection{Menino de Coro}

No caso do Menino de Coro, Santo António aparece vestido com túnica vermelha e roquete, numa alusão clara ao passo hagiográfico do milagre da cruz, nas escadas do coro da Sé de Lisboa. A ausência da murça distingue da contaminação, também sucedida, com as vestes dos cónegos seculares. Na Diocese do Porto existem dois exemplares de escultura: no Museu do Cabido ${ }^{3}$ e na Igreja do Colégio de São Lourenço ou Grilos ${ }^{4}$, trabalhos oitocentistas. Em ambos Santo António tem sobrepeliz (e não roquete) por cima da túnica. Em Grijó ${ }^{5}$ existem, também com esta temática, duas pinturas, aparecendo o Santo com roquete.

\subsection{Cónego regrante de Santa Cruz}

No que diz respeito à iconografia crúzia, Santo António veste quase sempre túnica branca, sobrepeliz de linho, redonda e ampla, que pode ser, no máximo, até aos joelhos, e murça preta, apertada apenas por um botão. Como notou Nogueira Gonçalves, há interpretações erradas nesta veste ${ }^{6}$. Estas figurações têm sempre relação com antigos mosteiros crúzios e deixam de ser executadas com a extinção das Ordens Religiosas, ocorrida em $1834^{7}$.

3 AZEVEDO, Carlos A. Moreira - Roteiro do culto antoniano na Diocese do Porto. Porto: Fundação Manuel Leão, 1996, p. 54.

4 Ibidem p. 53.

5 Ibidem, pp.300-301.

6 Cf. GONÇALVES, A. Nogueira - Certos aspectos do hábito dos cónegos regrantes da Congregação de Santa Cruz. Boletim Cultural da Câmara Municipal do Porto. 24 (1961) 328-337. Ver, também, MARQUES, José - Figurino crúzio visto da segunda metade do século XVIII. In I CONGRESSO INTERNACIONAL DO BARROCO.Actas. Porto: Reitoria da Universidade do Porto; Governo Civil do Porto, 1991, vol. 1, pp. $531-548$.

7 Os Cónegos Regrantes de Santo Agostinho, na diocese do Porto, tiveram os seguintes mosteiros: São Salvador de Lordelo (Paredes), Santa Eulália de Vandoma (Paredes), São Vicente de Tougues (Vila do Conde), São Salvador de Tabuado (Marco de Canaveses). São Pedro de Ferreira (Paços de Ferreira) foi extinto e unido à Catedral do Porto. Santo André de Ancede (Baião), até 1559, e São Martinho de Mancelos (Amarante) foram entregues à Ordem dos dominicanos. Em 1770 foram extintos São Salvador de Grijó (Vila Nova de Gaia), Vila 
1. Santo António Menino do coro. Porto, Museu do Cabido, século XIX. Roteiro, p. 53.

2. Santo António cónego regrante de Santo Agostinho, Moreira da Maia, Igreja Matriz, século XVII. Roteiro, p. 148.
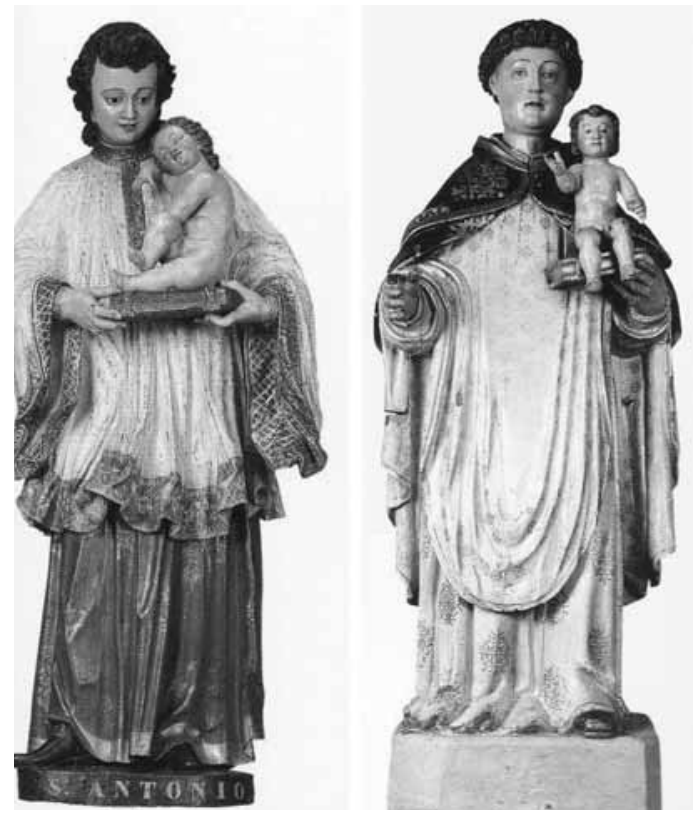

\subsection{Franciscano}

A adesão do cónego regrante ao movimento mendicante franciscano, animado pela passagem das relíquias dos mártires de Marrocos por Coimbra, irá provocar a difusão iconográfica de António de Lisboa como franciscano. Assim aparece vestido na grande parte das representações. Comecemos por observar um caso fora do comum. Vasco Fernandes, no painel da direita do tríptico Cook do MNAA (inv. 1868), de ca. 1520, representa a figura do franciscano português, tratado de forma original. Usa um capelo a cobrir a cabeça, escondendo a habitual tonsura. Segura o bordão, em evidente contaminação com Santo Antão. A posição das mãos, com o indicador da mão direita apoiando-se no polegar da esquerda, revela enumeração, gesto da argumentação escolástica. ${ }^{8}$ Gesto adequado para representar a cena do sermão aos peixes. Semelhante gesto aparece em colecção particular do Caramulo (ca. 1515-1520) ${ }^{9}$.

Boa do Bispo (Marco de Canaveses) e São Martinho de Caramos (Felgueiras), onde até 1834, no entanto, continuam a assegurar como pároco um monge. Permaneceram, até à extinção das Ordens, Santo Agostinho da Serra do Pilar (Vila Nova de Gaia), Santo Estêvão de Vilela (Paredes) e São Miguel de Vilarinho (Santo Tirso).

8 GRÃO Vasco e a pintura europeia do Renascimento. Lisboa: Com. Nac. para as Com. dos Descobrimentos Portugueses, 1992, pp. 148-149.

9 lbidem pp. 145-147. 

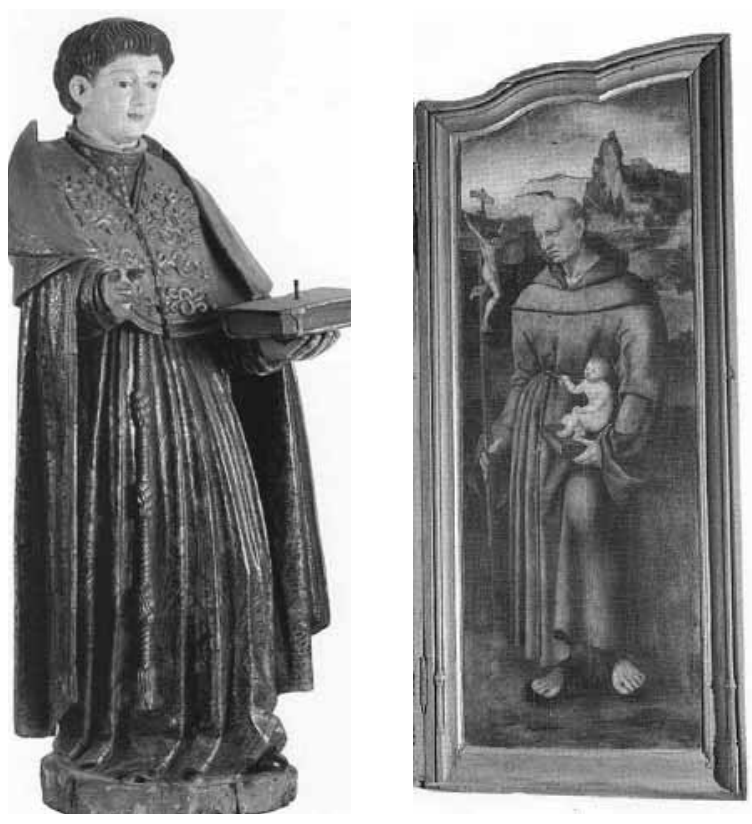

3. Santo António como doutor da Universidade de Coimbra. Lamego. Cristo fonte de esperança, n. 377, pp. 520-521.

4. Santo António, volante do tríptico da Igreja Matriz de Ancede - Baião. Escola flamenga, primeiro quartel do século XVI. Roteiro, p. 95.

Quanto às vestes franciscanas, há uma evolução. Até ao século XVII o hábito não tem manto. Na centúria seguinte divulga-se o uso do manto, perdurante até à actualidade. Por séculos, a tendência é continuamente decrescente. O manto faz o pleno no século XVIII e vai decaindo. Outro adereço das vestes é o capucho. Considerou-se o capucho como "erguido" sempre que se encontrava saliente. No século XVII cerca de $90 \%$ das obras produzidas têm o capucho erguido ${ }^{10}$. Nos séculos XVIII e XIX desce o número de casos.

Caso único conhecido é a escultura do século XVIII, que representa o franciscano com o adereço de Doutor, à maneira da Universidade de Coimbra. Conserva-se na igreja de São Francisco, em Lamego. O que seria declarado Doctor evangelicus (1946) mostra uma interpretação plástica original, mas profundamente significativa do seu serviço à Ordem franciscana e à Igreja. ${ }^{11}$

Ainda como adereço da veste, acrescenta-se o rosário, presente em algumas esculturas. Se olharmos para o peso deste adereço só na produção do século $\mathrm{XX}$, aquele número sobe.

10 Esta percentagem corresponde ao inventário das 477 paróquias da Diocese do Porto, que consideramos sondagem representativa e serve de base fundamental a esta apresentação.

11 Cf. CRISTO fonte de esperança. Porto: Diocese do Porto, 2000, pp. 520-521, n. 377. 
Numa água-forte de Klauber, do século XVIII, aparece Santo António a indicar a potência do Rosário ${ }^{12}$. As gravuras de finais do século XIX ajudaram a vulgarizar este elemento ${ }^{13}$.

Antes de nos determos na análise dos atributos, olhemos uma representação onde António aparece excepcionalmente como envelhecido.Trata-se de um tríptico do primeiro quartel do século XVI, de escola flamenga, conservado na Igreja Matriz de Ancede ${ }^{14}$, procedente da vizinha paróquia de São Bartolomeu de Campelo. O painel central é ocupado por São Bartolomeu; Santo André está na aba esquerda e Santo António na aba direita. O reverso dos volantes tem pintada a Anunciação. ${ }^{15}$

O painel de Santo António representa-o de pé, voltado três quartos para a esquerda, com auréola e de vestes franciscanas. Olha para a imagem do crucifixo de haste longa, sustentado pela mão direita. Com a esquerda segura um livro encadernado sobre o qual está sentado o Menino Jesus, que se agarra ao cordão do Santo. A paisagem do fundo é composta por arvoredos e altos penhascos. Aparecem vultos à direita. Na parte inferior pintam-se ervas e calhaus.

Luís Reis-Santos não poupa as palavras para enaltecer a qualidade notável desta pintura: “Elevado mérito artístico, a harmonia da composição e da cor, o vigor do desenho, a consistência da modelação, a sobriedade e a beleza do estilo, o poder de penetração psicológica e de caracterização moral"16. Tentando entrar nesta atitude interior transmitida pelo pintor, diz, com eloquência, o estudioso acerca do Santo representado nos nossos painéis quinhentistas: "dir-se-á que fala no grande políptico de S. Francisco de Évora; medita, reza, lê, evangeliza no tríptico de Vasco Fernandes; nas tábuas do Mestre da Lourinhã, de Frei Carlos e de Gregório Lopes, [...] etc.; exprime vida interior, sofrimento e fé, numa das nossas mais belas imagens do grande Santo português pintadas na primeira metade do século XVI: a da aba direita do tríptico da Igreja do Convento de Ansêde"17.

Com espírito franciscano, António sente-se irmão do corpo e da dor do Cristo que contempla. Adora aqueles braços feridos, aqueles pés doridos, aquele rosto desfigurado, e vê

${ }^{12}$ Cf. GIEBEN, Servus - Stampe ed incisioni antoniane nel Museo Francescano (Istituto Storico Cappucini, Roma). Il Santo. 19 (1979) 667-680.

${ }^{13}$ Cf. BRITO, Fernando Thomaz de - Vída e milagres de Santo António. Lisboa 1894.

14 Cf. AZEVEDO - Roteiro, pp. 94-95.

${ }^{15}$ A obra foi restaurada pelo Mestre Fernando Mardel, em 1940, depois da sua "descoberta" por Luís Reis-Santos. Integrou a exposição de "Os primitivos portugueses (1450-1550)."O Convento crúzio, fundado em 1107, no lugar do Ermedo, e mudado em 1160 para o sítio actual, tinha direito de apresentação do pároco de Campelo, que era Arcediago. Assim se compreende como o tríptico feito para Campelo tenha ido para Ancede. Em 1559 o Convento passou para a posse dos dominicanos, que reedificaram a igreja actual.

${ }^{16}$ REIS-SANTOS, Luís - O antigo retábulo da lgreja de Campelo. In IDEM - Estudos de pintura antiga. Lisboa 1943, p. 132.

17 IDEM - Santo António na pintura portuguesa do século XVI. [s.I.]: Ed. Ática, 1945, pp. 6-7. 
ali os gemidos de todas as criaturas, as lutas da humanidade, as solidões daquele coração aberto. A ternura e encanto da infância, que dá carne à novidade de todos os começos, está ali no Jesus pequenino, posto sobre a Palavra criadora e redentora. É uma faceta da vida, antes meditada. Agora, fita o amor crucificado que entristece, como aparente fim, essa humanidade ferida, na qual se revela o amor primeiro, dado até ao fim. Do Menino de Nazaré, pobre e nu, ao Cristo do Calvário, despojado, não há diferença de amor. Santo António como que colhe a sabedoria da cruz para a semear no vigor da pregação.

\section{Atributos das representações antonianas}

Dos muitos frescos que as igrejas medievais mostravam restam-nos poucos testemunhos. Na Igreja de São João Baptista de Gatão ${ }^{18}$, trabalho dos séculos XV-XVI, distinguem-se os atributos de Santo António: açucena na mão esquerda; Menino Jesus na direita, sobre um livro fechado. O Menino já ostenta o globo do mundo, encimado por uma cruz ${ }^{19}$. Tentemos perceber a evolução e o sentido da escolha dos elementos identificadores da figura antoniana.

\subsection{A cruz}

As primeiras representações portuguesas datam do século XV e mostram António com a cruz. É o caso do painel do Museu da Sé de Évora, São Francisco e Santo António com a cruz. Ainda do século XV é o Santo António da série dos quatro santos da oficina de Nuno Gonçalves. Duvidou-se se seria São Francisco ou Santo António, mas segundo Markl não há dúvida. ${ }^{20} \mathrm{~A}$ ausência de estigmas e a presença da cruz indicam que estamos perante o nosso santo.

Dos inícios do século XVI (entre 1503 e 1508) é a série franciscana de Francisco Henriques para o retábulo de São Francisco de Évora com a representação de São Bernardino de Siena e Santo António. Apresenta aqui o livro e o crucifixo.

O Mestre da Lourinhã mostra, no painel de Santo António do Santuário do Cabo Espichel (primeiro quartel do século XVI), a figura do franciscano com a cruz na direita e o livro aberto na esquerda. ${ }^{21}$

A cruz refere-se à Paixão e Morte e sublinha a salvação do mundo, operada pela sua vida entregue. A cruz nas mãos de António alude à vontade de querer seguir Cristo pobre e crucificado.

18 Cf. AZEVEDO - Roteiro, p. 75.

19 Cf. LACERDA, Aarão de - Os frescos da Igreja de Gatão: nótula. Prisma. 4 (1937) 255-258.

20 Cf. MARKL - Santo António, p. 39, fig.p. 92.

21 Cf. BATORÉO, Manuel - Pintura portuguesa do Renascimento: o Mestre da Lourinhã. Lisboa; Caleidoscópio, 2004, pp.101-102, fig. 43. 


\subsection{O Menino Jesus}

O Menino Jesus, ainda mais que o livro, é, desde o século XV, o atributo preferido da iconografia antoniana. Os primeiros exemplos que se conhecem são da primeira metade do século XV. A tardia introdução do Menino Jesus na iconografia antoniana tem uma razão óbvia. A fonte hagiográfica que serviu de base à sua representação é o Liber miraculorum, escrito por Arnaldo de Serrano entre 1369 e 1374. Esta obra ofereceu largo manancial para os artistas que dela fazem uso frequente, a partir do século $X V$. Neste domínio, é bem conhecida a obra de Lorenzo San Severino, de 1496. Das sessenta e cinco narrações do Liber miraculorum, vinte e quatro são material inédito, relativamente às legendas anteriores ${ }^{22}$. A Aparição do Menino a Santo António é uma história acolhida com sucesso na tradição iconográfica até aos nossos dias e muito preferida na idade barroca. Mas que narra a legenda? Acolhido por um benfazejo hospedeiro, numa das suas viagens por França ou Itália, foi o Santo visto pelo anfitrião, numa certa noite, a receber a visita de belíssimo infante. Tratava-se do Menino Jesus que descia do céu sobre um livro e passava aos

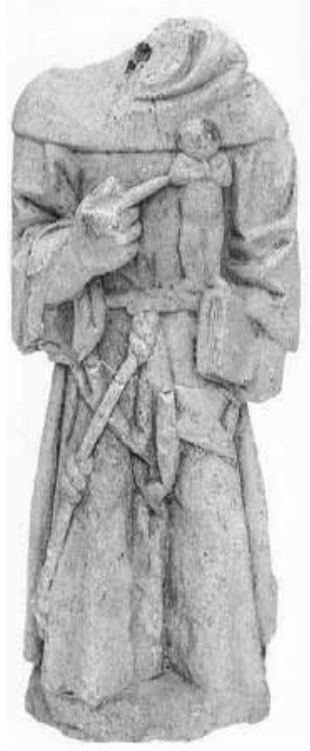

5. Santo António. Escultura de Meinedo, pedra anca, séculos XV-XVI. Roteiro, p. 138. braços do Santo. Tudo isto viu o burguês, por uma porta entreaberta. Prometeu guardar segredo. Assim fez até que António morreu. Em virtude deste "milagre", entra o Menino Jesus na iconografia.

O Menino começa por aparecer sobre o peito do Santo nalguns exemplares medievais, como é o caso da encantadora escultura de Meinedo ${ }^{23}$, recentemente descoberta. $O$ vigor do dedo indicador do Santo ganha a centralidade da obra.

É assim que surge o Menino em painel do primeiro quartel do século XVI, com São Francisco e Santo António em oração, existente no MNAA e proveniente do Mosteiro da Madre de Deus. ${ }^{24} \mathrm{O}$ Mestre da Lourinhã representa os santos ajoelhados à margem de um rio, que corre em fundo, e vestidos de burel castanho atado com cordão. No peito de Santo António está pintado um Jesus Menino, rodeado por auréola.

${ }^{22}$ Cf.TORRES BALLESTRERO, Nuria - San Antonio y el Niño en el arte de fines del gotico hispano. In CONGRESSO INTERNACIONAL"PENSAMENTO E TESTEMUNHO”,vol.2, p. 1297.

23 Cf. AZEVEDO - Roteiro, pp. 144-145.

${ }^{24}$ Cf. BATORÉO, Manuel - Pintura portuguesa do Renascimento: o Mestre da Lourinhã. Lisboa; Caleidoscópio, 2004, pp. 128-135. 
Para sublinhar a ideia de visão, o Menino é, por vezes, rodeado por raios em forma oval, que podem ser dourados, a sublinhar luz e divindade, ou roxos, a aludir à paixão. A arte barroca representou esta aparição como contemplação estática. O Menino, porém, perde a frieza de um atributo simbólico e adquire sentimentos evidenciados em gestos.

Muito original é a pintura do século XVI, proveniente do Convento de Jesus de Setúbal e no MNAA (inv.1966): Santo António e o Menino e Vanitas. De autor provavelmente luso-flamengo, mostra no reverso um memento mori, a caveira num nicho. A figura de António pretende ser um retrato. No cimo do livro fechado o menino, de pé, segura a cruz na esquerda. ${ }^{25}$

Há uma espiritualidade veiculada nesta associação do Menino Jesus, bem testemunhada nos sermões de Santo António. Os franciscanos meditaram sobre a humanidade de Jesus e valorizaram a devoção ao Menino com a promoção do presépio. $\mathrm{O}$ atributo antoniano harmonizava-se com esta linha espiritual e servia a causa da sua difusão, motivando a visualização de um amor ao Menino, ensinado na pregação popular. Há um poder evocador da inocência, candura, humildade, pureza, amor pela humanidade, patentes na vida de Cristo.

Na pintura portuguesa os primeiros testemunhos são da segunda metade do século XVI, na pintura de São Martinho de Sintra, onde o Menino está sobre o livro, abraçado ao pescoço de Santo António que ostenta a cruz. Em painel do Museu de Setúbal, da Igreja de Jesus, Santo António está ladeado por São Boaventura e São Bernardino de Siena. António segura o livro sobre o qual se vê o Menino de pé com a cruz, ao jeito do Cristo ressuscitado. ${ }^{26}$

$\mathrm{O}$ atributo do Menino na escultura antoniana é quase omnipresente. Na esmagadora maioria aparece do lado esquerdo. A posição mais frequente é do Menino sentado sobre o livro. Aparece, contudo, de pé e ao colo, em imaginativas poses.

Em painel atribuído a Frei Carlos, do Museu Nacional de Arte Antiga (inv. 64), Jesus Menino aparece a brincar com os livros que estão no genuflexório onde Santo António se ajoelha. ${ }^{27}$ As mãos do Menino tanto aparecem a segurar atributos ${ }^{28}$, como em gesto de falar; sobre o peito ou em posição de equilíbrio, mostrando o Menino a segurar-se ao capucho ou ao manto do Santo. São raros, mas também se encontram, casos do Menino a

25 OSANTO do Menino, catálogo n. 20.

${ }^{26}$ Semelhante tema ocorre em painel do Museu Regional Francisco Tavares Proença Júnior, de Castelo Branco. Nesta obra Santo António senta-se numa espécie de escabelo sob dossel adamascado.

27 Deve ser visto como possível volante de um tríptico a que pertenceria a estigmatização de São Francisco do mesmo museu (inv. 276). Cf. MARKL, Dagoberto L. - Santo António uma complexidade iconográfica. In OSANTO do Menino Jesus. Santo António Arte e História. Lisboa, 1996, pp. 37-45.

${ }^{28}$ Os atributos do Menino são muito diversificados, segundo a amostragem da diocese do Porto: globo do mundo (163), livro (72), açucena (25), pão (23), a que se junta o cesto do pão (4), coração (22), cruz (8), pomba (2), porquinho (1). O globo do mundo demonstra o seu poder salvador sobre a terra e a missão redentora da humanidade. 
brincar com o cordão do Santo ${ }^{29}$. Outra versão a ter em conta é a que apresenta o Menino vestido, preferido no século $X X$.

O livro passa de atributo da figura de Santo António para as mãos do Menino, em

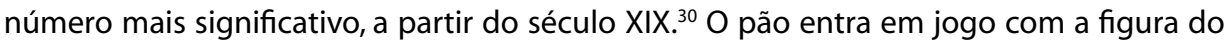
Menino na imaginária barroca. $\mathrm{O}$ atributo do coração surge nas mãos do Menino já nos finais do século XVII, faz o pleno no século XIX e praticamente desaparece no século XX.

\subsection{Livro}

O livro é atributo antigo e mais usado. Aparece geralmente na mão esquerda, ora aberto, ora fechado. O livro era usado habitualmente nas representações dos Apóstolos, dos Doutores e dos Bispos, como depositários da doutrina evangélica. Assim se queria sublinhar, em Santo António, a qualidade de apóstolo da Boa Nova e de "Arca do Testamento". Patenteava o escritor, o sábio. Quem viveu o Evangelho como "regra e forma de vida" e o anunciou fielmente é natural que segure o livro no átrio das suas mãos. Junto se coloca, frequentemente, o Evangelho vivo: o Menino Deus em pessoa nos braços do Santo. A imagem de Jesus, grande amor da vida de António de Lisboa, não decaiu nos seus lábios e não caiu dos seus braços. ${ }^{31}$

\subsection{Açucena}

A açucena forma parte do escudo de armas, da identidade de Santo António, do seu estilo de vida. É símbolo de pureza, de esplendor da carne ao vivo. Na expressão de uma didáctica pastoral significa transparência, brancura, beleza e fragância, como fruto da temperança e do rigor contra as tentações. Desde o século $\mathrm{XV}$, com a célebre escultura de Donatello, no altar-mor da Basílica de Pádua, o atributo adquire vasto uso. Esta flor aparece em meados do século XV e difunde-se no século XVI. Afirma-se, geralmente, que a razão da introdução deste elemento se prende com a necessidade de distinção entre Santo António e São Bernardino de Siena, canonizado em $1450^{32}$, o que se afigura estranho, dado que devia ser o último a aparecer a criar diferença de atributos.

29 Acontece no Lar de Santo António dos Capuchos e em Pinheiro (Roteiro Penafiel, 49, 56).

30 Alguns artistas do século XX preferem colocar a açucena nas mãos do Menino. Cerca de $90 \%$ dos casos em que acontece esta variante situam-se em época recente.

31 Cf. MATOS, Manuel Cadafaz de - Ideologia e práticas de representação antonianas na cultura ocidental do Renascimento: a imagem de Santo António na iconografia e na história do livro quinhentista. In CONGRESSO INTERNACIONAL“PENSAMENTO E TESTEMUNHO”, vol. 2, pp. 1233-1276.

32 Cf. MARKL, Dagoberto L. - Santo António: uma complexidade iconográfica. In SANTO (O) do Menino Jesus: Santo António. Arte e História. Lisboa: IPM; ICEP, 1995, pp. 39, 41. 
A presença da açucena, documentada desde a centúria de quinhentos, é mais constante a partir do século XVII, mas apenas no século XX ganha verdadeira expressão na escultura, projectada já pelo seu reaparecimento em finais do século XIX. Exemplo significativo da adopção deste atributo é a pequena tela do Museu de Arte Antiga (inv.2024) atribuída a Vieira Lusitano.

Há o costume de considerar lírio a flor aparecida como atributo de Santo António. Ora, como vimos, não é essa a flor que, regra geral, é representada nas mãos do Santo. A confusão deve-se à palavra italiana giglio, que tanto traduz lírio como açucena, da família das liliáceas. Em latim chama-se lilium candidum. É significativa a citação do Cântico dos Cânticos «Dilectus meus pascitur inter lilia» (Cant. 2,16), que as versões portuguesas traduzem por "açucenas". A palavra portuguesa açucena tem origem árabe as-susanâ, de susan = lírio. Por existir, em português, açucena corresponde a um sentido determinado e não é correcto usar indistintamente qualquer palavra. O lírio é da família das iridáceas (iris germanica), com folhas ensiformes e flores dispostas num cacho apical de cor lilás, azul ou branca. Muitas descrições de iconografia antoniana portuguesa terão de ser revistas neste ponto. A esmagadora maioria dos casos que encontramos tem como atributo a açucena. ${ }^{33}$

\subsection{Atributos por contaminação}

Os atributos da iconografia antoniana sofrem variações, quer por confusão, quer por contaminação. Eis alguns casos conhecidos. No princípio do século XIV aparece como atributo a palma ${ }^{34}$, sinal antigo para indicar a vitória sobre o mal, a incorruptibilidade, a imortalidade e as boas obras. Trata-se de confusão com a açucena. A chama, símbolo do amor divino, data de representações italianas do século XIV e deve-se a uma confusão iconográfica com Santo Antão Abade. Também o bastão e a protecção dos animais transitam de Antão para António. ${ }^{35} \mathrm{O}$ coração flamejante, que o Santo sustenta em obras italianas dos séculos XIV e $X V$, é uma variação da chama ${ }^{36}$, nada tendo a ver com qualquer contaminação agostiniana, como frequentemente se vê afirmado. A chama e o coração, nalguns exemplares, aparecem para significar a adoração apaixonada pelo Salvador e a veneração por Nossa Senhora. ${ }^{37}$

${ }^{33}$ Veja-se concretamente a descrição lírio para a representação açucena: SANTO (0) do Menino Jesus: Arte e História, p. 98 e os n. 56, 64-66.

${ }^{34}$ Cf. exemplar do século XVIII, proveniente da colecção Ernesto Vilhena, existente no MNAA inv. 2248. O SANTO do Menino, p. 112, n. 63.

${ }^{35}$ Cf. AZEVEDO - Roteiro, p. 1888, n. 21 Loureiro, pedra de ança, século XVI.

${ }^{36}$ Cf. STANO, Gaetano; CASANOVA, Maria Letizia - Antonio li Padova. In BIBLIOTHECA Sanctorum. Roma: Istituto Giovanni XXIII, 1962, vol, 2, p. 180.

${ }^{37}$ A custódia não é atributo antoniano. Pertence ao milagre eucarístico. Muito menos se pode afirmar que é "retirada a Santa Clara" (MARKL - Santo António, p. 39), pois não basta que haja uso de atributos comuns a outras figuras para se ver aí passagens ou contaminações. Trata-se, neste caso e tão-só isso, da necessi- 


\section{Santo António e as almas}

A relação de Santo António com as almas do Purgatório deve-se à confiança na sua intercessão, muito aliada ao poder do fundador São Francisco e, sobretudo, à mística do cordão da sua túnica. As composições dos painéis do Purgatório e das alminhas populares seguem um esquema repetitivo, dividido geralmente em duas zonas. Pessoas várias no suplício, entre chamas, em baixo, e, em cima, personagem que intervém a favor dos condenados, ${ }^{38}$ muitas vezes sob o olhar superior da Santíssima Trindade.

Na grande pintura da Igreja Matriz de Azurara ${ }^{39}$ aparece, a presidir à cena, a Santíssima Trindade, separada do resto por nuvens. Preenchem a composição diversos anjos, alguns com terço nas mãos. Santo António puxa um condenado do Purgatório. Em baixo, envol-

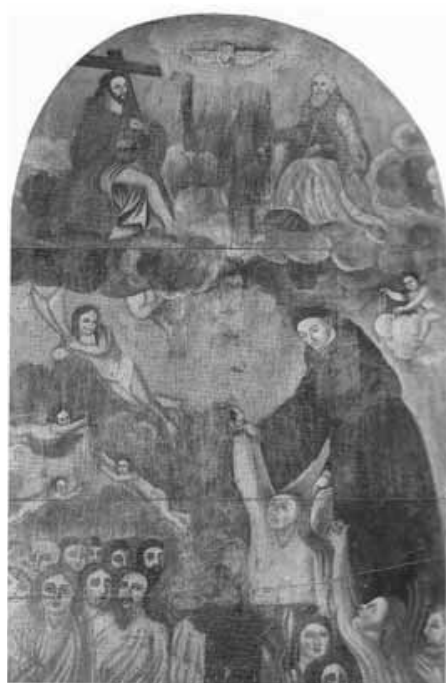

6. Pintura de Santo António e as almas. Igreja Matriz de Azurara - Vila do Conde, séculos XVI-XVII. Roteiro, p. 288. vidos em chamas, estão dez corpos do lado direito e cinco do lado esquerdo. Subjaz a esta pintura uma outra, possivelmente quinhentista e de excelente qualidade, a avaliar pelos rostos entretanto postos a descoberto. Só estudos futuros permitirão tomar as opções certas. ${ }^{40}$

Na Igreja Matriz de Campanhã ${ }^{41}$, a tábua policromada de um retábulo é também rematada pela figuração da Santíssima Trindade. Santo António aparece ao centro da composição, de joelhos sobre as nuvens, com o Menino nos braços. O Menino tem a mão direita em gesto de falar e segura uma cruz na esquerda, a revelar o sinal da salvação. Dois anjos

dade de relatar um milagre. Outros símbolos, mais raros, surgem ligados à iconografia antoniana: cálice, estrela, aspersório, devido à execução de acções próprias do milagre que se representa.

${ }^{38}$ Entre as figuras de recurso estão: Cristo crucificado, a Senhora do Carmo (com as variantes da Senhora das Dores e da Senhora do Rosário), São Miguel, São Francisco, Santo António. Mais raramente: São João, Santa Maria Madalena, São Pedro, São Bento, São Vítor, Santo André, São Patrício. No capítulo das "alminhas" dos caminhos, com a imagem do Santo português, apenas recolhemos alguns exemplos ilustrativos: Travanca do Monte, Carvalho de Rei (Amarante, 23), Fornos (Castelo de Paiva, 5), entre outros. As representações recolhidas são preferencialmente do interior das igrejas.

${ }^{39}$ Cf. AZEVEDO - Roteiro, pp. 288-289.

${ }^{40} \mathrm{Na}$ Igreja Matriz de Pombeiro (Felgueiras, 24) uma tábua relevada mostra a parte superior ocupada pelo Espírito Santo, em forma de pomba rodeada de resplendor dourado, e por cabeças de anjos. Na zona intermédia situam-se Nossa Senhora e Santo António, ambos de joelhos e sobre as nuvens. Na zona inferior, corpos entre chamas.

${ }^{41}$ Cf. AZEVEDO - Roteiro, p. 33. 
fazem o trabalho de retirar os condenados, situados no extremo da composição. Na parte inferior estão corpos entre chamas, cinco na direita e quatro na esquerda, entre eles um rei e um bispo, e um dos condenados está acorrentado.42

Santo António aparece acompanhado de Nossa Senhora ou de São Miguel. A inclusão de Santo António nas representações de alminhas revela o enorme poder intercessor, adquirido pela fama de santidade. Pela sua relação com as Confrarias das Almas, referimos entre os objectos de culto litúrgico, que assinalam presença devota antoniana, as bandeiras e as cruzes destinadas às procissões..$^{43}$

Também na escultura, a devoção às almas deixou marcas curiosas na diocese do Porto. Podemos registar os casos da Capela de Santo Antoninho da Igreja Matriz do Bonfim ${ }^{44} \mathrm{e}$ da Capela de Santo António e Almas de Canidelo ${ }^{45}$. No primeiro caso, três corpos entre

42 Na Igreja Matriz de Rio Tinto (Gondomar, 20) também a Santíssima Trindade preside no registo superior, com quatro pares de anjos envoltos em nuvens. Ao centro está Santo António, sentado sobre uma nuvem e ladeado por anjos. Na zona inferior, anjos exercem o serviço de retirar corpos das chamas. Cita-se, em latim, um texto de Job. Ainda do século XVIII é o quadro que remata o altar colateral esquerdo da lgreja Matriz de Telões (Amarante, 55). De reduzidas dimensões, nele se vê o Santo, envolto em nuvens, a retirar corpos das chamas, que se situam na parte inferior. Já do século XIX são outras representações como a da Casa-Museu da Ordem Terceira de São Francisco, de Ovar (16), datada de 1812 (restaurada em 1935). Aqui aparece no registo superior Cristo crucificado a presidir, com Nossa Senhora à direita e Santo António à esquerda. Sobre nuvens e rodeado de anjos, Santo António tem a cruz na direita e o livro fechado na esquerda. Cinco corpos entre chamas ocupam o registo inferior. Tem inscrição. Em Rossas (Arouca, 37) conservam-se umas alminhas, com data de 1827, no lugar de Barroca, com Cristo crucificado ao centro, ladeado por Santo António, à direita, e São Miguel, à esquerda. São seis os corpos entre chamas e tem dístico. No Museu Paroquial (Arouca, 39) guarda-se uma Bandeira das Almas, pintura sobre tela executada por João Vieira, em 1838, tendo como modelo o painel das alminhas da Barroca. Em Travanca (Feira,65) ainda se conserva uma bandeira das Almas, pintura sobre madeira, com Santo António de um lado e, no verso, São Miguel. Em São Tiago do Bougado (Santo Tirso, 10) um nicho de granito alberga uma pintura sobre madeira onde aparece apenas o Santo António com o Menino vestido e ao colo, os anjos e os corpos entre chamas.

${ }^{43}$ Entre os casos de bandeiras, registamos as de Grijó (V. N. de Gaia, 19-22), e as de Rossas (Arouca, 39) e Travanca (Feira, 65), já referidas. A mais antiga, de Grijó, data do século XVIII e tem forma oval. Santo António tem a particularidade de estar vestido como Cónego Regrante, com o Menino ao colo na esquerda. Dois anjos e a pomba, símbolo do Espírito Santo, estão pintados ao cimo. Ao fundo, representam-se corpos entre chamas. Do século XIX parecem datar os outros três exemplares de Grijó: uma pintura sobre madeira, de forma rectangular, rematada em oval, repete o tipo de esquema figurativo. Santo António sobre as nuvens, com as vestes de Menino de Coro, resplendor e cruz, segura o livro fechado, onde se senta o Menino. Oito corpos em chamas envolvem o Santo. Outra bandeira, com pintura sobre tela, mostra composição semelhante: apresenta o Santo vestido de Cónego Regrante, com cruz na direita e o Menino sentado sobre um livro fechado na esquerda. Ao cimo, está de novo a pomba e, ao fundo, oito condenados. Finalmente, outra bandeira, só com medalhão oval, apresenta sete corpos e o Santo, mais uma vez, vestido de crúzio.

${ }^{44}$ Cf. AZEVEDO - Roteiro, pp. 32-33.

${ }^{45}$ Cf. ibidem, pp. 298-299. 
7. Santo António com armas nacionais, Capela de Santo António, Pinheiro Penafiel, século XIX. Roteiro, p. 226.

8. Santo António e o pão dos pobres. Vila Maior - Santa Maria da Feira, século XVIII. Roteiro, p. 263.
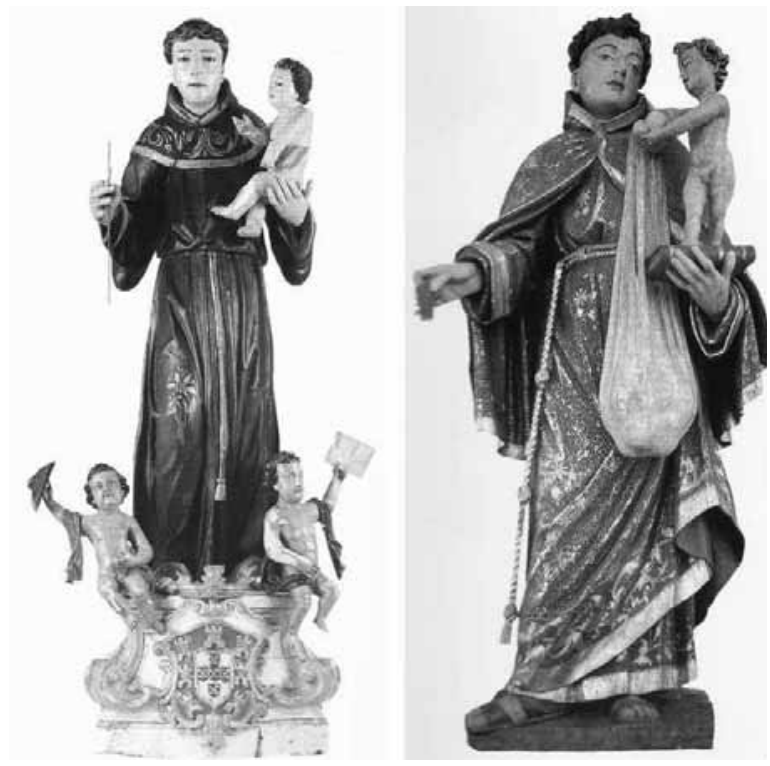

chamas erguem os braços para o intercessor. Em Canidelo, três corpos encontram-se de mãos postas, outro gesto revelador da mesma prece.

Para além de representações com cabeças de anjo na base de esculturas, em ambiente glorioso ${ }^{46}$, há uma escultura singular pelo seu nacionalismo. Esta obra da Capela de Santo António, na freguesia de Pinheiro - Penafiel ${ }^{47}$ mostra na base as armas nacionais, encimadas por coroas e ladeadas por duas figuras simetricamente colocadas. Uma com panejamento azul e livro aberto e a outra com panejamento vermelho e cartola.

\section{Expressão de devoção antoniana: o pão dos pobres}

Entre as manifestações de devoção a Santo António podem referir-se: exercícios piedosos, tais como novenas, trezenas e a terça-feira de Santo António, motivada pelo dia dos seus funerais com milagres abundantes; o breve de Santo António, ou costume de trazer uma medalha com a imagem do taumaturgo de um lado e, do outro, uma frase revelada pelo Santo a uma portuguesa endemoninhada do século XIII:“Ecce crucem Domini, fugite partes adversae! Vicit Leo de tribu luda, radix David, Alleluia, Alleluia"; o pão dos pobres, instituição assistencial criada pela devoção antoniana. Dava-se pão, como esmola,

${ }^{46}$ Cf. ibidem, pp. 41, 50, 197.

${ }^{47}$ Cf.ibidem, p. 239. 
aos pobres, para prestar honra ao Santo. A origem desta devoção remonta a um prodígio narrado pela Rigaldina e pelo Liber miraculorum. Certa mãe consegue a ressurreição do filhito, naufragado numa banheira. Para isso promete ao Santo dar aos pobres o peso da criança em trigo. A partir do fim do século XIX este movimento ganhou desenvolvimento por obra de Louise Bouffier di Tolone, após uma graça obtida, e foi promovida pelo Padre António Locatelli. O pão dos pobres tornou-se numa obra social gigantesca. A devoção popular antoniana dá, assim, frutos de muito pão que vai para a mesa dos necessitados. Graças ao desprendimento de muitos, provocado por Santo António, os pobres têm pão e comida quente ${ }^{48}$.

O Menino Jesus, às vezes, aparece como cúmplice na partilha da saca do pão. Cristo ensinou que quem dá ao pobre, dá a Ele. Esta mensagem não é oportunista demagogia, mas anúncio concreto de caridade realista. Colocar um Santo, com tanta devoção popular, a dar pão é factor provocante que entra pelos olhos e convida a imitar o gesto de partilha que se contempla. O povo devoto de Santo António responde com generosidade. As representações antonianas, que aludem ao motivo do pão, iniciam-se no século XVIII. ${ }^{49}$

\section{Expressão contemporânea}

Termino este breve percurso com uma original expressão da arte contemporânea, congregante de diversas variações e por isso capaz de assumir o papel de uma espécie de conclusão. De facto, na produção artística do século XX, lançam-se pontes entre formas mentais e formas vitais, em espontâneas e autênticas expressões, e delimitam-se contrastes evidentes. O relevo escultórico da Igreja Matriz de Santo António de Corim ${ }^{50}$, obra do Mestre João Barata Feyo, é das mais relevantes, a nosso ver, entre as obras de arte contemporânea com tema antoniano. A riqueza simbólica dos vários elementos, esculpidos em traços de sabor claramente medieval, e a capacidade criativa de uma composição com evidente originalidade conjugam-se para dar solenidade simples a esta obra moderna.

Santo António, enquadrado por um arco que evoca o convento onde residia, aparece revestido com hábito franciscano, segura o livro habitual, mas com as letras "EVANGELIUM", a tornar evidente a fonte da sua pregação e o alimento da sua sabedoria. $O$ ramo de açucena, junto ao livro, simboliza a pureza do seu coração entregue ao anúncio da palavra,

${ }^{48}$ Dos diversos casos de paróquias com o "Pão de Santo António" queremos destacar a de Campanhã, Porto, onde foi criado em 1944 e que, pouco depois, já distribuía dois mil e seiscentos pães nos dias treze de cada mês (Cf. PINTO, A. Ferreira - Actividade pastoral. Porto 1951, p. 159).

49 Em trinta e nove casos, do inventário da diocese do Porto, o Santo tem o alforge do pão sobre o ombro. Em figurações mais recentes segura o pão na mão.

${ }^{50}$ Cf. AZEVEDO - Roteiro, pp. 152-153. 
patente, também, na pureza transparente da sua doutrina. A outra mão estende-se à pobreza, numa plena coerência de ensino e vida. Assim se regista plasticamente a referência ao tradicional pão dos pobres, como dissemos.

No canto superior direito do relevo, aparecem inseridos, noutro arco, dois nobres jovens, representando, segundo a memória descritiva do autor, a figura dos cristãos-novos, judeus ou árabes. Logo abaixo, um arcanjo segura nas mãos uma fita com a inscrição:"DOCTOR ECCLESIAE"; assim se alude ao título dado pelo Papa Gregório IX em 1232, aquando da canonização de Santo António, e que a Igreja Católica atri-

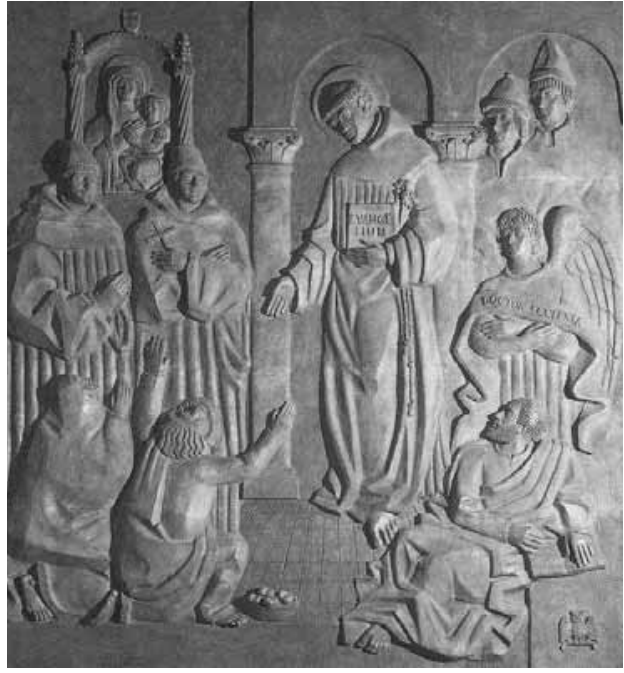

9. Placa cerâmica da Igreja Matriz de Corim - Maia, Barata Feyo, 1993. Roteiro, p. 152. bui aos Santos com particular realce na produção teológica. O título seria confirmado em 1946, por Pio XII. No canto inferior direito, encontra-se uma figura de barbas com um livro aberto sobre uma pedra rectangular, na qual está esculpido um mocho. É aqui representado o Mestre ("velho professor", segundo Barata Feyo) que estuda os sermões, para encontrar, neste espelho brilhante de oratória, o saber aí aberto e assinalado pelo símbolo da sabedoria (mocho).

Dentro de um nicho de decoração manuelina, no canto superior esquerdo, representa-se a Virgem com o Menino Jesus ao colo, aqui a testemunhar o milagre do aparecimento do Menino a Santo António. A encimar a arquivolta vê-se um escudete com uma cruz de braços iguais que representa, segundo a lenda, a cruz que o Santo gravou numa pedra da escadaria do coro da Sé de Lisboa. Por baixo, situam-se dois monges que, segundo o escultor, "representam as ordens monásticas da época e o acto público da sua nomeação como professor por São Francisco, que Ihe confia o ensino de Teologia aos seus frades". No canto inferior esquerdo representa o relevo um "casal de peregrinos" que rejubilam com a dádiva do pão de Santo António colocado num cesto, "sinal de santidade e de alimento" da vida.

Cruzam-se nesta escultura elementos de origem popular, como a Aparição do Menino e o Pão dos pobres, e dados de carácter erudito e inovador em representações antonianas: a sabedoria do Santo, a sua nomeação para professor e a proclamação como Doutor da Igreja. A introdução dos cristãos-novos em cenas do ciclo antoniano é original e constitui alusão ao campo de uma pregação que causou efeito. 



\title{
São Vasco Martins ou Frei Vasco Martins? A iconografia do fundador dos Jerónimos portugueses, a propósito de uma pintura de Valdés Leal
}

\author{
Joaquim Oliveira Caetano*
}

Em 1657 o pintor sevilhano Juan Valdés Leal recebeu o encargo de pintar uma série de painéis contendo a vida de São Jerónimo e alguns varões ilustres da ordem para a sacristia do Convento da Buenavista, nos arredores da cidade do Guadalquivir. Quem visitou por exemplo o Mosteiro de Guadalupe, onde permanece intacta a renovação da sacristia feita na primeira metade do século XVII por Zurbarán com um programa iconográfico similar, não pode ter dúvidas sobre a grandeza dos programas jeronimitas seiscentistas para o espaço da sacristia e ficará com uma ideia semelhante do que seria a sacristia decorada por Valdés Leal no convento de Sevilha, desmantelada após a desamortização de 1834.

Valdés Leal tinha 35 anos quando recebeu a empreitada, certamente o mais importante encargo que até aí tivera. Nascido em Maio de 1622, em Sevilha, filho do português Fernando de Nisa, natural de Torres Novas e de sua mulher a sevilhana Antónia de

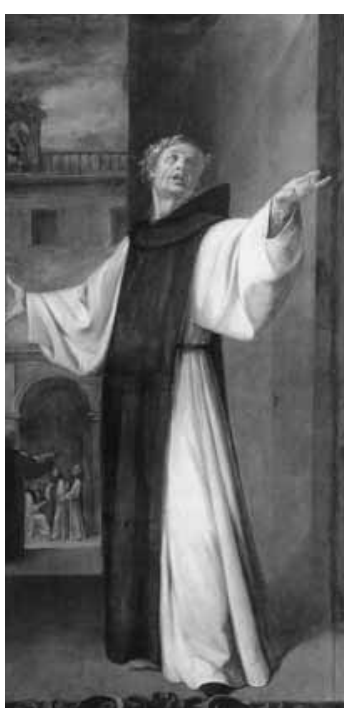

Juan Valdés Leal, Vasco Martins Baldés, aprendeu em Sevilha até ao início da década de 1640, mas não temos notícia segura do seu mestre, que talvez fosse António del Castillo. Sabemos sim que na segunda metade dessa década, por certo pela enorme concorrência do mercado sevilhano, se estabeleceu em Córdova, onde recebe as primeiras encomendas importantes. Só regressa definitivamente a Sevilha na altura da encomenda das pinturas da sacristia de São Jerónimo, que marcam o início da fase mais importante e reconhecida da sua carreira. Céan Bermudes, que ainda pôde ver a série in situ no final do século XVIII pôde atestar que era "do melhor que pintou". Bermudes refere"seis ou oito quadros grandes da vida do santo fundador, e outros que representam veneráveis desta religião com figuras em tamanho natural" 1 . O conjunto era, entre

\footnotetext{
* Museu de Évora.

1 Juan Agustín CEÁN BERMúDEZ,Diccionario Histórico de Los Más llustres Profesores de Las Bellas Artes en España, Madrid, 1800, tomo V, p. 114 (ed.fac-similada com prólogo de Miguel Morán Turina, Madrid, ed. Istmo, 2001).
} 
os dois ciclos de dezoito pinturas, das quais restam, no Museu de Bellas Artes de Sevilha, três grandes painéis da Vida de S. Jerónimo, e seis outros de representações de ilustres membros da ordem², incorporados após a extinção do convento dos arredores de Sevilha. Uma outra pintura do mesmo ciclo foi levada para Inglaterra e comprada em Londres em 1853 pela Gemäldehalerie de Dresden, onde ainda hoje se mostra ao público.É esta última pintura que aqui nos interessa, por ser a única, ao que sabemos, representação de Frei Vasco de Portugal, ou Fr. Vasco Martins, tradicionalmente entendido como o fundador dos Jerónimos Portugueses.

A pintura é sensivelmente do tamanho das outras da série, medindo $249 \times 127,5 \mathrm{~cm}$, resultando daí uma figura em tamanho natural.Vestido com o hábito jerónimo, Frei Vasco é representado a três quartos, de braços e mãos abertas, com o olhar elevado aos céus, de onde um raio de luz, caindo em oblíquo à direita, Ihe ilumina o rosto. Mais de metade do fundo, deste lado, enquadrando a figura, é uma simples parede acinzentada, mas do lado oposto uma parte do fundo mostra outra cena. Num exterior conventual, Frei Vasco, de braços abertos, como se fosse colhido de outro ângulo na mesma posição da cena principal, dirige-se a um conjunto de três monges, enquanto uns pequenos diabos tocam as campanas. Na base, numa cartela de "cartuches", semelhante às que encontramos noutras pinturas da série, inscreve-se o nome: M.I.V. Fr. Vasco de Portugal.

A cena secundária é esclarecida pelo capítulo V do Livro II da História de la Orden de San Jerónimo, um dos dois que o cronista Frei José de Siguenza dedica à vida de Frei Vasco. Escreve Siguenza que, estando Frei Vasco uma noite a dormir no convento que fundara em Córdova, viu o Demónio numa visão espantosa e, levantando-se, refugiou-se na igreja onde melhor o poderia combater. Mesmo aí o diabo lhe apareceu em figura de símio e com macacarias e gestos o inquietou, dizendo mil sem-vergonhices, invectivando-o para que voltasse a Portugal, pois não era "nenhum Jerónimo nem nenhum António", dando-se ao mesmo tempo como culpado por espalhar desavenças entre os monges, como as que tinham acontecido em Guadalupe, isto é, assume o demo a responsabilidade pelo cisma levado a cabo em Guadalupe pelo segundo Geral da Ordem em Espanha, D. Lope de Olmedo, fundador dos "Isidros", que só por intervenção de Filipe II se voltariam a reu-

2 As pinturas da Série de São Jerónimo são Baptismo de S. Jerónimo, $220 \times 225 \mathrm{~cm}$ (inv. ${ }^{\circ}$ CE0185P); Tentações de S. Jerónimo, 224 × 247 cm (inv. ${ }^{\circ}$ CE0183P); e S. Jerónimo Açoitado por Dois Anjos, 223,5 x $145,5 \mathrm{~cm}$ (inv. ${ }^{\circ}$ CE0178P). Os painéis dos ilustres Jerónimos representam Frei Fernando de Tavera, 249 x $127 \mathrm{~cm}$ (inv. ${ }^{\circ}$ CE0180P); Frei Juan de Ledesma, 249 x $129 \mathrm{~cm}$ (inv. ${ }^{\circ}$ CE0182P); Frei Fernando Yañez de Figueiroa, $246 \times 126 \mathrm{~cm}$ ( inv. ${ }^{\circ}$ CE0188P); Frei Alonso Fernández Pecha, $249 \times 128 \mathrm{~cm}$ (inv. ${ }^{\circ}$ CE0195P); Frei Pedro de Cabañuelas, 246 × $126 \mathrm{~cm}$ (inv. ${ }^{\circ}$ CE0193P); e Frei Pedro Fernández Pecha, $243 \times 126 \mathrm{~cm}$ (inv. ${ }^{\circ}$ CE0189P). 
nir aos Jerónimos quase século e meio depois ${ }^{3}$. Depreciando-o Frei Vasco, o Diabo correu sobre o dormitório dos monges, onde o Frade acorreu também a proteger os discípulos e, enquanto o Santo monge orava de braços no ar - diz a descrição, como a pintura:"levantou os seus braços ao céu, pedindo ao Senhor que guardasse os seus servos da raiva daquele lobo faminto"-, o demónio subiu ao sino que estava sobre o dormitório, pegado com a parede da igreja, e derrubou o sino sobre o telhado do dormitório. Acordados os monges em alvoroço, logo Fr. Vasco os sossegou dizendo que não era nada, senão um acidente com a campana que estava mal colocada, concluindo que era preciso não dar forças ao demónio, porque vencido em cada um o medo, vencido estava o diabo. ${ }^{4}$

A pintura segue muito fielmente a descrição do cronista, como aliás acontece em toda a série quer nos painéis relativos à vida do Santo quer nas representações dos ilustres varões da Ordem Jerónima e, de facto, os dois capítulos de Siguenza sobre Frei Vasco suplantam em muito o que se pode saber por outras fontes, quer nas restantes crónicas, ou nos memorialistas portugueses, como Jorge Cardoso, por exemplo, parco em factos sobre a sua memória, quer pelos documentos directos sobre a sua vida, dois únicos, a escritura de compra da Quinta da Penhalonga, em que aparece referido como "Frei Vasco Martins, hermitã de povre vida, natural de Leiria", datada de 5 de Agosto de $1390^{5}$ e a tomada de posse do Convento Cordovês de Valparaíso, em 5 de Agosto de 1408. ${ }^{6}$ Para além destes dois conventos, terá fundado também o de São Jerónimo do Mato, próximo de Alenquer. Siguënza viu no convento de Córdova oitenta hinos dados à sua autoria, mas infelizmente publicou apenas três, e Jorge Cardoso, transcreveu duas cartas assinadas por "Vasco pobre morador em Pedralonga".Estes parcos documentos, muito ajudados diga-se pelos registos das crónicas ${ }^{7}$, permitiram a Cândido dos Santos e sobretudo a José Adriano de Carvalho ${ }^{8}$

3 Lope de Olmedo foi eleito em 1418, e em 1424 viu autorizada uma nova congregação com a regra de "S. Jerónimo". Fundou o convento de Santo Isidoro del Campo de Santiponce. Vd. Cândido dos Santos, Os Jerónimos em Portugal. Das Origens aos fins do século XVII, Porto, Instituto Nacional de Investigação Científica - Centro de História da Universidade do Porto, 1980, p. 4, n. 4.

4 José Sigüenza, História de la Orden de San Jerónimo, Salamanca, Junta de Castilla y Léon, 2000, vol. I, pp. 250-251.

5 Escritura de compra da quinta da Penhalonga. AN/TT, Penha Longa, M. 1, n. ${ }^{\circ}$ 10. Publicada por Cândido dos Santos, op. cit., pp. 259-261.

6 Arquivo Histórico Nacional de Madrid, cod. 233B/8-10, referida por Josemaría Revuelta Somalo, Los Jerónimos - Una orden religiosa nacida en Guadalajara, Guadalajara, Institución Provincial de Cultura Marqués de Santillana, 1982, p. 260.

7 Além de Sigüenza, veja-se também Frei Pedro de la Veja, Cronica de la Orden de Sant Hieronymo, Alcalá de Henares, 1539.

8 José Adriano de F. Carvalho, Nas Origens dos Jerónimos na Península lbérica: Do Franciscanismo à Ordem de S. Jerónimo - O itinerário de Fr. Vasco de Portugal, separata da "Revista da Faculdade de Letras do Porto, n. ${ }^{\circ}$, Porto, 1984. 
situar a personalidade de Frei Vasco, do ponto de vista religioso e espiritual. Esta matriz permite considerar como válida a versão dos cronistas que dão a sua formação espiritual no círculo dos místicos franciscanos italianos de meados do século XIV, nomeadamente de Tommasucio de Siena ou de Foligno (c. 1319-1377). Embora Adriano de Carvalho Ihe recuse o papel de único mestre de Fr.Vasco, propondo a importância de outros Franciscanos como Fr. Pedro de Gualdo e Fr. Pedro de Regali e, de qualquer forma, a derivação do profetismo de Joachim de Fiore, a tradição dá-o como integrando o grupo de discípulos daquele que, regressados a Espanha, se instalaram nos montes de Toledo e daí derivaram para a expansão dos conventos Jerónimos peninsulares. Frei Vasco foi certamente um desses pioneiros, e para o caso, apenas isso nos importa agora. É esse o estatuto que Sigüenza lhe dá e era certamente esse o estatuto em que os seus confrades do século XVII o tinham. Mas curiosamente um estatuto e um relevo que, sendo imenso nos textos escritos, quase não passa para a iconografia. De facto esta é a única representação que conhecemos de Fr. Vasco e a própria proximidade absoluta com o texto da Crónica da Ordem de São Jerónimo parece indicar que o pintor não podia dispor de uma tradição visual para a imagem. Mesmo em Portugal, onde as séries das sacristias jerónimas foram quase inteiramente perdidas, não conhecemos registos documentais de ter havido uma pintura de Fr. Vasco. Porquê então em Sevilha e nesta data?

Um dos motivos prende-se obviamente com a força da crónica de Sigüenza publicada entre 1595 e 1605. Ela é, como dissemos, a fonte de todo o ciclo e dá uma considerável importância ao ermita português. Mas deve dizer-se que é também este texto que influencia as outras séries de sacristias jerónimas, como a de Guadalupe, onde a figura de frei Vasco não aparece, havendo sempre uma totalidade de monges espanhóis. Mesmo no caso do convento sevilhano, deve relembrar-se que a cena que influi na definição da representação de Fr.Vasco se passa no convento de Valparaíso de Córdova, convento onde faleceu Fr. Vasco e no qual talvez, na estreita ligação entre este mosteiro e o de Sevilha, esteja a razão da sua inclusão.

Agradar-nos-ia pensar que o pintor Juan Valdés Leal, filho de um português natural de Torres Novas, pudesse ter tido uma palavra a dizer, ele que longos anos vivera em Córdova, lembrando o conterrâneo do seu pai de tanta importância para esta cidade; mas em rigor o papel do pintor na definição da iconografia do conjunto não seria por certo decisivo. Resta-nos portanto a dúvida: porquê em Sevilha, em 1657, a única representação do ilustre português fundador dos Jerónimos. Talvez a resposta esteja no contexto histórico em que a série é feita. Sevilha era, antes de 1640, a cidade espanhola com a maior comunidade portuguesa. Já em 1638, foi de Sevilha e com milícias sevilhanas que partiram as tropas do Duque de Medina Sidónia para sufocar as rebeliões de Évora e do Algarve. Em 
40 a populosa colónia portuguesa, essencialmente de comerciantes, é quase integralmente repatriada; e mais, com o exército espanhol empenhado nas guerras europeias e da Catalunha, cabe a Sevilha garantir com os seus próprios meios a defesa das fronteiras da Andaluzia o esforço de guerra no Sul de Portugal, o que implicou enormes gastos e recrutamentos voluntários e forçados. Aliás o próprio Valdés Leal aparece em 1665 referindo no "padrão" um longo rol dos vizinhos da cidade capazes de tomar armas para o envio de tropas para Portugal". Neste contexto militar e político, com a presença constante da guerra com Portugal, a inserção de um santo português, ostentando directa e orgulhosamente o nome de Fr. Vasco de Portugal, entre os jerónimos prestigiados e de representação mais comum talvez fizesse um particular sentido, expressando a vontade de integração de Portugal na história comum ibérica; além disso, a personalidade de Frei Vasco, para quem as fronteiras nunca foram superiores à fé, fundador de conventos num e noutro lado da raia, podia expressar exactamente essa vontade de integração. 



\section{Isabel de Aragão, rainha e santa de Portugal: \\ o seu jacente medieval \\ como imagem excelsa de santidade}

Joana Ramôa*

O tema que no presente artigo nos propomos tratar diz respeito a uma das figuras maiores e mais aclamadas do mundo feminino português medieval, Rainha Santa Isabel, personagem intrigante na qual muitas das premissas da conceptualização mitificada que se abateu sobre a Idade Média se manifestam de forma privilegiada e com a mesma vivacidade das cores que no seu túmulo se combinam.

A própria adjectivação a que recorremos, caracterizando a figura e a actuação desta rainha como intrigantes, não é de todo inocente, oferecendo-se desde já como suporte de justificação do carácter preliminar e provisório com que apresentamos esta nossa reflexão, que mais do que almejar afirmações definitivas encerra a simples aspiração de questionar e encetar, para nós mesmos, novos caminhos de investigação.

Na verdade, a figura da Rainha Santa Isabel ofereceu-se como lugar privilegiado de convergência dos interesses dos nosso estudos e do Seminário de que estas actas resultaram e veio a afirmar-se como ponto de partida rico e, nalguns momentos mesmo, surpreendente dessa investigação de maior fôlego que agora iniciamos e que corresponde à Dissertação de Doutoramento - que se debruça precisamente sobre o lugar do género feminino na sociedade e na escultura medievais peninsulares. ${ }^{1}$

Isabel, filha de Dom Pedro III, o Grande, rei de Aragão, e de Dona Constança da Sicília, sua mulher ${ }^{2}$, nasceu, segundo a tradição, no dia 4 de Junho do ano de 1271 . $^{3}$ Saragoça tem

* Faculdade de Ciências Sociais e Humanas/Universidade Nova de Lisboa.

1 A Dissertação de Doutoramento que nos encontramos a realizar, com bolsa da Fundação para a Ciência e Tecnologia, tem por título O Género Feminino - A representação da mulher na escultura medieval em Portugal, Leão e Castela (séculos XII a XV) e é orientada pelo Professor Doutor José Custódio Vieira da Silva (FCSH - Nova de Lisboa) e co-orientada pela Professora Doutora María Etelvina A. Fernández González (FFL - Universidad de Léon). As reflexões que aqui desenvolvemos integram-se, de resto, no contexto do projecto de investigação IMAGO (POCTI/EAT/45922/2002), financiado pela Fundação para a Ciência e a Tecnologia (FCT), em que participámos em regime de bolseira.

2 Tinha, assim, como avô paterno Jaime I, o Conquistador, e como avô materno Manfredo, rei da Sicília (1258-1266), filho ilegítimo do imperador Frederico II de Hohenstaufen, imperador alemão (1212-1250) e rei da Sicília (1197-1250).

3 Recebeu o nome de Isabel em homenagem à princesa Isabel da Hungria, irmã de Violante da Hungria, segunda mulher de Jaime I, avô de Dona Isabel de Aragão. Isabel da Hungria tinha então já sido beatifi- 
sido a localidade com a qual mais frequentemente se identifica o nascimento da infanta, embora outras vozes se tenham já levantado a favor da cidade de Barcelona, tendo como justificação o facto de nesse mesmo ano de 1271 a corte aragonesa ter aí residido por longo tempo. Indubitável parece ser, de qualquer modo, a realidade de ter sido nesta última cidade que Dona Isabel passou toda a infância, até ter abandonado o seu reino natal para desposar o jovem rei português, Dom Dinis.

O nascimento da infanta de Aragão aparece, desde logo, associado a uma lenda, segundo a qual Dona Isabel teria nascido envolta numa pele - manifestando, assim, na própria chegada ao mundo, e portanto desde a sua origem, a vocação para uma existência excepcional (porque de forte comunhão com o divino) que, ao longo de toda a sua vida, mais não terá feito do que consolidar. Esta mesma tradição de reforço do carácter de santidade da rainha, de que provavelmente resultou essa versão, com contornos de milagre, do seu nascimento ${ }^{4}$, atribui- Ihe uma atitude e um comportamento beatíficos ao longo de toda a infância - dizendo-se que, já nessa altura, rezava muito, jejuava e, inclusivamente, se mortificava com cilícios.

Assim, no momento em que chega a Portugal, provavelmente com 11 anos de idade, e se encontra com Dom Dinis, a 24 de Junho de $1282^{5}$, Dona Isabel de Aragão "era bastante formosa; seu rosto, de uma beleza suave e simpática; seu coração, um tesouro de virtudes; sua caridade, inesgotável. Durante o longo reinado de seu esposo, em muitas e diversas ocasiões manifestou as superiores qualidades que adornavam a sua alma"6. Assim a descreve Francisco da Fonseca Benevides, uma das vozes da literatura romântica e lírica que, no século XIX, continuava a fazer eco da tradição devocional que desde os finais do século XIV (iniciando-se apenas algumas dezenas de anos depois do falecimento da rainha) foi dotando de uma aura de sobrenatural toda uma série de episódios da vida de Dona Isabel de Aragão e incrementando de lendas e considerações exaltantes o seu retrato - a mesma

cada, por Gregório IX, em 1235, a pedido expresso do citado imperador - e é muito interessante que, num processo certamente motivado, em larga medida, por esta mesma consanguinidade, as iconografias das duas santas, da mais antiga Isabel da Hungria e da posterior Isabel de Aragão, tenham tendido a aproximar-se de forma apreciável. A mesma relação explica que Isabel da Hungria se integre, como veremos, no grupo de personagens santas que figuram na arca tumular da Rainha Santa como focos particulares da sua devoção e garantes de uma sua ligação excepcional ao divino.

4 Esta mesma versão do nascimento da infanta não se pode dissociar do facto de este nascimento ter sido entendido por alguns autores como um ponto de concórdia, depois de algumas conturbações, entre os reis de Aragão.

5 Os esposos encontram-se já depois de se terem casado, por procuração, numa cerimónia realizada a 11 de Fevereiro de 1282, em Barcelona, e em que o monarca esteve representado por João Velho, João Martins e Vasco Pires.

6 Francisco da Fonseca Benevides - Rainhas de Portugal. Lisboa: Livros Horizonte, 2007, p. 163 (do original publicado pela Typographia Castro Irmão, 1878) 
tradição que determinou, em larga medida, que ela chegasse até nós como personagem de marcada excepcionalidade; excepcional na sua dupla condição de rainha e de santa, excepcional entre os homens e perante Deus.

O certo é que os atributos com que Fonseca Benevides, com maior ou menor benevolência, apresenta a infanta no momento em que esta pisa, pela primeira vez, o território português foram os mesmos que, na construção de uma memória de si própria (de que o túmulo se revelava como suporte primordial), Dona Isabel de Aragão quis e pôde consagrar, com a capacidade e a força de criar uma imagem que durou até aos nossos dias. Mais do que de imagem de uma realidade física (até porque o retrato, neste contexto tumular da plena medievalidade, não se orienta pela busca de veracidade que lhe dará sentido na época moderna), é de imagem idealizada que falamos, de um conceito, de um ideal que, na figura que encima o túmulo, se corporiza.Por isso, em lugar de uma discussão sobre a autenticidade desta representação de Dona Isabel de Aragão, que, face ao entendimento que fazemos do jacente medieval ${ }^{7}$ (e ao repinte tardio que a estátua sofreu ${ }^{8}$ ), se revelaria, em nosso entender, relativamente infrutuosa, interessa-nos, na presente reflexão, o perscrutar das razões maiores que levam a Rainha Santa à definição destes caracteres iconográficos para o seu jacente, o entender do significado profundo e do impacto duradouro dessas mesmas opções.

Curiosamente, nesta mesma imagem que cristalizou da rainha (e que a tradição sua veneradora quis fazer crer que era já, à época da sua feitura, uma imagem generalizada ${ }^{9}$ ), a figura jacente de Dona Isabel de Aragão revela-se particularmente inédita e original, associando às características modelares da representação da nobreza feminina trecentista (a realeza simbolizando-se sempre, em Portugal, apenas pelo uso da coroa) um conjunto de atributos (começando pela própria veste) que a tornam caso único, ao que cremos, no nosso país. Ainda assim, essa mesma concretização iconográfica não deixa de ser, como veremos, perfeitamente enquadrável no todo mental de que participa e, na sua individualidade, uma imagem tipificada de uma rainha que entende a sua excepcionalidade social como indissociável de uma igual singularidade na relação com Deus.

7 Neste entendimento seguimos largamente a proposta de José Custódio Vieira da Silva - Memória e Imagem. Reflexões sobre Escultura Tumular Portuguesa (séculos XIII e XIV). Revista de História da Arte. N. ${ }^{\circ}$ 1. Lisboa: Instituto de História da Arte - Faculdade de Ciências Sociais e Humanas da Universidade Nova de Lisboa, 2005.

8 Confirma-o Frei Manuel da Esperança que, em 1666, escreve:“Toda esta obra esteve descolorida, somente com a alvura natural da mesma pedra, e nesta nossa idade lhe forão dadas as cores: a o hábito, de pardo; a o veo, de preto; e tudo o mais, conforme são as figuras" (História Seráfica da Ordem dos Frades Menores de S. Francisco na Província de Portugal. Parte 2. a Lisboa: 1656-1666, pp. 310-311).

9 "Supõe-se geralmente que D. Isabel de Aragão, esposa de D. Dinis, rei de Portugal, foi objecto de culto religioso enquanto militava entre os mortais. Esta persuasão remonta aos fins do século XIV" (António de Vasconcelos - Rainha Santa Isabel.Vol. I. Coimbra/Castelo Branco: Alma Azul, 2005, p. 5). 
Essa singularidade tendeu a expressar-se, naturalmente, neste jacente de Isabel de Aragão, seguindo os valores maiores da espiritualidade da época, espiritualidade de que as ordens mendicantes eram já, nestes anos 30 do século XIV a que corresponde a feitura do túmulo, um dos principais estimuladores e instrumentos. De resto, ao longo da sua existência, Dona Isabel de Aragão manifesta, em várias atitudes, uma particular simpatia pela ordem franciscana, no que actua como agente de uma geral aproximação das elites aos mendicantes, que tende a definir o quadro social e religioso deste período dos séculos XIII a XV ${ }^{10}$. Será, aliás, neste contexto que assistiremos ao estabelecimento de uma relação íntima da rainha, nos últimos anos da sua vida, com o Mosteiro mendicante de Santa Claraa-Velha de Coimbra. É dentro deste quadro mental e religioso que deveremos entender a adopção, no jacente da rainha, do hábito de clarissa, para além de toda a simbólica de renúncia que uma tal assunção acarretava.

No entanto, se esta atitude compreende em si uma intenção clara de afirmar uma certa capacidade de abnegação, a verdade é que de despojado e pobre este túmulo tem pouco (ou nada). Por outro lado, se tivermos em conta a magnificência das peças que pertenceram ao tesouro da rainha e ainda hoje se conservam (no Museu Nacional de Machado de Castro, em Coimbra) e a própria ressalva que a mesma faz questão de deixar por escrito de nunca se comprometer, em vida, com o uso permanente do hábito nem de abdicar da gestão dos seus bens ${ }^{11}$, entenderemos que esta atitude que a Rainha Santa Isabel plasma na adopção do hábito de clarissa é fundamentalmente uma atitude intelectual - e a imagem visível de um conceito. ${ }^{12}$

${ }^{10}$ Giulia Rossi Vairo encara, inclusivamente, esta que parece ser uma preferência de Dona Isabel de Aragão pelos mendicantes como o reflexo de uma igual beneficiação que os mesmos sofreram no reino de Aragão, por parte da família real, nomeadamente de Dom Jaime I e de Dona Constança, avô e mãe da Rainha Santa, respectivamente. E acrescenta:"Isabella si accompagnava spesso ad esponenti degli Ordini Mendicanti: alcuni di suoi uomini di fiducia furono frati francescani; per sorvegliare e dirigere la fabbrica del monastero di Coimbra, aveva richiesto al pontefice, mediante supplica, di essere assistita da due frati del vicino Convento di San Francisco; frequentemente, negli atti rogati per sua volontà, compaiono come testimoni rappresentanti dei frati minori; così, fra gli esecutori testamentari, figurano vari frati, fra cui il Guardiano dell'Ordine" (Giulia Rossi Vairo - Le Origini del Processo di Canonizzazione di Isabella d'Aragona, Rainha Santa de Portugal, in un atto notarile del 27 luglio 1336. Collectanea Franciscana. 74/1-2. Roma: Istituto Storico dei Cappuccini, 2004, p. 153).

11 Estas intenções deixou-as a rainha redigidas em dois documentos, ao que se crê, ambos originais: um propositum redigido a 2 de Janeiro de 1325, e um protesto, que é, no fundo, a versão portuguesa do primeiro, datado de 18 de Janeiro do mesmo ano, um dia depois da morte de Dom Dinis.Cf. F. de Figanière - Memórias das Rainhas. Doc. XXVI. Lisboa: 1859, pp. 273-275 e Francisco Brandão - Monarchia Lusitana.VI Parte. Lisboa, IN-CM, 1988.

12 Ainda que, num primeiro entendimento, esta convergência de atitudes (a adopção da imagem de clarissa e a acumulação de riquezas) nos possa parecer, à luz dos valores da contemporaneidade, uma contradição, ela é, na verdade, o sinal de um ideal de pobreza, que nos séculos XIV e XV não corresponde 
Num quadro verdadeiramente histórico e com a racionalidade que a História sempre deve perseguir, teremos de reconhecer a Dona Isabel de Aragão um lugar destacado nalguns dos acontecimentos relevantes que Portugal (e mesmo a Península) viveu nesta época.

Desde logo, porque a união de Dona Isabel de Aragão com Dom Dinis significa, de acordo com a leitura que faz José Mattoso, a primeira demonstração do êxito da política peninsular que o rei não descurou por um segundo durante toda a sua liderança e que foi, de facto, uma das características preponderantes da sua longa governação. ${ }^{13}$

De resto, para além de garante e interveniente activa na preservação de uma posição favorável do nosso país relativamente a Aragão, assim como a Castela (relação na qual actuava na condição de mãe da monarca deste reino ${ }^{14}$, Dona Isabel de Aragão foi agente política, não só no modo como atendeu aos interesses de aragoneses instalados em Portugal e, reciprocamente, aos de portugueses fixados em terras de Aragão ${ }^{15}$, mas também, e sobretudo, no modo como parece ter intervindo na pacificação, por duas vezes, da contenda, desenrolada em vários episódios, entre Dom Dinis e o filho primogénito de ambos, Dom Afonso.

De facto, para lá dos vários aspectos lendários que ficaram associados à narração destes acontecimentos, bem como à definição do lugar que neles ocupou a Rainha Santa Isabel ${ }^{16}$ (pretendendo-se fazer de um conflito movido por interesses de classe, de uma nobreza ameaçada pela política de centralização régia que encontrou no infante Dom Afonso um instrumento privilegiado, um embate de inspiração pessoal, nascido de um provável des-

já tanto, entre os leigos, a um despojamento dos bens materiais, mas se relaciona sobretudo com um estado de espírito que disponibiliza o homem para uma aproximação aos pobres.

13 "Tratava-se de uma aliança valiosa, porque Aragão acabava então de adquirir uma importância fundamental na economia e na política mediterrânicas e porque Pedro III (1276-1285) e sobretudo seu filho, e irmão de Isabel, Jaime II (1391-1327), exerceram um papel de primeiro plano na diplomacia peninsular" (José Mattoso - Dois séculos de vicissitudes políticas. História de Portugal.Vol. II.Círculo de Leitores, 1993, p. 149).

${ }^{14}$ Neste contexto da pacificação e da consolidação das relações de Portugal com Castela, mas também de Castela com Aragão, tem de ser lembrado o facto de os dois filhos de Dom Dinis e de Dona Isabel de Aragão, Dona Constança e Dom Afonso, terem desposado o herdeiro do trono de Castela, futuro Dom Fernando IV, e a sua irmã, Dona Beatriz, em 1302 e 1304, respectivamente.

15 Esta atenção da Rainha Santa aos interesses de portugueses deslocados do seu reino natal aparece documentada pela correspondência que trocava com o irmão, o rei de Aragão, Dom Jaime II.

16 "Afirmam as crónicas que estando, no ano 1323, os exércitos inimigos perto do Campo Grande, a rainha, sozinha e montada em uma mula, atravessara as hostes que se gladiavam, no meio da refrega e dos projécteis das forças avançadas que já haviam travado peleja, e que a muito custo conseguiu evitar a batalha" conta Francisco da Fonseca Benevides, fazendo-se eco de uma lenda que, mais uma vez, serve o propósito muito claro de reforçar a aura de misticismo desta personagem régia (Ob. cit., pp. 165-166). 
contentamento do primogénito com o favorecimento que o rei fazia do bastardo Afonso Sanches $\left.{ }^{17}\right)$, o papel de Dona Isabel de Aragão parece ter sido efectivo e não deixa de ser revelador de um carácter firme e apaziguador, da procura de equilíbrio e de justiça que parecem compor o leque de virtudes desta rainha. De facto, esta capacidade mediadora parece ter constituído uma das grandes marcas da existência de Dona Isabel de Aragão, capacidade que se traduziu numa acção diplomática real (que merece ser explorada e já o começou a ser pela investigadora italiana Giulia Rossi Vairo), com reflexos em episódios como o Tratado de Torrellas (1304). ${ }^{18}$

É verdadeiramente um conjunto notável de virtudes este que temos vindo directa ou indirectamente apontando a Dona Isabel de Aragão - que aparece como mãe atenta (aos interesses de Dona Constança e de Dom Afonso), diplomata hábil, rainha piedosa e cristã devota (comportamento de que faz parte a beneficiação de uma série de obras religiosas e de instituições de assistência aos mais desfavorecidos ${ }^{19}$ ) -, virtudes que, por si só, seriam suficientes para que fosse lembrada como personagem excelsa, mas não para que figurasse entre os santos reconhecidos pela Igreja Católica. Este privilégio só lhe poderia advir, entre outros, do facto de lhe serem reconhecidos verdadeiros milagres, os quais têm no manuscrito intitulado Liber qui agit de onesta vita quam exercuit Regina Portugalliae Domina Elisabetha (ff. 436-472v), mais conhecido como Lenda e considerado como a primeira biografia da Rainha Santa, uma fonte primordial - escrito, como indicado no próprio

17 Afonso Sanches acabaria, efectivamente, por se revelar alvo preferencial das acusações da nobreza e saiu largamente desfavorecido deste conflito, tendo-Ihe sido retirado, por Dom Dinis, numa final cedência às exigências do herdeiro da coroa, o cargo de mordomo-mor do reino.

18 "Anche la documentazione d'archivio sembra confermare che Isabella d'Aragona si adoperò personalmente per la realizzazione dell'incontro decisivo di Torrellas (...). Così, nel 1304 Isabella partecipò assieme al consorte ai negoziati di pace in qualità di moglie, sorella e madre, ma anche nella veste istituzionale di regina lusitanorum, non una carica rappresentativa, ma espressione di un potere reale, effetivo, tutto sommato non così usuale per una donna nell'Europa degli inizi del XIV secolo" (Giulia Rossi Vairo - Isabella d'Aragona, "Rainha Santa de Portugal", Ambasciatrice di Pace nella Conferenza di Torrellas (1304). Actas del XVIII Congrés Internacional d'História de la Corona d'Aragó. La Mediterrània de la Corona d'Aragó, segles XIII-XVI\& VII Centenari de la Senténcia Arbitral de Torrellas, 1304-2004.Vol.II.Valencia:2005, pp. 2207 e 2209).

${ }_{19}$ Giulia Rossi Vairo nota, de resto, com muito interesse a dimensão privilegiadamente feminina da piedade e da acção assistencial de Dona Isabel, constatação que resulta do facto de, como se depreende da leitura do seu testamento (redigido em 1327), ter beneficiado sobretudo damas, quer laicas quer religiosas. A própria invocação que primeiramente faz no seu testamento é da Virgem Maria. E, efectivamente, observamos que são as figuras femininas que merecem destaque na arca de Isabel de Aragão, remetendo para uma devoção que tende a centrar-se em mulheres santas. Esta espiritualidade orientada para o feminino é ainda mais evidente no túmulo da neta de Dona Isabel de Aragão, também de nome Isabel e encomenda da rainha. Assim, na decoração dos quatro lados desta arca, assistimos a um claro protagonismo de figuras do referido género: a Virgem com o Menino, acompanhada de anjos ceriferários, no facial dos pés, santas no facial da cabeceira, e virgens e santas, num total de sete em cada lado, nos faciais maiores. 
documento, quando havia ainda "muitos homens, e molheres dignos de creer, que virão, e passarom as cousas que se adiante seguem".20

Haveria de ser Dom Manuel I, o aclamado Rei Venturoso, no século XVI, o verdadeiro iniciador do processo de canonização.

Assim, dando como primeiro sinal a referida tradição de veneração da rainha, que se terá iniciado poucos anos depois da sua morte e que se faria privilegiadamente em torno do seu túmulo medieval, o rei Dom Manuel I, em 1516, pede ao papa Leão X, através do embaixador Miguel da Silva, a beatificação de Dona Isabel de Aragão, o que aquele, por breve de 15 de Abril desse ano, se apressa a fazer, embora apenas para a cidade de Coimbra. Fica autorizado, por consequência, o culto solene na diocese coimbrã, a celebração do ofício litúrgico e a colocação sobre o altar de imagens representativas da beata. Em 1556, desta vez por intercessão do rei Dom João III, o papa Paulo IV concede a extensão a todo o reino da festividade comemorativa da Rainha Santa Isabel.

Assistindo ao aumento do fervor desta devoção, bem como ao seu alargamento geográfico progressivo, Dom Sebastião daria continuidade a este interesse que os monarcas portugueses foram manifestando, desde Dom Manuel, pelo reconhecimento da santidade de Dona Isabel de Aragão. Assim, foi ele quem, em 1576, encarregou oficialmente o bispo Dom Manuel de Menezes de proceder à reunião de todos os documentos que fizessem prova da vida santa da rainha, documentos que foram enviados a Roma, em 1578, e que constituiriam a base do processo de canonização apenas iniciado em 1612 e já a pedido de Filipe II de Portugal. O processo, apesar de tudo moroso, viria a ser terminado já no pontificado de Urbano VIII, reinando então Filipe III de Portugal. ${ }^{21}$ A cerimónia de canonização da beata Isabel teve lugar a 25 de Maio de 1625.

${ }^{20}$ Corresponde esta transcrição ao preâmbulo do referido manuscrito, traduzido por Giulia Rossi Vairo Le Origini del Processo di Canonizzazione di Isabella d'Aragona... Ob. cit., pp. 161-162. Entre os milagres que estão atribuídos à rainha, conta-se, naturalmente, o célebre milagre das rosas que, na verdade, tem duas facetas, pois Dona Isabel terá sido protagonista de dois milagres envolvendo as referidas flores: 0 primeiro decorrido em Alenquer, onde, no pagamento aos operários actuantes na construção de uma igreja do Espírito Santo, as rosas que a rainha lhes deu se transformaram em dinheiro; outro, decorrido em Coimbra, onde, no contexto da edificação do Mosteiro de Santa Clara, e a fim de ocultar a sua acção pecuniária ao marido, ali aparecido de súbito, Dona Isabel terá transformado em rosas as moedas de ouro que trazia no regaço, com o propósito de pagar aos trabalhadores.

${ }^{21}$ Este interesse dos Filipes pelo reconhecimento, por parte de Roma, desta devoção com grande expressão em vários pontos do território de Portugal (e não já apenas em Coimbra), através da proposta de canonização da mulher de Dom Dinis, deve ser entendido, como bem observou Giulia Rossi Vairo, no quadro de uma procura de pacificação do descontentamento gerado pela união, sob a mesma coroa, dos principais reinos peninsulares que, de certo modo, na rainha convergiam. De facto, esta canonização de Dona Isabel de Aragão implicou particular insistência e dedicação dos Filipes, na medida em que se 
Um dos elementos privilegiados para aprofundarmos o entendimento desta tradição de veneração da Rainha Santa Isabel e, mais até do que isso, para procurarmos delinear os verdadeiros contornos de uma personalidade e de uma existência reais cujo conhecimento aparece hoje largamente turvado por essa aura de sobrenatural com que as fontes tendem a tratá-las (seguindo, na maioria, o objectivo muito preciso de reforçar o carácter de santidade de Dona Isabel de Aragão) corresponde ao túmulo medieval da rainha, espaço de cristalização da memória que ela mesma quis deixar de si.

Com efeito, a feitura deste túmulo corresponde a uma encomenda directa de Dona Isabel, de resto como era relativamente habitual na época, funcionando esta atitude como parte de uma preocupação geral com a preparação da morte, na qual se integra a própria testamentária.

Segundo a tradição, o despertar dessa atenção de Dona Isabel de Aragão à feitura da sua arca terá estado relacionado com a morte do rei Dom Dinis, que faleceu a 7 de Janeiro de 1325, com 73 anos de idade e 45 de governo, tendo-Ihe Dona Isabel sobrevivido ainda onze anos. Nesse período de viuvez, a rainha recolheu-se, conforme havia prometido, ao paço que havia mandado construir com ligação ao Mosteiro de Santa Clara, em Coimbra (que ela própria beneficiara largamente), adoptando um modo de vida próximo do das clarissas mas sem nunca professar ou se comprometer com o uso permanente do hábito, como referimos. Aí passou os últimos dias da sua vida, embora viesse a falecer, em 1336, no castelo de Estremoz, no decurso da viagem que, à semelhança do que já anteriormente fizera, empreendeu com vista ao apaziguamento da contenda então activa entre Dom Afonso IV, rei de Portugal e seu filho, e Dom Afonso XI, rei de Castela e marido da sua neta dilecta, Dona Maria. O corpo da rainha foi, no entanto, em obediência ao que deixara determinado em testamento, transportado para o referido mosteiro de clarissas, onde ficou sepultado na arca tumular que ela própria mandara executar.Terminada cerca de seis anos antes, em 1330, é a sua figura jacente que nos interessa particularmente analisar. ${ }^{22}$

O túmulo da Rainha Santa apresenta-se como um sarcófago exento, de pedra calcária de Ançã, composto de uma arca paralelepipédica (com 292,5 cm de comprimento X $130 \mathrm{~cm}$ de largura $X 100 \mathrm{~cm}$ de altura), decorada nos quatro faciais, assente sobre seis leões e com jacente sobre a tampa.

processou justamente no momento em que o papa apostava numa política de restrição e de reafirmação da autoridade do Papado na nomeação dos novos santos.

22 Actualmente, os despojos mortais da Rainha Santa acham-se contidos num cofre de prata, para onde foram trasladados por ordem testamentária de Dom Afonso de Castelo-Branco, bispo de Coimbra (1585-1615), colocado no altar principal da igreja do Mosteiro de Santa Clara-a-Nova, mandado edificar por Dom João IV. No coro-baixo da mesma igreja monástica está guardado o moimento medieval. 
Embora os interesses que nos orientam na presente reflexão se centrem, conforme referimos, na figura jacente da rainha, a participação activa das figurações dos faciais da arca na construção do sentido global da peça e na construção dessa memória que Dona Isabel deixa de si mesma, por um lado, e o papel que essas mesmas representações, nomeadamente o tipo de enquadramento micro-arquitectural que lhes é dado, desempenham no carácter inaugurador (no contexto da produção escultórica de Coimbra) que tem sido reconhecido a este monumento, por outro, obrigam-nos, pelo menos, a uma indicação breve das iconografias que se esculpem nos quatro lados da arca paralelepipédica que serviu, em tempos, para a colocação dos despojos mortais da Rainha Santa Isabel. ${ }^{23}$

São essas representações: o Apostolado, com Cristo ocupando a posição central, no facial maior da esquerda; o leão tetramorfo, Santa Clara, Santa Catarina, Santa Isabel da Hungria ${ }^{24}$ e o boi representativo de São Lucas, no facial dos pés; um frade franciscano (que Francisco Pato de Macedo identificou como sendo São Francisco ${ }^{25}$ ), um bispo (que o referido autor considerou tratar-se de São Luís de Tolosa) e onze freiras clarissas, a primeira das quais representando porventura a própria Santa Clara (que assim figura, no túmulo, em duplicado $)^{26}$, no facial da direita; o anjo de São Mateus, Cristo entronizado, o Calvário, a Virgem com o Menino e a águia do Tetramorfo, no facial da cabeceira.

Sobre a tampa, dispõe-se a figura jacente da Rainha Santa Isabel.

Deitada de costas, seguindo aquela que é a posição dominante entre os jacentes medievais portugueses, a rainha abdica da túnica e do manto com que as damas trecentistas portuguesas se fazem representar, para envergar o hábito de clarissa, identificado pelo cordão de vários nós (seis nós visíveis) que o cinge ao nível da cintura. O bordão de peregrina, colocado sob o braço direito, e a esmoleira pendente da cintura, do lado

${ }^{23}$ Não é por desinteresse, mas por estratégia, que optámos por deixar de parte a análise detalhada das iconografias da arca na economia do texto. Já anteriormente tratámos com maior detalhe estas representações, concretamente na Dissertação de Mestrado que dedicámos a A lconografia do Calvário na Escultura Tumular Medieval Portuguesa (séculos XIII a XV), orientada pelo Professor Doutor José Custódio Vieira da Silva e apresentada à Faculdade de Ciências Sociais e Humanas da Universidade Nova de Lisboa, a 21 de Setembro de 2007.

${ }^{24}$ A presença de Santa Isabel da Hungria entre as figuras de devoção da rainha encontra razão acrescida no facto de Isabel de Aragão ter recebido o nome em homenagem, precisamente, à referida santa, sua tia-avó - Isabel da Hungria, santificada por Gregório IX, em 1235, era, como já referimos, irmã de Violante da Hungria, segunda mulher do rei Dom Jaime I.

${ }^{25}$ Francisco Pato de Macedo é autor da mais recente bibliografia respeitante ao túmulo da Rainha Santa: A Capela Funerária da Rainha D. Isabel de Aragão. Santa Clara-a-Velha de Coimbra. Singular Mosteiro Mendicante. Dissertação de Doutoramento apresentada à Faculdade de Letras da Universidade de Coimbra (policopiada). Coimbra: 2006, pp.641-698.

${ }^{26}$ Note-se como é a única das onze cujos pés não são visíveis, encontrando-se totalmente cobertos pelas pregas da hábito, mais longo que o das restantes clarissas. 
oposto ${ }^{27}$, assim como o Livro de Horas (o tradicional atributo das damas portuguesas na tumulária desta época) que discretamente segura com a mão direita, completam o programa original e amplamente cristão que a figura jacente de Dona Isabel concretiza e que se revela, deste modo, verdadeiramente ostentador da sua profunda ligação com o ramo feminino da ordem franciscana (ligação que aparece reforçada por várias das figurações da arca) e, mais ainda, da sua actuação irrepreensível como boa cristã.

No geral da sua composição, o jacente de Dona Isabel afirma, assim, a sua originalidade sobretudo pelo modo individual com que realiza a conjugação de caracteres iconográficos amplamente representativos de uma relação particular com o sagrado, mais que pelo (inexistente) absoluto ineditismo dos elementos que o compõem.

De facto, se a presença dos anjos, deitados sobre a tampa, que incensam a rainha e estabelecem a relação com o sagrado através do seu olhar para o alto, serve inquestionavelmente de elemento de reforço do carácter de santidade que todo o jacente respira, assim como a protecção do baldaquino que, apesar de tudo, encerra em si mesma um certo sentido de sacralização, a verdade é que uns e outro se encontram noutras representações da tumulária medieval portuguesa, adstritas inclusivamente a condições sociais aparentemente mais baixas e, sobretudo, a figuras jacentes sem esta ligação ao divino e concretizadoras de uma representação que é indissociável da realidade mundana. ${ }^{28}$ Desta, não se alheia também completamente a figura representativa de Dona Isabel de Aragão - cuja coroa e sapatos (que lhe cobrem os pés, enquanto as clarissas os ostentam descalços), ao relacionarem-se com os quatro pequenos cães, acompanhantes usuais das damas na tumulária do século XIV em Portugal, e com os vários escudos que se distribuem por sobre a tampa (num total de oito e representando alternadamente Portugal, Aragão e a Casa imperial de que descende, por via materna, Dona Isabel), concretizam a dimensão social deste túmulo, demonstrando que a rainha não esquece nem abdica da sua relação com o mundo dos homens (e da afirmação do lugar destacado que nele também ocupa).

${ }^{27}$ Esta representação da esmoleira como atributo na figuração de jacentes não é, como muito bem notou António Nogueira Gonçalves, exclusiva da Rainha Santa Isabel, embora seja, ainda assim, um elemento raro no contexto da tumulária medieval portuguesa (A Arte Medieval em Coimbra, séc. X-séc. XV, Estudos de História da Arte Medieval. Coimbra: Epartur, 1980, p. 761). Assim, apenas noutros dois jacentes (para o que se refere à tumulária anterior ou contemporânea do túmulo da Rainha Santa) podemos observar a sua representação, nomeadamente no da rainha Dona Beatriz (Panteão Régio de Alcobaça) e no de uma dama anónima, com túmulo num arcossólio do claustro da Sé de Lisboa.

${ }^{28}$ Particularmente representativo desta realidade é o jacente de dama desconhecida da Sé de Lisboa de que falámos na nota anterior e que reúne esses mesmos dois elementos fundamentais de sacralização do jacente, o baldaquino e os anjos. 
A completar a composição, vemos que a rainha repousa a cabeça, coberta por um véu soqueixado, sobre duas almofadas com borlas e assenta o corpo sobre uma pedra listada que sugere (até pelas borlas que se preservam no limite da arca junto aos pés do jacente) uma composição têxtil ${ }^{29}$ (no que este jacente se revela particularmente original), cujo desenho listado não deixa de remeter, ainda que vagamente, para a heráldica aragonesa.

De resto, as armas de Aragão, curiosamente presentes neste túmulo em número superior ao do próprio brasão de Portugal ${ }^{30}$, voltam a encontrar-se no reverso do baldaquino, ladeando uma das iconografias mais interessantes do contexto cristão medieval e que corresponde à representação do transporte, por um anjo, da alma da personagem inumada, sob a forma de uma criança, num lençol, em direcção aos céus. ${ }^{31}$ Com esta figuração continua a reforçar-se a ideia de cumprimento de uma vida santa, objectivo fundamental da Rainha Santa Isabel, com o qual se identifica e que é o garante de uma excepcionalidade que a rainha, por todos os meios, pretende afirmar.

Talvez possamos mesmo falar, tendo em conta as iconografias que preenchem os faciais da arca e o modo como a figura que a encima se apresenta, de uma quase obsessão com a invocação do sagrado. ${ }^{32}$ Essa invocação concretiza-se, nomeadamente, como vimos, na identificação do jacente (e, consequentemente, da inumada) com as práticas maiores da boa conduta cristã - através do bordão, alusivo às duas viagens de peregrinação a Compostela empreendidas pela rainha depois da morte do marido; da esmoleira, representativa da sua reconhecida caridade; do hábito franciscano, sinal da sua capacidade de despojamento e de uma ligação importante que acabou por estabelecer com a ordem das clarissas (e, particularmente, com o Mosteiro de Santa Clara-a-Velha de Coimbra). Essa

${ }^{29}$ Francisco de Simas Alves de Azevedo foi o primeiro a propor que a rainha se encontra deitada sobre uma colcha decorada com a sua heráldica: Alguns Monumentos Heráldicos de Santa Isabel de Aragão, Rainha de Portugal. Hidalguia - La Revista de Genealogia, Nobleza y Armas. Num. 76. Madrid: Insituto Salazar y Castro (C.S.I.C.), 1966, pp. 399-401.

30 São também as armas de Aragão que coroam, de ambos os lados, a representação do Calvário, no facial da cabeceira.

${ }^{31}$ Vergílio Correia aponta esta representação simbólica do transporte da alma como uma invenção da escultura tumular francesa do século XIII. Francisco Pato de Macedo, seguindo o estudo de Clementina-Julia Ara Gil (Escultura Gótica en Valladolid e su Província. Valladolid: 1977), sublinha que esta é uma iconografia frequente na tumulária gótica peninsular do século XIV, embora predomine a representação da alma a ser transportada por dois anjos e não apenas por um, como aparece no túmulo de Dona Isabel de Aragão: A Capela Funerária da Rainha D. Isabel de Aragão. Ob. cit., p. 649.

${ }^{32}$ Francisco Pato de Macedo encara este túmulo da Rainha Santa como testemunho privilegiado de uma mudança verificada no entendimento cristão do processo da morte, pautada pela conceptualização da ideia de purgatório (A Capela Funerária da Rainha D. Isabel de Aragão. Ob. cit., pp. 650-652). Daí a importância acrescida das orações de intercessão pela alma - preocupação que a rainha plasma nas escolhas iconográficas que faz para a sua arca. 
invocação do sagrado completa-se com o preenchimento de todas as edículas, definidas por microarquitecturas que ocupam as quatro faces da arca, com um tal rol de figuras santas e evangélicas que a própria representação do Calvário, que geralmente goza da totalidade do espaço de um dos faciais menores, se torna quase simplesmente, do ponto de vista visual, mais uma referência, entre outras, integrando um verdadeiro manancial da iconografia cristológica: Cristo Menino, Cristo Juiz, Cristo Crucificado, Cristo entre os Apóstolos... ${ }^{33}$

É, de resto, sobretudo ao nível de algumas destas representações, nomeadamente das do Apostolado e do Calvário, que se manifesta uma proximidade formal inegável (e já repetidas vezes sublinhada) com o trabalho da arca tumular de Dom Gonçalo Pereira, arcebispo de Braga, situada na Capela da Glória, da Sé de Braga. ${ }^{34}$ Deste túmulo ficou-nos o documento de registo oficial da encomenda, celebrada em Lisboa, a 11 de Junho de 1334, com os dois mestres das imagens, mestre Pêro, morador em Coimbra, e mestre Telo Garcia, cidadão de Lisboa, facto que tem permitido aos estudiosos, com base na referida aproximação, apontar uma provável autoria de mestre Pêro para o túmulo da Rainha Santa Isabel. Mestre Pêro será, segundo Pedro Dias, de proveniência aragonesa ${ }^{35}$, o que concorda em absoluto com aquela que parece ser a origem do tipo de enquadramento edicular das figuras que encontramos nos faciais do túmulo de Dona Isabel de Aragão. Se o princípio em si mesmo da organização da decoração dos faciais em arcadas não parece ser novidade do túmulo da Rainha Santa, pois existem composições deste género na tumulária portuguesa, que, em princípio, serão anteriores à feitura da arca da rainha ${ }^{36}$, a verdade é que o modelo muito concreto que vemos na arca de Dona Isabel de Aragão, nomeadamente o tipo de contrafortes terminados em coruchéus cogulhados a separar as edículas e o coroamento da cena do Calvário com a duplicação da heráldica (neste caso, de Aragão), é, inquestionavelmente, um modelo aragonês, diverso, apesar de tudo, desses túmulos precedentes.

${ }^{33}$ Nesta enumeração exaustiva de figuras santas e, portanto, de todas as figuras que eram objecto da devoção da rainha, a arca de Dona Isabel de Aragão talvez apenas encontre paralelo no túmulo de Fernão Gomes de Góis (Oliveira do Conde, Igreja de São Pedro), já do século XV.

${ }^{34}$ Parece-nos, de resto, muito mais coerente reconhecer e procurar esta ligação do que propriamente com o túmulo da Infanta Isabel (Mosteiro de Santa Clara-a-Nova, Coimbra), neta da Rainha Santa, que o encomendou.

${ }^{35}$ Pedro Dias - A pedra de Ançã, a escultura de Coimbra e a sua difusão na Galiza. Do Tardo-Gótico ao Maneirismo. Galiza e Portugal. Fundação Pedro Barrié de la Maza/Fundação Calouste Gulbenkian: 1995, pp. 11-12.

${ }^{36}$ Referimo-nos ao túmulo com jacente da rainha Dona Beatriz, falecida em 1304 (sito no Panteão Régio de Alcobaça), bem como à arca tumular de Dona Leonor Afonso, de cerca de 1325 (localizada na Igreja de Santa Clara de Santarém). 
A confirmar esta ligação a um modelo estético de Aragão, observamos que, como foi anteriormente notado por Pedro Dias, são inegáveis as proximidades com o jacente de Branca de Anjou, "obra de um outro mestre pêro que trabalhava igualmente nos reinos da coroa de Aragão"."37

Esta é, no entanto, matéria de uma outra e mais densa avaliação do túmulo que aqui não tem lugar e que só a continuidade dos estudos que nos encontramos a realizar nos permitirá aprofundar.

Recuperando algumas ideias expressas no início da nossa reflexão e procurando extrair algumas conclusões sobre esta representação que a Rainha Santa Isabel encomenda de si mesma, teremos de reconhecer o modo como quis e pôde, como dizíamos no encetar do nosso discurso, consagrar uma imagem da sua existência que tendeu a prolongar-se no tempo e que é a expressão visível de um ideal muito concreto.

Esse ideal é, naturalmente, o ideal de vida cristã activo no Portugal trecentista, que parece traduzir-se, assim, de forma privilegiada nas práticas da peregrinação e da caridade, às quais a rainha é repetidas vezes associada no discurso que a modernidade tendeu a desenvolver sobre ela - e que constituem afinal duas das práticas consagradas pela Igreja cristã medieval, duas facetas de uma mesma atenção dada às obras, cuja fortuna no contexto medievo nasce, em larga medida (e para além do prolongamento eventual de certos comportamentos pagãos), de uma necessidade, que vive no interior de cada cristão, de superar essa condição de pecador a que, à partida, se encontra sujeito. Talvez possamos mesmo falar de uma certa ideia de culpa que parece manifestar-se de modo permanente no seio da Cristandade, de uma tendência para o entendimento da existência cristã como uma luta constante do homem contra o Mal, luta que começa no interior de si mesmo e para a qual os leigos se encontram particularmente inaptos. A peregrinação e a esmola, assim como o jejum, aparecem, no fundo, como formas de superação do que durante muito tempo foi entendido como uma incompatibilidade natural do estado laico com a vida santa - e não deixa de ser significativo que essas mesmas formas sejam, simultaneamente, ainda vias de aproximação ao ideal de vida monástico, fora do qual continuará a ser, até ao final da Idade Média, difícil de conceber uma existência de santidade.

A obsessão da salvação e o desejo de imitar Cristo, que formam, segundo André Vauchez, as duas facetas de uma tendência para o ascetismo que marca a espiritualidade popular no decurso de toda a Idade Média ${ }^{38}$, constituem, sem dúvida, as duas orientações fundamentais a ter em conta na compreensão global deste túmulo de Dona Isabel de Aragão.

\footnotetext{
37 Pedro Dias - O Gótico. História da Arte em Portugal. Vol. 4. Lisboa: Publicações Alfa, pp. 119-120.

38 André Vauchez - A espiritualidade da Idade Média Ocidental. Sécs. VIII-XIII. Lisboa: Editorial Estampa, 1995, p. 61.
} 
Aqui, a obsessão da salvação concretiza-se, na arca, através da enumeração exaustiva de figuras capazes de interceder pela alma da rainha e, no jacente, com o leve rejúbilo de uma quase certeza, que nasce, precisamente, dessa capacidade revelada de imitar Cristo, que é por agora uma imitação da conduta em si corporizada e desembocará, no final agitado da Idade Média, numa predisposição para a identificação com os seus sofrimentos. De facto, Jesus Cristo continua a aparecer, de forma indirecta, como fonte de exemplos e modelo de um ideal de vida que é, antes de mais, apostólico, e não como objecto de qualquer enternecimento piedoso ou de qualquer reflexão sobre dor e humanidade, como o estava já a ser, neste momento, nalguns pontos do mundo cristão ocidental.

Neste sentido, parece-nos que a proposta deste jacente da rainha que se faz representar como santa (no sentido em que concorda com o ideal de vida santa então proposto) vem consolidar o que entendemos ser uma das conclusões passíveis de se estruturarem a partir do olhar sobre os túmulos portugueses medievais e que corresponde à constatação da ligação profunda que a piedade portuguesa do século XIV mantém com uma espiritualidade que André Vauchez atribui ao período que se situa entre o final do século $\mathrm{XI}$ e o início do século XIII ${ }^{39}$. Com efeito, de uma forma global, as escolhas iconográficas destas arcas manifestam a consciência profunda e generalizada da importância da Encarnação no processo de redenção da humanidade (e dos homens, individualmente) - o que dá novo sentido à presença nelas de iconografias como a do Calvário - e dos ensinamentos do Novo Testamento na preparação de um estado de graça post-mortem.

Neste contexto, não só as figuras de Jesus Cristo e da Virgem continuam a assumir, no monumento tumular de Dona Isabel de Aragão, um lugar destacado como intermediários privilegiados na comunicação com o sagrado (embora numa importância claramente diluída pela presença, no mesmo espaço tumular, de uma série de outras figuras santas), como a própria rainha, através do seu jacente, se faz afirmar como modelo desse modo de vida proposto nos Evangelhos, que associa, sem preconceitos, a uma declaração também fortíssima do seu estatuto laical superior.

O jacente de Dona Isabel de Aragão, objecto central desta reflexão, assume assim uma importância destacada, sob diversos pontos de vista: sob o ponto de vista das mentalidades, tanto globais (de que dá um testemunho exemplar) como individual (porque, nas originalidades que concretiza, é também manifestação de uma personalidade e de uma vontade próprias); e no quadro da escultura tumular medieval portuguesa, onde a importância deste túmulo se manifesta, quer no contexto geral da produção trecentista, na qual actua como peça maior da estética adstrita ao núcleo de Coimbra (genericamente iden-

39 Idem, ibidem, pp. 75-139. 
tificada com Mestre Pêro), entendendo-se a sua arca como inauguradora de um tipo de decoração que terá reflexos em composições não só coimbrãs (como vimos), quer no seio mais restrito da tumulária régia feminina, onde participa com o protagonismo natural de corresponder a um dos apenas três testemunhos de jacentes de rainhas sobreviventes para todo o século XIV português - Dona Beatriz (†1304, a crer que o jacente que se encontra no Panteão Régio de Alcobaça corresponde à mulher de Dom Afonso III), Dona Isabel de Aragão (de cerca de 1330) e Dona Inês de Castro (de cerca de 1360, com o carácter excepcional de se tratar de uma rainha póstuma). ${ }^{40}$

A rainha que se fez santa revela-se, assim, neste lugar último que preparou para si, porventura como em nenhum outro documento, sem inibições, sem humildades radicais e sem esse sentido de absoluto despojamento com que a modernidade muitas vezes procurou pintar o seu retrato. Parece-nos ser, pelo contrário, a consciência profunda da sua excepcionalidade social que aqui se revela e que serve também como via da ligação particular que pretende afirmar com o sagrado. A própria opção por um sepultamento isolado, no sentido em que, contrariando a prática mais comum, preferiu ficar separada do marido, Dom Dinis, sepultado em Odivelas, é talvez reveladora (para além de eventuais incompatibilidades entre os esposos) desse mesmo carácter afirmativo que a rainha parece manifestar em certas ocasiões, e de uma assunção de si mesma como agente de um poder próprio e individual.

${ }^{40} \mathrm{E}$ mesmo para o século XV dispomos apenas, no que se refere às rainhas, dos jacentes de Dona Filipa de Lencastre, mulher de Dom João I, e de Dona Leonor de Aragão, esposa de Dom Duarte. Relativamente a estes dois jacentes, remetemos para um artigo escrito em conjunto com José Custódio Vieira da Silva: O retrato de D. João I - um novo paradigma de representação - Revista de História da Arte, Instituto de História da Arte - Faculdade de Ciências Sociais e Humanas da Universidade Nova de Lisboa, n. 5 (no prelo). 

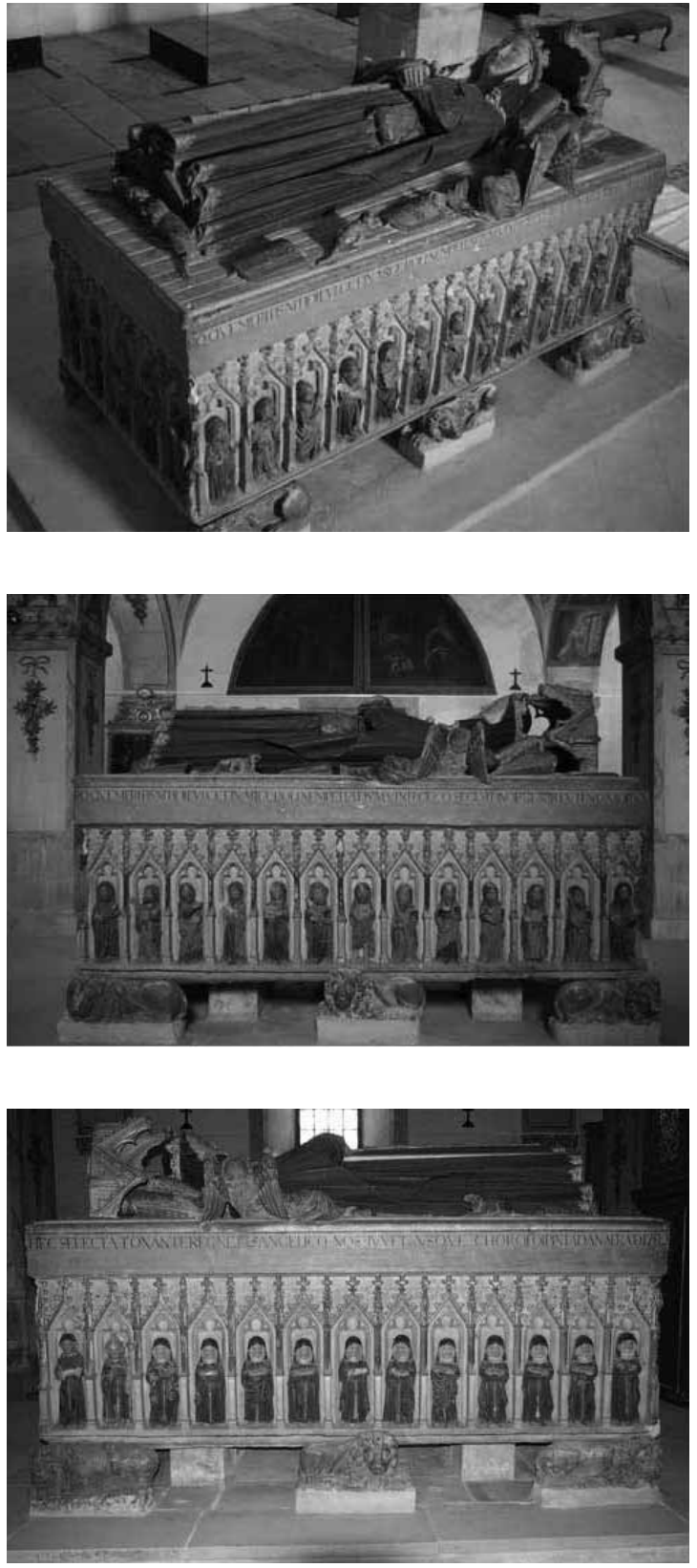

1. Túmulo com jacente de Dona Isabel de Aragão, a Rainha Santa - Vista geral. Foto: José Custódio Vieira da Silva.

Copyright:Projecto Imago

2. Túmulo com jacente de Dona Isabel de Aragão, a Rainha Santa - Facial da esquerda. Foto: José Custódio Vieira da Silva. Copyright: Projecto Imago

3. Túmulo com jacente de Dona Isabel de Aragão, a Rainha Santa - Facial da direita. Foto: José Custódio Vieira da Silva. Copyright: Projecto Imago 
4. Túmulo com jacente de Dona Isabel de Aragão, a Rainha Santa - Facial da cabeceira. Foto: José Custódio Vieira da Silva. Copyright: Projecto Imago

5. Túmulo com jacente de Dona Isabel de Aragão, a Rainha Santa - Facial dos pés. Foto: José Custódio Vieira da Silva. Copyright: Projecto Imago

6. Túmulo com jacente de Dona Isabel de Aragão, a Rainha Santa - Jacente. Foto: José Custódio Vieira da Silva. Copyright: Projecto Imago
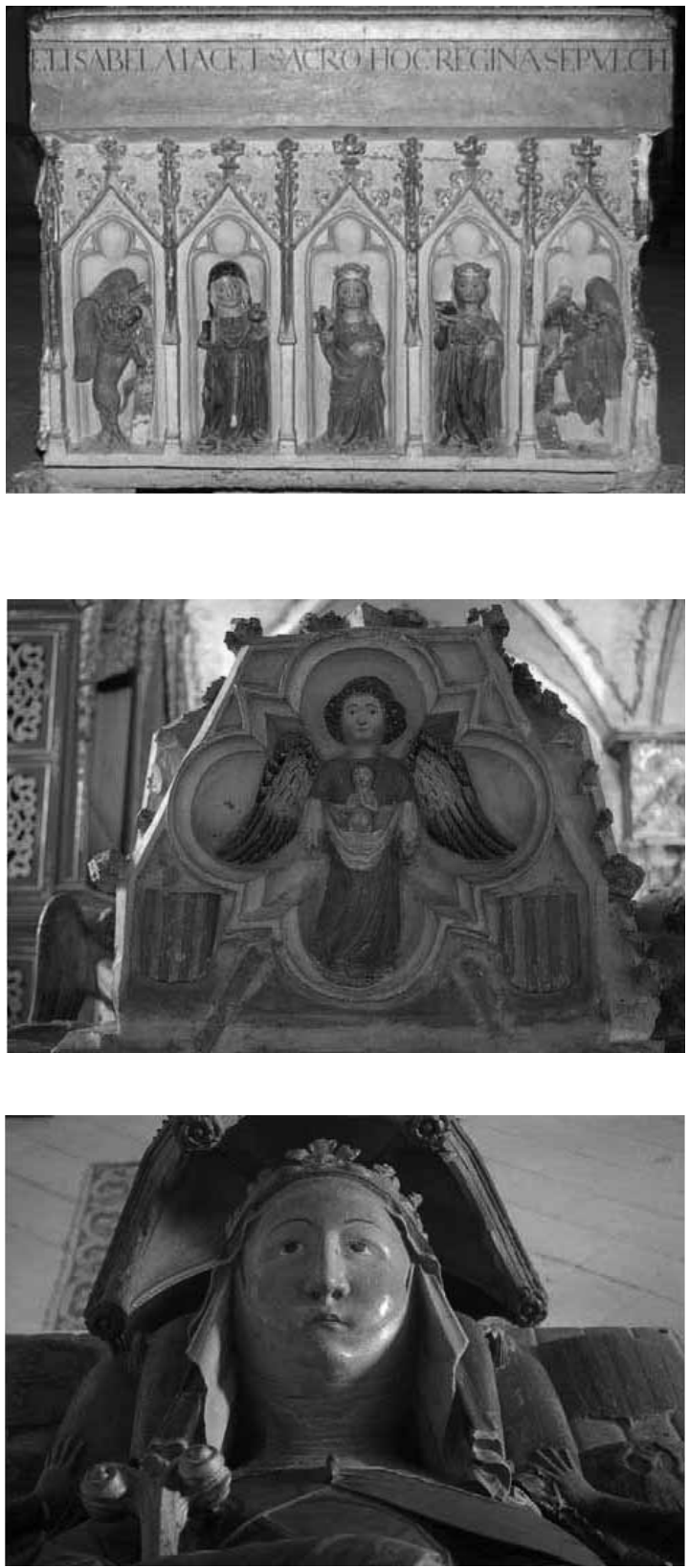


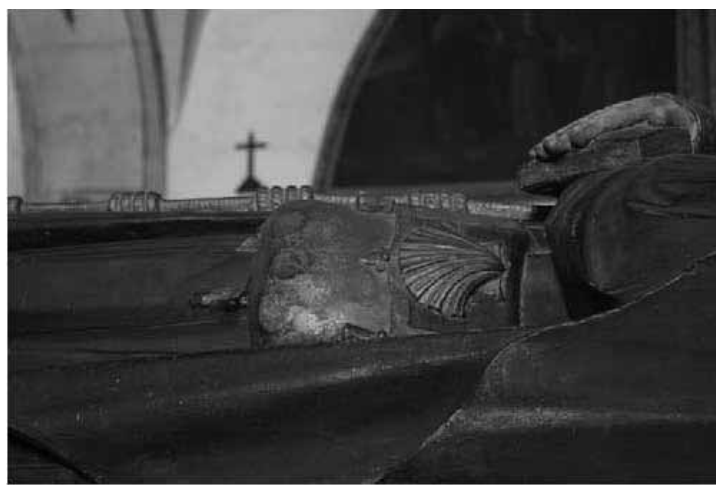

7. Túmulo com jacente de Dona Isabel de Aragão, a Rainha Santa - Jacente. Foto: José Custódio Vieira da Silva. Copyright: Projecto Imago

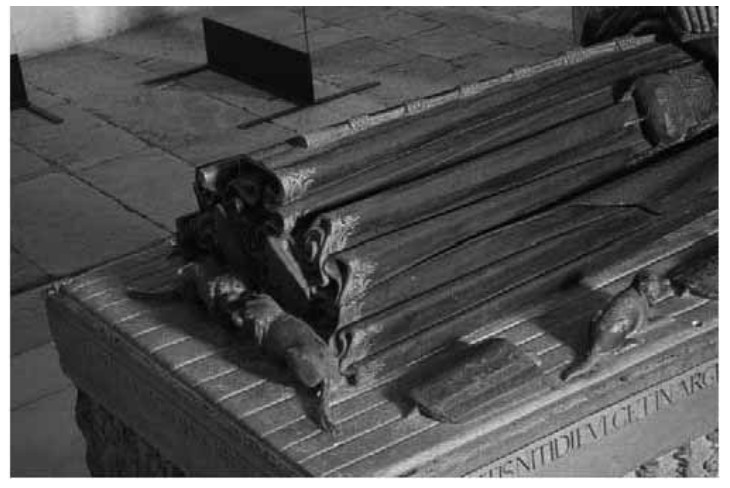

8. Túmulo com jacente de Dona Isabel de Aragão, a Rainha Santa - Jacente. Foto: José Custódio Vieira da Silva. Copyright: Projecto Imago 
9. Túmulo com jacente de Dona Isabel de Aragão, a Rainha Santa - Reverso do baldaquino. Foto: José Custódio Vieira da Silva. Copyright: Projecto Imago

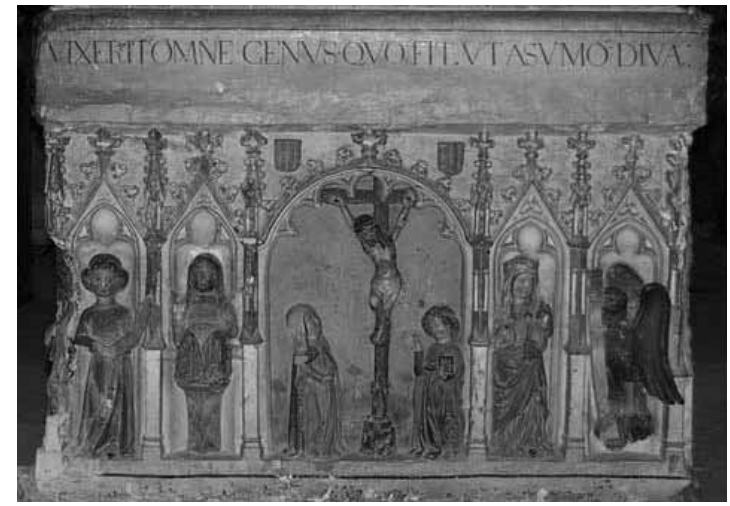

10. Túmulo com jacente de Dona Isabel de Aragão, a Rainha Santa - Jacente. Foto: José Custódio Vieira da Silva.

Copyright: Projecto Imago

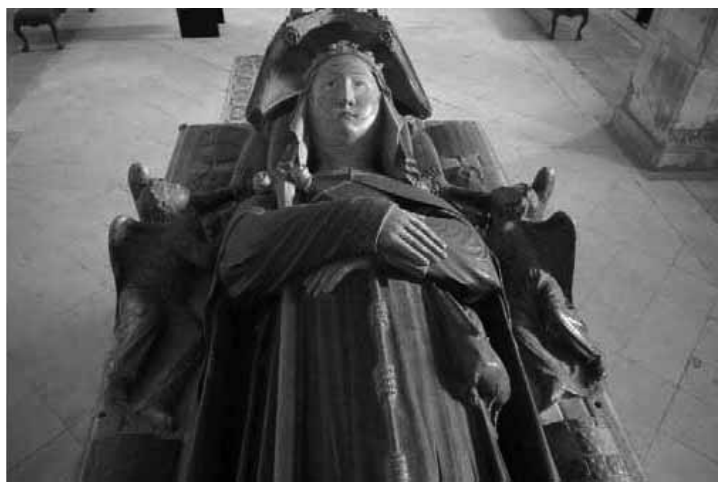





\title{
A representação gravada da Rainha Santa Isabel: política e devoção
}

\author{
António Filipe Pimentel*
}

A representação gravada da Rainha de Portugal D. Isabel de Aragão - a Rainha Santa não pode dissociar-se do processo político-devocional que rodeia, não somente a memória mas, muito particularmente, a divulgação e formalização do culto da insigne soberana. Com efeito, se as origens deste parecem coincidir com a sua própria morte, ocorrida já em halo de santidade, a propagação da sua imagem, nos diversos suportes mas, particularmente, com recurso à gravura, beneficiando do desenvolvimento das artes gráficas a que se assiste no século XVI (e do poder que revestem na comunicação de ideias e formas, numa sociedade onde a sua circulação era ainda necessariamente limitada), não poderá correctamente entender-se à margem do correlativo esforço (também simbólico e afectivo) desenvolvido pela Monarquia na obtenção de uma centralidade que se revelava indispensável à construção do Estado Moderno em paralelo empreendida.

Efectivamente, a produção da iconografia isabelina, se tem no mosteiro coimbrão de Santa Clara - fundação directa da Rainha e guardião dos seus despojos, rapidamente convertidos em relíquias - e nos círculos a ele afectos um dos seus inquestionáveis pólos de dinamização, cedo conheceria o apoio da hierarquia eclesiástica, por detrás do qual se perfila a própria Coroa, cientes ambas do seu papel mobilizador da devoção e do precioso elemento de pressão que daí resultaria em relação ao respectivo processo de canonização. ${ }^{1} \mathrm{E}$ nele, com efeito, se empenharia tenazmente D. Manuel I, como parte não despicienda do processo de centralização política e construção simbólica de um império em expansão, onde cabia à Coroa (a coroa que fora de Dinis e Isabel) um papel indeclinável de mobilização e aglutinação da comunidade nacional: o qual encontraria nos meios imagéticos e no discurso mitográfico adrede elaborado (também religioso) um dos instrumentos mais eficazes da sua afirmação. ${ }^{2}$

* Faculdade de Letras/Universidade de Coimbra.

1 Cf. PIMENTEL, António Filipe, "Propaganda Fidei. A representação gravada da Rainha Santa Isabel", CALVO RUATA, José Ignacio (coord.), Imagen de la Reina Santa. Santa Isabel, Infanta de Aragón y Reina de Portugal, Cat., Zaragoza, Diputación de Zaragoza, 1999, vol. I, pp. 65-66.

2 Cf. idem, "À Flandres por devoção e à Itália por ostentação - ou ao invés. As razões do Manuelino", Actas do Congresso Internacional Ao Modo da Flandres... Disponibilidade, inovação e mercado de arte na época dos Descobrimentos (1415-1580), Madrid, Fundación Carlos de Amberes, 2005, pp. 159-168. 
O breve de Leão X de 1516, que beatificaria a soberana sancionando o culto público já praticado na cidade de Coimbra, constituiria, assim, um ponto de chegada, rumo à ambicionada canonização, numa rota prosseguida, sem desfalecimentos, pelos sucessores do Venturoso - D. João III, D. Sebastião, D. Filipe I e D. Filipe II (nos quais acrescia a dupla qualidade de Reis de Portugal e de Aragão) - e que culminaria com a respectiva bula, emitida por Urbano VIII em 25 de Maio de $1625 .{ }^{3}$ E é neste contexto, com efeito, que se inscrevem as mais remotas figurações isabelinas conservadas, nimbadas já de uma aura explicitamente mística: desde logo o quadro da Gemäldegalerie de Berlim, aspirante a vera efígie e atribuível a um discípulo de Quentin Metsys (esse, na contemplação de cujas obras se comprazia - e comovia - Damião de Góis ${ }^{4}$ ) e a que evoca a peregrinação a Santiago, inscrita no manuscrito Genealogia dos Reis de Portugal (na British Library), iluminado entre 1530 e 1534 por Simão Bening, sobre desenhos de António de Holanda, por encomenda do Infante D. Fernando, filho de D. Manuel I. Poucos anos posterior (de meados do século) seria o pequeno retábulo ou ex-voto conservado em Coimbra, no Museu Machado de Castro e que parece relacionar-se com encomenda pessoal de Martim de Azpilcueta, o doutor navarro ${ }^{5}$, ilustre canonista contratado por D. João III no âmbito da transferência da Universidade: o que atestará o empenhamento directo dos meios intelectuais neste processo.

A esta altura, porém, correriam já impressas as primeiras representações gravadas da insigne soberana, iniciando um tipo novo de figuração, que, difundida sob a forma de ilustração de livros, integrando séries icónicas de crescente voga, enquanto mera estampa devocional ou na forma, mais ou menos popular, dos registos piedosos, adquiridos por ocasião das romarias, conheceria uma popularidade crescente, no decurso dos séculos XVII e XVIII e que não esmoreceria completamente nos séculos XIX e XX. Umas vezes em criação original, outras compondo autênticas genealogias iconográficas; as mais delas mil vezes repetidas por mãos progressivamente menos hábeis constituem um espólio relevante no estudo da devoção isabelina, de que marcam o ritmo e difusão.

De facto, sem reproduzirem, obviamente (mesmo quando a tal ingenuamente aspiram), o escopo físico ou sequer fisionómico da régia taumaturga, buscam recriar-lhe o perfil moral, compondo um arquétipo que se enraizará na memória colectiva, propagando uma fé viva na sua poderosa intercessão, alicerçada numa imagem que oscila entre a sedução

3 Sobre o culto e o processo canónico da Rainha, veja-se VASCONCELOS, António de, Evolução do culto de Dona Isabel de Aragão, esposa do rei lavrador Dom Dinis de Portugal (a Rainha Santa), Coimbra, Arquivo da Universidade, vol. I, ${ }^{2} 1993$, pp. $268-452$.

4 Cf.MARKL, Dagoberto e PEREIRA, Fernando António Baptista, História da Arte em Portugal, vol. 6, O Renascimento, Lisboa, Alfa, 1986, (nota 25) p. 94.

5 Cf. RINCÓN GARCIA, Wifredo, ROMERO SANTAMARIA, Alfredo, "Iconografia de Santa Isabel en el arte español y português", Imagen de la Reina Santa..., vol. I, pp. 48-49 e 58-49. 
pelo esplendor da realeza nimbada da compaixão pelo sofrimento e miséria dos humildes e a lição edificante da soberana que se despoja dos sinais terrenos, amortalhada no hábito de clarissa ou nos signos humildes de peregrina: a qual, estabilizada a partir da iconografia de sua própria tia, Isabel da Hungria, Duquesa da Turíngia ${ }^{6}$, valorizaria essencialmente, a par das ideias gerais de renúncia, humildade e paz (tessitura central da sua hagiografia), a caridade como tema central: ilustrada no motivo recorrente do óbulo ao mendigo, na cura da criança cega, na assistência aos enfermos e, muito particularmente, no milagre das rosas, o episódio que, mais do que qualquer outro, Ihe ficaria para sempre associado.

E seria justamente Coimbra, depositária do corpo milagroso da soberana, fonte contínua dos prodígios que alimentavam o seu culto ${ }^{7}$, a produzir, a partir dos prelos de João de Barreira, o documento icónico inicial:

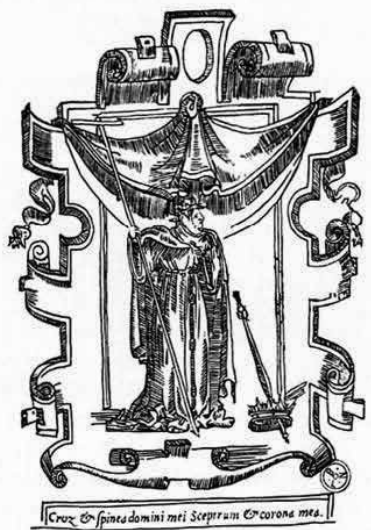

Vida \& milagres da gloriofa Raynha fancta Y fabei,molher do catholico Rey dó Dinis fexto de Portugal.Com ho compromiffo dacófraria do feu nome, \& graças a ella concedidas. M. D. L X.

1. ALFONSO, Diogo, Vida \& milagres da gloriosa Raynha santa Ysabel..., Coimbra, João de Barreira, 1560 (xilogravura). a gravura em madeira epigrafada cruz \& spinea domini mei secptrum \& corona mea, que ilustra o frontespício da obra, hoje raríssima, Vida \& milagres da gloriosa Raynha Sancta Ysabel, que incluía ainda ho compromisso da côfraria do seu nome, dada à estampa em 1560 (quatro anos depois de D. João III ter obtido a extensão do seu culto ao território nacional), por mandado dos mordomos e confrades da confraria da gloriosa Sancta Ysabel Raynha de Portugal e a instâncias da abadessa e sacristãs do cenóbio régio de Santa Clara. ${ }^{8}$ Nela, a imagem da Rainha, enquadrada por uma bela e floreada cartela maneirista, de que se desprende um amplo panejamento que the serve de dossel, avulta de corpo inteiro, trajada de clarissa, a fronte cingida da coroa de espinhos (referencial cristológico franciscano, estranho na sua usual iconografia), ostentando na mão um enorme tau de peregrina e, aos pés, o diadema régio atravessado pelo ceptro. ${ }^{9}$

6 Cf. SOARES, Ernesto, Dicionário de Iconografia Portuguesa (retratos de portugueses e de estrangeiros em relações com Portugal), suplemento A-Z, Lisboa, Instituto para a Alta Cultura, 1954, p. 179 e ROIG, Juan Fernando, Iconografia de los Santos,Barcelona, Ediciones Ómega, S.A., 1950, p. 142.

7 Cf.VASCONCELOS, A. de, ob. cit., vol. I, pp. 258ss.

8 Cf. SILVA, Armando Carneiro da, Retratos gravados de Santa Isabel, Coimbra, 1964, pp. 13-14 e SOARES, Ernesto e LIMA, Henrique de Campos Ferreira, Dicionário de Iconografia Portuguesa, Lisboa, Instituto para a Alta Cultura, 1948, vol. II, p. 155.

9 Cf. PIMENTEL, António Filipe, “Estampa da Rainha Santa Isabel "Cuz \& spinea domini meis Sceptrum \& corona mea", Imagen de la Reina Santa..., vol. I, p. 167. 


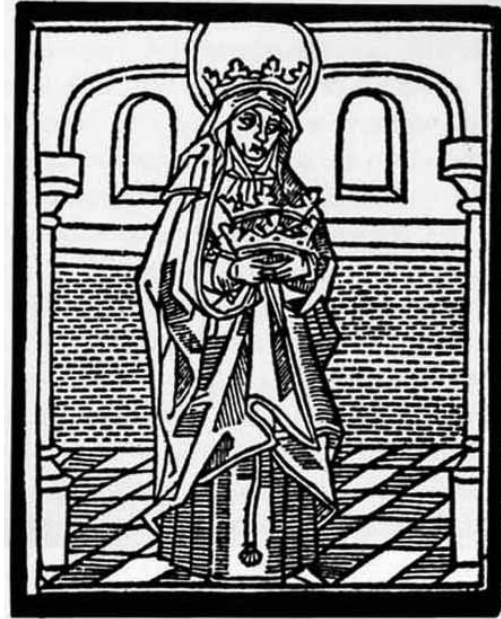

2. ROSÁRIO, Frei Diogo do, Histórias das vidas \& feitos heróicos \& vidas insignes dos sanctos, Braga, António de Mariz, 1567 (xilogravura).

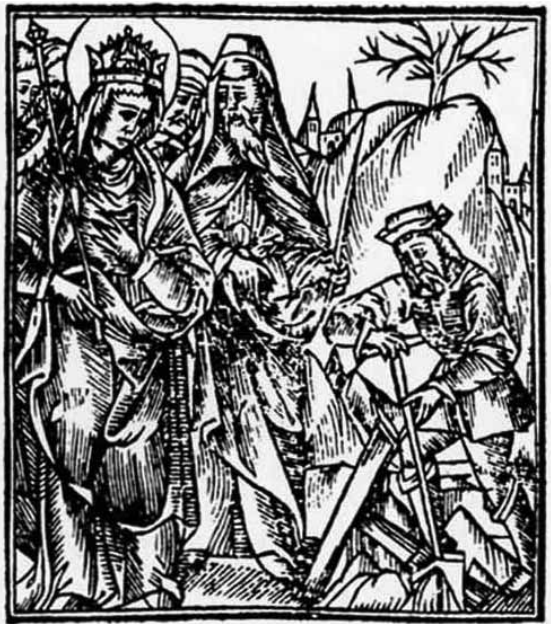

3. Flos Sanctorum das vidas e obras insignes dos sanctos, Lisboa, Baltazar Ribeiro, 1590 (xilogravura).

Dezassete anos mais tarde, em 1567, outra gravura isabelina, também em madeira, ilustraria a obra do dominicano Frei Diogo do Rosário, Histórias das vidas \& feitos heroi$\cos \&$ vidas insignes dos sanctos, impressa em Braga por António de Mariz, por ordem do arcebispo D. Frei Bartolomeu dos Mártires, no contexto da revitalização pós-tridentina da devoção aos santos (reeditada em Coimbra, pelo mesmo impressor, em 1577 e toscamente reproduzida, também em Coimbra, na edição de João Álvares do Officium Sanctae Elisabeth Portugalliae Quodam Reginae, de 1569)..$^{10}$ Nelas se figura a soberana de pé, em corpo inteiro, trajada com o hábito de clarissa, coroada e aureolada, sustendo nas mãos as coroas régias de Portugal e Aragão, alusivas à sua estirpe, motivo que emerge com alguma frequência nas suas mais antigas representações. O cenário, evocativo de um recinto claustral do gótico tardio, representa uma dependência de pavimento axadrezado (casa de capítulo?), iluminada por duas janelas em arco de meio ponto e cuja entrada se enquadra por um arco rebaixado assente em colunas de capitel liso, emoldurando a figura da Rainha, em clara (e abusiva, aliás) alusão à sua qualidade histórica de monja.

Obviamente relacionável - tanto pela paginação, como pelo uso deficiente da perspectiva - com as gravuras que ornamentam a edição de 1514 das Ordenações Manuelinas, mais de

${ }^{10}$ Cf. SILVA, A. C. da, ob. cit., pp. 41-44 e SOARES, E. e LIMA, H. C. F., ob. cit., vol. 2, p. 155. 
meio século anteriores, teria interesse, para o esclarecimento da problemática do seu desfasamento estético (mais evidente se cotejado com a cruz \& spinea, de 1560), o conhecimento, a par da sua fortuna, de uma eventual trajectória anterior. São, todavia, discretas vinhetas, sem o valor ornamental da gravura anterior (que adornaria, de resto, a primeira obra impressa dedicada à vida e milagres da santa Rainha), destinadas a ilustrar as suas biografias em hagiológios que, fortalecidos da beatificação outorgada em 1516 e da contínua extensão do culto alcançada pela pressão diplomática portuguesa na Cúria pontifícia, claramente se organizavam no sentido de propiciar o ambiente e o aparato critico necessários à ambicionada canonização. ${ }^{11}$

E nova xilogravura adornaria ainda o capítulo isabelino do Flos sanctorum das vidas e obras insignes dos santos, dado à estampa em Lisboa, em 1590, por Baltazar Ribeiro, obra polémica, por muitos considerada a terceira edição das Histórias de Fr. Diogo do Rosário, mas que constitui, seguramente, a mais interessante imagem da primeira geração das representações gravadas da Rainha Santa. Figurada desta vez num arrabalde de cidade, esquematicamente sugerido, em segundo plano, pelo céu aberto e por uma colina arborizada salpicada de altos edifícios, a soberana, nimbada e com coroa real e ceptro sobre o hábito monástico, assiste, rodeada pela sua comitiva, à construção das fundações do hospício junto aos seus paços de Santa Clara, anexos ao convento do mesmo nome, frente a Coimbra. A composição alude à lenda que relata como a soberana, certo dia, encontrou desenhada no solo a planta do hospital que projectava construir e parcialmente abertos já os respectivos alicerces, relacionando-se igualmente com outro relato, segundo o qual Santa Isabel teria pago com uma rosa a cada trabalhador, rosas que, de noite, se converteriam em moedas de ouro: reportando-se ambos os episódios, porventura, a essa outra tradição, que recolhe Frei Manuel da Esperança, segundo a qual ela mesma ideava as traças dos edifícios e desenhava depois as plantas, tão ajustadas às regras da boa arquitectura, que os mestres mais peritos se podiam governar por elas. ${ }^{12}$

Definindo uma sábia diagonal no grupo de personagens, que ajuda a sugerir profundidade, numa busca de perspectiva ainda não geométrica mas já claramente elaborada, o gravador utiliza a goiva com mestria, num jogo complexo de incisões, que produz um efeito rico de ritmos, sem descuidar a expressão fisionómica, especialmente patenteada no belo rosto de Isabel de Aragão, tudo contribuindo, por essa via, para converter a estampa num dos melhores exemplos de xilogravura dessa época. ${ }^{13}$

11 Cf. PIMENTEL, António Filipe, “Estampa da Rainha Santa Isabel”, Imagen de la Reina Santa..., vol. I, p. 168.

12 Cf. ESPERANÇA, Fr. Manuel da, História seráfica da ordem dos frades menores de S. Francisco da Província de Portugal, tomo II, Lisboa, 1666, p. 133 e SILVA, Innocencio Francisco da, Diccionario Bibliographico Portuguez, Lisboa, 1926, s.v. "Frei Manuel da Esperança”.

13 Cf. PIMENTEL, A. F., "Estampa da Rainha Santa Isabel”, Imagen de la Reina Santa..., p. 169. 


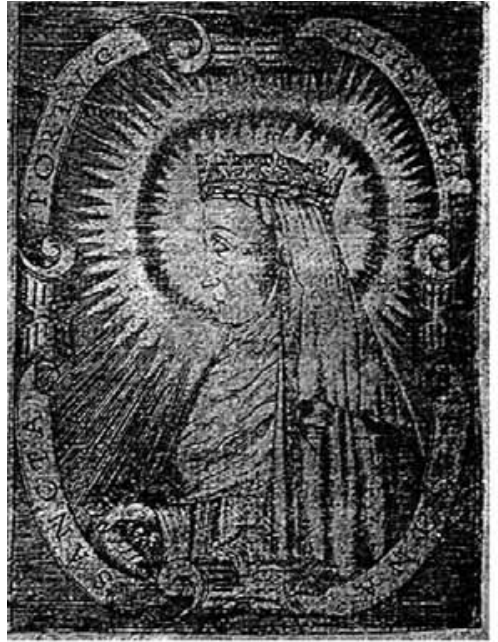

4. MARIZ, Pedro de, Diálogos de Varia Historia..., Coimbra, António de Mariz (buril).

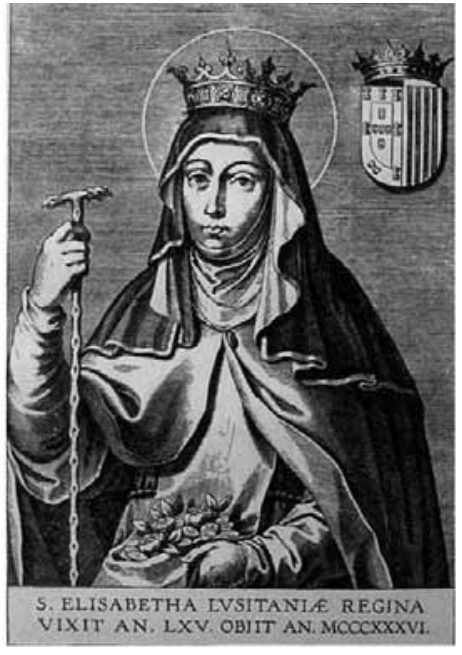

5. Cornelius Galle, S. Elisabetha Lvsitaniae Regina..., 1621.

$* * *$

Uma nova técnica de gravação (a gravura em cobre), porém, e uma nova utilidade para a memória de Isabel, encarada agora como elemento de prestígio de uma cadeia representativa, seriam inauguradas com os Diálogos de Varia Historia, de Pedro de Mariz, editados pela primeira vez em Coimbra em 1594, aí se iniciando, de facto, a integração isabelina nas séries icónicas (régias ou outras), que encontrariam nos séculos seguintes ávidos colecionadores. Mariz inclui a efígie da soberana, sob a epígrafe Elisabeth Regina Sancta Portug., entre a galeria dos Reis de Portugal e nesse sentido a sua história e personalidade lhe interessam. O belo buril que ilustra a sua obra, anónimo, é, de resto, interessante a vários níveis: pela qualidade da representação; pelo seu significado; pelo enigma que envolve.

Trata-se, com efeito, da obra de um artista culto. Composição elegante, rodeada por uma filactera com a inscrição. Um resplendor envolve a cabeça da santa, representada de perfil, coroada, vestida de clarissa, com barbeta de viúva e bordão e, com ela, pela primeira vez se figura Santa Isabel numa obra de índole histórica e não hagiográfica, onde o tratamento de Rainha Santa no contexto ilustrativo de uma série de monarcas actua explicitamente como estratégia de exaltação régia, em pleno quadro de ofensiva diplomática filipina.

E aqui radicaria o enigma que rodeou a obra de Pedro de Mariz, sacerdote e canonista, que chegaria a guarda-mor da livraria da Universidade de Coimbra: a supressão do texto 
do capítulo dedicado a Isabel de Aragão (diálogo III, capítulo II) da edição de 1597-1598, de Sernache dos Alhos - e das que se lhe seguiriam -, existente apenas na edição de Coimbra de 1597, hoje por completo ausente das bibliotecas públicas: matéria sobre a qual, de forma inconclusa, diversos autores se pronunciariam e onde poderá reconhecer-se a intervenção da Inquisição, por reputar extemporâneo o tratamento dado à venerável, mas ainda não canonizada, soberana. Do impacte que teve esta representação, contudo, dá eloquente testemunho a sua reprodução posterior, no interior de uma rica orla maneirista (ilustração, decerto, de obra perdida), integrada, no século XVIII, na colecção iconográfica de Barbosa Machado, conservada na Biblioteca do Rio de Janeiro. ${ }^{14}$

Por estes anos, todavia, a ilustração isabelina não deixaria de fazer o seu caminho nos meios e suportes técnicos tradicionais: com destaque para o manuscrito da Lenda, do Museu de Coimbra, datado de 1592 e mais propriamente designado Livro que fala da boa vida que fez a Rainha de Portugal Dona Isabel, e de seus bons feitos e milagres em sa vida e depois da morte, bela e ricamente ilustrado por mão anónima, a instâncias das monjas de Santa Clara (letras capitais, composição heráldica e figuração da soberana em fólios inteiros) e que constitui cópia quinhentista do relato - postulante da sua santidade - elaborado por autor desconhecido pouco após a sua morte e entretanto perdido. Nele, do mesmo passo que se testemunha o empenho activo da comunidade conimbricense no processo da canonização, retoma-se, com a inscrição, a iconografia franciscana da crux \& spinea, dada à estampa por João de Barreira em $1560^{15}$ e que estará longe de constituir a temática mais divulgada na figuração dos atributos da Rainha. Inversamente, volvido um quarto de século, em 1621, saía do buril de Cornellius Galle (o Velho), em Antuérpia, a imagem que haveria de marcar, por mais de um século, a iconografia isabelina e cuja repercussão se detecta em todos os domínios da criação plástica.

A esplêndida ilustração, legendada S. Elisabetha Lusitaniae Regina, destinava-se a ornar a obra Anacephalaeoses do jesuíta António de Vasconcelos, resumo apologético das crónicas lusitanas, editada nessa cidade, e não somente inspiraria, cinco anos depois, a belíssima estampa que adorna a Vita de S. Elisabeth Lusitanae Regina, publicada em Paris, em 1626, por A. F. Hilarione de Coste - o primeiro hagiológio expressamente dedicado à soberana portuguesa em consequência da canonização do ano anterior -, como ressurgiria, com

${ }^{14}$ Cf. SILVA, C. da, ob. cit., pp. 23-25; SOARES, E. e LIMA, H. C. F., ob. cit., vol. 2, p. 156 e PIMENTEL, António Filipe, "Estampa da Rainha Santa Isabel Elisabeth Regina Sancta Portug.,"Imagen de la Reina Santa..., vol. I, p. 170. Sobre a questão da supressão nas edições da obra de Mariz do texto do capítulo relativo à Rainha Santa (fls. 92-99), veja-se VASCONCELOS, A. de, ob. cit., vol. I, pp. 387-394.

15 Cf. MACEDO, Francisco Pato de, "Livro que fala da boa vida que fez a Rainha de Portugal Dona Isabel, e de seus bons feitos e milagres em sa vida e depois da morte", Imagem de la Reina Santa...., pp. 202-205. 
pequenas alterações, já em 1639, na obra Philippvs Prudens, do cisterciense João Caramul Lobkowitz, de novo impressa em Antuérpia. Mas, sobretudo, seria divulgada como estampa solta, em sucessivas reimpressões, por vezes assinada por outros membros da família Galle e cujo ponto de partida estaria nas que acompanhavam as pequenas biografias de Santa Isabel distribuídas em Roma pelas colónias portuguesa e castelhana, em Julho de 1625, no calor das festas de canonização: convertia-se, pois, por este modo, no primeiro registo popular da venerável Rainha, no momento em que a oficialização do seu culto determinava uma procura crescente das suas imagens piedosas.

Assenta a composição numa figuração austera, representando a soberana isolada contra um fundo neutro, coroada e aureolada, vestida de clarissa, com barbeta de viúva e apoiada no bordão de peregrina (descoberto em 1612, na primeira abertura do túmulo e cuja incorporação na iconografia isabelina decorrerá decerto do envio pelas monjas da parte inferior - bem como da bolsa das esmolas - em oferta à Rainha Margarida de Áustria, esposa de Filipe III de Espanha, Il de Portugal ${ }^{16}$ ) e recolhendo no escapulário as rosas do milagre. Como signo iconográfico, destacam-se, no ângulo superior direito, as armas partidas de Portugal e Aragão, motivo que, de agora em diante, acompanhará com frequência as representações da Rainha Santa.

Com efeito, a gravura de Cornélio Galle cumpria um papel do maior relevo na internacionalização da devoção isabelina - que, através da Flandres, rompia finalmente o espaço ibérico e em tudo o que se refere à difusão da sua imagem. Neste contexto, as circunstâncias congregar-se-iam para que esta figuração idealizada assumisse, de forma crescente, os contornos de uma vera efígie, a qual com uma força icónica talvez só comparável à que rodearia, em finais do século XIX, a estátua de Teixeira Lopes, de forma directa ou indirecta se deixa entrever nas representações a partir de então criadas: desde logo na primeira escultura a ela dedicada (a que se conserva na capela dos Reitores do Paço das Escolas da Universidade de Coimbra), mas também nas que se lhe seguiriam (como a que, em finais da centúria, ornaria o ciclo retabular que envolve a nave da igreja de Santa Clara-a-Nova) e, muito em especial, na maior parte das ilustrações gravadas ainda dos primeiros anos do século XVIII e na própria pintura, agora em franca expansão, dedicada à régia taumaturga. ${ }^{17}$ Do mesmo passo, é ela ainda que se afirma por detrás do desenho que ilustra a obra manuscrita de António Soares de Albergaria Triunfos dela nobleza lusitana y origen de sus blazones (fol. VII), de 1631, que se conserva na Biblioteca Nacional de Lisboa, realizada já em quadro pré-restauracionista.

${ }^{16}$ Cf. FACI BALLABRIGA, Mariano A.,"Algunos aspectos de la vida y muerte de Santa Isabel," ibidem, p. 32.

17 Cf. SILVA, A.C. da, ob. cit., pp. 25-26 e 28-29; SOARES, E., ob. cit., vol. 2, pp. 157-158; Biblioteca Nacional do Rio de Janeiro [Diogo BARBOSA MACHADO, Colecção dos Retratos, IC-18(1), n. $\left.{ }^{\circ} 115\right]$; PIMENTEL, António Filipe, "Estampa da Rainha Santa Isabel, S. Elisabetha Lvsitaneai Regina. Vixit an. LXV, Obiit an. MCCCXXXVI", Imagen de la Reina Santa..., vol. I, pp. 171-172. 
Com efeito, a reemergência, com a Restauração de 1640, de uma estirpe régia portuguesa autónoma mais não faria que reforçar a importância política do culto isabelino (que a ela em primeira mão ilustrava), situação que expressam, seja a decisão, por parte de D. João IV, de empreender a construção, em Coimbra, de um novo e imponente cenóbio, com o fito de pôr a salvo as suas relíquias do assoreamento progressivo do mosteiro velho (e cuja igreja receberia por orago a Rainha Santa Isabel) ${ }_{1}^{18}$ seja o realce que a virtuosa vida da soberana receberia nas páginas da nova História Seráfica da Ordem dos Frades Menores de S. Francisco na Província de Portugal, dada à estampa pelo cronista Frei Manuel da Esperança em 1666 ou, em 1672, na Monarquia Lusitana de Frei António Brandão.

Seria, porém, por efeito directo da canonização, ao outorgar dimensão pública e universal ao culto de Isabel de Aragão, que a sua iconografia se libertaria da estreita clausura dos círculos letrados (nos quais mesmo os hagiológios se incluíam), conferindo-lhe uma dimensão popular que haveria de multiplicar-lhe as formas e fórmulas, em resposta a uma comunidade progressivamente mais vasta e sedenta de representações. E por essa via nasceriam os registos, cuja vastíssima produção oscilaria entre o erudito e o popular e que terão tido, porventura, o primeiro exemplar cerca de 1630-50 no pequeno mas precioso buril legendado S. Elisabeth e assinado C.Galle. ${ }^{19}$ Abreviatura de Cornellius Galle, nome de dois dos representantes da ilustre família de gravadores anverrenses a que ficarão a dever-se tantas representações de Santa Isabel, constitui um belo apontamento rubensiano (de Cornellius Galle, o Velho, se conhecem diversas cópias gravadas de quadros de Rubens) que haveria igualmente de figurar como patriarca de uma numerosa prole de figurações gravadas da Rainha.

De facto, englobada então no mesmo complexo político que a Península Ibérica, a Flandres propiciaria, através da obra dos Galle, a projecção europeia da iconografia da Rainha Santa. Este particular registo, porém, inauguraria a vertente áulica da representação isabelina (de manto, jóias, indumentária cortesã), em confronto com a figuração tradicional, que consagrava apenas a simbólica régia - coroa(s), eventualmente ceptro -, o hábito clarista e a barbeta de viúva, nos quais se perseguia a ilustração da virtude que deveria abrir-lhe o caminho da canonização. O futuro se encarregaria de mostrar, na importância crescente que, na economia da sua representação, deveria adquirir a componente corte, até que ponto a dignidade de Rainha se revelaria estrutural no fascínio exercido pela Santa. Mas é um facto que, durante muito tempo, o modelo monástico continuaria a fazer sentir a sua força.

\footnotetext{
${ }^{18}$ Cf. PIMENTEL, António Filipe,"Mosteiro-Panteão/Mosteiro-Palácio: notas para o estudo do mosteiro novo de Santa Clara de Coimbra", Imagen de la Reina Santa..., vol. II, pp. 135-137.

${ }^{19}$ Cf. SILVA, A. C. da, ob. cit., p. 48 e SOARES, E., ob. cit., p. 180.
} 


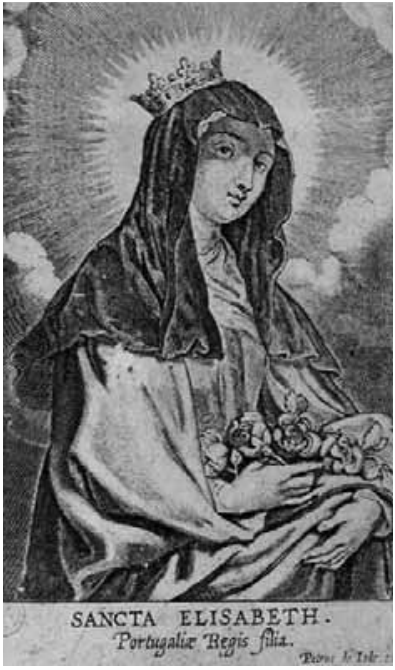

6. Petrus de lode, Sancta Elisabeth, 1660-70.

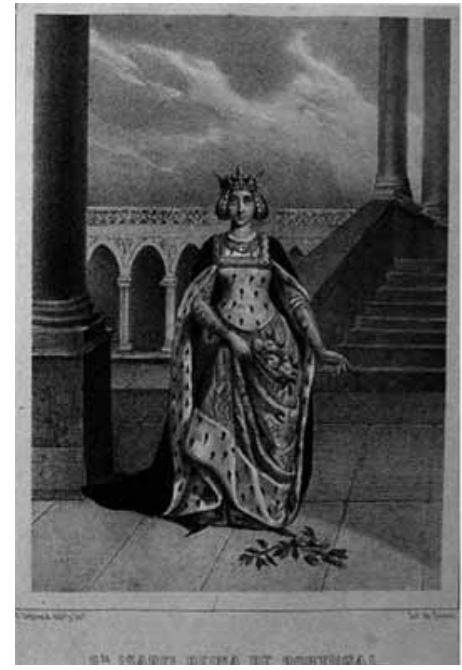

7.Domenico Duprà/Hieronymus Rossi, Dionysius I, Lusitaniae Rex et. Elisabetha coniux, 1791.

Efectivamente, está ainda neste caso (mesmo que numa versão de tal modo graciosa que exala um óbvio perfume cortesão) o belíssimo registo de Petrus de lode ${ }^{20}$, gravura a buril datável de cerca de 1660-70, figurando a Rainha sobre um fundo barroco de nuvens, resplandecente e representada em mais de meio corpo, coroada e vestida de clarissa, cingindo com incontestável graça o regaço de rosas, numa figuração onde tudo concorre deliberadamente para evocar a sua proverbial beleza. A qual, no próprio lapso epigráfico que encerra - Sancta Elisabeth Portugaliae Regis filia -, consagra afinal, de modo eloquente, a amplitude da difusão de um culto que ameaçava mesmo libertar-se do seu condicionalismo circunstancial. ${ }^{21}$ Igualmente representativo, ainda que de forma particular, da expansão extra-peninsular da devoção isabelina, será também um outro notável registo, gravado pelo buril de Abraham Bosse, em 1670, figurando igualmente a Rainha em trajes monásticos providos dos adereços de peregrina e cuja correctíssima legenda portuguesa - S. Isabel, Rainha de Port. cujo corpo esta depositado na Capella Mor do Real Mosteiro das

20 Cf. SILVA, A. C. da, ob. cit., pp. 49-50 e SOARES, E., ob. cit., p. 180.

21 Cf. PIMENTEL, A. F., "Estampa da Rainha santa Isabel Sancta Elisabeth. Portugaliae Regis filia”, Imagen de la Reina Santa..., vol.I, p. 173. 
Religiosas de S. Clara de Coimbra - parece indicar encomenda directa de personalidade lusa de passagem na Corte de Luís XIV. ${ }^{22}$

A composição de Bosse (155 x 104 mm), registo devocional embora, abria contudo, nas representações da venerável soberana, um capítulo novo, caracterizado por gravuras de dimensões médias e de esmeradas cercaduras de excelente efeito ornamental, que explicitamente inauguram o ciclo do Barroco. Nele se inscreverão, aliás, as primeiras produções de origem directa ou indirectamente portuguesa dedicadas, no século XVIII, à divulgação do culto isabelino: a magnífica composição Dionysius I. Lusitaniae Rex et D. Elisabetha Conivx, aberta em Roma sobre desenho de Domenico Duprà ${ }^{23}$,e a aparatosa gravura em cobre S. Joanna, S. Izabel, S. Sancha, S. Theresa, S. Mafalda, subscrita pelo monogramista M. F. para a obra de José Pereira Baião Portugal Glorioso e llustrado, editada em Lisboa em $1727^{24}$ e que não pode ser descontextualizada (tal como a de Duprà) do processo geral de afirmação do Reino no circuito político internacional dinamizado pela governação de D. João V.

Esta, com efeito, delineada em 1708 e dedicada a André de Melo e Castro, conde das Galveias e embaixador extraordinário de D. João V na Corte do Papa Clemente XI, integra a monumental série régia Lvsitanorum Regum Icones Ordinis Temporum Expositae, gravada em seis folhas com 28 estampas de primorosa execução, abertas por Hieronymus Rossi e Francesco Rastaini. Dela se conhecem duas versões: uma figurando o Rei Magnânimo de fisionomia juvenil e outra tomando por modelo uma representação mais madura - que deverá ser confrontada com a retratística do monarca realizada por Duprà em Portugal (Coimbra e Vila Viçosa) -, estampada em 1791 e que prolonga a galeria dos retratos régios até D. Maria I.

Num belo tondo, rasgado entre ramos de louro, sobreposto à cartela que contém a complexa legenda latina, a delicada água-forte, estampada na segunda folha, consagra também, no severo perfil da Rainha, a figuração concebida por Cornélio Galle para a Anacephalaeoses. Concedendo, porém, a Santa Isabel, honras de representação na galeria dos monarcas reinantes, Duprà não fazia mais que seguir a tradição inaugurada no século XVI com os Diálogos de Pedro de Mariz e sistematicamente observada posteriormente, quer se tratasse de séries icónicas, quer de galerias de retratos régios concebidas para mosteiros ou, mesmo, para a

22 SILVA, A.C. da, ob. cit., pp. 50-51; SOARES, E., ob. cit., p. 181; idem, Inventário da colecção de registos de santos, Biblioteca Nacional de Lisboa, Lisboa, 1955. Com efeito, a personalidade em causa revela mesmo ser particularmente bem informada, nomeadamente sobre o grandioso projecto do Mosteiro de Santa Clara-aNova, uma vez que o ataúde contendo o corpo da Rainha só viria a ser colocado na capela-mor da igreja (no interior do retábulo) em 1696. Quanto à gravura, não poderá ser posterior a 1676, data da morte de Abraham Bosse.

${ }^{23}$ Cf. SILVA, A. C. da, ob. cit., pp. 30-33; SOARES, Ernesto, História da Gravura Artística em Portugal, Lisboa, 1940, 2. ${ }^{\circ}$ vol., p. 540.

${ }^{24}$ Cf. SILVA, A. C. da, ob. cit., p. 30; SOARES, E., Dicionário, p. 181. 


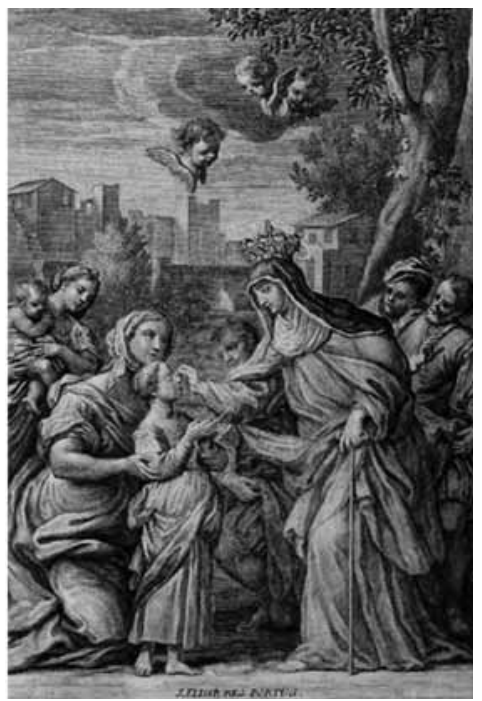

8. Sebastianus Conca/Hirenomymus Rossi, S. Elisab. Reg. Portug., 1730.
Universidade de Coimbra, em cujo seio a presença da soberana cumpria uma função objectivamente iconográfica, como elemento de relevo na dignificação da linhagem régia portuguesa. ${ }^{25}$

Quanto à S. Joanna, S. Izabel, S. Sancha, S. Theresa, S.Mafalda, do misterioso M.F., destinava-se a constituir o frontespício de um flos sanctorum especificamente dedicado à descrição da vida e virtudes das cinco santas da estirpe real portuguesa - ínvio tratado de apologética régia ${ }^{26}$-, apostando, inversamente, no efeito sumptuoso de um céu barroco, onde revolteiam putti, aureolando, no interior de um medalhão suportado pelo escudo das armas reais, a frisa das beatas dinásticas, a cujos pés jazem as competentes coroas e (sendo o caso) ceptros. Com estrutura análoga, porém com buril infinitamente superior e uma clara propensão para a sobriedade, produziria igualmente Debrie, o

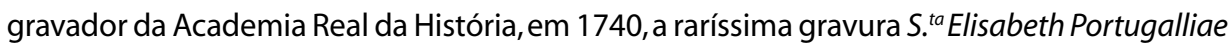
Regina ${ }^{27}$, verdadeiro ponto da situação das artes gráficas em Portugal ao tempo de D. João V e na qual perpassa ainda, claramente, a recorrente visão da Anacephalaeoses.

Por esse tempo, contudo, fora já realizada a primeira imagem impressa directamente relacionada com a pintura: a bela gravura a buril e água-forte de Hieronymus Rossi sobre desenho de Sebastiano Conca (notável parceria de artistas, cada um dos quais haveria de satisfazer, em diversas ocasiões, encomendas relacionadas com Portugal) e datada de Roma, $1730^{28}$ : dotada, na verdade, de assinalável qualidade, tanto plástica como técnica, qualidades que a convertem em obra do maior interesse para o estudo da iconografia da Rainha Santa.

Trata-se, com efeito, não somente da primeira realização plenamente (e não apenas formalmente) barroca - não em vão Conca havia sido devoto de Luca Giordano - mas, sobretudo, da primeira gravura directamente relacionada com as experiências pictóricas

${ }^{25}$ Cf. PIMENTEL, António Filipe, "Estampa da Rainha Santa Isabel Dionysius I. Lusitanae Rex et. Elisabetha conivx", Imagen de la Reina Santa..., p. 176.

${ }^{26}$ Veja-se, sobre a importância política deste conjunto de canonizações, PIMENTEL, António Filipe, Arquitectura e Poder: o Real Edifício de Mafra, Lisboa, Livros Horizonte, ${ }^{2} 2002$, pp. 32-33.

27 Cf. LIMA, H. C. F., ob. cit., vol. 2, p. 158. Pudemos ver a gravura na Biblioteca Nacional do Rio de Janeiro [Diogo BARBOSA MACHADO, Colecção dos retratos, IC-18(1), n. $\left.{ }^{\circ} 116\right]$, segundo julgamos a única instituição pública a possuí-la.

${ }^{28}$ Cf. SILVA, A. C., ob. cit., p. 63. 
contemporâneas. Efectivamente, o hagiológio isabelino (neste caso a cura de uma menina cega) motivaria aqui uma complexa composição, envolta num jogo subtil de claro-escuro. As personagens, envergando pesadas vestes que compõem densos pregueados, convergem num triângulo formado pela Rainha, coroada e vestida de clarissa, apoiando-se no bordão, e pela mãe que, ajoelhada, lhe apresenta a filha cega, a fim de que a toque, e cujo vértice assinala um pequeno bando de querubins que parecem seguir a soberana e observam, com sorridente atenção, o desenrolar dos acontecimentos. O fundo, cujo jogo lumínico cria uma sábia perspectiva, perde-se num núcleo de muros de edifícios, certamente evocativo do convento de Santa Clara-a-Velha.

De facto, provável (ainda que não documentado) encargo de alguma personalidade portuguesa na Cúria pontifícia, a estampa rompe, pela primeira vez, com a tradição das veras efigies, propondo a dramatização de um episódio da lenda piedosa, que estabelece uma relação infinitamente mais tensa com o fiel observador. ${ }^{29}$ Circunstâncias, uma e outra, que deveriam seguramente reunir-se para explicar a sua popularidade, que levaria a que fosse reproduzida parcialmente ${ }^{30}$ ou, mesmo, inspirasse, já em pleno período rococó, versões ingénuas e significativamente mais rudes, como a que deixou Andreas Rossi (1760). ${ }^{31}$

Em anos mais adiantados, aliás, duas raras gravuras anónimas, ambas de elegante feitura, partilhariam idêntica inspiração pictórica: a primeira, francesa, denominada S.te Elisabeth Reine de Portugal, vendia-se A Paris chez J. Mariett rue S.t Jacques aux Colonnes d'Hercule ${ }^{32} \mathrm{e}$ nela figura a Rainha, coroada e de vestes cortesãs, esmolando dois pedintes junto de uma clássica coluna; a segunda, espanhola mas comercializada em Paris [se viende en la Cassa Poilly en la Calle S.t Diago (sic)], ornada das armas reais castelhanas e portuguesas e legendada Santa Elisabet Reÿna de Portugal, reproduz idêntica cena, mas trajando a soberana de vestes monásticas. ${ }^{33}$

Ainda durante o século XVIII, teria Santa Isabel uma outra imagem do maior interesse: a bela e muito rara gravura em cobre de Pietro Bombilli sobre desenho de António Cavallaruci, realizada em Roma e legendada S. Elizabetta Regina di Portugallo e que reproduz a teoria de estátuas berninianas da Praça de São Pedro ${ }^{34}$, nova série iconográfica a integrar a antiga soberana. Os derradeiros anos da centúria seriam, porém, assinalados por alguns registos, alternando

29 Cf. PIMENTEL, António Filipe, "Estampa da Rainha Santa Isabel S. Elizab. Reg. Portug.", Imagen de la Reina Santa..., pp. 174-175.

30 Biblioteca Nacional de Lisboa (icon. Al. 9-A, fls. 56), gravura de Andreas Rossi, datada de 1760.

31 S. Elisabet [sic] Rainha de Portugal, s.a., buril e água-forte, Museu Nacional de Arte Antiga, Lisboa (inv. ${ }^{\circ}$ n. ${ }^{\circ}$ 8182 - Gravura).

32 Biblioteca Nacional do Rio de Janeiro [Diogo BARBOSA MACHADO, Colecção dos Retratos, IC-18(1), n. ${ }^{\circ} 114$ ].

33 Idem, ibidem, n. 110.

${ }^{34}$ Cf. SILVA, A. C. da, ob. cit., p. 55. 


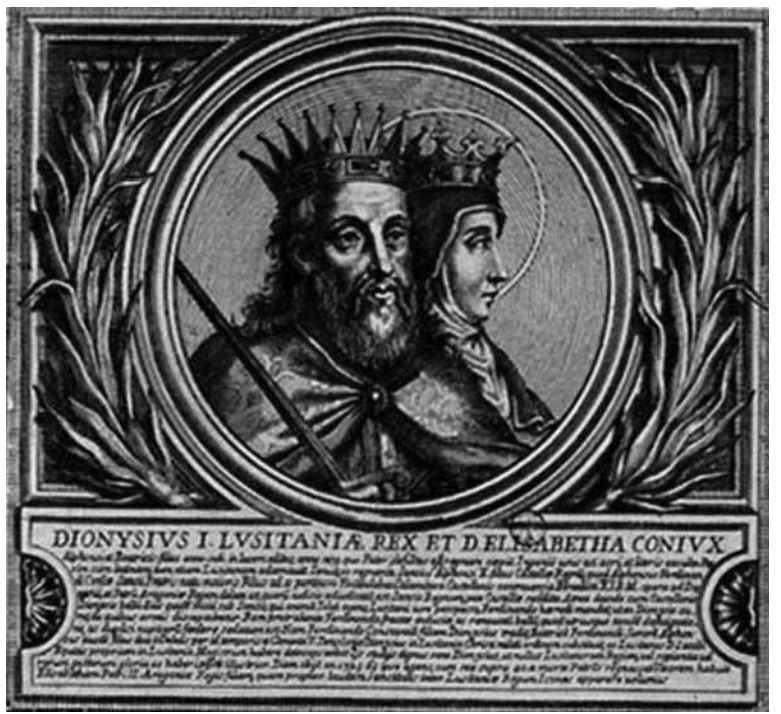

9. Manuel Dias de Oliveira, Fatto milagrozo de Santa Isabel Rainha de Portugal, 1798.

produções cultas - como o delicioso buril rocaille S. Elisabetha Regina, do gravador alemão Ignaz Sebastian Klauber, cujo sabor, claramente centro-europeu, testemunha a ampla difusão alcançada pelo culto isabelino na segunda metade do século XVIII ${ }^{35}$ - com outras de sabor mais popular, como a tão comum S. Izabel Rainha de Portugal, que se venera no Convento de Santa Clara de Coimbra, firmada Godinho e cujo rasto se pode seguir pelos alvores do século XIX. Nele, a Rainha, de coroa, ceptro e manto régio, onde cinge as rosas do milagre, entre o escudo das suas armas e a insígnia franciscana, destaca-se sobre um fundo de arquitecturas clássicas na atitude de dar esmola a um paralítico ${ }^{36}$, constituindo verdadeiramente o mais popular registo devocional de Isabel de Aragão entre finais do século XVIII e as primeiras décadas do seguinte e o mais intimamente ligado ao seu retiro conimbricense. E merece reparo a influência que obviamente detém na iconografia adoptada na formulação das insígnias da Real Ordem de Santa Isabel, instituto honorífico e assistencial feminino criado em 1801 pelo Príncipe Regente D. João, agregando, na dependência da soberana, vinte e seis damas nobres, "com o plausível motivo da paz e antiga devoção que ha n'estes [...] reinos á Rainha Santa."."37

${ }^{35}$ Cf. PIMENTEL, António Filipe, “Estampa de la Reina Santa Isabel S. Elisabetha Regina”, Imagen de la Reina Santa..., vol.I, p. 180.

${ }^{36} \mathrm{Cf}$. idem, "Estampa de la Reina Santa Isabel S. Izabel Rainha de Portugal que se venera no Conv. ${ }^{\text {to }}$ de S. ${ }^{\text {ta }}$ Clara de Coimbra", ibidem, vol. l, p. 180.

${ }^{37} \mathrm{Cf}$. idem, "A honra e os seus ícones. Sobre a joalharia de função", Oceanos, n. ${ }^{43}$, Lisboa, Julho-Setembro 2000, p. 104. 
Outra série de composições de igual carácter, figurando a Rainha em traje cortesão esmolando um paralítico e, por vezes, representando em fundo o episódio do forno da cal, teria a sua origem no Porto, em gravuras de molduras rococó, sob um rude buril que assina Santos ${ }^{38}$. Contudo, a composição que, mesmo em termos estéticos, marca o final da centúria, seria a grande e excelente gravura Fatto milagrozo de Santa Izabel Rainha de Portugal, água-forte e buril aberto em Roma, em 1798, pelo brasileiro Manuel Dias de Oliveira ${ }^{39}$, vasta e grandiloquente composição, elaborada num tom retórico, que assinala, no seu academismo de sabor escolar, a breve penetração do neoclassicismo na representação da Rainha Santa.

A composição, com efeito, estrutura-se com resolução e dispõe, numa rede explícita de horizontais e verticais, um conjunto numeroso de personagens que encenam, de forma dramática, o milagre das rosas. A acção decorre na entrada de um nobre edifício (o palácio real) assinalado por quatro colunas colossais, entre as quais se abre a porta, a que se acede por um patim de dois degraus, sobre o qual, ao centro, se encontram Santa Isabel e D. Dinis, ambos coroados e com trajes cortesãos de inspiração clássica, pondo em relevo a Rainha as rosas do regaço que o Rei, irado, Ihe descobre. Em primeiro plano, centrados a cada lado da composição, dois grupos de figuras (um de áulicos, outro de mendigos) comentam com estupefacção o prodígio a que acabam de assistir. ${ }^{40}$

Dedicada ao intendente-geral Pina Manique, sob cujos auspícios Oliveira se formara na Casa Pia de Lisboa e sob cuja protecção rumara a Roma, onde seria discípulo de Labruzzi e de Pompeo Battoni, a estampa constituiria a única gravura conhecida do artista (que adoptaria o apodo de brasiliense na cidade papal e de romano no regresso ao Brasil), mas o novo gosto neoclássico deveria ainda produzir, em 1804 e sob o buril de Jean Cardini, nova e interessante figuração da soberana, agora em vestes de patrícia romana, denominada Epitome da Vida da Rainha D. Isabel, integrada na série iconográfica então editada em Lisboa e denominada Retratos dos Grandes Homens da Nação Portuguesa, com epitomes das suas vidas, sendo posteriormente reaproveitada em outras publicações, como os Retratos, e elogios de varões e donas que illustraram a Nação Portuguesa, editados em dois volumes, igualmente em Lisboa, em 1817 e 1822. ${ }^{41}$ Figurada em busto, no interior de um austero medalhão, a soberana, com a cabeça coberta por um véu, qual patrícia da Roma antiga, surge agora despojada de toda a panóplia de elementos iconográficos que tinham distinguido a sua representação nos séculos XVII e XVIII, sucedendo, deste modo, o modelo da virtus clássica,

${ }^{38}$ Cf. SILVA, A. C. da, ob. cit., pp. 64-65 e LIMA, H. C. F., ob. cit., vol. 2, p. 160.

${ }^{39}$ Cf. LIMA, H. C. F., ob. cit., vol. 2, p. 159.

40 Cf. PIMENTEL, António Filipe, “Estampa de la Reina Santa Isabel Fatto milagrozo de Santa Isabel Rainha de Portugal", Imagen de la Reina Santa..., vol. I, p. 178.

${ }^{41}$ Cf. SILVA, A. C. da, ob. cit., p. 33. 
ainda que por brevíssimo tempo, ao modelo da virtude cristã que a iconografia barroca havia perseguido através do hábito de clarissa, da barbeta de viúva e dos adereços de peregrina: e tanto basta para conceder o maior interesse a esta rara imagem. ${ }^{42}$

Apesar disso, o Barroco faria ainda uma última aparição, já em 1822, agora em mãos espanholas: no elegante - mesmo que arcaizante - registo a água-forte Santa Isabel Reyna de Portugal, viuda y de la Tercera Orden de San Francisco, assinado A. Rodrigz. e M. Brandi e no qual, aliás, se registaria novo e curioso lapso, agora no que respeita à festa litúrgica da soberana, assinalada $A$ 8. de Julio. ${ }^{43}$ Mas o século XIX traria uma novidade importante no campo das artes gráficas, que em grande parte destronaria as técnicas tradicionais, justamente pela mesma ordem de razões que havia feito a sua fortuna: rapidez, economia, facilidade de reprodução - a litografia. Mais pictórica, liberta do penoso trabalho das incisões.

E será este, na verdade, o meio de expressão preferido por uma parte substancial das representações isabelinas oitocentistas, ao mesmo tempo que o fervor historicista, que domina todos os campos das artes plásticas, influencia poderosamente a figuração. Desse modo e ao longo da centúria, a iconografia da Rainha Santa repercutirá, com assinalável fidelidade, as sucessivas vagas que percorrem o ambiente cultural (e político) - o romantismo literário, o revivalismo barroco do II Império, o naturalismo historicista, o historicismo arqueológico -, onde o mito isabelino se inscreve oportunamente em todas as vertentes.

Desse ponto de vista, pois, a centúria abriria em 1842 com a litografia de Valentim S. Izabel, Rainha de Portugal, cópia fantasista (ainda que protestadamente fiel) da pintura existente na igreja de Santa Isabel de Lisboa, figurando a soberana em mais de meio corpo, de coroa e manto de arminhos, em cujas dobras desvenda uma mão-cheia de rosas ${ }^{44}$ e que, pelos mesmos anos, teria versão espanhola (S. ${ }^{\text {ta }}$ Isabel, Reina de Portugal), com pequenas alterações, da Lit. ${ }^{a}$ de Rubia y Virriri. ${ }^{45}$ Os anos de 1850 assistiriam, todavia, à criação de uma bela estampa colorida, com legenda bilingue francês-espanhol - S. ${ }^{\text {te }}$ Elisabeth/S. ${ }^{\text {ta }}$ Isabel -, litografia de Bécquet Frères, Paris ${ }^{46}$ a qual, num registo operático digno de Donizetti, encenaria simultaneamente o milagre das rosas e a prática da caridade. Pelos mesmos anos, uma

42 Cf. PIMENTEL, António Filipe, “Estampa de la Reina Santa Epitome da Vida da S. ${ }^{\text {ta }}$ Rainha D. Isabel", Imagen de la Reina Santa..., p. 181.

${ }^{43}$ Cf. SILVA, A. C. da, ob. cit., p. 61; PIMENTEL, António Filipe,“Estampa de la Reina Santa Santa Isabel Reyna de Portugal, viuda, y de la Tercera Orden de San Francisco A 8. de Júlio", Imagen de la Reina Santa..., p. 182.

${ }^{44}$ Cf. SILVA, A. C. da, ob. cit., p. 61 e LIMA, H. C. F., ob. cit., vol. 2, p. 159.

45 Biblioteca Nacional de Lisboa (icon. E. 3398. P.).

${ }^{46}$ Cf. SILVA, A. C. da, ob. cit., pp. 67-68. 


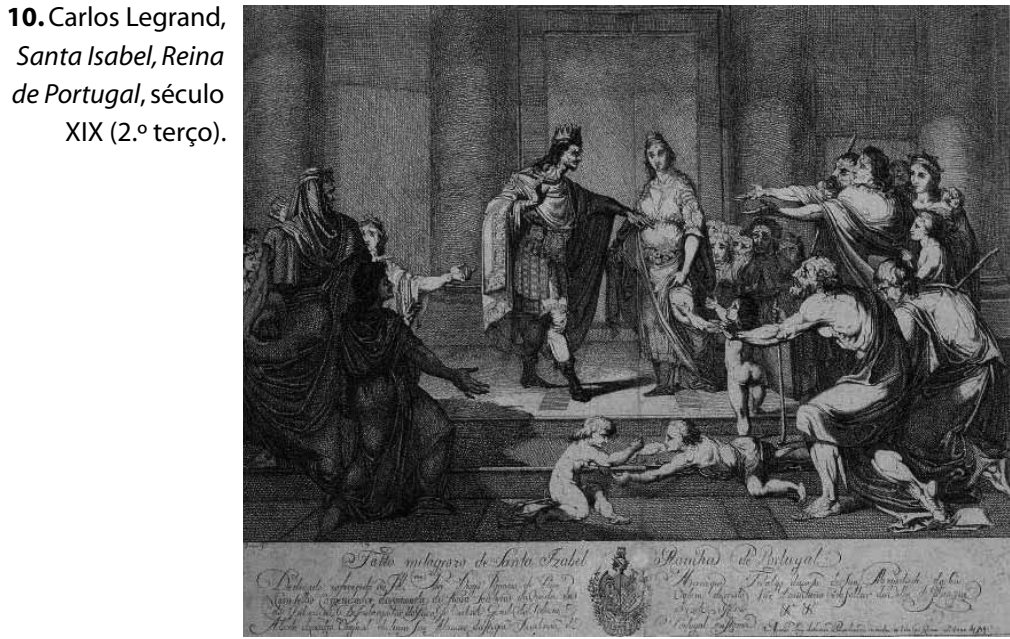

variante, se possível ainda mais sugestiva, agora em versão poliglota (francês-espanhol-alemão-italiano), seria vendida em Marselha Chez Dubreil. ${ }^{47}$

Em ambas, a opção representativa daria preferência à vertente áulica, com a Rainha coroada, em traje cortesão de inspiração medieval, evoluindo, entre mendigos, num cenário de contos de fadas. $O$ mesmo fenómeno se verificaria, aliás, mas num recorte mais densamente literário, numa outra família de gravuras contemporânea, figurando a soberana isolada, elegantemente vestida ao gosto medieval e rodeada de arquitecturas condicentes, soltando do regaço as rosas do milagre. Versão decerto popular, dela se encontram variantes litografadas em Portugal e Espanha - S. ${ }^{\text {ta }}$ Isabel Rainha (Maurin, Lisboa) ${ }^{48}$, S. ${ }^{\text {ta }}$ Isabel, Reina de Portugal (Carlos Legrand) ${ }^{49}-\mathrm{e}$, em França, a gravura a talho-doce S..$^{\text {te }}$ Elisabeth de Portugal (por M. ${ }^{\text {me }}$ Fournier sobre desenho de Leloir, para a obra de Godescart, Les Vies des Saints Pères et Martyrs, Paris, c. 1850). ${ }^{50}$

A gravura espanhola, na verdade, constitui notável expoente desta situação estética, com a sua elegante composição, de claro recorte cénico, representando Santa Isabel diante de um vasto pátio delimitado por uma arcaria gótica decorada de arabescos e por uma imponente escadaria clássica. Em primeiro plano, a Rainha, coroada e trajada luxuosamente ao gosto medieval, com mando e vestido de brocado orlados de arminhos, soer-

\footnotetext{
47 Idem, ibidem, p. 68.

${ }^{48}$ Cf. idem, ibidem, p. 66; LIMA, H. C. F., ob. cit., vol. 2, p. 161.

49 Colecção Armando Carneiro da Silva (Coimbra).

${ }^{50}$ Cf. SOARES, E., Dicionário, p. 181.
} 
gue levemente a falda, deixando tombar as rosas que leva no regaço. Com efeito, os ecos literários que perpassam por esta estampa, próprios das novelas de Walter Scott ou das óperas de Donizetti, outorgar-Ihe-iam clara popularidade, atestada pelas variantes que se conhecem (ao menos em Portugal e Espanha), colocando-a como exemplar particularmente representativo da iconografia romântica da devoção isabelina. ${ }^{51}$

Alguns anos mais tarde, pelos finais da década de 60, emergia uma outra corrente, marcada por um revivalismo barroco de gosto II Império, geradora de saborosas estampas de um mundanismo ingénuo, com repercussões na imaginária popular. De coroa, manto e ceptro sobre traje de baile contemporâneo, a Rainha, de pé, num caso sob um bardaquino, no outro em interior palaciano, entrega o óbulo ao mendigo ajoelhado. ${ }^{52}$ Os anos finais da centúria seriam, porém, marcados por uma produção mais séria, ainda que não menos popular, de teor vincadamente naturalista, geradora de composições de carácter evocativo, algumas de grandes dimensões (e também, muitas vezes, integradas em séries icónicas), prenunciadas ainda na década de 40 pela litografia de Kaeppelin (Lisboa, 1842) A Rainha Santa Isabel no meio dos dous exércitos hostis no Lumiar desarma os contendores e congraça o Pai e o Filho.53

Donde o êxito (nuns casos maior que noutros) registado por imagens como a que realizaram (sem título) C. J. e Alberto, cerca de $1880^{54}$, vezes sem conta reproduzida, representando a soberana, coroada e aureolada, em vestes cortesãs, distribuindo esmolas a uma legião de mendigos comprimida num cenário da Renascença; A Rainha Santa Isabel distribuindo esmolas, buril de Lallemant sobre desenho de João Correia ${ }^{55}$, da mesma época e igualmente popular, representando idêntica cena, mas agora em ambiente medieval; $A$ Rainha Santa Isabel atravessando as linhas do exército de D. Diniz e do Filho

D. Affonso, a fim de evitar o combate iminente, cromolitografia de José Bastos sobre aguarela de Roque Gameiro de grande efeito dramático ${ }^{56}$, ou ainda, adiantado já o século XX, a litografia anónima que reproduz o painel de azulejos de Jorge Colaço, do Palácio da Justiça de Coimbra, figurando o milagre das rosas. ${ }^{57} \mathrm{E}$ não deverão deixar de referir-se ainda as ilustrações de Conceição Silva para o romance histórico de Armando da Silva e Caldas

51 PIMENTEL, António Filipe, "Estampa de la Reina Santa Isabel S. ${ }^{\text {ta }}$ Isabel, Reina de Portugal", Imagen de la Reina Santa..., vol. I, p. 184.

52 Cf. SILVA, A.C. da, ob. cit., pp. 68-69 (Est. XLIII e XLIV).

${ }^{53}$ Cf. LIMA, H. C. F., ob. cit., vol. 2, p. 159.

54 Cf. SILVA, A. C. da, ob. cit., pp. 71-72.

55 Cf. idem, ibidem, pp. 75-76; LIMA, H. C. F., ob. cit., vol. 2, pp. 160-161.

${ }^{56}$ Cf. SOARES, E., Dicionário, p. 181. Integraria igualmente as ilustrações da História de Portugal de Pinheiro Chagas, agora com a legenda: A Rainha Santa Izabel separando os dois exércitos no campo d'Alvalade.

57 Biblioteca Nacional de Lisboa (icon. E. 201 R.). 
Cordeiro, A Rainha Santa, D. Isabel de Aragão, editado em 1903. Enfim e ainda dentro do mesmo gosto, a Real Academia de Nobles Artes de S. Fernando editaria, em 1872, uma água-forte de E. Maura, sob a legenda $S^{\text {ta }}$ Isabel, Reina de Portugal, representando, num cenário renascentista, a soberana coroada, de indumentária híbrida áulico-monástica, na atitude de lavar a cabeça a um pobre, enquanto as aias a auxiliam na assistência aos indigentes. ${ }^{58}$

De todas estas - quanto mais não fosse pela popularidade - merece especial referência A Rainha Santa Isabel distribuindo esmolas, gravada por Lallemant, como foi referido, a partir de um quadro de João Correia, antigo professor da Escola de Belas Artes do Porto e que, em finais do século XIX, constituiria uma das mais populares representações isabelinas, tanto como registo devocional, impresso a várias cores, com e sem legenda (tipografada), como ilustração de artigos na imprensa periódica, ou, mesmo, na ornamentação de programas dos festejos religiosos da padroeira de Coimbra. Produto da maré naturalista que invade a pintura contemporânea e do gosto pela evocação edificante de temas históricos, em que haveriam de distinguir-se Roque Gameiro e Jorge Colaço, a estampa encena a prática da caridade, virtude cívica de espectro seguramente mais consensual do que a temática piedosa do milagre das rosas.

Assim, num espaço pictórico delimitado por um arco de meio ponto, alinham-se em perspectiva construções medievais: um paço acastelado (o Paço de Santa Clara?), uma torre donde se vislumbra a base do escudo português (subterfúgio para evitar a representação da coroa?), um portal de arquivoltas (a celebrada porta da rosa de Santa Clara-a-Velha?). Diante destas apinham-se mendigos, entre os quais se destaca a bela nota produzida pela jovem mãe ajoelhada em primeiro plano. Emergindo do portal e rodeada de fâmulos com a cruz alçada, a Rainha - nobre figura enquadrada pela torre, de cujo valor semântico se apropria -, com trajes mais civis que majestáticos, estende compassivamente à jovem a mão que transporta o óbulo que afastará a fome do menino adormecido. $A$ composição, que parece respirar o ideário do cristianismo social, estrutura-se numa subtil diagonal, realçada pela cruz e pela sombra suave que projecta a fachada oculta da igreja..$^{59}$

O final do século XIX produziria ainda, porém, uma imagem isolada - Sainte Elisabeth de Portug., buril imitando gravura em madeira, integrado na obra do Abade Pradier La vie des saints pour touts les jours de l'année, Lille, $1889^{60}$ - de grande interesse na elegante paginação neogótica, não somente por documentar o gosto pelo revivalismo historicista, ao mesmo tempo que, rara ilustração como é, de um flos sanctorum de finais de Oitocentos,

58 Idem, ibidem (icon. E. 1407 V.).

59 PIMENTEL, António Filipe, "Estampa de la Reina Santa Isabel A Rainha Santa Isabel distribuindo esmolas", Imagen de la Reina Santa..., vol. I, p. 186.

${ }^{60}$ Cf. SILVA, A. C. da, ob. cit., p. 73. 
da intensificação do fervor religioso que (tanto como o laicismo) marcaria o declinar desse século e o alvorecer do seguinte, mas, muito particularmente, pela reinvenção que faz das ilustrações que ornavam os livros quinhentistas, num mimetismo que se estende ao aspecto gráfico das antigas xilogravuras.

Nesse sentido, o autor (anónimo) da gravura engendraria um marco arquitectónico definido por um arco conupial flamígero, cujos suportes albergam, sob dosséis, pequenos anjos que sustentam filacteras, donde emergem legendas alusivas ao milagre das rosas. E, no seu interior, desenhada com deliberada aproximação formal à estatuária gótica, a figura da Rainha, esbelta silhueta de rígidos pregueados com o tradicional hábito de clarissa, coroada e aureolada, cinge com ambas as mãos o regaço donde escapam as místicas rosas do prodígio. ${ }^{61}$

Mas a oferta a Coimbra, em 1896, pela Rainha Dona Amélia de Orléans, da bela escultura de Teixeira Lopes, marcaria doravante inexoravelmente, e como nenhuma outra, a imagem de Santa Isabel. E, na verdade, a partir de então, a história da iconografia gravada da soberana padroeira coincide em absoluto com a das inúmeras reproduções, pelas mais diversas técnicas, da famosa estátua, que acabaria por converter-se, no imaginário popular, na vera efígie de Isabel de Aragão. ${ }^{62}$ E desse perverso império da imagem de Teixeira Lopes, golpe da asa naturalista que uma vez mais consagraria a vertente áulica da iconografia da Rainha, somente merecerá destaque, porventura, o trabalho que em seu redor criaria A. Nunes Pereira, em belas xilogravuras dos anos 50 e 6063, especialmente a que legendou Rainha Santa Isabel Rogai Por Nós, datada de $1964 .{ }^{64}$

O final do século XIX assinalaria, contudo, um interesse mais directamente arqueológico pela figura da antiga soberana, que igualmente haveria de repercutir-se na gravura e que não pode deixar de mencionar-se. Estão nesse caso a reprodução, por Alberto sobre desenho de Columbano, do quadro de Berlim, então em Dusseldorf, a partir de uma cópia oferecida ao Rei D. Luís I quando de uma sua visita à Alemanha, a fim de ilustrar a obra de Fonseca Benevides Rainhas de Portugal $(1878)^{65}$, mas, sobretudo, as diversas reproduções do túmulo gótico que encerrou o seu corpo até ao século XVII, provavelmente inauguradas com a litografia de Mariz Júnior, de $1872 .^{66}$

Efectivamente, materializando simbolicamente a própria Caridade e a solicitude inesgotável pelos humildes aureolada pela sua condição histórica e social de Rainha; raiz de uma

61 PIMENTEL, António Filipe, "Estampa de la Reina Santa Isabel Sainte Elisabeth de Portug.", Imagen de la Reina Santa..., vol. I, p. 185.

62 Cf. SILVA, A. C. da, ob. cit., pp. 76-80; SOARES, E., Dicionário, p. 181.

${ }^{63}$ Cf. SILVA, A. C. da, ob. cit., pp. 80-81.

${ }^{64}$ Col. Armando Carneiro da Silva (Coimbra).

${ }^{65}$ Cf. SILVA, A. C. da, ob. cit., pp. 71-72; LIMA, H. C. F., ob. cit., vol. 2, p. 160.

${ }^{66}$ Cf. SILVA, A. C. da, ob. cit., pp. 85-88; LIMA, H. C. F., ob. cit., vol. 2, p. 160. 
devoção profundamente alicerçada na comunidade social, em particular na região em cuja capital entendeu descansar para sempre e cujas origens remontam à sua própria morte, ocorrida já em halo de santidade, o culto de Isabel de Aragão retiraria muito da sua inquestionável força dessa dupla valência de santa e soberana: valência essa que, no decurso do tempo e variando com as circunstâncias, haveria também de conferir à sua devoção um valor político que seria determinante na sua projecção, tanto no interior do Reino como fora dele. E que, por isso, se projectaria, ao longo de quase setecentos anos, num acervo notável de imagens, em todos os domínios da criação plástica À gravura caberia, contudo, neste processo, pela sua insubstituível capacidade de divulgação, um quinhão importantíssimo, que as suas especiais potencialidades fariam diversificar de forma impressionante. Desse modo se haveria de converter, não somente num instrumento de propaganda e difusão ao serviço dos desígnios cultuais e num suporte reprodutor de experiências realizadas noutros domínios, mas também, com frequência, num espaço de reflexão, donde a imagem de Isabel, depois de maturada, partiria, enfim, em demanda de novos suportes.E, nesse sentido, viria a afirmar-se como domínio incontornável no estudo da iconografia daquela que, desde sempre, haveria de consubstanciar, no imaginário colectivo, o próprio arquétipo de Rainha Santa. 



\title{
Estilo e iconografia \\ - As beatas de Portugal e a pintura romana
}

\author{
Nuno Saldanha*
}

O século XVII revelou-se bastante positivo no tocante ao enriquecimento do hagiológio lusitano, tendência que se conseguiu manter activa até inícios de Setecentos. Para além da canonização da Rainha Santa Isabel (1625), em 1671, o Papa Clemente X estende o culto de Gonçalo de Amarante (beatificado em 1561) à Ordem dos Pregadores e a todo o reino de Portugal, com missa e ofício litúrgicos próprios.

Seguir-se-ão outros processos de infantas portuguesas, mais prolíferos em termos de produção artística e iconográfica, que decorrem na viragem para o século XVIII. Primeiro, o da Princesa Santa Joana (1693) e, alguns anos depois, o das filhas de D. Sancho I - Teresa, Sancha (1704) e Mafalda (processo de 1700, embora beatificada apenas em 1792).

Estes processos, independentemente do seu sucesso, motivaram uma significativa produção de novas formas de representação. A proximidade com o poder papal, e com os centros de decisão, como o da Sagrada Congregação dos Ritos, levou consequentemente à opção por uma produção romana no tocante à origem das novas imagens.

Apesar de motivadas por intuitos de ordem religiosa, no sentido de suscitar a devoção e divulgar o culto, estas encomendas contribuíram não só para a criação de uma nova iconografia, como para o desenvolvimento de novos conceitos estilísticos e de vertentes do gosto. De facto, elas acabam por definir a preponderância das correntes italo-romanas, que marcariam o estilo predominante da pintura portuguesa ao longo da centúria seguinte.

Se a influência da pintura francesa esteve sobretudo mais associada ao retrato e a outros géneros mais profanos, no tocante à temática religiosa, as preferências tendem naturalmente a recair sobre a pintura italiana. $O$ florescimento desta corrente, em território nacional, surge também fora dos círculos cortesãos, resultando por seu lado, do empenho particular das ordens religiosas, nomeadamente de São Domingos e São Bernardo.

Efectivamente, ele deriva em grande parte do sucesso dos processos de canonização ou beatificação de alguns santos e santas portuguesas, ao longo do século XVII.Logo no início, em 1625, era canonizada aquela que se tornaria numa das figuras principais do hagiológio

* Escola Superior de Design (IADE). 
lusitano, Santa Isabel de Portugal, promovendo uma das mais divulgadas e diversificadas iconografias, que se estende, mormente em território peninsular, até ao século XIX.

Na segunda metade do século, já durante a regência de Pedro II, o Papa Clemente X (em 10 de Julho de 1671), estendeu o culto do beato Gonçalo de Amarante (cuja beatificação ocorrera em 1561) a toda a Ordem dos Pregadores e a todo o reino de Portugal, com missa e ofício litúrgicos próprios.

Muito provavelmente no seguimento desta circunstância, D. Frei Manuel Pereira, provincial dos dominicanos portugueses, e futuro secretário de Estado de Pedro II, encomendou uma nova capela para o convento de São Domingos de Benfica. Com evocação a São Gonçalo de Amarante, ali se encontra colocada uma imagem do beato, ao centro da decoração escultórica da capela. Frei Manuel Pereira esteve em Roma entre 1670 e 1677, precisamente no período em que Clemente $X$ promulga a extensão do culto. $A$ ideia para esta nova representação escultórica do beato deve situar-se assim nos inícios da década de $70^{1}$.

Mais prolíferos, em termos de produção artística e iconográfica, serão os seguintes processos, que terão lugar nos finais do século XVII e inícios do XVIII.

Primeiramente, o da Princesa Santa Joana (1693), por iniciativa do convento dominicano de Aveiro, ao que se segue, alguns anos depois, o das filhas de D. Sancho I, Teresa, Sancha (1704) e Mafalda (processo de 1700, embora beatificada apenas em 1792), graças às diligências dos mosteiros de Lorvão e de Arouca².

Tal como sucedeu com diversas outras situações, muitas destas santas ou beatas do nosso hagiológio eram já objecto de devoção em muitos conventos e capelas, mesmo antes da sua confirmação, resultante de processos que se arrastavam, frequentemente, por séculos. Para além do prestígio que a eleição das suas professas podia aportar, tanto ao mosteiro, como à sua Ordem, também não será de descurar o interesse político subjacente, na recuperação da tão abalada imagem do país. Esta interacção do foro político com o religioso acabou por se revelar de benefício comum. Além de assegurada a independência, a

\footnotetext{
A autoria destas nove esculturas foi atribuída por Carlos Moura ao genovês Filippo Parodi (Moura, 1988), e por Teresa Vale ao romano Ercole Ferrata (Vale, 2005). Relativamente à datação, parece-nos que Teresa Vale está mais próxima da verdade, ao indicar a década de 70, e não a de 80, como apontara Carlos Moura (Vale, 2005: 25). Contudo, não deixa de ser estranho que António Carvalho da Costa, na sua Corographia Portugueza, publicada em 1712, não refira sequer a existência da capela, na sua descrição minuciosa do dito convento (Costa, 1712:645-646), o que pode manter em aberto a questão da datação.

2 Sobre este assunto veja-se SALDANHA, Nuno,"A Iconografia das Santas Portuguesas da Ordem de Cister - Sancha, Teresa e Mafalda", Arte e Arquitectura das Abadias Cistercienses nos séculos XVI, XVII e XVIII, Actas do Congresso, Alcobaça, Novembro/1994, reed. em SALDANHA, Nuno, - Artistas, Imagens e Ideias na Pintura do Século XVIII - Estudos de Iconografia, Prática e Teoria Artística, Lisboa, Livros Horizonte, 1995.
} 
paz com a Espanha permitiu também o regresso à normalidade das relações com a Santa Sé, sem as quais estes processos não poderiam obter o sucesso que tiveram.

O primeiro cenóbio a revelar esta iniciativa junto da cúria romana foi o Mosteiro de Jesus de Aveiro, pela mão da sua prioresa, Dona Filipa de São Tiago, que nomeia como procurador da causa Frei Manuel Mascarenhas, prior da vizinha Igreja da Misericórdia naquela cidade.

O processo foi apresentado à Sagrada Congregação dos Ritos, e examinado pela Comissão de introdução da Causa da Beatificação ou Canonização, a 10 de Julho de 1688 (embora o processo já estivesse formado Auctoritate Ordinaria, por volta de 1622) (Bayam, 1727: 471). O Papa Inocêncio XI instruiu então o Bispo de Coimbra, D. João de Melo, a formar o processo de suas virtudes e milagres, dirigindo-se este a Aveiro no ano seguinte.

Entretanto, o tempo foi passando, a Inocêncio XI sucede Alexandre VIII, e depois, Inocêncio XII. Em Aveiro, Madre Ana de Belém substitui Filipa de São Tiago, e Frei Manuel Mascarenhas regressa a Portugal, deixando como procurador em Roma o Padre Frei Paulino Bernardino.

Depois de diversas instâncias, muitas cartas e súplicas, do próprio D. Pedro II, do Bispo de Coimbra, do Provincial da Ordem, prelados e nobres, o Papa acabou por a beatificar solenemente em 1693, como consta da bula Sacrosancti Apostolatus cura, de 4 de Abril (tendo-o feito dois anos antes por Vivae vocis oraculo). Para o sucesso do mesmo, contribuiu em muito o soberano, e o Bispo de Coimbra, que suportaram as elevadas despesas inerentes. A estes, bem como à rainha Maria Sofia, ao Geral da Ordem, Frei António Cloche, e ao referido procurador, se deveu a rapidez com que foi decretado o Ofício Divino do seu dia, o que sucedeu logo no ano seguinte (9 de Junho).

As grandes encomendas artísticas em louvor à recém-beatificada princesa têm início por esta altura. Sabemos que Pedro II, por ocasião da trasladação das suas relíquias, mandou imediatamente lavrar em Lisboa o seu novo túmulo, que custou ao soberano a soma de doze mil cruzados: “hum soberbo Mausoleo de pedra e finíssimos jaspes, que mandou vir de Itália com ricos lavoures, e embutidos de varias, e engraçadas cores, tão excellentes, que excedem às mais elegantes, e primorosas pinturas" (Bayam, 1927:476-477). O túmulo foi levado para Aveiro em peças, por mar, por Frei Pedro Monteiro, então prior do convento, em 1698. Por morte do dito padre, e outras dificuldades, a referida trasladação só ocorreria em 1711, reinando D. João V.

Terá igualmente sido por volta desta data que o referido prior da igreja dominicana da Senhora da Misericórdia de Aveiro, Frei Manuel Mascarenhas, resolveu encomendar as pinturas para o cadeiral da mesma. Este já se encontrava concluído desde 1675, por mão de Domingos Lopes, mestre de arquitectura do Porto (Brandão, 1984, I:425-426; Ferreira, 2005: 


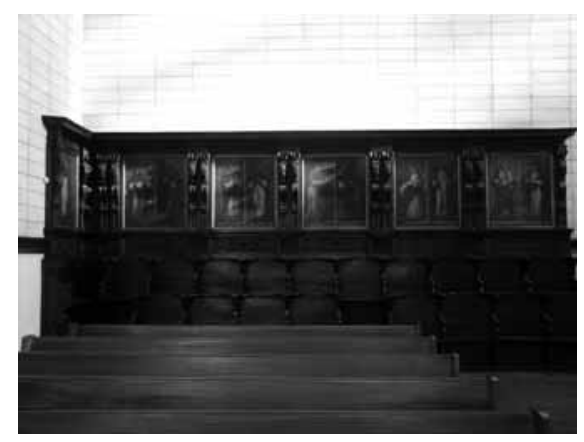

1.1694-1706 Odazzi, Cadeiral Epístola, S Aveiro.

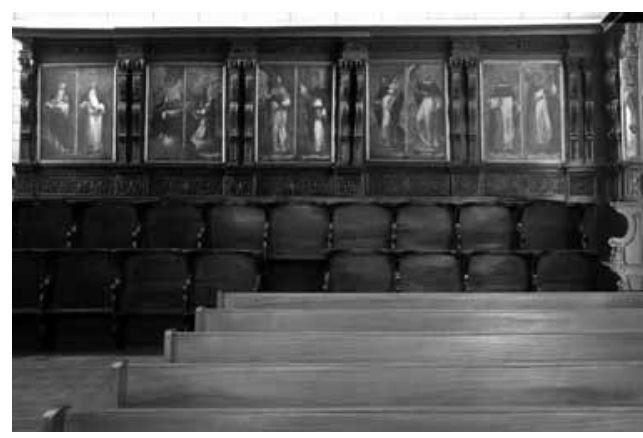

2. 1694-1706 Odazzi, Cadeiral Evangelho, S Aveiro.

106-108), e colocado primitivamente junto ao arco cruzeiro, numa disposição orientada de modo inverso ao actual. Constituído por duas ordens de cadeiras decoradas com máscaras humanas e considerado por Robert Smith como original e extraordinário (Smith, 1968: 39), era, segundo Nogueira Gonçalves, inicialmente revestido a folha de ouro (Nogueira Gonçalves, 1959: 109).

Por cima do cadeiral, foram posteriormente colocadas várias pinturas, representando os vários dignitários, pontífices, santos(as), beatos(as), mártires e virgens da Ordem de São Domingos, cuja identificação nos parece a seguinte: do lado do evangelho (não esquecer que actualmente se encontram em posição invertida), São Domingos de Gusmão (na parede do fundo), ladeado (da direita para a esquerda) por São Pedro de Verona e Beato João de Colónia, São Jacinto de Cracóvia e São Raimundo de Penaforte, Papa Bento IX e Santo Alberto Magno, Santa Inês de Montepulciano e Santa Catarina de Siena, Beata Ossana de Mântua e Santa Luzia de Siracusa. Liderando o lado da epístola, encontra-se São Tomás de Aquino, seguido (da esquerda para a direita) por São Vicente Ferrer e Beato Tiago de Mevânia, Beato Ambrósio de Siena e Beato Gonçalo de Amarante, Beato Papa Pio V e Santo Antonino de Florença, Beata Margarida de Sabóia e Beata Margarida de Castelo, Santa Rosa de Lima e Beata Princesa Joana de Portugal. De frisar que se trata de um conjunto de doze pinturas, e não de 22, como por vezes tem sido interpretado, dado que, para além das figuras tutelares de São Domingos e São Tomás, todas as outras se encontram representadas aos pares, sendo a própria pintura a fingir a existência de uma moldura a separá-las. [Figs. 1 e 2]

As obras encontram-se em deficiente estado de conservação, sobretudo as do lado do evangelho, cuja parte inferior praticamente desapareceu. Este facto, precisamente por ali se encontrar a legenda original que identificava cada uma das figuras, tem suscitado 
algumas dificuldades e erros de leitura. Entre elas, está a de Ossana Andreasi de Mântua, beatificada por Inocêncio XII em 1694, por vezes interpretada como sendo Lúcia de Narni V.O.P., beatificada por Clemente XI em 1710. Em alguns pontos, a sua iconografia apresenta de facto algumas semelhanças, como a presença de estigmas, embora esse aspecto não esteja figurado na pintura do cadeiral. No entanto, também os outros atributos de Ossana (coroa de espinhos, coração cruciforme na mão, lírio, o demónio a ser calcado) se encontram igualmente ausentes, enquanto a representação de Lúcia de Narni, segurando o Menino, é bastante comum. Será precisamente a questão da datação que nos leva a identificar a figura como sendo Ossana, dado que a beatificação de Lúcia é posterior à data da execução dos painéis do cadeiral.

Para além das questões de identificação iconográfica, coloca-se também a das atribuições de datação e autoria. Relativamente à primeira, sabemos que em 1706 já os quadros se encontravam nos respectivos lugares, como o comprova Frei Lucas de Santa Catarina na sua Quarta Parte da História de São Domingos. Efectivamente, o cronista da ordem, ao falar do recheio da igreja, menciona expressamente o"retabolo encostado (obra de talha bem dourada) repartido em molduras de quadro, em que se veem os Santos da Ordem com aquella valentia e propriedade com que o pincel Romano se costuma dar a conhecer por todo o Mundo" (Santa Catharina, 1846, III: 193). Embora a obra tenha sido publicada apenas em 1732, este excerto foi escrito em data bastante anterior. Isto é confirmado, não apenas por as licenças do Santo Ofício, do Ordinário e do Paço, terem sido emitidas em 1708 e 1709, mas porque o próprio autor, ao longo do texto, se refere explicitamente ao ano de 1706 (Santa Catharina, 1846, III: 101), mormente quando fala do mais recente cenóbio fundado pela Ordem de São Domingos, o convento de Santa Joanna Princeza, em Lisboa: "Esta he a ultima fundação, que nos deu asumpto até este anno de 1706 em que vamos escrevendo" (Santa Catharina, 1846, III: 238).

Posto isto, como limite de execução, teríamos o ano de 1706, portanto tratando-se de obra ainda dos finais do reinado de Pedro II. Existem ainda outros aspectos que comprovam esta baliza cronológica. Uma delas foi recentemente apresentada por Mons. João Gonçalves Gaspar, que cita a obra de Frei Lucas, mas que tem a ver com as personagens representadas no cadeiral, mais concretamente a figura do Papa Pio V, onde, na legenda respectiva, se lê ainda nitidamente "B. Pivs Pont. Max.", ou seja, ele é representado ainda como beato, e não como santo, o que só sucede a 22 de Maio de 1712.

No entanto, como vimos, podemos recuar mesmo alguns anos a esta última data. Para além das referências de Frei Lucas de Santa Catarina, é a própria figuração da beata Joana de Portugal que nos dá a indicação de estarmos frente a uma obra de época anterior ao reinado de D. João V. [Fig. 3, p. seguinte] Se olharmos para o brasão real ali representado, 


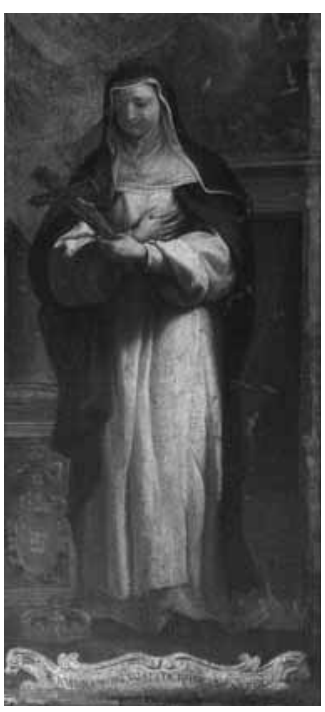

3. 1694-1706 Odazi, Santa Joana Princesa.

ele dá-nos uma indicação de que só poderia ter sido pintado antes da morte de Pedro II, em Dezembro de 1706, dado que é o seu escudo que ali está figurado. Efectivamente, este soberano adaptou-o às mais recentes modas da sua época, passando a coroa a ter cinco hastes, em vez de apenas três (como a que se encontra caída, em primeiro plano). O seu filho, D. João V, promove igualmente nova actualização dos respectivos ornamentos, passando a coroa a ser forrada de um barrete vermelho, e o escudo terminando em bico contracurvado, o chamado "escudo francês".

Determinados os limites máximos para a sua execução, em 1706, e tendo a princesa Joana sido beatificada em 1693 (e Ossana de Mântua em 1694), o conjunto deve situar-se entre este intervalo de tempo, possivelmente mais próximo da data em que foi decretada a extensão do seu culto (Semiduples para todo o clero, Duples a todos os Pregadores de São Domingos).

Estabelecidas as fronteiras cronológicas possíveis da execução, vejamos em seguida a questão da autoria. Nogueira Gonçalves, que percebera a excelente qualidade da mesma - do desenho, dos panejamentos e da luz -, atribui-a a um pintor de Lisboa, embora executada com base em gravuras estrangeiras (Nogueira Gonçalves, 1959: 109). Essa opinião é partilhada por António Costa Ferreira (Ferreira, 2005: 163-164), mais recentemente, conquanto as considere apenas inspiradas, e meramente copiadas das referidas gravuras, que permanecem por indicar. Depois disso, um investigador de responsabilidade chegou mesmo a aventurar a curiosa hipótese de as atribuir ao pintor francês Pierre-Antoine Quillard, que trabalhou em Lisboa entre 1728 e 1733, argumento prontamente rebatido pelo referido Mons. João Gonçalves Gaspar.

Olhando para a obra, podemos efectivamente perceber que se trata de um conjunto de pinturas cuja origem não poderia naturalmente ser local, ou mesmo nacional, mormente em confronto com o que se fazia na época. Certamente de origem italo-romana, como indica Frei Lucas de Santa Catarina, ela é provavelmente fruto de uma encomenda de Frei Manuel Mascarenhas, prior da referida igreja, por intermédio do procurador em Roma, Padre Frei Paulino Bernardino que, como vimos, foram precisamente os primeiros mandatários na causa de beatificação da Princesa Joana, ali já representada de acordo com o seu novo estatuto.

As afinidades de estilo, bem como da proximidade com a clientela portuguesa deste período, sustentam uma possível atribuição ao pintor Giovanni Odazzi (1663-1731), que 
executará posteriormente outras obras para o nosso país, quer em empreendimentos de características similares (processos de beatificação de Teresa, Sancha e Mafalda), como veremos, bem como para a prestigiosa basílica joanina de Mafra. Ele acaba assim por ser dos primeiros pintores de escola romana a trabalhar para Portugal ${ }^{3}$, logo na viragem para Setecentos, actividade que manteve até bem perto da data da sua morte.

Menos dúvidas, quer de datação, quer de autoria, nos revelam os processos seguintes, das filhas de Sancho I, por intermédio dos cenóbios cistercienses que, de igual modo, promoveram a difusão da pintura italiana em Portugal.

O processo de beatificação de D. Sancha iniciou-se em 1634, mas, dados os atrasos provocados pela Guerra de Independência, o assunto caiu no esquecimento. Novamente retomado em 1700, por vontade das próprias freiras de Lorvão, acabaria finalmente por ser beatificada com sua irmã, a 13 de Setembro de 1704, por Clemente XI.

Apesar de beatificada na mesma altura, o processo de Teresa é bastante anterior, tendo já D. Sebastião encarregue do processo D. Manuel de Meneses, Bispo de Coimbra e Conde de Arganil.Com o desastre de Alcácer-Quibir (morrendo o rei e o mesmo bispo), a iniciativa permaneceria no esquecimento. Em 1595 inicia-se novo processo, por meio dos prelados cistercienses, mas que não chega a ser enviado a Roma.

O sucesso da canonização de Santa Isabel, por Urbano VIII em 1625, como vimos, moveu as freiras de Lorvão a retomarem a causa de Teresa. Dado que o seu corpo se encontrara nas mesmas condições que o de Santa Isabel, moveu-se novo processo em 1634. Novamente as Guerras da Restauração fariam gorar as tentativas, que recomeçariam em 1695.

Foi então que se nomeou como procurador desta nova demanda o Doutor Frei Bernardo de Castello-Branco (fal. 1725), futuro Geral da Ordem de São Bernardo, cronista-mor do Reino e membro da Academia Real de História. Deslocou-se então a Roma (c. 1693-95), munido de amplos poderes, concedidos pelo Abade Geral da Ordem, Frei João Paião, num processo que decorreu até 13 de Setembro de 1704. Levava com ele várias cartas para Inocêncio XII e para a Sagrada Congregação dos Ritos, do rei D. Pedro II, da rainha e de vários cardeais.

Também o empenho pessoal da Abadessa Dona Joana Sarmento, e o das freiras de Lorvão, foi significativo para o bom andamento da causa, tendo elas acarretado todos os custos. Mais de dez anos passados sobre a beatificação, em 1715, a então abadessa, D. Bernarda Telles de Menezes, queixava-se de ter pago quarenta mil cruzados no processo, acrescentando que, em grande parte, o gasto tinha sido supérfluo.

3 Para Portugal, e não para uma clientela portuguesa, dado que se conhecem diversas encomendas a pintores italianos, de instituições e particulares, como vimos anteriormente. 
Frei Bernardo de Castello-Branco, durante a sua estadia na cidade pontifícia, encomendou diversas obras, algumas das quais chegam a Portugal nos inícios de Setecentos. Assim, desde o primeiro quartel do século, já aqui se encontravam diversas pinturas de origem romana, bem como as gravuras correspondentes ali impressas, circulando depois um pouco por toda a parte. O grande impacto que se fez sentir no meio artístico nacional é comprovado pelas diversas cópias a que deram origem.

Talvez não por acaso, o pintor escolhido foi novamente Giovanni Odazzi, cuja reputação se encontrava então em plena ascensão e que foi dos primeiros pintores de escola romana a laborar para a clientela lusitana. A Frei Bernardo cabe, assim, a responsabilidade da nova iconografia das beatas, bem como da correspondente difusão do novo gosto pictórico romano.

Odazzi nasceu a 25 de Março de 1663, em Roma, na Via Larina, filho de Giacomo, natural de Milão, e da romana Palma Francesca De Patriciis. Parece que ainda jovem terá trabaIhado por algum tempo com o mestre Bloemart. No entanto, mais inclinado para a pintura, acaba por estudar com Ciro Ferri e, tal como era habitual, inicia-se neste ofício, copiando as obras do mestre. Após a morte de Ferri (1698), muda-se para a oficina do prestigiado Giambattista Gaulli, acompanhando-o na execução de grandes frescos, técnica que depressa acabaria por dominar e que viria a influenciar a sua arte.

A sua primeira grande obra pública teve lugar ainda em finais de Seiscentos, ao realizar três frescos para a igreja de Santa Maria Aracoeli - Adoração dos Magos, Fuga para o Egipto, David. Mais tarde, executa duas novas obras para as ilhargas de uma capela em S. Salvatore in Lauro (Martírio de São Pedro e Queda de Simão Mago). Segundo parece, o agrado com que estas foram recebidas terá tornado o seu nome mais conhecido, o que lhe proporcionou novas encomendas para igrejas romanas - São João dos Genoveses, Santo Estêvão del Cacco, Santa Maria della Scala e São Salvador.

Entre as diversas obras que realizou ainda em finais do século XVII, destaque para a Aparição de Nossa Senhora a São Bruno, fresco de influência fortemente marattesca, para a Igreja cartuxa de Santa Maria dos Anjos, em 1699. Esta pintura tem sido considerada modelar para os seus trabalhos posteriores ${ }^{4}$. Bastante elogiada entre a opinião geral, destacava-se a apreciação do Cardeal Albani que, no ano seguinte, ascende ao trono pontifício como Clemente XI (23 de Novembro de 1700). Segundo refere Pascoli (cf. Pascoli, 1735), esta obra terá contribuído em muito para lhe granjear um prestígio internacional, sobretudo no tocante à pintura a fresco. 
Em 1705, pinta duas telas para a Igreja de S. Bernardo alle Terme (Virgem e Santos, Visão de São Bernardo), que constituem os seus melhores exemplos do rococó romano, tornando-se assim um dos protagonistas do panorama artístico do Papa Clemente XI. De facto, virá a participar nas maiores encomendas do seu tempo, como a decoração da Igreja de São Clemente (1714-1716) e a de São João de Latrão (Profeta Oseias, 1718).Depois de já ter sido nomeado"virtuoso del Pantheon",em 1692, alguns anos mais tarde, em Dezembro de 1706, é admitido na Academia de São Lucas.

Nos primeiros anos do século XVIII, pinta para o Arcebispo de Palestrina (1635-1709), o cordovês Luís Manuel Fernandez Portocarrero-Bocanegra y Moscoso (Santo Ildefonso e O Êxtase de Santa Teresa), iniciando assim os primeiros contactos com uma clientela peninsular ${ }^{5}$.

É precisamente por esta altura, no início do pontificado de Clemente $\mathrm{XI}$, e últimos anos do reinado de Pedro II, que Odazzi recebe as primeiras encomendas de Portugal, figurando as novas imagens das recém-beatificadas infantas, Teresa e Sancha. Dada a sua estreita ligação a cenóbios cistercienses, não é de descurar a hipótese de terem sido precisamente os monges bernardos daquela igreja romana a indicar o seu nome ao procurador português.

A importância do trabalho de Odazzi para o nosso país, mais do que a qualidade das obras, ou do contributo pioneiro para a renovação do estilo e do gosto pictórico nacionais, deriva simultaneamente do lugar que acabará por ocupar no desenvolvimento da iconografia nacional, em particular no das santas e beatas portuguesas.

Uma das imagens mais divulgadas foi precisamente a Aparição da Beata Sancha à Beata Teresa, de que existe uma versão na capela de Santo António, na Igreja de Santo António dos Portugueses em Roma. Dela nos fala o cronista José Pereira Baião, em 1727: "Quando forão Beatificadas ella (Sancha) e sua Irmãa (Teresa), se pintarão em Roma ambas juntas em fórma muyto vistosa, e engraçada. Està Santa Sancha em huma nuvem, como que dèsce do ceo, com a mão esquerda aponta para o mesmo Ceo, e com a direyta abraça a Santa Theresa, que esta absorta, e ellevada nas glorias da Irmãa, com os braços abertos, e meyo levantados, ambas em pé vestidas da mesma sorte, e muy resplandecentes, acompanhadas de Anjos, e dous de cima de huma nuvem as coroão com grinaldas de flores" ${ }^{\prime 6}$. [Fig.4, p. seguinte] Esta representação, em que aparecem apenas as infantas D. Sancha e D. Teresa, deriva do facto de apenas elas terem recebido a sua beatificação em 1704. Não deixa de ser original esta nova representação de D. Sancha, uma vez que a sua iconografia habitual,

\footnotetext{
Sabemos que no tempo de D. Pedro II, na galeria do Paço da Ribeira, feita por ocasião da vinda de Carlos III a Portugal, existia um retrato do Cardeal Luís Emmanuel Portocarrero, ainda como Arcebispo de Toledo.

6 BAYAM, Joseph Pereyra (1727), Portugal Glorioso, E Illustrado, com a Vida, e Virtudes das Bemaventuradas Rainhas Santas..., Lisboa: Off. de Pedro Ferreyra, pp. 54-55.
} 


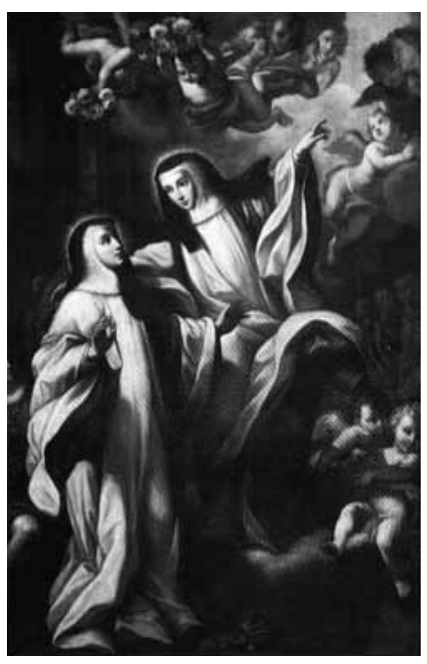

4. 1704 c Giovanni Odazzi, Beata Teresa e Sancha, ST Antonio Roma.

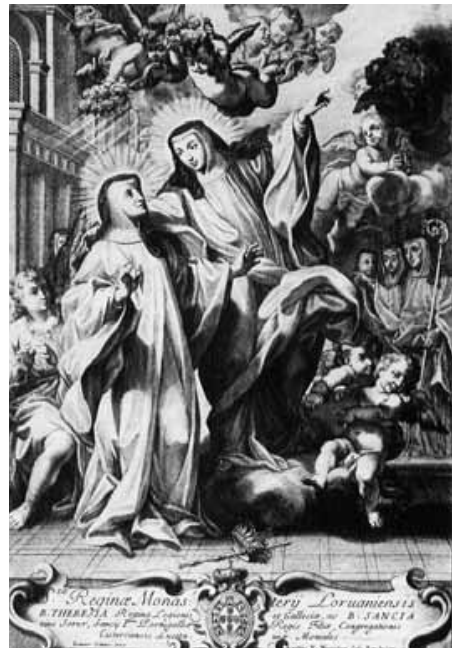

5. 1704 c Giovanni Odazzi, Beata Teresa e Sancha, gravura de Arnold Van Westerhout.

como "mostrão as pinturas antigas" (Bayam, 1727:38), estava sobretudo relacionada com a visão dos Mártires de Marrocos, que sucedera no Paço de Alenquer.

O quadro executado por Giovanni Odazzi foi posteriormente gravado por Arnold Van Westerhout (1651-1725) [Fig. 5], conhecido gravador de Antuérpia estabelecido em Roma desde 1700, tendo trabalhado por diversas vezes para a coroa portuguesa, de que se conhecem os retratos de D. Pedro II, de Curvo Semedo e do Padre António Vieira.

Esta circunstância favoreceu o grande número de cópias que dele se fizeram ${ }^{7}$, através das referidas gravuras, diversas vezes mencionadas por Baião. Apesar de desconhecermos quando foi impressa a gravura de Westerhout, ela é certamente anterior a 1715, como o comprova uma carta da abadessa de Lorvão, Bernarda Telles de Meneses. Datada desse ano (15 de Fevereiro de 1715), ali se refere a vontade de enviar a Baião“huma das Estampas, que vierão de Roma em papel Imperial".

7 Entre as cópias mais conhecidas, podemos enumerar o pequeno cobre que actualmente se encontra no museu episcopal da Sé do Porto; a tela de André Gonçalves na Igreja do Menino Deus, em Lisboa; duas versões no Mosteiro de Celas, em Coimbra (uma delas talvez se trate de um estudo ou de cópia enviada de Roma pelo Dr. Bernardo de Castello-Branco); e ainda uma outra, em Salzedas (cf. Saldanha, 1990; 1994). O mais interessante é o cobre existente no antigo Paço do Porto, muito possivelmente o modelo romano de Odazzi, enviado para Portugal, ou trazido posteriormente por Fr. José Maria Fonseca e Évora, quando da sua nomeação para o bispado daquela cidade. 
Também entre 1704 (ou talvez 1713, dado que é quando a concessão do "Termo de Reza e Missa" é estendido a "todo o reyno e domínios") e 1719, Frei Bernardo de Castello-Branco ofereceu a D. João V um quadro, representando as filhas de Sancho I, de execução romana, para ser colocado na Basílica Patriarcal. Devido às enormes dimensões do mesmo, seria depois substituído por outro mais pequeno (antes de 1719), onde as princesas eram figuradas ao lado de Santa Joana e Santa Isabel ${ }^{8}$ (Saldanha, 1995: 183).

Não sabemos exactamente de que obra se trata, pois a referência de Baião é ambígua, e o quadro entretanto desapareceu. Desconhecemos igualmente se estariam ali representadas as duas ou as três infantas. No entanto, é certo que, para além da pintura, tam-

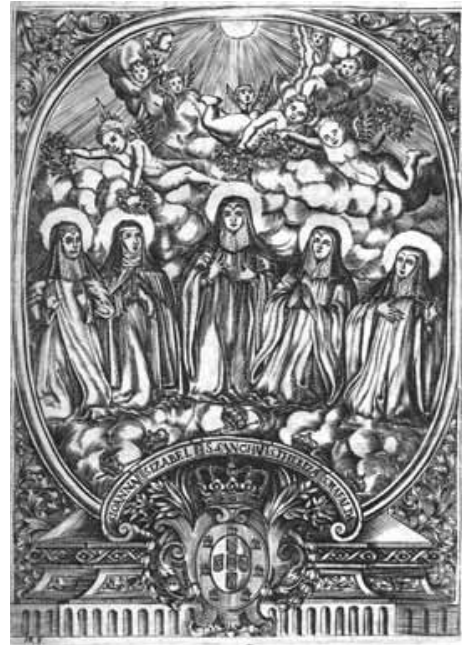

6. 1727 Manuel Freire, Beatas de Portugal, Portada. bém foi impressa em Roma uma versão em gravura, dada a qualidade e o agrado com que a mesma foi recebida, como o atestava Baião a Frei Bernardo, em 1719: "Tambem deve V.R. mandar estampar as ditas Santas no principio do Livro na fórma, que se estampàrão em Roma, para mais as dar a conhecer, e afervorar a devoção; porque está linda a pintura." (Bayam, 1727: §§§ 4).

Para além disso, o próprio Baião acabaria por mandar gravar uma imagem onde estavam representadas as três infantas:"com Estampas, que mandey fazer, das Santas todas tres juntas" (Bayam, 1727: Prologo), que ele próprio se encarregou de distribuir por Lorvão e Arouca. Além desta gravura, conhecemos ainda outra, feita à semelhança do novo quadro da Patriarcal, alinhando aquelas com Santa Isabel e Santa Joana, que viria a servir de portada da sua obra. Trata-se de uma fraca gravura a buril, executada pelo português Manuel Freyre, bem distante da qualidade das feitas anteriormente em Roma [Fig. 6].

Alguns anos depois, já em 1737, a Congregação da Igreja de Santo António dos Portugueses recebia um pedido de Martinho de Sousa, para se fazer "hua copia de 4 palmos das Santas Freiras Bernardas que estão na Capella maijor da parte do Euangelho [...] e

8 Carta de Joseph Pereyra Bayam ao Reverendíssimo Padre Doutor Fr. Bernardo de Castello-Branco, 9 de Setembro de 1719:"... na S. Bazilica Patriarcal, aonde na nova reformação, que nella se fez, se pintárão em huma Capella juntas com Santa Isabel, e Santa Joana, em lugar do fermoso Quadro de Roma, que V. R. prezentou a sua Magestade, que por sua grandeza se não pòde alli accõmodar" (Bayam, 1727: §§§ 4). 


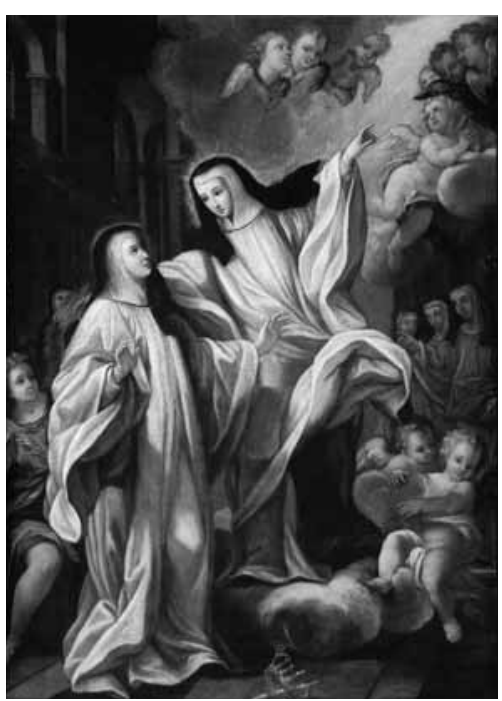

7. 1704 c Giovanni Odazzi, Beatas Teresa e Sancha, Mosteiro de Celas, Coimbra.

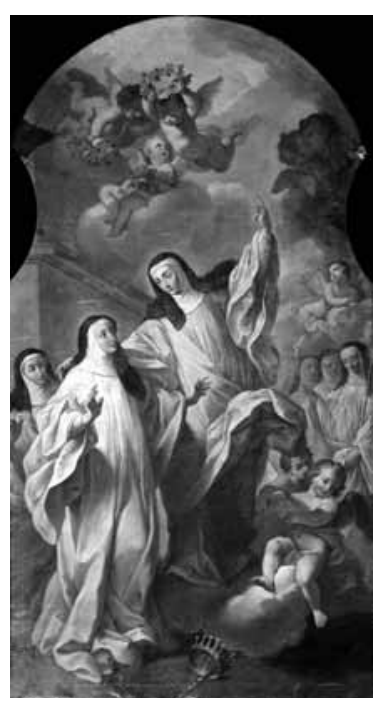

8. 1735 André Gonçalves, Beatas Teresa e Sancha, Menino Deus.

quero que V.M. me mande mas seija a minha custa"9 ${ }^{\prime 2}$. Esta cópia, no seguimento de outra já pedida anteriormente, do quadro de Giacinto Calandrucci figurando Nossa Senhora com o Menino e Santo António, destinava-se a uma sobrinha de Sousa, então professa num convento aqui em Portugal. Embora a documentação não refira o desfecho do pedido, é natural que o pequeno quadro $(c .88 \mathrm{~cm})$ tenha vindo para a referida sobrinha, identificável com alguma das várias versões existentes, possivelmente a que está em Celas ${ }^{10}$ [Fig. 7].

O caso do processo de D. Mafalda revelou-se bastante mais complicado, e a sua beatificação só se concretizaria em 1792. As fontes mostram que tinha sido bastante difícil a beatificação de Teresa e Sancha ao mesmo tempo, quando alguns membros mais críticos defendiam que o privilégio fosse concedido a apenas uma delas. $O$ sucesso das três candidaturas revelava-se assim quase impossível, ainda para mais dada a falta de meios disponíveis por parte do convento de Arouca.

9 Carta de Martinho de Sousa, 7 de Março de 1737. AIPSAR, Libro di copie di lettere della Ven. Chiesa et Ospedale di S. Antonio de Portughesi di Roma, 1733-48, fol. 48.

10 Para além das versões existentes já referidas, a de André Gonçalves para a igreja do Menino Deus em Lisboa tem a curiosidade de representar as três beatas, incluindo assim Mafalda. Naturalmente, o pintor inspirou-se na versão encomendada para a Patriarcal Joanina, dado que não nos parece possível que o artista assumisse a responsabilidade de tal “liberdade iconográfica” [Fig. 8]. 
No entanto, isto não impediu que D. Mafalda também acabasse por ser figurada, como vimos, ao lado das irmãs, e mesmo em outras obras particulares. Isso deve-se também ao facto de que, desde 1700, data em que é apresentada a causa da sua canonização, a Sagrada Congregação dos Ritos em Roma tenha dado licença para se pintar a sua imagem.

Assim, similarmente de comprovada origem romana é a representação de um dos milagres da Beata Mafalda, existente em Arouca. Efectivamente, também a abadessa de Arouca, Dona Elena de Robles, não quis que a princesa da sua devoção ficasse esquecida. E, logo em 1720 (13 de Setembro), confirma a origem da execução dos quadros do seu mosteiro, assim como das correspondentes gravuras, numa carta a Pereira Baião: "Fico a V.M. muyto obrigada pela remessa das

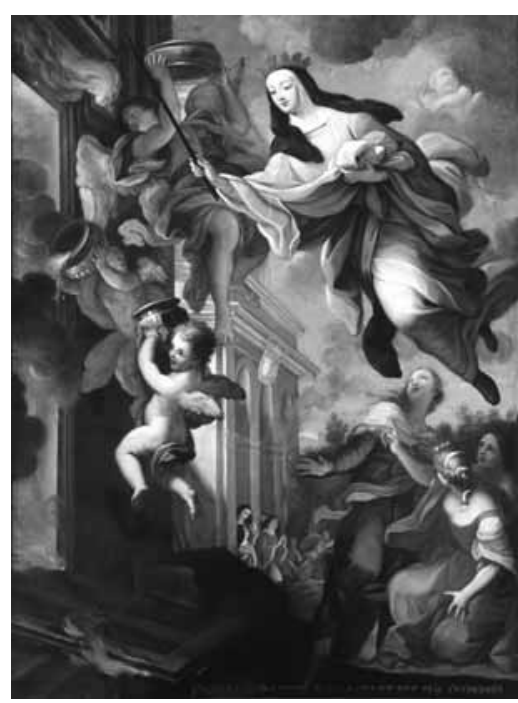

9. 1704-25 Giovanni Odazzi, Beata Mafalda salva convento do incêndio, Museu de Arouca. Estampas; e suposto, que este Mosteyro tem os seus Quadros feytos em Roma, não deixo de agradecer esta atenção de V.M. e o cuydado de fazer mais notorios os seus nomes".

Embora geralmente consideradas como obras da segunda metade do século XVIII, são diversas as provas de que a sua realização remonta a data bastante anterior. Em primeiro lugar, o facto de Baião a descrever, de forma perfeita, na sua obra terminada em 1726 (impressa no ano seguinte):"A fórma da pintura he esta. Està a Santa rainha em huma nuvem vestida no habito de religiosa, Coroa na cabeça, com a mão esquerda prende o habito, e o une ao peyto, e com o seu bordão na direyta faz o sinal da Cruz sobre o mosteyro, que se abraza em chammas; acompanhão-na muytos Anjos lançando agua no fogo, e representa o sucesso do primeyro milagre, que fica referido acima" (Bayam, 1727:216) [Fig.9].

Por outro lado, igualmente comprovativo de uma execução ainda dos inícios de Setecentos, é o facto de a mesma ter sido apresentada por Frei Bernardo de CastelloBranco ao papa Clemente XI. Ora, se o pontífice romano faleceu em 1721, Frei Bernardo também não deve ter regressado a Portugal muito depois de 1711, ficando assim claramente estabelecidos os limites cronológicos da sua realização.

As duas pinturas existentes no Museu do Mosteiro de Arouca representam o milagre de Mafalda quando de um incêndio do dito convento. $O$ primeiro, em que a beata se encontra elevada nos ares, corresponde inteiramente à descrição dada por Baião. O segundo trata-se provavelmente de uma segunda versão da mesma história, mas com uma iconografia 


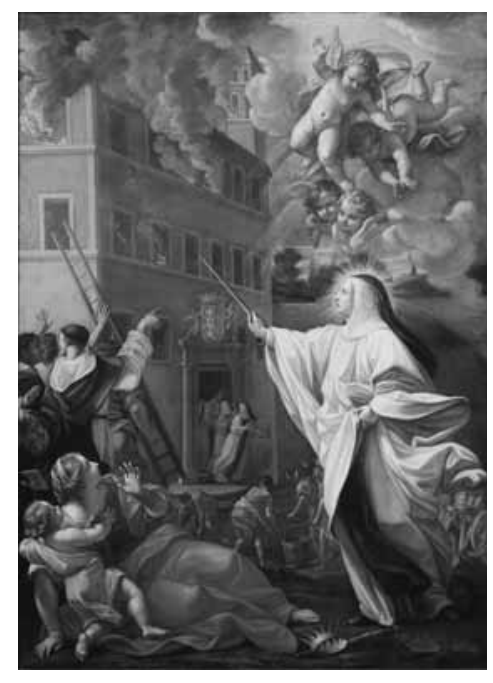

10. 1704-25 Giovanni Odazzi, Beata Mafalda salva convento do incêndio, Museu de Arouca.

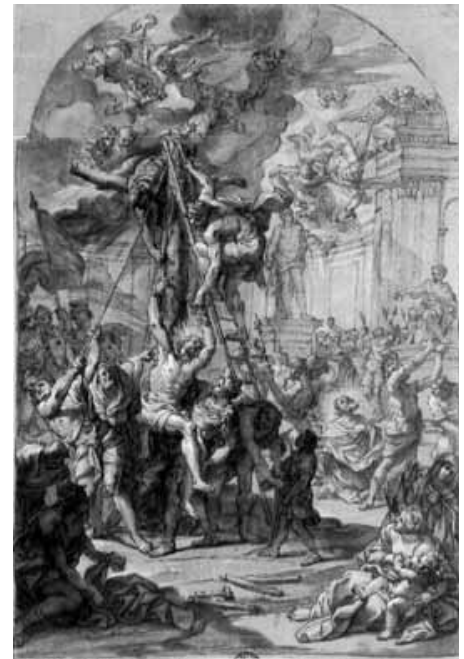

11. 1714 Giovanni Odazzi, Martírio de Filipe e Tiago Menor, Kustmuseum, Dusseldorf.

e tratamento bem diverso, mais "naturalista" e menos retórico. Efectivamente, aqui não há intervenção dos anjos, e quem contribui para a extinção do fogo são alguns frades e populares, o que lhe concede um efeito mais dramático, acentuado pelo toque mais evidenciado do convento em chamas. Neste, Mafalda não aparece coroada, tendo os atributos reais (ceptro e coroa) colocados a seus pés (atributos semelhantes aos da Beata Teresa) [Fig. 10].

Um dos aspectos, deste segundo quadro, que permite associar a sua factura a Giovanni Odazzi são as figuras em primeiro plano, do lado esquerdo, representando uma mulher segurando o filho, clara derivação da Caridade. Se invertermos a posição destas figuras, elas são muito idênticas às representadas num desenho de Odazzi, representando o Martírio dos apóstolos Filipe e Tiago Menor ${ }^{11}$, datado de 1714 [Fig. 11]. Segundo Dieter Graf, trata-se de um estudo dum quadro para um dos altares da igreja dos Santos Apóstolos em Roma (Bowron \& Rishel, 2000: 537-538), enquanto, para Jesus Urrea Fernandez (Fernandez, 1977: 287), de um esboço para o quadro Martírio de Santo Agapito, pintado para a catedral de Toledo em 1708.

11 Desenho existente no Graphische Sammlungen do Kunstmuseum Düsseldorf im Ehrenhof. 


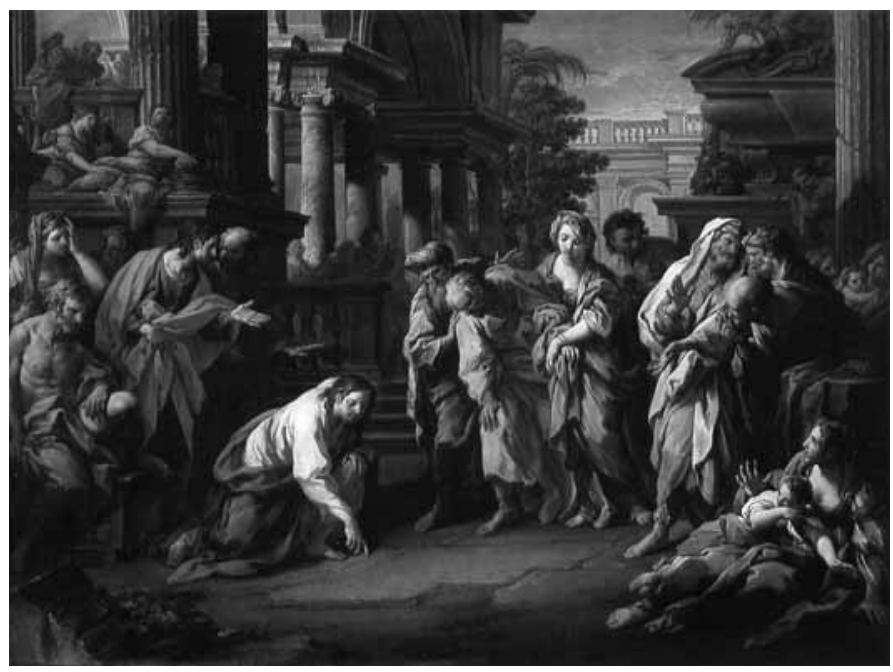

12. 1741 Sebastiano Conca, Cristo e a mulher adúltera, CP Washington.

Efectivamente, estas figuras são bastante semelhantes nas duas obras de Odazzi, o que é um claro sintoma duma reutilização de recursos em diferentes momentos, pelo que não destoaria vê-las no quadro da Beata Mafalda. No fundo, estas tipologias recorrentes acabam por se converter em modelos clássicos da pintura, dado terem sido tomadas de um quadro do seu mestre G. B. Gaulli (A continência de Cipião, Palácio Dória, Génova). Alguns anos mais tarde, também o célebre Sebastiano Conca retomaria esta figura (e a mais próxima da pintura de Odazzi), numa obra figurando Cristo e a mulher adúltera [Fig. 12].

Naturalmente, na "versão portuguesa", as duas personagens aparecem-nos bastante mais vestidas que nas outras obras, onde a mulher deixa de segurar no seio, afastando-se assim da tradicional imagem da Caridade. Em verdade, havia que ter em conta o meio mais conservador, e o facto de que a pintura se destinava a um cenóbio de freiras.

Para além destas figuras, sobressaem nas telas de Arouca os movimentos suaves das composições de Odazzi, as cores esbatidas derivadas da técnica do fresco, ou os panejamentos dobrados em longas pregas.

Ora, como pudemos ver, com o desenvolvimento desta sucessão de necessidades de representação, associadas ao prestígio das mais recentes figuras do hagiológio lusitano, das ordens religiosas que as patrocinaram, e da imagem do próprio país, inicia-se assim um 
processo tendente à generalização dos modelos pictóricos romanos. Este irá receber forte impulso ao longo do reinado de $\mathrm{D}$. João $\mathrm{V}$, com a consequente aceitação e crescimento de um novo gosto, de teor mais classicista, que ultrapassaria os ditames mais estritos do seiscentismo barroco.

Efectivamente, assistiremos à expressão de idênticos valores estéticos e vertentes do gosto nacional, em diversos conventos e igrejas do país, e que fazem parte dum amplo movimento, conducente à introdução do novo estilo.

Conforme referia Sandra Vasco Rocca, começam a concretizar-se as relações culturais entre Roma e Lisboa, que colocavam a capital portuguesa na órbita romana, segundo um processo de assimilação-emulação que, no segundo quartel de Setecentos, atingiria o maior sucesso, de acordo com as expectativas de D. João V e da sua corte (Borghini e Rocca, 1995: 289).

No entanto, esta ascensão do primado da cultura visual romana tende a manifestar-se ainda antes da subida ao trono do Magnífico, durante os reinados de Afonso VI e Pedro II'

Por outro lado, também não cremos, como muitas vezes parece suceder na historiografia italiana, que o papel de Lisboa se tenha resumido ao de uma espécie de província periférica da "escola romana". Para além da ligação a outros centros artísticos, é facto assente o papel dinamizador e impulsionador que tiveram mecenas, encomendadores, ou coleccionadores portugueses, no desenvolvimento da própria arte italiana, mormente num período em que o mecenato papal decrescera de modo significativo relativamente aos séculos precedentes (cf. Haskell, 1980).

12 Efectivamente, Sandra Vasco Rocca considera que esta mudança, da cultura espanhola para a romana, se estabelece apenas a partir da morte de Pedro II, resultado, segundo esta investigadora, da afirmação nacional portuguesa, apenas consolidada após o tratado de Utreque, em 1713, e do influxo das riquezas do Brasil (Borghini e Rocca, 1995: 289). 


\title{
Relance sobre a iconografia da padroeira de Aveiro: de 1470 (?) a 2008
}

\author{
Mons. João Gonçalves Gaspar*
}

\section{Introdução}

Na qualidade de aveirense e ministro da Igreja, apraz-me registar o interesse da organização do ciclo de conferências /conografia Religiosa das Invocações Nacionais pela figura da Princesa Santa Joana, venerável Padroeira da cidade de Aveiro. De um modo sucinto, irei apontar algumas brevíssimas efemérides biográficas de Santa Joana e, num curto relance, enunciar alguns testemunhos iconográficos.

\section{Pintura quatrocentista}

Filha de D. Afonso V, rei de Portugal, e de sua mulher e prima co-irmã, a rainha D. Isabel, D. Joana nasceu na cidade de Lisboa, em 6 de Fevereiro de 1452, logo jurada e aclamada como Princesa e Herdeira do Trono; o nascimento de D. João em 1455 fê-la perder esse título, embora os coevos e pósteros persistissem no trato de Princesa. O País, desde 1415,

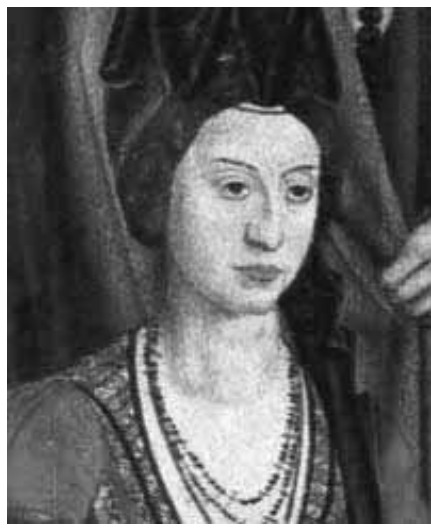

Rainha D. Isabel (?)

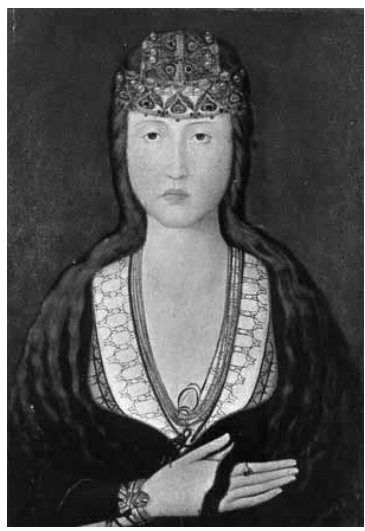

Princesa Santa Joana (c. 1470)

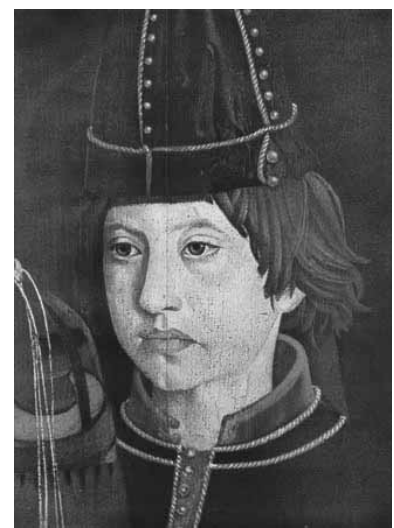

Príncipe D. João

* Diocese de Aveiro. 
vivia o período dos sonhos e grandezas da epopeia dos Descobrimentos, em que os portugueses se davam corajosamente a uma actividade pioneira e protagonista na globalização mundial dos povos e no encontro de culturas e civilizações. Órfã de mãe aos três anos e dez meses de idade, foi entregue aos cuidados da infanta D. Filipa, sua tia materna e senhora muito culta, e de D. Brites de Meneses, viúva de Aires Gomes da Silva, segundo senhor de Vagos e governador de Lisboa. Desde menina, procurou praticar as mais edificantes virtudes humanas e cristãs, tanto no desprendimento das grandezas da Corte e das facilidades do mundo, como na profunda piedade e vida interior, na franca devoção à paixão de Cristo e na sincera caridade em favor dos pobres e dos necessitados. Para manifestar tal género de sentir e de viver, escolheu por distintivo pessoal a coroa de espinhos. Simultaneamente, foi-se instruindo na cultura humanista do tempo, de nítida influência italiana - que era apanágio dos reis e dos príncipes da Dinastia de Avis.

Graças ao singular prestígio de que gozava o Portugal quatrocentista na Europa de então, era lógico que as filhas e parentes próximas dos nossos reis fossem pretendidas como esposas de infantes e de príncipes estrangeiros, até porque tais casamentos faziam parte importante de negociações políticas entre os Estados, estando acima dos interesses dos indivíduos. D. Joana não seria excepção; uma sua contemporânea no Mosteiro de Jesus de Aveiro - soror Margarida Pinheira ou soror Catarina Pinheira - escreveu no chamado Memorial, que é uma verdadeira biografia:

«Voaua por todas as partes da Crystindade a ffama da grãde excellẽcia da fremosura e ỹdustria do entẽder e saber desta Ifãte princesa. $E$ a todos reys e principes de diuerssos Regnos poynha ẽ grãde cobijça e desejo de a veer e ouvir. E porque Ihes era ĩpossivel por a distancia e alonguamẽto dos regnos e terras, mãdauã pĩtores muỹ perfeytos que a vissẽ e tirassẽ per ho natural, pera poderẽ assy pyntada gozar de tanta fremosura. Antre os quaes foy o muỹ serenissymo Luys, rey de França, primo de ell rrey dõ Affonsso, padre da dita Senhora. E ho ĩperador d Alta Lemanha, cunhado seu, casado cõ hũa Irmãa do dito rey dom Affonso. Certificauã e jurauã os pyntores nõ podijã nẽ tijnhã sciẽcia pera poder penetrar e pyntar tanta graça e fremosura. Porem cõtudo trabalhauã por a afemẽçar e pĩtar. Del rrey de França seu tyo se afirmou que, vẽedo a pĩtura a qual se diz era muito natural, que, postos os giolhos ẽ terra, deu graças e louuores ao Senhor Deus. Começarõ algũus reys e princepes de a demandar a el rrey, seu padre pera casamento, aos quaes por entom nõ daua conssẽtimẽto por sua tenrra jdade, o qual aĩda entom nõ penetrava ho consselho diuinal, que nõ de rey terreal mas do celestrial e eternal avia de seer sposa.» (fl., $50 \mathrm{r}$ a - $50 \mathrm{v}$ a).

«Era de jdade de quinze annos; e cantos a vijã julgauã seer de vĩnte cynco, tã grãde ẽ statura e fremosura era» [...] e de «grãde prudẽcia e saber.» (Memorial, fl. 50 v b; fl., 56, r a). 
«Era no rostro e corpo muỹ aposta, a frõte muito graciosa, os olhos verdes mũi fremosos, ho naryz meaão e de boa ffeiçã, a boca grossa e revolta, rosto redondo, ho caram aluo cõ algũa canta quer coor bẽ posta, muito fremosa gargãta e maãos maes do que se podesse achar e veer a ninhũa outra molher, alta e grãde de corpo dereyto, muỹ aposto e ayroso, aa vista e reprẽsentaçã de grãde senhora e estado.» (fl. 56 ra-56 rb).

Este texto - como se referiu - foi extraído do manuscrito conservado pelas religiosas dominicanas no espólio do seu Mosteiro de Jesus e, após 1911, no do Museu Nacional de Aveiro. O documento apenas seria publicado na sua totalidade em 1939, graças ao trabalho em colaboração do Dr. António Gomes da Rocha Madaíl e do Dr. Francisco Ferreira Neves, com o título Crónica da Fundação do Mosteiro de Jesus de Aveiro e Memorial da Infanta Santa Joana, Filha de El-Rei Dom Afonso V.

A mencionada descrição parece harmonizar-se com os traços fisionómicos da magnífica pintura também guardada no dito Museu, que talvez se possa datar de 1471, ou pouco antes; de um autor anónimo, obedeceu aos princípios da escola portuguesa do pintor régio Nuno Gonçalves. As próprias feições são análogas às dos seus familiares, particularmente às do seu irmão, o «Príncipe-Perfeito» e futuro rei $D$. João II, tais como nos aparecem no «Painel do Infante».

Sendo assim, presume-se que se trata da primeira figuração da linda e jovem Princesa, decerto encomendada ou consentida por seu pai para circular pela Europa, na qual ela nos é revelada em todo o esplendor e riqueza da Corte e à moda da sua época, com o ajustado cromatismo nos traços multicolores e com as adequadas particularidades nas abundantes jóias de ouro e tecidos raros.

Vestem-na graciosamente uma decotada camisa de cambraia bordada a retrós de seda preta, um corpete de brocado com guarnições a ouro, um vestido aberto mas apertado por um trogalho escuro no extremo do recorte, um grosso cordão de ouro em quatro voltas como principal adorno caindo sobre o peito, um anel precioso no indicador da mão direita, uma fita de pano entrelaçada como pulseira, um toucado cintilante de pérolas, safiras e rubis... Mas o que sobretudo transparece da policromia é uma atraente e rara beleza na suavidade da face oval em tez rosada, na ternura do olhar de bondade e de misticismo, na proporção do nariz levemente alongado, na graciosidade da pequena boca e dos lábios recurvados, na alvura acetinada do pescoço e do colo, no peculiar encanto dos ombros descaídos, nos pormenores dos louros cabelos compridos descendo em ondas soltas sobre o busto, na ligeira indicação dos seios com especial delicadeza, no detalhe da mão aristocrática em forma alongada, na esbelta elegância de um corpo alto e bem proporcionado - atributos estes que denunciam a sua nobre ascendência da Família dos Lencastres e da Dinastia de Avis. 
No dia 19 de Março de 1490, poucas semanas antes de morrer, a Princesa redigiu o próprio testamento (Memorial, fl. 92, va); entre as diversas disposições, deixou «aa Senhora minha tya [D. Filipa] ho vulto», além de legar o «roby grãde do anel ao princepe meu Senhor» e «a meu sobrinho ho pendẽte das tres pedras e ho pendẽte da esmeralda». Contudo, o retrato continuou em Aveiro e, passados quase duzentos anos, precisamente em 1687 no decurso do processo de beatificação, o bispo de Coimbra D. João de Melo, aquando de uma visita ao Mosteiro de Jesus enamorou-se dele e, para o retirar do possível culto durante os autos e com o consentimento das religiosas, levou-o para o paço episcopal, onde o teve por algum tempo. De facto, sendo de valor incalculável, esta obra, só por si, vale uma viagem a Aveiro - como em 1895 escreveu Joaquim de Vasconcelos, abalizado crítico de arte.

No mês de Dezembro de 1471, contando dezanove anos de idade, com a permissão do pai, a Princesa recolheu-se no Mosteiro de Odivelas, das monjas bernardas, apesar das reclamações dos procuradores das cidades e vilas do Reino. Deste modo, até foi possível suprimir as despesas que o Erário Régio despendia com a manutenção do Paço da Rainha, em São Cristóvão, onde D. Joana vivia "com tam grande casa de donas e donzellas e offyciaaes como se fora rainha" - conforme fora determinado pelo monarca aquando da morte de D. Isabel, sua mãe. O descuidado cronista Rui de Pina, que a isto se refere (Crónica de D. Afonso V, CLXVIII), também diz que, com o encerramento do Palácio, evitar-se-iam «alguns escandalos e perjuyzos que em sua Casa por nom ser casada se podiam seguir.» D. Afonso V saberia defender a dignidade da filha de qualquer má fama ou de um provável ambiente menos próprio, resultante da vida menos correcta de um ou outro dos servidores e servidoras.

Após a permanência de sete meses em Odivelas, a Princesa dirigiu-se para a então pobre e insalubre vila de Aveiro, apesar da resistência do irmão e dos nobres da Corte, teimosamente decidida a defender a sua liberdade de opção como jovem e como mulher; e, em 4 de Agosto de 1472, deu entrada no Mosteiro de Jesus, a que ela chamava «a sua Lisboa, a pequena».Cumprindo desta forma a sua vocação precoce, aí viveu em austeridade claustral e em fervor religioso, vestindo o hábito de São Domingos até à morte, ocorrida em 12 de Maio de 1490, quando contava apenas trinta e oito anos e três meses de idade. O cadáver da extinta foi então sepultado em campa rasa, no coro de baixo do mesmo Convento, contíguo à respectiva igreja, satisfazendo-se assim o desejo que havia manifestado.

Pelo teor do seu modesto viver, norteado pela fé coerente em Deus e pela abnegada caridade em favor do próximo, ela foi definida como «excelente Infanta e singular Princesa» e a lembrança colectiva logo a considerou como uma pessoa adornada por extraordinários valores de santidade. Rui de Pina (Crónica de $D$. Afonso $V$, idem) escreveu que «sem casar com nome de onesta e muy virtuosa, acabou despois sua vida»; Garcia de Resende (Crónica de D. João II, XXII) também informou que «solteira sem casar, com vida e obras 
de muy virtuosa e catholica Princesa, se finou», acrescentando ainda que fora "singular Princesa, de muytas virtudes, bondades e perfeições, muyto catholica, deuota e amiga de Deos e muy obediente a el Rey seu irmam» (Idem, CXVI); e Damião de Góis (Crónica do Príncipe D. João, XXXIII) acrescentaria que viveu no Mosteiro de Jesus, de Aveiro, «até que Deos houve por seu serviço a chamar desta vida para a sempiterna, [...] deyxando de si singular exemplo de virtudes, com hum nome de verdadeyra e catholica christãa.»

Depois do falecimento, o povo de Aveiro - que não apenas as religiosas do Mosteiro - começou a venerá-la e a denominá-la de «santa» e, mais tarde, acabou por a escolher como sua especial amiga e protectora junto de Deus - como o fora durante a vida, lutando pela liberdade e pelos direitos dos seus habitantes. Em consequência, o aniversário da sua morte não era nem seria comemorado com as habituais orações de sufrágio por uma defunta, mas com velas acesas, perfumes e incenso sobre o túmulo, diante da referida pintura do século XV exposta num altar, com o canto solene do Ofício Divino e com a celebração da Eucaristia em que eram usados os textos do «Comum de Todos-os-Santos». No futuro, as referências iconográficas e os escritos biográficos proliferariam em lugares religiosos e em comunidades conventuais, de norte a sul de Portugal. Pela sua parte, os prelados, que disso tinham conhecimento, fechavam os olhos; também alguns deles, convencidos da virtude heróica de D. Joana, se encomendavam ao seu valimento.

\section{Antes da beatificação}

Por outro lado, é evidente que, a partir de então e ao longo destes mais de quinhentos anos, a Santa Princesa tem sido evocada de diversos modos. Assim, ainda antes da beatificação, três biógrafos organizaram a sua vida por escrito, baseando-se no supramencionado Memorial manuscrito. Foram eles:

- Frei Nicolau Dias, com o livro Vida da Sereníssima Princesa Dona Joana, [...], cuja primeira edição é de 1585, segunda edição de 1594, terceira edição de 1674 e edição fac-similada de 1987;

- Frei Jerónimo Roman, com a História de los dos Religiosos Infantes de Portugal [...], D. Fernando e D. Joana, escrita em castelhano e publicada em 1595, na cidade de Medina del Campo;

- e D. Fernando Correia de Lacerda, bispo do Porto, com o volume intitulado Virtuosa Vida e Santa Morte da Princesa Dona Joana [...], impresso em 1674. Além disto, diversos autores deixaram-nos pequenos relatos biográficos, em latim, castelhano, francês e italiano.

Outrossim, nos mesmos séculos XVI e XVII, surgiram diversas figurações pictóricas que representavam a Princesa vestida com o hábito dominicano. Entre elas, destaco a pintura 
mural existente desde 1623 na cidade siciliana de Taormina, no afamado «San Domenico Palace Hotel», instalado num antigo convento da Ordem dos Pregadores, em que a figurada, de rosto erguido ao Céu, lança para o chão uma coroa real, preferindo-lhe a caveira pousada sobre uma mesa. Por outra parte, em 28 de Julho de 1689, no decorrer do processo para a respectiva beatificação, além da referência à pintura em meio-corpo e em trajes seculares, «na forma em que veio para aquele Convento», a qual, segundo o parecer dos «oficiais antigos» António da Mota e Francisco Alberto, era o próprio original e «não cópia dele», registou-se a existência de quatro pinturas:

- uma pequena no coro de cima da igreja conventual, com a coroa de espinhos nas mãos, sobre a qual os peritos disseram ter a idade de cento e oitenta anos, portanto de 1509;

- outra, aureolada e em tamanho grande, no mesmo coro de cima, de corpo inteiro, tendo uma coroa de espinhos e uma palma nas mãos, e três coroas aos pés, feita por um certo Manuel da Costa, da cidade do Porto, em 1675-1677;

- outra na capela dos Santos da Ordem, junto à enfermaria, estampada no tecto oitavado sobre o retábulo do altar, numa envolvência de luz, com três coroas aos pés e uma açucena e um livro nas mãos, que foi atribuída a «António André, pintor da cidade do Porto», mas aveirense ou filho de aveirenses, e executada durante o segundo priorado de soror Mariana de Belém ou Noronha (1625-1629) e por sua ordem, a qual se conserva no Museu Nacional de Aveiro;

- ainda outra entre as janelas da imposta do tecto da igreja conventual também de 1625-1629, data em que foram forradas de azulejo as paredes do templo, pintado o tecto e reformado o alpendre; neste quadro desenharam-se três coroas aos pés e, ao lado, as armas de Portugal, sob a qual, em 1694, vieram a levantar o altar e o retábulo da Venerável.

Nos autos do processo em ordem à beatificação de D. Joana, que decorreu não apenas em Aveiro mas também em Évora e Lisboa, dá-se conta de diversas representações da Princesa, sempre vestida com o hábito dominicano e com um ou mais dos seus atributos. Se se alargasse o inventário, certamente que se encontrariam figurações de Santa Joana em diferentes conventos da Ordem dos Pregadores, tanto masculinos como femininos, executadas antes da beatificação.

Em Évora, no dia 4 de Dezembro de 1688, anotou-se que no Convento de Santa Catarina de Sena, desde tempos antigos, havia um quadro com a imagem pintada com auréola, resplendor e título; no Convento de São Domingos, uma pintura com a designação e outra, com auréola - «pintura a fresco» - numa meia-laranja da escada principal, talvez de 1523; e na sacristia do Convento de Nossa Senhora da Saudação, uma outra pintura.

Em Lisboa, em depoimentos de 2 e 3 de Dezembro de 1689 e de 13 de Janeiro de 1690, apontou-se que no Convento do Salvador e seu noviciado estava um retrato pintado a 


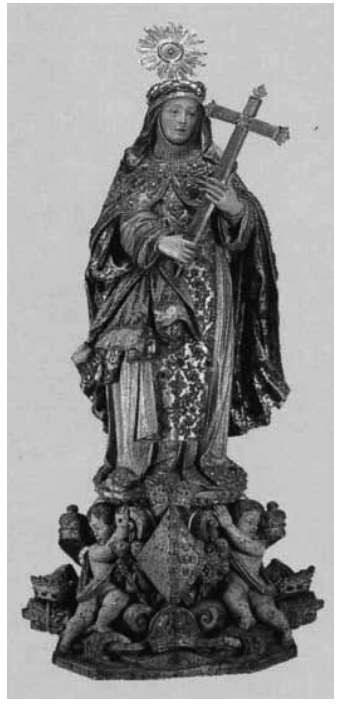

Primeira imagem (1694)

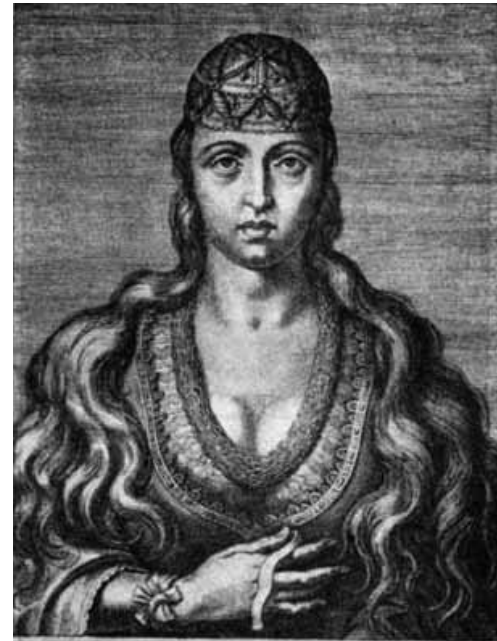

IOANNA PORTVGALLLE PRINCEPS. VIXIT AN. XXXVIII. OBIIT Á.MCCCCXC.

Gravura $\left(1621,1 .^{a}\right)$, Roma

óleo, de quatro palmos, a meio-corpo com hábito dominicano, «de tempo antigo, por lho mandarem da vila de Aveiro, como cópia dos que lá conservão antiquíssimos»; ainda no mesmo convento, num dos flancos do retábulo de uma das capelas da igreja, outra representação, identificada aos pés com o seu nome; no Convento da Anunciada, uma imagem «pintada em huma porta de hum nicho em forma de oratório», tendo aos pés as armas reais de Portugal; no Convento de São Domingos, numa parede de uma das capelas da igreja, «huma effigie de meo corpo, pintada em painel de pano com suas molduras negras», com o crucifixo na mão, para o qual inclinava o semblante, tendo no alto as letras «B. Joanna Ord.Pred. filia Regis Portugaliæ»; e também no mesmo Convento, no dormitório, outra pintura com a coroa de espinhos na cabeça e a auréola de Bem-aventurada.

Igualmente se conhecem da época anterior à beatificação pelo menos cinco figurações da Princesa gravadas a buril, inspiradas no retrato quatrocentista:

- uma de 1621, incluída na primeira edição do famoso Anacephalæoses, id est, summa capita actorum regum Lusitaniæ, texto que teve por autor o padre António de Vasconcelos, sacerdote da Companhia de Jesus, onde os traços do retrato excederam a delicadeza do modelo quatrocentista;

- outra de 1630,já iniciado o primeiro processo para a beatificação, publicada por Jacques de Fontnay entre uma série de retratos régios portugueses, sob o título Brief recueil des vies et moeurs des roys et reynes de Portugal [...] - Extrait de divers auteurs; 
- outra de 1639, patente no livro do monsenhor João Caramuel Lobkowitz, saído do prelo em Antuérpia sob o título Philippus prudens Caroli V, imp., filius Lusitaniæ, Algarbiæ, Indiæ, Brasiliæ Legitimus Rex demonstratus;

- outra de 1685, inserida num dos livros dos Bolandistas (grupo de jesuítas que redigiu a inestimável obra Acta Sanctorum [...], em cinquenta e seis volumes in-fólio e que tomou o nome do seu iniciador, o padre Jean Bolland, de Antuérpia), onde ao cimo se desenhou uma estrela, lendo-se no rodapé, entre rosas e açucenas, que a gravura foi feita naquele ano por Philibertus Bouttats Junior;

- e ainda outra de 1693, «vera efígie» no traço delicadíssimo de Cataldus, em meio-corpo, com a cabeça irradiando luz, a coroa de espinhos junto ao peito e uma cruz pousada sobre uma caveira assente numa mesa de onde cai a coroa régia, a qual ilustra a Breve narratione della vita della Beata Giovanne principessa di Portogallo.

\section{Depois da beatificação}

Este movimento popular, em face de tal halo de santidade, fez naturalmente pensar na possível beatificação da serva de Deus - o que felizmente haveria de acontecer. Depois de um demorado processo de dezenas de anos, o culto imemorial, que lhe era prestado desde a primeira hora, foi reconhecido, sancionado e superiormente permitido pelo papa Inocêncio XII, com o breve Sacrosancti apostolatus cura, de 4 de Abril de 1693.

Como seria de prever, logo após a beatificação da Princesa, aconteceram festas em sua honra, quer em Aveiro e em Lisboa, quer noutras localidades do País. Em Aveiro surgiu a lembrança - senão mesmo a necessidade - de que fosse esculpida em madeira uma imagem de Santa Joana para o culto litúrgico. Encomendada a sua execução, talvez inspirada em qualquer das pinturas existentes no Convento, a escultura não demorou a estar pronta de tal forma que, uma vez apresentada em público, pôde ser conduzida em triunfo na procissão de 12 de Maio de 1694 e ser colocada num retábulo próprio, então magnificentemente levantado no templo conventual, em frente da entrada exterior. A representação, vestida com o hábito dominicano e primorosamente estofada a ouro, tem a coroa de espinhos na cabeça e pousa numa peanha enriquecida por anjos, pelo seu brasão e por brasões reais. A par da ícone da centúria quatrocentista, também a referida escultura começou a servir de fonte inspiradora de outras figurações futuras. Passados brevíssimos anos, para prevenir que não se danificasse essa imagem pela sua utilização nas procissões, executou-se uma outra em roca e mais leve - trabalho de inspiração italiana, que se apresenta com o hábito albi-negro da Ordem Dominicana, confeccionado em cetim e bordado profusamente a ouro, o qual, já deteriorado pelo uso, foi substituído há pouco tempo por 
um mais modesto. Esta segunda imagem consta no catálogo oficial de 1859, decretado pelo Ministério das Finanças.

Sem parança, após a beatificação, também se curou da redacção dos respectivos textos e orações para a festa litúrgica; procedeu-se ao riquíssimo trabalho em talha dourada de arte barroca, tanto na sala onde a Princesa havia falecido e no coro de baixo onde fora sepultada, como sobretudo na igreja conventual de Jesus; multiplicaram-se pinturas e quadros azulejares que retratam vários episódios da sua vida; ergueu-se a monumental fachada exterior do Mosteiro de Jesus - o que deu um aspecto de grandiosidade ao conjunto de modestos edifícios, conferindo-lhe simultaneamente uma unidade no estilo setecentista.

Tratou-se ainda, com particular desvelo, da execução de um mausoléu para condignamente acolher os restos mortais da Princesa. Para a sua concepção, foi escolhido o notável arquitecto lisbonense da Casa Real, João Antunes (1643-1712), cujos honorários foram pagos pelo próprio monarca D. Pedro II, o qual magistralmente planeou e minuciosamente acompanhou o trabalho da sumptuosa jazida. A obra, iniciada em 1698, terminou em 1709; para aí se trasladaram as relíquias dos ossos em 1711, os quais - segundo o exame de 1 de Junho de 1750 feito por peritos, nomeadamente pelo Dr. Brás Luís de Abreu, médico e sacerdote, aquando do processo para a canonização (Memorial cit., fl. 180 v) - constam "da caveira, queixo de baixo com dous dentes, canas das pernas e brassos e mais ossos insignes e muitos dos pequenos." No essencial, o sepulcro, assente sobre um bloco de pedra, é uma arca rectangular com base e cornija, cuja separação é feita nos extremos das faces por mísulas alongadas e finamente trabalhadas. São vários os elementos decorativos e os símbolos religiosos, que enriquecem a osteoteca em cada uma das quatro faces, como a cruz, a coroa de espinhos, a palma, o lírio, as flores e as ramagens. Em baixo e aos cantos, quatro querubins, alados e de braços erguidos, seguram-na e «transportam-na» ao céu e a fénix; no centro, aponta o renascer «ex cínere»; como remate superior emerge, também suportado por anjos, o brasão português, encimado pela coroa real, entre volutas. Magnífico e admirável exemplar de entalhados multicolores de mármore, embutidos com suma delicadeza e perfeição, é no seu género uma peça incomparável no embrechado, equilibrada no desenho e adequada ao barroco nacional.

Facto de extrema importância para a solenização pública das festas anuais foi a posterior provisão régia, com data de 12 de Fevereiro de 1807, onde se determinou que a procissão fosse considerada real. Por isso, nela tomariam parte os membros do Senado da Câmara, o qual nomearia as pessoas para pegarem no pálio e nas alfaias principais, bem como determinaria o giro regular e decente da mesma procissão. Os autarcas também assistiriam à Missa com as insígnias municipais. 


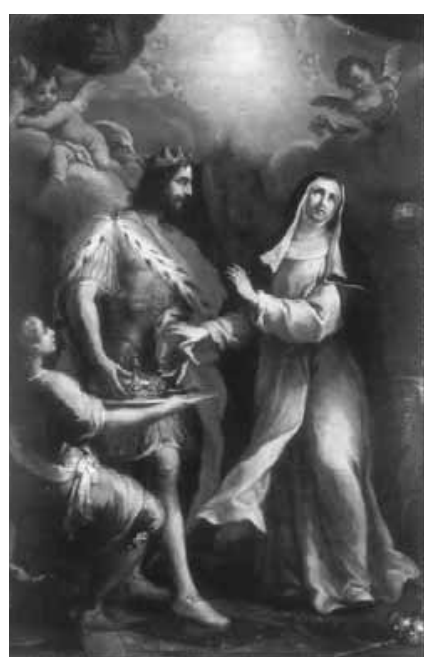

Cerruti (início do século XVIII)

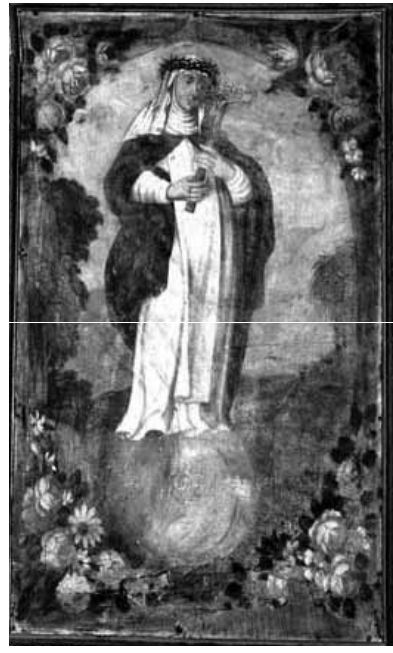

Vila Nova de Gaia

Mas, desde a beatificação da Princesa, nos séculos XVIII, XIX e XX, ao lado de muitas publicações biográficas que foram aparecendo - umas expressamente em livros e outras menos ou mais desenvolvidas em enciclopédias, revistas, breviários litúrgicos e santorais -, multiplicaram-se as representações de Santa Joana não apenas em Aveiro, mas também em diversas localidades, mesmo além-fronteiras. Vários artistas, cada um com a inspiração do seu talento e com a riqueza da sua perícia, têm concebido e interpretado a efígie da Princesa, quer em trajo de Corte quer em hábito de São Domingos, na tábua, no azulejo, no vidro, na tela e no papel; uns tantos têm-na entalhado na madeira, modelado no barro, cinzelado na pedra, figurado no bronze, ou gravado no ouro, na prata e no cobre; até mesmo crianças, adolescentes e jovens têm-na figurado em traços singelos mas reveladores da sua afeição.

Começo por referir a pintura a óleo num dos cadeirais da antiga igreja do Convento de São Domingos - actual Sé de Aveiro - pintura essa que nos vem de 1694-1706 e que faz parte de um conjunto de oito santas e catorze santos da Ordem dos Pregadores. Sobre esta colecção hagiográfica escreveu frei Lucas de Santa Catarina, em 1708 (História de S. Domingos, parte IV, livro I, cap. XXIX), afirmando que aí se representam os «santos da Ordem com aquela valentia e propriedade com que o pincel romano se costuma dar a conhecer por todo o mundo».

Também aludo às três pinturas patentes em Roma: 


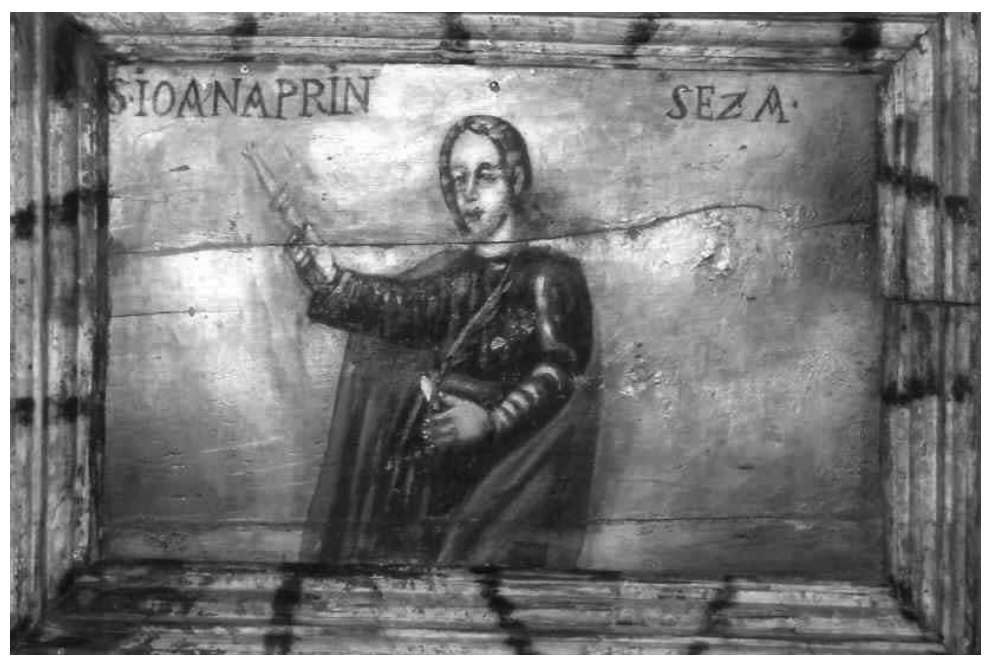

Vila Nova de Paiva (século XVIII)

- uma no tecto da basílica de Santa Anastácia, no Palatino - templo profundamente restaurado e enriquecido pela generosidade do nosso cardeal D. Nuno da Cunha e Ataíde, aquando da sua estadia nessa cidade em 1721-1722;

- e as outras duas na igreja de Santo António dos Portugueses, na abóbada e na capela-mor. Esta, de grandes dimensões, vem-nos dos primeiros anos do século XVIII, deve-se ao génio artístico do conhecido pintor Michelangelo Cerruti (1666-1748) e lembra-nos a atitude de el-Rei D. João Il a teimar com a irmã para anuir a uma das hipóteses de casamento, prontamente recusada com decisão.

Não olvido a galante e insólita pintura de 1710-1715, cujo original é atribuído ao italiano Giovanni Battista Pachini, pintor romano que viveu e trabalhou no Porto, onde faleceu em 1740; Santa Joana é retratada com uma criança nos braços - talvez o sobrinhito D. Jorge, que ela criara e educara desde os três meses de idade. Há diversas variantes deste quadro, quer no Museu Nacional de Aveiro, no Mosteiro beneditino de São Martinho de Tibães e na Reitoria da Universidade de Coimbra, quer numa moradia da família Rodrigues da Graça em Águeda, numa casa particular em Abrantes e na Quinta do Pombal em Santarém.

Uma particularidade de interesse aparece na tela do extinto Convento do Corpus Christi, em Vila Nova de Gaia: a irmã Joana é retratada como noviça dominicana, usando não apenas a túnica e o escapulário mas também o véu totalmente brancos. De facto, ela foi constrangida a interromper o noviciado claustral de preparação monástica; mas, no mesmo dia em que tal aconteceu, obteve da prioresa a anuência para continuar a usar sempre o 
mesmo hábito por devoção. Se nos aparece vulgarmente retratada como religiosa professa, com a túnica e o escapulário na cor branca e com o véu na cor preta, será por singular veneração de quem sempre a quis ver na plena concretização do seu ideal, e não como "freira sem profissão" - segundo escreveu frei Luís de Sousa (História de S.Domingos, parte II, livro V, cap. VI).

Outra particularidade, que não deixo passar em claro, é a tábua setecentista, entre as demais de santos e santas que guarnecem o tecto da nave da igreja matriz de São Sebastião de Vila Nova de Paiva, do Distrito de Viseu e da Diocese de Lamego. A execução do conjunto foi confiada a um artista de limitados recursos, ao contrário do trabalho no tecto da capela-mor - este com figuras bíblicas da árvore genealógica de Cristo, cujo desenho e colorido revelam um pincel experimentado. A Princesa, com identificação escrita, aí nos aparece na representação oficial, segurando um ceptro na mão direita, além de um livro e de uma palma na mão esquerda; de facto, coube-lhe aquela responsabilidade, meramente formal, na ausência do pai e do irmão durante a terceira campanha militar em Marrocos, nos meses de Agosto e Setembro de 1471.

À maneira de exemplo, não esqueço de apontar apenas três gravuras:

- uma a buril, inserta na segunda edição de Anacephalæoses, feita em 1793 na Imprensa da Universidade de Coimbra;

- outra também a buril, incluída na colecção dos Retratos e elogios dos Varões e Donas que ilustraram a Nação Portuguesa em virtudes, armas e artes, assim nacionais, como estranhos, tanto antigos, como modernos, impressa em 1817;

- e ainda outra, esta em madeira, de Francisco Pastor que, em 1880, ilustrou a segunda edição da História de Portugal, de Manuel Pinheiro Chagas.

Avanço nos anos e passo ao lado de tantas figurações antigas!... Eis algumas:

- no Mosteiro da Batalha, uma escultura setecentista em madeira, de muito bom corte, tendo na mão direita uma caveira e aos pés as três costumadas coroas da realeza;

- nas igrejas dominicanas de Monserrate, em Viana do Castelo, e de Cristo Rei, no Porto, com as vestes de freira - esta talvez proveniente do extinto Convento de Santa Joana, de Lisboa;

• em Ponte de Sor (Alentejo), onde,com a designação popular de «Santa Joana Domingas», é invocada como celeste advogada em tempo de seca atroz;

- numa capela particular com a sua invocação, sita na cidade de Ovar, rememorada em imagem do século XVIII;

- as telas do espólio do Museu Nacional de Arte Antiga, em Lisboa, e a da igreja de São Domingos de Elvas - esta, pelas suas características, imediatamente consecutiva à bula da beatificação; 
- a encantadora miniatura em chapa de cobre que, sendo hoje propriedade de uma conhecida família de Águeda, pertenceu a D. José Aves de Mariz que, antes de ser bispo de Bragança (1885-1912), viveu em Aveiro durante algum tempo;

- e o pequeno quadro, também em cobre, que faz parte da colecção do Museu Nacional de Aveiro, onde Santa Joana, vestida de dominicana, tem aos pés o brasão das armas de Portugal.

No limiar do século XIX, decorreu em Portugal o período difícil das Invasões Francesas. $\mathrm{Na}$ aflição decorrente da primeira incursão, iniciada em Novembro de 1807, D. António José

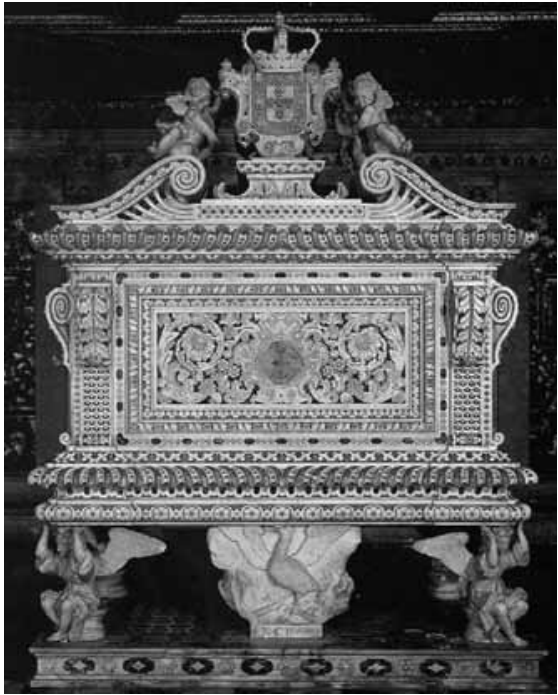

Túmulo de Santa Joana (1698-1709) Cordeiro, bispo de Aveiro e insigne patriota, entusiasmou as pessoas à resistência e ordenou procissões de penitência até ao túmulo de Santa Joana, «a quem já desde o princípio da nossa consternação havíamos tomado por medianeira para com o Pai de Misericórdias» - escreveu em documento circular de 5 de Agosto de 1808. Ele próprio, descalço, sem vestes episcopais e com uma corda pendente do pescoço, em preces comoventes e lágrimas doloridas, juntou-se aos devotos suplicantes que, saindo da sé ou igreja da Misericórdia, acompanhavam piedosamente a imagem do Senhor «Ecce Homo».O antístite daria semelhantes ordens durante as outras duas invasões napoleónicas, que se seguiram em 1809 e 1810 .

Restaurada a Diocese de Aveiro em 11 de Dezembro de 1938, o primeiro prelado, D. João Evangelista de Lima Vidal, logo procurou manifestar o seu agradecimento a Santa Joana, incentivando peregrinações e romagens ao túmulo e animando a veneração litúrgica; ao seu patrocínio, desde o início, tinha sido confiada a pretensão dos católicos em favor do Bispado. E, volvidos vinte e seis anos, o papa Paulo VI, com o breve Sanctitatis Flos de 5 de Janeiro de 1965, atendendo favoravelmente a petição do bispo de Aveiro, D. Manuel de Almeida Trindade, oficializou-a como Padroeira da Cidade e da Diocese de Aveiro, «com todas as honras anexas e privilégios litúrgicos que legalmente competem aos padroeiros principais dos lugares», como se fosse canonizada. O mesmo prelado, em 1969, instituiu a reitoria de Santa Joana, no perímetro da cidade de Aveiro, a qual seria elevada à categoria definitiva de paróquia, precisamente em 10 de Setembro de 1976 - dia em que foi dedicada liturgicamente a sua igreja matriz. 


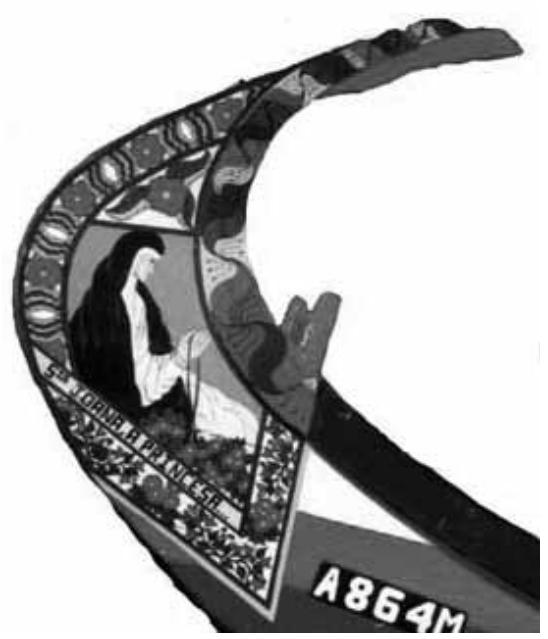

Barco moliceiro, Ria de Aveiro

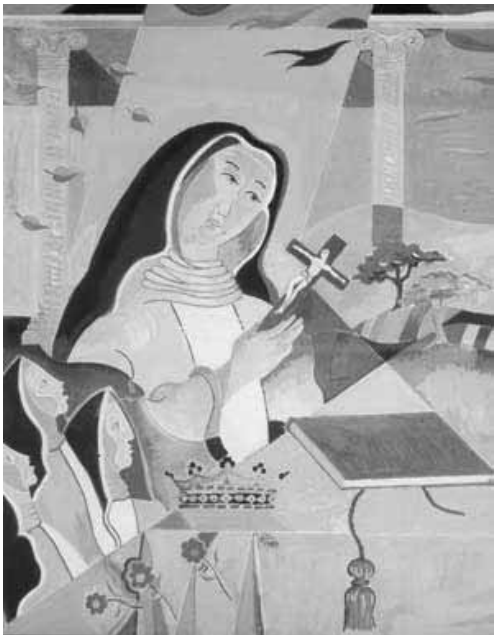

Jeremias Bandarra (cartaz, 1989)

Em Lisboa, o cardeal-patriarca D. Manuel Gonçalves Cerejeira, ao reformular a divisão paroquial da cidade, em 1959 houve por bem criar a paróquia de «Santa Joana Princesa»; o templo e o seu complexo, projectados por Diogo Lino Pimentel, Rita Falcão e Hugo Venado, após muitos trabalhos e canseiras apenas seriam inaugurados em 30 de Maio de 2002.

$E$, entre numerosas comunidades e instituições que a têm como sua titular, quer em Portugal quer no estrangeiro, não posso deixar de fazer duas anotações:

- a pequena freguesia transmontana de Salselas, no concelho de Macedo de Cavaleiros, no Distrito e Diocese de Bragança, invoca Santa Joana como sua singular protectora e assim anualmente a festeja, subalternizando o tradicional padroeiro, que é o mártir São Lourenço;

- e no Brasil, no Estado de São Paulo, na Diocese de São José do Rio Preto, na cidade de Votuporanga, há uma paróquia com o nome de «Santa Joana Princesa».

\section{Depois de 1938}

Para abreviar este meu esboço, detenho-me nos últimos decénios da centúria novecentista. Sobretudo a partir de 1938, deparamos com dezenas e dezenas de representações da Princesa Santa Joana, em diferentes materiais e processos; até há barcos moliceiros a vogar na ria de Aveiro que a ostentam garbosamente nas proas como tutelar das suas lides. 


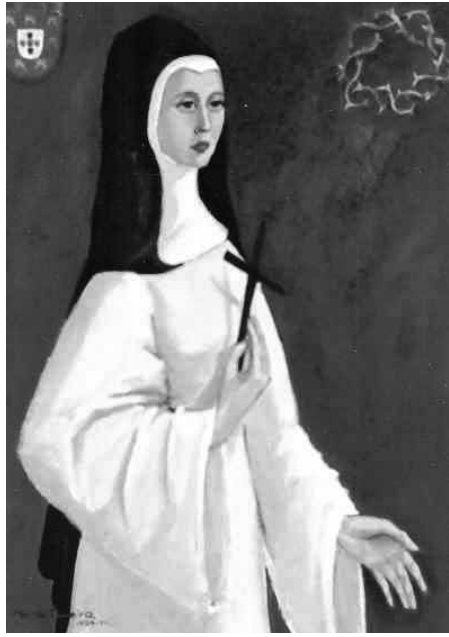

Maria Taveira (1959)

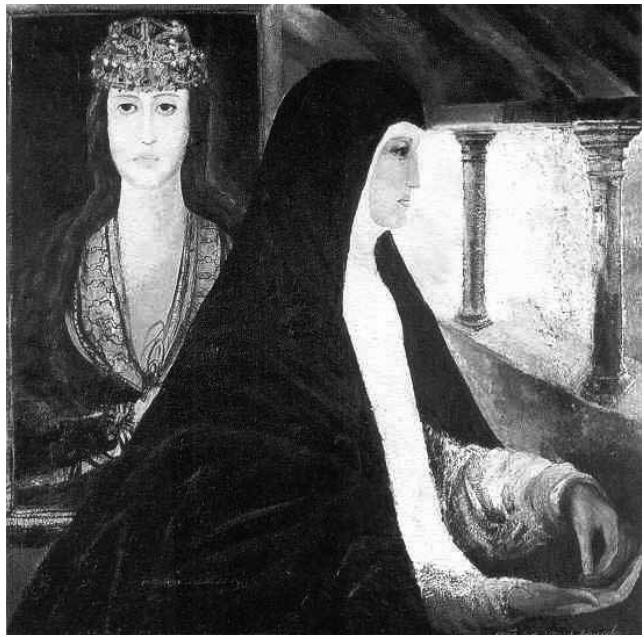

Sousa Araújo (1988)

Não pretendo ser exaustivo nem quero ser enfadonho na enumeração de todas elas - umas de maior mérito e outras de menor interesse. Todavia, sinto-me na obrigação de enunciar alguns espécimes:

- os ex-votos, os registos, as pagelas, os postais, os calendários, os desdobráveis e os cartazes anunciadores de festas ou comemorativos de efemérides - alguns ilustrados especificamente por artistas aveirenses, como Jeremias Bandarra;

- a tela depositada no Museu Municipal do Dr. Santos Rocha, na Figueira da Foz, da autoria de Eugénia Coelho que, em 1943, a recordou na hora da agonia;

- a xilografia de Mons. Augusto Nunes Pereira, ilustre sacerdote de Coimbra, de 1952, figurando a Princesa a olhar para um crucifixo que segura na mão esquerda, com um feixe de luz a iluminar o rosto e com dois querubins a esvoaçar sobre a cabeça;

- os dois selos de correio de 1952, reproduzindo a tábua quatrocentista em cores diferentes, numa edição de quatro milhões de exemplares para um valor uninominal de um escudo e de trezentos e cinquenta mil de três escudos e cinquenta centavos, os quais foram pintados por Martins Barata;

- o retrato feito por Manuel Lapa que João Ameal incluiu no seu livro Santos Portugueses, saído do prelo em 1957;

- a evocação do funeral de Santa Joana, pintado por Emmérico Nunes, de 1958, que outrora ilustrava «A Morte da Princesa» no Livro de Leitura da $3 .{ }^{a}$ Classe do Ensino Elementar, 
editado pelo Ministério da Educação Nacional, no tempo do regime político do Estado Novo;

- a tela de Maria Taveira, exposta no Seminário Diocesano de Aveiro, de 1959, cujos atributos são o hábito de São Domingos e uma cruz na mão direita, olhando em frente e manifestando a determinação e o vigor da juventude;

- o políptico em tábua do Arq. Luís Cunha na igreja matriz de Santa Joana, em Aveiro, de 1976, com diversos episódios da sua vida em redor da reprodução do quadro do século XV, em traços um pouco livres;

- a pintura a óleo de João de Sousa Araújo, de 1988, propriedade da Câmara Municipal de Aveiro, que duplamente a retrata, como Princesa da Corte e como religiosa dominicana que volta as costas à primeira figuração;

- a pintura do multifacetado aveirense Helder Bandarra, de 1990, com o rosto baseado na tábua multicentenária, tendo por fundo a paisagem da Ria de Aveiro com alguns barcos a flutuar;

- a tela patente na Livraria de Santa Joana, em Aveiro, onde a Princesa, olhando de frente, segura um livro onde se transcrevem algumas das suas últimas palavras, ditas às irmãs religiosas do convento: «Fica-vos muito e boa livraria com que podeis tomar consolação e prazer espiritual»;

- a estampa impressa em Brugge (Bélgica) no ano de 1889, reeditada em 1990 pela Diocese de Aveiro com a oração de D. João Evangelista de Lima Vidal no verso, para comemorar o quinto centenário da sua morte;

- o quadro do iraniano Onik Sahakian, colaborador e discípulo do catalão Salvador Dalí (1904-1989), de 1993, que a colocou sobre um chão ladrilhado mas envolvida pelos fulgores da glória de Bernini, na basílica de São Pedro do Vaticano;

- as diversas pinturas a óleo e as numerosas aguarelas do mencionado Jeremias Bandarra, de cariz espiritualizante e várias em traços inovadores, não esquecendo as suas ilustrações propositadamente feitas para o livro Santa Joana de Aveiro, de 1997, da minha autoria;

- a aguarela de Jorge Trindade, de 2003, que, libertando-se dos modelos anteriores, desenhou-a como uma jovem religiosa dando acolhimento a uma pomba branca que a acaricia no seu rosto ou quiçá lhe comunica uma qualquer inspiração pacificadora de Deus;

- as ilustrações de Laura de Carvalho Chicharo no seu livro Lenda da Princesa Santa Joana, de 2006;

- o desenho de Augusto Trigo, que evoca a Princesa solicitando ao pai a permissão para se recolher num convento, publicado em 2007 no livro «10 Grandes Portugueses», cuja autora é Maria Isabel de Mendonça Soares; 


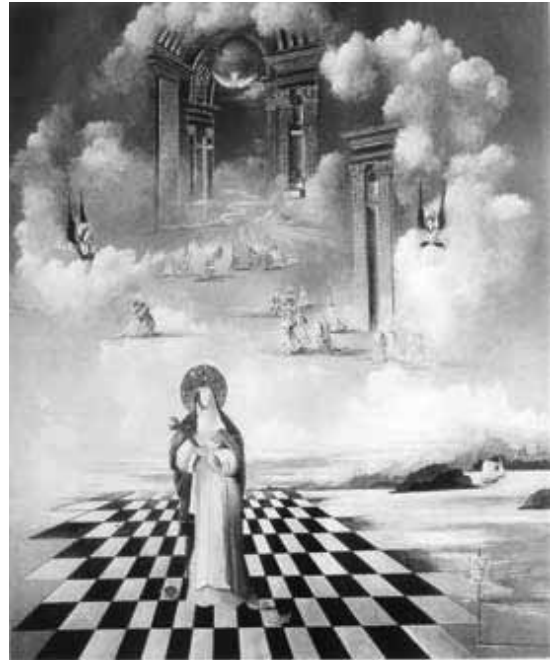

Onik Sahakian (1993)

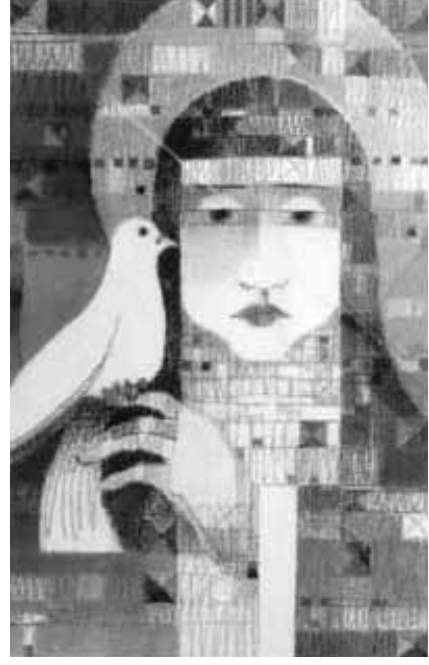

Jorge Trindade (2003)

- as várias representações de Gaspar Albino, outro aveirense com rara sensibilidade, sendo a última de 2007;

- os numerosos desenhos de linhas ingénuas e simples que, a cada passo, os alunos e as alunas dos diversos ciclos do Ensino nos vão surpreendendo, com a simplicidade e a devoção próprias das suas idades;

- e a «visita virtual» do sítio informático Era uma vez em Aveiro, da responsabilidade do Museu Nacional de Aveiro, na qual, em primorosos traços apropriados para crianças e adolescentes (e não só!...), nos são apresentados, com movimento, som e fala, vários episódios do dia-a-dia conventual e da vida de Santa Joana.

No vitral, destaca-se o que enobrece uma das duas janelas num dos átrios de entrada da Casa das Irmãs Dominicanas de Santa Catarina de Sena, em Fátima; vestida com o hábito religioso albinegro, ostenta o crucifixo na mão esquerda e a coroa de espinhos na direita. O rectângulo polícromo, de 1950, foi enriquecido com três coroas reais, pousadas no chão, e com os brasões da Princesa e de São Domingos de Gusmão; por cima da cabeça, de que irradia a auréola de santidade, foi colocada a coroa real.

Na medalhística, há gravações, mesmo em ouro e prata, tanto do tradicional quadro como do seu brasão e do seu mausoléu, umas por iniciativa da Câmara Municipal de Aveiro (1990) e da Paróquia de Santa Joana de Lisboa (2002) e outras por empenho de casas comerciais. 


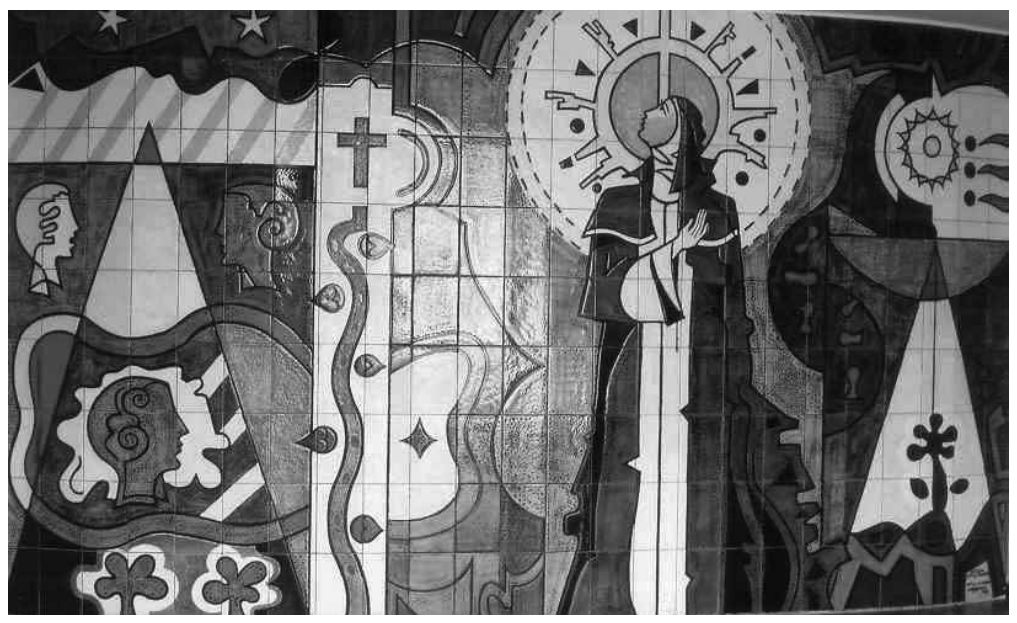

Casa das Dominicanas, Fátima (vitral)

Na azulejaria, igualmente Santa Joana não tem sido esquecida, como já sabemos pela alusão aos painéis setecentistas que adornam a igreja do velho Mosteiro de Jesus, entre outros. Neste momento, recordo apenas alguns dos exemplares modernos:

- os quadros azulejares pintados por operários da Fábrica Aleluia e das Faianças de São Roque, de Aveiro, copiando a tábua do século XV ou caracterizando-a com os atributos monásticos;

- o grande painel na Granja do Marquês, em Sintra, onde se localiza a Base Aérea Militar n. ${ }^{\circ}$;

- um outro painel, também de grandes dimensões, que, desde 1995, dignifica a entrada do edifício da sede da Junta de Freguesia de Santa Joana, em Aveiro, genialmente desenhado por Jeremias Bandarra e executado pelo artista-oleiro José Augusto, onde a personagem central, emergindo do azul da ria, cercada por resplendores da luz celeste, belamente envolvida por colorações de bustos humanos e florações da natureza e com a mão direita sobre o peito, olha extasiada e atentamente para as alturas de Deus;

- o rectângulo do artista ovarense Marcos Muge, de 2002, ladeado pelas pinturas de São Domingos e da irmã Santa Joana, na feição tradicional, em cujo centro se reproduz a reconstituição do medieval Convento dos Padres da Ordem dos Pregadores, em Aveiro esta sem qualquer identificação dos autores mas originalmente delineada em 1985 por mim próprio e por Saul Marques Pereira.

Na faiança e na porcelana, há algumas edições de artísticos espécimes, como os dois jarrões polícromos, profusamente ilustrados com a entrada da Princesa no Mosteiro de Jesus 


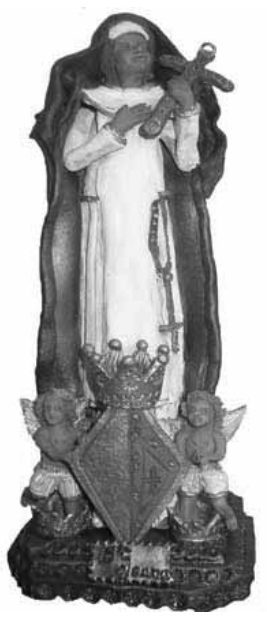

Atelier de São Miguel, Caldas da Rainha (2008).

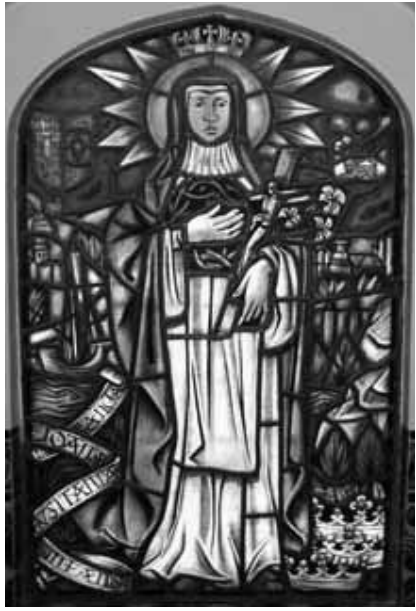

Jeremias Bandarra, Junta de Freguesia de Santa Joana

(1995).

e o seu falecimento, que são propriedade particular de uma família aveirense, e o prato do Colégio de Santa Joana, anterior a 1910, onde se desenhou o seu brasão. Salienta-se, porém, o prato do Natal cuja execução, em 2005, foi da iniciativa do «Círculo de Leitores» em colaboração com o Instituto Português do Património Arquitectónico; efectivado em porcelana, primorosamente reproduz a pintura sobre tela que existe na igreja do extinto mosteiro beneditino de Tibães - já mencionada.

\section{Imagens, estátuas, estatuetas}

No programa que me propus, não posso omitir neste elenco algumas imagens religiosas de várias estatuetas e das duas estátuas da Princesa - estas últimas implantadas na cidade de Aveiro. Entre as imagens, relaciono as seguintes:

- em Válega (Ovar), a santa lembrada numa modesta escultura saída das mãos do artista-santeiro Guilherme Ferreira Thedim (1900-1985) e por este assinada.

Dando preferência a Aveiro, tenho presentes as imagens, em madeira, que se veneram nesta cidade, além da que está na igreja de Jesus, atrás referida:

- uma, que foi a titular da capela construída dentro dos limites da freguesia de São Bernardo (Aveiro) e que hoje se guarda no Hospital do Infante D. Pedro; 
- outra, agarrando a cruz que encosta devotamente ao peito, exposta no refeitório do Seminário Diocesano, feita em 1984 pelo mestre-santeiro Avelino Moreira Vinhas, de São Mamede de Coronado (Trofa);

- e ainda outra, que dá o nome a uma das capelas laterais da catedral, talhada em 1987 pelo escultor Anselmo Dias Brandão, de São Tiago de Riba-UI (Oliveira de Azeméis), cujos traços obedeceram ao estilo seiscentista do retábulo para onde foi destinada.

Quanto a estatuetas, de valor desigual, indico somente algumas delas, entre as cerca de trinta exemplares que tenho registado:

- a de Maria Graciosa Mendes Carvalho, em barro vermelho (1983), apertando a cruz junto ao peito;

- a de Jorge José de Figueiredo, em biscuit da Vista Alegre (1983), segurando o crucifixo e olhando para o alto;

- as do artesão aveirense José Augusto (vários anos), em diferentes desenhos;

- a do Alelier de São Miguel, Caldas da Rainha (2007), em atitude de oração;

- e as das lojas chinesas, na feição tradicional.

E a série não vai ficar por aqui, porque, volta e meia, em escaparates comerciais, apareceram duas para venda. Dentro dos limites da cidade de Aveiro, erguem-se duas estátuas da sua celeste Padroeira, em bronze. Vou finalizar a minha modesta e aligeirada comunicação, referindo-me ligeiramente a elas.

Nos princípios de 1989, despontou um certo movimento de opinião em Aveiro, no sentido de se projectar e localizar na praça do Milenário, fronteira à catedral e ao Museu Nacional, um grupo escultórico que simbolizasse a arte e o artesanato da cerâmica, em virtude de esta ser uma ocupação tradicional e milenar entre nós; supunha-se que tal monumento aí se ajustaria, por ter existido nas proximidades o antigo Bairro dos Oleiros. Contudo, imediatamente surgiu uma ideia diferente, lançada em ambiente restrito, porque logo se entendeu que o sítio deveria ser ocupado por algo que publicamente recordasse a Princesa Santa Joana, que tinha residido no vizinho Mosteiro e cujo cenotáfio aí se encontra. Então, não se cruzaram os braços... nem se deixaram cair na imobilidade. Chegado tal pensamento aos responsáveis da Diocese, logo estes também julgaram ser urgente preencher o espaço. Por isso, sem grandes alardes, imediatamente se encomendou uma estátua da Padroeira, a executar mesmo com a quase ausência de qualquer estudo prévio, apenas inspirada numa das miniaturas existentes. Responsabilizou-se pelo trabalho o escultor-santeiro Joaquim Alves Cardoso, da Vergada (Santa Maria da Feira); aprontada 
com a celeridade que as circunstâncias impunham, a estátua foi descerrada no referido largo, em 10 de Dezembro do mesmo ano de 1989. O acontecimento, público e solene, foi simultaneamente o primeiro acto comemorativo do quinto centenário da morte da Princesa, que ocorreria no ano seguinte. Em finais de 2001, o bispo da Diocese, D. António Baltasar Marcelino, achou por bem que ela fosse transferida para o adro da igreja da paróquia citadina de Santa Joana.

Entretanto,já se tinha conjecturado que o local, situado dentro do perímetro histórico da cidade, merecia uma obra de maior e melhor vulto. Dessa forma, no decurso dos trabalhos da construção do viaduto da Sé e do consequente arranjo da praça, foi-se sonhando com um novo e condigno

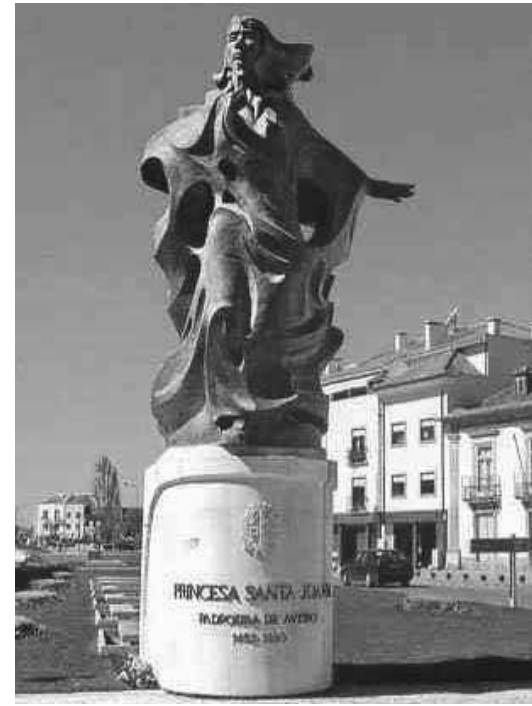

Helder Bandarra (estátua, 2002) monumento brônzeo. Em 2001, numa linha de concretização, a Câmara Municipal de Aveiro confiou o projecto da imagem ao artista aveirense Helder Bandarra; completado este e apresentada a respectiva maquete, a edilidade logo o aprovou em ordem à sua concretização. Uma vez fundida na oficina de Araújo \& Guedes, de Vila Nova de Gaia, a estátua foi inaugurada na manhã de 12 de Maio de 2002, com a bênção proferida pelo prelado aveirense, na presença de Suas Altezas Reais, D. Duarte Pio, duque de Bragança, e de sua mulher, D. Isabel de Herédia, dos autarcas locais, de diversas autoridades, de representantes de várias associações e de muitas outras pessoas.

Segundo o pensamento do artista, a Princesa Santa Joana surge-nos em espaço aberto, exprimindo determinação, tenacidade, perseverança e urgência em chegar a Aveiro, com a desenvoltura das vestes, agitadas pelo caminhar voluntarioso ou batidas pelo vento persistente do mar e da ria. Num movimento de ligeireza, bem expresso no pé direito que quase coloca fora do plinto, sem qualquer dúvida de retrocesso na rejeição deliberada de outras sugestões com o gesto decidido da mão esquerda, numa postura firme de olhar sempre em frente, os traços escultóricos da estátua apontam aos aveirenses e aos turistas, jovens e idosos, a personalidade de alguém que tem pressa em jubilosamente lhes testemunhar Jesus Cristo, simbolizado pela cruz que ostenta na mão direita.

Efectivamente, embora de aparência débil, Santa Joana era dotada de fortaleza e de energia.Para defender a sua vocação e a sua liberdade, ergueu-se inflexível mas serena, e mostrou-se perseverante na decisão tomada, disposta a sustentá-la até ao fim, surgisse o que surgisse. 
Se se pretendesse definir a vida da Princesa - a irmã do voluntarioso D. João II -, dir-se-ia que foi uma luta constante entre o imperativo da sua consciência e a razão de Estado.Porém, valeu a pena ser persistente e firme; porque, quando a persistência e a firmeza se aliam à verdade, existe aí um valor de virtude heróica. Olhando para a estátua, também isto mesmo se deduz, tão ao jeito daquela que nasceu em Lisboa e, na pujança dos seus vinte anos, se mudou para a modéstia de Aveiro, onde morreu e é amada e venerada como conterrânea e protectora.

Nas discretas manifestações de reverência, nas silenciosas visitas ao seu túmulo, nas festas anuais com a participação de multidões, nas numerosas representações iconográficas, nos corações agradecidos ao seu exemplo e à sua intercessão, na escolha de «Joana» para muitas meninas por devoção dos pais, na preferência do seu nome para escolas, estabelecimentos de serviço público e outras instituições, na simples recordação desta «excelente Infanta e singular Princesa»... 


\title{
Quitéria, uma santa da Lusitânia nas terras de Entre-Douro-e-Minho
}

\author{
Luís Alberto Casimiro*
}

\section{Introdução}

O intuito de abordar a figura de Santa Quitéria está no nosso horizonte avivar a memória de uma jovem mártir que, embora não se encontre entre as personalidades mais destacadas e mais populares da hagiologia lusitana e, nos tempos modernos, tenha caído quase no esquecimento, é objecto de um culto popular que permanece vivo em certas localidades e de expressões iconográficas que importa conhecer e preservar. Sendo considerada, com toda a segurança, uma jovem donzela que se consagrou a Deus e que, recusando-se a contrair matrimónio, foi martirizada pelo próprio pretendente, verifica-se que a sua vida se encontra repleta de aspectos lendários que se multiplicam e diferem de país para país. De salientar que o actual Martirologium Romanum (2004) a situa no dia 22 de Maio, tal como indica a tradição mais remota, mas não a reconhece como mártir, pois refere apenas: In pago Aturénsi in Aquitánia, sanctae Quitériae, vírginis ${ }^{1}$. Porém, tal não acontece no Martyrologio Romano de 1748, nem no de 1591, onde se pode ler, na tradução portuguesa: "Em Hespanha, de Santa Quitéria Virgem, e Martyr"2. Também nas recensões antigas se conserva a sua condição de mártir.

Neste contexto, importa, pois, recordar algumas das facetas mais marcantes da sua biografia, ao mesmo tempo que apresentamos alguns registos iconográficos que a ilustram. Assim, começamos por falar da vida de Santa Quitéria, principalmente no que diz respeito à tradição portuguesa, referindo pormenores que permitem esclarecer e contextualizar detalhes do seu martírio. Prosseguiremos com breves referências relativas ao culto e, por fim, percorreremos, com mais detalhe, os caminhos das expressões iconográficas, cen-

* Faculdade de Letras/Universidade do Porto.

1 Cf.MARTYROLOGIUM ROMANUM. Ex decreto sacrosancti oecumenici Concilii Vaticani Il instauratum auctoritate loannis Pauli PP.II promulgatum. Editio Altera. Città del Vaticano:Libreria Editrice Vaticana, 2004, p. 297.

2 Cf., respectivamente, MARTYROLOGIO ROMANO dado à luz por mandado do Papa Gregório XIII. Enovamente accrescentado por authoridade do Papa ClementeX. Lisboa: Na Regia Officina Sylviana, e da Academia Real, 1748, p. 125 e, MARTYROLOGIO ROMANO acomodado a todos os dias do anno conforme à nova ordem do calendario, que se reformou por mandado do papa Gregório XIII. Coimbra:Casa de António Maris, Impressor da Universidade, 1591, p. 102. 
trando-nos essencialmente no Santuário de Santa Quitéria, em Felgueiras, o qual pretendemos destacar.

Santa Quitéria é reivindicada por outros países, como a França e a Espanha, mas também o povo crente de Portugal assume, para si, o direito de contar a história desta santa que surge, de forma abreviada, em 1666, no Agiológio Lusitano de Jorge Cardoso e, em 1722, na biografia de Frei Bento da Ascensão. Ambos situam o nascimento e o martírio de Santa Quitéria em terras lusitanas.

Segundo a Bibliotheca Sanctorum ${ }^{3}$, apenas no século VII se começou a atribuir-lhe a intercessão em certos milagres, sendo o seu martírio referido, pela primeira vez, apenas no século XII, no Martirológio de São Severo. Por sua vez, o Martirologium Romanum dos finais do século XVI apresenta Santa Quitéria como uma santa mártir de Espanha, enquanto o actual Martirologium Romanum a situa em Aquitânia (região da França limitada pela Espanha e pelo oceano Atlântico). Apesar de escassos, os aspectos conhecidos, ainda que possam ter fundamentos lendários, mostraram-se suficientes para que a sua iconografia, se tenha desenvolvido e implantado, motivo pelo qual merece ser conhecida.

\section{Apontamentos biográficos}

Na versão francesa sobre a vida de Santa Quitéria, esta surge no século V, época atribulada dos finais do Império Romano, vivendo em Landes, região da Aquitânia, lugar relacionado com as peregrinações a Santiago de Compostela. Jovem de linhagem influente, desde cedo consagrara a sua virgindade a Cristo e, como se negava a casar, o seu pai acabou por a decapitar, tendo surgido uma fonte no local do martírio. Outras versões referem que o seu martírio ocorreu em 22 de Maio de 478, a mando de Euric, rei dos Godos, pelo facto de professar o catolicismo. Naquela época, os Godos controlavam uma grande parte da Península Ibérica a partir da povoação de Aire-sur-l'Adour, um importante centro e palco do martírio de Santa Quitéria. Reza a lenda que após ter sido decapitada a jovem recolheu a sua própria cabeça e, guiada por um anjo, encaminhou-se para a igreja cujas portas estavam fechadas. Porém, ao aproximar-se, abriram-se de par em par. Desceu então as escadas que conduziam à cripta e, depois de se acomodar no sarcófago previamente preparado para sua sepultura, «acabou de morrer» ${ }^{4}$. O sarcófago que se encontra na cripta da igreja, junto ao local da fonte surgida milagrosamente, é um testemunho eloquente da arte do século $\mathrm{V}$.

3 ENCICLOPÉDIA DEI SANTI. Bibliotheca Sanctorum. III Ristampa. Roma: Città Nuova Edirice 1998, vol. X, pp. 1334-1335.

4 Cf. RÉAU, Louis - Iconografía del arte cristiano. Iconografía de los santos. Barcelona: Ediciones del Serbal, 2000, tomo 2, vol. 5, p. 113. 
Outra lenda, mais comum em Espanha, situa os acontecimentos na antiga região de Balcagia, a actual Bayona, na costa galega, sede de Lúcio Caio Atílio Severo, régulo da Galiza e de Portugal. Nela se afirma que, no século II, durante a perseguição feita aos cristãos, as nove irmãs, filhas de Lúcio Severo, e nascidas de um só parto, sem que o governador disso tivesse conhecimento, tinham consagrado a sua virgindade a Deus. Denunciadas pelos pagãos e levadas à presença do governador, este procurou, sob ameaça de suplícios, persuadi-las para que negassem a sua fé. Impressionado pela firmeza e convicção das jovens e reparando numa estranha parecença com Cálcia Lúcia, sua esposa, mandou chamá-la a qual as reconheceu como as filhas que tinha abandonado à nascença, e às quais procurara dar a morte. No seu coração de pai teve, então, lugar uma luta entre o amor paterno e a autoridade de juiz, pelo que redobrou de empenho em tentar convencê-las a adorar os deuses romanos. Tudo foi em vão. Enfurecido, o pai renovou as ameaças e deu-lhes um dia de prazo para se decidirem. As irmãs, para evitarem que o seu próprio pai praticasse tão grande crime, fugiram da cidade tomando caminhos diferentes.

A jovem Quitéria retirou-se para a solidão de um monte, onde viveu em oração durante algum tempo, até que um anjo do Senhor lhe disse para regressar à casa paterna. Regressando a Bayona, entrou no palácio do pai que a recebeu com admiração e alegria, voltando a persuadi-la para que se casasse com Germano, um jovem rico e nobre. A esta proposta Quitéria respondeu que não se iria entregar a nenhum esposo na terra porque o seu esposo era Jesus Cristo, o rei do Universo, ao qual amava de todo o coração e que Ele tanto a amava também que tinha dado a sua vida por ela. $O$ pai comunicou a Germano esta decisão de sua filha e deu-lhe indicações para que lhe cortasse a cabeça vingando-se de tal ofensa. Quitéria, porém, conseguiu escapar fugindo durante a noite. Por indicação de um anjo, seguiu em direcção aos montes de Toledo, local onde o mesmo anjo lhe indicara que iria receber a palma do martírio. Todavia, Germano também conseguiu chegar até àquelas terras. Sabendo-se perseguida, Quitéria escondeu-se no tronco oco de uma árvore, tendo previamente pedido a um pastor das redondezas que, caso perguntassem por ela, não a denunciasse. Quando Germano chegou, inquiriu o pastor, que lhe afirmou que não tinha visto ninguém, ao mesmo tempo que, com o dedo, apontava para o refúgio de Santa Quitéria. Uma vez descoberta e retirada do seu refúgio, ordenou que lhe fosse cortada a cabeça. A jovem ajoelhou-se, pronta para receber o martírio, e orou a Deus para que recebesse a sua alma e livrasse de todas as enfermidades aqueles que a Ele recorressem por seu intermédio. A esta oração, uma voz no Céu lhe respondeu dizendo que tal desejo lhe fora concedido, na glória de Deus, como ela o tinha pedido no seu martírio.

Reza ainda a lenda que, por sua intercessão, se realizaram muitos milagres, a começar pelo pastor que a denunciou, dado que os seus cães, depois de Santa Quitéria ter sido 
encontrada, ficaram raivosos e Ihe causaram muitas feridas com as suas mordeduras. $\mathrm{O}$ pastor ferido ajoelhou-se diante da jovem prestes a ser martirizada, a qual lhe perdoou mandando que fosse lavar as feridas com a água da fonte que Santa Quitéria fez brotar.Por isso, é invocada como advogada contra a raiva, motivo que explica, na iconografia de Santa Quitéria, a presença de um ou mais cães como atributo.

Queremos, porém, centrar a nossa atenção nos relatos da vida de Santa Quitéria que a situam em terras lusitanas e que apresentam, na sua estrutura geral, muitas semelhanças com as restantes hagiologias, embora com pequenas variantes que influenciam a sua iconografia.

Depois do Agiológio Lusitano, de Jorge Cardoso, encontramos indicações biográficas sobre Santa Quitéria no livro que Frei Bento da Ascensão publicou, em 1722, intitulado Vida, e martyrio da insigne virgem, e martyr prodigioza Santa Quitéria, sereníssima Infante de Portugal, no Monte de Pombeyro, o qual continua a ser uma das fontes mais importantes para o conhecimento da vida da jovem mártir. Segundo aquele monge beneditino, Santa Quitéria teria nascido, pelo ano 120, na região do Império Romano conhecida, então, como Bracara-Augusta, a actual cidade de Braga. Seu pai, Lúcio Caio Atílio Severo, era régulo de uma província do Império Romano que abrangia parte da Galiza e da antiga Lusitânia. Estava casado com Cálcia Lúcia. Sendo ambos de famílias ilustres, embora pagãs, estiveram muitos anos sem terem descendência até que Cálcia Lúcia concebeu nove meninas que nasceram de um só parto, numa ocasião em que o marido se encontrava ausente acompanhando o imperador Adriano que viajava pela Península.

Cálcia, que considerou agoirento o nascimento de nove filhas, com o intuito de se subtrair às troças do mundo e a uma eventual indignação ou suspeições do marido sobre qualquer infidelidade, congeminou um plano para matar as filhas, mandando-as afogar no rio. Encarregou de concretizar este plano Cita, jovem donzela, devota e cristã oculta, que tinha sido a única pessoa a assistir ao parto. Foram-lhe dadas indicações para que divulgasse a notícia de que o parto tinha corrido mal e que as crianças tinham morrido à nascença. Todavia, Cita, movida por elevados sentimentos cristãos, levou as meninas de casa, como combinado, mas estava decidida não só a salvar a vida das nove irmãs, como também a dar-lhes a vida nova do Espírito, pelo sacramento do baptismo. Assim, em vez de atentar contra a sua vida, entregou-as a Santo Ovídio, arcebispo de Braga, que lhes administrou o baptismo e Ihes atribuiu os seguintes nomes: Quitéria, Eufémia, Germana, Liberata (ou Librada), Vitória, Basília, Marinha, Genebra e Marciana.

Conhecendo a tragédia que pesava sobre as inocentes crianças, e que quase as vitimara, Santo Ovídio, depois do baptismo, entregou-as aos cuidados de diversas famílias cristãs, para que tomassem conta delas durante a infância, dando-lhes educação religiosa, encarregando-se o arcebispo de prover a todas as despesas. Refere Frei Bento da Ascensão 
que a educação religiosa recebida pelas nove meninas, na infância, produziu nelas um tal domínio em seus corações que, durante a sua breve existência e até ao seu termo, sempre souberam pôr em prática as grandes virtudes e calcar aos pés as grandezas e vaidades do mundo a fim de glorificarem apenas a Jesus Cristo.

À medida que foram crescendo, as nove irmãs tomaram conhecimento do destino a que a mãe as tinha votado, entregando-as para morrerem, e o modo como foram salvas pela criada cristã. Sentindo-se particularmente agradecidas à Divina Providência, não só pelo facto de lhes ter salvo a vida do corpo, como por Ihes ter dado uma vida nova pelo sacramento do Baptismo e terem crescido no conhecimento dos princípios da vida cristã, decidiram afastar-se do mundo e viver juntas, como num convento, para um maior aperfeiçoamento da sua vida de piedade, para servirem a Deus de modo mais perfeito e para crescerem na prática das virtudes pelo mútuo auxílio e exemplo de vida. Para concretizarem este seu projecto contactaram o generoso arcebispo, Santo Ovídio e dele obtiveram a necessária aprovação. $\mathrm{O}$ modo de vida que seguiram rapidamente as tornou conhecidas entre todos, pois o exemplo de vida cristã evidenciado no fervor, na caridade, na mútua obediência, no serviço e na alegria despertavam a admiração de quantos com elas contactavam.

Refere ainda Frei Bento da Ascensão um pormenor importante para compreendermos certas representações iconográficas de Santa Quitéria e que, por isso, passamos a transcrever:

Abrasadas estas santas meninas no fogo do amor divino, cada qual de per si, e umas na presença das outras, fizeram todas voto de castidade, consagrando a sua virginal pureza àquele soberano Senhor que as fizera nascer dum tão milagroso parto, e depois de nascidas as livrara da morte, que sua mãe Ihes mandara dar, criando-as e sustentando-as até ali, com providência tão particular. Fechando pois os olhos ao mundo, e empregando-se só em seu divino esposo, Lhe sacrificaram as suas almas e juntamente com elas os seus corpos, vivendo, naquela tenra idade, estas esposas de Jesus Cristo, santas nos costumes, puras nos corpos, e abrasadas nas almas com as chamas da caridade e com o fogo do amor divino. ${ }^{5}$

Com esta passagem, queremos sublinhar o facto de Quitéria, tal como as irmãs, ter consagrado a sua virgindade a Cristo, seu divino esposo, facto que aparecerá bem destacado numa das capelas do percurso ao ar livre do santuário de Felgueiras, na qual o pergaminho que Santa Quitéria apresenta ao seu pretendente patenteia, precisamente, estes esponsais divinos: «Jesus é o meu esposo». 
Por ocasião de uma perseguição aos cristãos, levada a cabo pelo imperador Adriano (117-138) que alastrou a todo o império romano, também a região de Braga, onde viviam as nove irmãs, se tornou palco de prisões e martírio dos que professavam a fé cristã. Cumprindo ordens, Lúcio Caio Severo ordenou que fossem detidos todos os cristãos encontrados nos seus domínios. Sendo conhecidas como cristãs exemplares, as irmãs foram levadas à presença do governador. Este, sem saber que era seu pai, ficou deveras impressionado com a atitude das jovens e interrogou-as para saber quem eram, onde viviam, quem eram os seus familiares. Foi então que Germana, tomando a palavra, respondeu em nome de todas, com coragem e desassombro, que eram naturais de Braga, filhas do próprio governador e que adoravam Jesus Cristo, único e verdadeiro Deus, estando prontas a tudo sofrer por amor a Jesus e em defesa da sua fé.Verdadeiramente impressionado e surpreendido, Lúcio Severo quis ficar sozinho com as suas filhas, a esposa e Cita, a criada que tinha salvo a vida das irmãs. Ficou, então, a par dos pormenores que rodearam o nascimento das crianças e, nessa altura, manifestou todo o seu afecto por elas. Recordando-lhes a antiga nobreza da família; falou-lhes do seu futuro do qual faziam parte grandes casamentos com rapazes ricos e nobres sendo, necessário, primeiro, renunciarem à fé cristã. ${ }^{6}$

Ao ouvir a resposta negativa das filhas, o pai enfureceu-se e deixou-as a sós na sala do palácio onde se encontravam. Em oração invocaram do Céu a graça e a coragem de resistirem às propostas do pai que eram contrárias à vontade de Deus. Foi então que um anjo Ihes apareceu e as avisou para saírem do palácio. Ao regressar à sala, Lúcio Severo ficou furioso por não as encontrar e mandou os soldados em sua perseguição. Todas se dispersaram por diversas regiões, sobretudo pela Espanha, e apenas Santa Quitéria foi presa e trazida à presença do governador.

Os diversos relatos são unânimes em referir que as oito irmãs de Santa Quitéria foram martirizadas. Resumimos o relato que apresenta Frei Bento da Ascensão:

Santa Marinha encaminhou-se para a Galiza onde ficou durante algum tempo ao serviço de uma lavradeira, perto de Orense. Denunciada como cristã, foi perseguida e martirizada mediante variados e horríveis suplícios que passaram pelo dilaceramento das suas carnes, por ser lançada num tanque de água do qual saiu milagrosamente viva, atirada para uma fornalha de enormes labaredas as quais se afastaram sem lhe terem causado qualquer dano. Por fim, quando contava apenas dezoito anos foi degolada em Águas Santas, perto da cidade de Orense, na Galiza. No local o rei Afonso, o Magno mandou erguer uma igreja.?

6 Cf. NUNES, Pinho Pe. - Vida de Santa Quitéria. [s.I.]: Edição da Casa da Confraria, [s.d.], p. 15.

7 Citado a partir de LEITE, José, S. J. (org.) - Santos de cada dia II, p. 164. Cf. NUNES, Pinho Pe. - Vida de Santa Quitéria,pp.16-17. 
Santa Vitória foi martirizada em Córdova recebendo «tormentos esquisitos», de acordo com a expressão de Frei Bento da Ascensão, que passaram pelo fogo, pela roda de navaIhas e, finalmente, por ser crivada de setas. Decorria o ano de 138 e Santa Vitória contava, apenas, dezasseis anos. ${ }^{8}$

Santa Genebra padeceu o martírio numa região da Galiza, onde hoje se situa a cidade de Tuy, contando dezasseis anos, embora não se conheçam pormenores do seu martírio.

Sobre Santa Marciana pouco se sabe, apenas que terá dado a sua vida em defesa do Evangelho na cidade de Toledo, com a idade de 35 anos.

Relativamente a Santa Germana, não são conhecidos pormenores quanto à data ou local em que entregou a sua vida a Deus, apenas se levanta a hipótese de que poderá ter sido martirizada em África ou em Águas Santas.

No que se refere a Santa Liberata, permanecem as mesmas incertezas que envolvem a vida das outras suas irmãs quanto à data e ao local da sua morte. São apresentados três lugares como possíveis locais onde foi martirizada, sofrendo o suplício da cruz: Miragaia (Porto), Castelo Branco e Águas Santas (norte do Porto). Segundo a tradição, nesse local terá brotado uma fonte denominada "santa» atendendo aos efeitos milagrosos das suas águas que beneficiavam a todos quantos a ela acorriam em cura das suas enfermidades. ${ }^{9}$

Por fim, a tradição refere que Santa Eufémia viveu durante cerca de dois anos nas serras do Gerês e, no fim desse tempo, foi perseguida por ser cristã. Depois de ter sofrido maus tratos, foi lançada na prisão. Aí recebe a visita de um anjo que a cura de forma milagrosa de todas as suas feridas. Padeceu, então, novos suplícios, no fim dos quais foi degolada, estando as suas relíquias na Sé de Ourense. ${ }^{10}$

Quanto a Santa Quitéria, podemos dizer que foi presa e conduzida à presença de seu pai, o qual tentou, uma vez mais, demovê-la de professar a fé cristã. Deu-lhe também a notícia de que tinha sido prometida em casamento a Germano, um nobre rico. Quitéria pede ao pai um tempo para pensar. O seu anjo custódio aconselhou-a a refugiar-se no Monte Pombeiro, no cimo do qual se erguia uma pequena capela dedicada a São Pedro, nas imediações de uma cidade denominada Eufrásia, destruída nas invasões dos Mouros e que era governada por Lenciano (ou Leuciano), feroz perseguidor de cristãos. Lenciano, tendo descoberto o refúgio de Santa Quitéria e das demais donzelas que a ela se tinham juntado a fim de viverem em comunidade cristã, prendeu-as e informou o pai sobre o seu paradeiro. ${ }^{11}$ Estiveram na prisão três dias sem receberem qualquer alimento. Durante o tempo de

\footnotetext{
8 lbidem.

9 Citado a partir de LEITE, José, S. J. (org.) - Santos de cada dia II, p. 165.

10 lbidem.

11 Cf. NUNES, Pinho Pe. - Vida de Santa Quitéria, p. 18.
} 
cativeiro foram confortadas por um anjo e observaram-se situações inesperadas: os guardas foram convertidos ao cristianismo pela instrução recebida, enquanto alguns doentes obtiveram a cura dos seus males. Entre estes últimos se insere a iconografia do doente de raiva curado por Santa Quitéria, tal como é representado no Quinto Passo do Santuário de Santa Quitéria, em Felgueiras.

Lúcio Severo enviou então emissários para convencerem a sua filha a aceitar o seu casamento com Germano.Todavia, a decisão da jovem não se alterou. Germano, acompanhado de vários soldados, vai ao seu encontro com ordens para a matar. Ele mesmo, na manhã do dia 22 do ano de 135, tomou a espada e decapitou Santa Quitéria que, assim, se tornou a primeira mártir em terra que depois viria a ser portuguesa. Diz a tradição que, no local do martírio, brotou uma fonte e que os soldados e o próprio Germano ficaram cegos, enquanto Lenciano, entretanto convertido, tal como as donzelas da comunidade de Santa Quitéria, bem como outros cristãos foram martirizados naquele monte e sepultados junto da capela de São Pedro. Talvez este relato venha justificar as dezenas de sepulturas com imensas ossadas que foram encontradas no local quando foi escavado a fim de construir as fundações da actual igreja. ${ }^{12}$

Santa Quitéria é invocada pelos devotos contra a raiva, a mordedura dos cães raivosos e a loucura, sendo-Ihe, igualmente, atribuída a ajuda para que as crianças que apresentavam atrasos no andar pudessem começar a caminhar.

Por sua vez, Jorge Cardoso, no Agiológio Lusitano, não recorre a uma descrição tão pormenorizada, mas inclui alguns detalhes que são relevantes para a compreensão da iconografia de Santa Quitéria. No que se refere à infância das nove irmãs, apenas dá a indicação que, tendo sido salvas da morte prematura, enquanto recém-nascidas, tiveram que se ausentar de sua casa para fugirem à perseguição que os romanos fizeram, dispersando-se por diversas partes do mundo, dispostas a darem a vida por Cristo. Os seus perseguidores apenas conseguiram prender Quitéria. Levada à presença de seu pai, este tentou dissuadi-la de professar a sua fé. Como nada conseguia e, para não perder a sua filha como tinha acontecido com as restantes, permitiu que se retirasse para o monte e vivesse de acordo com a sua fé. Aí era continuamente visitada por anjos que a sustentavam na graça divina. Porém, a maldade de certos pagãos levantou suspeitas sobre os honestos fins deste retiro. Tais calúnias chegaram aos ouvidos do pai que a chamou para pedir explicações. Santa Quitéria respondeu de forma satisfatória, pelo que o seu pai permitiu que continuasse a viver como até então. Foi nessa altura que lhe apareceu um anjo que Ihe disse ter "chegado o tempo de imitar as suas irmãs e seguir por rigoroso martírio, o louvável exemplo que

12 Ibidem, p. 22. 
elas Ihe deixaram."13 A notícia deixou a jovem muito satisfeita e, regressada a casa, encontrou dois pretendentes de linhagem real que a queriam como esposa. $O$ pai, vendo que qualquer deles seria um bom partido, destinou-lhe Germano para seu esposo. O Agiólogo Lusitano esclarece que Santa Quitéria tinha consagrado a sua virgindade a Cristo, pelo que pediu algum tempo para deliberar. A negação da proposta valeu-lhe a prisão, na qual lhe apareceu um anjo a consolá-la bem como a própria Virgem Maria que sobre ela derramou um vaso de odoríferos perfumes e lhe deu uma cruz dizendo que triunfaria com ela dos três inimigos da alma: o mundo, o diabo e a carne. Depois colocou-lhe um anel no dedo em sinal dos seus desposórios espirituais e assegurou-lhe que conservaria, durante a sua vida, a jóia da pureza. Prometeu-lhe ainda que os molestados pela raiva ou o furor, tanto que invocassem o seu patrocínio, alcançariam a perfeita saúde. ${ }^{14}$

Ausentando-se a Virgem Maria, imediatamente surgiu um anjo que a tirou do cárcere e lhe disse que a acompanharia até ao monte onde Deus Ihe tinha guardado a palma do martírio. No silêncio da noite e acompanhada de outras donzelas, subiu ao monte onde se encontrava a ermida de São Pedro. Seu pai entristeceu-se quando soube da sua partida e mais mágoa ainda sentiu Germano que a pretendia ter por esposa. Ordenou, então, aos seus criados que fossem atrás dela e quando a encontrassem a persuadissem a regressar a fim de contrair matrimónio com Germano. Sabendo das intenções de Germano, Quitéria responde aos criados: “Dizei a meu pai que não me é licito receber a homem na terra por esposo, quando tenho ao Rei do Céu, a quem amo de todo o coração, e Ele me ama tanto, que chegou a dar a vida por meu respeito, no sagrado Lenho da Cruz." Esta resposta tem a sua representação iconográfica no Sexto Passo da vida de Santa Quitéria, tal como é apresentada no Santuário, em Felgueiras, no qual se pode ver a jovem com um pergaminho na mão esquerda enquanto a direita se ergue em sinal de quem está em posse da palavra. No pergaminho pode ler-se «O meu esposo é Jesus». Torna-se, pois, clara a opção de Quitéria em permanecer fiel ao seu desposório espiritual com Jesus, a quem entregara a sua virgindade. De novo Quitéria voltou a ser presa, desta vez por ordem de Lenciano, senhor daquele monte que a manteve no cárcere, juntamente com os restantes companheiros, durante três dias sem Ihes fornecer qualquer tipo de alimento. Apenas receberam o alimento espiritual proporcionado pela palavra divina que animava Quitéria e a todos para receberem o martírio. Foi então que, à meia-noite, quando todos se encontravam em oração, desceu do Céu um resplendor luminoso que afastou as trevas do cárcere, quebrou

${ }^{13}$ CARDOSO, Jorge - Agiológio Lusitano. Edição fac-similada do original de 1666. Porto: Faculdade de Letras da Universidade do Porto, 2002, vol. III, p. 355.

14 Ibidem, pp. 355-356. 
as cadeias dos prisioneiros e abriu as portas da cela, acontecimentos que motivaram a conversão e o baptismo das sentinelas.

Estas notícias chegaram rapidamente aos ouvidos de Lenciano que, tomando-os como resultantes do poder do demónio, se dirigiu à prisão para lhes tirar a vida. Valeu-lhes uma intervenção divina que paralisou Lenciano e Ihe incapacitou os sentidos, deixando-o como "um tronco insensível."Foi nesse estado que o apresentaram diante de Santa Quitéria que o curou de todos os males, por virtude do Altíssimo, fazendo sobre ele o sinal da cruz, depois de uma oração. ${ }^{15}$ Foi assim que converteu Lenciano, o qual, reconhecendo as suas más atitudes para com os cristãos, restituiu às igrejas e aos cristãos todos os tesouros que deles tinha usurpado. Com este gesto viu aprovada a sua conversão pelas palavras da própria Quitéria, que Ihe garantiu estar Deus e os seus Anjos rejubilando de alegria. Salienta-se o facto de o tema da conversão de Lenciano se encontrar representado no Quarto Passo do Santuário de Santa Quitéria.

Por esses dias, Germano chegou ao monte acompanhado de gente resolvida a descobrir e a matar Santa Quitéria. Não a tendo encontrado de imediato, dispersaram-se os seus perseguidores para mais rapidamente a encontrarem. Quem deu com ela foi Dumano, um cristão que tinha apostatado a fé cristã. Jorge Cardoso relata do seguinte modo o martírio de Quitéria:

E dizendo ella que eístava prestes para o sacrifício, offereceo a garganta ao cutello, \& de hum golpe foi descabeçada, caindo o copo para hua parte, \& a cabeça para a outra. Baixarão logo do Ceo muitos spiritus Angélicos, a cantaremlhe a galla da victoria, os quaes Ihe disserão: Levantate Quitéria, toma nas mãos tua cabeça, \& vamos ao lugar deputado para tua sepultura. A Sancta, como se estivera viva, o fez assi, levandoa distancia de 72 estadios (que saõ mais de duas legoas) atê a Ermida de S. Pedro onde a enterrarão com hymnus, \& cânticos celestiais. ${ }^{16}$

No comentário que Jorge Cardoso faz após concluir o relato da vida de Santa Quitéria, esclarece determinados aspectos que são confirmados por outras biografias. Assim, refere que o seu pai era régulo e senhor de Braga, embora tivesse a sua corte em Belcagia, actual Bayona. Conclui também que Santa Quitéria era efectivamente portuguesa, tal como seus pais, e não francesa, como outros autores pretendem. Refere ainda o dia 22 de Maio do ano 130 como sendo a data do martírio de Santa Quitéria. Esclarece o facto de os castelhanos invocarem Santa Quitéria contra as angústias do coração e mordeduras de cães raivosos, o mesmo sucedendo com os portugueses. E cita o caso do aparecimento da imagem de

\footnotetext{
15 Ibidem, p. 357.

16 Ibidem, p. 359.
} 
Santa Quitéria em Meca, no termo de Alenquer, por intermédio da qual se realizam inúmeros milagres, tanto nos enfermos, como nos cães danados, pois estes dando-lhes pão molhado no azeite de sua lâmpada ficam visivelmente sarados.

Em seguida sublinha o aparecimento milagroso da imagem de Santa Quitéria de Meca. Segundo a tradição, a imagem foi encontrada por alguns pastores que viram ao longe, sobre um espinheiro, uma grande luz. Quando chegaram perto, verificaram que a claridade saía de uma formosa imagem de Santa Quitéria, identificada por meio de um letreiro. Avisado o prior, este seguiu com mais clero e o povo em direcção ao local e trouxeram a santa em grande festa para a igreja. Todavia, de forma milagrosa, a imagem voltou para o local do seu aparecimento, o que foi entendido por todos como a expressão da ordem divina de se construir naquele local uma igreja, a qual, depois de muitos anos, por ameaçar ruir, foi reedificada no ano de 1569. Diz a lenda que, enquanto todo o Portugal era consumido pela peste, naquela região ninguém ficou doente, facto que é atribuído à intercessão miraculosa de Santa Quitéria. ${ }^{17}$

Para terminar referimos a indicação de Jorge Cardoso que enumera os livros que tratam de Santa Quitéria. Entre eles destacamos os Martirológios Romano, Galicano, Lusitano, Castelhano e Hispânico, os Breviários de Toledo, Compostela, Granada, Palência, Pamplona Valência, Cuenca, Sigüença, Saragoça e Braga. Surge também nos Flos Sanctorum de Veja, Marieta, Emilliano e Villegas, todos no mesmo dia. ${ }^{18}$

\section{Culto}

O principal centro de culto de Santa Quitéria situa-se, como referimos, na região francesa da Aquitânia, mais precisamente na localidade de Aire-sur-l'Adour, povoação classificada pela Unesco como património mundial e que se encontra num dos «Caminho de Santiago».Segundo a tradição, a igreja foi construída no local do martírio de Santa Quitéria, e ali se conservam as suas relíquias, bem como o sarcófago e a fonte que brotou no local da sua decapitação. Apresentamos, na Figura 1 (p. seguinte), a imagem de Santa Quitéria venerada em Aire-sur-l'Adour. O culto desta jovem mártir também se verifica noutras localidades francesas como Bordéus, Tours e Marselha e na diocese de Rouen, na Normandia.

Por sua vez, em Espanha, o culto a Santa Quitéria foi introduzido no século XII pelo bispo de Sigüenza, Bernardo de Agén (1121-1152), que a converteu em padroeira da sua sede episcopal.Também é venerada noutros locais como Zaragoza, Tarragona, Palencia, Toledo, Aragão,

\footnotetext{
17 Ibidem, p. 369.

18 Ibidem, p. 370.
} 


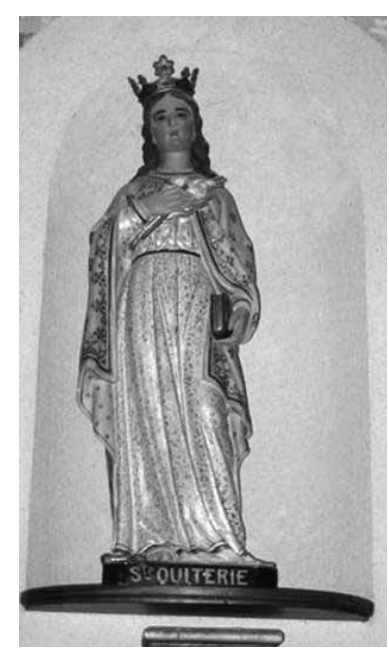

1. Santa Quitéria. Aire-surI'Adour (França).

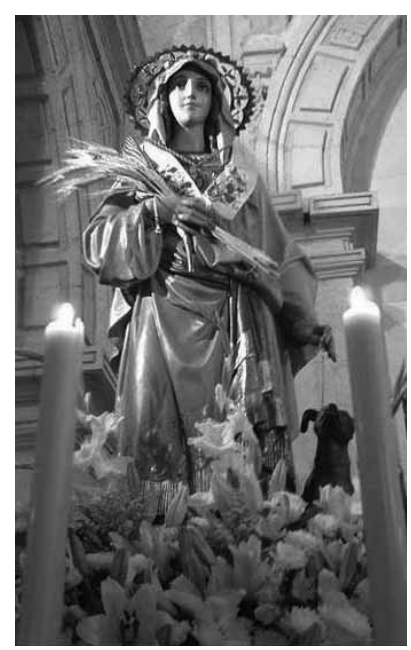

2. Santa Quitéria. Sorihuela del Guadalimar (Espanha).

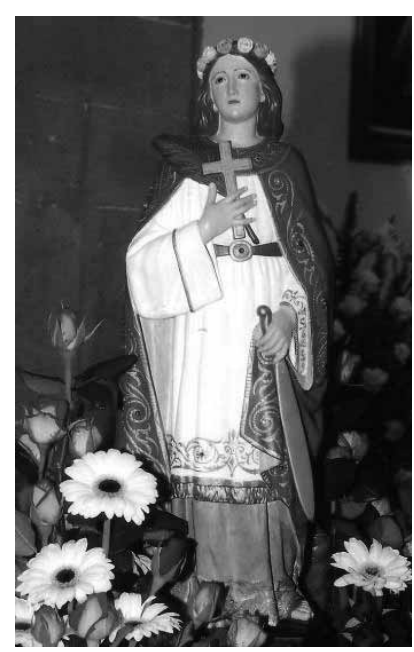

3. Santa Quitéria. Paróquia de Boaventura, Funchal.

Palma de Maiorca e Alcázar de San Juan, bem como em Sorihuela del Guadalimar (Jaén) que tem Santa Quitéria como co-padroeira e da qual apresentamos uma imagem (Fig. 2).

O Brasil, decerto por influências lusitanas, tem em certas localidades um especial apreço por Santa Quitéria. Assim, para citar alguns exemplos, referimos a existência da micro-região de Santa Quitéria e da cidade com o mesmo nome, fundada em 1856, no estado de Ceará; o rio de Santa Quitéria, que nasce no estado do Paraná; a paróquia de Santa Quitéria em Curitiba; a cidade de Santa Quitéria do estado do Maranhão, fundada em 1935, que possui um clube de futebol significativamente designado por «Santa Quitéria Futebol Clube».

Em Portugal, o culto a Santa Quitéria começa a manifestar-se no início do século XVI e, embora, como acima referimos, não seja das figuras hagiográficas mais conhecidas, a veneração desta jovem mártir está difundida um pouco por todo o país e mesmo nas regiões autónomas. $O$ culto não tem expressão tão ampla como sucede com outros santos, permanecendo mais localizado em certas dioceses (como Évora, Coimbra ou Porto) ou, em particular, em certas paróquias. De facto, se iniciarmos pela ilha da Madeira, verificamos que Santa Quitéria deu nome a várias capelas em diversas freguesias ao longo da história, como seja Curral das Freiras, Calheta e Madalena do Mar. Além disso, Santa Quitéria é orago na paróquia de Boaventura, no Funchal (Fig. 3), cuja igreja foi construída em 1731 e remodelada em 1835, sendo fixada nela a sede da paróquia criada em 1836. Nesta paróquia, as festas de Santa Quitéria realizam-se no quarto domingo do mês de Maio. 
Também no Funchal, o Colégio e a igreja de São João Evangelista, outrora pertencente à Companhia de Jesus e permanecendo como o maior conjunto edificado no Funchal até ao século XIX, possui, do lado do Evangelho, uma capela dedicada a Santa Quitéria.

Há celebrações anuais de Santa Quitéria em Silveirinho (Penacova), em Quintiães (Barcelos) e em Ferrel. É por demais conhecido o antiquíssimo culto a Santa Quitéria em Meca, freguesia do concelho de Alenquer, com uma romaria anual que tem lugar no primeiro domingo depois do dia 22 de Maio. A romaria baseia-se na citada lenda da imagem de Santa Quitéria com poderes milagrosos que apareceu num espinheiro, em 1238, na quinta de São Brás, perto de Meca, povoação onde hoje se ergue uma imponente basílica cuja construção, de meados do século XVIII, se deve à Confraria de Santa Quitéria, que beneficiou da protecção da rainha D. Maria I.

De referir, também, a capela de Santa Quitéria, antiga sinagoga, em Vila Nova de Foz Côa. E, por fim, aludimos ao Santuário de Santa Quitéria, no antigo monte Pombeiro, em Felgueiras, construído em 1719 no mesmo local onde outrora se encontrava uma capelinha dedicada a São Pedro.

Do culto a esta santa fazem parte as festas, romarias e procissões, mas também novenas e outras orações que lhe são dirigidas pedindo a sua intercessão contra a loucura e a mordedura de animais raivosos. Esta invocação em particular fica a dever-se, entre os factores já referidos, também ao facto de se acreditar que, enquanto vivia, a sua presença amainava a ira dos cães raivosos. Por este motivo, em algumas das suas representações surge acompanhada por um ou mais cães como indicação desta sua protecção.

\section{Iconografia}

Embora as representações de Santa Quitéria não sejam muito frequentes, nem muito variados os seus atributos, elas são conhecidas sobretudo nos locais onde a tradição consagrou as festas religiosas em honra da jovem mártir, locais esses onde pudemos encontrar diversas imagens. Assim, entre outras, salientamos a da paróquia de Santa Quitéria em Curitiba, no Brasil; a da igreja de Santa Quitéria em Aire-sur-l'Adour (Fig. 1); a de Sorihuela del Guadalimar (Jaén, Espanha, Fig.2), na qual se pode apreciar a presença de um cão junto aos pés da santa; a pequena escultura do século XVIII que se encontra no Palácio Nacional de Sintra, cujo atributo é unicamente um livro; a da paróquia de Boaventura, no Funchal (Fig. 3); os medalhões com as pinturas do tecto da basílica de Santa Quitéria, em Meca; a gravura do conjunto das nove irmãs, outrora veneradas no Colégio de São Lourenço, dos Religiosos Agostinhos Descalços do Porto (Fig. 4, p. seguinte); o grupo escultórico das nove irmãs que se encontra na capela do Castelo de Póvoa de Lanhoso; o da Igreja do Seminário 


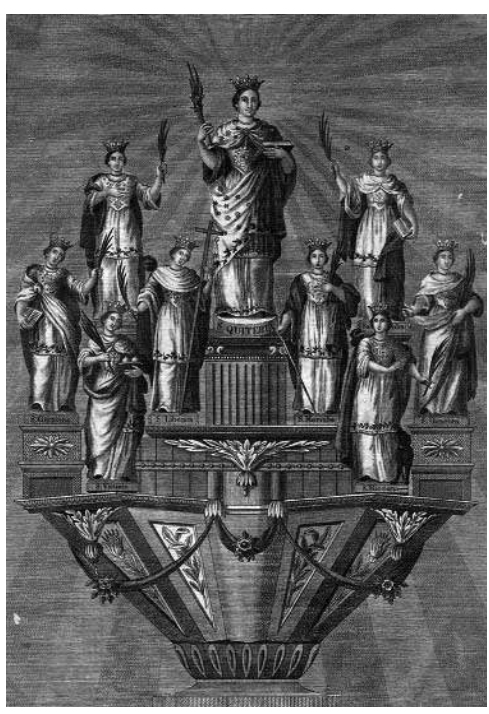

4. Santa Quitéria e suas oito irmãs. Gravura.

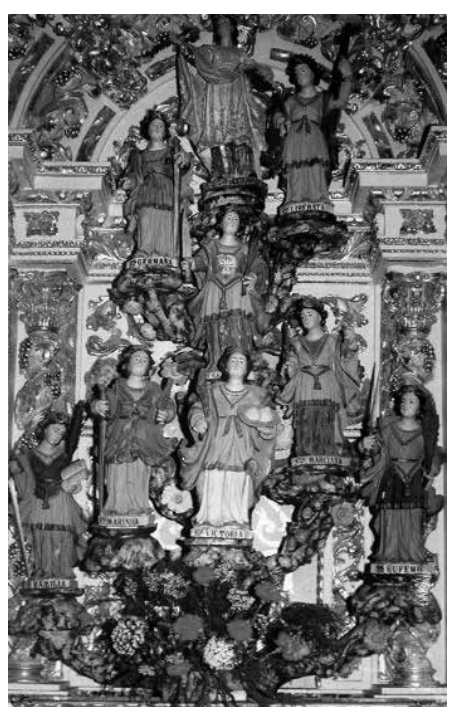

5. Santa Quitéria e suas oito irmãs.

Felgueiras, Santuário de Santa Quitéria.

Maior do Porto, bem como o que ornamenta o pequeno retábulo da capela do lado da Epístola, no Santuário de Santa Quitéria, em Felgueiras (Fig.5), ao qual faremos referência de forma mais detalhada.

Em certas manifestações iconográficas Santa Quitéria é representada tendo, como atributos, a palma, que a identifica como mártir, ou um ramo de açucenas, sinal da sua pureza, um livro aludindo ao Santo Evangelho pelo qual entregou a sua vida e uma coroa de rosas, símbolo da glória. Assim se verifica, por exemplo, nas imagens supracitadas da paróquia de Santa Quitéria, em Curitiba, na igreja de Aire-sur-l'Adour, bem como no coroamento do conjunto escultórico de Felgueiras que ilustramos na Figura 6. Estes atributos são demasiado generalistas e característicos de muitos outros santos mártires, além de Santa Quitéria, que, deste modo, deles assim não se consegue diferenciar.

Todavia, alguns episódios da sua vida, a que acima fizemos referência, deram origem a uma iconografia mais variada e a atributos específicos que permitem uma identificação mais rigorosa.

Assim, o episódio hagiográfico em que se refere o facto de que, depois de ser decapitada, pegou na sua cabeça e se encaminhou para a cripta da igreja onde iria ser sepultada, motivou a representação da jovem com sua própria cabeça cortada segura nas mãos tal 


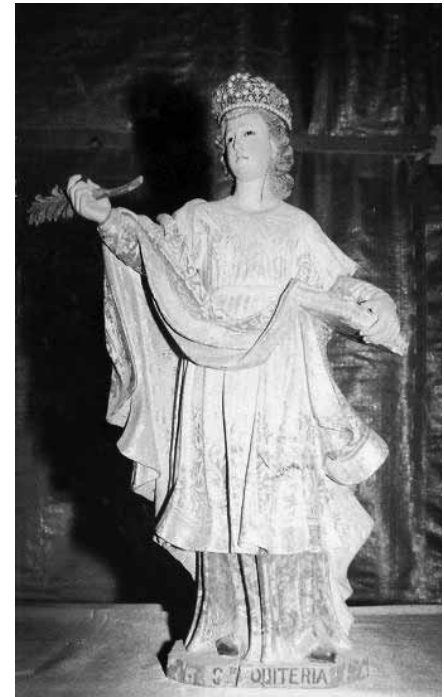

6. Santa Quitéria. Felgueiras, Santuário de Santa Quitéria.

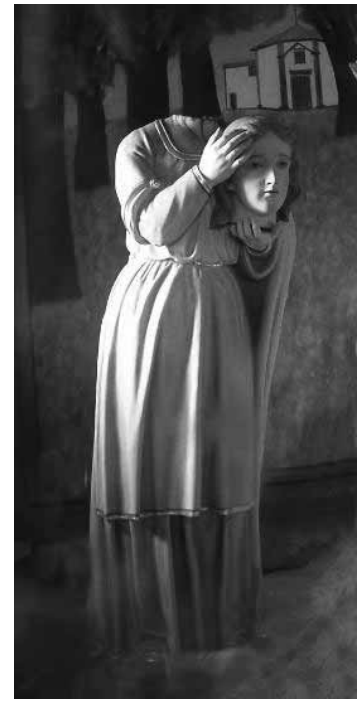

10. Santa Quitéria martirizada segura a cabeça. Felgueiras, Capela 8 do Santuário de Santa Quitéria.

como podemos ver numa imagem pertencente ao arquivo do Santuário de Santa Quitéria, de Felgueiras, representação esta que se verifica, igualmente, no conjunto escultórico da última capela do percurso que os peregrinos realizam no mesmo Santuário e na qual se regista o oitavo passo da vida de Santa Quitéria (Fig. 10).

Por sua vez, os relatos alusivos ao apaziguamento de cães raivosos, ou à cura milagrosa das feridas que eles causaram, embora diferenciando um pouco nos pormenores, coincidem no essencial e justificam a invocação que se faz de Santa Quitéria como advogada contra a mordedura de cães raivosos. Assim se compreende a representação de um ou mais cães, colocados aos seus pés e presos com uma corrente e, por vezes, com a língua de fora, indicando estarem afectados pela raiva.

Atendendo aos episódios iniciais da sua vida, relacionados com as suas irmãs, Santa Quitéria costuma ser representada juntamente com elas. Deste modo, ao falarmos da iconografia de Santa Quitéria impõe-se, naturalmente, referir também a das suas oito irmãs, bem como a do Arcebispo Santo Ovídio e da criada Cita, figuras fundamentais nos primeiros anos da sua existência e da sua formação cristã. 


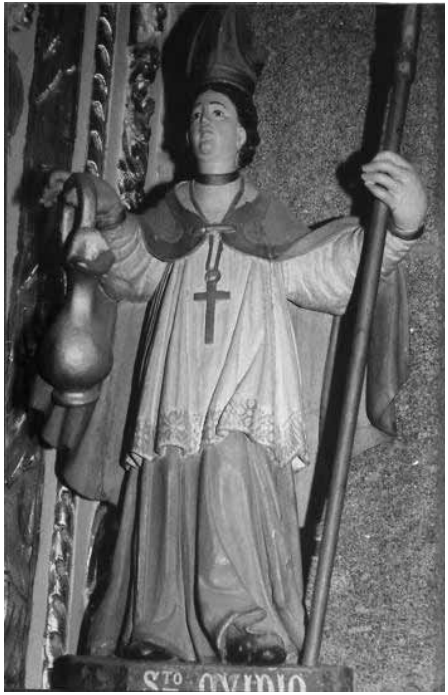

7. Santo Ovídio, Arcebispo de Braga. Felgueiras, Santuário de Santa Quitéria.

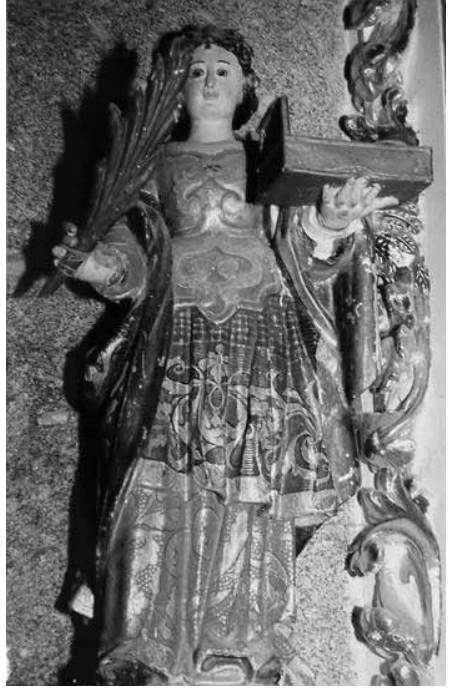

8. A criada Cita. Felgueiras, Santuário de Santa Quitéria.

Assim, tomando como elementos de referência a gravura do Colégio de São Lourenço (Fig. 4) e o belíssimo conjunto escultórico do Santuário de Felgueiras, onde são representadas as nove irmãs (Fig. 5), juntamente com o Arcebispo e Cita, passaremos a descrever, de forma sucinta, cada uma das figuras fazendo uma referência particular aos respectivos atributos.

Começando por Santo Ovídio (Fig. 7), podemos apreciar as suas vestes eclesiásticas, a mitra e o báculo que ostenta na mão esquerda, enquanto a direita segura um gomil de cerâmica numa clara alusão ao facto de ter ministrado o sacramento do baptismo às nove irmãs. Quanto à jovem criada Cita, devido ao facto de ter salvo de uma morte certa as crianças recém-nascidas, transportando-as para casa do Arcebispo, surge representada com um berço, como atributo mais singular (Fig. 8). Além disso, possui na mão direita a palma do martírio e ostenta ricas vestes romanas, o que não se enquadra com a sua condição de empregada, situação que ocupava em casa de Cálcia Lúcia.

No que se refere às irmãs de Santa Quitéria, baseando-nos em certos pormenores da sua hagiografia, supracitados, podemos compreender certas características da respectiva iconografia. Assim, na representação de Santa Marinha, a jovem mártir possui como atributos a palma do martírio e a espada, instrumento alusivo à sua decapitação. Por sua vez, a ico- 
nografia de Santa Vitória coloca-lhe, na mão direita, a palma e na esquerda uma bandeja, sobre a qual se encontram dois seios. Neste aspecto particular, poderá ter havido alguma confusão iconográfica com sua irmã, Santa Marinha, a qual sofreu, efectivamente, queimaduras no peito causadas por um ferro incandescente. ${ }^{19}$

No conjunto escultórico a que nos temos referido, Santa Genebra possui, como atributos, a palma e um cutelo, sem que sejam conhecidos pormenores do seu martírio que justifiquem a representação de tal instrumento. $O$ pouco que se conhece sobre Santa Marciana também não permite esclarecer o facto de se encontrar representada, no Santuário de Felgueiras, com a espada na mão direita, embora se compreenda a figuração do livro na esquerda.

Por sua vez, Santa Liberata, devido ao facto de, segundo a tradição, ter sofrido o suplício da cruz, pode estar representada com os braços em cruz, como se estivesse crucificada ou, em alternância, sustentar a cruz numa das mãos, enquanto na outra apresenta a palma do martírio, tal como se verifica na gravura e no conjunto escultórico de Felgueiras.

A espada, como instrumento do martírio de Santa Eufémia, é um dos seus atributos, juntamente com a palma, como sucede com outras das suas irmãs.

Para concluir, impõe-se uma alusão aos oito passos da vida de Santa Quitéria, representados, no Santuário de Felgueiras, por meio de outras tantas encenações, que podem ser seguidos percorrendo as oito capelas quadrangulares, dispostas ao longo do monte e unidas entre si por um caminho, em terra batida, íngreme e sinuoso que tem início junto da povoação e termina diante do Santuário, junto da escadaria que Ihe dá acesso. Ainda que as imagens, bem como todo o cenário e os demais elementos envolventes, possam não ser detentoras de uma grandiosa qualidade e valor artístico, constituem, em termos iconográficos, um registo importante e relativamente raro sobre a vida de Santa Quitéria, motivo pelo qual importa ser referido e salientado.

Assim, o Primeiro Passo refere-se ao episódio em que a criada Cita salva as crianças do fim cruel a que sua mãe as tinha destinado e tem como legenda a seguinte inscrição: "A

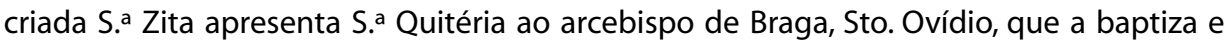
manda educar assim como às 8 irmãs.20 Tendo como pano de fundo a Sé Catedral de Braga, a figura de Santo Ovídio, ostentando batina e pálio, de braços abertos, recebe Quitéria, ainda bebé, que se encontra nos braços de Cita que veste de forma singela.

No Segundo Passo a inscrição "S. a Zita é incumbida da educação de Santa Quitéria" esclarece o motivo da cena na qual podemos ver a jovem Quitéria, ainda em idade infantil, com um livro nas mãos, em sinal da sua capacidade de ler. Está acompanhada de uma

19 Cf. LEITE, José, S. J. (org.) - Santos de cada dia II, p. 164.

20 Regista-se alguma confusão entre o nome de Cita, que é o mais vulgarizado para a jovem que salvou as nove irmãs (século II), e a figura de Santa Zita (1218-1278). 
figura feminina adulta que pretenderá representar Cita. Ambas se encontram diante de um cenário que mostra uma ampla sala avarandada, com vistas para uma paisagem verdejante. Numa figuração anacrónica, podemos observar diversos instrumentos musicais e partituras numa alusão à esmerada educação recebida por Santa Quitéria.

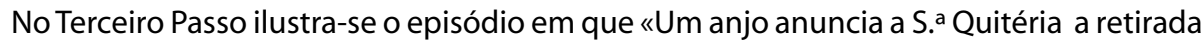
da casa paterna para o monte Pombeiro». A cena decorre no pátio do palácio de Lúcio Severo, estando a jovem adolescente vestida de túnica, sobretúnica, manto e véu sobre a cabeça, enquanto o anjo, de asas baixas e túnica verde, situado a maior altura e de expressão serena, ergue a mão direita em sua direcção.

O Quarto Passo constitui uma alusão à conversão de Lenciano, podendo ler-se na inscrição: «S. ${ }^{a}$ Quitéria converte Lenciano, régulo de Eufrásia, vulgo Sergude». Diante do palácio do governador, Quitéria, envergando vestes idênticas à do passo anterior, segura uma cruz na mão esquerda, enquanto ergue a direita apontando para o alto. A figuração da cruz poderá ter a sua origem no relato de Jorge Cardoso, acima referido, no qual se afirma que, tendo a Virgem Maria visitado Quitéria quando esta se encontrava na prisão e antes da conversão de Lenciano, lhe entregou uma cruz dizendo que com ela triunfaria dos três inimigos da alma: o mundo, o diabo e a carne.

Por sua vez, o governador, vestindo túnica e manto, de grandes barbas grisalhas e ostentando uma coroa na cabeça, com as mãos postas ergue os olhos ao alto, mostrando assim o reconhecimento de Deus como seu Senhor. O Quinto Passo está identificado pela legenda: «Santa Quitéria, na prisão, cura um hidrófobo». ${ }^{21}$ Esta representação alude à intercessão milagrosa de Santa Quitéria na cura da raiva. De facto, o homem que, como a jovem, se encontrava na prisão, tal como pretende indicar as paredes de pedra do cenário, apresenta algumas feridas nos membros superiores, sobre as quais Santa Quitéria derrama um unguento a partir de um pequeno gomil metálico.

No Sexto Passo «S. ${ }^{\text {a }}$ Quitéria recebe o embaixador, com a proposta de casamento, que rejeita». Num ambiente natural, com uma floresta ao fundo, um jovem nobre, ricamente vestido e de olhar baixo, parece ter ficado desapontado com a resposta dada pela jovem à sua proposta de casamento. De facto, Santa Quitéria, que, como vimos, tinha consagrado a sua virgindade a Deus e tinha celebrado com Jesus os esponsais místicos, volta as costas ao jovem pretendente e apresenta um pergaminho desenrolado, que segura com a mão esquerda e no qual se pode ler: «O meu esposo é Jesus».Com a mão direita erguida, aponta para o alto, confirmando esta sua firme decisão (Fig. 9).

${ }^{21}$ O vocábulo hidrofobia é uma designação imprópria, mas vulgarizada para a doença da raiva. 
Esta tomada de posição valeu-lhe, como sabemos, o martírio. Por isso, o Sétimo Passo, identificado pela legenda: «S.a Quitéria prestes a ser degolada por Germano, seu pretendente», ilustra o seu martírio, por degolação. Tendo como pano de fundo uma floresta na qual se agita o cavalo branco de Germano, como se tivesse consciência da tragédia que estava para acontecer, a jovem Quitéria, ajoelhada no chão e de mãos postas, ergue os olhos ao alto, em oração. O facto de se encontrar representada nesta atitude orante ilustra o que acima foi referido quando apresentámos a lenda mais conhecida em Espanha. Confiante na glória que a aguarda junto de Deus, não oferece qualquer resistência e entrega a sua vida na fidelidade ao seu Senhor. Germano, vestido como soldado romano, agitado e de olhos crispados postos na jovem, ergue bem ao alto a espada com a qual desfe-

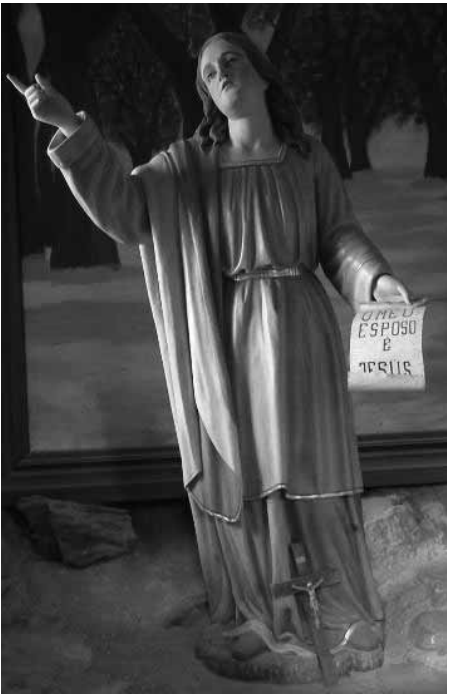

9. Santa Quitéria com o pergaminho. Felgueiras, Capela 6 do Santuário de Santa Quitéria. rirá o golpe fatal.

Por fim, o Oitavo Passo ilustra a lenda que se transcreve na pedra colocada no local:"S. ${ }^{a}$ Quitéria, decapitada, um anjo a coroá-la; e ela com a cabeça nas mãos recolhe à ermida 'há muito transformada em seu majestoso santuário'". O cenário remete-nos para o cimo do antigo monte Pombeiro, um terreno verdejante semeado de frondosas árvores, por entre as quais se vislumbra a mancha branca do corpo central do santuário, de forma octogonal. O anjo que acompanha Santa Quitéria representa o que nos relatos hagiográficos ordena à jovem martirizada que pegue na sua cabeça e se dirija para a igreja onde descansará definitivamente. Com túnica verde, asas baixas, agita os braços como quem se encontra em posse da palavra, dando indicações. Por sua vez, Santa Quitéria segura nas mãos a cabeça degolada enquanto do pescoço escorre sangue resultante do recente martírio.

Desta forma simples, visualmente atractiva e apelando ao essencial da vida de Santa Quitéria, o culto que os fiéis lhe dedicam torna-se quase tangível, recordando o valor, a coragem e a fé de uma jovem que, como muitas outras, preferiu dar a vida a fim de manter intacta a sua consagração a Jesus, o único que queria para seu esposo. Através do exemplo de vida cristã, das orações, festividades e da sua intercessão, na busca da saúde ou da protecção, se apela à integridade e ao fortalecimento da fé em Cristo, fim único do culto dos santos e santas e da sua representação iconográfica. 


\section{Bibliografia}

ASCENSAM, Bento da, Fr. Vida, e martyrio da insigne virgem, e martyr prodigioza Santa Quitéria, serenissima Infante de Portugal, no Monte de Pombeyro. Lisboa: Off. Ferreyriana, 1722.

CARDOSO, Jorge. Agiológio Lusitano. Edição fac-similada do original de 1666. Porto: Faculdade de Letras da Universidade do Porto, 2002, vol. III.

ENCICLOPÉDIA DEI SANTI. Bibliotheca Sanctorum. III Ristampa. Roma: Città Nuova Edirice 1998, vol.X.

FERRANDO ROIG, Juan. Iconografia de los Santos. Barcelona: Ediciones Ómega, S.A., 1950.

LEITE, José, S. J. (org.). Santos de cada dia Il. 4. a edição. Braga: Editorial A. O., 2003.

LUIS REPETTO, José. Todos los santos. Santos y beatos del Martirologio Romano. Madrid:BAC, 2007. MARTYROLOGIO ROMANO acomodado a todos os dias do anno conforme à nova ordem do calendario, que se reformou por mandado do papa Gregório XIII. Coimbra: Casa de António Maris, Impressor da Universidade, 1591.

MARTYROLOGIO ROMANO dado à luz por mandado do Papa Gregório XIII. E novamente accrescentado por authoridade do Papa Clemente X. Lisboa: Na Regia Officina Sylviana, e da Academia Real, 1748.

MARTYROLOGIUM ROMANUM. Ex decreto sacrosancti oecumenici Concilii Vaticani II instauratum auctoritate loannis Pauli PP. II promulgatum. Editio Altera. Città del Vaticano: Libreria Editrice Vaticana, 2004.

NUNES, Pinho Pe. Vida de Santa Quitéria. [s.I.]: Edição da Casa da Confraria, [s.d.].

RÉAU, Louis. Iconografía del arte cristiano. Iconografía de los santos. Barcelona: Ediciones del Serbal, 2000, tomo 2, vol. 5 . 


\title{
O martírio de Inácio de Azevedo \\ e dos seus trinta e nove companheiros (1570) na hagiografia da Companhia de Jesus entre os séculos XVI e XIX
}

\author{
Maria Cristina Osswald*
}

"Los que muertos veneramos por su Dios. si non los seguimos nos, que ganamos?" (José de Anchieta, Los que muertos veneramos - cantiga)

\section{Aspectos gerais do significado do martírio de Inácio de Azevedo e dos seus trinta e nove companheiros para a Companhia de Jesus}

No dia 15 de Julho de 1570 o jesuíta português Inácio de Azevedo, trinta e oito companheiros (trinta portugueses e oito espanhóis) e ainda o candidato à Companhia Juan de San Juan, que era sobrinho do capitão da nau, foram "distinguidos com a Coroa do Martírio" nos mares das Ilhas Canárias às mãos de corsários comandados pelo calvinista francês Jacques Soria, quando se dirigiam para a Missão do Brasil. No dia seguinte foi martirizado o irmão jesuíta Simão Costa.

Este martírio constituiu um episódio de grande actualidade devocional e iconográfica em uma época caracterizada por inúmeros episódios de martírio cristão, em especial de jesuítas, dentro e fora da Europa. Reflectindo tal facto, a cornija de // Gesù, então igreja mãe da Companhia de Jesus, durante as celebrações da dupla canonização de Inácio de Loiola e Francisco Xavier, os dois primeiros santos jesuítas, em 1622, foi decorada com um friso de imagens representando os cento e um jesuítas mortos pela fé até à data ${ }^{1}$. Todavia, este número conheceu um significativo e rápido aumento. A principal obra em honra dos mártires jesuítas pelo flamengo Mathias Tanner de 1675 menciona nada menos que trezentos e quatro mártires jesuítas².

* Pós-doutoranda na Universidade do Minho, UNED (Madrid) e UNICAMP (Brasil).

1 Azzolini SI, Ilario M., Le immagini dei martiri della Compagnia di Gesù nell'addobbo del tempio farnesiano per la canonizzazione del 1622, in Canonizzazione dei Santi Ignazio di Loyola Fondatore della Compagnia di Gesù e Francesco Saverio Apostolo dell'Oriente, Comitato Romano Ispano per le Centenarie Onoranze (ed.), Roma, Grafia, 1922, pp. 94-99 e Osswald, Maria Cristina, Iconografia das Cerimónias de Canonização no Contexto Português, in Brotéria 163 (2006), p. 338.

2 Tanner, Mathias, Societas lesu usque ad Sanguinis et vitae profusionem militans in Europa, América, Ásia, et Africa, Praga, Typ. Universitatis Carolo-Ferdinandeae, 1675. 


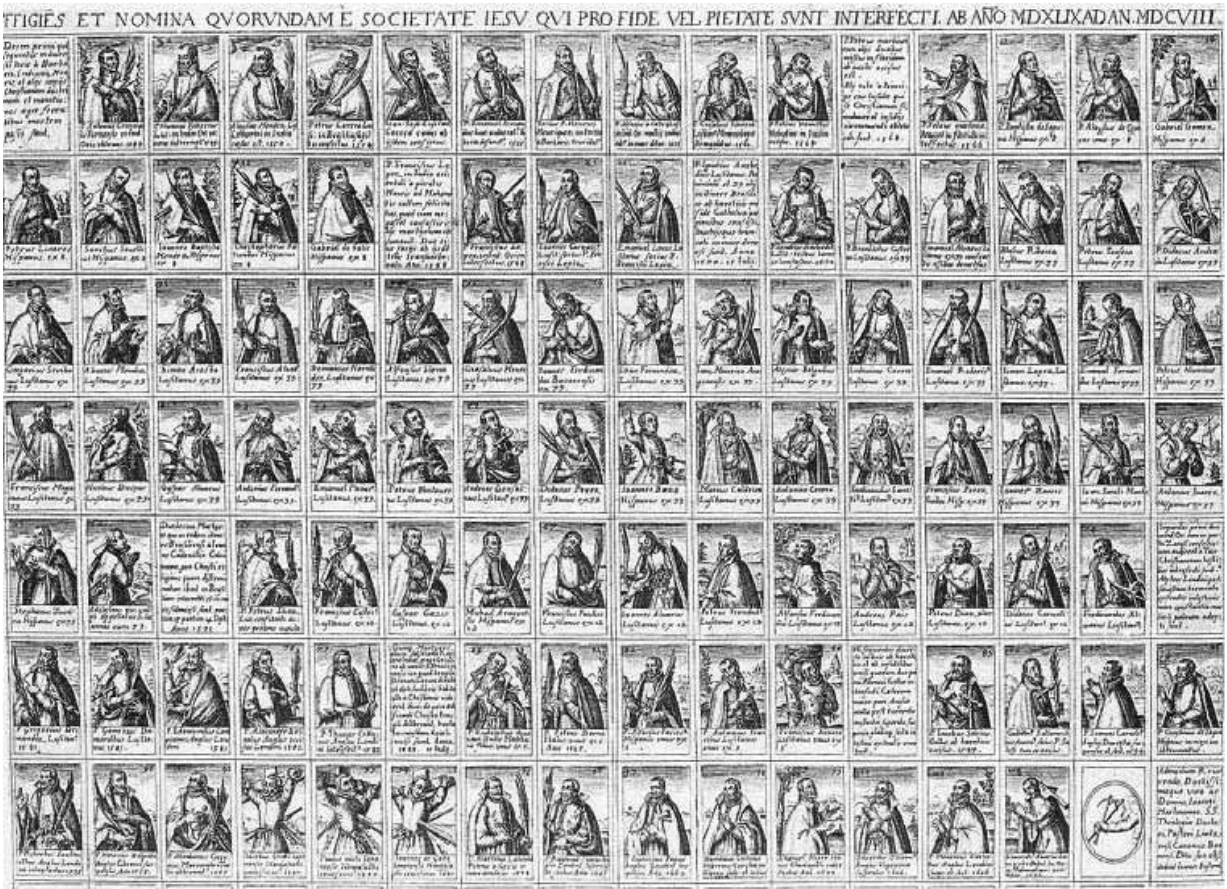

1. Johann Bussemacher, Galeria de mártires da Companhia, 1609, col. privada.

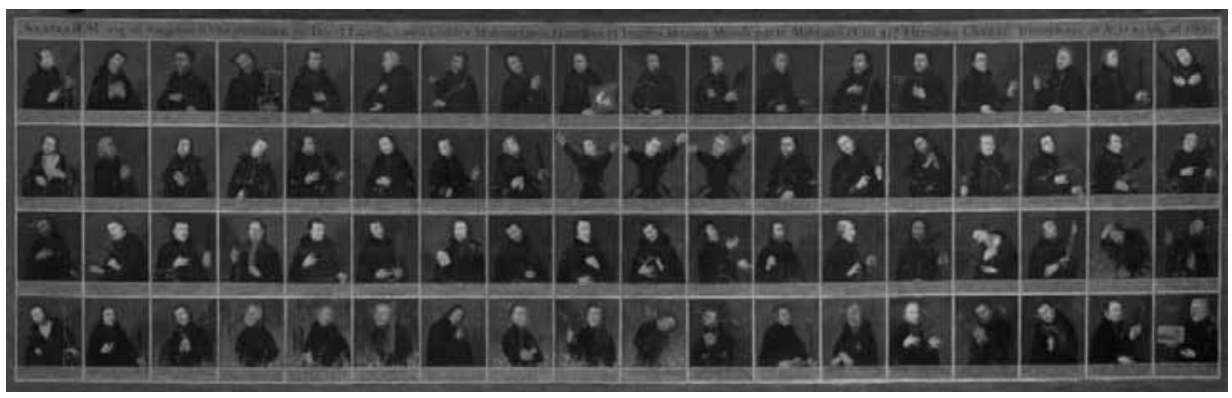

2. Autor anónimo (alemão?), Galeria de mártires da Companhia, óleo, 1695, Museu Diocesano de Paderborn (cortesia de Johannes Meier).

O tema do martírio assumiu um carácter especial para os jesuítas, que foram com os oratorianos os grandes fomentadores ou mecenas desta iconografia. Entre finais do século XVI e a segunda década do século XVII todas as casas da Companhia de Jesus em Roma 
foram decoradas com ciclos de pinturas a fresco representando episódios individuais ou colectivos de martírio. O Geral Claudio Acquaviva (1543-1605), uma das figuras mais marcantes da história da Velha Companhia, foi igualmente decisivo no fomento do culto dos mártires. Cláudio Acquaviva (1543-1605), cujo sobrinho Rodolfo chefiava o grupo de jesuítas mártires na vila de Salsete de Goa em 1583, tinha uma colecção de quadros de mártires e beatos jesuítas nos seus aposentos para a sua meditação individual.É ainda importante realçar o facto de que Claudio Acquaviva concebeu o programa iconográfico do noviciado romano de Sant'Andrea al Quirinale. É ainda provável que o Geral Acquaviva tenha encomendado outros ciclos pictóricos com cenas de martírio ${ }^{3}$.

(Figs. 1 e 2) Regressando ao episódio de martírio de 1570, atribuímos ao mesmo um alto valor simbólico, dado "reunir" os dois mundos ou contextos geográfico-culturais, nos quais aconteciam estes episódios: a Europa dilacerada pelas guerras de religião e as missões católicas fora da Europa ${ }^{4}$. Esta expedição foi simultaneamente a expedição com maior número de jesuítas partindo de Lisboa para as missões ultramarinas e o martírio colectivo mais numeroso em toda a Época Moderna. Por tal razão, as assim denominadas galerias de mártires jesuítas, que foram pintadas e impressas a partir da beatificação de Inácio de Loyola (1609), são constituídas sobretudo por retratos dos mártires de $1570^{5}$.

A partir do primeiro relato do martírio destes quarenta homens por Maurizio Serpe (1572), a hagiografia destaca o facto de Inácio de Azevedo ter sido a primeira pessoa, a quem foi concedida autorização papal para levar consigo uma cópia da imagem da Madonna di San Luca. Esta imagem, que se conserva na Basílica de Santa Maria Maior, era, ao tempo, considerada uma acheiropoieton, isto é, uma imagem com carácter divino e com capacidades taumatúrgicas. Pensava-se que a mesma imagem fosse um retrato de Nossa Senhora ao vivo pelo Apóstolo São Lucas ${ }^{6}$.

3 Bailey, Gauvin Alexander, Between Renaissance and Baroque, Jesuit Art in Rome, 1565-1610. Toronto/ Buffalo/London: University of Toronto Press, 2003, p. 13.

4 Hernández Palomo, José e Osswald, Maria Cristina, Aspectos del culto a Ignacio de Azevedo y sus treinta y nueve compañeros mártires en 1570, in Sevilla y América en la historia de la Compañía de Jesus, ed. por José Hernández Palomo e José del Rey Fajardo SJ, Roma-Sevilha, Institutum Historicum Societatis lesu e Escuela de Estudios Hispano-Americanos/Consejo Superior de Investigaciones Científicas (no prelo).

5 Estas galerias, que aparentemente foram exclusivas da Companhia de Jesus, mostram os jesuítas por ordem cronológica do seu martírio. Os jesuítas têm nas mãos uma palma. Trata-se do tradicional atributo do martírio e, em alguns casos, ainda outros instrumentos de martírio que, todavia, nem sempre correspondem aos instrumentos mencionados nas fontes documentais.

6 No relato de Paolo de Angelis descrevendo a construção e decoração da Capela Paulina (1606 a 1613), onde esta imagem devia ser guardada, defende-se que esta imagem tinha sido concluída por anjos. (De Angelis, Paolo, Basilicae S. Mariae Maioris de Vrbe a Liberio papa 1. vsque ad Paulum 5. Pont. Max. descriptio 


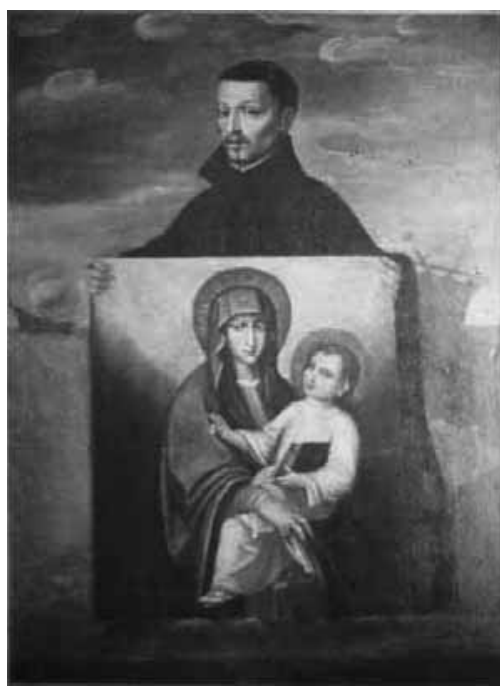

3. Pintor português, O Beato Inácio de Azevedo com a imagem da Madona di San Luca nas mãos, óleo, século XVIII, colecção particular.
(Fig. 3) Em especial, o protótipo iconográfico de Inácio de Azevedo com um retrato da Madonna de San Luca nas mãos, enquanto expirava às mãos dos corsários, fixou definitivamente na hagiografia e na iconografia a ligação entre este mártir e o culto tipicamente jesuíta da Madonna di San Luca. Na origem desta ligação encontra-se o facto de que se deve a Inácio de Azevedo a introdução deste culto em Portugal ${ }^{7}$. $O$ jesuíta mártir, que tinha sido encarregado pelo Geral Francisco de Borja (1510-1572) de levar uma cópia da Madona ditípicam San Luca para a Rainha de Portugal D.Catarina, mandou fazer reproduções desta mesma imagem, as quais colocou à veneração nos colégios jesuítas de Coimbra e Évora8 ${ }^{8}$.

Azevedo está ainda ligado de forma indirecta ao sucesso deste culto no Brasil. Até ao século XVIII acreditava-se que a imagem da Madonna di S. Luca na actual Catedral e antiga Igreja do Colégio Jesuíta de Salvador da Bahia era a mesma imagem que Azevedo teria nas mãos quando foi martirizado. Segundo alguns autores seiscentistas e setecentistas, esta imagem tinha ainda vestígios do sangue dos dedos de Inácio de Azevedo, pois os piratas tinham sido incapazes de a tirar das mãos do cadáver. Na versão mais difundida desta lenda, o corpo de Azevedo ficou a boiar segurando esta imagem até que o seu braço direito a depositou suavemente nas mãos dum homem católico, que seguia numa outra nau. Na ilha da Madeira, este homem teria entregue a imagem aos jesuítas que a fizeram chegar ao colégio da Bahia?

(Figs. 4 e 5) De igual modo, o significado especial deste episódio dentro da hagiografia está relacionado com a figura de Santa Teresa de Ávila, que foi uma das figuras mais relevantes da espiritualidade pós-tridentina. A visão contemporânea do martírio por parte de Teresa de Ávila, episódio que foi incluído nos processos da sua canonização, foi o pre-

et delineatio, Roma, typographia Bartholomaei Zannetti, 1621 e Ostrow, Stephen, Art and Spirituality in Counter-Reformation Rome, Cambridge, Cambridge University Press, 1996, pp. 122-123 e 118-151.)

7 Franco, António, Imagem da Virtude em o noviciado da Companhia de Jesus no Real Collegio de Jesus de Coimbra em Portugal,Évora, Officina da Universidade, 1719, vol. II, pp. 77-78.

8 Idem, ibidem, pp. 193-194.

9 Cabral, Antonio, Relación del martyrio de los quarenta martyres de la Compañia de Jesus: vida del venerable martyr P. Ignacio Acevedo, Madrid, Imprensa y Libraria de Manuel Fernandez, 1744, pp. 206-207. 


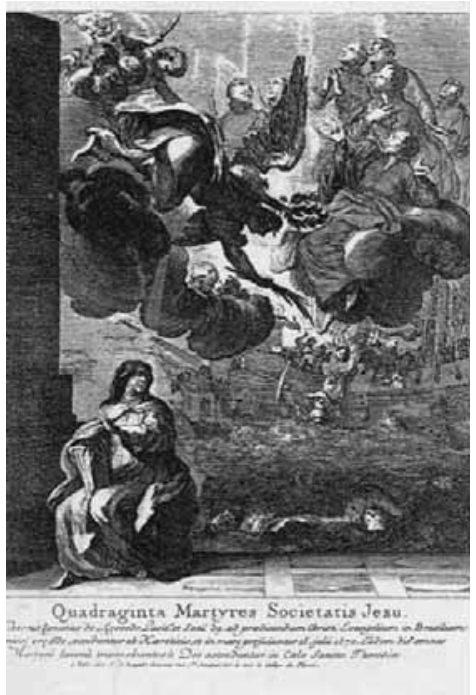

4. Giuseppe Baguasco, O Martírio de Inácio de Azevedo, óleo, 1855, Casa Professa da Companhia de Jesus, Roma (cortesia da Vice-Procuradoria dos mártires do Brasil).

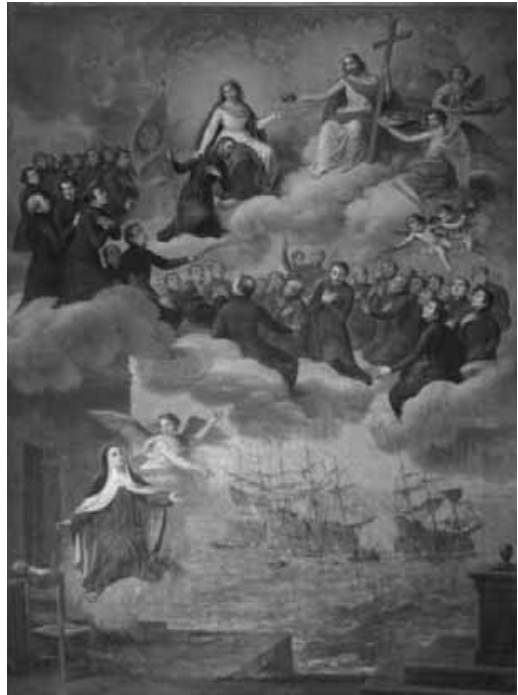

5. Gravura representando o Martírio de Inácio de Azevedo e a respectiva visão de Teresa de Ávila, in Hamy, Hamy SJ, Alfred, Gallerie illustrée de la Compagnie de Jesus, Paris, chez l'auteur, 1893, vol. I, s/p, s/nr. (cortesia do Archivum Historicum Societas lesu, Roma).

sumível milagre que esteve na origem da beatificação dos mártires jesuítas. Por tal razão, a iconografia oficial pós-beatificação estabeleceu a visão de Teresa de Ávila em conjunto com a glorificação dos quarenta mártires em 1570, como um dos mais representativos protótipos iconográficos destes mártires fixados durante a época da beatificação, como vemos em um quadro de Giuseppe Baguasco de 1855 e na respectiva gravura do Beato Inácio de Azevedo ilustrando a obra do P. Alfredo Hamy de $1893^{10}$.

Pensamos que este episódio assumiu simultaneamente um carácter político. Como observado por Zulmira Coelho dos Santos, os esforços da Província do Brasil para fomentar o culto do seu "apóstolo" Anchieta e os mártires de 1570 inserem-se numa estratégia, aliás sem grande êxito, de promoção da Missão do Brasil por alguns responsáveis jesuítas. O objectivo era ademais contrabalançar o peso da Missão do Oriente e da figura de Francisco Xavier ${ }^{11}$.

10 Hamy SJ, Alfred, Gallerie illustrée de la Compagnie de Jesus, Paris, chez l'auteur, 1893, vol. I, s/p, s/nr.

11 Coelho dos Santos, Zulmira, Em busca do paraíso perdido: a Chronica da Companhia de Jesu do Estado do Brasil de Simão de Vasconcellos S. J., in Quando os Frades faziam Hstória - De Marcos de Lisboa a Simão de Vasconcellos, Porto, Centro Interuniversitário de História da Espiritualidade, 2001, pp. 174- -175. 
Gostaríamos ainda de relacionar com esta política a muito provável participação directa nesta causa do P.António Vieira durante a sua estadia em Roma entre 1669 e 1673 e o facto de esta mesma causa ter sido financiada pela Província do Brasil'12.

\section{Características fundamentais e evolução do culto dos quarenta mártires}

Os processos de beatificação destes quarenta mártires começaram em 1628 em Coimbra, em conjunto com os processos de um segundo grupo de doze jesuítas igualmente martirizados nos mares das Canárias a caminho do Brasil no ano seguinte. Os processos foram depois limitados aos mártires de 1570, devido ao grande número de jesuítas martirizados $^{13}$.Em 1742 Bento XIV reconheceu o martírio dos quarenta mártires de 1570. A sua beatificação data de 11 de Maio de 1854, decorrendo os processos para a sua canonização ${ }^{14}$.

Este grupo de mártires ficou conhecido na hagiografia por mártires do Brasil, dado o destino da sua viagem. Todavia, nas Canárias estes mártires são chamados de mártires de Tazacorte, cidade onde celebraram a sua última missa em terra firme, antes de embarcarem pela última vez.

O culto destes quarenta homens começou pouco depois do próprio evento. A carta de Pedro Diaz de 17 de Agosto de 1570 (líder da segunda expedição de jesuítas mártires em 1571), que constitui o relato mais antigo deste martírio, foi traduzida para italiano e incluída na obra Nuovi Avisi publicada em Roma ainda em $1570^{15}$. Entre os mais importantes e antigos devotos dos quarenta mártires, encontrava-se o Geral Francisco de Borja, que tinha contactado em Roma com Inácio de Azevedo. Segundo a hagiografia, o Geral Borja tinha por hábito encomendar-se diariamente aos quarenta mártires.

12 Citamos uma das várias afirmações do P. António Vieira, que nos permitem acreditar num seu envolvimento directo com esta causa:"Fico tratando da canonização dos mártires, em que brevemente se tomarão a última resolução, depois da qual saberei o que há-de de ser de mim." (Carta do P. António Vieira a D. Rodrigo de Menezes, 23.2.1671, in Cartas do Padre António Vieira, coordenadas e anotadas por J.Lúcio de Azevedo, Lisboa, Imprensa Nacional-Casa da Moeda, 1970, vol. II, p. 327 e ver também Alden, Dauril, The making of an enterprise, the society of Jesus in Portugal, its empire, and beyond, Stanford, Stanford University Press, 1996, p. 641).

13 Tal dificuldade foi sentida pelo P. António Vieira: “Eu fico trabalhando na canonização dos mártires, que por muitos, e portugueses, têm encontrado grandes embaraços na emulação; contudo esperamos que antes da Páscoa nos dê Sua Santidade estas boas festas" (Carta do P. António Vieira SJ ao Marquês de Gouveia, 31.1.1671, in Cartas do P. António Vieira, ed. João Lúcio Azevedo, Lisboa, Imprensa Nacional, 1971, vol. II, p. 317).

14 Archivio della Postulazione [AdP], 20 Brasilien. Redingrationis Cultus Ven. Servorum Dei lgnatii de Azevedo et XXXIX. Sociorum Martyrium E. Soc. lesu. Summarium Super Dubio, 21 Set. 1742, F.F. A Cardinalis Guadagni Pro Prafectus e AdP. 20, Decretum Brasilien Redingrationis Culturs Ven. Servorum Dei Igntatii de Azevedo et XXXIX. Sociorum Martyrum et Societate Jesu, 1854.

15 Leite, Serafim, Novas Páginas da História do Brasil, São Paulo, Comp. Editora Nacional, 1965, p. 129. 
Em 1571 Pio V honrou os quarenta mártires ao referir o seu martírio voluntário (motu proprio) na breve Dum Indefese de 7 de Julho ${ }^{16}$. Quando foi consultado acerca do culto a estes mártires, o Geral Francisco de Borja respondeu: "Estes mártires começaram a ser venerados desde a sua morte, graças à autorização dos bispos e também em Roma. Por indulto da Sé Apostólica, estes mártires começaram a ser venerados com as honras de mártires em muitas praças." ${ }^{17}$

O culto destes quarenta mártires caracterizou-se, desde os seus primórdios, pelo seu carácter internacional. Uma das provas de facto apresentadas pelo postulador Cláudio Bouillaud em 1671 era "a pública voz e fama nunca negada ou colocada em causa" que gozavam estes mártires não apenas nas Índias, como também em Portugal, Espanha, França, Inglaterra, Alemanha, Itália e ainda na Flandres. Tal veneração pública por estes mártires tinha sido referida por dezanove pessoas durante as audições realizadas em Roma ${ }^{18}$. Sobretudo o Decreto de Beatificação de 1854 refere a existência de especiais culto e fama pública destes mártires em Portugal, Brasil, Espanha e Itália ${ }^{19}$.

Naturalmente, este culto afirmou-se desde cedo nas Ilhas Canárias. Segundo se lê no relato de meados do século XVIII por Cesare Cordara, que era então cronista oficial da Companhia de Jesus, pouco depois do massacre, os habitantes de Masso, pequena vila na Ilha de Palma, deliberaram a fundação duma confraria em memória destes homens ${ }^{20}$. Em 1632 os quarenta mártires foram nomeados padroeiros da mesma ilha ${ }^{21}$.

Logo que chegou a notícia do martírio ao Brasil, os cristãos locais começaram a recorrer à intercessão destes jesuítas. Um notório aumento da religiosidade verificado em várias aldeias do Brasil foi atribuído à intercessão dos quarenta mártires. Provavelmente a mesma

${ }^{16}$ Relaçam da gloriosa morte do Padre Inacio de Azeuedo da Companhia de Jesu, p. 265 e Os Quarenta Mártires do Brasil, Relação da Biblioteca da Ajuda sobre o martírio do P. Inácio de Azevedo e seus companheiros, apresentado por Eduardo Brazão, Coimbra, Coimbra Editora Limitada, 1943, p. 44.

17 Leite, Serafim, História da Companhia de Jesus no Brasil, Lisboa e Rio de Janeiro, Portugália e Civilização Brasileira, 1938, vol. Il, p. 264.

${ }^{18}$ AdP, Roma, 13. RISTRETTO del Sommario presentato alla S. Congregatione de Riti L'Anno MDCCLXX. Nella Causa de Venerabili Sevi di Dio IGNATIO di Azebedo, e trenta nove altri della Compagnia di GIESV. Col Fatto, Prove, Oppositioni, Risposte, Miracoli, e Nomi. Dato in LVCE DAL SIGNOR CLAVDIO BOUILLAUD Procuratore della Causa, Roma, Stamperia Della Reverenda Camara Apostolica, 1671, p. 4.

19 Gostaríamos de salientar a prática comum no Brasil e em Portugal de as crianças cantarem as virtudes destes mártires pelas ruas no início do século XVII.

${ }^{20}$ A primeira impressão deste relato data de 1743 e foi da responsabilidade da tipografia António Rossi em Roma (utilizámos neste trabalho a segunda edição de 1854, ou seja, precisamente do ano da beatificação:Cordara, Cesare, Istoria della vita e della gloriosa morte del Beato Ignazio de Azevedo e di altri trentanove beati martiri della Compagnia di Gesù, Roma, Tip. di B. Morini, 1854, p. 142).

${ }^{21}$ Ecribaño Garrido, Julián, El Padre Ignacio de Azevedo y Compañeros «Mártires de Tazacorte», La Palma, Parroquia de San Miguel Arcángel de Tazacorte y Arciprestazgo de los Llanos de Aridane, 1992, p. 12. 
razão e a presença da imagem da Madonna di San Luca (a presença desta imagem na Bahia encontra-se documentalmente comprovada a partir de 1573) ditaram que a primeira celebração em honra dos mártires do Brasil tivesse sido realizada em Salvador da Bahia em 1574. Os mártires foram declarados padroeiros do Brasil na mesma ocasião22.

Em Portugal, o culto destes mártires parece ter sido inicialmente importante sobretudo em Évora. Uma oração composta por um escolástico anónimo do noviciado da mesma cidade, quando soube do "ditoso sucesso", diz o seguinte:

Quanto mais, que outra aução tem Evora, em que faz ventagem a toda a Província; que os dos outros Collegios, quasi todos estam vivos, os deste estam no Ceo, \& deixaram os seus lugares vazios. Pareçeme que ouço aquelles dous innocentisinhos Aleyxo Delgado, \& Pedro Nunes, bradar por seus Mestres, cõdiscipulos, \& Itmãos, que neste Collegio estam. ${ }^{23}$

O sucesso desta devoção na cidade de Évora estará com certeza relacionado com o facto de vários dos mártires de 1570 serem originários ou terem sido noviços na mesma cidade e com a passagem de Maurizio Serpe por Évora, onde lia o seu relato nos refeitórios de padres e noviços jesuítas nos dias do aniversário do martírio ${ }^{24}$.

Várias testemunhas ouvidas durante os processos do Porto (1628) e de Coimbra (1631) mencionaram um culto especial na cidade do Porto pelo jovem mártir António Correia (1553-1570), companheiro de Azevedo e natural da mesma cidade. Uma irmã de António Correia, que era freira beneditina e vivia na década de 1630 na mesma cidade, era conhecida ao tempo como "a Irmã do Mártir"25.

O Bispo de Pamplona, Monsenhor Uriz y Labaryru (1861-1870), obteve de Roma a aprovação da celebração do ofício com festa de Esteban de Zudaire (1551-1570) na diocese de Pamplona a realizar no dia 30 de Agosto $^{26}$.

Bartolomeu Guerreiro, na sua obra panegírica do martírio jesuíta intitulada Gloriosa coroa d'esforçados religiosos da Companhia de Jesu mortos polla fe catholica nas conquistas dos reynos da coroa de Portugal, fez o elogio dos vários mártires companheiros de Inácio

22 Leite, Serafim. História da Companhia de Jesus no Brasil, vol. Il, p. 264 e Leite, História da Companhia de Jesus no Brasil, 1949, Lisboa e Rio de Janeiro, Portugália e Instituto Nacional do Livro, vol. VIII, p. 69.

${ }_{23}$ Franco, António, Imagem da virtude em o noviciado da Companhia de Jesus do Real Colégio do Espírito Santo de Évora do reino de Portugal, na qual se Contém a Fundação, Lisboa, Officina Deslandes, 1714, p. 239.

${ }^{24}$ Gonçalves da Costa, Manuel, Inácio de Azevedo e a Informação da sua morte, in Brotéria 38 (1944), p. 170.

25 ADP.31. Azevedo Processi Originali 1628, Informat.vo Ordina.o in Oporto 1628, f. 9, e AdP, 31. Azevedo Processi Originali 1631, Informativo Apostolico, Coimbra, 1631, ff. 8v, 11v, e www.iberopuebla.edu.mx.

${ }^{26}$ Hernández Palomo, e Osswald, Aspectos del culto a Ignacio de Azevedo y sus treinta y nueve compañeros mártires en 1570. 
de Azevedo, dedicando-Ihes capítulos intitulados "elogios". Na organização destes "elogios" Bartolomeu Guerreiro seguiu critérios variados. Por exemplo, um dos elogios é dedicado aos seis jesuítas Manuel Rodrigues, Manuel Pacheco, Estevam Zuraire, João da Zafra, Marcos Caldeira "designados por Azevedo para animarem os restantes companheiros", enquanto os três companheiros Luiz Correa, Luiz Rodrigues e Manuel Alvares foram honrados no mesmo capítulo, devido ao facto de serem todos naturais da cidade de Évora ${ }^{27}$.

Do ponto de vista da iconografia, existem referências esparsas nos processos de beatificação a quadros com retratos de António Correia. Miguel Leitão de Andrade, primo do mártir Diogo de Andrade, terá visto em 1629 um quadro com o retrato do mesmo Diogo de Andrade na Igreja de São Roque. Diogo de Andrade encontra-se retratado no frontispício duma obra pelo seu primo Diogo de Andrade de $1629^{28}$.

Observa-se, todavia, desde os seus primórdios, uma concentração da hagiografia e da iconografia relativa a este episódio no próprio episódio e na figura do seu líder Inácio de Azevedo. Tal escassez de informação documental explica-se, por um lado, pela extrema juventude de uma grande parte dos companheiros de Azevedo. Por outro lado, uma dispersão devocional e iconográfica poderia constituir uma dificuldade para a sua rápida identificação por parte dos crentes ${ }^{29}$.

\section{A inserção deste episódio na cultura do martírio e a reunião das principais virtudes pós-tridentinas}

Este episódio de 1570 inseriu-se e encontrou uma justificação numa cultura de martírio que ligava o martírio páleo-cristão ao martírio contemporâneo. Neste sentido, a hagiografia realçou o número quarenta. Este número permitiu relacionar este episódio da Época Moderna com o episódio antigo dos quarenta mártires de Sebaste, Arménia, que terá ocorrido entre 316 e 370.

Inácio de Azevedo era descendente de duas das então mais ilustres linhagens nacionais: os Malafaya e os Azevedo, enquanto Francisco Perez Gody era parente de Teresa de Ávila.

No seu relato de edificação, António Cabral Cabral classifica o único jesuíta que foi poupado ao "ditoso sucesso", Juan Sanchez, como rude e porco, tendo sido substituído pelo

27 Guerreiro, Bartolomeu, Gloriosa coroa d'esforçados religiosos da Companhia de Jesu mortos polla fe catholica nas conquistas dos reynos da coroa de Portugal, Lisboa, Antonio Alvarez, 1642, pp. 351-352 e pp. $357-359$.

28 Andrade, Miguel Leitão de, Miscellanea do sitio de N. Sa. da Luz do Pedrogão Grande: apparecimto. de sua sta. imagem, fundação do seu Convto. e da See de Lxa com mtas. curiozidades e poezias diversas, Lisboa, Matheus Pinheiro, 1629, p. 100.

29 Hernández Palomo e Osswald, Aspectos del culto a Ignacio de Azevedo y sus treinta y nueve compañeros mártires en 1570. 
jovem "de belíssimo aspecto, naturales e amables prendas Juan de San Juan" ${ }^{\prime 30}$. Esta curiosa e quase divertida afirmação aos olhos dum leitor do século XXI serve-nos para ilustrar a ideia de que a nobreza de sangue ligada à extrema juventude de alguns dos mártires companheiros de Azevedo foi, com certeza, um aspecto que contribuiu para a heroicidade dada a este episódio à época. Estas duas componentes fundamentais da concepção pós-tridentina de santidade foram decisivas para o alto potencial de emulação entre os jovens indiapetae (jovens europeus que escreviam cartas ao Geral da Companhia de Jesus a pedir para serem enviados para as missões das Índias).

Vários missionários mencionavam os quarenta mártires como os modelos a seguir nas suas cartas ou informações ao Geral da Companhia de Jesus. Assim o fez, por exemplo, o P. Gerónimo Pallas para quem:

foi insigne missionário o Padre Inácio de Azevedo, o qual, regressando com o ofício de provincial foi glorioso caudilho de quarenta mártires seus companheiros, que indo para a missão do Brasil foram cruelmente martirizados pelos hereges franceses em ódio da fé que

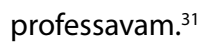

Para além de a sua vida e de o seu martírio exemplares terem inspirado novos indiapetae, alguns dos hagiógrafos dos mártires do Brasil divulgaram episódios relacionando estes mártires com outros mártires jesuítas. Tal foi o caso do paralelismo cronológico errado estabelecido pelo relato de Maurizio Serpe e transmitido a menológios posteriores, segundo o qual o martírio dos cinco jesuítas em Salsete em 1583 teria ocorrido não a 25 de Julho, mas a 15 de Julho, dia do martírio dos quarenta Jesuítas nos mares das Canárias. De igual modo, António Cabral escreveu que o futuro mártir do Japão Marcello Mastrilli teria tido uma visão do episódio de 1570 antes de partir para o Oriente, quando se dirigia em peregrinação ao Santuário do Loreto ${ }^{32}$.

Uma vida em comum feita de oração e práticas pias em Val de Rosal (Caparica) e no barco aparece referida na documentação oficial incluída nos processos preparatórios da beatificação e por isso na cronística ${ }^{33}$. Inácio de Azevedo, Francisco Godoy e António

30 Cabral, Antonio, Relación del martyrio de los quarenta martyres de la Compañia de Jesus: vida del venerable martyr P. Ignacio Acevedo, Madrid, Imprensa y Libraria de Manuel Fernandez, 1744, p. 194.

31 Missión a las Indias por el P. Gerónimo Pallas. De Roma a Lima: La "Misión a las Indias", 1619 (Razón y visión de una peregrinación sin retorno), ed. José J. Hernández Palomo, Madrid, Consejo Superior de Investigaciones Cientificas, 2006, p. 305.

32 Não se encontra tal referência em nenhum dos hagiógrafos clássicos de Marcello Mastrilli.

33 ADP. 16, Summarium Additionale. De Sanctitae Vitae P. Ignatij, \& Sociorum, \& Reliogissima praeparatione ad Aposticam Praedicationem (1-8), ff. 25 e32. 
Correia eram particularmente dados à oração. Azevedo rezava durante muitas horas ao dia e, com frequência, ainda durante a maior parte da noite ${ }^{34}$. Francisco Peres Godoy teria estado nada menos que sete horas seguidas em oração. António Correia teria sido distinguido com uma revelação divina do seu futuro martírio, quando se encontrava, como era seu hábito, em recolhimento e contemplação do Santíssimo Sacramento ${ }^{35}$.

A parte final da vida terrena destes homens, que foi descrita como "mais de anjos do que de homens", ter-se-ia caracterizado ainda por costumes e práticas de pobreza, humildade e sacrifício ou mesmo mortificação. Um episódio, segundo o qual Azevedo teria trocado com uma pobre a sua camisa por roupas andrajosas, foi relatado por testemunhas durante os processos de Braga em 1631 e difundido pela hagiografia de Azevedo, após a sua autenticação pelo Summarium Aditionale de 1671. Em particular, o hagiógrafo francês Gilles François Beauvais, em meados do século XVIII acentuou o carácter de sacrifício ou mortificação deste episódio, quando escreveu que Azevedo teria ficado vários dias ao frio, antes de mandar fazer uma vestimenta de tecidos grosseiros ${ }^{36}$. Um outro episódio que se celebrizou na sua hagiografia foi a história segundo a qual Inácio de Azevedo entrou em Barcelos, levando a pé um jumento montado pelo noviço ${ }^{37}$.

Como escreveu o hagiógrafo António Franco, "em penitências, jejuns, disciplinas e cilícios foi tal o seu excesso [de Azevedo], que se enfraqueceu sobremaneira" ${ }^{38}$. Azevedo teria afirmado um dia que "não era digno de comer pão alvo, mas que desejava comer pão dos farelos que dão aos cães da casa" ${ }^{\prime \prime 2}$. Reza a hagiografia que durante a sua estadia em Barcelos tinha por hábito distribuir a comida que lhe davam entre os pobres, limitando-se as suas refeições a apenas um bocado de pão de cevada e a uma laranja ${ }^{40}$.

${ }^{34}$ Franco, António, Annus Gloriosus, Viena, typis J.B. Schilgen, 1720, p. 394 e Franco, António, Imagem da Virtude em o noviciado da Companhia de Jesus no Real Collegio de Jesus de Coimbra em Portugal, vol. II, p. 69.

35 Relaçam da Gloriosa Morte, p. 192, Vasconcelos, Simão de, Chronica da Companhia de Jesu do Estado do Brasil e do que obrarão seus filhos nesta parte do Novo Mundo: tomo primeiro da entrada da Companhia de Jesu nas partes do Brasil e dos fundamentos que nellas lançârão \& continuárão seus religiosos, Lisboa, Officina de Henrique Valente de Oliveira, 1663, pp. 397-398 e p. 446 e Franco, António, Beato Inácio de Azevedo e Companheiros mortos; Una gloria de la Iglesia, Braga, Pe. A. Santiago, 1964, p. 37.

${ }^{36}$ Bauvais, Gilles François, La vie du venerable Pere Ignace Azevedo de la Compagnie de Jesus, L'Histoire de son martyre, \& de celui de trente neuf autres de la même Compagnie. Le tout tiré des Procès-verbaux dressés pour leur Canonisation, Paris, Hyppolyte-Louis Guerin, 1744, p. 82.

${ }^{37}$ Franco, António, Imagem da Virtude em o noviciado da Companhia de Jesus no Real Collegio de Jesus de Coimbra em Portugal, vol. II, p. 73.

38 Idem, ibidem, vol. Il, p. 64 .

39 Franco, António, Vida e martyrio do Beato Ignacio de Azevedo e seus bemaventurados companheiros da Companhia de Jesus: extrahida da "imagem da virtude em o noviciado de Coimbra, Lisboa, Administração do "Novo Mensageiro", 1890, p. 4.

${ }^{40}$ Cabral, Relación del martyrio de los quarenta martyres de la Compañia de Jesus, pp. 78-80. 
Maurizio Serpe escreveu que, durante a sua estadia em Val de Rosal, os futuros mártires do Brasil tinham o hábito de andarem vestidos pobremente e pedirem esmola de porta em porta. Todos os companheiros que se reuniram em Val de Rosal vieram a pé e vivendo de esmolas. Muitos jejuavam vários dias por semana, em particular à sexta e ao sábado, praticando ainda disciplinas diárias ${ }^{41}$.

\section{Alguns milagres}

No seu Ristretto Cláudio Bouillaud enunciou quatro milagres post mortem como os milagres oficialmente atribuídos a Inácio de Azevedo e aos seus companheiros mártires. Tratou-se da tão apregoada impossibilidade de os piratas conseguirem tirar a imagem da Madonna di San Luca das mãos de Azevedo morto, do corpo a boiar então considerado contra as leis da Natureza, da história que quatro destes piratas teriam cegado imediatamente, após terem participado na carnificina, e a observação feita por vários navegadores, que o lugar do martírio ganhava, com frequência, uma tonalidade púrpura e um gosto de sangue ${ }^{42}$. As profecias e revelações divinas são milagres muito característicos da concepção pós-tridentina de santidade e que também encontramos nos relatos hagiográficos relativos aos quarenta mártires. Quando se dirigia em 1616 para o Paraguai, onde foi martirizado, o jesuíta Mario Falconi terá tido uma visão do martírio dos quarenta companheiros espeIhado no local onde o mesmo tinha ocorrido. Este episódio foi oficializado enquanto milagre dos quarenta mártires, pois foi referido pelo Postulador Cláudio Bouillard na Compendiaria Collectio apresentada à Sagrada Congregação dos Ritos em 1671 e ainda no Martirologio de Mathias Tanner ${ }^{43}$.

A hagiografia realçou sobretudo episódios de revelação divina do martírio próximo a Inácio de Azevedo, que terão ocorrido não só em terra (Tazacorte e Ilha da Madeira), como no mar. Difundiu-se uma história, que, no barco, Azevedo suspirava continuamente pela morte, dizendo:"Ó meu Deus, se é seguro que irei morrer por Vós! Ó que felicidade! Ó que preciosa morte! Ó que tardam os hereges! Ó quando se delata o meu desejo"44.

Para além de Inácio Azevedo, cinco dos futuros mártires do Brasil foram distinguidos com a revelação divina do seu martírio. Segundo o cronista do Brasil Simão de Vasconcelos, Deus

41 Relaçam da Gloriosa Morte, pp. 201-207.

42 ADP. 13. Ristretto, p. 20.

43 ADP 16. Compendiaria Collectio Summarij exhibiti SAC COMGREG RITVVM Anno 1670. La causa Venerabilis Servis Dei IGNATII AZEBEDI, \& triginta nouem Sociorum è Societ. IESV, ed, Claudio Bouillaud, Roma, Ex Typographya Reuerendae Camerae Apostolicae, 1671, p. 15 e Tanner, Societas lesu usque ad Sanguinis et vitae profusionem militans in Europa, pp. 171 e 177.

${ }^{44}$ Cabral, Relación del martyrio de los quarenta martyres de la Compañia de Jesus, p. 149. 
teria mesmo revelado ao antigo pastor Manuel Álvares a forma como os hereges matariam, ou seja, cortando-Ihe as pernas e os braços, antes de o lançarem ao mar ${ }^{45}$. Por volta de 1640,D. António Pinheiro, Bispo de Miranda, tinha o hábito de pregar as revelações consideradas sinais sobrenaturais, com as quais teriam sido distinguidos Inácio de Azevedo, Nicolau Diniz, António Correia, Manuel Alvarez, Estêvão Zuraire e Marcos Caldeira ${ }^{46}$. Como se encontra referido pela Acta Beatificacionis, 1853, nos processos de Évora de 1631 o P. Fernando Rebelo SJ, visitador do Colégio de Bragança, tinha testemunhado acerca da visão do P. Diniz e ainda que tinha visto vários quadros mostrando o P. António Correia de joelhos perante o Santíssimo Sacramento, simbolizando com isso a revelação que Correia teria tido do seu martírio, quando se encontrava em adoração ao Santíssimo ${ }^{47}$.

Azevedo não só morreu no mar, como dois dos cinco milagres mais comuns e atribuídos pela hagiografia à sua actividade in vitam teriam ocorrido num contexto marítimo. Durante uma travessia do Rio Prado a caminho de Barcelos, Inácio de Azevedo teria salvo o barco onde seguia do naufrágio certo, ao afastar com um simples gesto da mão um tronco gigantesco ${ }^{48}$. O mesmo episódio aparece referido em sentido inverso em alguns relatos ${ }^{49}$.

Quando Inácio de Azevedo fazia a travessia por mar entre São Vicente e a Bahia em Julho de 1567, teria conseguido evitar um naufrágio certo, acalmando uma baleia que se preparava para cuspir água para cima do barco onde viajavam Azevedo, Anchieta, Nóbrega e o Bispo do Brasil, Pedro Leitão. Este milagre é normalmente atribuído a Anchieta.Todavia, em alguma literatura coeva, Anchieta atribui o mesmo milagre a Azevedo. Cabral citou assim uma carta de Anchieta, na qual o mesmo Anchieta, conhecido pelas suas capacidades taumatúrgicas, relaciona esta salvação milagrosa com a presença a bordo de Inácio de Azevedo:

nos miraban desde la nao el señor Obispo, y todos los astros con compasión, dandones y mirandones como perdidos. Solo confiaban en Dios, y en su Majestad esperaban, que nos libraria con poderosa mano, porque en aquel batel venia con nosotros aquel tan caro amigo de Dios P. Ignacio Acevedo. ${ }^{50}$

45 Vasconcelos, Chronica da Companhia de Jesu do Estado do Brasil, p. 442.

${ }^{46}$ AdP 17. Brasilien. Canonizationes, seu declarationes Martirij Servorum Dei Ignatij Azevedi, \& triginta octo Sociorum è Societate lesu, \& alterius Adaucti.: Informatio D. Jo. Bottinii Sac. Consistorii advocati, cum responsionibus iuris ad oppositiones R. P.D. Fidei Promotonis, Romae, 1671, pp. 33-38.

47 AdP. 20, Acta Beatificacionis, Roma, 1713-1853.

48 AdP 4., Brasilien Canonizationis Servi Dei Ignaty Azevedi et Sociorum Martyrum e Societate IESU Processus añcte apostolica fabricatus in Civitat.e Coimbra anno 1631,f. 89 e Franco, Imagem da Virtude em o Noviciado da Companhia de Coimbra, vol. II, p. 71.

49 Cabral, Relación del martyrio de los quarenta martyres de la Compañia de Jesus, pp. 81-82.

50 Cabral, Relación del martyrio de los quarenta martyres de la Compañia de Jesus, p. 107. 


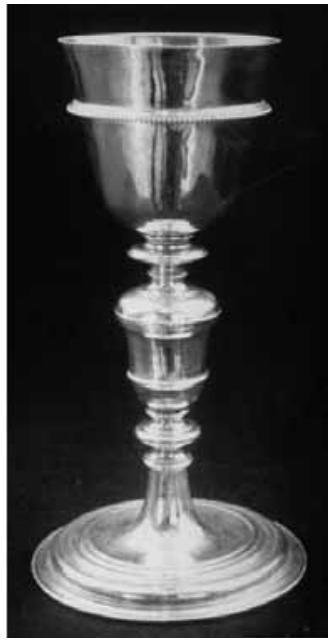

6. Cálice, prata dourada, ermida de São Miguel de Tazacorte, Canárias. (Cortesia de José Hernández Palomo.)

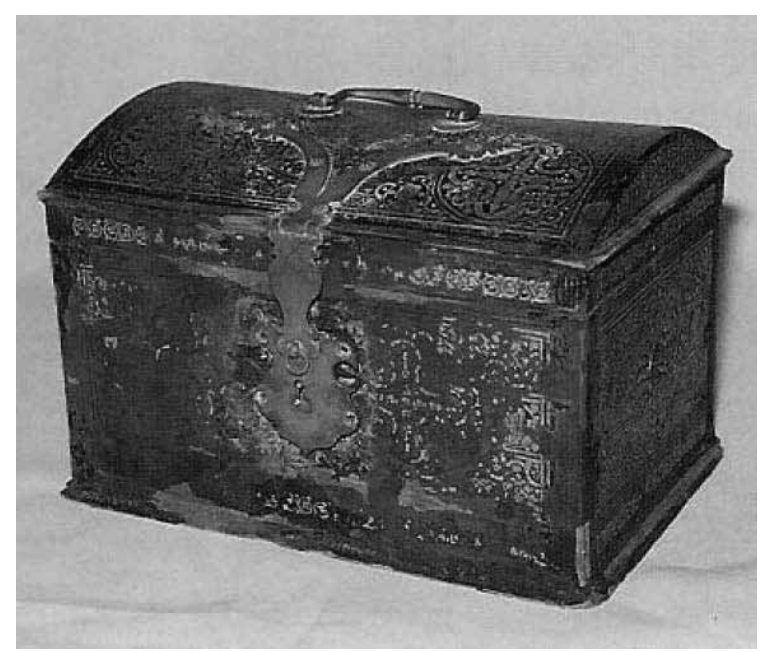

7. Cofre que, segundo a tradição local, conterá alguns objectos litúrgicos oferecidos por Inácio de Azevedo, couro e tecido. (Cortesia de José Hernández Palomo.)

De igual modo, Simão de Vasconcelos escreveu:

E atribuindose commummente a milagre a intercessam de loseph, o humilde servo o atribue ao Padre Ignacio, \& mais companheiros, dizendo assi: Estava o Bispo, \& os mais do nauio a la mira, esperando o sucesso com grande temor; mas confiados que não perigariam, por hir allì o Padre Ignacio com seus companheiros..$^{51}$

\section{A veneração pelas escassas relíquias e pelos lugares associados a estes mártires}

(Fig. 6) Um dos problemas encontrados pelos responsáveis jesuítas interessados em fomentarem este novo culto foi a escassez de relíquias. Entre os raríssimos objectos ligados a estes mártires, destaca-se o cálice conservado na Capela de São Miguel de Tazacorte, com o qual Inácio de Azevedo teria celebrado a sua última missa em Tazacorte no dia 13 de Julho de 1570. De acordo com a lenda hagiográfica, foi exactamente ao beber deste

51 Vasconcelos, Simão de, Vida do P. Joseph Anchieta, Rio de Janeiro, Imprensa Nacional, 1943, p. 113. 
cálice que Inácio de Azevedo teria tido uma visão do seu martírio próximo. Esta visão ter-lhe-ia causado uma tal impressão, que teria mordido com enorme força o bordo do cálice, deixando assim uma marca dos dentes no mesmo ${ }^{52}$

(Fig. 7) Um outro objecto, mais concretamente, um cofre igualmente conservado na Ermida de São Miguel de Tazacorte, guardará alguns objectos litúrgicos que Inácio de Azevedo teria oferecido ao seu amigo Melchior de Monteverde y Pruss, seu anfitrião durante a sua curta estadia em Tazacorte ${ }^{53}$.

Entre os pouquíssimos objectos que teriam sido salvos da "fúria herética" encontrar-se-ia uma sotaina usada por um dos mártires. Lemos no Processo de Coimbra de 1631 que uma testemunha tinha ouvido de Diego de Roas, Senhor da Ilhas de Hierro e Gomera, Canárias, que o seu pai tinha conseguido obter uma sotaina dos corsários. Em finais do século XVIII esta sotaina era objecto de devoção especial na Ilha de Gomera ${ }^{54}$.

O cronista Giulio Cesare Cordara considerou mesmo que tenha existido mais do que uma sotaina à veneração pública em Gomera, quando afirmou:

O Governador de Gomera distribuía vestes como relíquias dos mártires para sua veneração em toda a Ilha. Foi tanto fervor aceso nestes cidadãos que muitos escreveram cartas ao Sumo Pontífice pedindo canonização formal dos mártires, sendo então eleitos por protectores..$^{55}$

Em Portugal, duas cruzes que estariam ligadas aos mártires foram, por isso, consideradas objectos de especial devoção. A cruz, junto à qual os futuros mártires se dirigiam em oração durante a sua estadia em Vale de Rosal, constituía uma inestimável relíquia. António Franco, no início do século XVIII, afirmou que esta cruz tinha sido transportada para a Capela de Santo Antão, em Lisboa, pouco tempo antes de escrever a obra Imagem de Virtude no Noviciado de Coimbra. Em 1659 um procurador do Brasil tinha mandado erguer uma cruz em mármore no local onde se encontrava antes a cruz visitada pelos mártires ${ }^{56}$.

52 Rumeau de Armas, Antonio, La expedición misionera al Brasil martirizada en aguas de Canarias (1570), in Missionalia Hispânica, 11 (1947), p. 340.

53 Las Casas, José Apolo, Piratas de los siglos XVI y XVII en aguas de Canarias - Los Mártires de Tazacorte, Madrid, Magisterio Español, 1943, pp. 28-29.

${ }^{54}$ Vera y Clavijo, José, Noticia de la historia general de las Islas Canarias, Madrid, Imprenta Blas Román, 1776, tomo III, p. 29.

55 Cordara, Istoria della vita e della gloriosa morte del Beato Ignazio de Azevedo, p. 142.

56 Franco, Imagem da Virtude em o noviciado da Companhia de Jesus no Real Collegio de Jesus de Coimbra em Portugal, vol. II, pp. 84 e 90 e Gonçalves da Costa, Manuel, Inácio de Azevedo - O homem e a sua época (1526-1570), Braga, Livraria Cruz, 1957, p. 363. 
Antonio Cabral dá-nos, todavia, uma versão bem diferente. Cabral relata que esta cruz tinha sido dividida em fragmentos vários, que se encontravam na época em posse dos colégios jesuítas da Bahia, de Coimbra e ainda em Vale de Rosal ${ }^{57}$.

Conta-se que, por milagre, um raio que caiu na capela onde se guardava esta cruz não fez quaisquer estragos ao altar-mor e às imagens na capela. A este episódio deve-se a criação da fama destes mártires como padroeiros contra o fogo e outras intempéries naturais. Os mártires passaram a ser considerados advogados contra as tempestades, sendo imagens suas, por isso, colocadas nos lugares mais expostos às intempéries da Natureza ${ }^{58}$.

Uma tradição circulando na Idade Moderna na Madeira dizia que Azevedo e os seus futuros companheiros de martírio tinham estado na Quinta do Pico do Cardo, onde tinham colocado uma cruz actualmente desaparecida. O P. Luiz Severim escreveu em 1683 que mandara fazer um retábulo para a imagem de Nossa Senhora de San Luca deixada por Azevedo ao colégio e novo caixilho para a mesma cruz. Em 1743, o P. Manuel Lobo, reitor do Colégio do Funchal, mandou erguer uma cruz para substituir a cruz tresladada ${ }^{59}$.

Alguns dos locais onde os mártires passaram desenvolveram-se em lugares de peregrinação. O Summarium de 1671 destacou os relatos de várias pessoas ouvidas durante os processos da Bahia e que tinham referido uma grande devoção por alguns dos lugares que os mártires teriam frequentado durante a sua estadia na llha de Palma ${ }^{60}$.

Finalmente, uma imagem de Nossa Senhora (provavelmente da Madona di San Luca) que existia na capela do Noviciado da Companhia de Jesus em Évora em meados do século XVII era objecto de especial devoção. Esta imagem tinha sido oferecida pelo P. Inácio de Azevedo e era da da autoria do Irmão Juan Maiorga, companheiro-mártir de Azevedo ${ }^{61}$.

\section{A literatura hagiográfica}

O texto escrito e muitas vezes impresso foi, sem dúvida, um aspecto fundamental no fomento do culto destes quarenta mártires. Compreensivelmente, os principais cronistas das Províncias jesuítas de Portugal, Brasil e Castela deram especial relevo a este episódio ${ }^{62}$.

57 Cabral, Relación del martyrio de los quarenta martyres de la Compañia de Jesus, p. 129.

58 Cabral, Relación del martyrio de los quarenta martyres de la Compañia de Jesus, p. 131.

59 Biblioteca Pública Municipal do Porto [BPMP]:Manuscr. 162: Chronica dos PP. Jezuitas de Portugal, finais séc. XVII/,ff. 833-835, e Domingues, Ernesto, Raízes terrestres de 40 mártires, Braga, Sep. Mensageiro, 1971 , p. 9.

60 AdP. 16, Summarium Aditionale (1671), f. 163.

61 Franco, Imagem da virtude em o noviciado da Companhia de Jesus do Real Colégio do Espírito Santo de Évora, p. 368.

62 Teles, Baltasar, Chronica da Companhia de Jesu, na Provincia de Portugal; e do que fizeram, nas conquistas d'este Reyno, os religiosos, que na mesma Provincia entràram, nos annos em que viveo S. Ignacio de Loyola, 
A inclusão deste episódio nas crónicas das missões da Companhia de Jesus no Oriente a partir da crónica pelo italiano Giovanni Pietro Maffei de 1573 parece-nos sinal inequívoco da especial importância deste episódio para a história da Companhia latum sensum ${ }^{63}$.

Ainda da década de 1570 data a relação mais antiga deste martírio pelo P. Maurício Serpe (esta obra foi escrita em duas fases, ou seja, entre 1571 e 1572 e entre 1574 e 1575) ${ }^{64}$, que se baseou no testemunho presencial de João Sanches, único jesuíta poupado à morte, devido a ser cozinheiro. Esta relação, ou seja, duas versões deste relato, foram apenas publicadas no século $X X^{65}$.Todavia, os principais autores que trataram o episódio tiveram acesso ao mesmo relato, como podemos ler na crónica do noviciado de Coimbra pelo P. António Franco:

Temos desta matéria huma devota Historia escrita pelo Padre Mauricio, Confessor Del-Rey Dom Sebastião, da qual ainda que se aproveitaraõ, os que destes gloriozos Martyres escreverão, sempre foi muito pollo grosso, (...). ${ }^{66}$

$\mathrm{Na}$ origem da emulação de muitos indiapetae antes mencionada encontra-se uma estratégia de fomento deste culto entre os noviços e colegiais. Dentro da Companhia este culto foi fomentado, entre outras medidas, através da introdução deste episódio nos menológios ou catálogos, que eram lidos nos aniversários dos jesuítas ilustres, após a leitura da Sagrada Escritura ${ }^{67}$.

Em termos gerais, este culto foi objecto até ao século XIX duma ampla variedade e quantidade de bibliografia. Em particular, o postulador da causa Cláudio Bouillaud, autor do Ristretto del Sommario apresentado à Sacra Congregação dos Ritos em 1671, informa-nos que o tema foi tratado por noventa e seis autores entre 1572 e $1665^{68}$.

O tema interessou igualmente a autores fora da própria Companhia, entre eles, o cronista do Rei de Espanha, António Herrera, parte 2, libro 1, cap. 17, facto que aparece,

Vasconcelos, Chronica da Companhia de Jesus do Estado do Brasil, Lisboa, Paulo Craesbeeck, 1645-1647, 2 vols. e Alcazar, Bartholomé, Chrono-historia de la Compañia de Jesus, en la Provincia de Toledo y elogios de sus varones, Madrid, Juan Garcia Infançon, 1710.

${ }^{63}$ Maffei, Giovanni Pietro, Rerum a Societatis lesu in Oriente gestarum volumen primum, Nápoles, aedibus Decii Lachaei, 1579, pp. 230-233.

${ }^{64}$ Gonçalves da Costa, Inácio de Azevedo e a informação da sua morte, p. 170.

${ }^{65}$ Ver nota 16.

${ }^{66}$ Franco, Imagem da Virtude em o Noviciado da Companhia de Jesús de Coimbra, vol. II, p. 80.

${ }^{67}$ Ver, por exemplo, na Biblioteca Nacional de Portugal [BNP], FG. Ms. 1647, Catalogo di alcuni martírio e uomini insigni dellaCompagnia di Gesù, che si legge dopo la Sacra Scrittura secondo l'ordine dei giorni nel refettorio della Casa Professa di Roma, Évora, nell'anno 1759.

${ }^{68}$ AdP. 13. Ristretto, pp. 12-13. 
aliás, incluído como prova de facto no Ristretto del Sommario em $1671^{69}$. Parece-nos particularmente ilustrativo da rápida ressonância que este episódio teve na altura o facto de o mesmo episódio ter sido narrado por várias histórias do mundo, a partir da obra do autor italiano Lorenzo Surius, Commentarius brevis rerum in orbe gestarum ab anno 1500. Usque in anno 1574. ex optimis quibusque scriptoribus congestus, Colónia, Johann Erben, 1578.

A biografia De Vita et morte P. Ignatii Azevedii et sociorum eius e Societate lesu, da autoria do italiano Pedro Possino, que foi publicada em Roma em 1679, foi a primeira biografia impressa dos mártires ${ }^{70}$. No entanto, a primeira biografia do Geral Francisco de Borja pelo biógrafo mais importante da Velha Companhia, o P. Pedro Ribadeneira, que é datada de 1594, menciona o martírio dos quarenta jesuítas a caminho do Brasil ${ }^{71}$. A partir de Ribadeneira, os biógrafos de Borja vão por norma incluir este martírio. Em especial, as obras de edificação pelo jesuíta António Franco constituem um manancial de informação fundamental em relação aos quarenta mártires.

O tema foi naturalmente destacado pelos principais autores dos martirológios jesuítas, entre eles Richard Verstegen, Philip Alegambe e obviamente o português Bartolomeu Guerreiro, que aliás tinha sido ouvido como testemunha durante os processos relativos à beatificação dos quarenta mártires realizados em Évora em $1631^{72}$. Gostaríamos sobretudo de salientar que o principal martiriológio jesuíta de toda a Época Moderna, o martirológio de Mathias Tanner, contém uma gravura colectiva do martírio e ainda uma gravura de Inácio de Azevedo sozinho ${ }^{73}$.

A devoção mariana de Inácio de Azevedo, que se teria manifestado desde a sua infância, e sobretudo a importância deste mártir na difusão do culto da Madonna di San Luca foram provavelmente os factores que determinaram a inclusão deste episódio de martírio em calendários marianos, tais como o Calendario Virginiis de Antonius de Balinghaen e

69 Idem, ibidem, p. 4.

70 Possino, Pietro, De vita et morte P. Ignatii Azevedii et sociorum eius e Societate lesu, Roma, ex typographia Varesij, 1679.

${ }^{71}$ A edição por nós consultada na preparação do presente texto foi uma edição de 1945: Ribanedeira, Pedro de: Vida del P. Francisco de Borja, in Historias de la Contrarreforma: vida de los Padres Ignacio de Loyola, Diego Laínez, Alfonso Salmerón y Francisco de Borja. Historia del cisma de Inglaterra. Exhortación a los capitanes y soldados de La Invencible, ed. Eusebio Rey, Madrid, 1945, pp. 781-787.

72 Alegambe, Philippe, Mortes illustres et gesta eorum de Societate lesu. Extremos aliquot annos, mortesque illustres usque ad annum MDCLV adiecit loannes Nadasi, Roma, ex typographia Varesij, anno 1657, p. 49, Verstegen, Richard, Theatrum Crudelitatum Haereticorum nostri Temporis. Antuérpia, Adrianum Huberti, 1588, p. 54 e Guerreiro, Bartolomeu, Gloriosa coroa d'esforçados religiosos da Companhia de Jesu mortos polla fe catholica, pp.331-359.

73 Tanner, Societas lesu usque ad Sanguinis et vitae profusionem militans in Europa, pp. 174 e 178. 
o Hortus Marianus de François de La Croix ou outras obras de devoção mariana como o Giardinetto della Madonna de Ludovico Florio $^{74}$.

O tema encontrou igualmente um importante eco na poesia jesuítica. José de Anchieta, que era natural das Canárias e conheceu Inácio de Azevedo no Brasil, compilou o Cancioneiro dos Mártires do Brasil. Trata-se de dois poemas dedicados aos mártires do Brasil, dois poemas dedicados a Inácio de Azevedo, um poema dedicado ao seu companheiro Manuel Álvares e ainda dois poemas honrando o grupo de onze jesuítas dirigidos por Pedro Diaz que foram martirizados um ano depois no mar, igualmente a caminho do Brasil $^{75}$.

No contexto europeu, o jesuíta e poeta italiano Francesco Benci compôs um poema em memória destes mártires, o qual incluiu na sua obra em honra dos mártires de Salsete de Goa $(1583)^{76}$. O hagiógrafo italiano Antonio Rossi publicou em 1743 uma laude composta pelo P. Juan Madureira morto pela sua fé nas Costas da Inglaterra em $1601^{77}$. Nas listas de documentação relativas aos mártires e conservadas no Archivio della Postulazione são ainda referidos um epigrama que terá ficado manuscrito pelo P. Adriano da Bologna em honra de Azevedo e ainda um poema pelo alemão Andreas Kanon, ambos de meados do século $\mathrm{XVII}^{78}$.

Destaca-se o autor Gerardo Van den Berghe Montanus (conhecido igualmente como Gerardo Verga, Montanus ou Oranus), que juntou à colectânea latina de Cícero um epigrama sobre cada um dos mártires de 1570 e ainda sobre o P. Miguel Aragonês morto com P. Diaz no ano de 1571. Estes epigramas tiveram uma enorme divulgação até ao século XVIII, como demonstram as suas sucessivas reedições a partir de $1623^{79}$.

74 Balinghaen, Antonious de, Kalendarium SS. Virginis Dei Genitricis Mariae, Duaci, Ex Typographia Balthazaris Belleri, 1629, p. 348, De la Croix, Hortulus Marianus, Duaci, Typ. B. Belleri, 1622, p. 50 e Ludovico Florio, Giardinetto della Madonna, Roma, Il Mascardi, 1641, p. 65.

75 Este cancioneiro foi publicado integralmente por Armando Cardoso em 1984. (P. Joseph Anchieta, obras completas, introdução e notas por Armando Cardoso, São Paulo, Loyola, 1984, 3 vol., pp. 92-100.)

76 Benci, Francesco, Poëmatis de quinque martiryribus, Roma, Typographia Vaticana, 1592, libro 3, p. 196.

77 Juan Madureira foi muito importante na vida de Inácio de Azevedo, pois convenceu Inácio de Azevedo a realizar os Exercícios Espirituais em Coimbra, após os quais Inácio de Azevedo entrou na Companhia de Jesus. (Rossi, António, Relazione della vita, e martirio del venerabil Padre Ignazio de Azevedo ucciso dagli eretici con altri trentanove della Compagnia di Gesú, Roma, Stamperia di Antonio dé Rossi, 1743, p. 177 e Teles, Chronica da Companhia de Jesu, na Provincia de Portugal; vol. I., p. 271.)

78 Bologna, Adriano da, Epigrammatum, Tournai, 1642, epig. 159, f. 154 e Kanon, Andreas, Lirici, Cracóvia, Christoph Schedel, 1642, Lib. 4, Ode 15.

79 M. T. Ciceronis Orationis selectae duodecim, cum Libris de Amiticia, Senectute, Paradoxis et ex Epistolis aliquot. Metaphasis poética in Canticum Canticorum. Centuria Epigrammatum in Martyres Societatis, Madrid, Luiz Sanchez, 1623 e Escalera, Juan, Berghe (Montanus), Gerardo Van den, in Diccionario histórico de la 
De igual modo, é fundamental referir a inclusão destes poemas em duas crónicas de províncias jesuítas. Simão de Vasconcelos escolheu introduzir os poemas dedicados a Inácio de Azevedo e ao seu companheiro e pastor-mártir Manuel Álvares na sua crónica da Província do Brasil ${ }^{80}$. Por sua vez, Bartholomé Alcazar, na sua crónica da Província Jesuítica de Toledo, publicou todos os poemas de Montanus em honra dos mártires companheiros de Azevedo e de nacionalidade espanhola ${ }^{81}$.

Finalmente, este martírio foi tratado pelo teatro da Companhia de Jesus. O V acto da peça de Vincenzo Guiniggi Ignatius in Monte Serrato, levado à cena em 1623 em Roma, é dedicado a Inácio de Azevedo. Compreensivelmente, os mártires foram sobretudo destacados pela coreografia das festas portuguesas da dupla canonização de 1622. Em Lisboa, uma das carroças representava uma nau desfilando pela cidade e carregada com os figurantes dos santos mártires da Companhia comandados por Inácio Azevedo e António Criminale, o primeiro jesuíta mártir do Oriente em $1546^{82}$.

\section{A iconografia (alguns dados histórico-hagiográficos e principais protótipos)}

O espólio iconográfico deste martírio anterior ao século XIX é, na actualidade, reduzido. Limita-se essencialmente a alguns quadros e a gravuras representando Inácio de Azevedo ou o martírio colectivo, e ainda inserido em representações panegíricas colectivas de membros da Companhia de Jesus.

(Fig. 8) Entre estas últimas, destacamos o célebre tecto da sacristia do antigo colégio jesuíta de São Salvador da Bahia, Brasil, pintado entre 1683 e 1694 e as assim chamadas galerias de mártires já referidas ${ }^{83}$.

Compañía de Jesús: biográfico-temático, Charles E. O’Neill, S.I., Joaquín M. Domínguez, S.I. (Directores), Roma, Institutum Historicum Societatis lesu, 2001, vol. I, p. 415.

80 Vasconcelos, Chrónica da Companhia de Jesus do Estado do Brasil, p. 446.

81 Alcazar, Bartholomé, Chrono-historia de la Compañia de Jesus, en la Provincia de Toledo, vol, I, pp. $317-318$.

82 Relaçam Geral da Festas que fez a Companhia de Jesús na Provincia de Portugal, na canonização dos gloriosos Sancto Ignacio, \& S. Francisco Xavier Apostolo da India Oriental no anno de 1622, Lisboa, Pedro Craesbeeck, 1623, f. 24, Relacion de las fiestas, que la Compañia de Jesu haze en la ciudad de Lisboa a la canonizacion de S. Inacio de Loyola y de S. Francisco Xavier: comiençanse en 30. de Julio, y acabanse en 7. de Agosto, Lisboa, Geraldo de la Vinha, 1622, f. 5, e Osswald, Iconografia das Cerimónias de Canonização no contexto português, p. 338.

${ }^{83}$ Moura Sobral, Luís de, Espiritualidade e propaganda nos programas iconográficos dos Jesuítas Portugueses, in A Companhia de Jesus na Península Ibérica nos sécs. XVI e XVII, Porto, Instituto de Cultura Portuguesa da Faculdade de Letras da Universidade do Porto/Centro Interuniversitário de História da Espiritualidade da Universidade do Porto, 2005, pp. 411-415. 
Não obstante a lamentável escassez iconográfica actual deste martírio, a pesquisa realizada até ao momento permite-nos afirmar que os jesuítas, como era aliás apanágio seu, usaram a representação artística deste martírio como instrumento fundamental na difusão do mesmo durante a Época Moderna. A sua difusão iconográfica iniciou-se logo após o evento. $\mathrm{O}$ primeiro retrato post-mortem de Inácio de Azevedo foi provavelmente um retrato encomendado pelo seu irmão Jerónimo de Azevedo ao ser informado do martírio de Inácio ${ }^{84}$. Mais impacto teve, sem dúvida, uma relação ilustrada com gravuras e encomendada pelo Geral Francisco de Borgia, pois sabe-se que esta relação teve uma ampla difusão dentro e fora da Companhia ${ }^{85}$.

Com autorização do Papa Gregório XV, imagens destes mártires com suas insígnias e atri-

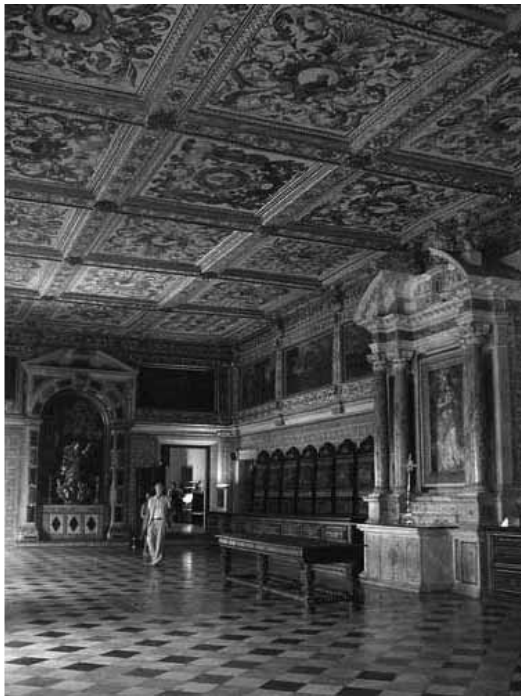

8. Autor anónimo, tecto da sacristia da actual catedral e igreja do antigo colégio da Companhia de Jesus em Salvador da Bahia, óleo, entre 1683 e 1694 (cortesia de A. Silva). butos passaram a ser objecto de veneração no il Gesù, igreja principal da Companhia de Jesus, assim como em várias outras igrejas jesuítas, até que os decretos de Urbano VIII em 1625 obrigaram à distinção entre santos canonizados e não canonizados ${ }^{86}$. Esta limitação foi, todavia, alterada no século seguinte. Em 1742, o Papa Bento XIV ordenou a multiplicação ilimitada das imagens deste martírio para fomentar o culto a estes mártires, devido à escassez de relíquias ${ }^{87}$.

Durante os processos de Coimbra em 1631, treze pessoas testemunharam positivamente ao quesito se sabiam "que forão pintados com as insígnias do martírio e seus nomes esculpidos e como os sabe". Cinco destas testemunhas referiram uma reacção de grande devoção suscitada entre os crentes pelos quadros e gravuras destes mártires. Estas imagens eram uma fonte de tal emoção entre os crentes, que chegavam a suscitar as suas lágrimas ${ }^{88}$. Aliás, referências a retratos pintados, esculturas e gravuras destes mártires abundam nos textos de todos os processos de beatificação.

${ }^{84}$ Cabral, Relación del martyrio de los quarenta martyres de la Compañia de Jesus, p. 212.

${ }_{85}$ Cordara, Istoria della vita e della gloriosa morte del Beato Ignazio de Azevedo, p. 6.

${ }^{86}$ Idem, ibidem, pp. 228-229.

87 AdP.20 Brasilien. Redingrationis Cultus Ven. Servorum Dei Ignatii de Azevedo et XXXIX. Sociorum Martyrium, f. 27.

${ }^{88}$ Domingues, Ernesto, Inácio d'Azevedo Retratos e Parentes, separata do Arquivo dos Jesuítas, 1977, s/p. 


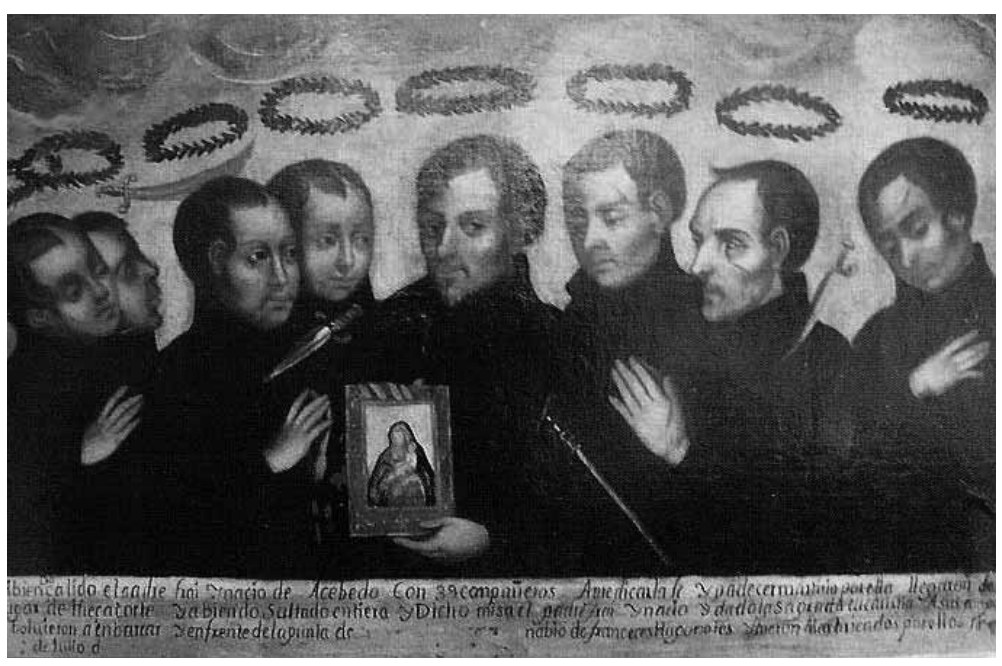

9. Pintor espanhol, Inácio de Azevedo e companheiros mártires, século XVII, Ermida de São Miguel de Tazcorte (cortesia de José Hernandez Palomo).

(Fig. 9) Coincidência ou não, de visita às Ilhas Canárias entre 1631 e 1633, ou seja, na altura em que decorriam os primeiros processos de beatificação destes mártires, O P. Alonso Cano deu-se conta de que apenas alguns anciãos conheciam ainda a história do martírio de 1570. Por essa razão, este jesuíta decidiu encomendar a pintura dum óleo com o mesmo tema, actualmente desaparecida, mas que influenciou três quadros nas igrejas de São Miguel de Tazacorte, São Salvador de Santa Cruz en La Palma e no Museu Diocesano de Arte Sacra da Catedral de Santa Ana de Las Palmas ${ }^{89}$.

Os jesuítas em Roma demonstraram igualmente um interesse imediato pela representação artística deste martírio. Destacam-se neste contexto as gravuras com este martírio que decoram os frontispícios das vitae de Inácio de Loyola e Francisco Xavier impressas em 1622 para comemorar a canonização de Inácio de Loyola e Francisco Xavier. Merece ainda menção o facto de que Inácio de Azevedo segurando a imagem da Madonna di San Luca nas mãos foi esculpido entre os membros mais distintos da Companhia de Jesus na parte fron-

${ }^{89}$ Escudero,José Guilherme,Los Mártires deTazacorte:Los cuadros de El Salvador, 12 din Anchieta Red lgnatiana de Canárias, 12 de Julho de 2007, in http://redanchieta.org/ e Fraga González, Cármen, Iconografia de los PP. Azevedo y Anchieta, y del Hermano Pedro de Bethencourt, in Colóquio de História Canária Americana, 1977, pp. 445-452. 
tal do túmulo de Santo Inácio de Loyola na Igreja de II Gesù em 1637 pelo escultor Alessandro Algardi ${ }^{90}$.

Este grupo de mártires tornou-se modelo iconográfico e devocional favorito para representar e emular os inúmeros mártires e membros da Companhia durante a Época Moderna. Em Roma estes mártires foram com frequência os mártires plasticizados pela arte para criar novas vocações de missionários prontos a morrerem ad maiorem Dei gloriam. Neste sentido, surgem nos processos de beatificação e em biografias de muitos indapetae e futuros mártires [entre eles, os dois futuros mártires do Japão Carlo Spínola (1622) e Marcello Mastrilli (1637), traziam consigo estampas dos mártires de 1570]191.

(Fig. 10) De igual modo, um quadro a óleo com este martírio foi pendurado antes de 1597 no noviciado de Sant'Andrea al Quirinale, fazendo pendant

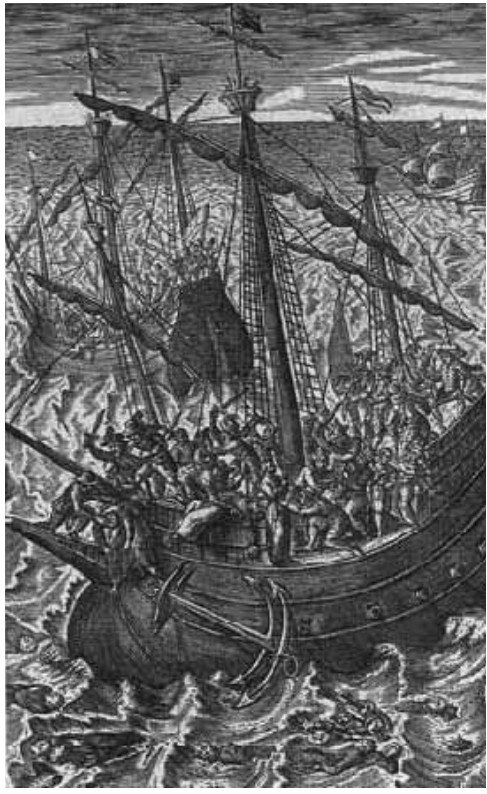

10. Gravura em Louis de Richeome, 1611 (cortesia de Christoph Nebgen). com um quadro que representava o Martírio dos cinco jesuítas de Salsete em 1583. Este quadro encontra-se reproduzido numa gravura ilustrando a obra do jesuíta francês Louis de Richeome intitulada La Peinture Spirituelle ou l'art d'admirer, aimer et louer Dieu en toutes ses oeuvres, et tirer de toutes profit saluter, e que contém a descrição dos ciclos pintados no Noviciado de Sant'Andrea Quirinale antes de $1597^{92}$. À semelhança do ciclo de San Tommaso di Canterbury, este ciclo de pinturas de Sant'Andrea al Quirinale é tanto mais interessante pela sua contemporaneidade. O famoso iconógrafo francês de arte cristã Emile Mâle fez aliás a sugestão de que o quadro com o chamado episódio dos Quarenta Mártires do Brasil (1570) que se encontrava na sala de estar tenha sido pintado pouco tempo depois da sua ocorrência ${ }^{93}$.

90 Bricarelli, Carlo, Alcune Sculture all'altare di Sant'lgnazio nel Gesù di Roma, in La Canonizzazione dei Santi Ignazio di Loiola Fondatore della Compagnia di Gesù e Francesco Saverio Apostolo dell'Oriente, ed. Comitato Romano Ispano per le Centenarie Onoranze (ed.), Roma, Grafia, 1922, p. 113.

91 Spinola, Fabio Ambrosio, Vita P.Caroli Spinola, Roma, Francesco Corbelletti, 1627, p. 183 e Cinami, Leonardo, Vita Patris Marcello Franciscii Mastrilli, Viterbo, Diotallevi, 1645, p. 13.

92 Osswald, Maria Cristina, A iconografia do martírio para a Companhia de Jesus entre os sécs. XVI e XVIII, in Revista Portuguesa de Filosofia (no prelo).

93 Mâle, Emile, L'Art Religieux après le Concile de Trente, etude sur l'iconographie de la fin du XVI siècle, du XVII, du XVIII siècle; Italie, France, Espagne, Flandres. Paris, Collin, 1932, p. 118. 
O Geral Nickel Oliva encarregou o célebre pintor de batalhas marítimas Giacomo Cortese (1621-1676), conhecido como II Borgognese, após este ter entrado no mesmo noviciado em 1657, de pintar um óleo com este martírio ${ }^{94}$. Este quadro, que foi a última obra de II Borgognese, encontra-se na colecção do Palazzo del Quirinale em Roma.

Inácio de Azevedo, sozinho ou acompanhado pelos restantes companheiros de martírio e vestidos com a tradicional sotaina, segura a imagem de Nossa Senhora de S. Luca que em alguns casos é ainda destacada pelo tamanho demasiado grande em relação ao dos mártires. Em todas as imagens que conhecemos Inácio de Azevedo tem sempre barba para mostrar a sua meia-idade à data da morte em comparação com a já antes referida extrema juventude de quase todos os seus companheiros (os únicos dois sacerdotes jesuítas de quatro votos a bordo eram Inácio de Azevedo e Diogo de Andrade).

Nas representações colectivas deste martírio, encontramos duas iconografias principais. Um destes modelos ilustra o próprio episódio do martírio em que se vêem os mártires a serem torturados, mortos e lançados ao mar. A partir da gravura ilustrando a obra do jesuíta francês Louis de Richeome, verifica-se que em várias imagens alguns dos mártires no mar têm os braços levantados, representando os mártires que foram lançados ainda vivos ao mar ${ }^{95}$. Entre as representações colectivas do martírio de 1570 podemos ainda inserir as representações mostrando a visão de Teresa de Ávila em simultâneo com este episódio de martírio e em muitas das quais os mártires já aparecem glorificados no céu e a serem coroados.

Um segundo protótipo claramente menos movimentado mostra Inácio de Azevedo à frente ou ladeado pelos seus companheiros "distinguidos com a coroa do martírio". No caso das pinturas em Tazacorte e Salvador os mártires são representados com alguns dos vários instrumentos usados no seu martírio e ainda com a coroa de santos no caso do quadro em Tazacorte.

Ainda dentro do contexto de iconografias colectivas, à semelhança da decoração do Il Gesù, as galerias de mártires incluem ainda, por vezes, os santos da Companhia e/ou devoções populares entres os jesuítas e episódios bíblicos ${ }^{96}$.

94 Baldinucci, Filippo, Vite de' pittori, scultori, ed architetti moderni, Perugia, Electa Editori Umbri, 1992, p. 215 e Pascoli, Lione, Vite de' pittori, scultori ed architetti moderni, Roma, De Rossi, 1730, pp. 180-181.

95 Richeôme, Louis de, La Peinture Spirituelle ou l'art d'admirer, aimer et louer Dieu en toutes ses oeuvres, et tirer de toutes profit saluter, Lyon, I'imprimerie d'Amy de Polier, 1611, p. 237. (Ver igualmente Bailey, Gauvin Alexander, Between Renaissance and Baroque Jesuit Art in Rome, 1565-1610, Toronto, University of Toronto Press, 2003, pp. 65-66.)

${ }^{96}$ Fondo Schurhammer, Navarra, Schurhammer-III-870 e Schurhammer-III-957. 


\title{
A iconografia dos Santos Mártires de Lisboa em quatro pinturas do século XVI: linguagem e significados
}

\author{
Manuel Batoréo*
}

Faz parte da colecção do Museu Carlos Machado, em Ponta Delgada, um conjunto de painéis de pintura renascentista portuguesa, da primeira metade do século XVI, evocando, em quatro cenas, a vida e os martírios dos Santos Mártires de Lisboa, Veríssimo, Máxima e Júlia.

Desconhece-se, documentadamente, a origem das tábuas, mas uma referência feita em 1817 por Cunha Taborda diz-nos que estiveram na casa do Marquês de Borba. ${ }^{1}$ Qual foi a trajectória, anterior e posterior, das muito interessantes pinturas? Não podemos determiná-lo com exactidão. Apenas sabemos que também pertenceu à colecção do proprietário e industrial açoriano Vasco Bensaúde, que as adquiriu no leilão da colecção Ameal, em 1921 , onde foram vendidas por 3561\$00 cada. Em meados do século XX os herdeiros de Vasco Bensaúde doaram os painéis ao Museu Carlos Machado.

Iconograficamente, as pinturas referem a vida dos mártires Veríssimo, Máxima e Júlia, três irmãos que, segundo um códice de finais do século XV, eram filhos de um senador romano e foram martirizados em Lisboa, no século IV, ao tempo do imperador Diocleciano. ${ }^{2}$

As fontes, variadas e dispersas pelo tempo, não são particularmente explícitas, nem mesmo rigorosamente coincidentes no que refere aos diferentes aspectos da vida dos santos, mas repetem muito proximamente o discurso relativo a outros mártires, dos quais o mais conhecido será São Vicente.

As primeiras referências conhecidas aos três santos constam do Martirológio de Usuardo, obra do século VIII (858), embora para o que nos interessa seja mais adequado seguir o Códice quatrocentista estudado pelo Pe. Mário Martins, que também estudou o Livro e Legenda dos Santos Mártires ${ }^{3}$, obra do século XII, e ainda o Flos Sanctorum en lengoage ${ }^{4}$, edi-

* Professor Jubilado da Faculdade de Letras/Universidade de Lisboa.

1 Cunha Taborda, José da, Regras da Arte da Pintura, Lisboa, 1815, p. 149. Os painéis são aqui atribuídos a Vasco Fernandes, como era hábito na época relativamente à pintura portuguesa do Renascimento.

2 Martins, Mário, "A legenda dos santos mártires Veríssimo, Máxima e Júlia, do cód. CV/I-23 d., da Biblioteca de Évora", separata da Revista Portuguesa de História, Coimbra, 1964.

3 Mário Martins, A Legenda dos Santos Mártires Veríssimo, Máxima e Júlia, do cod. CV/1-23, da Biblioteca de Évora, separata, Coimbra, 1964.

4 Ho Flos Sanctorum en Lingoage: os Santos Extravagantes, ed. Maria Clara Almeida Lucas, Lisboa, INIC, 1988, pp. 153-157. 
tado em 1513. Posteriores à execução das pinturas devem também destacar-se a História Eclesiástica de Lisboa, do bispo D. Rodrigo da Cunha5 ${ }^{5}$, de 1642, o Jardim de Portugal, de Frei Luís dos Anjos, de 1626, e ainda a Historia tripartita comprehendida em três tratados..., de Frei Agostinho de Santa Maria, datada de 1724.

Segundo a lenda transmitida pelos séculos, os três Santos Mártires de Lisboa, Veríssimo, Máxima e Júlia, viveram na época em que ocorreram as grandes perseguições aos cristãos ${ }^{6}$ e surgiram numerosos mártires dos quais destacaríamos São Vicente, provavelmente o mais importante no culto português, e também os irmãos São Crispim e São Crispiniano, só reconhecidos entre nós a partir da conquista de Lisboa, por ter sido a 25 de Outubro que a cidade foi tomada aos mouros. Todavia, é importante notar que, nessa mesma data, já Veríssimo, Máxima e Júlia eram venerados em Lisboa, como atesta o relato do cruzado Osberno, em duas passagens do seu texto, escrito muito pouco tempo depois.

Vale a pena citar:

Sob o domínio dos reis cristãos, antes que os mouros a tomassem, num lugar junto da cidade, e que se chama Campolide, venera-se a memória dos três mártires Veríssimo, Máxima e Júlia, virgem, de cuja igreja, totalmente arrasada pelos mouros, restam somente três pedras como lembrança da sua destruição, as quais nunca dali puderam ser retiradas. ${ }^{7}$

Noutra passagem, são referidas as palavras dirigidas aos mouros, junto às muralhas de Lisboa, por D. João Peculiar, arcebispo de Braga:

Há já 358 anos que injustamente tendes as nossas cidades e a posse das terras, havidas antes de vós pelos cristãos, aos quais não levou para a fé a espada do exactor, mas a quem a palavra da pregação os tornou filhos adoptivos de Deus, no tempo do nosso Apóstolo S. Tiago e dos seus continuadores, Donato, Torcato, Secundo, Aleixo, Eufrásio, Tesifonte.Vitório, Pelágio e muitos outros varões de carácter apostólico. Nesta mesma cidade é testemunha disso o

5 D. Rodrigo da Cunha, Historia ecclesiastica da lgreja de Lisboa..., 1642.

6 No texto do Ho Flos Sanctorum ... (ver nota 1) lê-se, a propósito do que se passava no império romano: "Trabalhando-se per todas maneiras tirar o nome de Jhesu Christo do mundo, pollo qual, por tormentos nom cuidados e novamente inventados, atormentavam os servos de Christo. Assi que nom havia i lugar, nem ainda villa nem povoaçom ou aldea onde nom [houvesse] cruel persecuçam contra os christaãos (...) [defen]ssores do nome de Christo".

7 José Augusto de Oliveira (trad.), Conquista de Lisboa aos mouros. Narrada pelo cruzado Osberno, testemunha presencial. Lisboa, 1935, pp. 42-43. 
sangue dos mártires Máxima, Verissimo e Júlia virgem, derramado pelo nome de Cristo, no tempo de Ageiano, governador romano. ${ }^{8}$

Temos, consequentemente, a justificação do culto dos Santos Mártires de Lisboa como a mais antiga da cidade, não havendo, como se comprova, menção a São Crispim e a São Crispiniano, nem mesmo a São Vicente. No tempo de Afonso Henriques foi edificada na zona de Santos-o-Velho uma ermida dedicada aos três irmãos, cuja guarda foi dada às comendadeiras da Ordem de Santiago.

As versões conhecidas sobre a vida dos santos mártires são mais ou menos extensas, assim como os milagres feitos e, também, os episódios relativos à transferência das relíquias, como adiante veremos.

A fim de melhor ilustrar os vários passos da sua vida, recorremos a imagens mais recentes mostradas em azulejos e telas do século XVIII, posteriores em mais de duzentos anos às pinturas que vamos apreciar, mas mais pormenorizadas quanto às fases descritas no hagiológio. Estes azulejos e telas encontram-se na Igreja do antigo Convento de Santos-o-Novo.

Diz a lenda que os três santos mártires estavam em Roma quando Ihes apareceu um anjo que Ihes disse para irem a Portugal, onde, segundo D. Rodrigo da Cunha,"alcançariam a coroa do martírio, que com tanta ânsia procuravam"9.

Os três irmãos embarcam para Lisboa, onde são recebidos por uma autoridade que os leva à presença de Tarquínio, o representante de Diocleciano nestas terras. ManifestaramIhe a decisão de submeter-se ao sofrimento corporal para defesa da fé católica e foram, por isso, submetidos a vários martírios. Por força desta decisão os santos foram presos, espancados e submetidos a diversas torturas, como o açoitamento com "varas ásperas e cheias de espinhos", arrastamento pelas ruas da cidade, suplícios que sempre suportaram. Como os mártires tivessem suportado todas as torturas, Tarquínio determinou que fossem lançados ao mar com pesadas pedras atadas ao pescoço. Mas ocorreu então um milagre. Atirados às águas entre Lisboa e Almada, logo os corpos voltaram à margem, mesmo antes do regresso do barco que os levou para o meio das águas.

Podemos ver, na Igreja de Santos-o-Velho, junto à capela dos santos mártires, três enormes pedras que a lenda alega serem as mesmas a que os santos foram presos e teriam as marcas das cinco chagas de Cristo, hoje impossíveis de identificar.

8 Idem, p. 53. Segundo o Pe. Miguel de Oliveira, Ageiano deve ser descuido de algum copista que deve ter confundido com Diocleciano.

9 D. Rodrigo da Cunha, op. cit., p. 39. 
As relíquias dos três santos, cujos restos mortais, recolhidos na sequência do sonho da comendadeira D. Sancha, ao tempo de D. Afonso III, foram transferidas, já no tempo de D. João II, para outro cenóbio chamado de Santos-o-Novo, próximo do local onde foi reconstruído, no tempo de Filipe II, aquele de que ainda hoje se pode ver uma boa parte. Cremos, no entanto, que entre a primeira construção e a de Filipe II terá havido obras, como pode comprovar o arco manuelino, hoje integrado no espólio do Museu da Cidade.

Recorde-se ainda que, em finais do século XV, o culto dos três santos era bastante vivo na cidade de Lisboa, como o comprova o relato da transferência das relíquias de Santos-o-Velho para Santos-o-Novo, ocorrida em 1492 por iniciativa de D. João II, e referida nas crónicas de Garcia de Resende e Rui de Pina. As relíquias estavam encerradas numa "tumba dourada" e foram levadas em solene procissão, a pé, pela comendadeira de Santos e todas as donas do convento, acompanhadas com grande solenidade pelo cabido, todas as ordens e Cruzes do mosteiro.

Os painéis de azulejos com a iconografia da vida e martírios dos santos Veríssimo, Máxima e Júlia encontram-se na Igreja do antigo convento de Santos-o-Novo, que pertenceu, como o antecessor, à Ordem de Santiago e é hoje recolhimento de idosos. É nessa mesma igreja que se podem ver várias telas, do século XVIII, de autor desconhecido, colocadas no registo superior da nave do templo.

As imagens azulejares representam, por ordem, os três santos mártires, em Roma, envergando trajes de corte, o aparecimento do anjo que os envia em peregrinação a Lisboa, o embarque para Lisboa, a flagelação, os corpos que depois de lançados à água chegam à margem intactos e, por fim, a cena dos primeiros martírios.

Da perspectiva da História da Arte, estamos perante um conjunto de painéis de dimensões apreciáveis, mas de qualidade pouco relevante, conforme considerou Santos Simões na sua obra sobre a azulejaria portuguesa do século XVIII. ${ }^{10}$

As telas, de autor desconhecido, como dissemos atrás, encontram-se em estado de conservação muito deficiente, muito escurecidas e de difícil observação, também pela escassa iluminação. Apesar destas limitações poderíamos adiantar, com as devidas reservas, que se trata de um conjunto de pinturas onde a influência de modelos franceses estará presente.

Já do ponto de vista iconográfico, é possível verificar que desenvolvem a lenda dos três santos, acrescentando-lhe alguns passos relacionados com o culto desenvolvido em Portugal. De destacar, por exemplo, o enriquecimento dessa mesma iconografia, num tempo em que se acentua o chamado "triunfo da Igreja" na perspectiva das determinações do Concílio de Trento, pelas quais se recomenda aos bispos e outros responsáveis

10 J. J. Santos Simões, Azulejaria em Portugal no século XVIII, Fundação Calouste Gulbenkian, 1979. 
que "instruam diligentemente os fiéis primeiramente acerca da intercessão dos santos, sua invocação, veneração das relíquias e legítimo uso das imagens, e lhe ensinem que os santos que reinam juntamente com Cristo, oferecem a Deus pelos homens as suas orações, e que é bom e útil invocá-los humildemente e recorrer às suas orações poder e auxílio para alcançar benefícios de Deus, por seu Filho Jesus Cristo nosso Senhor, que é o nosso único redentor e salvador".

Entre essas cenas devem destacar-se a primeira, que evoca a chegada dos mártires a Lisboa onde são apresentados por um personagem, à esquerda, que será, provavelmente, o doador das pinturas. Noutra tela está representada a comendadeira D. Sancha a mandar dar sepultura aos restos mortais dos mártires e outra, quiçá com iconografia anacrónica, mostrando a transferência das relíquias.

Voltando aos azulejos, característicos da cerâmica barroca decorativa de finais da época joanina, notamos que as cenas são desenhadas e enquadradas por bordaduras com um estilo que poderíamos aproximar do modo de um painel da antiga capela do Palácio da Mitra - não muito distante do Convento de Santos-o-Novo - e que hoje se encontra aplicado num dos muros interiores do Palácio Galveias.

\section{A vida e o percurso dos painéis}

Cabe agora iniciar o percurso pelo estudo dos quatro painéis quinhentistas expostos no Museu de Ponta Delgada.

As pinturas representam o Anúncio do Martírio, o Desembarque em Lisboa, a Flagelação e o Arrastamento pelas ruas. São obras de relativamente pequena dimensão (máximos de $860 \mathrm{~mm}$ de alto por 730 milímetros de largo) e que raramente foram expostas. Deste conjunto só duas tábuas foram apresentadas na exposição Primitivos Portugueses (Anúncio do Martírio e Desembarque em Lisboa) - referenciadas como pertencendo a Colecção Particular ${ }^{11}$-, mas não estiveram integradas no alargado elenco reunido na exposição "Mestres do Sardoal e Abrantes" promovida pela Fundação Calouste Gulbenkian em 1971. Só um dos painéis, o do Desembarque em Lisboa, esteve na XVII Exposição Europeia de Arte Ciência e Cultura, em 1983, mas o conjunto foi apresentado em Génova, no ano anterior, no âmbito da Exposição Internacional que decorreu naquela cidade.Todavia, como referimos, desde finais dos anos sessenta que as tábuas se encontram no Museu Carlos Machado, em Ponta Delgada, doadas pelos herdeiros do Dr.Vasco Bensaúde.

11 Estão registadas no catálogo da exposição com os números 194 e 195, mas não vêm reproduzidas nessa publicação nem mesmo na obra de Reinaldo dos Santos, Os Primitivos Portugueses, que não Ihes faz qualquer referência. 
Numa primeira aproximação ao conjunto, podemos verificar que as cenas decorrem em meio fechado, mesmo a primeira, a da Anunciação do Anjo, onde a cidade ao fundo cria um cenário que impede a leitura do horizonte longínquo, embora contribua para a caracterização iconográfica da narrativa. Um outro aspecto que percorre todos os quatro painéis, mesmo aquele onde os mártires são arrastados pelas ruas, é o da exaltação da beleza física dos três irmãos, aspecto que, tal como a perfeição moral, faz parte dos estereótipos hagiográficos medievais descritos nos textos e se estende à pintura tardo-medieval e renascentista, neste caso também à pintura portuguesa decorrente do modo flamengo, mais exactamente antuerpiano. Haverá aqui que referir o facto de este conjunto retabular procurar uma síntese das principais cenas significantes, estando, por isso, já distante do modo medieval onde era frequente uma narrativa mais discursiva, como se pode ver na pintura de finais de quatrocentos ainda conservada em grande quantidade por diversas igrejas da Estremadura espanhola.

A preocupação pela beleza dos protagonistas encontra, nestas pinturas, um momento de coincidência, ou ajustamento, com o gosto pelo vestuário e aparato que percorreu a época de $D$. João II e também a manuelino-joanina, tempo de riqueza procedente das descobertas e da possibilidade de importação das sedas da Itália e adquiridas nas feiras das cidades e vilas de Castela, conforme atesta Garcia de Resende. Repare-se, por exemplo, nos tecidos, onde é possível distinguir o veludo e o arminho, e nos toucados bem elaborados e enriquecidos com dourados.

A Anunciação do Martírio, primeiro painel da série (Fig. 1), mostra os três irmãos recebendo o "Anuncio" da sua viagem para a conquista da glória em defesa da palavra suprema. A sua postura e expressões acentuam quer a obediência quer a convicção do significado da missão que Ihes está a ser atribuída. Sendo uma pintura religiosa, como era toda a pintura do tempo - pelo menos a que chegou até nós -, não deixa de se vincular estilisticamente ao realismo que o Renascimento do Norte da Europa havia desenvolvido desde o primeiro quartel do século XV. As figuras, fossem de santos ou de personagens bíblicas, passaram nessa altura a ocupar um espaço e um relevo que anteriormente não Ihes era atribuído.

Conforme indicam os textos, os três santos encontravam-se em Roma quando o anjo lhes apareceu. E é de Roma a imagem que vemos ao fundo. O pintor não terá lá estado, mas foi recolher a imagem a uma xilogravura, provavelmente de Michael Wolgemut, inserida na Crónica de Nuremberga, o incunábulo ilustrado com maior divulgação a partir de finais do século XV e fonte de inspiração para muita da pintura portuguesa da primeira metade do século XVI.Pelo que podemos identificar, à esquerda, em baixo, está o Castelo de Sant'Angelo e, ao cimo, o Palácio papal na construção anterior ao edifício barroco que hoje conhecemos. 


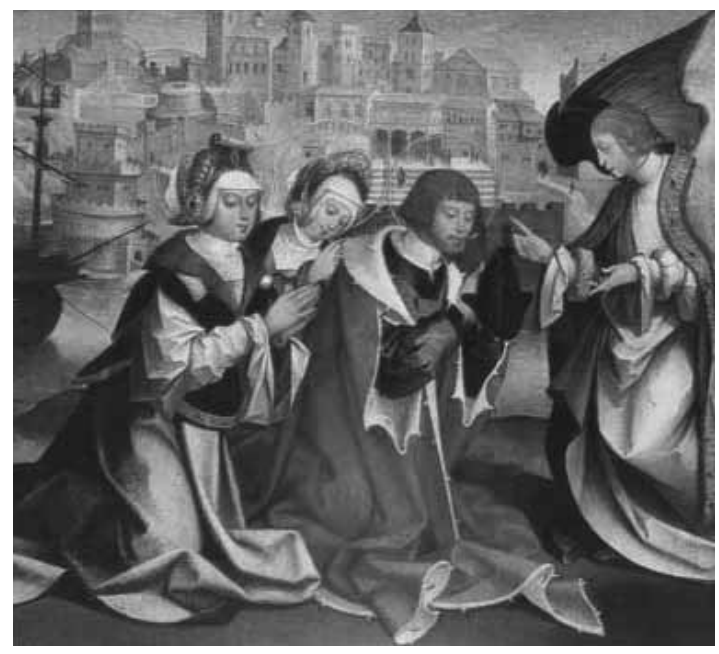

1. Anúncio do Martírio.

Poderemos dizer que nesta pintura há uma sequência narrativa que mostra o momento do anúncio e, ao fundo, o local de embarque onde se encontra a nau em que Veríssimo, Máxima e Júlia iriam viajar. Note-se que se trata de uma sequencialidade dada no mesmo plano e integrada numa mesma perspectiva de conjunto, com a preocupação de dar relevo às figuras principais.

Esta mesma sequencialidade surge no painel Desembarque em Lisboa, onde, ao fundo, à esquerda, se vê a nau que transportou os três irmãos a Lisboa e, junto dela, o pequeno bote que os trouxe até à margem. Os três santos saem no embarcadouro, ao que parece representando o Terreiro do Paço, local que não corresponde ao referido nos textos. É a construção fundeira que sugere a localização. $O$ edifício representa muito aproximadamente as descrições conhecidas do Paço da Ribeira para onde D.Manuel I transferiu a residência real, antes localizada na alcáçova do Castelo de São Jorge. Vêem-se, claramente, a torre com o baluarte (substituído no tempo de Filipe II). Uma loggia abre-se no baluarte em quatro arcarias sob as quais estão esculpidos dois escudos. Ao lado, para norte, uma galeria de nove arcos onde várias pessoas assistem ao desembarque.

Nuno Senos ${ }^{12}$, que dedica ao tema um cuidadoso e indispensável estudo, considera que “o autor anónimo deste quadro, porventura mais próximo de um ideário estético classicizante, terá fornecido aqui a sua versão adaptada de um elemento arquitectónico manue-

12 Nuno Senos, O Paço da Ribeira, Lisboa, Editorial Notícias, 2002, pp. 98-102. 


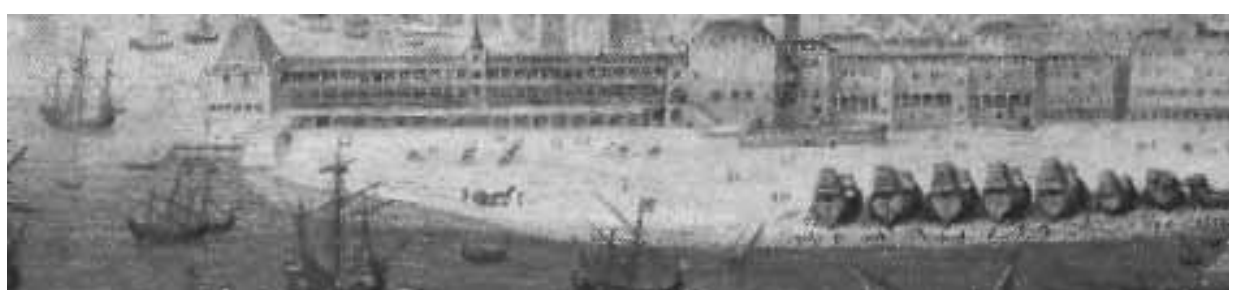

2. Vista de Lisboa (pormenor) do Livro de Horas dito de D. Manuel.

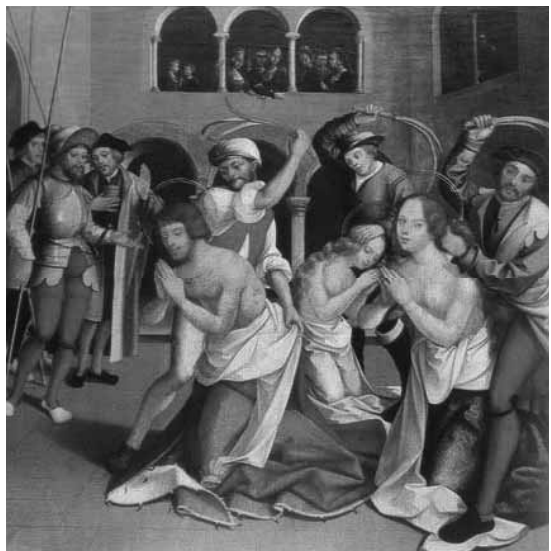

3. Flagelação.

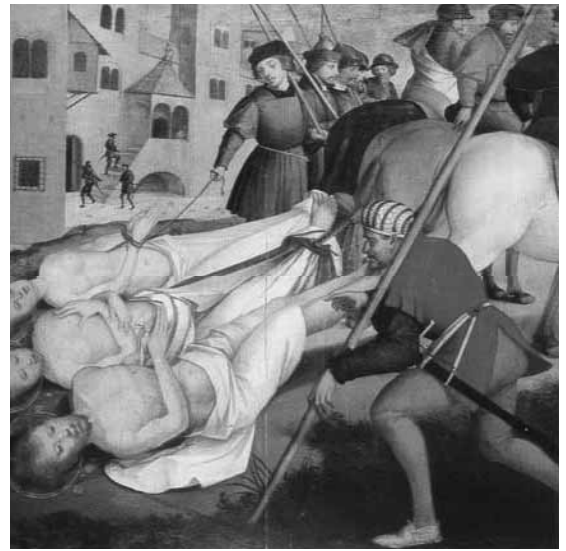

4. Arrastamento dos corpos.

lino, conferindo-lhe um aspecto italianizante, sem se afastar radicalmente do objecto que retratava". Mesmo que haja esta adaptação, há a notar, como também o faz Nuno Senos, que a "corda que emoldura as janelas" é um "motivo decorativo frequente no manuelino". Mesmo com a introdução deste gosto aggiornato, a representação revela tanto o sentido de "grandioso e sumptuoso" como de "máquina de guerra" que avança para o mar, conforme escreveu Damião de Góis. Uma representação do Terreiro do Paço do Livro de Horas de D. Manuel (Fig. 2), confirmará a validade da apreciação.

Esta pintura, como a anterior, é também um óptimo documento para conhecer o vestuário da época. Vítor Pavão dos Santos ${ }^{13}$ referiu-se-lhe largamente destacando a moda dos golpes no tecido e a marcação das cinturas, ao tempo preferencialmente acima ou abaixo do ponto onde anatomicamente se coloca. Acentua este autor que "o grupo dos três san-

13 Vítor Pavão dos Santos, "Os santos mártires de Lisboa. Desembarque de S. Veríssimo e das santas Júlia e Máxima em Lisboa",XVII Exposição Europeia de Arte, Ciência e Cultura. Casa dos Bicos, Lisboa, 1983, pp. 121-123. 
tos mártires de Lisboa oferece alguns bons pormenores para o conhecimento de como se vestiam as gentes da primeira metade do século XVI, com os seus fatos ainda amplos e coloridos, tendendo à horizontalidade, talhados em tecido simples, vivendo muito do sábio uso dos golpes, longe do rigor da moda espanhola, do fato negro e justo ao corpo, que não tardaria a triunfar". Prova desta apreciação encontra-se facilmente nos retratos de D. João III e D. Catarina, poucos anos posteriores às pinturas de Ponta Delgada.

Verificaremos, ainda, que a construção serve de fundo para enquadrar e fechar a cena narrativa, assim como para pôr em relevo as figuras dos protagonistas, trajando luxuosamente, de acordo com a sua estirpe, mas também com a necessidade de mostrar a beleza e dignidade dos santos. A preocupação compositiva vai notar-se, também, no cromatismo, onde os toques do vermelho contribuem para acentuar ou delimitar a dramaticidade das cenas.

Na sequência da lenda, e não referindo a descrita apresentação dos santos mártires a Tarquínio, o representante de Roma, está figurada a Flagelação (Fig. 3). Os três irmãos são chicoteados pelos algozes num pátio da cidade. Mais uma vez, temos a cena enquadrada e "fechada" por arquitectura urbana, com os edifícios e arcarias da época. Poderemos verificar que essas arquitecturas correspondem, no estilo, às da grande galeria do Paço da Ribeira.

Mais uma vez é o cromatismo que vai contribuir para o equilíbrio da cena, com a alternância entre as cores vivas e as cores frias, onde os vermelhos vivos das calças dos algozes funcionam com verticais a delimitarem o episódio do martírio.

Por fim, o Arrastamento (Fig. 4).É a pintura que encerra o ciclo narrativo, que não inclui, por exemplo, o lançamento dos corpos ao Tejo e regresso à costa, nem o achamento das relíquias. Note-se, para além de aspectos já referidos, a opção de arquitecturas a enquadrar a cena e os cromatismos, a definição de dois espaços separados pelo longo bastão seguro pelo que virá a ser o responsável pela execução do martírio.

Refiram-se, ainda, os problemas da autoria e da datação. Desconhece-se quem fez, já há anos, a atribuição dos painéis dos Santos Mártires ao pintor Garcia Fernandes, activo entre 1514 e $1560^{14}$, presumindo-se que a ideia tenha sido de Reinaldo dos Santos. O mestre fez parte da oficina do pintor régio Jorge Afonso e que teve a seu cargo numerosas encomendas, muitas delas referidas num conhecido documento de 1540. Sabe-se, assim, com segurança, que trabalhou para a Misericórdia de Lisboa e que teve a seu cargo o retábulo de Santa Catarina, para a Sé de Goa, e o retábulo da Vida da Virgem, para a Igreja de Santa Maria

14 A referência a Garcia Fernandes consta do texto inserido na História da Arte em Portugal, de 1986, onde se diz (p. 123) que a obra atesta "afinidades de estilo com a obra do pintor Garcia Fernandes", mas desconhecemos se se trata da primeira atribuição ao pintor. 


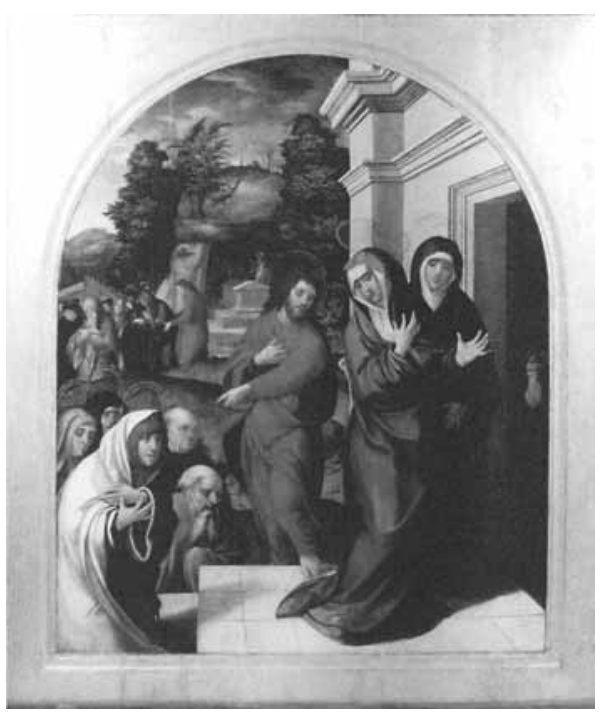

5. Garcia Fernandes, Visita das Santas Mulheres ao Túmulo, colecção particular.

da Alcáçova de Montemor-o-Velho ${ }^{15}$, ainda hoje existentes. Foi também encarregado de concluir o retábulo do Tribunal da Relação, hoje desaparecido. Muitas outras obras the são atribuídas, por comparação estilística, entre elas este conjunto do Museu de Ponta Delgada. A documentação é lacunar quanto a eventuais relações directas de Garcia Fernandes com a comunidade espatária de Santos-o-Novo, mas não podemos esquecer que, se acaso são da sua oficina os painéis do chamado Retábulo de Santa Auta, para a Madre de Deus, é bem possível que se possa, com todas as reservas, encontrar aí o elo de ligação entre os dois conjuntos.

Mais recentemente, surgiu nova proposta de atribuição, da autoria de Fernando António Baptista Pereira. ${ }^{16}$ Defende este autor que o retábulo será de Cristóvão de Utreque, um pintor cuja obra se desconhece mas que é referido em dois documentos, um como testemunha no contrato para os retábulos de Ferreirim (1533) e outro, posterior, dando-o como residente em Lisboa, na freguesia de Santa Justa. Baseia-se esta atribuição no facto de haver "afinidades formais e compositivas" entre este retábulo e o de São Roque, onde o autor identifica uma inscrição como sendo a assinatura de Cristóvão de Utreque.

Esta atribuição merece ser discutida porque as afinidades formais não são muito evidentes, designadamente no cromatismo e na construção do espaço, como as opções compositivas nos parecem diferir claramente. No caso do retábulo de São Roque, cada painel tem duas cenas, claramente separadas e não forçosamente sequenciais, nunca se situando no mesmo espaço de enquadramento.

Como se prova pela pintura de Garcia Fernandes Santas Mulheres junto ao Túmulo (Fig.5), de colecção particular, as duas cenas sequenciais são dadas no mesmo plano, como a gestualidade das mãos - uma das características consensuais da pintura de Garcia Fernandes - é muitíssimo aproximada.

15 Manuel Batoréo,"O Retábulo da Vida da Virgem,"Uma Família de Coleccionadores. Poder e Cultura (Catálogo da exposição), Casa-Museu Anastácio Gonçalves, 2001, pp. 104-109.

${ }_{16}$ Pereira, Fernando António Baptista, Imagens e Histórias de Devoção. Espaço, Tempo e Narrativa na Pintura Portuguesa do Renascimento (1450-1550), Lisboa, 2001, Dissertação de Doutormento (policopiado). 
Embora não acompanhemos a atribuição atrás referida, estamos de acordo com Fernando António Baptista Pereira ao afirmar que "o carácter mais acentuadamente'renascimental' dos enquadramentos e, sobretudo, dos adereços levam-nos a propor uma datação mais recente, do início dos anos trinta".

As pinturas, claramente manuelino-joaninas, terão sido executadas para o Mosteiro de Santos-o-Novo e terão constituído o retábulo do altar-mor da edificação que antecedeu a actual, e cujo arco de acesso à entrada, hoje no Museu da Cidade, comprova ter havido obras no tempo de D. Manuel, provavelmente no começo da segunda década do século XVI.

\section{Bibliografia}

ANJOS, Fr. Luís dos. Jardim de Portugal: em que se da noticia de alguas Sanctas, \& outras molheres illustres em virtude, as quais nascerão, ou viverão, ou estão sepultadas neste Reino, \& suas cõquistas, Coimbra, em casa de Nicolao Carvalho, 1626.

BATORÉO, Manuel. "O Retábulo da Vida da Virgem", Uma Família de Coleccionadores. Poder e Cultura (Catálogo da exposição), Casa-Museu Anastácio Gonçalves, 2001, pp. 104-109.

BREIDENBACH, Bernardus. Peregrinatio in Terram Sanctam, 1486.

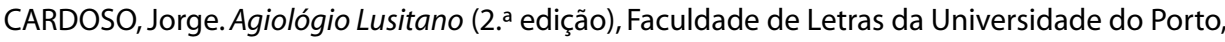
2002.

CARNEIRO,Odília Alves. “Sociologia e geografia do culto medieval dos Santos Mártires de Lisboa”, Lisboa Medieval. Os Rostos da Cidade (coord. Luís Krus), Lisboa, Horizonte, 2007, pp. 371-387.

CASTILHO, Júlio de. A Ribeira de Lisboa, vol. 5, Lisboa, 1944.

CUNHA, D. Rodrigo da Cunha. Historia Ecclesiástica da Igreja de Lisboa, Lisboa, 1642.

CURVELO, Alexandra. “Uma vista de Roma nos painéis dos Mártires de Lisboa," Revista História, Junho de 1998, p. 6.

DIAS, Pedro (coord.). O Manuelino. História da Arte em Portugal, vol. 5, Lisboa, Alfa, 1986, p. 123. FLÓREZ, Henrique. España Sagrada, tomo 14, 1786, pp. 397-398.

GAMEIRO, Odília Alves. "Sociologia e geografia do culto medieval dos Sanatois Mártires de Lisboa", Lisboa Medieval. Os rostos da cidade (ed.Luís Krus), Lisboa, Horizonte, 2007, pp. 371-387. GOUVEIA, Mário de. “O culto dos santos mártires de Lisboa na fronteira ocidental do reino de Leão (sécs. IX-XI), Lisboa Medieval. Os Rostos da Cidade (coord. Luís Krus), Lisboa, Horizonte, 2007, pp. 388-399.

LEITE, Ana Cristina. “Os centros simbólicos," História da Arte Portuguesa (dir. Paulo Pereira), vol. II, 1995, pp. 69-90. 
LOUREIRO, Fátima. “As artes dos tecidos", O Manuelino. História da Arte em Portugal, vol. 5, Lisboa, Alfa, 1986, p.p 147-148.

LUCAS, Maria Clara de Almeida. Ho Flos Sanctorum em lengoage: os Santos Extravagantes, Lisboa, INIC, 1988.

MARTINS, Mário. "A Legenda dos Santos Mártires e o Flos Sanctorum de 1513", Brotéria, 72, Lisboa, 1961, pp. 155-165.

MARTINS, Mário."A legenda dos santos mártires Veríssimo, Máxima e Júlia, do cód. CV/I-23 d., da Biblioteca de Évora", separata da Revista Portuguesa de História, Coimbra, 1964.

MARTINS, Mário. “Bernardo de Brihuega, compilador do «Livro e legenda que fala de todolos feitos e paixões dos santos mártires»",Brotéria, 76, Lisboa, 1963, pp. 411-423.

MARTINS, Mário. Peregrinações e Livros de Milagres na nossa Idade Média, Lisboa, 1957.

MATA, Joel. A Comunidade Feminina da Ordem de Santiago: A Comenda de Santos na Idade Média, Lisboa, 1991 (tese de mestrado, policopiado).

OLIVEIRA, José Augusto de (ed.). Conquista de Lisboa aos Mouros (1147). Narrada pelo cruzado Osberno, testemunha presencial, Lisboa, CML,1935, pp. 42-43

OLIVEIRA, Pe. Miguel de. “Os santos Mártires de Lisboa Veríssimo, Máxima e Júlia”, Novidades Letras e Artes, Lisboa, 30 de Setembro de 1945.

OLIVEIRA, Pe. Miguel de. Lenda e História: Estudos hagiográficos, Lisboa, União Gráfica, 1964.

PEREIRA, Fernando António Baptista. Imagens e Histórias de Devoção. Espaço, Tempo e Narrativa na Pintura Portuguesa do Renascimento (1450-1550), tese de doutoramento, Lisboa, 2001, pp. 396-399.

PAULINO, Francisco Faria (coord.). Un'Aventura di Secoli per Inventare il Futuro, Catálogo da Exposição, Génova, 1992, pp. 56-62.

PEREIRA, Fernando António Baptista. Imagens e Histórias de Devoção. Espaço, Tempo e Narrativa na Pintura Portuguesa do Renascimento (1450-1550), Lisboa, 2001, dissertação de doutoramento (policopiado).

PINA, Rui de; introd. Manuel Lopes de Almeida. Crónicas, Porto, Lello \& Irmão, 1977.

RESENDE, Garcia de; introd. de Joaquim Veríssimo Serrão. Crónica de D. João II, Lisboa, Imprensa Nacional-Casa da Moeda, 1992.

ROSÁRIO, Fr. Diogo do. Historia das vidas e feitos heroycos \& obras insignes dos sanctos : cõ muitos sermões \& praticas spirituais que seruem a muytas festas do anno / reuistas \& cotejadas com os seus originaes... polo padre frey Diogo do Rosayro da ordem de São Domingos de mandado do... senhor Dom Frey Bartholameu [sic] dos Martyres... , Em Lisboa: per Antonio Ribeiro: a custa de Ioão Despanha e Miguel Darenas, liureiros, 1585

SANTA MARIA, Frei Agostinho de. Historia tripartita comprehendida em três tratados..., Lisboa Occidental, na Off. de Antonio Pedrozo Galram, 1724. 
SANTOS, Vítor Pavão dos. “Os Santos Mártires de Lisboa. Desembarque de S. Veríssimo e das Santas Júlia e Máxima em Lisboa", Os Descobrimentos Portugueses e a Europa do Renascimento - Casa dos Bicos, Catálogo da XVII Exposição Europeia de Arte, Ciência e Cultura, Lisboa, 1983, pp. 121-123.

SCHEDEL, Hartmann. Liber Cronicarum, 1493.

SENOS, Nuno. O Paço da Ribeira (1501-1581), Editorial Notícias, 2002.

SOALHEIRO, João. "Veríssimo, Máxima e Júlia, mártires de Lisboa", Cristo Fonte de Esperança, Catálogo, Diocese do Porto, 2000, pp. 188-189.

SOBRAL, Cristina. Adições Portuguesas no Flos Sanctorum de 1513 (estudo e edição crítica), Lisboa, 2000 (tese de doutoramento, policopiado). 



\title{
Os Santos Mártires de Évora
}

\author{
Artur Goulart de Melo Borges*
}

\section{Os lugares de culto}

Em 1308, o bispo de Évora, D. Fernando II, consagrava na sua Sé o altar-mor à Virgem Santa Maria e uma série de altares dedicados a vários santos, entre eles um ao mártir eborense Vicente, e suas irmãs Sabina e Cristeta. A lápide comemorativa, hoje incrustada numa das paredes do cruzeiro da catedral, especifica, para além do da Virgem Santa Maria, todos os outros: São Bartolomeu, São João Baptista, São Lourenço, São Juliano, São Bonifácio e Santa Luzia, a que se acrescentou mais tarde São Manços. Trata-se da primeira referência documental conhecida à devoção dos mártires eborenses.

Nova referência aos três irmãos mártires só vem a encontrar-se mais de um século depois, no Livro $3 .^{\circ}$ dos aniversários de 1470 , desta vez numa alusão ao altar como forma mais precisa de localizar um enterramento. Segundo informação do Prof. Doutor Joaquim Lavajo, a quem devo a gentileza destes dados e que prepara um extenso trabalho sobre a história da Catedral, parece inferir-se do texto que o altar estaria situado no esteio do arco triunfal do lado do evangelho.

No final do século XV, o estado ruinoso de parte do edifício da Sé levou o bispo D. Afonso de Portugal (1485-1522) a abalançar-se a grandes obras de restauro, depois de obtida a conveniente autorização papal. Por essa altura devem ter sido alteradas e desmontadas algumas das capelas, pois em 1537, na primeira visitação à Sé do Cardeal Infante D. Afonso (1523-1540), apesar da minúcia da enumeração e descrição de todas as capelas, a dos Santos Mártires Vicente, Sabina e Cristeta não é mencionada. Não temos dados suficientes para saber se isso se terá devido apenas por exigência das referidas obras ou se não se estaria perante uma diminuição da devoção aos santos eborenses. O que sabemos, sim, é que no século seguinte a devoção iria ter um grande incremento.

Ao que se supõe, no pontificado de D. João de Melo (1564-1574), que se seguiu ao primeiro período de arcebispado do Infante D. Henrique (1540-1564), a disposição interior da Sé foi alvo de profundas alterações, sendo construídas nove capelas laterais, seis do lado da epístola e três do lado do evangelho, em substituição dos antigos altares adossados

\footnotetext{
* Inventário da Arquidiocese de Évora.
} 
às colunas da nave central. Só permaneceu até hoje o de Nossa Senhora do Ó. Ao mesmo tempo desapareceram as antigas frestas dando lugar a janelões altos e largos ao gosto da época. A quarta capela do lado da epístola era precisamente a dedicada aos santos mártires Vicente, Sabina e Cristeta. Como todas as outras foi construída em arco de volta perfeita penetrando nas grossas paredes laterais, tendo sido posteriormente fechada com grades de ferro e afrescada (D. Frei Luís da Silva Teles, 1691-1703) e adornada com uma estrutura retabular de talha dourada a emoldurar um painel pictórico representando os três irmãos mártires e Santo António de Lisboa, hoje exposto no Museu de Arte Sacra da Sé. Apesar da diminuição do culto, assim permaneceu como sinal evidente da devoção eborense até aos anos 40 do século passado, quando a Direcção dos Monumentos Nacionais resolveu voltar a dar à igreja, pretensamente, o seu aspecto primitivo, repondo as antigas frestas e fazendo desaparecer todas as capelas, enchendo todos os vãos, desmontando edifícios anexos, apagando irremediavelmente os testemunhos de vários séculos de história da catedral eborense.

Não se reduziu apenas à Catedral o culto aos três irmãos mártires. Um documento notarial de 1459 afirma que o Cabido da Sé "deu hua casa (...) pera se fazer em ella a Igreja de Sam Vicente..." e terá sido esta a origem da primitiva igreja mandada construir por Luis Loy, da casa do Infante D. Henrique e porteiro do Cabido.Vários documentos até ao final do século XV já fazem menção da Travessa de São Vicente ou de confrontações prediais com a ermida. André de Resende na sua História da Antiguidade da Cidade de Évora, publicada em 1553, lamenta-se do mau estado da construção:

en esse tempo tevemos tres nobilíssimos cijdadãos s. hos gloriosos martyres Vincentio e suas hirmãas Sabina e Christheta, nados e moradores en esta cijdade, en haquella pobre hermida que de seu nome se chama. Do que eu por ha parte que me cabe da patria:muitas vezes hei vergonha, e bee olhado, ha cijdade devia haver por affronta non ha teer tanto tempo ha melhorado. (Cap. IX) ${ }^{1}$

A igreja, sufragânea da freguesia de São Pedro, em acto público notarial de 13 de Julho de 1559, perante os responsáveis paroquiais, mordomos da confraria de São Vicente e representantes municipais, será desanexada com a condição de nunca ser paróquia, nem ter pia de baptizar, nem prejudicar a igreja matriz, e entregue o seu padroado à Câmara porque "sendo o dito Santo natural desta cidade, e nacido na dita Casa e Igreja de São Vicente, e padroeiro

1 RESENDE, André de - História da Antiguidade da Cidade de Évora. Évora: André de Burgos, 1553. Disponível em www.bdalentejo.net/BDAObra/BDADigital/Obra.aspx?id=386\# 
da terra, posto que assim fosse, a sua casa estava muito pobre assim de ornamentos como de templo, e todo o mais que convinha, e era necessário para serviço e honra do dito Santo (...) porque nisto farião serviço a Deus e à cidade e Povo della muita esmola e mercê".2

Será já por iniciativa e empenho da Câmara que, a instâncias de André de Resende que contribuiu com doação testamentária, no final do segundo quartel do século XVI, a igreja será totalmente remodelada, de três naves e capela-mor funda, e retábulo de alvenaria com pintura mural representando os três mártires. Foi encontrado em 1965 já muito destruído ao ser desmontado e restaurado o actual retábulo quinhentista do início da década de 90.0 visitador do arcebispado, Mestre Gaspar Gomes, em Dezembro de 1597, já acusa a presença deste último retábulo:"no Altar moor hum Retavollo novo já pintado muito grande e estaa ainda hum pedaço por acabar de dourar e pintar (...)."Já no início do século XVII, desapareceram dois painéis, no primeiro nível do retábulo, dando origem a dois nichos onde foram colocadas as imagens das santas Sabina e Cristeta. O retábulo anterior, de que existe fotografia, voltou a ser escondido pelo actual, de estrutura clássica de madeira entalhada em planta plana, três tramos, banco com duas pequenas tábuas laterais, dois corpos, o primeiro com três nichos, o segundo com três painéis e ático rematado no arco da abóbada, com painel no fecho do tramo central e molduras triangulares simples laterais. Na parede do lado do evangelho, uma pedra de granito, saliente, e hoje protegida por caixa envidraçada, mostra as pretensas e milagrosas pegadas do Santo ao renegar Júpiter.

É importante referir, tendo em conta a dependência do município da Igreja de São Vicente e as motivações de ordem de cidadania que podem ter estado na origem desta relação, que a igreja, em capela do lado da epístola, tem o altar de Nossa Senhora da Vitória, mandado construir pela respectiva confraria. Toda a decoração do entalhado, de motivos bélicos, relembra o histórico facto. Segundo a tradição, a confraria foi instituída após a batalha do Salado, pelo bispo D. Martinho II. Extinta no tempo de Filipe II, foi restaurada pelo arcebispo D. Alexandre de Bragança e hoje já não existe. ${ }^{3}$

\section{Quem são os mártires de Évora?}

Ho flos sanctorum em lingoajem português, publicado em Lisboa em 1513, no fol. CCXLVII, descreve "A vida e paixã dos sanctos tres irmaãos martires .s. vincente: sabina: e cristeta

2 ESPANCA, Túlio - Fundações e Evolução Histórica da Igreja dos Mártires de Évora: S. Vicente, Sabina e Cristeta. A Cidade de Évora.29-30 (1952) 472-483.

3 ESPANCA, Túlio - Inventário Artístico de Portugal: Concelho de Évora. Lisboa: Academia Nacional de BelasArtes, 1966, pp 178-180. 
naturaes da cidade de Évora"Trata-se da primeira narração em português da vida dos santos mártires. ${ }^{4}$

No início do século IV, o governador romano da Lusitânia, Daciano, homem perverso e cruel, perseguia os cristãos. Em Évora, tendo sido informado da existência de um jovem Vicente que, com suas irmãs Sabina e Cristeta, adoravam a Cristo, mandou prendê-lo e interrogou-o sobre a sua fé, acusando-o de blasfemar por não adorar os deuses. Ordenou que o conduzissem perante a estátua de Júpiter para que sacrificasse ao grande deus, se não seria entregue à morte. Ao chegar junto da estátua, a pedra da base em que pôs os pés amoleceu como cera deixando impressas as suas pegadas. Perante tal maravilha, não se cansavam os soldados que o acompanhavam de proclamar que "não há outro Deus senão o que Vicente adora". Não se atreveram a matá-lo, levando-o para a prisão, onde foi visitado por suas irmãs. Lamentando-se que já eram órfãs e que sem o irmão perderiam o seu amparo e sustento, convenceram-no a que fugissem os três, pois mais valia perecerem todos do que ficarem sem ele. Assim aconteceu, e puseram-se a caminho de Sevilha. Avisado, Daciano mandou persegui-los, tendo sido apanhados perto de Mérida, onde foram presos, despidos, maltratados e mortos à paulada e à pedrada. O texto é minucioso na descrição do martírio:"(...) com outros mui fortes paus dando fortemente sobre suas cabeças assim Ihe lançaram os miolos fora". Atiraram os seus corpos às feras num monte próximo, ameaçando quem os honrasse ou procurasse sepultá-los. Uma grande serpente que por ali costumava causar grande temor andava ao redor deles não deixando ninguém aproximar-se. Um judeu, demasiado ousado, "querendo ganhar fama" e ver os corpos mais de perto, foi apanhado pela serpente que nele se enroscou causando-lhe grande sufoco. Ao ver-se em tal aflição, prometeu converter-se a Jesus Cristo, enterrar os corpos dos mártires e construir uma igreja em seu nome. Imediatamente se viu livre da serpente e veio a cumprir o prometido.

É este em resumo o texto do Flos Sanctorum. Alguns pormenores, todavia, não seguem a lenda tradicional, contrariam até factos posteriores. Refiro-me à localização da sua fuga e consequente morte.

Em 1548, era publicado o Breviário Eborense ${ }^{5}$, mandado elaborar e redigir ao Mestre André de Resende pelo Cardeal D. Henrique (nomeado cardeal em 1545), primeiro arcebispo de Évora. O dia 27 de Outubro, dia da festa dos três santos mártires, além do ofício comum do dia e do tempo a ser recitado, inclui uma oração própria e as nove lições de

4 Ho flos sanctõ[rum] em lingoaje[m] p[or]tugue[s]. - Lixboa: per Herman de campis bombardero del rey \& Roberte rabelo, 15 Março 1513. - [10],CCLXV, [2] f.: il.Disponível em http://purl.pt/12097.SOBRAL, Cristina - O Flos Sanctorum e suas adições portuguesas. Lusitania Sacra. 2. a série, 13-14 (2001-2002) 531-568.

5 Breviarium Eborense. Lisboa: apud Ludovicum Rotorigium, 1548. 
Matinas, em que, num latim fluente e apurado, se narra a lendária perseguição e martírio. Em linhas gerais segue o Flos Sanctorum, com maior colorido nos diálogos entre Daciano e Vicente e, sobretudo, pondo de lado a referência a Sevilha e a Mérida como caminho da fuga. Os mártires fogem sim para Ávila, em cujos arredores são martirizados, transformando-se depois nos patronos da cidade em que foram sepultados e que lhes ergueu um notável santuário começado a construir no século XI.

Não é, todavia, o sítio do seu martírio que causa qualquer divergência de opiniões, mas o da sua naturalidade. Segundo tradição espanhola, a Évora de que falam textos antigos não seria a portuguesa, mas a espanhola, como seria conhecida a actual Talavera de la Reina (Toledo). André de Resende procurou dirimir a questão a favor da sua cidade, como sempre fez em tudo o que fosse para dignificar e honrar a sua Évora natal. Em 1567 edita uma sua carta a Bartolomeu de Quevedo, em resposta a algumas questões que Ihe teriam sido postas por aquele douto sacerdote toledano (Epistola ad Bartholomaeum Kebedium. L. Andr. Resendii /pro sanctis Christi martyribus Vincentio Olisiponensi patrono, Vincentio, Sabina et Christetide, Eborensibus civibus, et quaedam alia Responsio. Ad Bartholomaeum kebedium, sanctae Toletanae ecclesiae sacerdotem, virum doctissimum. Évora, 1567. Editada em fac-símile em 1988, com um profuso estudo introdutório, transcrição e tradução, pela Dra.Virgínia Soares Pereira). Entre dúvidas surge a da naturalidade dos santos Vicente, Sabina e Cristeta, que Resende resolve a favor de Évora com uma argumentação cerrada que se pode resumir ao seguinte, segundo a Dra. Soares Pereira: se o martírio dos santos foi, como se diz, no tempo de Daciano (303-304), só pode ter sido Évora e não Talavera, que é mais recente; as designações Ebora e Elbora, ambas antigas, uma correcta e a outra deturpada, são da mesma cidade: Évora; não há provas da existência de Elbora entre Toledo e Mérida; a distância entre Évora e Ávila não era impedimento para a fuga; o receio que Talavera fique sem nome não conta, pois já lhe foram atribuídos sete e só um é correcto:Talavera.

Aceitando ou não, ou Évora ou Talavera de la Reina, como terra de naturalidade dos três Santos Mártires ${ }^{6}$, o facto é que a partir de meados do século XVI se nota um grande incremento na sua devoção, mercê dos factores atrás apontados, e que se foi mantendo com oscilações até muito recentemente com o desaparecimento do seu altar próprio na Sé e com a desafectação ao culto da Igreja de São Vicente, hoje praticamente utilizada pelo município como galeria de exposições temporárias.

\footnotetext{
6 LAVAJO, Joaquim Chorão - Hagiologia de André de Resende e o Santoral eborense. Eborensia. Ano XIV, 27-28 (2001)153-157.
} 


\section{Iconografia - Como são representados}

Até agora não se encontrou nenhuma representação dos irmãos mártires anterior ao século XVI. Para tal será necessário viajar até Ávila, ao magnífico sepulcro de São Vicente, do século XII, com um portentoso baldaquino também em calcário, do século XV. À volta do sarcófago, alinham-se em alto relevo as principais cenas da paixão dos três santos: Daciano exige que Vicente renegue a Cristo; Vicente é obrigado a sacrificar a Júpiter e deixa as pegadas na pedra; visita de suas irmãs à prisão; Daciano manda os soldados em perseguição; os três santos chegam às portas de Ávila; são detidos e despojados das vestes; martirizados; mortos por lapidação e subida das almas ao céu; o judeu e a serpente; o judeu preparando as sepulturas. ${ }^{7}$

Toda a obra denuncia um mestre escultor, com uma grande desenvoltura no desenho e composição das cenas, a proporcionar um forte realismo nas representações, evidente na crueza do martírio e ao mesmo tempo de grande ternura e compaixão. Tudo se traduz na grande eficácia da mensagem iconográfica, que alia a riqueza do pormenor ao objectivo catequético do conjunto, e que não tem correspondência nas posteriores representações eborenses.

Na zona de Évora, alguns lugares, que por serem denominados São Vicente poderiam indiciar a alusão ao mártir eborense, têm como referência o outro São Vicente, levita e mártir, popularmente chamado de "São Vicente dos corvos". Assim, são muito poucas as representações conhecidas dos três santos mártires e podem organizar-se em dois grupos:

- a imagem/"retrato" dos santos - os três mártires são representados juntos, em corpo inteiro ou meio-corpo, em atitude gozosa de santificados. O centro é ocupado por São Vicente, ladeado pelas irmãs. Todos trazem a palma para serem identificados como mártires. Geralmente, São Vicente segura um livro fechado (aberto num dos casos), sinal da fidelidade à doutrina, e, por vezes, também as irmãs. Uma vez que a palma e o livro são atributos comuns à generalidade de todos os santos mártires, e que estes eborenses não possuem nenhuns outros mais específicos, costumam ser identificados com o próprio nome, em legenda, para que não restem dúvidas.

- ciclo da paixão e morte - apenas um exemplo na igreja eborense de São Vicente.

Do primeiro grupo são conhecidos os seguintes exemplares:

\footnotetext{
Sobre a história, iconografia, estudo e processo de restauro do sepulcro de São Vicente, em Ávila, ver o sítio http://www.sepulcrodesanvicente.es/iconografia.htm.
} 
Os santos mártires de Évora e Santo António. Painel que ocupava o centro do retábulo da demolida Capela dos Santos Mártires de Évora, situada na parede lateral do lado da epístola da Sé de Évora. Representa os três mártires eborenses acompanhados de Santo António, figuras de corpo inteiro, em pé, num espaço campestre com grandes ruínas em fundo. Os três mártires, identificados inferiormente S. CHRISTETA, S. VINCENTE, S. SABINA, trazem a palma e São Vicente, entre as duas irmãs, segura um livro ligeiramente entreaberto com a mão direita, coberta pelo manto em sinal de respeito pelo texto sagrado, enquanto aponta com a esquerda. Todavia, a forma como aponta permite duvidar se o faz directamente para o livro, se para Santo António que, de hábito franciscano, com a cruz na direita e o livro aberto na mão esquerda, não necessita de outra identificação. Num caso ou noutro, é evidente o objectivo pedagógico e catequético da representação, embora não seja muito clara a inclusão de Santo António no retábulo da capela dedicada aos santos mártires de Évora, quando também ele tinha capela própria muito próxima e na mesma nave da catedral. A fidelidade à mensagem cristã, quer simbolizada no livro sagrado, quer personificada no douto pregador e confessor, é o principal e indubitável objectivo.

A pintura (óleo sobre madeira, $160 \times 135 \mathrm{~cm}$, inv. EV.SE.1.013 pin) poderá ser atribuída a um discípulo de Francisco de Campos, datável entre 1564 e 1570. O pintor revela um colorido aberto, composição de certa rigidez, embora eficaz, com um pouco valorizado tratamento dos fundos e sem a expressividade cenográfica habitual em Campos.

São Manços e outros seis santos. Pertence a um conjunto de quatro painéis, de composição e características semelhantes, que têm como figuras centrais São Miguel, São Brás, São Manços e São Sebastião, e que pertenciam a outros tantos altares da Sé. ${ }^{8}$ A figura principal, de corpo inteiro, domina o centro do quadro entre duas colunas de um pórtico coberto, com um fundo de paisagem. Lateralmente, abrem-se três nichos rectangulares de cada lado, perspectivados, cada um com seu santo, identificados pelas respectivas legendas, como se fossem prateleiras com bustos-relicários. Uma tal profusão de santos faz pensar na hipótese de representação iconográfica do Santoral eborense, que à época mantinha características muito específicas, quando liturgicamente ainda existia o "costume de Évora", embora o Cardeal Infante D. Afonso, o último bispo de Évora, tivesse tornado obrigatório o "costume romano", com aprovação do Papa Paulo III, em 1538. ${ }^{9}$

A tábua de São Manços (205 x 152 cm; inv. EV.SE.1.003 pin) tem a acompanhá-lo de um dos lados Santa Marta, Santo Ivo e Santo Antão, eremita; do outro, os mártires eborenses São Vicente, Santa Sabina e Santa Cristeta. São Vicente ocupa o registo superior, rosto bar-

\footnotetext{
8 MENDEIROS, José Filipe - Guia do Museu de Arte Sacra da Catedral de Évora. Évora, 1985.

9 GUERREIRO, J. Alcântara - Galeria dos Prelados de Évora. Évora: Gráfica Eborense, 1971, p 42.
} 
bado e cabeça descoberta, a olhar para o livro aberto que segura na mão direita e com a palma na esquerda. Na moldura inferior, a legenda S. VICEMTE.DEVORA. Segue-se Santa Sabina, de túnica azul e véu branco pela cabeça, empunhando a palma, e por último, igualmente com a palma, Santa Cristeta, colocada de perfil, cabeça coberta por um toucado recamado de gemas, trajada com um manto rosa, cuja mancha de tratamento bastante fruste ocupa boa parte do espaço.

Segundo Joaquim Oliveira Caetano, a datação será cerca de 1560 e a autoria deve atribuir-se a um pintor local, ainda não identificado, o mesmo que pintou os quadros do retábulo da ermida de São Brás, de Évora, que manifesta nítidas influências de Garcia Fernandes. $^{10}$

Santos mártires de Évora. Predela. Com mais outras quatro pequenas tábuas faz parte de uma banqueta, hoje exposta no Museu de Arte Sacra da Catedral de Évora, e que, segundo Vítor Serrão, pertenceria a um "desmembrado 'Sepulcro' da capela-mor, uma obra opulenta que foi lavrada em 1588 pelos entalhadores Ascenso Fernandes e Gaspar Gonçalves, sob o risco do arquitecto régio Nicolau de Frias, e que foi pintada e dourada, em 1629, por uma companhia de pintores da cidade integrando os mestres Manuel Fernandes, Diogo Vogado, António Vogado e Pedro Nunes pelo preço excepcional de 600.000 rs."11 As tabuinhas representam Cristo e a Samaritana (central), o Profeta Elias e um Anjo, os santos mártires de Évora, Santo António que ressuscita um morto, e um Milagre de dois santos franciscanos. Os santos eborenses ( $17 \times 39 \mathrm{~cm}$, inv. EV.SE.1.022/2 pin), sem a legenda identificativa habitual, estão figurados de pé, São Vicente no meio das duas irmãs ligeiramente voltadas para ele. Todos seguram a palma e o livro.

Santos Mártires de Évora. Predela. Pertence ao retábulo de Nossa Senhora da Visitação, predela única (16 x $147 \mathrm{~cm}$, inv. RE.SS.1.006/3 pin) da banqueta do altar colateral do lado da epístola, da igreja de Santa Susana, concelho de Redondo. ${ }^{12}$ Os santos estão representados a meio-corpo, todos com a palma, São Vicente ao centro com o livro, em posição frontal, e as irmãs ligeiramente voltadas para ele. Identificados na parte superior do quadro: S. CRISTETA / S. VICENTE DEVORA / S. SIBINA (sic). Sobre fundo negro, as figuras destacam-se com um desenho seguro e modelação delicada, um colorido condizente com a qualidade do desconhecido pintor.

${ }^{10}$ CAETANO, Joaquim Oliveira - Garcia Fernandes: Uma Exposição à procura de um Pintor. In SANTA CASA DA MISERICÓRDIA (Lisboa) - Garcia Fernandes: Um Pintor do Renascimento: Eleitor da Misericórdia de Lisboa. Lisboa:S.C.M., imp. 1998, p 74.

11 SERRÃO, Vítor - Banqueta. In Cristo Fonte de Esperança: catálogo: exposição do grande jubileu do ano 2000. Porto: Diocese, 2000, p 322.

12 ESPANCA, Túlio - Inventário Artístico de Portugal: Distrito de Évora. Lisboa: Academia Nacional de Belas Artes, 1975. 
Ciclo do Martírio e Morte dos Santos Vicente, Cristeta e Sabina. Quatro painéis do retábulo-mor da Igreja de São Vicente em Évora descrevem as principais cenas do martírio dos três santos. Organizado em banco, dois corpos, três tramos e ático, com painéis no banco, corpo superior e ático, e o corpo inferior com três nichos com as imagens dos santos mártires, que praticamente repetem em escultura os modelos pictóricos. $\mathrm{O}$ nicho central é ocupado por São Vicente, maior e melhor escultura do que as das duas irmãs, que, segundo Túlio Espanca, são posteriores e colocadas em nichos mais recentes a substituir antigos painéis. A tábua central representa Cristo expirante na cruz, e a redução do entablamento no tramo central vai permitir manter uma ligação mais perceptível com a tábua superior, já no ático, com a figura de Deus Pai.

As outras tábuas do retábulo constituem o ciclo da perseguição e martírio dos três santos eborenses: duas de maiores dimensões no corpo superior, de nítidas influências italianas, que já deviam estar colocadas em 1597 quando da Visitação de Mestre Gaspar, e duas pequenas predelas de menor qualidade e de aparente feitura posterior, possivelmente já do início do século XVII. A leitura sequencial faz-se a partir da predela do lado da epístola, subindo ao corpo superior e descendo pelo lado oposto:

1. Daciano ordena a Vicente que sacrifique a Júpiter. Cena que preenche o lado direito da tábua, vendo-se o governador Daciano, em cavalo ajaezado, voltado para Vicente de mãos atadas entre dois guardas, a apontar para a estátua de Júpiter que se ergue,à esquerda, sobre uma base circular a degraus. Junto à base do monumento, desenrola-se já a cena seguinte - dois soldados espantam-se com as pegadas do santo gravadas na pedra. Aliás, na capela-mor da igreja, embutido na parede do lado do evangelho, um bloco de granito mostra, gravadas, as pretensas pegadas, tornando assim palpável aos fiéis o facto miraculoso e, ao mesmo tempo, dando eficácia à representação pictórica.

2. A prisão de Vicente e a visita das irmãs. Do lado esquerdo do quadro, em primeiro plano, as duas irmãs voltam-se uma para a outra junto à janela da prisão em que aparece Vicente por detrás das grades. À direita, ao fundo, através de um grande arco de uma construção acastelada, avista-se a fuga dos três irmãos.

3. O martírio. Vicente, caído de joelhos e de mãos postas, é morto à paulada por dois algozes, perante as irmãs; de pé, junto dele, também de mãos postas, um grupo de pessoas.

4. Os corpos dos mártires e o judeu atacado pela serpente. Em primeiro plano, do lado direito, os corpos dos mártires caídos no chão, segundo a lenda em que foram atirados por terra num monte próximo. Salienta-se o corpo de São Vicente que veste 
uma longa túnica vermelha. Todos estão vestidos de acordo com o local de culto e os costumes, ao contrário da lenda em que foram despidos e mortos. Do lado esquerdo, uma grande serpente enrosca-se à volta do corpo do judeu, que de braços abertos clama pelo socorro divino.

A leitura iconográfica deste ciclo da perseguição, martírio e morte dos santos eborenses, que incide sobre os pontos essenciais como a fidelidade à mensagem cristã até à morte e bem assim a salvação através do arrependimento e da fé, não ficaria completa se não fosse vista no conjunto do retábulo. Todo o ciclo rodeia e focaliza o Crucificado, o Mártir por excelência, o Salvador que se entregou voluntariamente até à morte na cruz, e que domina visualmente o centro do retábulo. Trata-se, portanto, de um programa iconográfico eminentemente catequético que, através do percurso dos mártires de Évora, conduz os crentes à compreensão do essencial da mensagem evangélica, razão de ser da fidelidade e do martírio.

Quanto à representação dos três santos, sempre juntos, referida no primeiro grupo, e que aparentemente não tem qualquer significado a não ser uma simples referência visual de alguém que existiu e que atingiu a santidade, julgo que passa a ter um sentido mais profundo e também catequético, se atendermos ao texto litúrgico que lhes é dedicado na sua festa própria, a 27 de Outubro.

O Cardeal D. Henrique, quando arcebispo de Évora, encarregou o seu capelão e cónego da Sé, Diogo Velho, de elaborar um novo missal. Feito o trabalho, foi enviado para o Cabido para que "o visse e o examinasse".Porém, "antes que fosse visto faleceu o dito Diogo Velho.E o Cabido mandou que se guardasse em seu cartório". Não chegou a ser publicado. Todavia, o texto, ao menos no que se refere à missa própria dos Santos Mártires Vicente, Sabina e Cristeta, se não era o já utilizado, passou a sê-lo. Para a epístola foi escolhida a passagem de São Paulo aos Efésios (4, 1-7), convite premente à unidade,"(...) graças à vossa vocação, fostes chamados a uma só esperança, um só Senhor, uma só fé (...)". Para o evangelho, um excerto de São Mateus $(12,46-50)$ em que Jesus explica quem são os seus verdadeiros parentes:"(...) todo aquele que fizer a vontade de meu Pai que está nos céus, esse é para mim irmão, irmã e mãe." É sobretudo na oração, que traduzo, que tudo se torna mais explícito: “Deus que associaste os santos irmãos, teus mártires Vicente, Sabina e Cristeta, unidos pela caridade e pelo martírio, à confissão da Trindade divina, concede que, por sua intercessão, permaneçamos no verdadeiro amor e sempre na unidade da fé".

Assim, a palavra litúrgica vai explicitar o profundo sentido da representação iconográfica. Não é relevante serem irmãos para o facto de serem representados sempre juntos, mas sim porque manifestam a mesma esperança, o mesmo amor na unidade da fé. 


\title{
A invocação e o culto do Senhor Santo Cristo em Ponta Delgada - São Miguel
}

\author{
Maria Fernanda Enes*
}

\section{A invocação e a sua imagem}

O estudo e reflexão que aqui trago, sobre o culto do Senhor Santo Cristo dos Milagres nos Açores ilha de são Miguel -, enquadra-se no amplo campo temático que a titulação das Jornadas - Iconografia Religiosa das Invocações Nacionais - abrange. A natureza cristológica daquela invocação e a sua compósita formulação - Senhor Santo Cristo - abre a hipótese de não ser entendida como substantivação, lida como O Senhor e O Santo, mas antes como adjectivação. E neste segundo caso Aquele a quem é atribuído o epíteto de Santo revela o seu atributo - a Santidade - nos milagres que realiza enquanto participação na Santidade que o transcende.

Quero com isto dizer que de alguma forma a invocação do Senhor Santo Cristo traz para o nível da singularidade a entidade transcendente da segunda

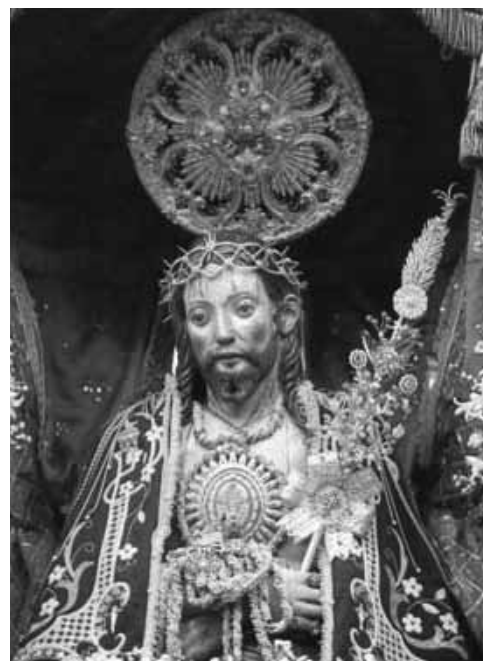

1. Veneranda imagem do Senhor Santo Cristo dos Milagres. pessoa da Santíssima Trindade, apresentando-se como uma apropriação, por parte dos devotos, de uma vertente específica da natureza divina da entidade referida. Ao estabelecer-se a conexão entre a Invocação e uma dada e específica imagem - ícone -, efectua-se a passagem do universal para o particular, para o fenoménico.

Representando aquela imagem o Cristo Sofredor, o Ecce Homo, Senhor da Paixão, a intercessão e a protecção, impetradas pelos fiéis, dependem não apenas do que a imagem representa mas da mesma representação.

É um caso paradigmático em que a invocação e a iconografia de suporte surgem indissociavelmente ligadas; o Senhor Santo Cristo dos Milagres é aquela imagem (Fig.1), é ela e só

\footnotetext{
* Faculdade de Ciências Sociais e Humanas/Universidade Nova da Lisboa.
} 
ela que efectua milagres e é a ela que o culto deve ser prestado. Iremos ver como a partir de finais do século XVII se desenvolveu a pedagogia do culto a esta imagem específica, partindo de um mito fundador remetido para os finais da primeira metade de quinhentos, altura em que o povoamento e o enquadramento religioso dos Açores se intensificavam.

\section{Tradição e carácter regional}

O painel em que está integrado este estudo remete para o nível da regionalização, das tradições e formas particulares de devoção. De resto, a questão da forma particular de devoção está ligada à especificidade do sensível, da fenomenologia do agir e sentir já aludido no anterior parágrafo. Se bem que toda a forma de piedade envolva a dimensão interior da pessoa pia e, nessa medida, a própria subjectividade do sentir, ela é também universal, objectiva.

Mas não é neste sentido que a regionalização e a forma particular de devoção aqui são entendidas. Elas referem-se à diferenciação deste culto, relativamente à dimensão oficial da hierarquia eclesial e clerical e da sua inserção no calendário litúrgico católico. Uma coisa é certa: a invocação referida àquela imagem específica e, mais ainda, a Festa que Ihe é votada revestem-se de um carácter eminentemente regionalista, tanto sob o ponto de vista geográfico, como sociopolítico e também religioso.

A invocação, o culto e a Festa são apropriados pelos açorianos como factores de identidade, como marcas de pertença a uma comunidade, a uma sociedade, à Região Autónoma dos Açores.

Ora o culto do Senhor Santo Cristo dos Milagres, porém, não cabe apenas no campo da tradição, entendida como referência a uma construção na temporalidade histórica, que apenas se mantêm como memória desse passado mas desligada do presente e suas vivências características. Não, a invocação e o culto do Senhor Santo Cristo apresentam-se ainda nos nossos dias, em tempos de forte laicização da sociedade, como marca identitária constitutiva da açorianidade, ao lado das festas do Espírito Santo.

Todavia, enquanto estas são apropriadas pelas estruturas societais de base em todas as ilhas do Arquipélago e na diáspora, o culto do Senhor Santo Cristo organiza-se em torno da imagem do Ecce homo que se encontra no Santuário do Convento de Nossa Senhora da Esperança em Ponta Delgada.

A festa realizada anualmente apenas nesta cidade da ilha de São Miguel propaga o seu influxo pelas demais ilhas e emigração açoriana. Apesar de esta mesma devoção tomar outras designações em outras localidades do Arquipélago - o Senhor da Pedra no Pico da Pedra em São Miguel e em São Mateus da ilha do Pico -, a festa e a devoção ao Senhor 
Santo Cristo dos Milagres do Convento da Esperança têm uma projecção incomparavelmente maior, afirmando-se como um culto regional.

Continuando com a analogia entre as festas dos maiores portadores de profundas vivências religiosas: no Santo Cristo ou no Espírito Santo, a piedade popular tem como epicentro o mistério central do cristianismo, a sua mais profunda universalidade; no entanto, tanto num como noutro caso, constitui-se como eminentemente local, regional e também de matriz popular; as festas do Divino, designação popular das tradicionais festas do Espírito Santo, destinguem-se pelo seu carácter sincrético; as do Santo Cristo pela ligação a um determinado ícone - a imagem do Senhor Santo Cristo que está no coro baixo do Convento da Esperança. Tanto num como noutro caso, elas não dependem em exclusivo da hierarquia diocesana e, embora apoiadas pelo clero, ele não as domina. Organizaram-se e afirmaram-se ao sabor da acção desenvolvida quer pelas comunidades devotas, no caso das festas do Espírito Santo; quer pela piedade de determinadas pessoas cujo envolvimento místico tornou eficaz o alargamento e enraízamento social da devoção, no caso do culto em análise.

Mas deixemos as festas ao Divino de parte... A historicidade do seu culto diferencia-se totalmente daquele que aqui nos ocupa, até porque em finais do século XIV, começos do povoamento, era já uma realidade que não cessaria de evoluir por iniciativa e ao serviço das comunidades locais.

\section{O contexto da emergência do culto - momento fundador}

O culto do Senhor Santo Cristo não nasce nas comunidades de base, nem se implanta e desenvolve de forma anímica, imbuindo de sagrado a vivência quotidiana das gentes insulares entregues ao afã da superação das dificuldades, tornadas mais agudas pela indómita natureza de origem vulcânica e pela insularidade. Ele tem a sua origem em comunidades sim, mas nas criadas voluntariamente pelo desígnio da consagração religiosa, onde se buscava a construção da santidade individual em prol da colectiva pela comunhão mística com Deus.

No culto piedoso do Ecce Homo, cuja festa recai no tempo pascal, se integram as vias da penitência e desagravo - purgativa - e da glória da redenção de Cristo - contemplativa -, específicas da santidade individual no seio da comunidade monástica. A exemplaridade que vem da Idade Média com São Francisco e Santa Clara, do período clássico com Santa Teresa de Ávila e São João da Cruz, aprofundada e difundida em seiscentos com a devoção barroca franciscana, ${ }^{1}$ iria projectar a via do rigor consagrado e a da piedade em torno da figura de Cristo, das suas chagas e do seu sangue redentor.

\footnotetext{
Cf. as obras do autor paradigmático da espiritualidade franciscana barroca, Fr. António das Chagas, Obras espirituais, Lisboa, off. Miguel Deslandes, 1684; - Obras espirituais póstumas , Lisboa, off. Miguel Deslandes,
} 


\section{Na ilha de São Miguel}

A primeira comunidade monástica feminina da ilha de São Miguel teve a sua origem na decisão, diríamos quase espontânea, de duas senhoras a que se foram juntando outras de se encerrarem numa pequena ermida junto ao mar, num lugar então denominado de Val dos Cabaços da vila de Água de Pau, hoje Caloura, entre Vila Franca do Campo e Ponta Delgada. A conjuntura era favorável ao desenvolvimento místico, de resto incitado pela pregação popular franciscana que nos períodos mais agudos de calamidades naturais orientava procissões mais ou menos espontâneas pela ilha, autênticos cortejos penitenciais. $^{2}$

Torna-se natural que após 1522, data da subterração da capital da ilha pelo deslizamento de terras provocado por uma crise sísmica com consequências na vaga epidémica que grassara pela ilha nas décadas seguintes, o fervor religioso tivesse impelido aquelas jovens à consagração contemplativa. A premente consciência da contingência, aliada ao convicto sentimento de culpabilidade, impelia à aproximação ao sobrenatural, intensificando a vontade de entrega a Deus.

Assim, a comunidade foi crescendo com o apoio das populações vizinhas e da Câmara de Água de Pau e das gentes da nobreza. A casa anexa à ermida de Nossa Senhora da Conceição foi levantada por iniciativa dos mesmos populares e, com o patrocínio do capitão do donatário, dos franciscanos e do ouvidor do eclesiástico, também convencidos da relevância espiritual da opção.

A descrição que o cronista quinhentista Gaspar Frutuoso nos legou, ${ }^{3}$ sobejamente analisada criticamente, nomeadamente pela geração positivista de finais do século XIX, do Arquivo dos Açores, mostra como se criou ali a primeira comunidade monacal de clarissas cujo padroeiro, o capitão do donatário Ruy Gonçalves da Câmara, mandara buscar a Roma as respectivas Bulas Apostólicas com vista à erecção canónica. ${ }^{4}$

1684; - Sermões genuínos e práticas espirituais, Lisboa, off. Miguel Deslandes, 1690; - Cartas espirituais, Lisboa, off. Miguel Deslandes, 1736.

2 Cf.Maria Fernanda Enes, Reforma Tridentina e Religião Vivida - Os Açores na Época Moderna, Ponta Delgada, Signo, 1991, pp.

3 "soando isto por toda a ilha [o encerramento daquelas senhoras na ermida] foi outra vez seu pai ... com pessoas honradas de Vila Franca e alguns padres de S. Francisco, o capitão Rui Gonçalves e o ouvidor do eclesiástico, a ver o que determinava Maria de Jesus e a sua companheira. Mas tanta foi a constância de seu propósito, que nem pai, nem irmãos, nem capitão com sua justiça, nem o ouvidor da Igreja, nem pessoas letradas... as puderam mover nem tirar do que tinham na vontade...e por fim disse o capitão: isto é obra de Deus..."Gaspar Frutuoso,Saudades da Terra (1580), Ponta Delgada, Instituto Cultural de Ponta Delgada, 1981, Lv. IV, vol. II, pp. 341-349, cit.p. 344.

4 Ibidem, p. 347. 
Aí se manteve a comunidade até cerca dos anos quarenta, período em que se intensificou não só a ameaça da peste mas também a dos corsários. Estas ameaças e o crescimento excessivo da população conventual relativamente à exiguidade do convento encrustado na rocha junto ao mar motivaram a deslocação para outras paragens.

Dividida então a comunidade, o grupo mais numeroso e socialmente mais relevante instalou-se num Convento de Santo André de Vila Franca, construído para o efeito; as restantes foram um pouco mais tarde para Ponta Delgada e constituíram o embrião do Convento da Esperança, invocação da ermida em torno da qual se construiu o respectivo convento, a expensas de outros protectores e sob a vigilância atenta da Província franciscana, cujo convento lhe estava contíguo. ${ }^{5}$

\section{A imagem do Senhor Santo Cristo dos Milagres - a ocultação}

A tradição difundiu a ideia de que o Papa, talvez Paulo III ou Clemente VII, juntamente com a concessão às clarissas das Bulas referidas, aquando da deslocação de duas delas a Roma, também Ihes havia oferecido uma imagem-sacrário do Ecce Homo. E, não obstante o silêncio a esse respeito no relato frutuosiano, nem por isso deixou de ganhar autoridade tal ideia. Ela foi fortalecida pelo relato do naufrágio sofrido nas costas da ilha pelo barco em que era transportada. $O$ desaparecimento nas águas oceânicas e posterior aportação à costa, precisamente no lugar onde se encontrava o conventículo do Val de Cabaços, ${ }^{6}$ veio originar a aura de taumaturgia que lhe está indelevelmente associada. Não sem antes, porém, ter conhecido um longo período de ocultamento.

Aquele é o momento fundador do mito que irá servir de base à força taumatúrgica do ícone de rara beleza e força expressiva. Como todos os mitos, sempre tardios relativamente ao acto primordial narrado, e que foge à verificação, também este se formula tardiamente. Ao silêncio do salamantino de quinhentos associa-se o mutismo dos cronistas franciscanos de seiscentos.

Frei Diogo das Chagas, vigário provincial nos Açores em meados de seiscentos, na sua monumental obra Espelho Cristalino e Jardim de Várias Flores ${ }^{7}$, em que regista os factos mais relevantes, seguindo de resto as descrições de Gaspar Frutuoso para os primeiros tempos do povoamento e aditando outros até à sua época, apoiado nos arquivos da ordem

5 Ibidem, pp. 348 e ss.

6 A notícia mais clara da procedência desta imagem está no texto dos primeiros estatutos da Irmandade do Senhor Santo Cristo, datados de 21 de Abril de 1765, portanto mais de dois séculos após o facto narrado. In Convento da Esperança de Ponta Delgada, Arquivo da Irmandade do SS Cristo dos Milagres.

7 Que só conheceria edição no ano de 1989, dirigida por Artur Teodoro de Matos, Ponta Delgada, Secretaria Regional de Educação e Cultura e Universidade dos Açores. 
seráfica que desde os inícios havia enquadrado todas as ilhas ${ }^{8}$, refere-se ao Convento da Esperança "de nossa obediência", fundado pelas freiras do primeiro convento de clarissas, que,"por serem as mais pobres", não foram para Santo André.

Justifica ainda a desvinculação do padroado do capitão do donatário, na exigência de um mais profundo rigor e fidelidade à regra franciscana - clarissas -, pelo que teriam ficado directamente sujeitas ao respectivo comissário. ${ }^{9}$ Não refere, porém, a imagem que, volto a repetir, segundo a tradição teria acompanhado as freiras mais pobres, entre as quais se encontrava a sua mais estrénua devota, Inês de Santa Iria.

Um outro cronista, Fr. Agostinho de Mont'Alverne ${ }^{10}$, que escrevera as Crónicas da Província de S. João Evangelista das Ilhas dos Açores, ou seja, a história franciscana, também não refere a existência da imagem nem de qualquer culto sob a invocação de Senhor Santo Cristo ou do Ecce Homo. Este silêncio é tanto mais de estranhar quanto a crónica se reporta em especial à obediência franciscana até ao ano de 1695 e o seu autor exercera o cargo de comissário a cuja obediência estava sujeito aquele convento da Esperança, de estrita observância.

Acresce a estas circunstâncias o facto de, ao contrário do rigor típico de Frutuoso e de Chagas, Frei Agostinho de Mont'Alverne utilizar um estilo efabulatório e fantasioso, bem ao gosto da historiografia seiscentista de matiz alcobacense, o que impediu que as suas crónicas fossem tidas como fontes pelos historiógrafos de pendor positivista e de terem sido tão tardiamente sido editadas.

Impõe-se a pergunta: Porque não introduziria ele, então, um facto assaz notável como a existência de uma imagem portadora de história tão singular e tão relevante para a afirmação da sacralidade da mesma: a doação do Sumo Pontífice e o aportamento miracu-

8 Existiam conventos franciscanos em todas as ilhas do Arquipélago, com excepção do Corvo; em São Miguel existiam seis, três na Terceira e dois na ilha do Pico.

9 Espelho Cristalino, p. 148 e p.150 e ss. Em apêndice Fr. Diogo das Chagas transcreve um documento onde se pode ler o seguinte:" “... que por o ditto Mosteiro [do Val dos Cabaços] não estar em lugar conveniente, as freiras e a Abadessa, que então eram do dito se determinaram mudar, e as freiras mais principais e mais ricas, e a sua Abadessa se mudarão pera Villa Franca, e ahi ordenarão hum mosteiro, que ora hy está muito nobre.// Que algũas sete, ou outo freiras pobres ficarão no ditto mosteiro e por ahi estarem mal, e o ditto A. [Manuel Gonçalves da Câmara, filho do capitão do donatário padroeiro, entretanto falecido] as não prover, se sahirão dahi, e ordenarão com esmolas, e ajuda dos fiéis christãos hum mosteiro na Ponta delgada, o qual d'effeito ordenarão ... // Que des que o ditto mosteiro foi fundade ate agora, sempre ellas// tiveram seus syndicos, e procuradores, e mordomos, e por estarem mais religiosamente, derão a obrediência ao Guardião, e Commissairo do mosteiro de S. Francisco de frades claustrais, que na ditta Ilha e cidade ha, e por elles foram sempre visitadas, e lhes deu sempre confessores." pp. 629 e ss.

${ }^{10}$ Frei Agostinho de Kmonte Alverne, Crónicas da Província de São João Evangelista das Ilhas dos Açores, 3 vol.

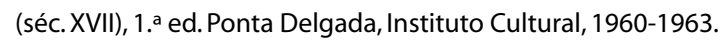


loso às costas da Caloira após o naufrágio? No entanto, é consenso generalizado que a imagem de madeira policromada, venerada hoje no Convento da Esperança, parece ser renascentista, embora nenhum dos estudiosos que sobre ela dissertaram o afirmem com total segurança.

Há uma outra vertente deste ocultamento mais estranha que o silêncio sobre a imagem e a invocação, aquando da história dos Conventos onde a tradição coloca o seu nascimento. A associação privilegiada da vida consagrada contemplativa e a construção da santidade foram uma realidade que se impôs no devir histórico. As clarissas da Esperança não fugiram à regra. Num dos primeiros processos de santidade, datado de 1634 e coligido pelo visitador do Bispado, reporta os testemunhos dos milagres da freira Inês de Santa Iria em ordem ao processo de beatificação. Esta foi uma das primeiras freiras da Esperança a quem a tradição atribui a presença daquela imagem neste convento e não no de Santo André de Vila Franca. Lógico seria então que na narrativa dos milagres surgisse a referência à taumatúrgica imagem do Ecce Homo, ou ao menos a uma especial devoção e à invocação do Senhor Santo Cristo dos Milagres.

Como explicar que nunca Ihes seja feita qualquer referência? Frei Diogo das Chagas é relativamente parco nas informações: transcreve a Carta Testemunhal ${ }^{11}$ para sustentar o relato que a respeito da dita monja faz no seu texto, contornando assim as narrativas fantasiosas. A autoridade dos relatores, pessoas de prestígio e algumas companheiras da Beata Inês, beneficiadas por curas miraculosas, por intercessão de relíquias da clarissa, funcionaria como prova de veracidade. A fama de santidade, que tinha justificado a divulgação do tratamento de Beata e o recurso à sua intercessão, vinha das provas em vida, da sua inquebrantável fé, da entrega à oração e aos exercícios de penitência continuada. O paradigma da santidade que parece transparecer dos mesmos factos relatados aproxima-se da identificação com Cristo da Paixão, de resto bem ao estilo do modelo das clarissas - Santa Clara.

Tão estranha quanto a ocultação total da invocação e imagem do Senhor Santo Cristo em Diogo das Chagas é a referência ao Ecce Homo em Agostinho de Mont'Alverne, coetânio de Madre Teresa da Anunciada (1658-1731). Reportando a exemplaridade da vida da clarissa de Val de Cabaços - Inês de Santa Iria - e seguindo informações do Arquivo da Ordem, afirma:

... em uma procissão que foi pelo Campo, em Quinta-feira Maior, onde naquele tempo levavam uma imagem do Ecce Homo, que ainda hoje está na Misericórdia, no altar onde dizem

11 "Artigo 4.․ Em que se botão os testemunhos de algũas pessoas, que diante, digo tirados do instromento e carta testemunhavel" in Fr. Diogo das Chagas, Espelho Cristalino e Jardim de Várias Flores, pp. 636-643. 


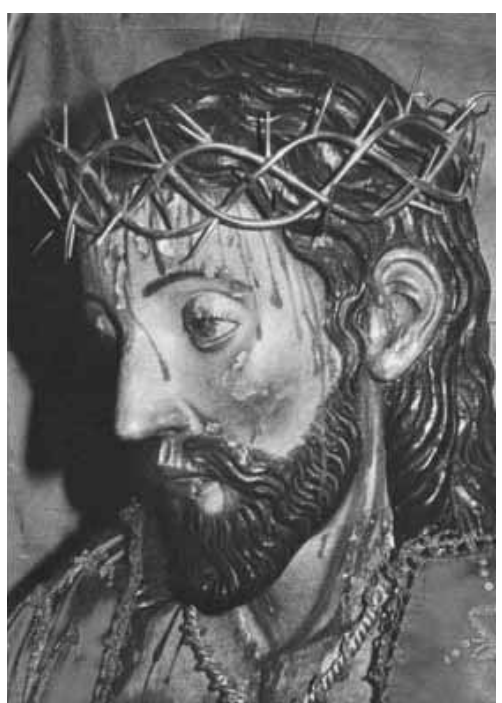

2. Perfil do rosto.

missa aos doentes na enfermaria, parando os que levavam esta santa imagem, sem saberem quem os fazia parar, entrou com ela no coro, e no cantinho em que estava orando, Ihe falou, todo banhado em sangue - ainda que és minha e eu todo teu, eis aqui o estado em que me puseram os homens... ${ }^{12}$

Realmente há aqui a afirmação da existência de uma imagem do Ecce Homo (Fig. 2) nos tempos promordiais do mito, no século XVI, porém, não pertencia ao Mosteiro da Esperança mas sim à Misericórdia, ao tempo também sob alçada franciscana.

O relator, seguido pelo cronista, não estabelece qualquer ligação desta imagem com o conventículo de Nossa Senhora da Conceição da Caloira nem com a eventual oferta papal. Todavia, não restam dúvidas de que a devoção ao Ecce Homo e a centralidade da espiritualidade cristocêntrica estão presentes nos momentos iniciais do Convento da Esperança, o que não é de admirar se pensarmos na espiritualidade dos fundadores São Francisco e Santa Clara estigmatizados.

O autor das Crónicas, porém, refere-se a Madre Teresa da Anunciada como a apóstola de Cristo sob esta invocação. ${ }^{13}$ Entrara no Convento da Esperança em $1681^{14}$ e não cessaria de pugnar pelo incremento do culto a uma imagem que encontrara, mais ou menos abandonada, em uma capela no interior da cerca conventual dedicada a Nossa Senhora da Paz. O biógrafo de Teresa de Anunciada, Padre Clemente, na sua obra Vida da Venerável Madre Teresa da Anunciada fez um denodado esforço por apresentá-la como dotada de uma missão espiritual ao serviço da difusão devocional a Cristo sofredor. Estamos em face de uma hagiografia em que a imaginação cumpre a função de autoridade, tendo, ainda assim,

12 Ag. De Mont'Alverne, Crónica da Província de S. João Evangelista nas Ilhas dos Açores, v. II, p. 73.

13 "Tem este mosteiro uma imagem do Ecce Homo de muita veneração, fazendo-se-lhe uma capelinha na em pena do coro baixo. Sóror Tereza da Anunciada, por ser sacristã desta imagem dava de comer aos homens que nela andavam trabalhando, sucedeu em sexta-feira, onze de Abril de 1698, que não tendo pão ... abrindo o armário lhe caíram trinta e cinco pães com que ficou desmaiada..." Ag. De Mont'Alverne, O.c., p. 82.

14 Após a oposição sucessiva de seus familiares e a obtenção de autorização por parte do provincial dos franciscanos, obteve a concessão de dote de seu cunhado Manuel Fernandes Teixeira. Arquivo de Ponta Delgada, Ministério das Obras Públicas/-CONEPDL/166, Liv. N. 8 (1555-1700), fls. 766. 
conhecido mais de duas dezenas de edições. A devoção popular interpretou a narrativa como a exaltação da imagem do Senhor Santo Cristo e menos como prova de santidade de Madre Teresa. Este livro é conhecido pelo vulgo como o Livro do Senhor Santo Cristo. A relação pessoal de Teresa com o Ecce Homo apresenta-se apenas como meio de exaltação. Cito um significativo excerto do relato do biógrafo:

Representou-se-lhe em huma noite, que tinha na mão hum ramo de assucenas, tão bellas e engraçadas, que ... determinava offerece-lo à imagem. Caminhando com este intento para o coro baixo, encontrou huma dilatada procisão, e no fim della o Senhor com a Cruz às costas, todo ferido, e emanando rios de sangue. ${ }^{15}$

É uma constante a participação da devota no sofrimento redentor. Esta convicção esteve na base do apoio às práticas devocionais, desde as novenas dos espinhos até às vigílias e procissões.

Esta clarissa quis e conseguiu transportar a imagem para um lugar mais digno no interior do espaço sagrado do convento, no coro baixo da capela de Nossa Senhora da Esperança. Mas tal ocorre mais de século e meio volvido sobre a fundação do próprio mosteiro de Ponta Delgada.

\section{O esplendor do culto do Senhor Santo Cristo}

Efectivamente com a devoção de Madre Teresa, cessa o período de ocultamento; abre-se o da efectiva criação do culto da imagem que Ihe dá corpo.É ela a grande artífice do culto do Senhor Santo Cristo, como hoje o conhecemos.

As primeiras obras do coro baixo foram efectuadas sob a sua orientação. A medida da espiritualidade em torno do Senhor Santo Cristo é a da construção da santidade de sua apóstola. Ou seja, todo o processo de veneração da imagem foi acompanhado por actos miraculosos atribuídos à imagem ou à própria Teresa. ${ }^{16}$

O relator da vida de Teresa no Convento da Esperança, e da sua odisseia em revitalizar a devoção a Santo Cristo, pinta-nos um quadro verdadeiramente épico, onde as citações de milagres operados pela imagem são recorrentes. Estamos perante uma hagiografia em que a imaginação cumpre a função da autoridade. Todavia, o que nos interessa, pelo facto de o esforço da freira ter sido bem sucedido, é salientar que a apresentação que se faz da ima-

15 P. José Clemente, Vida da Venerável Teresa da Anunciada,Lisboa, off. de Lino da Silva Godinho, 3. a ed., 1824, p. 89.

${ }^{16} \mathrm{O}$ biógrafo foi o Presbytero do Oratorio de S. Filipe de Neri, José Clemente, O.C. 


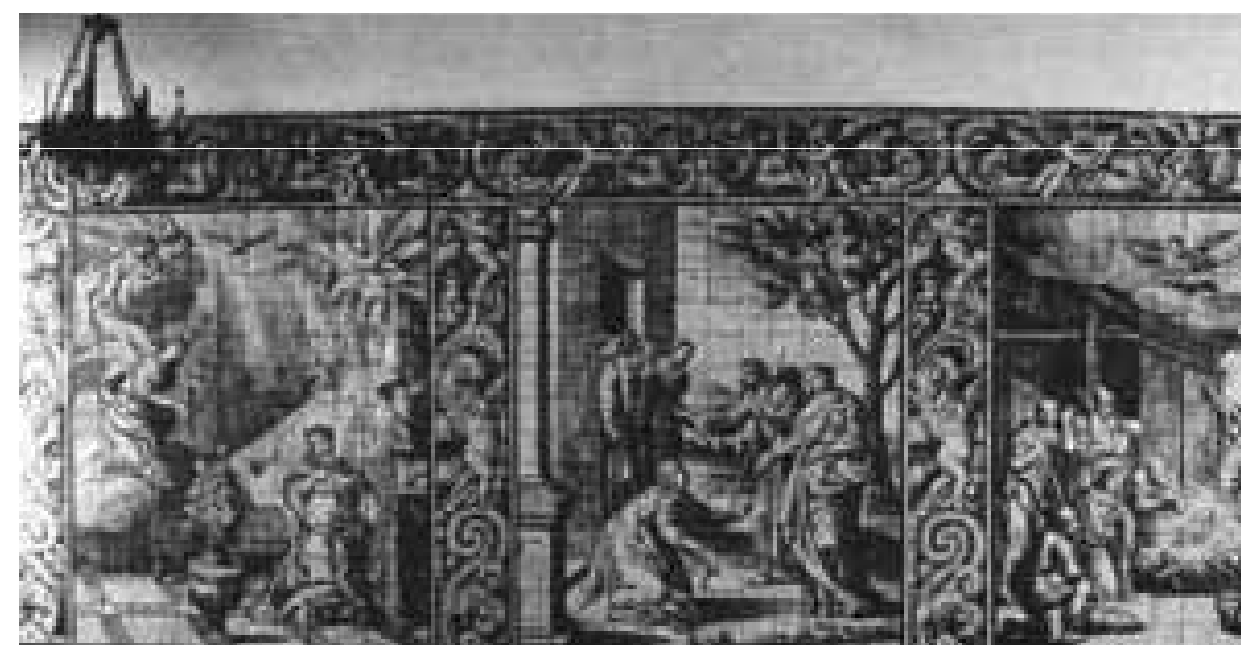

3. Azulejos do coro baixo.

gem do Senhor Santo Cristo é a da taumaturgia. Os milagres por ela operados estão directamente relacionados com a expressão de dor, os suores de água ensanguentada que escorre da sua face flagelada, a tristeza profunda do esquecimento a que o seu culto havia sido votado, a ausência de práticas penitenciais, nomeadamente a da flagelação. À semelhança de Teresa de Ávila, também a da Anunciada se vê confrontada com o sangue de Cristo na sua própria boca, após a recepção da hóstia consagrada. Foi a convicção desta, e de outras freiras que a apoiaram na sua determinação devocional, nomeadamente da sua irmã de sangue e também de religião, Joana, que acabou por impor a prática da procissão do Senhor Santo Cristo que se efectua desde os inícios do século XVIII, ano de 1700 ou 1703.17

O fervor piedoso desta freira moveu a compreensão generosa das autoridades e da aristocracia da ilha de molde a conseguir dignificar o espaço sagrado e as alfaias litúrgicas que, no seu entender, eram indispensáveis à dignificação da santa imagem. Movimento que se prolongaria muito para além da acção directa de Teresa da Anunciada. Na realidade, múltiplas são as certidões de doação por parte dos condes da Ribeira Grande, ${ }^{18}$ que de geração em geração mantiveram a protecção deste culto; diversas foram as isenções régias, dentre as quais se deve destacar o alvará de mercê de 12 mil réis que S. Majestade

17 Cf. Senhor Santo Cristo (texto: Margarida Sá Nogueira), Ponta Delgada, Ver Açores, 2007, p. 32.

18 Múltiplas são as jóias integradas no Tesouro do Senhor Santo Cristo, doadas por esta família, conforme certidões no dito tesouro no Convento da Esperança em Ponta Delgada. 

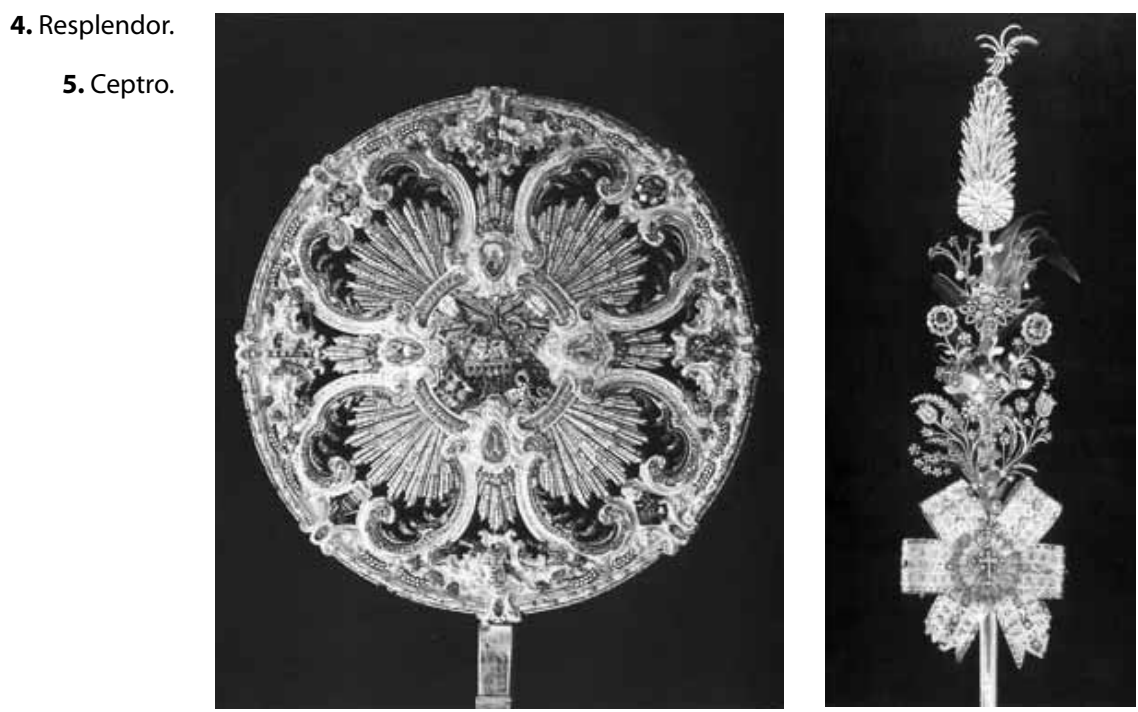

fez à imagem do Ecce Homo das freiras da Esperança, em $1701,{ }^{19}$ e das autoridades da ilha em relação a isenções de impostos ou atribuição de donativos. ${ }^{20}$

O revestimento de azulejaria portuguesa, da Real Fábrica do Rato, do coro baixo representa a humanidade de Cristo (Fig. 3). Nos painéis estão representadas as cenas do nascimento e da paixão, sendo ainda contemporâneos de Madre Teresa. A igreja encontra-se revestida também de painéis de azulejos recentes, com a figuração dos milagres e feitos de Madre Teresa da Anunciada.

As jóias esplendorosas, quase todas peças de ourivesaria de finais de seiscentos e de setecentos, integram resplendores, o mais belo dos quais é de platina revestida a ouro e incrustações de pedras preciosas, diamantes, rubis, esmeraldas, safiras, ametistas e topázios $^{21}$ (Fig.4); ceptros majestosos cobertos de pedras preciosas e integrando jóias pessoais de famílias, nomeadamente a Cruz da Ordem de Cristo e de Malta ${ }^{22}$ (Fig. 5); coroas de espinhos também elas de ouro, diamantes e rubis (Fig. 6, p. seguinte); relicário, também

19 Arquivo Ponta Delgada / ACD - Alfândega PD /003/1363, Livro oitavo dos registos (1686-1743), fls. 272.

20 Idem, MON - CONV PD/002, doc. N. ${ }^{\circ} 21$; ACD - Alf. PD /003/1365, Livro de registo /1727-1812), fls. 348.

21 Segundo carta do $6 .{ }^{\circ}$ conde da Ribeira Grande (Luís António J. M.Gonçalves, 1754-1802), dirigida a 15 de Janeiro de 1786 a Madre Quitéria:“E como por minha ordem remeteu António Luís o diadema do Senhor Santo Christo espero que o mesmo Senhor tenha permitido que o navio chegasse a tempo". Arquivo particular de Hugo Moreira.

22 Esta havia pertencido, segundo inscrição no verso de uma das folhas, ao $4 .{ }^{\circ}$ conde da Ribeira Grande. 


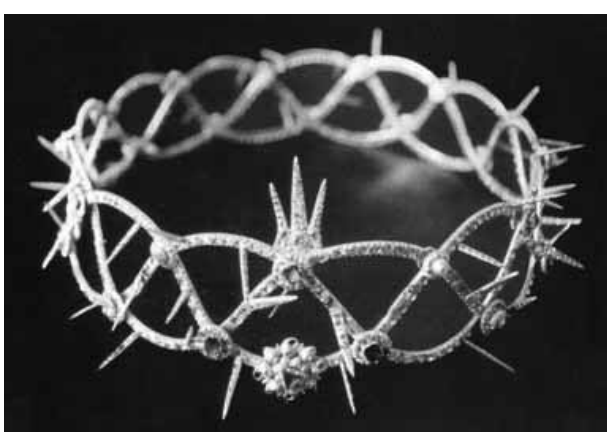

6. Coroa de espinhos.

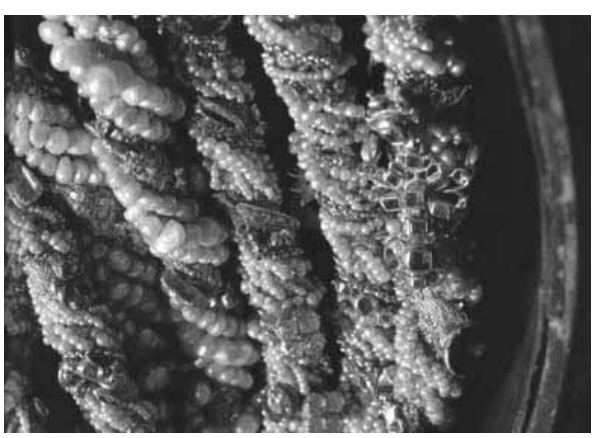

7. Pormenor das cordas.

peça notável de joalharia portuguesa do século XVIII; cordas de aljôfares, pérolas e jóias familiares (Fig. 7).Todo este rico tesouro encerra a devoção profunda de destacadas figuras e de devotos anónimos movidos ao despojamento por piedade profunda ao Ecce Homo.

As 25 capas, destinadas a cobrir o busto, são todas elas em seda natural, brocado, bordadas a ouro e com maior ou menor número de jóias incrustadas. Umas são obra das próprias freiras do convento, mas a maioria é oferta de fiéis. De destacar a capa feita do mesmo tecido do manto real de D.João V, oferecida pela rainha D. Mariana de Áustria e outra oferecida pelo franciscano Frei Francisco das Chagas (n. 1703). As esmolas dos fiéis, em cera e em dinheiro, mantêm um elevado nível. Em 1782 orçava o montante de um milhão setecentos e trinta mil cento e setenta e quatro réis.

Tratando-se de um culto passional, integra-se no tempo pascal. Associa ao carácter penitencial, que a procissão ainda hoje mantém, a alegria da dimensão redentora do sofrimento, que os enfeites da própria imagem denotam. A convicção mantida até aos nossos dias de que a procissão constitui um acto de desagravo a Cristo sofredor move muitos crentes a incorporarem-se nela descalços, carregando pesados fardos de cera, fazendo de joelhos o percurso à volta do Campo de São Francisco (largo em frente do convento), em regra em cumprimento de votos. A multidão que a segue traja de negro em sinal de luto. A taumaturgia da imagem manifesta-se nos múltiplos pedidos atendidos que os ex-votos de madeira, tela ou bronze atestam (Fig. 8).

Esta festividade tem ainda uma componente de sociabilidade comunitária, em torno de uma mesma vivência que une pobres e ricos, letrados e iletrados. Numa sociedade ainda fortemente segmentada, a visita à igreja, para onde a imagem se desloca do coro-baixo do convento, em cortejo processional no sábado da festa, para passar em frente da imagem milagrosamente expressiva, constitui um momento impressionante de fraternidade. 


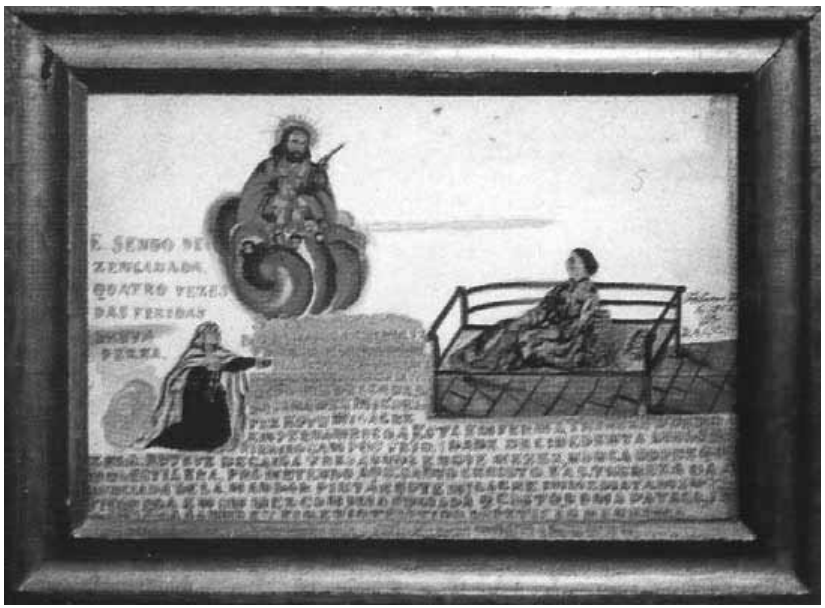

8. Exemplo de ex-votos.

Todos aguardam em fila pela sua vez, todos se sentem igualmente pecadores em face do Senhor Santo Cristo.

À festa do Senhor Santo Cristo está associada uma irmandade - Irmandade do Senhor Santo Cristo dos Milagres. Os primeiros Estatutos datam de 21 de Abril de 1765. Neles se faz o historial resumido da imagem e se afirma o voto da procissão por ser "do devino agrado que no dia 11 de Abril de cada hum anno se lhe fizece hum publico festejo para seu mayor culto".23 Neles se estatuem os direitos e deveres dos irmãos, a composição da Mesa, o seu objectivo, a difusão e sustentação do culto do Santo Cristo, as quotas dos irmãos. Todavia, a guarda e a organização do culto ficaram sempre nas mãos das freiras do convento da Esperança. Cabia-Ihes também o transporte do andor nas diversas procissões no interior do convento que precediam a festa.

À Irmandade compete organizar os aspectos exteriores do culto, nomeadamente ordenar a procissão, a ornamentação do percurso, contratar as bandas de música, os sacerdotes e os diversos corpos de autoridades civis e militares. Cabe-lhe a ornamentação do frontal da igreja com motivos da paixão - cravos, martelo, cruzes, espinhos, etc. - profusamente iluminado; tratar do fogo-de-artifício ou, simplesmente de ruído, de modo a assinalar as festividades. Estava-Ihe ainda cometida a função de recolha das esmolas pelas portas dos

${ }^{23}$ Cf. O Convento de Nossa Senhora da Esperança e o culto do Senhor Santo Cristo dos Milagres - Comemoração do tricentenário da Procissão, Ponta Delgada, Mesa da Irmandade do Senhor Santo Cristo dos Milagres, 2000 . 
fiéis e da venda dos círios que os mesmos desejassem comprar e queimar. A esta irmandade pertenceram as figuras mais destacadas da sociedade micaelense, tradição que ainda se mantém, entre as quais rotativamente cabia a função de mesários. Como irmãos, solidários na paixão de Cristo nos actos dos vivos e sufrágios dos mortos, podiam participar todos os crentes.

Em 1832, com a lei de supressão dos conventos masculinos e de impedimento de entrada de noviças para os femininos nos Açores, o Convento da Esperança foi duramente afectado. Tinha, porém, um número considerável de freiras que garantiram a manutenção do culto do Ecce Homo, sem grandes flutuações, não obstante o envelhecimento da comunidade. Entretanto, a irmandade procurou junto do governo do reino em 1894 que fossem para ela transferidos os bens do Convento da Esperança, o que Ihes foi negado. ${ }^{24} \mathrm{Não}$ obstante todas as espoliações a que estiveram sujeitos os bens dos conventos, durante o período liberal, nomeadamente aquando da referida extinção, os bens deste convento montavam em 1860 a um total de cerca de vinte e um contos de réis, o que à época representava uma fortuna. Hoje a Irmandade reparte com as freiras do Convento da Esperança as responsabilidades da manutenção do culto.

\section{O culto e as suas expressões festivas}

Como já se referiu, o culto do Ecce Homo sob a invocação do Senhor Santo Cristo toma consistência verdadeiramente no dealbar do século XVIII. A primeira procissão ter-se-ia efectuado entre 1698 e 1701.

Cedo se começou a realizar anualmente, apenas com três excepções, em que se efectuaria fora do tempo previsto. Uma delas foi a do ano de 1713, aquando de uma forte crise sísmica que cessaria no momento em que a imagem, assim reza a tradição, caindo, teria tocado a terra. Foi a partir dessa data que a invocação passou a integrar o epíteto "dos Milagres" - Senhor Santo Cristo dos Milagres.

Trata-se de uma manifestação complexa: há um primeiro cortejo processional privado, em que só as freiras participam e os membros da irmandade podem assistir de fora do circuito, porque ele se faz por território da clausura para os claustros até ao quarto da Roda onde se procede à ornamentação da imagem para a festa. De resto, o facto de esta imagem estar no coro baixo, separado da igreja aberta a todos os crentes por enorme grade, revela a apropriação pela comunidade monacal desta forma específica de culto do Senhor; pelas $16 \mathrm{~h} 30$ bate à porta do quarto da Roda o Provedor da Irmandade. Esta

${ }^{24}$ Cf. APD, Ministério das Obras Públicas - Convento da Esperança de Ponta Delgada, n. ${ }^{\circ}$ 160, 4 de Maio de 1894. 
abre-se e surge então o andor preparado com a imagem revestida das mais sumptuosas vestes e símbolos da realeza - coroa e ceptro -, adornado com o resplendor da Santidade e o medalhão relicário, visíveis as cordas evocando o Ecce Homo, o da flagelação. Este é o momento em que a imagem sai do espaço conventual para o secular, em que é confiada à irmandade. Dá-se início ao que é conhecido como a procissão da mudança.É nesta que as práticas penitenciais, as promessas, adquirem maior significado; já no altar da igreja, é então feito o sermão da mudança e, a partir daí, até à hora da missa da festa do dia seguinte, ela fica exposta e aberta à recepção de todos os devotos. É neste momento que a fraternidade cristã fica mais patente. Durante o resto da tarde e por toda a noite há uma fila consistente de fiéis, sem qualquer diferenciação funcional, social ou de classe, que aguarda a vez de se aproximar da imagem venerada. A grande procissão, que integra todas as autoridades civis e eclesiásticas, membros de todas as corporações religiosas ou laicas e profissionais, largas dezenas de milhares de fiéis vindos de toda a parte onde existem açorianos, e não só, inicia-se por volta do meio da tarde para retornar à igreja já noite cerrada; o recolher da imagem não tem lugar antes de, postada à porta da Igreja, receber a guarda de honra dos militares, bombeiros, corpos de escuteiros e da grande multidão reunida no Campo de São Francisco. Uma impressionante salva de tiros da marinha e de fogo encerram o cortejo processional e, de novo, o regresso da veneranda imagem ao recesso clausural.

A longevidade e a adesão ampla da sociedade diocesana a este culto foram-se lentamente impondo à hierarquia diocesana. É que, nem a supressão dos conventos em 1832 por Mouzinho da Silveira em terras açorianas, nem a extinção das ordens religiosas por Joaquim António de Aguiar em 34, impediram a continuidade. Parece que antes a reforçaram. Apesar da espoliação dos bens, repetida na República, as dádivas dos fiéis em dinheiro, cera, jóias mantiveram a riqueza do Convento.

Efectivamente, em finais do século XIX, após a morte da última clarissa, o culto foi mantido pelas senhoras recolhidas naquele convento. A nacionalização dos bens conventuais não impediu a sobrevivência nem do culto nem da comunidade sustentada pela generosidade dos fiéis. Nos ínicios do século XX este convento, foi povoado pela congregação de São José de Cluny. A sua vocação para o magistério levou-a à construção de um colégio para onde se mudaram, vindo a ser substituída pela congregação espanhola das Religiosas de Maria Imaculada, que ainda continua a sua meritória obra assistencial e o zelo da imagem e do culto.

O arraigamento do culto na população açoriana é expresso, também, pela difusão dos "registos" (Fig. 9, p. seguinte) da veneranda imagem pelos lares micaelenses. Acompanharam os emigrantes que em grandes contingentes abandonaram estas ilhas 


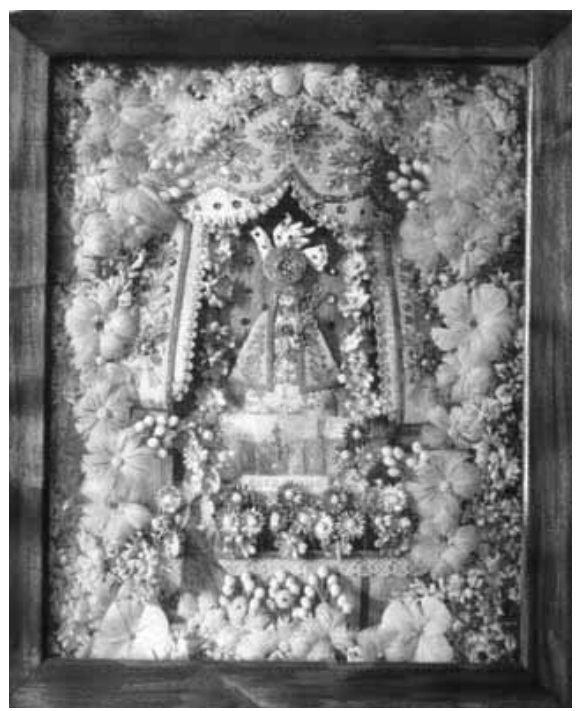

em busca do el dorado americano, culto recuperado nas comunidades recém-implantadas nas terras de acolhimento.

A crescente participação nas devoções em torno da imagem e talvez o reconhecimento da validade pastoral deste culto diocesano levaram o prelado angrense no último quartel do século XX a elevar à categoria de Santuário a Igreja do Convento da Esperança e a transformar a festa do Senhor Santo Cristo numa das mais destacadas no âmbito diocesano.

9. Exemplo de "registo".

Nota: as imagens foram retiradas da publicação em Honra do Senhor Santo Cristo, editada pela Irmandade, cuja citação fazemos no corpo do texto. 


\title{
Nossa Senhora de Brotas: Um exemplo de regionalismo na iconografia mariana
}

\author{
Ana Paula Rebelo Correia*
}

O culto de Nossa Senhora de Brotas tem como origem um suposto milagre ocorrido na localidade de Brotas no Alto Alentejo, na primeira metade do século $\mathrm{XV}$ '. Um pastor, que levara a sua vaca a pastar, vê o animal cair num barranco, partir uma pata e morrer. Desolado, prepara-se para o esfolar quando surge Nossa Senhora. A Virgem fala com o pastor, explica-Ihe que vai ressuscitar a vaca e pede-Ihe para construir um santuário no local. Este milagre, que vai dar origem a um culto de características rurais, constitui um curioso exemplo de regionalismo na iconografia mariana, inserindo-se nas cerca de mil invocações que integram o culto de Maria em Portugal².

É com base no referido milagre que, na localidade de Brotas, até então desabitada, surge, em finais do

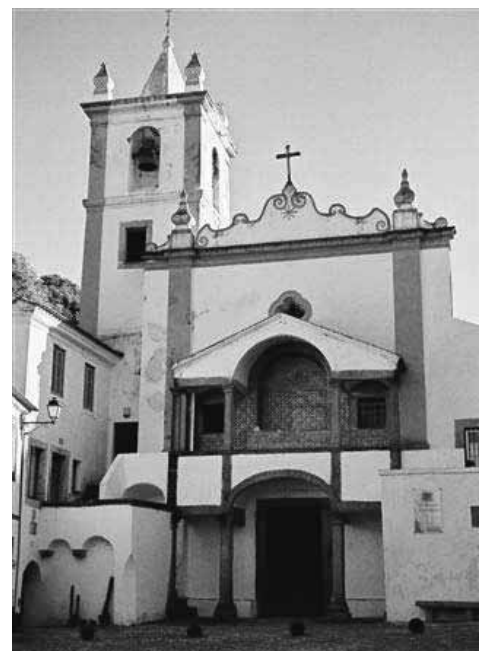

1.Santuário de Nossa Senhora de Brotas. século XV, um santuário, ponto de partida para a actual igreja, que se torna rapidamente um centro de peregrinação dedicado a Nossa Senhora (Fig. 1).

A rua da Igreja, a única que permite aceder directamente ao templo, revela a progressiva presença de confrarias que foram construindo ao longo do caminho as suas casas para peregrinos $^{3}$. No interior da Igreja conservava-se a imagem milagrosa de Nossa Senhora de

* Escola Superior de Artes Decorativas/Fundação Ricardo do Espírito Santo Silva.

1 Segundo Fr. Agostinho de Santa Maria, "Affirma-se que o apparecimento da Senhora fora no dia de sua Natividade, \& na era de 1470 \& tantos."Fr. Manuel Agostinho de Santa MARIA, Santuário Mariano e Historia das Imagens Milagrosas de N. Senhora (...), tomo sexto, Lisboa Occidental, of. de António Pedrozo Galram, 1718 , p. 130. Severim de Faria situa o milagre cerca de 1520. FARIA, Manuel Severim de, Nossa Senhora das Brotas. Descripçao da ermida a 6 leguas de Évora. BN. Res. Cod. 7642, fl. 146.

2 Veja-se sobre este tema Sílvia FERREIRA, "Do Culto de Nossa Senhora em Portugal - Esplendor e Função das Imagens", in Brotéria, n. ${ }^{\circ}$ 158, Março de 2004, pp. 269-286.

3 Sobre a igreja de Brotas, consulte-se Anastásia Mestrinho SALGADO, Margarida Almeida SANTOS, Abílio José SALGADO, O Culto de Nossa Senhora de Brotas e a respectiva Igreja. Sua relação com o povoado. Edição 
Brotas, que seria originalmente em osso e, segundo Frei Agostinho de Santa Maria,"obrada pelas mãos dos Anjos"4.

Na realidade, a iconografia relativa ao milagre de Brotas é escassa e o culto não parece ter suscitado um imaginário relevante. As poucas descrições que chegaram aos nossos dias, embora sejam divergentes nalguns pontos, inspiram-se claramente umas nas outras.

Destacamos os dois textos mais completos: o primeiro, redigido em 1604 por Severim de Faria ${ }^{5}$, e o segundo, já do século XVIII, compilado por Frei Agostinho de Santa Maria no seu Santuário Mariano.

Segundo Severim de Faria, o milagre acontece por volta de 1520, certamente num local ermo, sem qualquer aglomerado de habitações, e pouco tempo depois aí se construiu uma pequena ermida 6 . Quando o pastor se apercebe de que Nossa Senhora ressuscitou a sua vaca, ficou tão surpreendido com o sucedido, que "foi dar logo o recado aos vizinhos da aldea ou Vila das Agueas donde elle era, os quaes vendo o milagre levantaram logo hua pequena hermida (..." $)^{\prime \prime}$. Esta descrição intui que a aldeia mais perto era a Vila das Águias e que no local em que o pastor se encontrava não havia nada.

Frei Agostinho de Santa Maria situa o milagre uns anos antes, por volta de 1470, e dá-nos uma descrição mais pormenorizada, empola os aspectos pitorescos, exagera as descrições da igreja e da imagem de Nossa Senhora. Apresenta o pastor como um homem muito pobre cuja vaca era "todo o seu remédio porque com o leyte della sustentava a sua pobre família" e descreve a pequena igreja como "hum sumptuoso templo" construído entre "duas grandes serras ou montes altíssimos".

Segundo Severim de Faria, Nossa Senhora aparece ao pastor no momento em que este começa a esfolar a vaca, pede-lhe para construir um santuário e, milagrosamente, faz uma pequena imagem com o osso do animal, que entretanto ressuscitou: “Começou de a esfolar e tendo já cortada huma mão como he costume lhe apareceu a Sra e lhe disse que lhe

da Câmara Municipal de Mora, 1987. Helena VINAGRE, O Santuário de Nossa Senhora de Brotas, Câmara Municipal de Mora, 2005. Abílio José Salgado, Lina SOARES, Natália da GRAÇA, Ana Paula FRIAS, Santuário de Nossa Senhora de Brotas, Religiosidade Popular no Alentejo, Edições Colibri, 2004.

4 Fr. Agostinho de Santa MARIA, Santuário Mariano e Historia das Imagens Milagrosas de N. Senhora (...), tomo sexto, Lisboa Occidental, of. de António Pedrozo Galram, 1718, p. 128.

5 Manuel Severim de FARIA, Nossa Senhora das Brotas. Descripçao da ermida a 6 leguas de Évora. BN. Res. Cod. 7642, fl. 146. Fr. Agostinho de Santa MARIA, Santuário Mariano e Historia das Imagens Milagrosas de N. Senhora (...), tomo sexto, Lisboa Occidental, of. de António Pedrozo Galram, 1718.

6 Estas referências cronológicas não estão documentadas. Segundo o Livro das Demarcações 3-1-72, de 1424, conservado no Cabido da Sé de Évora, em 1424 já havia em Brotas uma pequena ermida dedicada a Nossa Senhora, o que leva a supor que o milagre terá ocorrido uns anos antes.

7 Manuel Severim de FARIA, Nossa Senhora das Brotas. Descripçao da ermida a 6 leguas de Évora. BN. Res. Cod. 7642, fl. 147. 
fizesse hua casa naquelle logar e venerasse nella aquela imagem a qual fez milagrosamente logo da canella da vaca que o pastor tinha cortado. $\mathrm{E}$ subitamente desapareceu ficando a vaca viva e sem lezão em algum membro"8.

Frei Agostinho de Santa Maria apresenta outra versão. O pastor já tinha esfolado parte da vaca e cortado uma das patas, quando se vê envolto numa luz e ouve a voz da Virgem que lhe diz para ir chamar todos os vizinhos para que estes presenciem o milagre. Quando estes chegam ao local do acontecimento, encontram a vaca viva e uma imagem feita pelos anjos com o osso da canela do animal: "Estando ocupado nisto \& tendo já esfo-

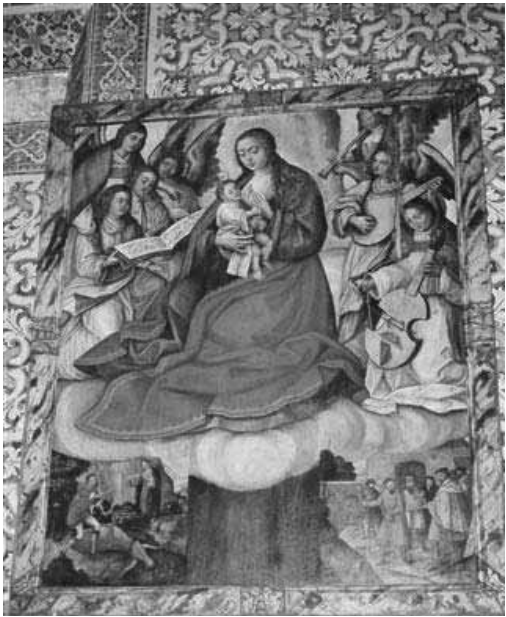

2. Óleo sobre madeira. Nossa Senhora de Brotas. lado parte da vaca, \& cortada huma das mãos, se vio cercado de huma grande luz, \& dentro nella ouvio huma voz que lhe disse: não temas, nem te desconsoles, vay ao lugar \& chama a gente $\&$ quando vieres, acharas a tua vaca viva (...). Quando voltou, achou a sua vaca ressuscitada, \& pastando, como se nada lhe houvesse succedido. Da cana da mão da mesma vaca se achou huma imagem da Senhora, formada pelas mãos dos Anjos, que tem menos de hum palmo, \& he como de meyo relevo, porque pelas costas se reconhece ser obrada da cana de uma vaca $(\ldots)^{\prime \prime \prime}$.

Na pouca iconografia que chegou aos nossos dias apenas conhecemos uma representação narrativa, ilustrando dois episódios do milagre. É uma pintura a óleo sobre madeira, de finais do século XVI, que se encontra na própria igreja, exposta na parede da nave, à direita de quem entra. O quadro representa, na parte superior, Nossa Senhora e o menino rodeados por um grupo de anjos músicos. As figuras estão inseridas numa nuvem que parece sustentada por um tronco robusto, alusão à árvore em cima da qual teria aparecido a Virgem (Fig. 2) ${ }^{10}$. Na parte inferior da pintura, separados um do outro pelo referido tronco, estão representados os dois momentos do milagre: à esquerda, o pastor, de faca na mão, prepara-se para esfolar

8 Manuel Severim de FARIA, Nossa Senhora das Brotas. Descripçao da ermida a 6 leguas de Évora. BN. Res. Cod. 7642, fl. 147.

9 Fr. Agostinho de Santa MARIA, Santuário Mariano e Historia das Imagens Milagrosas de N. Senhora (...), tomo sexto, Lisboa Occidental, of. de António Pedrozo Galram, 1718, p. 129.

10 "Outros dizem que a Senhora lhe apparecera sobre hum pinheyro, \& que lhe fallara, \& Ihe mandara, que naquelle lugar se Ihe edificasse huma casa." Fr. Manuel Agostinho de Santa MARIA, Santuário Mariano e Historia das Imagens Milagrosas de N. Senhora (...), tomo sexto, Lisboa Occidental, of. de António Pedrozo Galram, 1718, p. 129. 

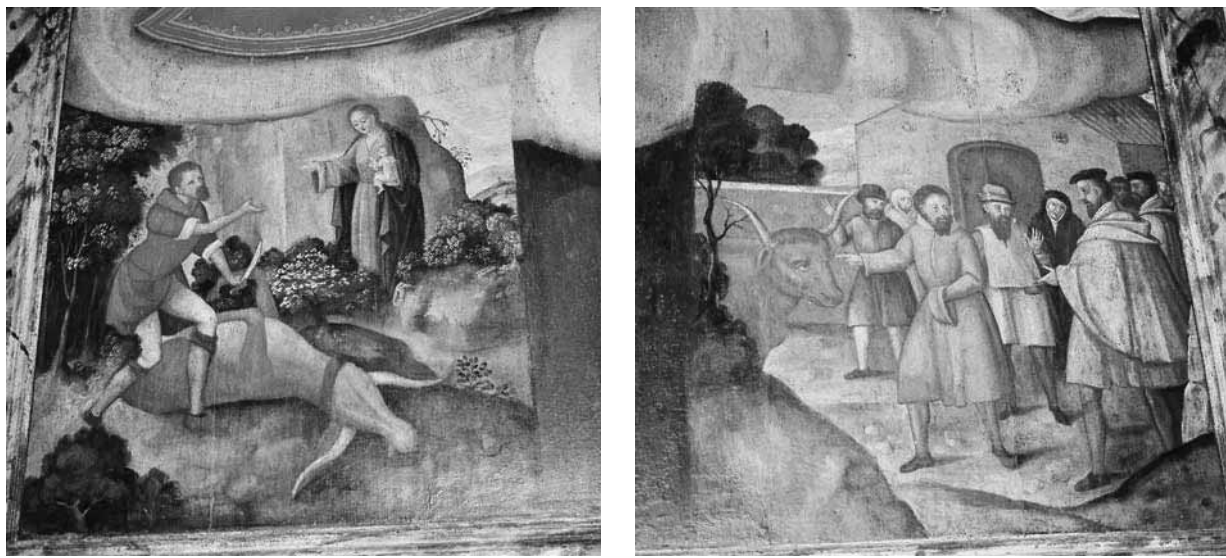

3./4. Óleos sobre madeira. Milagre de Nossa Senhora de Brotas.

a vaca quando Ihe aparece Nossa Senhora. A Virgem é representada em pé, de cabelo solto, sem coroa, vestida com túnica castanha e manto azul, e segurando o menino ao colo (Fig. 3); do lado direito do quadro, o pastor mostra aos habitantes da Vila das Águias, entre os quais se conta uma religiosa, que o animal ressuscitou. Uma das figuras, vestida com capa, boina preta e gola branca de renda, poderá representar o senhor de Vila das Águias, D. Francisco Manuel, primeiro conde de Atalaia (Fig. 4). Esta pintura, de nítida influência flamenga, possivelmente realizada numa das oficinas de Évora, constitui a mais completa iconografia relativa ao milagre de Nossa Senhora Brotas, e é, só por isso, um precioso documento. A pintura é anterior aos relatos de Severim de Faria e de Frei Agostinho de Santa Maria e poderá ter sido realizada com base na tradição oral, ou num texto anterior que actualmente desconhecemos.

É também na Igreja de Brotas que se encontra a imagem de Nossa Senhora de Brotas, exposta numa redoma de vidro no nicho do altar das almas. É uma escultura em marfim, de pequenas dimensões, de produção relativamente simples e rude, realizada provavelmente no século XVI. Nossa Senhora está representada em pé, sem o menino, envolta num amplo manto que lhe tapa completamente o braço esquerdo, e coroada com uma coroa simples, esculpida no mesmo bloco de marfim, sem qualquer incrustação. A mão direita foi colada ao corpo com uma mistura à base de cera (Fig. 5). Certamente que esta imagem já não é a original que, segundo Frei Agostinho de Santa Maria, era esculpida em osso e tinha uma coroa de ouro com uma esmeralda:"Não se ve nesta Sagrada Imagem mais que a mão direyta, a esquerda mostra estar dentro da escultura. Tem a Senhora na cabeça huma coroa 


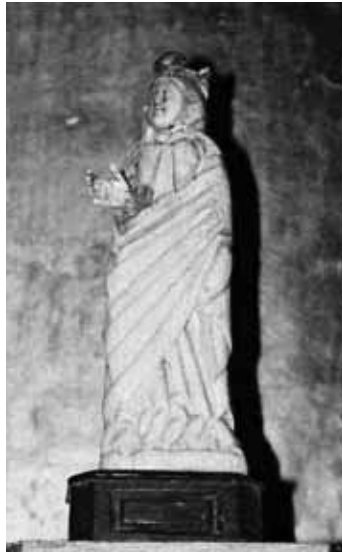

5. Imagem de Nossa Senhora de Brotas. Marfim.

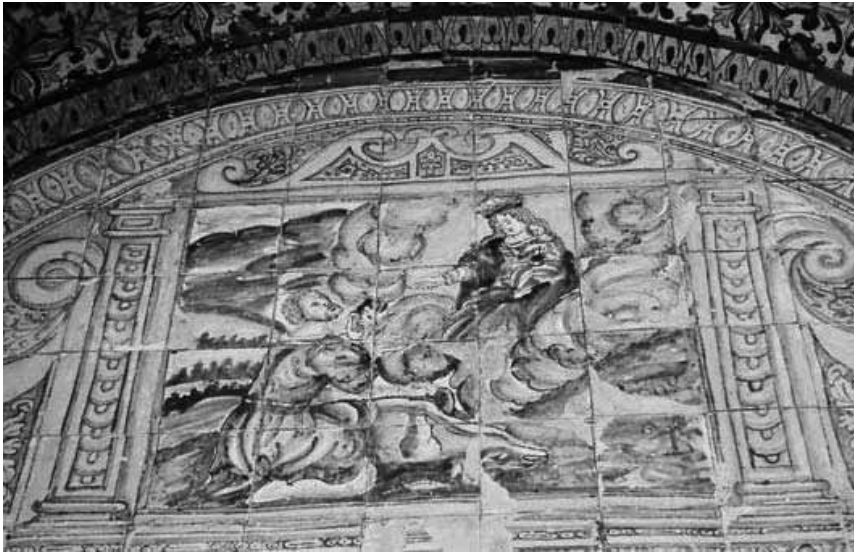

6. Painel de azulejo.

de ouro com huma esmeralda de grande preço. Não tem menino. Naquella pequenhez se descobre na Sagrada Imagem huma Divindade grande e huma celestial fermosura."11

Na varanda exterior do templo, totalmente revestida a azulejos seiscentistas e conservando ainda um altar com o seu frontal azulejar, o painel que reveste a parede do fundo simula um retábulo em talha dourada e representa o momento em que o pastor se prepara para esfolar a vaca quando Nossa Senhora Ihe aparece. Neste painel, a Virgem está representada sentada numa nuvem, coroada e vestida com um amplo manto azul, segurando no menino ao colo.

O pastor, vestido com uma túnica cinzenta, está ajoelhado no chão, com os braços erguidos para a Virgem. Na mão esquerda segura a pata da vaca, que acabou de cortar. Aos seus pés vê-se a faca e a vaca morta, deitada de barriga para cima (Fig.6). Este painel é característico da azulejaria seiscentista, no gosto ingénuo pela imitação de formas e materiais, como o enquadramento em "talha dourada" pintado em amarelo intenso. Iconograficamente é nítida a influência da pintura a óleo que se encontra na igreja na representação do pastor e da sua vaca. No entanto, Nossa Senhora surge coroada (com a coroa real), iconografia que remete para a sua eleição como padroeira de Portugal ${ }^{12}$. Esta mistura de referências

${ }^{11}$ Fr. Agostinho de Santa MARIA, Santuário Mariano e Historia das Imagens Milagrosas de N. Senhora (...), tomo sexto, Lisboa Occidental, of. de António Pedrozo Galram, 1718, pp. 129-130.

12 Em Março de 1646, nas cortes de Lisboa, D. João IV elege Nossa Senhora da Conceição como padroeira de Portugal, depondo simbolicamente a coroa real aos pés da Virgem. Veja-se sobre este tema Sílvia FERREIRA, op. cit., p. 270. 


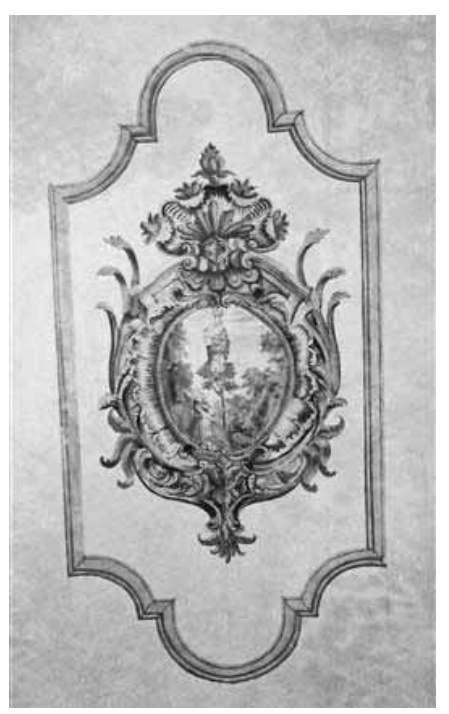

7. Imagem de Nossa Senhora de Brotas. Pintura sobre estuque. Abóbada da nave. 1785

iconográficas é própria do carácter regionalista das representações de Nossa Senhora de Brotas, realizadas por artesãos sem formação académica. Estes artistas tinham como base para as representações do milagre a tradição oral, e sobretudo imagens às quais recorriam como modelo e que adaptavam à história que pretendiam contar.

Ainda na igreja, resta-nos uma última imagem, igualmente alusiva a Nossa Senhora de Brotas, pintada no centro da abóbada da nave em 1785. Representa o pastor ajoelhado aos pés de uma árvore, na copa da qual se vê Nossa Senhora em pé, vestida com uma túnica branca e um manto azul, coroada e segurando o menino ao colo (Fig. 7). No chão, aos pés do pastor, jaz a vaca morta. É uma pintura ingénua, de composição simples, que reúne várias fontes iconográficas: o conhecimento do milagre, a representação de Nossa Senhora coroada com a coroa real (padroeira de Portugal), e Nossa Senhora aparecendo em cima de uma árvore, representação que se inspira nitidamente nas iconografias de Nossa Senhora da Atalaia ou de Nossa Senhora do Espinheiro ${ }^{13}$.

Estas quatro obras, em materiais diferentes, pintura sobre madeira, escultura em marfim, azulejo e pintura mural, constituem o essencial da iconografia de Nossa Senhora de Brotas em Portuga ${ }^{14}$. Não há, nestas representações, uma coerência iconográfica. Nossa Senhora pode surgir com ou sem coroa, com ou sem menino, em pé ou em cima de uma árvore. $O$ culto, apesar de ter suscitado movimentos de peregrinação, manteve-se essencialmente na região do Alentejo, num contexto rural e relativamente isolado. Os peregrinos vinham de Évora, Estremoz, Vila Viçosa, Mora, Arraiolos e outras vilas alentejanas e reuniam-se em Brotas para as festas em honra de Nossa Senhora. Segundo Frei Agostinho de Santa Maria,

${ }^{13}$ Consulte-se Ernesto SOARES, Inventário da Colecção de Registos de Santos, Biblioteca Nacional, Lisboa 1955.

14 Houve uma irradiação do culto de Nossa Senhora de Brotas dentro e fora de Portugal. No entanto, este culto perde muitas vezes a relação com as suas origens e não suscitou novas iconografias. As obras que existem limitam-se a copiar ou adaptar a representação de Nossa Senhora aparecendo ao pastor. Nalguns casos, apenas se representa a imagem de Nossa Senhora, sendo evidente que o milagre de Brotas é desconhecido. Veja-se, sobre a divulgação do culto, Anastásia Mestrinho SALGADO, Margarida Almeida SANTOS, Abílio José SALGADO, O Culto de Nossa Senhora de Brotas e a respectiva Igreja. Sua relação com o povoado. Edição da Câmara Municipal de Mora, 1987, pp. 12-23. 
"O lugar e território da Senhora he tão pobre, \& a terra parece tão estéril, que apenas dará o sustento a doze, ou quinze moradores que alli vivem". Esta pequena descrição dá-nos a dimensão do isolamento e ruralidade da vila de Brotas, o que explica a escassez e pouca qualidade artística das obras alusivas ao milagre que chegaram aos nossos dias.

Embora não sejam obras de destaque pela qualidade da produção artística nem pela sua dimensão estética, constituem, pela sua ligação intrínseca a um determinado contexto, que é limitado e isolado, e por terem resistido às vicissitudes do tempo e chegado aos nossos dias, um elemento muito importante para o estudo dos regionalismos na iconografia mariana. 



\title{
A iconografia da Senhora de Fátima: da criação ex nihilo às composições plásticas dos artistas
}

\author{
Marco Daniel Duarte*
}

\section{Uma criação ex nihilo}

O mais divulgado modelo iconográfico mariano da época contemporânea, presente em quase todos os templos católicos do mundo, nasceu em Portugal na sequência das Aparições de Fátima de 1917. Não teria o conhecido desenvolvimento sem que no processo cultual interviesse a disciplina escultórica que logo em 1920 faria cristalizar, através do escopro de um santeiro, a imagem de Nossa Senhora do Rosário de Fátima. O estudo do tipo, do arquétipo e dos subtipos da Virgem de Fátima, primeiramente produzidos em oficinais trabalhos de santeiros e, em fase posterior, interpretados por artistas, permite entender os contornos do nascimento de uma realidade imagética, isto é, de uma iconografia ex nihilo e o seu, necessariamente, tardio desenvolvimento estético.

Embora a imagem de Nossa Senhora de Fátima se desenvolva, obviamente, a partir das aparições de 1917, o rigor da cronologia faz recuar a primeira evocação figurativa de Nossa Senhora de Fátima ao século XVIII, porquanto não terminara ainda o ciclo das aparições e já na Cova da Iria se experimentava a necessidade de cristalizar em suporte material, como "recordação da Fátima", uma encenação das aparições na qual se fazia aparecer a imagem da Virgem Maria'. Não havendo ainda modelo iconográfico para a pagela ali distribuída nesse $\mathrm{dia}^{2}$, procurou-se uma imagem mariana, contudo bem distinta da que viria a ser o ícone de Fátima. Procurou-se na catedral de Leiria, ao retábulo do topo do transepto, do

* Departamento de Arte e Património/Museu do Santuário de Fátima.

1 Já antes existira uma pagela da Virgem Maria, mas não temos certeza se com ela se quis fazer figurar a Aparição. Realmente, no Processo Canónico Diocesano, fala-se de uma "fotografia duma imagem religiosa (Nossa Senhora)" (Processo Canónico Diocesano - Relatório Oficial, AEL, Documentos de Fátima, I-12B: Processo Canónico Diocesano - Relatório Oficial, fls. 3v-55v; veja-se Documentação Crítica de Fátima. II Processo Canónico Diocesano (1922-1930), Fátima, Santuário de Fátima, 1999 - doravante, DCF II - ,doc. 9 , pp. 197 e 198).

2 Confronte-se a publicação das duas versões deste documento em Documentação Crítica de Fátima. III - Das Aparições ao Processo Canónico 1 (1917-1918), Fátima, Santuário de Fátima, 2002 (doravante, DCF III-1), doc. 43, de 1917.10.11 ('ante').Veja-se também a reprodução contida no catálogo Memórias. Sinais. Afectos. Nos 90 anos das Aparições de Fátima, catálogo da exposição com o mesmo nome, coordenação-geral de Carlos A. Moreira Azevedo, comissariado científico de Marco Daniel Duarte, Lisboa, 2007, p. 70. 
lado do evangelho. Foi, portanto, uma Imaculada Conceição, de finais de Setecentos ou inícios da centúria seguinte, que serviu para a fotocomposição ${ }^{3}$ distribuída naquele dia com a titulatura de "Nossa Senhora da Paz (Regina Pacis, ora pro nobis)." Com a parte superior dessa escultura, envolta numa coroa de nuvens, à maneira de glória de anjos ou de vera mandorla, quis-se figurar a Virgem aparecida a três crianças ${ }^{4}$ que, de joelhos, de mãos postas e de cabeça levantada, se inscreveram no fundo do quadro em relação psicológica com o rosto da Imaculada, o qual, fazendo-se sublinha da criteriosa escolha, nem de propósito, se inclina sobre eles.

Porém, e ainda que a Aparição não exigisse que a disciplina escultórica interviesse na criação de Fátima (antes a arquitectónica:"façam aqui uma capelinha"5), em 1919 há diligências para que se muna o espaço miraculado com uma imagem que viesse a presidir ao culto ali desenvolvido. É em Agosto de 1919 que Gilberto Fernandes dos Santos (1892$1964)^{6}$ vai "a Lisboa para comprar a Imagem de N. Senhora para colocar na pequena Capela existente no logar da Fátima"7. Nada encontrando "que servisse", o devoto teve de a "mandar fazer aos Snrs. Fanzeres em Braga"8, cidade que era - e continua a ser - a grande montra da produção escultórica saint-sulpliciana tão ao uso da piedade de Oitocentos.

A mesma fonte de que nos temos munido informa ainda de outro interveniente no processo - Manuel Nunes Formigão (1883-1958) ${ }^{9}$-, embora não possamos ter cabal avaliação acerca do grau de intervenção deste sacerdote, um dos maiores conhecedores das descrições dos videntes (pois a ele se devem vários dos interrogatórios que levaram ao estudo canónico do fenómeno), no resultado escultórico final. Mesmo "á pressa", o padre Manuel Nunes Formigão estivera em Braga e ali havia "deixado um papelito" com anotações ${ }^{10}$ que, como ninguém, estava à altura de transmitir, como se reconhece também numa outra

3 Acerca desta e doutras fotocomposições deveras interessantes para o desenvolvimento iconográfico de Fátima, veja-se A. A. Borges, Para a história das fotografias dos videntes de Fátima, em Stella, ano 24, n. ${ }^{\circ} 276$, Ag, 1960, pp. 10-11; n. ${ }^{2} 278$, Outubro, 1960, p. 10; n. ${ }^{\circ} 279$, Novembro, 1960, p. 10.

4 Numa das versões deste quadro aparecem apenas duas meninas e o tronco da árvore. Veja-se a fonte documental acima citada.

5 Documentação Crítica de Fátima. I - Interrogatórios aos Videntes - 1917, Fátima, Santuário de Fátima, 1992, doc. 31, 266.

6 Frederico da Silva Serôdio, Santos, Gilberto Fernandes dos, em Enciclopédia de Fátima (1892-1964), Enciclopédia de Fátima, coord. Carlos A. Moreira Azevedo e Luciano Cristino, Estoril, Principia, 2007, pp. 511-512.

7 Documentação Crítica de Fátima. III - Das Aparições ao Processo Canónico Diocesano 2 (1918-1920), Fátima, Santuário de Fátima, 2004 (doravante, DCF III-2), doc. 404, p. 108.

8 DCF III-2, doc. 404, p. 108.

9 Jesué Pinharanda Gomes, Formigão, Manuel Nunes (1883-1958), em Enciclopédia de Fátima..., pp. 232-237.

10 Carta de Gilberto Fernandes dos Santos para Manuel Nunes Formigão, datada de Torres Novas, de 1919.11.03, DCF III-2, doc. 415, p. 144. 
1. Escultura de Nossa Senhora do Rosário de Fátima

(Capelinha das Aparições, Fátima), José Ferreira Thedim, 1920 (primeira fotografia da escultura de Nossa Senhora de Fátima, anterior a 1920.04.26, publicada em Documentação Crítica de Fátima III-2, doc. 481).

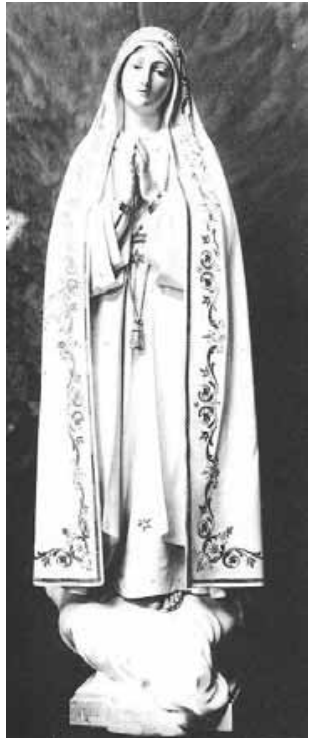

missiva que, dirigida à vidente Lúcia, alude à imagem: a escultura "[...] foi mandada fazer segundo as indicações que déstes ao Snr. Dr. Formigão de Santarem"11.

A imagem que Gilberto dos Santos mandou fazer, oferecida "para colocar na pequena capela"12, teve, por conseguinte, intervenientes vários entre os quais, os mais directos, como vemos, são, para além do encomendante, Manuel Nunes Formigão, Américo Fânzeres, dono da casa onde foi feita a encomenda, e, obviamente, o escultor a quem este último incumbiria o trabalho de escultura, um entre os vários santeiros que, através de modelos escolhidos por catálogo, elaborou tantas imagens que presidiram ao culto católico de finais de Oitocentos e da centúria de Novecentos ${ }^{13}$.

Como em tantos outros casos, a importância de um modelo foi fundamental e, desde a descoberta do historiador Bernardo Xavier Coutinho, sabemos que a imagem foi derivada de uma outra inclusa no catálogo da Casa Estrela, do Porto, com o número 47. Como demonstrou o mesmo historiador da arte, a escultura cuja fotografia se incluía naquele

11 Carta de Celina Gameiro a Lúcia, datada de Torres Novas, 1919.08.08, DCF III-2, p. 102.

12 DCF III-2, doc. 497, p. 301.

13 Veja-se sobre esta matéria o importante contributo das seguintes obras: Sérgio de Oliveira e SÁ, Santeiros da Maia no último ciclo da escultura cristã em Portugal, Maia, edição de Autor, 2002; Tedim, José Manuel Alves, Os santeiros da Maia, em Bracara Augusta, tomo 32, fascículos 73-74, n. 85-86, Braga, Janeiro-Dezembro de 1978; Mestre Guilherme Ferreira Thedim: 1900-1985. Uma oficina de escultura religiosa em Matosinhos, Matosinhos, Câmara Municipal, 2004. 
catálogo seria o protótipo da imagem de Nossa Senhora de Fátima. Com efeito, é ali que José Ferreira Thedim (1892-1971) ${ }^{14}$ irá procurar as formas antigas para fazer aparecer novas formas em ordem a dar molde a uma nova iconografia. Pode falar-se, com toda a propriedade dos conceitos, num verdadeiro arquétipo, pois nessa Nossa Senhora da Lapa (como se designa a escultura do catálogo) estão as raízes de uma nova imagem que, pelas exigências dos encomendantes, teria de ser adaptada à história do lugar a que se destinava como objecto cultual.

A imagem do catálogo de 1910 é a que se encontra na igreja de Labruja de Ponte de Lima (diocese de Viana do Castelo) ${ }^{15}$, assinada e datada, com efeito, com "A. A. Estrella Esculp Porto $1908^{\prime \prime 16}$. Com as alterações ao figurino, teve-se em mente criar um modelo que correspondesse às descrições e, por essa razão, houve necessidade de não incluir na iconografia de Fátima o Menino que se encontrava aos pés da Senhora da Lapa, os anjos que lhe habitavam a nuvem, a mantilha que esta tinha sobre a cabeça. Alguns elementos, porém, foram mantidos, como são o formato das mangas e a complexa maneira de vestir que inclui uma sobretúnica entre o vestido e o manto ${ }^{17}$. A alvura das vestes, a serenidade delicodoce do rosto e alguns elementos ornamentais como são as estrelas do vestido (uma na zona da cintura e outra na parte inferior da veste), um cordão dourado com uma borla na extremidade e um terço no braço direito foram acrescentados em ordem à individualização do modelo que se requeria novo e representativo da recente titulatura ${ }^{18}$.

${ }^{14}$ Sobre este autor leia-se a resenha biográfica [Thedim, José Ferreira (1898-1971)] assinada por Marco Daniel Duarte em Enciclopédia de Fátima, pp.546-549. Leia-se também o trabalho de Sérgio de Oliveira e SÁ, Santeiros da Maia..., p. 122.

${ }^{15}$ Averiguação que se deve a Luciano Coelho Cristino; veja-se À procura de Nossa Senhora da Lapa, em Voz da Fátima, ano 88, n. ${ }^{\circ}$ 976, 2004.01.13, p. 2; idem, Foi encontrada a Senhora da Lapa, em Voz da Fátima, ano 88, n. $980,2004.05 .13$, p. 2 .

${ }^{16}$ Inscrição na base de policromia marmoreada da escultura de Nossa Senhora da Lapa, da igreja de Labruja.

17 Numa carta de Gonçalo de Almeida Garrett para Manuel Nunes Formigão, que não conhecia o arquétipo, refere-se, com clara estranheza, ao "vestido fóra do vulgar":"A estampa está muito bem feita, e diz-me V. Exa que ella é reprodução da Imagem, feita segundo as indicações de Lucia. Parece que a Estampa alem do vestido e manto, mostra uma especie de tunica descendo um pouco abaixo do joelho e aberta ao centro. É um vestido fóra do vulgar em Nossa Senhora" (Carta de Gonçalo de Almeida Garrett para Manuel Nunes Formigão, datada de Entre-os-Rios, 1920.07.27; DCF III-2, doc. 556, p. 407).

${ }^{18}$ Não desenvolveremos todas estas temáticas que tencionamos tratar de forma mais aprofundada na dissertação de doutoramento que temos em mãos. Remetemos, no entanto, acerca da questão do terço, para os documentos números 481 e 486 de DCF III-2, onde encontraremos como personagem principal Gilberto Fernandes dos Santos. Algumas reflexões mais desenvolvidas já poderão ser colhidas no que escrevemos com o título Fátima, Lugar da Iconografia Mariana, em Actas do Congresso Internacional Fátima para o Século XXI (no prelo). 
Juntamente com a imagem que seria a oficial, seguia uma esculturinha mais pequena, "de 0,30 d'alto", a primeira imagem doméstica de Nossa Senhora de Fátima ${ }^{19}$. No relatório redigido por Manuel Nunes Formigão diz-se, com efeito, que "é rara a igreja nos domínios da República que não tenha um altar ou ao menos uma imagem de Nossa Senhora de Fátima"20. Ao lermos um texto de 1930, bem sentimos a percepção de como evoluíra o culto da Virgem de Fátima. O culto não se propaga sem a presença de imagens, o que prova, na verdade, como durante as décadas de vinte e de trinta houve uma proliferação imensa de esculturas devocionais que povoavam as igrejas, capelas e oratórios do país e de várias partes do mundo.

Avaliadas as imagens que nessa época foram colocadas nos altares, pode perceber-se como elas tiveram uma evolução plástica no sentido de se tornarem mais barrocas, isto é, de se verem mais avultadas na volumetria, nos panejamentos. Sendo uma tendência que a alguns críticos e historiadores da arte tem parecido natural em qualquer estilo artístico ${ }^{21}$, esta tendência encontrava-se mesmo na senda do gosto dos santeiros que eram hábeis trabalhadores da madeira, conhecendo bem os mecanismos que lhes permitiam tirar pregas bem lançadas, reproduzir drapeados de ínfimos franzidos, talhar plissados como ninguém ${ }^{22}$. Assim se notam sinuosos recortes em imagens de Nossa Senhora de Fátima, como os que se podem observar nas esculturas que se encontram ao culto na igreja do Sagrado Coração de Jesus em Lisboa, na igreja de Nossa Senhora das Mercês, na mesma cidade, na igreja da Santíssima Trindade do Porto, na catedral de Bragança, na paroquial de Valega (Ovar), na paroquial de Espinho, na Ordem Terceira do Porto, entre outras ${ }^{23}$.

Embora não tenha sido a única razão, pois - sobremodo num dos tipos de que adiante falaremos - haverá razões relacionadas com o próprio desenvolvimento da mensagem de Fátima, a alteração de modelo também se deverá a uma intenção de mudança formal. Efectivamente, os testemunhos escritos que da vidente Lúcia sobre esta matéria se conservam levam a concluir que existiu uma decepção relativamente ao considerado exagero de

${ }^{19}$ Confronte-se Documentação Crítica de Fátima. III - Das Aparições ao Processo Canónico Diocesano 3 (1920-1922), Fátima, Santuário de Fátima, 2005, doc. 482, p. 270.

20 Processo Canónico Diocesano - Relatório Oficial, publicado em DCF II, doc. 9, p. 215.

${ }^{21}$ Há, como é sabido, correntes historiográficas que defendem que o 'estádio' barroco acontece em cada estilo artístico. Veja-se por exemplo Arnold Hauser, O Conceito de Barroco, Lisboa, Veja, 1997; Erwin Panofsky, Qu'est-ce que le baroque?, em Trois Essais sur le Style, Paris, Le Promeneur, 1996; Eugénio D'Ors, O Barroco, Lisboa, Vega, 1990; Severo Sarduy, Barroco, Lisboa, Vega, 1989.

22 Leia-se o que diz Sérgio Sá, Santeiros da Maia..., pp. 69-79.

${ }^{23}$ Outra característica virá ainda a marcar esta iconografia, como é a de o rosto da imagem exibir uma ambiência de tristura, marca tardia que, pensamos, se encontra relacionada com a imagem de Teixeira Lopes. 
pregas e decoração que se ia apondo na imagem de Nossa Senhora de Fátima. Lúcia, em carta datada dos inícios de Dezembro de 1937, diz:"nas estampas de Nossa Senhora que tenho visto, paresse ter dois mantos".E acrescenta, em claro decreto iconográfico:"paresse-me que se eu soubesse pintar, ainda que não seria capáz de pinta-la como Ela é, porque sei que isso é impossivel, assim como impossivel me é dize-lo ou descreve-lo, no intanto para fazer a pintura o mais parcida possivel poria somente uma tunica o mais simples e branca possivel e o manto caindo desde a cabeça até ao fundo da tunica, e como não poderia pintar a luz e a beleza que a adornava, suprimia todos os enfeites á excessão d'um fiinho dourado à volta do manto. Este sobresaia como se fosse um raio de sol brilhando mais intensamente".Tendo noção da dificuldade da linguagem, terminava, sobre este assunto:"a comparação fica muito aquem da realidade, mas é o milhor que me sei explicar"24.

Passará ainda uma década até que a depuração do modelo seja efectivamente cristalizada. Os novos modelos que deste sentir surgiriam datam de 1948, mas já antes se haviam iniciado ensaios em ordem a uma nova iconografia ou, talvez mais bem explicado, em ordem a uma correcção da iconografia que se estava a desenvolver. Existe notícia desses ensaios que, inclusivamente, usavam técnicas diversificadas de fixação da imagem como são o antigo método de pose para o pintor de cavalete, como, até, os modernos meios fotográficos para registarem a que se queria vera efígie da Aparição: data de 1945 uma fotografia que pereniza, precisamente, a religiosa doroteia, "indicando como se Ihe manifestou o Coração Imaculado de Maria"25; data da mesma época uma série de outras fotografias onde se vê "Maria Vitória Valera Palmero, uma das duas alunas de Tuy, [...] preparada, pela Irmã Lúcia, e com vestidos arranjados também por esta, para servir de modelo para a imagem da Virgem Peregrina" e esta mesma aluna servindo de "modelo do Coração Imaculado de Maria"26.

A confirmação do que deixamos explicado pode ser colhida na forma como Sebastião Martins dos Reis (1913-1984) ${ }^{27}$ opera a legenda desta última fotografia referida, escrevendo que foi a própria vidente a sentir o anseio de formalizar o modelo:“Desejosa de ficar com um modelo, o mais perfeito possível, do modo como a Senhora Ihe tinha aparecido, - 'sem tantos balandraus', como A representavam..., - a Vidente foi, com a aluna, à quinta

${ }^{24}$ Carta de Maria Lúcia de Jesus, r. S. D., para D. José Alves Correia da Silva, datada de Tuy, 1937.12.05, pp. 2-4, AEL. Dossiê Fátima, B1-46, 1937.12.05. doc. 2585.1.

25 Esta fotografia foi publicada por Sebastião Martins dos Reis, Síntese Crítica de Fátima. Incidências e repercussões, s.l., s.n., 1967 [estampa 5, do grupo final de imagens].

26 Usamos as palavras com que Sebastião Martins dos Reis legenda as referidas fotografias no seu apêndice de imagens de Síntese Crítica de Fátima. Incidências e repercussões, supracitada: vejam-se as estampas que coloca em $90 .^{\circ}$ e $91 . .^{\circ}$ lugares.

27 Veja-se, sobre esta importante personalidade dos estudos de Fátima, o que diz José Geraldes Freire no verbete Reis, Sebastião Martins dos (1913-1984), em Enciclopédia de Fátima..., pp. 450-455. 
de uma senhora, em Tuy, em 1945, tirar esta fotografia, depois de em casa, muito particularmente, ter feito de modelo para este mesmo modelo, - cujo tecido, de 'mousseline' alvíssima, a própria Irmã Lúcia foi autorizada a ir comprar, em pessoa..."28.

Para além dos meios fotográficos, existem preciosos apontamentos que podem ser tomados como os esboços do que viria a ser esta nova iconografia do "Coração Imaculado de Maria de Fátima", como virá a ser conhecido entre os fabricantes destas imagens ${ }^{29}$. Os desenhos que se conservam ${ }^{30}$, quatro em papel de gramagem superior e três outros em papel de fina gramagem, constituem, pelo lápis da religiosa Henriqueta Malheiro, doroteia colega de Lúcia, a primeva fonte para analisar o pensamento imagético que se encontra subliminar ao modelo iconográfico ${ }^{31}$.

Num deles pode ler-se quer um desabafo da pintora ("esta foi a primeira que tirei pela propria Ir. Dôres em menos de uma hora! (no Sardão, em 946)"), quer uma aprovação-correcção da própria Irmã Lúcia que passamos a transcrever: "Gosto mais desta: a Mão esquerda um nadinha mais fichada: o braço direito menos para fora e a mãos com uma enclinaçãosinha mais de fichada. Era preciso suprimir o cabelo que cai sobre os ombros e pescoço"32.

A grafia da vidente pode ainda ser notada num dos vegetais, precisamente a assinalar o lugar onde faltava a estrela que, desde os anos vinte, vinha fazendo parte da iconografia tradicional da Senhora de Fátima:"aqui uma estrela"33.

Este esboço terá ido parar à mão de um escultor, provavelmente, José Ferreira Thedim, pelo menos isso se depreende da anotação colocada no canto inferior esquerdo deste mesmo desenho: “Vae p.a verificar e vão todas p.a entre todas escolher e mostra-las ao esculptor que seberá melhor do que eu fazer as modificações porque estão habituados".

Também à Irmã Lúcia o desenho foi enviado, a julgar pela anotação registada no verso do segundo desenho, que, tal como o primeiro, se encontra assinado e datado com "Sr. Malh XI-1946":"P.a a Ir. Dores/ Remete Ir. de Jesus Malheiro".

$\mathrm{Na}$ verdade, não sabemos com plenitude se os desenhos tiveram o destino indiciado por estas frases, pois não se encontra totalmente estudada a reunião deste espólio que,

${ }^{28}$ Legenda da fotografia $\mathrm{n} .{ }^{\circ}[91]$.

${ }^{29}$ Veja-se, no catálogo supracitado Mestre Guilherme Ferreira Thedim..., o fac-símile de uma carta onde, no terceiro parágrafo, aparece esta expressão, 39.

30 Desenhos de Henriqueta Malheiro, Museu do Santuário de Fátima, Reserva.

31 Dois dos primeiros são paginados com numeração romana (I,II) e um encontra-se assinado e datado ("Sr. Malh XI1946";"Ir. Malheiro XI-1946").

${ }^{32}$ Margem inferior esquerda, escrito de baixo para cima, sensivelmente a meio da referida margem.

${ }^{33}$ Esta frase encontra-se replicada mais abaixo, desta feita pelo punho da irmã desenhadora que, provavelmente temendo que a letra de Lúcia se esbatesse, decidiu fazer uma chamada de atenção à maneira de nota de pé de página. 

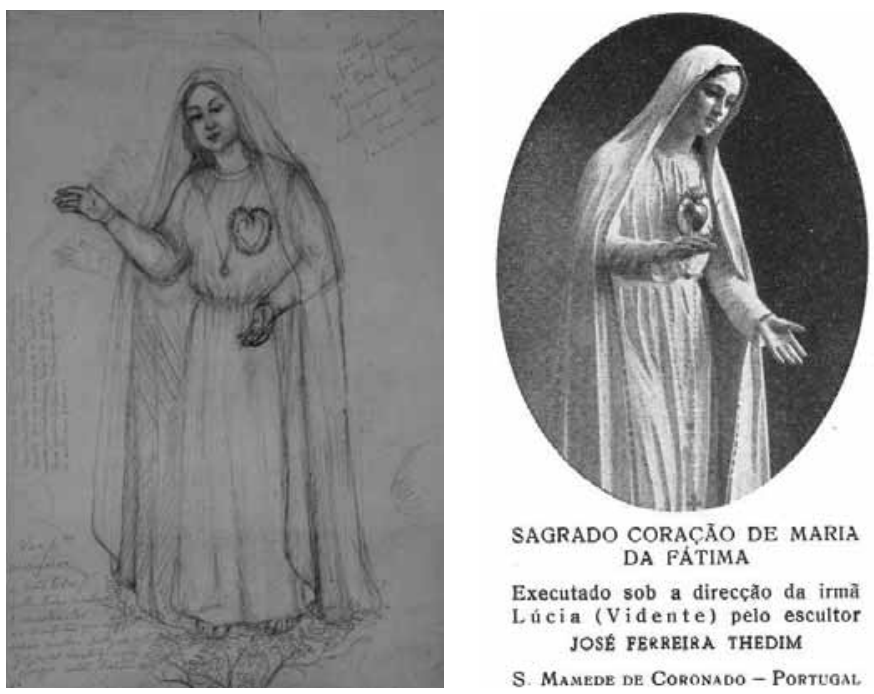

2. Estudo para a pintura do Imaculado Coração de Maria, de Maria Henriqueta de Jesus Malheiro, 1946 (Museu do Santuário de Fátima, fotografia do Arquivo do Santuário de Fátima).

3. Pagela que reproduz a escultura do Imaculado Coração de Maria do Carmelo de Santa Teresa de Coimbra (Museu do Santuário de Fátima, Colecção de Estampas, espólio de Avelino Martins da Costa).

segundo nota de Sebastião Martins dos Reis, parece ter sido agrupado pela Madre Maria José Martins, superiora do Instituto de Santa Doroteia a que pertencera Lúcia até $1948^{34}$.

Os desenhos ora evocados serviram, depois, de inspiração a Madre Malheiro em ordem à execução de óleos como o que se guarda no Museu do Santuário, integrando o mesmo espólio dos desenhos, com data de $1946^{35}$, ou como o que pertence à Associação dos Servitas de Nossa Senhora de Fátima, datado de $1949^{36}$.

Estes ensaios levaram ao aparecimento do que, em linguagem do saber iconográfico, poderemos considerar de subtipo iconográfico, particularidade da iconografia de Fátima que a torna numa das mais interessantes da época contemporânea. Assim aparece o subtipo Virgem Peregrina e Imaculado Coração de Maria.

${ }^{34}$ Veja-se acerca deste espólio arquivístico, bem assim do do Cónego Sebastião Martins dos Reis, os pontos 3.3 e 3.4 do verbete de Pedro Penteado, Arquivo, em Enciclopédia de Fátima..., p. 50.

35 Esta tela, de 35,5 × $48 \mathrm{~cm}$, tem no verso a frase latina da carta aos Hebreus $(5,7)$ "Com ['sic', por 'cum'] clamore valida" e encontra-se assinado e datado da forma que segue:"S. H. de J. Malheiro 1946". Mais uma prova de como o espólio que estamos analisando esteve à guarda de Sebastião Martins dos Reis ou de que, pelo menos, este teve contacto com ele é a estampa reproduzida nas páginas iniciais da sua obra Síntese Crítica de Fátima. Incidências e repercussões, s.l., s.n., 1967, com a explícita legenda "Retrato da Vidente de Fátima Lúcia de Jesus Santos - servindo de modelo explicativo do modo como Ihe apareceu o Coração Imaculado de Maria (quadro a óleo, de 1946, da discípula de Malhoa, Madre Henriqueta Malheiro, R.S.D.)".

${ }^{36}$ Memórias. Sinais. Afectos...; veja-se o n. 3 do catálogo, pp. 48 e 49. Também o que anota José Geraldes Freire num artigo intitulado Uma pintura valiosa do Imaculado Coração de Maria, em O Distrito de Portalegre, 1978.10.27, p. 6 . 
Se o primeiro destes nomes não teve antecedentes na história da arte, pelo menos como designativo de uma iconografia, o segundo, como é sabido, era já uma temática abordada pela imaginária cultual, pelo menos desde o século XVII e com grande expansão, sobretudo, ao longo dos dias de Oitocentos $^{37}$. A primeira iconografia adopta o nome da condição inerente à "iniciativa de levar em peregrinação para fora do santuário a própria imagem da Capelinha"38.

Poderemos cotejar o texto ao qual anteriormente chamávamos de decreto iconográfico da Irmã Lúcia com as novas imagens de Nossa Senhora de Fátima e vemos como, de facto, houve preocupação de depurar a imagem em ordem à simplicidade formal que se coadunará, inclusivamente, com a defendida austeridade no vestir que da mensagem de Fátima emana ${ }^{39}$.

A novidade do modelo do Coração Imaculado de Maria de Fátima é sobretudo a de se estabelecer por base a imagem da Senhora de Fátima, já remodelada das complexas vestimentas que a transformou no modelo de Virgem Peregrina. Mas na figura do coração propriamente dito surgem modificações

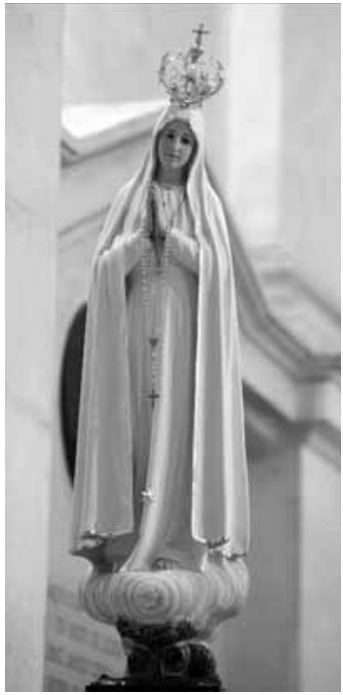

4. Escultura da Virgem Peregrina, de José Ferreira Thedim, 1947, actualmente na Basílica do Rosário do Santuário de Fátima (fotografia do Arquivo do Santuário de Fátima). que nos parecem relevantes em relação aos modelos vindos,

${ }^{37}$ De tal sorte assim é que não foi fácil a cristalização do nome quando relacionado com Fátima, como se prova pelas pagelas, correspondência e notas de encomendas dos santeiros que, não raro, se referiam a este tipo como Sagrado Coração de Maria de Fátima; veja-se, por exemplo, a pagela que integra a Colecção de Estampas e outros materiais iconográficos do Santuário de Fátima (espólio de Avelino Martins da Costa, álbum n. ${ }^{\circ} 19$ [folha n. ${ }^{\circ} 19 \mathrm{v}$ ] com a legenda:"SAGRADO CORAÇÃO DE MARIA DE FÁTIMA. Executado sob a direcção da irmã Lúcia (Vidente) pelo escultor JOSÉ FERREIRA THEDIM S. Mamede de Coronado - Portugal".

${ }^{38}$ Luciano Cristino, Virgem Peregrina, em Enciclopédia de Fátima, pp.605-609. Com efeito, a primeira imagem peregrina é a da Capelinha das Aparições, feita em 1920, mas o modelo que virá a assumir este nome é verdadeiramente uma correcção dessa mesma iconografia.

39 Para sermos sucintos na argumentação basta lembrarmos os versos do canto oficial de Fátima: «Falou contra o luxo, contra o impudor de imodestas modas de uso pecador». Sem que queiramos exagerar relativamente às vestes da escultura da Capelinha das Aparições que, obviamente, não correspondem à descrição do hino, podemos percebê-las como mais luxuosas que as que o modelo da Virgem Peregrina viria a envergar. Acerca deste hino, de autoria de Afonso Lopes Vieira, leia-se o que dizemos no estudo "Em Fátima rezei por ti": uma abordagem aos testemunhos materiais da peregrinação, em Memórias. Sinais. Afectos, supracitado, p. 15, e a publicação do manuscrito no número 33, p.59, do mesmo catálogo. 
sobretudo, do século $\mathrm{XIX}{ }^{40}$. Enquanto estes se vêem acompanhados, não raro, por uma pequena espada e por uma cinta de espinhos ou, também possível, de lírios, o coração nascido de Fátima aparece, como os tradicionais, coroado por uma chama de fogo, mas cingido sempre por uma coroa de espinhos. O símbolo torna-se ainda mais diverso quanto a forma que apresenta se afastar da consagrada pela iconografia relativa aos antigos tipos do Sagrado Coração de Maria. Se nestes o coração se encontrava apertado pela referida cinta, o de Fátima encontra-se libertado, metido no campo traçado pelo círculo composto, nas palavras de Lúcia, por um "tojo" de espinhos ${ }^{41}$. Embora pareça um pormenor com parcial importância, a mudança de que aqui fazemos nota é substancial, porque dá uma maior expressividade ao coração, colocando-o como que ostentado pela cercadura de espinhos. Trata-se assim de um ostensório, com as consequências iconográficas e doutrinárias que Ihe advêm desta formulação plástica.

O coração da Virgem Maria, antes enquadrado pelas mãos da Virgem, aparece agora também cercado pelo "tojo" de que fala Lúcia. As mãos de Maria libertam-se mais e não o indicam, como outrora; antes se colocam em interacção com o mundo: desenham-se, a direita, apontada ao alto e, a esquerda, dirigida ao mundo. Assim repetirão o modelo os que, mais artesãos ou mais artistas, se debruçam sobre esta nova imagem de Nossa Senhora de Fátima, criada a partir das indicações da vidente ${ }^{42}$.

40 Manfred Lurker, no Dicionário de Figuras e Símbolos Bíblicos, São Paulo, Paulos, 1993, p. 68, lembra que a figuração plástica do culto ao Imaculado Coração de Maria data do século XVII:"pelos fins do século XVII surgiram as imagens do Coração de Maria, que, em recordação da profecia do velho Simeão ('e a ti, uma espada transpassará tua alma'), é apresentado transpassado por uma espada". Em Portugal, a figuração antropomorfa do Coração de Maria será posterior. Datam deste século XVII umas figurações plásticas, mas conceptuais, que aludem aos corações de Jesus e de Maria, como se pode ver, por exemplo, no mosteiro de Santa Maria de Lorvão, no retábulo dos Sagrados Corações. Veja-se Nelson Correia Borges, Arte monástica em Lorvão: sombras e realidade: das origens a 1737, Lisboa, Fundação Calouste Gulbenkian, 2001, Vol. I, pp. 378-379. Por se tratar também de um lugar onde o desenvolvimento desta iconografia tem uma estação quase inaugural, leia-se o que diz Nuno Saldanha, A "Quinta Chaga" de Cristo. A Basílica das Carmelitas Descalças do Coração de Jesus à Estrela, em Monumentos, Lisboa, MAOTDR/DGEMN, n. ${ }^{\circ}$ 16, Março de 2002, pp. 8-15, e Giuseppina Raggi, As pinturas de Pompeo Batoni: 'Status Quaestonis', ibidem, pp. 46-53.

${ }^{41}$ Antunes Borges no estudo Como surgiu a primeira imagem do Imaculado Coração de Maria, em Fátima 50, ano 2, n. ${ }^{\circ} 23,1969.03 .13$, pp. 10-14.

42 Uma das mais célebres esculturas do Imaculado Coração de Maria, inaugurada em 1958 e colocada no nicho da torre da basílica do Santuário no ano seguinte, é obra do artista dominicano Thomas McGlynn; veja-se Thomas McGlynn, Vision of Fatima, Boston, Little, Brown and Company, 1948, e Richard A. McAlister, Thomas McGlynn. Priest and Sculptor, Providence, Providence College Press, 1981, pp. 54-83, passim. 


\section{As composições plásticas dos artistas}

Já em data bem anterior à conclusão de todos estes ciclos iconográficos, a imagem de Nossa Senhora de Fátima havia sido objecto de atenção de artistas de maior monta. Embora já antes Gerardus van Krieken (1864-1933), autor do projecto da basílica, se tivesse detido sobre o ícone da Virgem de Fátima, o mais célebre episódio nesta história acontece logo nos finais da década de vinte, quando António Teixeira Lopes esculpe a Senhora aparecida em Fátima.

Os diversos escopros e pincéis deram origem a formulações plásticas distintas, conforme a sensibilidade estética e as correntes artísticas em que se integram os autores. Comum a todos é a omnipresente tentativa de fugir ao cânone estabelecido e repetidamente talhado pelos santeiros. Essa atitude, obviamente relacionada com o tempo da contemporaneidade artística, levou a que determinado modelo possa ter tido menos aceitação por parte da comunidade de cultuadores para a qual determinada imagem fora criada, situação que se verificou, desde logo, a partir daquela especial imagem de Teixeira Lopes e que teve, por exemplo, no caso do convento dos dominicanos de Fátima um epílogo deveras interessante cuja rejeição levou inclusivamente à retirada da escultura da peanha que ela havia ocupado desde o dia da dedicação da igreja, em $1965^{43}$.

Almejar encontrar as razões do descontentamento com a imagem criada pelo artista mostra-se sempre tarefa que atrai os que analisam o tema e é incorrer na, porventura, pouco salutar tentação de operar um exercício comparativo entre a imagem da Virgem de Fátima de 1920, de José Ferreira Thedim, e a dos artistas que daquele tema se ocuparam ${ }^{44}$. Cremos que o infortúnio passou, certamente, quer pelo desprezo da silhueta tradicional ${ }^{45}$, quer pelo desrespeito pelos sinais iconográficos que os crentes se habituavam a ver na Senhora de Fátima. Com efeito, Teixeira Lopes criou uma escultura deveras diferente da composição dos anos vinte. A estrela da iconografia, em vez de figurar no

${ }_{43}$ Acerca deste templo, riscado por Luiz Cunha, veja-se o que dizemos em Arte Sacra em Fátima..., pp. 30-31.

${ }^{44}$ Cremos que esta visão terá também uma quota-parte de responsabilidade pelo infortúnio cultual que a peça de Teixeira Lopes sofreu. Colocar a imagem de Teixeira Lopes como concorrente da de Ferreira Thedim não foi, decerto, a melhor opção, pois elas não se deveriam ter afigurado como incompatíveis. Estamos convencido de que o escultor não terá querido que a sua imagem ocupasse o nicho da rústica capela das aparições. Ao contrário, as datas de elaboração da escultura no ateliê de Vila Nova de Gaia compadecem-se antes com a tese de esta escultura ter sido elaborada para outro espaço cultual, talvez, provisoriamente, a chamada capela das missas e a basílica. $O$ templo maior do santuário, com grande pé-direito, suportaria a imagem que, é bom que se destaque este facto que não tem sido evidenciado, é a primeira imagem feita após o reconhecimento oficial das aparições.

${ }^{45}$ Lembremos que, quando falamos de um culto tão perseguido e com tanta adesão popular, uma década é um tempo em que se firma, com efeito, uma tradição muito vincada. 
vestido, foi colocada sobre a cabeça e o rosário também não tinha as contas canonicamente contadas ${ }^{46}$.

A imagem contribuiu, no entanto, para modificações na maneira de esculpir a Virgem de Fátima, porquanto mesmo os imaginários usaram de maior liberdade ao estabelecer o perfil da Senhora de Fátima, nomeadamente no que respeita à curvatura do corpo reclinado sobre o espaço psicológico dos pastorinhos, habitado, no caso da escultura cultual, pelos fiéis. São exemplo disso várias esculturas de Albano França, que se agigantam com bastante nitidez, designadamente a da igreja dos Mártires de $1941^{47}$.

Teixeira Lopes não respeita, no entanto, o ar estereotipado que a escultura de Thedim, na esteira da estatuária religiosa saint-sulpliciana, ostenta ${ }^{48}$. A escultura de Teixeira Lopes, que marcaria para sempre esta dicotomia entre arte erudita e arte popular ${ }^{49}$, entronca, assim o defendemos, numa vontade de elevar a arte em Fátima e as datas da sua concepção levam a considerá-la a primeira imagem destinada ao santuário no período após a oficialização do culto que data de $1930^{50}$. Apesar das críticas que terá sofrido ${ }^{51}$, ou até por causa delas, houve quem a defendesse, desde os mais conhecidos escritores do tempo, como Júlio Dantas ${ }^{52}$, até aos mais anónimos. Digna de registo é a apreciação em verso que Maria Feio Ihe tece, na pagela que, não obstante, continua a publicar no rosto a escultura de Ferreira Thedim. Os sonetos, segundo a própria, "feitos em expontanea inspiração no dia 13 de Julho de 1931, na Foz do Douro, após a visita ao atelier de Teixeira Lopes" mereceriam detença maior, porquanto caracterizam a escultura como "A Maravilhosa Imagem"

46 Leia-se a crítica severa que se escreve em Lírios. Revista antoniana de cultura, Lisboa, composição, impressão e gravuras de Bertrand, Irmãos Ltda., 1932, número único, pp. 11-13.

47 Veja-se estudo mais pormenorizado sobre a escultura da Casa França em Memórias. Sinais. Afectos..., p. 155. Outro exemplo pode observar-se no trono do retábulo-mor da igreja paroquial de Nossa Senhora de Fátima (paróquia de São Martinho), escultura datada de 1945 e assinada pelo mesmo autor.

48 Ainda assim, a própria escultura de Teixeira Lopes não escapou à crítica de uma ambiência saint-sulpliciana: veja-se Clara Menéres (Artes plásticas de temática religiosa, em A lgreja e a Cultura Contemporânea em Portugal. 1950-2000, coordenação de Manuel Braga da Cruz e Natália Correia Guedes, Lisboa, Universidade Católica Portuguesa, 2001) que caracteriza a escultura como uma obra "erudita e meritória, apesar de manifestar um inequívoco estilo académico e passadista, quase saint-sulpiciano," p. 61.

49 Assim o temos escrito; veja-se o ponto 3 do artigo Arte (Arquitectura, escultura, pintura, artes decorativas) que intitulámos "A paradigmática discussão de sempre: Teixeira Lopes versus Ferreira Thedim ou a arte sacra em Fátima", em Enciclopédia de Fátima, supracitada, pp. 64-66.

50 A magna carta através da qual o bispo de Leiria declara dignas de crédito as aparições de Fátima, intitulada Carta Pastoral sobre o culto de Nossa Senhora da Fátima, data de 13 de Outubro de 1930; veja-se DCF II, doc. 11, pp. 263-276.

51 Veio contra ela o referido artigo da revista Lírios, já citado, e também o que escreve Abel Salazar, intitulado O escultor Teixeira Lopes, no periódico O Diabo. Grande semanário de literatura e crítica, p. 1.

52 Depois de publicado no Comércio do Porto, o texto foi incluído, com o título A Virgem de Teixeira Lopes, em Voz da Fátima, n. ${ }^{\circ} 173,1937.02 .13$, p. 3. 


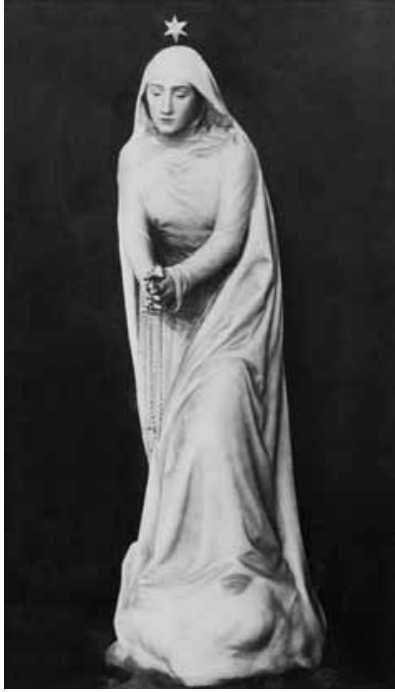

5. Escultura de Nossa Senhora de Fátima (reitoria do Santuário de Fátima), de António Teixeira Lopes, 1931 (fotografia do Arquivo do Santuário de Fátima).

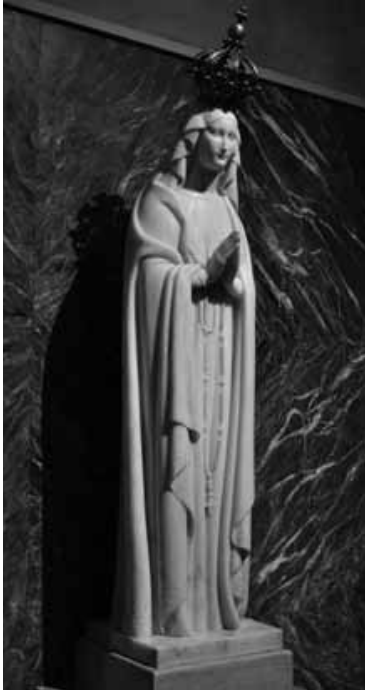

6. Escultura de Nossa Senhora de Fátima (igreja de Nossa Senhora de Fátima, Lisboa), de Leopoldo de Almeida, 1938 (fotografia de Alexandre Salgueiro).

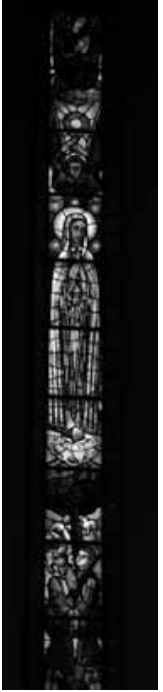

7. Vitral de Nossa Senhora de Fátima (igreja de Nossa Senhora de Fátima, Lisboa), de José de Almada Negreiros, 1938 (fotografia de Alexandre Salgueiro).

e, inclusivamente, "A Nova Aparição"53, porquanto falam de uma "maravilha de escultura" ("obra-prima de escultura") de "sobre-humana e excelsa formosura", caracterizando, ainda, o"bloco de madeira" de "alado vulto", não se coibindo, até, de a apelidar de "milagre do céu". Nas palavras da poetisa, a escultura é "uma sublime e Nova Aparição" que se aproxima do que consideraríamos o conceito de arte cultual: "cinzelar da Arte em Oração".

Ainda na mesma década de trinta aparecerá o tema trabalhado por outros artistas de renome. Para a igreja de Nossa Senhora de Fátima de Lisboa, sob projecto de Porfírio Pardal Monteiro (1897-1957), será encomendada a escultura titular do templo a Leopoldo de Almeida. Este escultor fará a imagem da Virgem de Fátima através de uma esguia coluna de alvo mármore, a qual, anos mais tarde, viria a ostentar uma coroa fechada de metal. A modelação que o autor imprimiu à obra produziu uma Senhora de Fátima de severidade formal, porventura condizente com a descrição dos videntes que asseverava

53 Agradecemos ao Rev.mo Senhor Cón. Dr. Luciano Coelho Cristino a informação acerca destes sonetos que nos merecem a publicação no final deste artigo. 
que a Aparição se manifestara séria, não sorrindo ${ }^{54}$. Esta característica, no entanto, confere à escultura uma dignidade de linhas que se impõem ao crente que não a rejeitou como imagem de oração. Não fora a ausência da estrela e da borla, a iconografia teria sido plenamente respeitada, nomeadamente no que concerne à posição das mãos, juntas, de molde a que o manto possa ser enquadrado pela forma dos braços que, pelo menos do lado esquerdo, exerce a justificação do pregueado. Em vez de um terço do rosário, Leopoldo de Almeida prefere colocar um rosário completo a pender da escultura da Virgem. O drapejado visível de alto a baixo da escultura não contraria a austeridade que o autor consegue com esta peça totalmente branca, construída da alvura natural do mármore que, não obstante ser uma matéria fria, não afastou a devoção dos fiéis, paroquianos da capital lisboeta.

Ainda no mesmo espaço sagrado, o tema da Virgem de Fátima aparece tratado por Almada Negreiros, numa das frestas com vitrais deste autor. Situada no lado da epístola, a Virgem de Fátima aparece entre o programa iconográfico mariano que o autor criou para o templo ${ }^{55}$. Na composição esguia que o recorte da abertura da janela - uma retícula na vertical - Ihe determina, Almada constrói o desenho da evocação da Senhora de Fátima em vários registos, guardando o do meio para a silhueta da Senhora de Fátima tratada nas cores branca, azul e rósea, de mãos postas em oração das quais lhe pende um rosário que quase toca os pés assentes na nuvem que paira sobre a verdejante azinheira junto da qual, de joelhos, se concentram as crianças videntes. Estas colocam as mãos à imitação da Virgem e viram o rosto ao alto para percepcionarem a visão. Francisco encontra-se representado de frente e as videntes Lúcia e Jacinta permanecem de costas, em primeiro plano. José de Almada Negreiros, conhecendo a história das aparições, sabe que as crianças disseram terem visto não só uma Senhora, mas também um anjo e, por isso, figura-o

${ }^{54}$ Sem querermos desenvolver este tema, indicamos apenas duas fontes para que possa explorar-se: veja-se o que se diz, acerca da fisionomia da Aparição, na carta magna de D. José Alves Correia da Silva, supracitada: "O rosto, duma beleza celeste, sobrenatural, apresentava-se sereno, grave e toldado duma leve sombra de tristeza" (p. 268 do doc. 11 da DCF II); veja-se, ainda, o que o Pe. Manuel Nunes Formigão, sob o pseudónimo de Visconde de Montelo, escreve na mesma linha em Os Episódios Maravilhosos de Fátima, Guarda, Casa Editora Empresa Veritas, 1921, p. 8:“O rosto, de uma nobreza de linhas irreprehensivel e que tinha um não sei quê de sobrenatural e divino, apresentava-se sereno e grave e como que toldado de uma leve sombra de tristeza", p. 8. Embora as alusões ao rosto triste da Aparição nos pareçam um tema mais tardio, já no interrogatório do P. José Ferreira de Lacerda, datado de 1917.10.19, aparece uma referência ao estado psicológico (não propriamente ao rosto) da Virgem:"[...] A Senhora estava triste quando dizia isto" (DCF I, doc. 47, p. 337); contudo, o mais comum é aparecer a expressão "séria" para caracterizar o rosto da Aparição. A resposta contida no interrogatório do mesmo Pe. Manuel Nunes Formigão, datado de 1917.09.27, é clara neste aspecto:"- Sorriu-se alguma vez ou mostrou-se triste? - Nunca se sorriu nem se mostrou triste, mas sempre séria." (DCF I, doc. 7, p. 57).

${ }^{55}$ Entre outras denominações da Virgem, surgem Nossa Senhora do Carmo, Rainha dos Apóstolos, Nossa Senhora do Rosário, Nossa Senhora das Dores. 
no registo acima do da Senhora de Fátima, o que confere ao vitral um discurso fílmico, porquanto este anjo aparece, na narrativa pictórica, antes da figuração da aparição mariana. Em sintonia com os relatos de Lúcia, o anjo aparece como custódio da Eucaristia, mas ao mesmo tempo como seu adorador $^{56}$. No registo mais ao cimo, surge uma outra personagem alada que cremos ser a tradução icónica da Mensagem de Fátima, cristalizada no díptico "Penitência-Oração", pois o anjo encontra-se figurado de joelhos, de mãos postas e com a veste roxa, a cor litúrgica dos tempos penitenciais ${ }^{57}$.

Ainda no exterior da igreja de Fátima, no ângulo superior esquerdo da fachada, encontra-se uma escultura pétrea da titular do templo, de autoria de António da Costa (1899-1970), discípulo de Simões de Almeida, que exibe um dos mais estilizados rosários das esculturas de Nossa Senhora de Fátima, pendendo de forma centrada relativamente às vestes da estátua. A zona inferior do manto faz lembrar um pouco a escultura do interior da igreja, do escopro de Leopoldo de Almeida, pela sucessão de planos que a sua orla cria, mas o rosto da estátua exterior surge muito menos

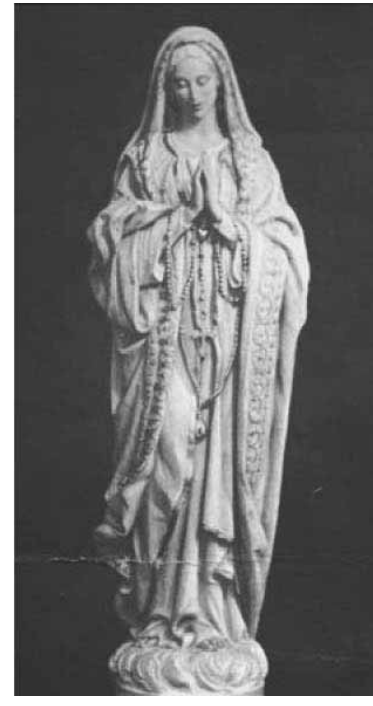

8. Escultura de Nossa Senhora de Fátima (capela do Palácio Nacional de Queluz), Raul Xavier (reprodução de uma estampa do Museu do Santuário de Fátima, Colecção de Estampas). austero. As mãos encontram-se ostensivamente postas em oração, à altura do peito, abrindo uma concavidade na zona de vazio. Observada de lado, percebe-se uma ligeira curvatura formada pelas pernas, opção que ajuda a criar um movimento no traçado escultórico.

Embora a simplificação do modelo que deriva da escultura da Capelinha das Aparições se revele, entre os autores eruditos, vincada tendência, também vemos exemplos em que esse modelo não aparece assim tão simplificado. Raul Xavier (1894-1964), na escultura de Nossa Senhora de Fátima do Palácio de Queluz, efectua um vulto bem apegado à barroquizante tradição que a imagem da Virgem de Fátima estava a sofrer por parte das oficinas nortenhas. Na peça de Queluz, de $1942^{58}$, não cometendo exageros formais que a

56 Na mesma personagem, Almada consegue transmitir estas duas dimensões, colocando-o a sustentar um ostensório e, pela posição com que lhe desenha o rosto inclinado, em posição reverencial.

57 Permitimo-nos usar, na descrição deste vitral, as mesmas palavras que inserimos no catálogo da exposição Memórias. Sinais. Afectos..., n. ${ }^{\circ} 463$.

58 A data consta de uma estampa da colecção do Santuário de Fátima que reproduzimos neste estudo. À data da exposição, já várias vezes mencionada, não se sabia o paradeiro desta escultura que, segundo a legenda da referida estampa, pertencera ao Palácio de Queluz. 
pudessem conotar com obra de santeiro, Xavier não se afasta do modelo do Santuário de Fátima, antes o enfatiza através de formas mais acentuadamente escavadas, o que confere à escultura um movimento muito vivo. Segue, como dizemos, o figurino da Senhora da Capelinha das Aparições, mas modela, em jogo de cheios e vazios, as vestes que esculpe com pormenor, não esquecendo as sobremangas e, até, o fio, neste caso, já com uma esfera pendente ${ }^{59}$.

Este mesmo motivo da esfera suspensa a pender do fio da Senhora de Fátima aparece outrossim na obra de Ernesto Canto da Maia (1890-1981), pertencente ao Museu do Caramulo $^{60}$. Datada de 1946, a escultura, em barro cozido e deixado na cor natural, denota uma interessante variante como é a de o fio ostentar não uma bola mas outra forma que radica na espiritualidade de Fátima. $\mathrm{O}$ autor, não figurando a típica primeva borla, pois já se deveria encontrar informado das alterações iconográficas dos anos 40 , coloca a pender do fio um coração que ali aparece como se fosse uma medalha de adorno pessoal. $O$ escultor transforma, assim, a bola - que antigamente era uma borla - em coração, que é o elemento mais recente da iconografia de Fátima. Não lhe coloca, porém, os espinhos nem as chamas típicas da imagética cordimariana e faz dele um adorno da Senhora de Fátima. O vestido faz já eco da simplificação operada na década de 40, nomeadamente no franzido da cintura, mas o plissado tem muito mais movimento que as esculturas da chamada Virgem Peregrina ou da imagem denominada Imaculado Coração de Maria saídas dos escopros dos santeiros. A posição da escultura parece encarnar um corpo que acaba de poisar sobre uma superfície rugosa: para isso contribui tanto a colocação dos pés, estando o direito mais adiantado e o esquerdo atrás e mais alto, bem assim a maneira como as mãos esculpidas na vertical e direccionadas ao chão abrem o manto. Este assume uma das fórmulas exploradas também por Maria Amélia Carvalheira da Silva que é a de, na zona da cabeça, se transformar em capuz, à maneira do abrigo de uma pastora.

Efectivamente, assim acontece em várias esculturas de Nossa Senhora de Fátima de Carvalheira da Silva, desde logo na que a escultora criou para a igreja de São João de Brito, em Alvalade (Lisboa), para a capela do Seminário do Verbo Divino, em Fátima, ou para o monumento da Aparição de Agosto, nos Valinhos, também em Fátima.

Anteriores a estas são as esculturas que Leopoldo de Almeida fez para a capela de Nossa Senhora de Fátima na igreja de Santo Eugénio, em Roma, e para a capela do Seminário de

${ }^{59}$ Esta esfera relaciona-se com a iconografia mais específica do subtipo que designamos por Virgem Peregrina.

${ }^{60}$ Escultura próxima desta é a que o autor possuía em sua casa, em Paris. Veja-se uma reprodução incluída em Fátima. Altar do Mundo, vol. I (O Culto de Nossa Senhora em Portugal), Porto, Ocidental Editora, 1953, p. 310. Nesta escultura, o terço pende do braço direito e a Virgem não ostenta qualquer fio sobre o peito. 
Cristo Rei, Olivais (Lisboa). A escultura da igreja romana ${ }^{61}$ toma uma volumetria bem mais desenvolvida que a escultura da paroquial de Fátima que anteriormente descrevíamos. Feita para ser suspensa numa parede que suporta pintura mural, a escultura exibe com bastante clareza uma ambiguidade formal com o tema da Assunção da Virgem. A silhueta piramidal é marcada pela movimentação do manto bastante ondulado na zona inferior, recortando-se de forma quase simétrica de molde a enquadrar as contas em forma de rosário que se enrola nas mãos, a estrela do fundo do vestido e os pés que se distendem quase em linha recta em direcção ao solo. Embora a sugestão se refira à Senhora que desce do Céu à Terra, a forma dos pés que, como dissemos, veremos nalgumas das esculturas de Maria Amélia Carvalheira da Silva mostra-se sinal de aproximação à iconografia da Assunção. Embora a cronologia já lhe permitisse operar uma imagem de Fátima segundo o modelo da Virgem Peregrina, Leopoldo de Almeida prefere continuar a guiar-se pelas vestes da primitiva imagem da Capela das Aparições e, deste modo, não prescinde da sobretúnica e das mangas largas que esculpe na sua imagem para a igreja em honra de Santo Eugénio ${ }^{62}$. A cabeça figura ligeiramente inclinada para a frente, como voltará a repetir na escultura do Seminário dos Olivais, com a diferença de que na da igreja de Santo Eugénio a escultura se inclina apenas para diante de forma frontal.

Para a imagem de Nossa Senhora de Fátima do Seminário dos Olivais, templo em que também participou Almada Negreiros, Leopoldo de Almeida parece ter construído uma solução de compromisso, embora isto não signifique despretensiosa cópia, mas antes erudita linhagem entre as criações do mesmo tema. Não obstante o volume das vestes, designadamente da parte inferior do manto do trabalho escultórico, o escopro de Leopoldo de Almeida ditou para a capela do Seminário dos Olivais uma imagem de Nossa Senhora de Fátima novamente esguia. A comparação surge inevitável com a que o autor esculpiu para a paroquial igreja de Fátima. A dos Olivais revela-se tão serena como a dos anos 30, mas mostra-se, e sem que a adjectivação seja inconciliável, menos severa, apresentando maciez no

${ }^{61}$ A criação da escultura para a igreja de Santo Eugénio resulta da adesão do embaixador português, António Carneiro Pacheco, à iniciativa do Vaticano de, por altura do jubileu do papa Pio XII, se construir uma igreja dedicada ao santo onomástico do papa (Eugénio Pacelli). Encontra-se documentação relativa a esta encomenda no Instituto dos Arquivos Nacionais - Torre do Tombo (IAN/ANTT) que neste momento estamos a investigar; veja-se naquele artigo o fundo intitulado: Comissão Nacional da Capela de Nossa Senhora de Fátima da lgreja de Santo Eugénio, em Roma, com documentação datada entre 1942 e 1955. Acerca do entusiasmo que esta homenagem provocou no mundo católico português, nomeadamente, no mundo católico de Fátima, leia-se Fátima. Altar do Mundo, vol. Il (História das Aparições), Porto, Ocidental Editora, 1953, pp. 192-194.

${ }^{62} \mathrm{O}$ que dizemos sobre esta escultura pode aplicar-se à que, do mesmo autor, se encontra na capela do monumento de Cristo Rei, de Almada, que se mostra semelhante a esta. 


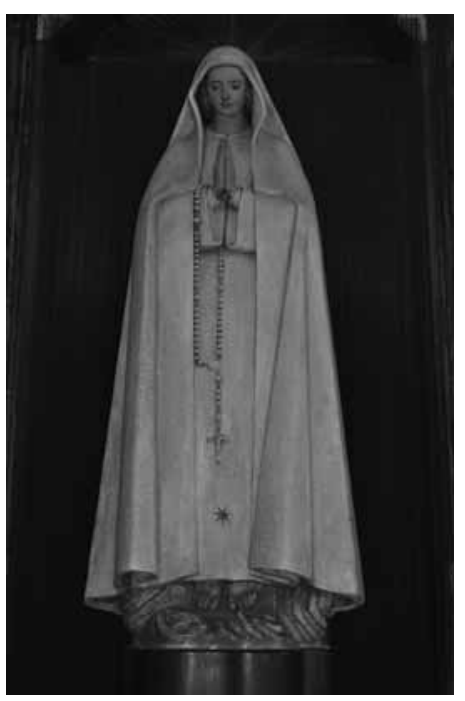

9. Escultura de Nossa Senhora de Fátima (igreja de São João de Brito, Lisboa), Maria Amélia Carvalheira da Silva (fotografia de Alexandre Salgueiro). movimento tão delicado como se ondeasse ao sabor de uma brisa, mas muito presente: pode afirmar-se que as vestes surgem, simultaneamente, diáfanas e corpóreas. Retomando, nesta peça, a inclinação do rosto para a frente, tal atitude auferiu novos valores, porquanto a cabeça surge também ligeiramente inclinada à direita, conseguindo com esta opção tornar-se mais próxima e intuitivamente mais interpeladora. Das mãos postas, sem que as palmas se encontrem coincidentes, pende um rosário sobreposto às sobremangas e ao restante drapejado, sempre leve, da sobretúnica. Os pés, descalços, assentam directamente na base da escultura, da mesma peça pétrea. Longe de lhe avolumar, em pirâmide, as vestes, como aconteceu no modelo que o autor criou para a capela de Nossa Senhora de Fátima de Santo Eugénio, o tema da Senhora de Fátima tornou a colher inspiração na escultura da igreja de Lisboa com aquele nome, não a tratando como coluna escultórica, mas, em novo exercício de escultura, citando-a ${ }^{63}$.

Maria Amélia Carvalheira da Silva (1904-1998) trabalhou, como já referimos, inúmeras vezes o tema de Fátima, quer para esculturas cultuais, quer para pequenas peças devocionais ${ }^{64}$. Uma das suas obras mais interessantes é a da igreja de São João de Brito, em Lisboa, não apenas pelas colossais dimensões que apresenta - cerca de 2,30 metros de altura mas também pela sobriedade com que o tema é tratado. Ainda que num ou noutro ponto, normalmente ligado a uma dulcificação das temáticas, as esculturas de Carvalheira surpreendam, não poderemos esperar que esta autora rompa com a tradicional iconografia da Virgem de Fátima ${ }^{65}$. Ao invés, parece-nos que a tenta assumir com muita fidelidade, nunca

${ }^{63}$ Retomamos a análise que incluímos em Memórias. Sinais. Afectos, n. ${ }^{\circ} 467$.

64 Acerca destas últimas remetemos para as considerações que fizemos no estudo "Em Fátima rezei por ti": uma abordagem aos testemunhos materiais da peregrinação, em Memórias. Sinais. Afectos..., p. 33. Aí tivemos oportunidade de apontar, para a falta de qualidade dos objectos religiosos que os peregrinos compram em Fátima, culpas à comunidade de artistas que nunca se terá interessado pelo tema. Maria Amélia Carvalheira da Silva parece ter sido uma ilha nesta matéria. O citado catálogo reproduz algumas peças desta índole nas pp. 132-133 (n.os 382-385).

65 Neste contexto merece a pena lembrar o que escreve Clara Menéres sobre esta autora que "era muito recomendada pela hierarquia":"o seu tipo de trabalho conciliava uma aparente modernidade com fórmulas tradicionais, num estilo que agradava ao gosto comum" (Artes plásticas de temática religiosa..., p. 71). 
descuidando os atributos clássicos da Mãe de Deus aparecida em Fátima: a estrela, o rosário, a brancura das vestes. Não surge infrequente a opção tomada para a escultura de São João de Brito de colorir as vestes de branco-creme, não maculando o símbolo da alvura, mas, antes, aproximando a imagem dos fiéis, tornando-a menos fria na intensidade lumínica: a mesma solução adoptará em modelos que passa ao barro cozido, como se vê na escultura da casa das Irmãs da Apresentação de Maria, em Fátima, ou na da casa de Retiros Bom Pastor, na Buraca (Lisboa), que reproduzem um modelo criado, respectivamente, para a Capela do Verbo Divino, em Fátima, e para a paroquial de São José de Coimbra, a primeira de 1956 e esta última de 1961.

Na peça da igreja de São João de Brito, que faz contraponto com a escultura do Sagrado Coração de Jesus, da mesma autora, vê-se uma enorme massa moldada, onde se vislumbra grande simplificação das vestes que, no entanto, se fazem bem espessas, como se se constituíssem por panos mais toscos. A estrela pontifica na parte inferior do vestido e, mais acima, encontra-se a cruz do terço que pende do braço direito da Virgem, tal como acontecera no início com a escultura de José Ferreira Thedim que se quis tornar modelo físico das descrições dos videntes. A cabeça inclinada para a frente ajuda a criar um diálogo com o observador, ao mesmo tempo que confere à Senhora esculpida uma atmosfera de reverência.

No ano seguinte, Maria Amélia Carvalheira da Silva assina mais algumas obras representativas da Senhora de Fátima, precisamente para a terra das Aparições. Data, efectivamente, de 1956 a escultura que, no lugar dos Valinhos, comemora a aparição de 19 de Agosto de $1917^{66}$. Nesta obra, Carvalheira da Silva não se mostra tão escrupulosa no respeito da posição do terço, e dos dedos da escultura faz pender um largo rosário, disposto mais ou menos a meio das mãos orantes. O manto, também de grossa espessura, envolve o rosto da escultura à maneira de capuz, como se vê outrossim na obra que assinou dedicada a fazer figura de Nossa Senhora do Verbo Divino, para o altar do lado do Evangelho da capela do Seminário da Sociedade do Verbo Divino ${ }^{67}$. O manto que a escultura do monumento da Aparição de Agosto segura com os braços e que, ao fundo, cai em degraus forma um campo de exposição muito interessante na zona do rosto, transformando-se numa

${ }^{66}$ Conforme é sabido, a aparição de Agosto não ocorreu no dia 13, mas seis dias depois, nos Valinhos, perto da casa dos videntes. Neste lugar, o Santuário de Fátima mandou erigir um monumento. $\mathrm{O}$ arranjo arquitectónico deste monumento foi entregue ao arquitecto António Lino e a escultura foi dada a conceber a Maria Amélia Carvalheira da Silva. No monumento, um templete de planta quadrangular rematado por jogos triangulares e aberto em todas as faces, observam-se símbolos iconográficos de Fátima, como pombas, a estrela e o coração cercado de espinhos.

67 Esta escultura situa-se no altar lateral, lado do Evangelho, fazendo'pendant' com uma escultura de similar volumetria representativa de São José com o Menino. 
espécie de ostensório. Os pés assentam numa nuvem ludicamente estilizada, através de enrolamentos de grandes proporções, e mostram-se, como os que já analisámos, conotáveis com a iconografia da Assunção da Virgem.

É muito curioso o exercício de comparação que com esta escultura se pode operar relativamente à Senhora de Fátima criada pelo escultor António Duarte (1912-1998) para a catedral de Nampula, em Moçambique. Na pedra de ançã, António Duarte faz, no mesmo ano, uma escultura idêntica à de Carvalheira, o que prova que a iconografia da Senhora de Fátima, por ser de tal modo vincada, pôde fazer com que os artistas obtivessem resultados similares. Com efeito, assim aconteceu neste caso específico, o que se revela curioso, dada a grande diferença plástica existente entre um e outro escultor. As esculturas de Carvalheira e de Duarte aproximam-se na brancura da pedra, no recurso ao manto largo, no uso do rosário, na utilização da estrela e na forma de colocação dos pés, postos quase em linha vertical. A obra de António Duarte surge mais intelectual, cheia de linhas artificialmente desenhadas que parecem resultar de régua e compasso, o que não assegura, contudo, que tal escultura se torne superior à criação de Carvalheira. Como esta, também o manto se afasta do rosto, criando um espaço de exposição que, no caso da escultura de Nampula, alberga também as mãos postas, cujas palmas se desenharam afastadas uma da outra. $A$ nuvem da escultura de Duarte tem uma estilização bem diversa da de Carvalheira e condiz com os panejamentos mais finos que começam na zona do rosto, mais à maneira de lenço e menos de capuz.

No mesmo ano de 1956, Maria Amélia Carvalheira da Silva apôs o seu nome a outra escultura de mármore, feita para um dos altares laterais da capela do Verbo Divino, em Fátima. Esta peça virá depois a ser reproduzida na capela das Irmãs da Apresentação de Maria (também na terra das Aparições) em terracota policromada, com as mesmas cores que já víramos na da igreja de São João de Brito. Aliás, o próprio modelo que aqui se toma bem pode considerar-se o mesmo, embora muito reduzido no tamanho: sobre uma túnica totalmente lisa que rente ao pescoço exibe um pequeno talhe, surge o manto, bastante afastado do rosto, de modo a conferir-lhe ênfase. Este não se encontra apanhado pelos antebraços, mas cai na vertical, produzindo ligeiro ondeado no fundo da escultura. Sobre a manga larga do braço direito, aparece enfiado um terço, cuja cruz, onde se esculpiu um pequeno Cristo, chega quase até à estrela de sete pontas insculpida no fundo do manto. A nuvem e os pés da Virgem apresentam-se de acordo com a já analisada escultura dos Valinhos.

Encontramos desta mesma autora outras formas de esculpir a Senhora de Fátima, da qual destacamos a que Carvalheira operou, a expensas do prelado da diocese eminiense, D. Ernesto Sena de Oliveira (bispo de Coimbra entre 1948 e 1967), para a paróquia de São 
José da cidade mondeguina ${ }^{68}$. A escultura desta igreja é em pedra calcária e não tem policromia, ao contrário dos modelos que a partir dela a autora reproduz e que são por si tratados com cromatismos de tons pastéis em combinação com dourados mates, conferindo à peça uma atmosfera quente e afectiva, como é o caso da referida escultura da capela da Casa de Retiros Bom Pastor (Buraca, Lisboa) ${ }^{69}$. Do ponto de vista iconográfico, denota-se uma procura de novos modelos para a figuração da Senhora de Fátima: tratando-se de uma escultura da época pós-coroação da imagem da Capelinha das Aparições, Maria Amélia Carvalheira da Silva vai adicionar-Ihe a coroa que, a partir de 1946, passará a fazer parte integrante da imagem de Fátima. Assim, a escultora colocou uma coroa aberta sobre o manto da imagem que, no lado esquerdo de quem observa, cai por detrás do braço. As mãos, ainda que sugiram nascer da posição mais comummente observada nas imagens da Senhora de Fátima, não se juntam ao centro pelas palmas, mas viram-se ao observador. Pouco mais abaixo, vêem-se as contas de um rosário distribuídas também pelo antebraço da escultura, terminando numa cruz sobre a qual Carvalheira da Silva fez questão de representar o crucificado, na vizinhança da estrela de cinco pontas que se distingue no vestido que cai até à base da peça ${ }^{70}$.

Anteriores a esta obra são os trabalhos escultóricos de Salvador Barata Feyo para a Capela de Santa Bárbara, em Barrocal do Douro, na Barragem do Picote. Para além de um importante crucificado e de uma imagem de Santa Bárbara, este autor esculpe, em 1958, uma imagem de Nossa Senhora de Fátima, precisamente a fazer paralelo com a representativa do orago da capela. O professor de escultura da Escola de Belas-Artes do Porto criou uma imagem da Senhora de Fátima constituída por um contido cepo habilmente desbastado, em diálogo com a referida escultura de Santa Bárbara, como aquela, também formada por uma esguia coluna de lenho. Com goiva e formão a produzirem corte certeiro, o autor, através de Manuel Nogueira (entalhador), consegue a imagem da Senhora de Fátima segundo a fisionomia simplificada que, normalmente, este tema apre-

${ }^{68}$ Tivemos oportunidade de consultar a documentação paroquial relativa a esta escultura. Maria Amélia Carvalheira da Silva trabalha para a igreja de São José de Coimbra, porque os responsáveis deste templo apreciaram muito a via-sacra que a escultora havia feito, anos antes, para a capela do Verbo Divino, em Fátima, e que apelidam de "maravilhosa obra" (Arquivo Paroquial de São José de Coimbra, Livro n. ${ }^{\circ} 2$. Actas da Comissão Pró-construção da igreja de S. José, acta de 1961.05.20, f. 3). Segundo se lê noutra passagem da mesma fonte, é inclusivamente "mediante indicação do Senhor Arcebispo" que a "confecção das Imagens de S. José e Nossa Senhora" é entregue a Carvalheira da Silva (ibidem, acta de 1961.11.05, f. 4v). Veja-se o trabalho de Marco Daniel Duarte, O Vitral da Ressurreição. Exegese iconográfica da última obra de Augusto Nunes Pereira, Coimbra, Gráfica de Coimbra, 2004, nota 260, p. 170.

${ }^{69}$ Veja-se Memórias. Sinais. Afectos..., n. ${ }^{\circ} 466$, p. 157.

${ }^{70} \mathrm{Na}$ escultura de barro policromado a estrela encontra-se insculpida. 
senta quando é versado por artistas: o tratamento das mangas é sintético e a roupagem é um pouco mais movimentada, mas sem se desvincular da contenção, na zona meã da escultura. Apesar de o talhe das mãos e braços se mostrar vigoroso, não se nota, mesmo nesta área da escultura, a fuga à simplificação geral operada nas vestes, opção que, contudo, não impediu o escultor de traçar um manto que, quando comparado com o trabaIho escultórico da parte inferior da peça, se apresenta, sobre a cabeça, de espessura bem robusta e esquematicamente delineado de uma força plástica notória. Toda a roupagem da escultura, onde se notam apenas as linhas de recorte, ajuda à ambiência grave que a composição ostenta; porém, a austeridade é aligeirada pelo tom do lenho deixado na aparência natural. Embora se torne discreto, o terço que, nascido das mãos postas, o autor plasmou junto ao corpo esculpido é um interessante elemento no troço de maior intensidade plástica da obra ${ }^{71}$.

Também esguia, mas de trato muito mais doce, é a escultura que Álvaro de Brée oferece à igreja de São Domingos de Lisboa ${ }^{72}$. A sua escultura, de cerca de 2,85 metros de altura, surge na alvura do mármore a contrastar com a metálica coroa aberta que possui sobre a cabeça. É uma das esculturas da Virgem de Fátima mais bem conseguidas, porquanto não dispensa qualquer dos elementos iconográficos, mas os enquadra de uma forma plena de originalidade. Resolve a questão da azinheira reduzindo-a, ou guindando-a, a atributo iconográfico, não a trabalhando como elemento cénico ${ }^{73}$. Coloca-a na base da estátua, onde também regista o escudo nacional, precisamente sob a azinheira, provavelmente a significar ser a terra daquela árvore eleita pela Virgem. É também na copa da pequena azinheira que coloca o símbolo iconográfico da estrela, neste caso de dez pontas. Brée deixa dois discretos recantos laterais ao tronco da árvore para assinar e datar a obra. É assim formada a base da escultura que ocupa cerca de um terço da composição total. Para cima, desenvolve-se um drapeado esguio, pleno de angulosidades, que, não obstante, nunca ferem, porque dispostas de forma simétrica e muito grácil. As mãos, coladas uma à outra à altura do peito, são esguias como toda a coluna esculpida. Delas pendem duas largas mangas

71 Operámos esta análise no catálogo da exposição Memórias. Sinais. Afectos..., n. 465, p. 156. Pela coloração e até pela síntese, este trabalho escultórico aproxima-se de um outro, a que aludiremos mais adiante, feito bastantes anos depois por Laureano Ribatua para a igreja de Santo António das Antas.

72 A oferta ficou grafada na própria peça do seguinte modo:"O DONATÁRIO ESC./ ÁLVARO DE BRÉE/ FEZ NO ANO D. 1962/ P.A A IGREJA DE/ S. DOMINGOS DE LX.A".

${ }^{73}$ Parece-nos ser este o maior problema da azinheira nas esculturas da Virgem Peregrina e do Imaculado Coração de Maria, nas quais se vê uma azinheira de diminutas, quase ridículas, dimensões. Outra forma era a utilização deste elemento nas esculturas dos anos 30 e 40 que a usavam como elemento cénico, mas com grande vigor escultórico: vejam-se as esculturas da paroquial de Espinho, da igreja da Trindade do Porto ou das Mercês de Lisboa. 
e delas saem as abas do manto que, lateralmente, se abrem nas já referidas ondulações angulosas. O manto é formado sobre os ombros da Senhora e não sobre a cabeça, como é mais tradicional. Sobre esta encontra-se uma mantilha ou véu disposto em citação formal à silhueta do manto. Embora o escultor alinhasse a maioria das contas do terço sem a divisão dos padre-nossos pela mediana vertical da escultura, elas partem do braço direito, o que pode revelar uma documentada autoridade do escultor ${ }^{74}$.

A década de 60 fora, com efeito, pródiga na representação da Virgem de Fátima por diferentes escultores que para ela encontraram soluções plásticas diversas. Quase todas as imagens tiveram intenções cultuais, como a de Irene Vilar, da igreja da Senhora da Hora, em Matosinhos, a de Luísa Leite, da igreja do convento dominicano de Fátima, ou a de Luiz Cunha na igreja paroquial de Nossa Senhora de Fátima, de Aveiro. Não sendo fácil avaliar com precisão o poder que as esculturas têm sobre a devoção dos fiéis de uma determinada comunidade, sobretudo porque não se encontra documentação que o demonstre, talvez seja simples concluir que no templo de Aveiro a escultura tenha sido bem acolhida, pois não há outra imagem da Senhora de Fátima e, como já referimos, esta igreja é dedicada a Nossa Senhora de Fátima ${ }^{75}$. Na igreja de Matosinhos, a escultura sofreu um avivamento da policromia, o que pode também levar a concluir que os fiéis pudessem preferi-la um pouco mais expressiva (no seu entendimento, claro está...) e não tivessem entendido a opção da escultora. No entanto, nem uma nem outra foram objecto de retirada do espaço cultual, o que sucedera na igreja dos padres dominicanos de Fátima com a escultura de Luísa Leite, porventura a mais audaciosa escultura da Virgem de Fátima que se terá criado. São três peças de grande qualidade artística que merecem a detença que lhes dedicamos.

Esculpida em 1963 para a Igreja da Senhora da Hora de Matosinhos, a Senhora de Fátima de Irene Vilar integra um grupo de outras imagens que a autora assinou para veneração dos fiéis naquele templo. $O$ estudioso, à distância de quatro décadas, terá de abstrair-se da coloração que, a posteriori e sem conhecimento da autora, Ihe foi adicionada pois a policromia da peça era muito menos acentuada, antes dotada de suavidade condizente com as formas delineadas que ostenta. Apesar da repintura, a peça consegue manifestar uma composição cujas linhas de força se mostram reveladoras da sinuosidade do mistério que a escultora quis transmitir, sobretudo nas linhas do manto que se agiganta, sem que com

${ }^{74}$ Ao contrário da escultura de Leopoldo de Almeida da paroquial de Fátima, em Lisboa, esta escultura não terá tido fortuna cultual. Parece-nos que a não-adesão dos fiéis à escultura estará relacionada com o facto de na mesma igreja, num outro altar, se encontrar uma imagem de santeiro que desperta, por intuição, uma maior devoção popular.

${ }^{75}$ Cremos que a ambiência construtiva de todo o templo ajuda ao enquadramento, pois a linguagem moderna subjaz a todos os pormenores daquela igreja. 
isso a escultura perca expressão de etérea leveza. Este tipo de silhueta é muito comum em Irene Vilar, sobremodo em esculturas que se relacionam com a Mensagem de Fátima, como poderemos observar no anjo que a escultora idealizou para o Poço do Arneiro, em Aljustrel ${ }^{76}$, e nos modelos que fez do Coração Imaculado de Maria, bem diversos da iconografia original ${ }^{77}$. Com efeito, uma sinuosidade de linhas que se aproximam de enevoadas formas aparece nestes trabalhos escultóricos como exibidora de uma atmosfera de misteriosa aparição que bem se coaduna com o tema de Fátima. Das mãos postas da imagem, que se mostra, ao mesmo tempo, anunciadora de uma mensagem e, outrossim, curvada perante essa mesma mensagem, pende um longo rosário que, na parte inferior, se faz acompanhante da linha do manto. Mais abaixo, encontra-se um dos elementos iconográficos da imagem de Fátima, a estrela, símbolo que a documentada autora não dispensa na sua peça.

Data de 1968 a escultura patrona do templo de Aveiro, projectado pelo arquitecto Luiz Cunha, que também assinou a imagem que ora tomamos. A escultura de vulto pleno, em madeira recortada e sobreposta em lâminas segundo uma quase lúdica construção volumétrica, assume, em modernidade de linhas, a vetusta figuração da Senhora de Fátima conforme os seus mais antigos traços. Com efeito, ainda que a plástica geral da peça a afaste da devocional escultura da Capelinha das Aparições, o autor não Ihe modificou a silhueta e, não fora a técnica, não teríamos substanciais diferenças ao nível da iconografia que da imagem de 1920 saía das mãos de José Ferreira Thedim. Luiz Cunha nem sequer Ihe adicionou a coroa de rainha que a escultura da Cova da Iria viria a ostentar a partir de 1946. Antes Ihe colocou uma auréola, adorno típico que os anos vinte e trinta adicionaram à escultura de Nossa Senhora de Fátima. Num jogo de madeiras em avanços e recuos, vêem-se, assim, as mangas e sobremangas das vestes da escultura, a nuvem sobre a qual assenta a imagem e o terço pendente do braço direito, como os santeiros dos anos vinte faziam questão de representar aquela específica invocação mariana. O estilo ousado, atendendo a que se trata da imagem titular de uma igreja paroquial (projectada pelo mesmo autor da escultura), inscreve-se na incessante procura de formas para a arte sacra por parte deste arquitecto ${ }^{78}$.

76 Veja-se o que sobre esta peça dizemos em Arte Sacra em Fátima..., p. 152.

77 Tivemos oportunidade de analisar um destes, criado em 1993 para monumento público em Alcochete, no catálogo Memórias. Sinais. Afectos..., n. ${ }^{\circ} 470$. Dentro deste contexto mereceria ainda análise a escultura de Santa Maria do Imaculado Coração que Irene Vilar operou para o Mosteiro do Coração Imaculado de Maria de Bande (Paços de Ferreira).

78 Efectivamente, já se vêem nesta imagem caminhos artísticos relacionados com a arte computacional que o autor, mais tarde, viria também a explorar; veja-se, entre outros, Luiz Cunha. Janelas para o Reino. Pintura 
10. Escultura de Nossa Senhora de Fátima (igreja de Nossa Senhora do Rosário, Convento de São Domingos, Fátima), de Luísa Leite, 1965 (fotografia de Marco Daniel Duarte).

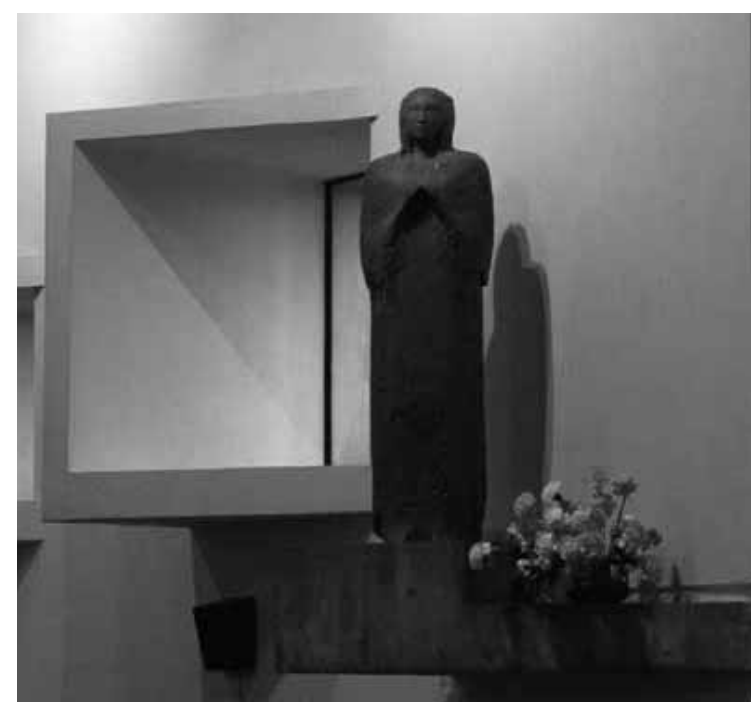

Como dissemos, parece-nos que estas obras, não obstante se mostrarem perscrutadoras de novas linguagens para um tema cultual, tiveram o mínimo de aceitação por parte da comunidade que em torno delas se reunia. Não acontecera assim, todavia, com a que de seguida analisaremos.

A imagem da criação de Luísa Marinho Leite feita em 1965 para figurar na mísula disponibilizada por Luiz Cunha, arquitecto da igreja de Nossa Senhora do Rosário do Convento dos Padres Dominicanos, será bom exemplo para aferir a dificuldade de diálogo entre o escultor criador e o usufrutuário de uma criação sacra destinada à devoção ${ }^{79}$. Não se tendo estabelecido este diálogo, a imagem será colocada de parte, retirada do ambiente para a qual fora criada. Tal apartamento não se baseia, contudo, numa atitude iconoclasta, pois a devoção precisa de assentar na imagem; no lugar daquela aparecerá uma outra imagem, bem menos artística, mas de cariz devocional inegável ${ }^{80}$.

Ainda que possamos, porventura em exercitação académica estéril, indagar culpas e culpados por tais situações (de onde nos viriam à lembrança, à guisa de resposta, entre outros, os divórcios entre a arte contemporânea e a lgreja e vice-versa e a pouca formação artística da maioria dos agentes eclesiais), mais nos interessa perceber o que, em concreto,

de Temática Cristã. Windows over the Kingdom, Novembro de 2005 (catálogo da exposição com o mesmo nome, patente ao público no edifício do antigo Convento das Mónicas, Lisboa, em Novembro de 2005).

79 Tomaremos a análise que já operámos em Arte Sacra em Fátima..., pp. 134-135.

80 Trata-se de uma peça de santeiro, tipicamente derivada da repetição do modelo iconográfico matriz. 
a escultura criada por Luísa Marinho Leite (1936-) possui de arte sacra e, obviamente, os motivos que levaram a que a escultura fosse retirada de um espaço cultual.

Ao analisarmos a escultura de per si, percebemos que há nela características que a tornam distante dos fiéis. Desde logo, epidermicamente falando, a frieza do material, que, porventura, se afigura em honestidade exagerada no contexto de uma escultura com objectivo devocional. Com efeito, a escultura apresenta-se na cor metálica fosca que a afasta das imagens que habitam o quotidiano dos fiéis, feito de cores e não de um cinzento metálico. Produzirá uma frieza no observador que nela queira encontrar verosimilhança com a vida humana e, não será difícil depreendê-lo, será, aos olhos do rezador, pouco quente e emocional. Em face destas características, dificilmente os cultuadores da Virgem de Fátima considerarão esta imagem como ícone visível da realidade invisível.

Adicionado à aparência pouco devocional, a imagem de Luísa Leite padecerá ainda de um outro importante elemento que concorre para a questionação da sua utilidade: a falta de referenciais iconográficos levará a que a identificação da imagem não seja imediata. Com efeito, numa crítica rigorosa ao resultado da escultura, poder-se-á apontar que a autora incorreu em verdadeiros descuidos iconográficos: ignora a coroa da Virgem de Fátima que, desde Maio de 1946, passou a integrar a completude icónica da Senhora de Fátima; não faz trajar a Senhora de Fátima com as roupagens típicas, não Ihe colocando nem a borla (ou bola), nem a estrela no vestido; não alude à cor branca que, incondicionalmente, se encontra aliada à imagem da Virgem de Fátima ${ }^{81}$.

Porém, por paradoxal que esta aferição possa parecer, são alguns dos indicativos que tomávamos como alicerçadores da recusa da escultura da Virgem de Fátima enquanto objecto cultal que lhe abonarão o justo epíteto de arte sacra. Esculpida num contexto de mutações profundas na maneira de entender a arte sacra em Portugal, a Virgem de Fátima de Luísa Leite procura afastar-se dos cânones delicodoces das imagens dos santeiros de arte religiosa. Subjacente a esta escolha, encontrar-se-á uma profunda reflexão vivida por vários artistas e por vários encarregados eclesiásticos; entre estes,

${ }^{81}$ A situação geográfica no enorme espaço do templo, ainda que lhe dê lugar destacado, não terá um efeito diferente do da camuflagem, pois a cor das paredes do betão aparente é similar à cor do metal aparente da superfície escultórica. Obviamente, o fiel terá dificuldade em entender que não consiga ver os sinais de que precisa, pois certamente não serão estes entraves que ele procura no templo. Ao invés desta escultura, a imagem de São Domingos da mesma igreja, sob modelo de José Grade, não obstante se apresentar na mesma materialidade da cor cinzenta, não colocou entraves aos veneradores. Pensamos que o tema explicará a intocabilidade da imagem da Virgem Maria aparecida em Fátima e a admissibilidade de uma expressividade artística no tocante a uma figura corporeamente mais próxima do mundo: um santo do século XIII (sobre esta escultura, veja-se o que dizemos em Arte Sacra em Fátima..., pp. 136-137). 
sem dúvida, o arquitecto Luiz Cunha e, de um modo geral, os responsáveis pela Ordem Dominicana ${ }^{82}$

Se por um lado a depuração formal das medidas da escultura leva a uma frieza, por outra parte, percebemos que a obra não se afasta, deste ponto de vista formal, da típica formulação da maioria das imagens devocionais. Como estas, o vulto da Senhora de Fátima não transgride o espaço, não extravasa a silhueta da modelação escultórica. As suas mãos encontram-se, com pouco destaque, coladas ao corpo e assumem a posição orante da tradicional iconografia da Virgem com as mãos postas em reza. Apenas as abre um pouco para as colocar como significadoras de protecção, o que poderia ajudar o fiel a encontrar-se à sombra do arco descrito pela posição das mãos.

Julgando a imagética da Virgem de Fátima suficientemente adquirida e divulgada, a autora considerava chegado o momento de depurar aqueles sinais plásticos através de uma estilizadora erudição. Relegando a indumentária iconográfica, a escultora percebeu a importância das linhas corpóreas desenhadas pelo ícone da escultura de Fátima; retirou o acrescento de 1946 (a coroa preciosa) e não modelou na imagem que criou qualquer pormenor decorativo. Apenas sugere esse pormenor numa rugosidade de qualidades texturais. No entanto, apresenta delicadeza no rosto da escultura, egocentricamente trabalhado: isto é, na peça modelada, apenas e só o rosto teve direito a fino tratamento. Tal opção da escultora deverá levar a reflectir sobre a importância daquele rosto, pois só ele teve tratamento de excepção. Pensamos que este preciso semblante da Senhora de Fátima modelado pela escultora portuense será dos que mais se aproxima da mensagem da Cova da Iria, pois mostra-se (e/ou oculta-se) ao mesmo tempo como rosto misterioso, velado. Não obstante uma inegável serenidade que dele emana, o rosto da Virgem, como a mensagem da Cova da Iria, será cabalmente insondável e perturbadoramente inquietante. Salvaguardadas as distâncias estéticas, atrevemo-nos a comparar a imagem da igreja do convento de São Domingos com a que João de Sousa Araújo pintou, pelas mesmas datas (1967), na grande tela do retábulo-mor da basílica do santuário, de onde se percebe, ou melhor, se intui, uma mensagem que, na indefinição de linhas visivelmente nubladas, a ninguém deixará de produzir perturbação.

Esta formulação da imagem escultórica da Senhora de Fátima exibe uma noção de intemporalidade e de transtemporalidade. Aparece como habitando fora do tempo e, por isso, gozará do privilégio de perpassar diversidades cronológicas. O paradoxo continuará

82 Não poderemos descontextualizar a situação artística do convento de Fátima de alguns outros espaços dominicanos em Portugal: Convento do Imaculado Coração de Maria, em Aldeia Nova (Olival, Ourém), Convento de São Domingos de Lisboa (projecto dos arquitectos João Paulo Providência Santarém e José Fernando Castro Gonçalves)... 
a existir no afirmar que a imagem retirada de um espaço cultual, porque não compreendida, será, no futuro, admirada e contemplada como uma tentativa de tornar erudita uma iconografia que já não terá de ser descrita, mas apenas sugerida ${ }^{83}$.

No fundo, aquela imagem é mais uma coluna ou pilar de betão,com valores plásticos que a luz ajuda a potenciar, mas que se anula entre tantas linhas de betão da mesma cor. Esta anulação da escultura torna-a, ao mesmo tempo, presente e ausente: a escultura da Virgem anula-se em ordem a privilegiar o altar que surge como peça central de toda a composição arquitectónica ${ }^{84}$. O fiel do terceiro milénio poderá encontrar aqui uma das maiores razões para equacionar a escultura de Luísa Leite no âmbito da arte sacra, pois esta característica faz dela uma verdadeira escultura para o "culto" e, menos, para a "devoção"85.

Um pouco anterior a esta obra é a escultura de Domingos Soares Branco, datada de 1960, e presentemente colocada no arranjo exterior do centro Pastoral Paulo VI, numa rotunda relvada. Segundo o autor, a escultura terá sido encomendada para um dos mais importantes espaços do santuário, a basílica do Rosário: a "estátua, de mármore branco de Estremoz, foi executada por José Raimundo, de Pêro Pinheiro, e esteve prevista para ser colocada por detrás do altar-mor da basílica do Santuário, para poder ser elevada por um dispositivo mecânico adequado" ${ }^{\prime \prime 6}$. Tal não sucedeu e, segundo o escultor, "a imagem esteve 16 anos em Pêro Pinheiro". A escultura foi, depois, colocada junto à estrada do Santuário, daí lhe advindo o nome por que era conhecida entre os frequentadores da Cova da Iria: "Nossa Senhora Caminheira" ${ }^{87}$.

${ }^{83}$ A intemporalidade de uma imagem que exibe formas comuns às que eram usadas por povos da Antiguidade pré-clássica (veja-se a silhueta que tanto lembra as formas egípcias) sustenta-se na fuga à figuração humana evidente para esculpir o divino.

${ }^{84}$ Lembremo-nos que Luiz Cunha, o arquitecto do templo, é mestre nos cânones de enfatização do altar: talvez a obra em que mais eloquentemente se observa esta questão seja a sua intervenção, não sem que despertasse acesa polémica, na capela-mor da Sé de Viseu.

${ }^{85}$ Como deixámos explicado no estudo elaborado para a abertura da exposição "Salve Rainha, Mãe de Misericórdia", no âmbito do Congresso Internacional - Fátima para o Século XXI, a escultura de Luísa Leite retomou o seu lugar de origem nos inícios de 2008. Veja-se Fátima, lugar da iconografia mariana, em Actas do Congresso Internacional - Fátima para o Século XXI (no prelo).

86 Informações colhidas por Luciano Coelho Cristino em colóquio com o artista. Desse colóquio, o director do Serviço de Estudos e Difusão da Mensagem de Fátima registou interessantes notas que conservou em ASF [Arquivo do Santuário de Fátima]-SESDI, Branco, Domingos Soares, 1J3.2.

87 Vemos verosimilhança nesta indicação porquanto, à época, o templo maior do santuário não tinha uma escultura artística de Nossa Senhora de Fátima, como aliás não chegou a ter. As imagens que, ao longo do tempo, ali estiveram eram esculturas de santeiros, salientando-se uma peça que actualmente se encontra na capela de São José que se mostrava uma boa interpretação da Virgem Peregrina. Desde Dezembro de 2003, encontra-se, na peanha criada por Erich Corsépius, a primeira das esculturas do modelo da Virgem Peregrina, oferecida por D. José Alves Correia da Silva para essa peregrinação e coroada em 1947 pelo arcebispo de Évora (ver Voz da Fátima, 1947.06.13 e 1947.07.13) Segundo se lê numa notícia do jornal do 
A escultura de Soares Branco que, reiteramos, cumpriria muito bem a função cultual na basílica do santuário foi colocada no exterior, passando, deste modo, a ter de comportar outra função: a de monumento evocativo. É uma escultura que trata a silhueta da Virgem de Fátima segundo linhas de verticalidade, característica realçada pelo omnipresente plissado que o vestido ostenta e que confere ao tronco esculpido uma ritmada textura. $A$ Senhora de Fátima inclina a cabeça no eixo vertical que também serve de guia às contas do rosário esculpidas pela frente das mãos postas. $O$ autor não dispensa a estrela que escoIhe desenhar com oito pontas pouco acima da borda do vestido. Se a nuvem sobre a qual os pés descansam se apresenta com tratamento arcaizante, a azinheira surge esculpida de forma delicadamente naturalista, em sugestão e não mostrada de forma exaustiva, apenas composta por delgados ramos que sobem do solo.

A este grupo dos anos 60 pertence também a representação pictórica que João de Sousa Araújo fez para a basílica de Fátima que, não sendo uma escultura, é pano de fundo das celebrações daquele espaço. Não se trata da representação isolada da Senhora de Fátima, mas antes de uma alegoria, onde a figura central é, efectivamente, a Virgem das Aparições. Sendo uma pintura, é natural que se preste a uma narratologia mais alargada, o que efectivamente acontece. Na densidade das cores nebulosas, o quadro do grande retábulo da basílica do Santuário de Fátima apresenta a mensagem de Fátima com a profundidade de quem nela reflectiu e com ela está familiarizado. Mais do que narrativa, a obra é demonstradora da fenomenologia de Fátima e condensadora da história das Aparições e dos acontecimentos relacionados com o santuário.

Em espaço contíguo vislumbram-se, ou melhor, intuem-se, várias personagens, entre as quais se destaca a silhueta feminina, mais esboçada que desenhada, representadora da Virgem aparecida em Fátima. Não se furtando à iconografia tradicional da Senhora de Fátima, Sousa Araújo, ao desenhá-la de um modo diáfano, aproxima-a da escultura de Teixeira Lopes, não em inspiração directa, mas em consonância com as restantes figurações existentes no painel, também elas diáfanas e vaporizadas como normalmente são as figurações da galeria artística deste autor: deste modo se codificaram os três videntes

santuário, também esta escultura começa a ter importância de relíquia e por isso se colocou em lugar de honra de modo a adquirir sacralidade, para a qual concorre também o facto de a escultura ser afastada da sua inicial função que era a de ser peregrina: "[...] a Reitoria do Santuário de Fátima entendeu que ela não deveria sair mais habitualmente, mas só por alguma circunstância extraordinária. Em Maio de 2000 foi colocada na exposição 'Fátima Luz e Paz', onde foi venerada por dezenas de milhares de visitantes. Passados três anos, mais precisamente no dia 8 de Dezembro de 2003, solenidade da Imaculada Conceição, a Imagem foi entronizada na Basílica do mesmo Santuário de Fátima, tendo sido colocada numa coluna junto do Altar Mor" (leia-se o texto de António Valinho, Nossa Senhora de Fátima Peregrina do Mundo, em "Voz da Fátima",2004.05.13, p. 1). 
Lúcia, Francisco e Jacinta, o anjo, as alegorias da oração e da graça e os papas Pio XII, João XXIII e Paulo VI.Mais alguns anjos ajudam a preencher o fundo da cena:uns sobem e outros descem degraus de espiritual significação, em lembrança da veterotestamentária escada de Jacob, conforme representam, respectivamente, as preces dos homens (orações) e os favores de Deus para com a Humanidade (graças) ${ }^{88}$.

Do ponto de vista plástico, o quadro faz reminiscência de arquétipos relacionados com o maneirismo do grande El Greco, mais nas formas esbatidas que nas cores soturnas das telas de Fátima. Mas, com efeito, as linhas delicadamente esticadas ao alto operam lembrança daquele mestre das páginas da história da arte e apelam a uma interioridade não quieta de interrogações sobre a mensagem e mistérios expostos: os anjos ao fundo que também se fazem figuração da Oração, da Penitência e da Reparação pedidas pela Senhora de Fátima; o anjo anunciador destas realidades, que se faz custódio da Eucaristia aos videntes, e o magistério eclesial representado pelos seus mais altos dignitários, a começar pelo bispo da diocese de Leiria que aceita como dignas de crédito as Aparições (junto às crianças «videntes) e pelos sumos pontífices relacionados com a história do santuário e do culto mariano de Fátima (Pio XII a entregar a coroa à Virgem, João XXIII que se fez peregrino de Fátima, anos antes de iniciar o seu pontificado, e Paulo VI com a Rosa de Ouro). Por detrás dos três pontífices, João de Sousa Araújo pintou a silhueta da cúpula de São Pedro do Vaticano que representará "a Igreja que acolhe e promove o culto de Nossa Senhora de Fátima"89.

Outros artistas trabalharam o tema Senhora de Fátima, como Carlos Escobar ${ }^{90}$, Emília Nadal (sobretudo, mas não só, em inúmeros cartazes e outras solicitações gráficas que

${ }^{88}$ A ambiência deste quadro tem prolongamento em quatro outras telas, em forma de semitondos, colocadas nas capelas do transepto. Estas representam cenas relacionadas com a história dos videntes e com a história de Fátima (na capela tumular de Francisco, os pastorinhos e o episódio da mortificação corporal através da corda e D. José Alves Correia da Silva, o bispo de Nossa Senhora, lendo o reconhecimento eclesiástico da autenticidade das Aparições; na capela do túmulo de Jacinta, o papa em oração, segundo a visão de Jacinta e a pastorinha Jacinta com as ovelhas).

${ }^{89}$ Esta última expressão encontra-se a finalizar a legenda publicada na badana da sobrecapa da Enciclopédia de Fátima. Nas palavras iniciais da mesma legenda a sobrecapa publica "a pintura de João de Sousa Araújo intitulada A Glorificação de Nossa Senhora de Fátima (Óleo, 1966, 3,00 × 4,00 m), actualmente no altar-mor da Basílica de Nossa Senhora do Rosário de Fátima". Parece-nos antes tratar-se do esboço para a tela do mesmo altar-mor e não a pintura do retábulo do altar, como as dissemelhanças ao nível das asas do anjo, do coração e do rosário da Virgem, e dos pormenores de acabamento bem elucidam. Parece-nos, inclusivamente, que tal esboço tenha sido retocado de modo a avivar alguns elementos e, quiçá, até a introduzi-los, como é o caso do coração que não se encontra figurado na tela do retábulo-mor da basílica de Fátima.

${ }^{90}$ Existe uma escultura, de pequenas dimensões, deste autor num dos espaços do Convento de São Domingos de Fátima. 
o Santuário de Fátima fez a esta pintora ${ }^{91}$, o pintor Nuno de Siqueira (1924-) na Estação do Metropolitano de Olivais, em Lisboa, ou Laureano Ribatua, na igreja de Santo António das Antas. Neste último caso, embora a designação da escultura seja Nossa Senhora do Rosário e o referido título não aluda especificamente a Fátima, trata-se indubitavelmente da iconografia de uma Senhora de Fátima à qual não falta uma silhueta contida, as mãos postas de onde pende um rosário e até a coroa, em estilização moderna.

Terminamos este percurso que pretende evidenciar o tratamento do tema "Senhora de Fátima" por artistas com a escultura encomendada a Clara Menéres (1943-) para a paróquia de Nossa Senhora da Encarnação de Olhalvo, no Patriarcado de Lisboa. Datada de 1984, parece-nos ser um bom exemplo de como o tratamento da Virgem de Fátima é feito seguindo a iconografia, mas ao mesmo tempo afastando-se dela e colocando elementos que também revelam acerca da autora.

Ainda que a escultora prescinda da alvura típica das vestimentas da Senhora de Fátima, pintando a túnica de pérola luminoso e o manto em tons de bege mate, a imagem modelada por Clara

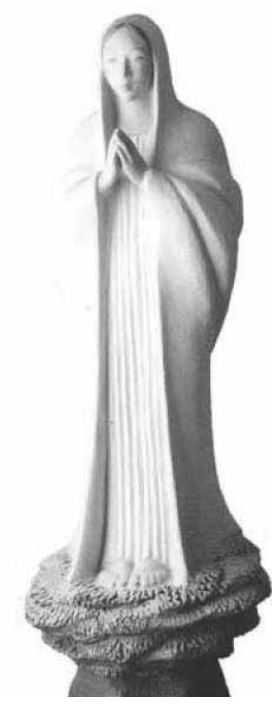

11. Escultura de Nossa Senhora de Fátima (igreja de Nossa Senhora da Encarnação, Olhalvo), de Clara Menéres, 1984 (fotografia de Mário Fonseca). Menéres transmite, também por causa da textura do manto e dos sulcos verticais do vestido, a serenidade inerente à da cor alva. Concorre igualmente para este equilíbrio a linha vertical que formam os elementos de carnação (rosto em oval, mãos em pirâmide, pés em equidistância), inscritos numa espécie de parábola muito esguia formada pela orla do manto. A finura do rosto, em amêndoa enfatizada pela silhueta do cabelo, contrasta com a dimensão da zona dos braços que toma grandeza semelhante à da base da escultura, à qual a autora conferiu cuidadosa atenção, não negligenciando outorgar vultuoso tratamento plástico ao tema da azinheira. A proporção emprestada a este elemento é bem condizente com a autora de obras como a emblemática "MulherTerraVida"92, de 1977; esta meditação sobre a importância do feminino e sobre a importância da natureza, no contexto de uma escultura cultual, ganha incomensurável valora-

${ }^{91}$ E não apenas o Santuário de Fátima, como o Movimento da Mensagem de Fátima, que lhe solicitou a bandeira processional deste movimento assim como o lettering para papel e sobrescritos daquela Associação. Veja-se a descrição que operamos no catálogo Memórias. Sinais. Afectos..., n. 461, p. 152.

92 Veja-se, na p.643, de História da Arte Portuguesa, direcção de Paulo Pereira, Lisboa, Temas e Debates, 1997, terceiro volume, de Paulo Pereira, uma reprodução deste trabalho de Clara Menéres. 
ção quando esse símbolo do feminino que é a terra se encontra associado à Mulher que, descendo do Céu, se manifesta a três crianças sobre um pavimento de verdura, na terra da Cova da Iria: a Mãe de Deus, a 'Theotokos', assim proclamada no Concílio de Éfeso, será para Clara Menéres transcendente coincidência da maternidade humana e divina. Ainda que percebamos a ausência de alguns elementos da tradição iconográfica que cremos ajudariam a entender a escultura por parte dos seus usufruidores, parece-nos que os artistas teriam na Senhora de Fátima tema de exploração que os levaria - assim o almejassem - a formas renovadas.

Provavelmente, a escultura do novo templo do Santuário de Fátima, dedicado à Santíssima Trindade, inaugura um período novo na iconografia da Virgem de Fátima. Não tanto pelas suas formas compositivas que nos parecem ter já sido utilizadas, por exemplo, por Irene Vilar em esculturas congéneres, mas sobretudo pela síntese que na escultura da igreja de Fátima se encontra reunida. Benedetto Pietrogrande, embora também não tenha sido o primeiro a utilizar ao mesmo tempo o coração de Maria e o terço do rosário como atributos de uma mesma escultura da Senhora de Fátima, fá-lo numa nova era em que há plena consciência do valor artístico do tempo presente, daí resultando uma peça que, não sendo de raiz devocional, poderá, sem abdicar dos conceitos estéticos do momento, vir a transformar-se nisso 93 .

A escultura de Pietrogrande prescinde da referência à nuvem, à azinheira, à estrela e à coroa e de qualquer apontamento de policromia ou douramento. Exibe com grande força a total brancura que sai do brilho marmóreo, um terço na mão direita, conforme a descrição da imagem da Aparição feita pelos videntes, e o coração ao centro. Parece-nos ter sido pensada a partir das descrições primevas, principalmente em relação à géstica da Aparição e menos a partir da construção da imagem da Capelinha das Aparições ao longo do tempo. A liberdade de mostrar a cabeça da Virgem Maria na totalidade não belisca em nada o pendor sacro da peça, ao mesmo tempo que a torna mais jovem e próxima da Virgem dos Evangelhos, visitada pelo Anjo em Nazaré ${ }^{44}$. A Senhora de Fátima não tem um

${ }^{93}$ Com efeito, já em esculturas anteriores podemos encontrar estes mesmos elementos iconográficos, aos quais, no caso da imagem de Nossa Senhora de Fátima da paróquia da Senhora da Conceição do Porto, da lavra do escultor França, se somam até os elementos azinheira e pombas. Trata-se, obviamente, de uma escultura mais devocional e segundo os arquétipos das imagens de santeiros, o que mais uma vez vem demonstrar o tradicional caminho de a iconografia de Fátima chegar à arte sacra contemporânea de forma muito tardia.

94 Curiosamente, esta consciência de a Virgem aparecida na Cova da Iria ser a"mesma mulher que nas Bodas de Caná e em Fátima" intercede pela humanidade encontra-se muito vincada na Oratória comemorativa dos noventa anos das Aparições: veja-se o "libreto" Fátima, Sinal de Esperança para a Humanidade [Oratória comemorativa dos 90 anos das Aparições de Fátima], Fátima, Santuário de Fátima, 2007, p. 26:“É 
12. Escultura de Nossa Senhora de Fátima (igreja da Santíssima Trindade, Santuário de Fátima), de Benedetto

Pietrogrande, e pormenor da representação de Nossa

Senhora de Fátima com os videntes, no Mosaico da Jerusalém Celeste, de Marco Ivan Rupnik, 2007 (fotografia do Arquivo do Santuário de Fátima).

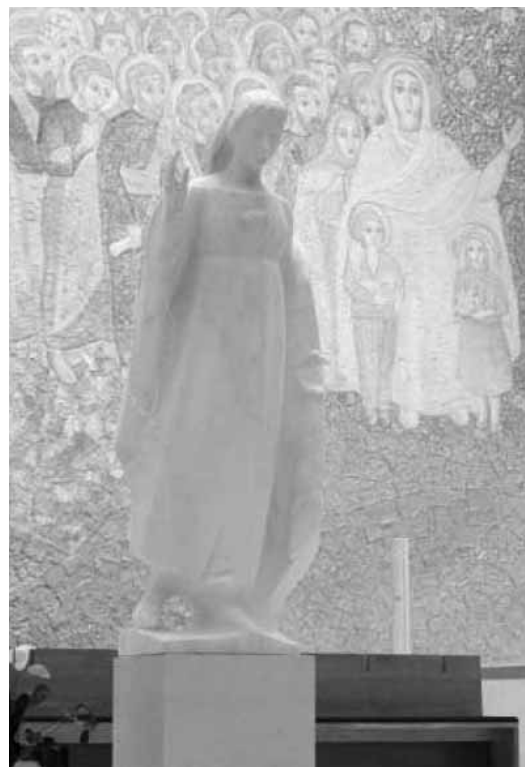

manto, mas antes um leve lenço (existente ou mesmo quase inexistente) que se confunde com o cabelo. Também este aspecto concorre para que o rosto se mostre verdadeiramente jovem, assim como o facto de a túnica, ao cimo, deixar ver parte do colo.

A opção tomada por Marko Ivan Rupnik (autor do grande mural que, composto de milhentas tesselas, no mesmo templo desenha a Jerusalém Celeste) em ordem à figuração da Virgem Maria foi bem mais tradicionalista, não obstante o conceito tradicionalista não se revele desprovido de erudição histórica, como veremos. A Senhora de Fátima traja de branco e de tons dourados, comuns a todo o painel, mas usados de forma a conferirem ao figurino mariano uma imagem de maior alvura. Encontra-se totalmente coberta por um manto que traça, à frente, à maneira das antigas figuras dos mosaicos da paleocristandade. Completamente agasalhada com as vestes que também acolhem, à maneira da iconografia da 'Mater Misericordiae', os dois beatos, toca no pastorinho Francisco com a mão direita, acentuando a ideia de protecção. A esquerda deve ser lida como indicadora do caminho a seguir, transformando a Virgem de Fátima em 'Hodegetria' (aquela que, como nos antigos 
ícones, indica a via a seguir) ${ }^{95}$. A imagem integra-se no contexto de uma 'Déeisis' constituída pela figura de João Baptista, no lado oposto, e pela imagem de um enorme cordeiro subtilmente desenhado entre o muito brilho aurífero das tesselas centrais ${ }^{96}$. A sobreposição simbólica de uma colossal cruz ao símbolo do cordeiro vem clarificar esse caminho indicado quer pela Senhora de Fátima, quer por João Baptista.

Ao contrário desta versão da Virgem de Fátima - que não ostenta rosário (este aparece nas mãos da vidente Lúcia, aqui figurada enquanto religiosa carmelita) -, a escultura de Benedetto Pietrogrande tem um vigoroso rosário, porventura a parte mais rude da escultura que, na sua geral atmosfera, se mostra bastante delicada. As mãos, que estarão relacionadas com a descrição que alude ao facto de a Senhora aparecida "abrir as mãos"97, desenham uma via ascensional típica das esculturas sagradas ${ }^{98}$ : ambas as mãos viram as palmas a quem para elas olha, a esquerda dirige-se à terra e a direita ergue-se ao céu, podendo traçar-se, intuitivamente, uma linha que se inicia na sinistra e se encaminha ao alto, tendo como ápice a mão dextra que aponta e, ao mesmo tempo, intercede em gesto antigo de oração (palma virada para a frente e dedos esticados ao alto ${ }^{99}$ ). A fórmula de assentar os pés na base sugere movimento que é acentuado por todas as pregas, vincos e

95 Não desenvolvemos o tema das figurações orientalizantes da Senhora de Fátima que tem um ponto importante no Ícone da Santa Mãe de Deus de Fátima, da igreja de Tsarskoe Selo (Pushkin-São Petersburgo), criado pelo ortodoxo russo Ivan Lvovich com a intervenção do Padre Aleksandr Burgos. Existe uma reprodução deste ícone no Santuário de Fátima, oferecida em Maio de 2007 (de Voz da Fátima, ano 85, n. $1018,2007.07 .13$, p. 2).

96 De tal forma era subtil, que não tardou a acentuação da cor deste cordeiro que, depois de alguns meses da inauguração, passou a vestir de branco.

97 Veja-se a documentação que a seguir se regista: "mãos erguidas e quando falava alargava os braços e mãos abertas" (DCF I, doc. 1, p. 8); "tinha as mãos erguidas" (doc. 2, p. 12);“mãos erguidas á cintura e abriam separando-as quando falava [...] umas contas brancas nas mãos seguras entre o dedo polegar e indicador" (doc. 3, p. 16); "as mãos estão postassobre o peito, com os dedos voltados para cima" (doc. 7, p. 50);"Tinha as mãos erguidas. Ás vezes tem as palmas voltadas para o céu" (doc. 11, p. 92); “[...] A Senhora apontou com o dedo para a banda onde está o sol” (doc. 16, p. 153); “Tinha as mãos postas, um pouco acima da cintura e d'ellas pendia um terço branco. Todas as vezes que fallava, separava as mãos, pouco mais ou menos, á distancia dos hombros" (doc. 31, pp. 257-258); "[...] trazia umas contas muito branquinhas penduradas nas mãos, que tinha erguidas á cintura, e que separava uma da outra, pouco mais ou menos á largura dos hombros, quando fallava á Lucia" (doc. 31, p. 269). É curioso que não se encontrem presentes as reflexões tidas pela Ir. Lúcia no respeitante ao Imaculado Coração de Maria (veja-se o que dizemos no ponto acerca dos esboços guardados nas Reservas do Museu do Santuário de Fátima), como bem se notam na posição das mãos da escultura da igreja da Senhora da Conceição do Porto.

${ }_{98}$ Realmente é um gesto muito frequente. Dizemos algo sobre o mesmo no estudo O Vitral da Ressurreição da Igreja de São José de Coimbra. Exegese iconográfica da última obra de Augusto Nunes Pereira, Coimbra, Gráfica de Coimbra, 2004, p. 162, a propósito do gesto da figura de Cristo Ressuscitado.

99 Posição das figuras orantes da arte paleocristã, aqui apenas visível na mão direita da escultura. A escultura que atrás citámos de Irene Vilar, feita para uma praça de Alcochete, tem as mãos com a mesma ideia, mas inversa- 
golpes de incisão que o cinzel cravou na escultura. A ligeira inclinação do vulto escultórico para a frente, esquema compositivo que deriva já, como vimos, da primitiva imagem elaborada por José Ferreira Thedim, sublinha esse movimento perceptível de todos os ângulos da peça. O manto, sobretudo na parte direita de quem observa, desprende-se do corpo da Virgem que enverga uma túnica com a cintura subida ligeiramente plissada. Sobre o peito esculpe-se um coração que parece transbordar do corpo da Virgem ${ }^{100}$.

A fortuna desta escultura virá a ser medida através de variados aspectos, sendo um dos mais importantes a sua sorte enquanto imagem cultual e bem assim a sua sorte enquanto peça artística. Vingará como imagem de culto? Perdurará enquanto peça escultórica, criando novas formas de ideação artístico-iconográfica em torno da Virgem de Fátima? Acreditamos que Fátima, longe de se encontrar cabalmente desenhada, continuará a ser motor de iconografias ciclicamente renovadas.

\section{Apêndice documental ${ }^{101}$}

\section{A Maravilhosa Imagem}

Ante essa maravilha de escultura

A alma fica em êxtase a sentir

Emoções que não podem definir

Tão sobrehumana e excelsa formosura.

Em forma de grácil iluminura

Do bloco de madeira a emergir

mente colocadas: a esquerda mais ao alto e a direita dirigida ao solo e deixando cair um fino e longo rosário como se de grãos de areia se constituísse (veja-se o que dizemos em Memórias. Sinais. Afectos..., p. 161).

${ }^{100}$ A solução, sendo próxima da que utilizou em 1993 Irene Vilar na estátua de Alcochete (veja-se Memórias. Sinais. Afectos..., p. 161), revela-se mais ostensiva, porquanto Pietrogrande faz um alto-relevo e Irene Vilar uma subtil incisão.

${ }^{101}$ Transcrevem-se, na íntegra, os dois sonetos de Maria Feio sobre a escultura "Nossa Senhora de Fátima", de António Teixeira Lopes, datada de 1931. Trata-se de dois textos insertos num pequeno opúsculo à maneira de pagela, de quatro páginas, com as dimensões de $7 \times 12 \mathrm{~cm}$. Apesar de as composições se referirem à escultura criada por Teixeira Lopes, a capa da pequena pagela tem como imagem a escultura da Capelinha das Aparições, criada por José Ferreira Thedim em 1920. Numa espécie de explicação introdutória, lê-se: "Estes sonetos fôram feitos em expontanea inspiração no dia 13 de Julho de 1931, na Foz do Douro, após a visita ao atelier de Teixeira Lopes[,] Artista a quem ofereço a singela homenagem da mais profunda admiração. Maria Feyo". Existe um exemplar na Biblioteca do Santuário de Fátima com a cota FCx 1931.09. 
É tão alado vulto o reflorir

Da Fé que no amôr cristão perdura.

E cada golpe do buril do artista

É genial centelha em que persista

Um sopro da divina inspiração.

Que a Virgem canta em nova ladainha

E reza o poema da "Salve Rainha"

No cinzelar da Arte em Oração.

A Nova Aparição

E“Tôrre Ebúrnea”,“Estrêla Matutina”

É a celeste Imagem bem decerto

Um milagre do céu, um livro aberto

Á virtude que as almas ilumina

Nimbada em luz etérea, cristalina,

As mãos crispadas em ancioso aperto,

Ela é a Mãe que os filhos quer bem perto

Do peito envolto em gazes de neblina.

Que vem dizer-lhes, "vosso amor imploro,

Como por vós padeço e quanto choro,

Ó ímpios pecadores sem devoção."

Por isso a obra prima de escultura

É na fluidez de angélica ternura

Uma sublime e Nova Aparição.

Maria Feio 


\section{Autores}

\section{Ana Paula Rebelo Correia}

Doutorada em História da Arte pela Université Catholique de Louvain, onde fez igualmente a Agregação em Metodologia das Artes Plásticas, é docente na Escola Superior de Artes Decorativas da Fundação Ricardo Espírito Santo Silva. Colaborou com a Fundação Calouste Gulbenkian na exposição A Arte Efémera em Portugal (1999/2000). Foi responsável pelo Inventário temático"Azulejo" e pelo Tesauro de Iconografia e de Azulejaria na Direcção-Geral dos Edifícios e Monumentos Nacionais (2000/2006). Como investigadora, tem estudado sobretudo a temática mitológica na azulejaria barroca. É autora de diversos estudos na área da iconografia e fontes de inspiração do azulejo português, destacando-se "Um retrato real nos jardins do Palácio Fronteira", in Revista Monumentos, n. ${ }^{\circ} 25$, Setembro de 2006; "Mitologia greco-romana nos azulejos da Casa Museu Verdades Faria" in Revista de História da Arte, n. ${ }^{\circ} 3,2007$, Instituto de História da Arte da Faculdade de Ciências Sociais e Humanas - UNL; “As metamorfoses de Ovídio na azulejaria barroca portuguesa", in Ovídio, exílio e poesia, Centro de Estudos Clássicos da Faculdade de Letras de Lisboa, 2008.

\section{António Filipe Pimentel}

Licenciado em História, variante de História da Arte, em 1985, na Faculdade de Letras da Universidade de Coimbra, obteve também aí o grau de mestre em História Cultural e Política da Época Moderna, em 1991, com a dissertação intitulada Arquitectura e Poder: o Real Edifício de Mafra, galardoada com o Prémio Gulbenkian de História da Arte 1992/04 e há muito editada; prestou provas de doutoramento em 2002, com a dissertação A Morada da Sabedoria. I - O Paço Real de Coimbra:das origens ao estabelecimento da Universidade, publicada em 2005. Desde 1986 que é professor do respectivo Instituto de História da Arte, de que é também, presentemente, Director, exercendo igualmente, desde 2007, as funções de Pró-Reitor da Universidade para o Património. O seu trabalho tem incidido, fundamentalmente, sobre a arte barroca portuguesa, em diversos domínios, mas o seu interesse pelos mecanismos de representação do poder levou-o a centrar os seus estudos no âmbito da arquitectura áulica e palaciana (como obra-de-arte-total), que tem procurado delimitar enquanto área científica, que projecta para uma necessária diacronia, ao mesmo tempo que impõe uma nova metodologia, necessariamente transversal, no que respeita ao modo de fazer História da Arte. Académico correspondente nacional da 
Academia Nacional de Belas Artes, membro da Sociedade Científica da Universidade Católica Portuguesa e membro permanente do Júri do Prémio Dr. Vasco Valente de artes decorativas e do Círculo Dr. José de Figueiredo do Museu Nacional de Soares dos Reis (Porto), conta com mais de meia centena de trabalhos publicados, a grande maioria em prestigiadas publicações científicas nacionais e estrangeiras ou catálogos de exposições, em Espanha, França, Inglaterra, Bélgica, Alemanha, Polónia, Eslováquia, Eslovénia e Brasil.

\section{Artur Goulart de Melo Borges}

Licenciado em Arqueologia. Estudos de pós-graduação em Museologia e História da Arte. Curso Superior de Teologia. Curso Superior Livre de Estudos Árabes. Técnico superior do Museu de Évora de 1979 a 1999, exercendo o cargo de director durante sete anos. Nesse âmbito, trabalhos de inventariação, investigação, elaboração de pareceres na área da museologia e do acervo artístico do Museu de Évora. Organização de exposições, participação em congressos, seminários e publicações sobre estudos árabes, património artístico e cultural. Vogal da Comissão Diocesana dos Bens Culturais da Igreja, da Arquidiocese de Évora e, desde Março de 2002, coordenador do Inventário do Património Artístico Móvel da Arquidiocese de Évora, tendo sido comissário da exposição "Tesouros de Arte e Devoção", de Dezembro 2003 a Maio de 2004.

\section{Carlos A. Moreira Azevedo}

Bispo Auxiliar de Lisboa. Director da Escola das Artes (Ext. Lisboa) da Universidade Católica Portuguesa. Professor Associado da Faculdade de Teologia da UCP. Doutor em História Eclesiástica pela Faculdade de História Eclesiástica da Universidade Gregoriana de Roma. Investigador e comissário de exposições, é autor de inúmeras publicações nos domínios da História Religiosa, Arte Sacra, Património e Iconografia.

\section{Joana Ramôa}

Licenciada em História da Arte pela Faculdade de Ciências Sociais e Humanas da Universidade Nova de Lisboa, em 2005, é Mestre em História da Arte Medieval, pela mesma Faculdade, com a Tese de Mestrado A Iconografia do Calvário na Escultura Tumular Medieval Portuguesa (sécs. XII $a$ XV). Bolseira da Fundação para a Ciência e a Tecnologia no Projecto de Investigação IMAGO, sediado na Faculdade de Ciências Sociais e Humanas da Universidade Nova de Lisboa e destinado à criação de uma base de dados de iconografia medieval portuguesa. Contratada no ano lectivo de 2007-2008 para leccionar as cadeiras de História da Arte Manuelina e História da Arte Românica e Gótica em Portugal, da licenciatura de História da Arte da Faculdade de Ciências Sociais e Humanas da Universidade Nova de Lisboa. Os seus trabalhos de investigação dirigidos para a arte medieval concretizaram-se na publicação dos artigos: "Arte Moçárabe. 
O estado da questão", Revista de História da Arte, Instituto de História da Arte - Faculdade de Ciências Sociais e Humanas da Universidade Nova de Lisboa, n. ${ }^{\circ} 3$, pp. 305-323; “Projecto Imago", Revista de História da Arte, Instituto de História da Arte - Faculdade de Ciências Sociais e Humanas da Universidade Nova de Lisboa, n. 3, pp. 324-326; "Recensão Crítica - Michael Camille, Le Monde gothique, Paris, Flammarion, 1996", Medievalista online, Instituto de Estudos

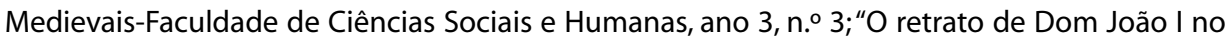
Mosteiro de Santa Maria da Vitória na Batalha", Revista de História da Arte, Instituto de História da Arte - Faculdade de Ciências Sociais e Humanas da Universidade Nova de Lisboa, n. 5 (no prelo);"Recensão Crítica - Alexandra Barradas, Ourém e Porto de Mós. A obra mecenática de D. Afonso, $4 .{ }^{\circ}$ conde de Ourém, Lisboa, Edições Colibri, Dezembro de 2006", Revista de História da Arte, Instituto de História da Arte - Faculdade de Ciências Sociais e Humanas da Universidade Nova de Lisboa, n. 5 (no prelo).

\section{Mons. João Gonçalves Gaspar}

Vigário-geral e ecónomo da Diocese de Aveiro.Delegado episcopal para os presbíteros. Membro da Comissão dos Bens Culturais da Igreja da Diocese de Aveiro.

\section{Joaquim Oliveira Caetano}

Historiador da Arte. Director do Museu de Évora. Assistente da Universidade de Évora. Publica regularmente sobre História da Arte Portuguesa desde 1985. Foi comissário de várias exposições em Portugal e Espanha.

\section{José Carlos Meneses Rodrigues}

Doutor em História da Arte pela Faculdade de Letras da Universidade do Porto. Docente no Instituto de Estudos Superiores de Fafe. Membro da direcção da Associação Portuguesa de Historiadores da Arte (APHA). Investigador do CEPESE (Universidade do Porto). Destacam-se entre as suas principais publicações: (2007) Artistas e Artífices no Baixo Tâmega e no Vale do Sousa (Séculos XVII-XIX), in Actas do VII Colóquio Luso-Brasileiro de História da Arte, Maia, FLUP; (2001), A Talha Nacional e Joanina em Marco de Canaveses, 2 vols., Santa Maria da Feira, Câmara Municipal do Marco de Canaveses; (2001), O Concelho de Santa Cruz de Ribatâmega nos Séculos XVIII e XIX, in Amarante Congresso Histórico, Actas, Amarante, Câmara Municipal.

\section{Luís Alberto Casimiro}

É licenciado em Artes Plásticas-Pintura, e doutorado em História da Arte pela FLUP.Desde 1998 que participa em encontros de natureza científica, registando publicações em actas e revistas da especialidade. Fez a inventariação e estudo das pinturas dos Museus Pio XII e da Sé de Braga. É sócio da Associação Portuguesa de Historiadores da Arte, do Centro de Estudos da População, 
Economia e Sociedade, unidade de investigação da Universidade do Porto e membro direcção do Círculo Dr. José de Figueiredo (M. N. Soares dos Reis). Actualmente desenvolve investigação de pós-doutoramento, como bolseiro da FCT.

\section{Luís Urbano Afonso}

Doutorado em História (2006), especialização em História da Arte, pela Universidade de Lisboa com a tese A Pintura Mural Portuguesa entre o Gótico Internacional e o Fim do Renascimento: Formas, Significados, Funções. Mestre em História da Arte (1999) pela Faculdade de Ciências Sociais e Humanas da Universidade Nova de Lisboa com a dissertação As Pinturas Murais da Igreja do Convento de São Francisco de Leiria. Licenciado em História (1995), variante em História da Arte, pela FLUL. Docente do Departamento de História, área de História da Arte, da Faculdade de Letras da Universidade de Lisboa desde Outubro de 1997 até ao presente. Livros publicados: L. Afonso e V. Serrão (eds.), 2007. Out of the Stream: studies in Medieval and Renaissance mural painting, Newcastle, Cambridge Scholars Publishing. L. U. Afonso, 2003. O Ser e o Tempo. As idades do homem no gótico português, Casal de Cambra, Caleidoscópio. Idem, 2003. Convento de S. Francisco de Leiria. Estudo monográfico, Lisboa, Livros Horizonte. Artigos recentes: (com A. J. Cruz) "On the date and contents of a Portuguese medieval technical book on illumination: O livro de como se fazem as cores", in The Medieval History Journal, vol. 11, n. 1, 2008. "Uma nota sobre as 'fremosas donzellas' do Livro da Vertuosa Benfeytoria", in eHumanista. Journal of Iberian Studies, vol. 8, 2007, pp. 106-116 (http://www.spanport.ucsb.edu/projects/ ehumanista/volumes/volume_08/ index.shtml); “Life's circle: some notes on two Portuguese Gothic tombs", in B. Borngässer, H. Karge e B. Klein (eds.), Grabkunst und Sepulkralkultur in Spanien und Portugal, Frankfurt, Vervuert, 2006, pp. 193-205; "Propaganda institucional beneditina e meta-narrativa cristã nos frescos de Pombeiro", in Estudos/Património, n. ${ }^{\circ}$ 8, 2005, pp. 37-45. Cargos em publicações científicas: membro do Conselho de Redacção da revista Goya, desde 2007; membro do International Advisory Board da revista South African Journal of Art History, desde 2006; membro do Conselho de Redacção da revista Artis, desde 2002.

\section{Manuel Batoréo}

Doutorado em História da Arte. Professor Jubilado da Faculdade de Letras de Lisboa. Especializou-se no estudo da pintura portuguesa do Renascimento, tema que tem sido tratado em diversos artigos e intervenções em congressos, e também no estudo das obras dessa época com o apoio de métodos laboratoriais. É autor de Pintura do Renascimento Português. O Mestre da Lourinhã (Prémio José de Figueiredo 2005, da Academia Nacional de Belas Artes). Foi coordenador da obra colectiva A Pintura e os Pintores da Igreja da Misericórdia da Lourinhã. Doutorou-se com a tese A Gravura na Pintura Portuguesa do Renascimento, c. 1500-c. 1540, com publicação em estudo em edição inglesa. Actualmente desenvolve o Estudo do desenho 
subjacente nos painéis do antigo retábulo da Igreja do Convento de Jesus de Setúbal (Execução e apreciação dos exames a infravermelhos) e prepara um pós-doutoramento na Faculdade de Belas-Artes de Lisboa subordinado ao tema Os Fundos de Paisagem na Pintura Portuguesa em Tempo de Descobrimentos. Simbolismo e Técnica das Composições, da sua Flora e da sua Fauna (c. 1500-c. 1540).

\section{Marco Daniel Duarte}

Bolseiro da Universidade de Coimbra, encontra-se a finalizar doutoramento em História da Arte sobre o Santuário de Fátima enquanto complexo artístico de fé. Director do Departamento de Arte e Património do Museu do Santuário de Fátima. É autor de vários estudos publicados em revistas científicas e de cinco trabalhos editados em livro. Pertence à Academia Portuguesa da História, como Académico Correspondente, é sócio efectivo da Associação Portuguesa de Historiadores da Arte e colaborador do Centro de Estudos Interdisciplinares do Século XX da Universidade de Coimbra. Comissariou a exposição “Memórias. Sinais. Afectos. Nos 90 anos das Aparições de Fátima" (Patriarcado de Lisboa, Outubro de 2007 - Janeiro de 2008).

\section{Maria Cristina Osswald}

Licenciada e mestre em História de Arte pela Faculdade de Letras da Universidade do Porto, e Phd pelo Instituto Universitário Europeu de Florença (2003) com uma tese acerca da Arte da Companhia de Jesus em Goa (séculos XVI-XVII). Pós-doutoranda na Universidade do Minho, UNED (Madrid) e UNICAMP (Brasil). Investigadora do Centro Interuniversitário de História da Espiritualidade da Universidade do Porto. As suas publicações e apresentações centram-se na hagiografia e iconografia da Companhia de Jesus, em questões relativas ao orientalismo e ainda na cultura material da Época Moderna. Presentemente, encontra-se a preparar um livro sobre o ciclo de pinturas do tecto do antigo colégio da Companhia de Jesus em Braga.

\section{Maria Fernanda Enes}

Investigadora do Centro de História da Cultura da Universidade Nova de Lisboa (CHC/UNL). Professora associada da Faculdade de Ciências Sociais e Humanas da Universidade Nova de Lisboa (FCSH/UNL), onde tem leccionado nos Departamentos de Filosofia e de Estudos Políticos. Doutora em História e Teoria das Ideias.

\section{Nuno Saldanha}

Professor da Escola Superior de Design (IADE). Doutorado em História da Arte pela FCH/UCP, mestre em História das Ideias Estéticas, pela FCSH/UNL e licenciado em História - variante História da Arte pela FL/UL. Investigador e historiador da Arte e das Ideias, tem várias obras publicadas e artigos em diversas revistas, catálogos e dicionários, nomeadamente sobre 
História da Arte, Iconografia, Crítica e Teoria da Arte (sécs. XVIII a XX), e tem participado em diversas conferências nacionais e internacionais. Foi investigador e membro da Comissão Científica do Centro de História da Cultura (UNL), é Académico Correspondente da Academia Nacional de Belas Artes e membro da UNIDCOM/IADE. Na área museológica, desempenhou funções de director da Galeria de Pintura Rei D. Luís no Palácio Nacional da Ajuda, consultor da Direcção do Museu da Fundação Ricardo do Espírito Santo Silva e director da Casa-Museu dos Patudos, Alpiarça. Foi Comissário de várias exposições, entre as quais: Da Utilidade do Desenho (BNL); Giovanni Battista Piranesi (Galeria Rei D. Luís); Joanni V Magnifico - A Pintura em Portugal ao tempo de D. João V - 1706-1750 (Galeria Rei D. Luís); Jean Pillement 1728--1808 (FRESS); Carlos de Haes 1826/1898, Casa-Museu dos Patudos, Alpiarça, 2000; Memórias de Viagem - Um olhar Europeu sobre o Portugal do século XVIII, Palácio Foz, Lisboa, 2000; José Malhoa - Na colecção de José Relvas, Casa-Museu dos Patudos, Alpiarça, 2001. 


\section{Authors}

\section{Ana Paula Rebelo Correia}

$\mathrm{PhD}$ in the History of Art from the Universite Catholique de Louvain, where she also did her Aggregation in the Methodology of Plastic Arts. She is a member of the teaching staff of the Escola Superior de Artes Decorativas at the Fundação Ricardo Espírito Santo Silva. She collaborated with the Calouste Gulbenkian Foundation on the exhibition A Arte Efémera em Portugal (Ephemeral Art in Portugal - 1999/2000). She was responsible for the thematic inventory "Azulejo" and for the Thesaurus of Iconography and Tiles for the Directorate-General of National Buildings and Monuments (2000/2006). As a researcher she has mainly studied mythological themes in baroque tiles. She is the author of various studies in the area of iconography and the sources of inspiration for the Portuguese tile, with the following being of particular note: "Um retrato real nos jardins do Palácio Fronteira", (A royal portrait in the Palácio Fronteira gardens) in Revista Monumentos, No. 25, September 2006; "Mitologia greco-romana nos azulejos da Casa Museu Verdades Faria" (Graeco-Roman mythology in the tiles of the Verdades Faria House-Museum), in Revista de História da Arte, No. 3, 2007, Instituto de História da Arte of the Faculdade de Ciências Sociais e Humanas - UNL; "As Metamorfoses de Ovídio na azulejaria barroca portuguesa" (Ovid's Metamorphoses in Portuguese baroque tiles), in Ovídio, exílio e poesi (Ovid, exile and poetry), Centro de Estudos Clássicos of the Faculdade de Letras de Lisboa, 2008.

\section{António Filipe Pimentel}

Graduate in History, in the area of the History of Art in 1985 at the Faculdade de Letras of the Universidade de Coimbra, where he also earned a Master's degree in Cultural and Political History of the Modern Era in 1991 with a dissertation entitled Arquitectura e Poder: o Real Edifício de Mafra, (Architecture and Power, the Royal Mafra Building), awarded the 1992/94 Gulbenkian Prize for the History of Art. He submitted his doctoral work in 2002, with the dissertation A Morada da Sabedoria. I - O Paço Real de Coimbra:das origens ao estabelecimento da Universidade (The House of Wisdom. I - The Royal Palace of Coimbra: from its origins to the foundation of the University), published in 2005. He has been a Professor at the respective Institute of Art History since 1986, of which he is also currently Dean, as well as carrying out the duties of a Pro-Rector of the University, being responsible for Patrimony. His work has mainly been concentrated on Portuguese baroque art, in various domains, but his interest in the mechanisms of the representations of 
power would lead him to centre his studies on noble and palatial architecture (as a total-workof-art), which he has sought to delimit as an academic area, which projects towards a necessary diachrony, whilst at the same time establishing a new, necessarily cross-disciplinary methodology, regarding the way in which the History of Art should be carried out. He is a national academic correspondent for the National Academy of Fine Arts, a member of the Academic Committee of the Portuguese Catholic University and a permanent member of the jury which awards the Dr. Vasco Valente Prize for decorative arts, for the Círculo Dr. José de Figueiredo of the Soares dos Reis National Museum. He has published more than fifty published articles, mostly in prestigious national and international journals or in exhibition catalogues in Spain, France, England, Belgium, Germany, Poland . Slovakia, Slovenia and Brazil.

\section{Artur Goulart de Melo Borges}

Graduate in Archaeology. Postgraduate studies in Museology and the History of Art. Higher Educational Course in Theology. Optional Higher Educational Course in Arab Studies. Graduate Technician at the Museum of Évora from 1979 to 1999, including the post of director for seven years. This has involved carrying out an inventory, research, the drawing up of protocols in the area of museology and the artistic archive of the Museum of Évora. Organization of exhibitions, participation in conferences, seminars and publications on Arab studies and artistic and cultural heritage. Member of the Diocesan Committee for the Cultural Heritage of the Church, of the Archdiocese of Évora and, since March 2002, coordinator of the Inventory of the Moveable Artistic Patrimony of the Archdiocese of Évora, having been the commissioner of the exhibition "Tesouros de Arte e Devoção" (Treasures of Art and Devotion), from December 2003 to May 2004.

\section{Carlos A. Moreira Azevedo}

Auxiliary Bishop of Lisbon. Dean of the School of the Arts (Lisbon campus) of the Universidade Católica Portuguesa. Associate Professor of the Faculdade de Teologia at UCP. Ph.D. in Ecclesiastical History from the Faculty of Ecclesiastical History of the Gregorian University in Rome. Researcher and exhibition commissioner, he is the author of numerous publications in the fields of Religious History, Religious Art, Heritage and Iconography.

\section{Joana Ramôa}

BA in the History of Art from the Faculdade de Ciências Sociais e Humanas of the Universidade Nova de Lisboa in 2005, and an MA in the History of Medieval Art from the same Faculty, with a Master's thesis on A Iconografia do Calvário na Escultura Tumular Medieval Portuguesa (sécs. XII $a X V$ ). (The Iconography of Calvary on Portuguese Medieval Tumular Sculpture, $12^{\text {th }}$ to the $15^{\text {th }}$ Century).Scholarship Holder for the Portuguese Foundation for Science and Technology IMAGO Research Project, based at the Faculdade de Ciências Sociais e Humanas of the Universidade Nova 
de Lisboa designed to create a database of Portuguese medieval iconography. She was contracted in the 2007/2008 academic year to teach the subjects History of Manueline Art and the History of Romanesque and Gothic Art in Portugal on the degree course in the History of Art at the Faculdade de Ciências Sociais e Humanas of the Universidade Nova de Lisboa. Her research work on medieval art has led to the publication of the following articles: "Arte Moçárabe. O estado da questão" (Mozarab Art. The current state of affairs), Revista de História da Arte, Instituto de História da Arte - Faculdade de Ciências Sociais e Humanas of the Universidade Nova de Lisboa, No. 3, pp. 305-323;"Projecto Imago", Revista de História da Arte, Instituto de História da Arte - Faculdade de Ciências Sociais e Humanas of the Universidade Nova de Lisboa, No. 3, pp. 324-326; "Critical Review- Michael Camille, Le monde gothique, Paris, Flammarion, 1996", Medievalista online, Instituto de Estudos Medievais-Faculdade de Ciências Sociais e Humanas, ano 3, No. 3; “O retrato de Dom João I no Mosteiro de Santa Maria da Vitória na Batalha", (The portrait of Dom João I in the Monastery of Santa Maria da Vitória in Batalha), Revista de História da Arte, Instituto de História da Arte - Faculdade de Ciências Sociais e Humanas da Universidade Nova de Lisboa, No. 5 (in press);"Critical Review- Alexandra Barradas, Ourém e Porto de Mós. A obra mecenática de D. Afonso, 4 conde de Ourém (The patronage work of D. Afonso, 4th Earl of Ourém), Lisbon, Edições Colibri, December 2006, Revista de História da Arte, Instituto de História da Arte - Faculdade de Ciências Sociais e Humanas da Universidade Nova de Lisboa, No. 5 (in press).

\section{Msgr. João Gonçalves Gaspar}

Vicar General and administrator of the Diocese of Aveiro. Episcopal delegate for the priests. Member of the Committee for the Cultural Heritage of the Church for the Diocese of Aveiro.

\section{Joaquim Oliveira Caetano}

Art Historian Director of the Évora Museum. Junior Lecturer at the Universidade de Évora. He has published regularly on Portuguese Art History since 1985. He has been the commissioner of several exhibitions in Portugal and Spain.

\section{José Carlos Meneses Rodrigues}

$\mathrm{PhD}$ in the History of Art from the Faculdade de Letras of the Universidade do Porto. Member of the academic staff of the Instituto de Estudos Superiores de Fafe. Member of the Managing Board of the Portuguese Association of Art Historians (APHA). Researcher at CEPESE (University of Porto). Prominent among his major publications: (2007) Artistas e Artífices no Baixo Tâmega e no Vale do Sousa (Séculos XVII-XIX). (Artists and Artisans of the Baixa Tâmega and the Vale do Sousa) $\left(17^{\text {th }}-19^{\text {th }}\right.$ Centuries), in Actas do VII Colóquio Luso-Brasileiro de História da Arte, Maia, FLUP; (2001), A Talha Nacional e Joanina em Marco de Canaveses (National Carving and Joanina in Marco de Canaveses), 2 vols., Santa Maria da Feira, Câmara Municipal do Marco de Canaveses; (2001) 
, O Concelho de Santa Cruz de Ribatâmega nos Séculos XVIII e XIX (The Council of Santa Cruz de Ribatâmega in the eighteenth and nineteenth Centuries), Amarante Historical Conference. Proceedings, Amarante, Town Hall.

\section{Luís Alberto Casimiro}

Luís Alberto Casimiro is a graduate in Plastic Arts - Painting, and has a PhD in the History of Art from FLUP. Since 1998 he has participated in academic meetings and has published in specialist journals and collected proceedings. He carried out the inventory and study of the paintings at the Pio XII Museum and Braga Cathedral. He is a member of the Portuguese Association of Art Historians, of the Centre for the Studies of Population, Economics and Society, a research unit of the University of Porto and a member of the board of the Círculo Dr. José de Figueiredo (M. N. Soares dos Reis). He is currently carrying out post-doctoral work with a scholarship from FCT.

\section{Luís Urbano Afonso}

Ph.D. in History (2006), specialization in the History of Art from the Universidade de Lisboa with the thesis 'Portuguese Mural Painting between the International Gothic and the End of the Renaissance. Forms, Meanings, Roles.' (A Pintura Mural Portuguesa entre o Gótico Internacional e o Fim do Renascimento). Formas, Significados, Funções. Master's in the History of Art (1999) from the Faculdade de Ciências Sociais e Humanas of the Universidade Nova de Lisboa with a dissertation on the Mural Paintings of the Church of the Convent of St. Francis in Leiria. B.A. in History (1995), in the area of the History of Art, from FLUL. Member of the academic staff of the Department of History, History of Art area, of the Faculdade de Letras of the Universidade de Lisboa from October 1997 to the present. Books published: L. Afonso and V. Serrao (eds.), 2007. Out of the Stream: studies in Medieval and Renaissance mural painting, Newcastle, Cambridge Scholars Publishing. L. U. Afonso, 2003. O Ser e o Tempo. As idades do homem no gótico português (Being and Time. The ages of man in the Portuguese Gothic), Casal de Cambra, Caleidoscópio. Idem, 2003. Convento de S. Francisco de Leiria. Estudo monográfico (The Convent of Saint Francis of Leiria. Monographic study), Lisbon, Livros Horizonte. Recent articles: (with A. J. Cruz) "On the date and contents of a Portuguese medieval technical book on illumination: O livro de como se fazem as cores", in The Medieval History Journal, vol. 11, n. 1, 2008. “Uma nota sobre as «fremosas donzellas» do Livro da Vertuosa Benfeytoria", in eHumanista. Journal of Iberian Studies, vol. 8, 2007, pp. 106-116 (http://www. spanport.ucsb.edu/projects/ehumanista/volumes/volume_08/ index.shtml). “Life's circle: some notes on two Portuguese Gothic tombs", in B. Borngässer, H. Karge e B. Klein (eds.), Grabkunst und Sepulkralkultur in Spanien und Portugal, Frankfurt, Vervuert, 2006, pp. 193-205. "Propaganda institucional beneditina e meta-narrativa cristã nos frescos de Pombeiro" (Institutional Benedictine Propaganda and Christian meta-narrative in the frescoes of Pombeiro), in Estudos/Património, $\mathrm{n}^{\circ}$ 8, 2005, pp. 37-45. Posts in academic publications: member of the Editorial Board of the journal 
Goya since 2007; member of the International Advisory Board of the journal South African Journal of Art History since 2006; member of the Editorial Board of the journal Artis since 2002.

\section{Manuel Batoréo}

$\mathrm{PhD}$ in the History of Art. Professor Emeritus at the Faculdade de Letras de Lisboa. He has specialised in the study of Portuguese Renaissance painting, a topic which he has written about in various papers and presented at various conferences, as well as the study of works of this period using laboratory techniques. He is the author of Pintura do Renascimento Português. O Mestre da Lourinhã (Painting from the Portuguese Renaissance. The Maestro of Lourinhã) (2005 José de Figueiredo Prize, of the National Academy of Fine Arts). He was the coordinator of the joint work $A$ pintura e os Pintores da Igreja da Misericórdia da Lourinhã. (The painting and Painters of the Church of Misericórdia of Lourinhã). He obtained his doctorate with the thesis A Gravura na Pintura Portuguesa do Renascimento (Engraving in Portuguese Painting of the Renaissance) c. 1500-c. 1540, and has published an English version of the study. He is currently developing the Estudo do desenho subjacente nos painéis do antigo retábulo da Igreja do Convento de Jesus de Setúbal (The Study of the underlying design in the panels of the former Church of the Convent of Jesus in Setúbal). (Carrying out the project and analysis of the infra-red examinations) and preparing post-doctoral work at the Faculdade de Belas-Artes de Lisboa on the theme Os Fundos de Paisagem na Pintura Portuguesa em Tempo de Descobrimentos. Simbolismo e Técnica das Composições, da sua Flora e da sua Fauna (The landscape backgrounds in Portuguese Painting at the Time of the Discoveries. Symbolism and Composition Techniques of their Flora and Fauna) (c. 1500-c. 1540).

\section{Marco Daniel Duarte}

Scholarship holder from the University of Coimbra, he is finishing off his $\mathrm{PhD}$ studies in the History of Art on the theme of the sanctuary at Fátima as an artistic complex of faith. He is the Director of the Department of Art and Heritage of the Museum of the Sanctuary at Fátima. He is the author of various studies published in academic journals and five published books. He belongs to the Portuguese Academy of History, as an Academic Correspondent, is a Life Member of the Portuguese Association for Art Historians and a collaborator at the Centre for 20th Century Interdisciplinary Studies at the University of Coimbra. He commissioned the exhibition "Memórias. Sinais. Afectos. Nos 90 anos das Aparições de Fátima" (Memories. Signs. Affections. The 90 years of the Apparitions at Fátima). (Archdiocese of Lisbon, October 2007 - January 2008).

\section{Maria Cristina Osswald}

Graduate and holder of a Master's in the History of Art from the Faculdade de Letras of the Universidade do Porto, and a PhD from the European University Institute of Florence (2003) with a thesis on the Society of Jesus em Goa (16th-17th centuries). Post-doctoral work at the Universi- 
dade do Minho, UNED (Madrid) and UNICAMP (Brazil). Researcher at the Interuniversity Centre for the History of Spirituality at the Universidade do Porto. Her publications and presentations deal with the hagiography and iconography of the Company of Jesus, in matters relating to orientalism and also cultural material of the Modern Age. She is currently writing a book on the cycle of ceiling paintings of the former college of the Company of Jesus in Braga.

\section{Maria Fernanda Enes}

Researcher at the Centre for the History of Culture at Universidade Nova de Lisboa (CHC/UNL). Associate Professor at the Faculdade de Ciências Sociais e Humanas of the Universidade Nova da Lisboa (FCSH/UNL), where she has taught in the Departments of Philosophy and Political Studies. Doctorate in the History and Theory of Ideas.

\section{Nuno Saldanha}

Professor of the Escola Superior de Design (IADE). PhD in the History of Art from FCH/UCP, Master's in the History of Aesthetic Ideas from FCSH/UNL and a graduate in History - area History of Art from FL/UL. Researcher and historian of Art and Ideas, he has published a number of books and articles in various journals, catalogues and dictionaries, including on the History of Art, Iconography, Art Theory and Criticism ( $18^{\text {th }}$ to $20^{\text {th }}$ centuries), and has participated in various national and international conferences. Researcher and member of the Academic Committee of the Centre for History of Culture (UNL), he is an Academic Correspondent for the National Academy of Fine Arts. In the museological area, he has served as the director of the King D. Luís Painting Gallery in the National Palace of Ajuda, Consultant for the Board of the Museum of the Ricardo Espírito Santo Silva Foundation and Director of the House-Museum of Patudos, Alpiarça. He has been the commissioner of various exhibitions, including: Da Utilidade do Desenho (BNL); Giovanni Battista Piranesi (King D. Luís Gallery); Joanni V Magnifico - A Pintura em Portugal ao tempo de D. João V-1706-1750 (King D. Luís Gallery); Jean Pillement 1728-1808 (FRESS); Carlos de Haes 1826/1898, House-Museum of Patudos, Alpiarça, 2000; Memórias de Viagem - Um olhar Europeu sobre o Portugal do século XVIII, Palácio Foz, Lisboa, 2000; José Malhoa - Na colecção de José Relvas, House-Museum of Patudos, Alpiarça, 2001. 


\section{Resumos e palavras-chave}

\section{Devoções maiores e devoções menores na pintura mural portuguesa dos séculos XV e XVI Luís Urbano Afonso}

Existem perto de 140 monumentos portugueses que ainda conservam pintura mural realizada entre os finais do século XV e os meados do século XVI. Por vicissitudes históricas diversas, a distribuição destes monumentos pelo território nacional é muito desigual, verificando-se uma concentração em templos rurais situados sobretudo no território de Entre-Douro-e-Minho (c. 30\%), em Trás-os-Montes (c. 25\%) e na Beira Interior (c. 20\%).

A análise da iconografia destas pinturas permite tirar várias conclusões a respeito das principais devoções da época. Verifica-se que São Sebastião era o santo mais representado, seguido por Santo António (de Pádua), Santa Catarina, São Pedro, São Miguel, São João Baptista e São Tiago, ao mesmo tempo que apenas a Anunciação e o Calvário têm uma representatividade equiparável à dos santos mencionados. Também é possível concluir que a preferência pelos santos referidos não estava dependente da invocação dos templos. Conclui-se, igualmente, que existe uma nítida diferenciação entre as imagens sacras representadas na zona dos templos cujo cuidado pertencia aos fregueses, a nave, e a zona sob a responsabilidade dos padroeiros, a cabeceira.

Nesta comunicação pretende-se explicar quais os motivos que justificam a preeminência da representação de determinadas figuras do hagiológio cristão durante o período em causa, bem como a ausência de outras cuja presença seria expectável. Pretende-se explicar também as razões que ditam a diferenciação entre a iconografia das cabeceiras e a iconografia das paredes da nave. A análise conjugada destes dados permite trazer alguma luz sobre os motivos que justificam as principais devoções dos portugueses da época, sobretudo os que viviam em ambientes rurais.

\section{Imagens da devoção nacional em retábulos do Baixo Tâmega e do Vale do Sousa José Carlos Meneses Rodrigues}

O pintor tem espaço nos retábulos maneiristas, diminuindo o seu desempenho a favor do entalhador, à medida que o programa do Barroco Nacional se impõe na arte da talha. Em Portugal, nos séculos XVII e XVIII, definem-se os ofícios com fronteiras frágeis. Entalhador 
pode significar escultor, imaginário ou ensamblador - assim como o dourador é mencionado, muitas vezes, como pintor e estofador, numa polivalência artística notável. Cabe ao imaginário, na gramática barroca, apropriar-se dos espaços intercolúnios, entre outros, para cumprir as encomendas dos santos em concordância com as determinações do Concílio de Trento.

Os inventários, as Memórias Ressuscitadas de Entre-Douro-e-Minho (Francisco Craesbeeck, 1726), as Memórias Paroquiais de 1758 (A.N.T.T.) e um levantamento fotográfico privilegiam o percurso escultórico dos oragos e das invocações retabulares de templos no Baixo Tâmega e no Vale do Sousa. Neste sentido, pretende-se desenhar uma matriz dos espécimes mais recorrentes, estabelecendo assim a mancha das devoções nacionais nos concelhos de Amarante, Marco de Canaveses, Felgueiras e Penafiel.

\section{Variantes iconográficas nas representações antonianas}

D. Carlos A. Moreira Azevedo

A intervenção percorre a história dos atributos antonianos, iniciando-se pela figura e suas vestes: Menino de coro, Cónego regrante de Santo Agostinho e Franciscano. Analisa a evolução das vestes franciscanas e o caso único com adereços de Doutor. As primeiras representações portuguesas mostram António com o atributo da cruz, reveladora de um seguidor de Cristo pobre e crucificado. O livro aparece aberto ou fechado e caracteriza um depositário da doutrina evangélica.

O Menino Jesus é atributo preferido desde o século XV. Começa por aparecer sobre o peito e depois a aparição adopta variadíssimas posições em relação, muitas vezes, com o livro. A açucena, documentada desde quinhentos, torna-se mais habitual desde o século XVII. Estudam-se também os atributos por contaminação com Santo Antão Abade. Novos temas relacionam o Santo com as almas do Purgatório e com a devoção ao pão dos pobres, muito divulgada no século XIX.

\section{São Vasco Martins ou Frei Vasco Martins? A iconografia do fundador dos Jerónimos portugueses, a propósito de uma pintura de Valdés Leal Joaquim Oliveira Caetano}

A Gemaldegalerie de Dresden expõe uma pintura de Valdés Leal, executada entre os anos de 1656 e 1658, uma das doze que executou para o convento dos Jerónimos de Sevilha mostrando os santos da Ordem. A figura histórica de Vasco Martins, leiriense, "ermjtam de prove vida", fundador do convento da Penha Longa, é conhecida nos seus traços mais significativos, mas 
menos presente hoje está a sua iconografia e o culto que mereceu, aspectos sobre os quais nos debruçamos.

\section{Isabel de Aragão, rainha e santa de Portugal: o seu jacente medieval como imagem excelsa de santidade Joana Ramôa}

Dona Isabel, infanta de Aragão (filha de Pedro III) e rainha de Portugal (mulher de Dom Dinis), nasceu, segundo a tradição, no ano de 1271 e foi santificada pelo papa Urbano VIII a 25 de Maio de 1625. Pelo caminho, deixou o testemunho material de uma vida dedicada às boas obras, na figura de clarissa de que fez dotar o seu moimento, marcando, com grande significado, uma intenção bem determinada de deixar de si a memória de uma fiel devota. Acompanhando de muito perto a feitura do seu lugar último (realizado provavelmente cerca de 1330, portanto ainda em vida da rainha, falecida em 1336), Dona Isabel de Aragão revelou-se promotora de uma iconografia de marcada originalidade, quer porque, no seu modelado considerado típico de Mestre Pêro, lhe coube inaugurar uma nova fase na escultura tumular coimbrã, quer pelo carácter ostensivamente religioso da sua representação, conseguido inclusivamente pela adopção de caracteres iconográficos de considerável inovação. Aos atributos, apesar de tudo, mais divulgados do Livro de Horas, dos anjos e do baldaquino (conformador também de um certo sentido de sagrado), o jacente de Dona Isabel acrescenta o hábito de clarissa (numa proposta verdadeiramente original, embora repetida noutros jacentes posteriormente), a esmoleira à cintura com a concha de Santiago e o bordão de peregrina, identificadores das virtudes cristãs da caridade e da peregrinatio - todos estes elementos articulando-se com outros de uma representação tipificada da nobreza feminina trecentista (a realeza simbolizando-se apenas pelo uso da coroa) para dar à imagem última de Isabel de Aragão o sentido pleno de uma rainha de santidade.

\section{A representação gravada da Rainha Santa Isabel: política e devoção} António Filipe Pimentel

A representação em gravura de D. Isabel de Aragão não pode dissociar-se do processo político-devocional que rodeia primeiro a memória e depois a formalização do culto da insigne soberana e do papel outorgado à gravura na comunicação de ideias e formas numa sociedade onde a sua circulação é necessariamente limitada.Com efeito, se os ritmos do processo canónico e da própria divulgação do culto seguem de perto os avatares do poder real - num processo 
reconhecível, de múltiplas formas, entre os alvores do século XVI e o declinar do século XVIII -, a produção imagética em torno da devoção à Rainha Santa e, dentro dela, a produção gravada (necessariamente dependente dos progressos dos meios tipográficos) permitem acompanhar, em termos genéricos e conjunturais, esse mesmo ritmo afirmativo de um culto que se revelaria estrutural na afirmação de valores centrais à dimensão nacional e à projecção exterior da soberania e que o próprio estatuto régio da sua titular favorecia. Neste contexto, a projecção em gravura da devoção à solícita e caridosa Rainha, ilustre pelo sangue e pelas obras, constitui, inegavelmente, um objecto do maior interesse, não somente no domínio da História da Arte, mas no da própria História.

\section{Estilo e iconografia - As beatas de Portugal e a pintura romana}

Nuno Saldanha

O século XVII revelou-se bastante positivo no tocante ao enriquecimento do hagiológio lusitano, tendência que se conseguiu manter activa até inícios de Setecentos. Para além da canonização da Rainha Santa Isabel (1625), em 1671, o Papa Clemente X estende o culto de Gonçalo de Amarante (beatificado em 1561) à Ordem dos Pregadores e a todo o reino de Portugal, com missa e ofício litúrgicos próprios.

Seguir-se-ão outros processos de infantas portuguesas, mais prolíferos em termos de produção artística e iconográfica, que decorrem na viragem para o século XVIII. Primeiro, o da Princesa Santa Joana (1693) e, alguns anos depois, o das filhas de D. Sancho I - Teresa, Sancha (1704) e Mafalda (processo iniciado em 1700, embora beatificada apenas em 1792).

Estes processos, independentemente do seu sucesso, motivaram uma significativa produção de novas formas de representação. A proximidade com o poder papal, e com os centros de decisão, como o da Sagrada Congregação dos Ritos, levou consequentemente à opção por uma produção romana no tocante à origem das novas imagens.

Apesar de motivadas por intuitos de ordem religiosa, no sentido de suscitar a devoção e divulgar o culto, estas encomendas contribuíram não só para a criação de uma nova iconografia, como para o desenvolvimento de novos conceitos estilísticos e de vertentes do gosto. De facto, elas acabam por definir a preponderância das correntes italo-romanas, que marcariam o estilo predominante da pintura portuguesa, ao longo da centúria seguinte. 


\section{Relance sobre a iconografia da Padroeira de Aveiro: de 1470 (?) a 2008}

Mons. João Gonçalves Gaspar

Graças ao singular prestígio de que gozava o Portugal quatrocentista na Europa de então, era lógico que as filhas e parentes próximas dos nossos reis fossem pretendidas como esposas de infantes e de príncipes estrangeiros; não seria excepção D. Joana, filha de D. Afonso V e irmã de D. João II. Os seus traços fisionómicos estão patentes na pintura guardada no Museu Nacional de Aveiro, que talvez se possa datar de 1471, ou pouco antes; de um autor anónimo, obedeceu aos princípios da escola do pintor Nuno Gonçalves. Nos séculos XVI e XVII, surgiram diversas figurações pictóricas que representam a princesa vestida com o hábito dominicano.

Como seria de prever, logo após a beatificação (1693), em Aveiro surgiu a lembrança de que fosse esculpida em madeira uma imagem de Santa Joana para o culto litúrgico. Posteriormente, ao lado de muitas publicações biográficas, multiplicaram-se as representações de Santa Joana, mesmo além-fronteiras. Refiro especialmente as duas que estão patentes em Roma na igreja de Santo António dos Portugueses.

Para abreviar este esboço, detenho-me nos últimos decénios da centúria novecentista. Sobretudo a partir de 1938, deparamos com dezenas e dezenas de representações da Princesa Santa Joana, em diferentes materiais e processos, devidas sobretudo à concepção e à arte de aveirenses; até há barcos moliceiros a vogar na ria, que a ostentam garbosamente nas proas. Para finalizar, refiro uma das estátuas que se erguem no perímetro da cidade de Aveiro; trata-se daquela que se encontra no largo fronteiro à Sé e ao antigo Mosteiro de Jesus, inaugurada em 2002. O seu escultor, Helder Bandarra, exprimiu-a com determinação, perseverança e decisão para viver e anunciar Jesus Cristo.

\section{Quitéria, uma santa da Lusitânia nas terras de Entre-Douro-e-Minho}

\section{Luís Alberto Casimiro}

O nosso artigo visa o estudo hagiográfico de Santa Quitéria, uma jovem mártir do século Il, cuja vida se encontra envolvida em aspectos lendários, ainda pouco estudados. Filha de um nobre pagão, terá nascido na região de Braga, juntamente com mais oito irmãs gémeas. Os primeiros milagres datam do século VIII, altura em que começou a ser venerada como mártir, destino que partilhou com suas irmãs. O martírio é referido, pela primeira vez, no século XII, estando relatado nos Flos Sanctorum de Alonso de Villegas e de Diogo do Rosário e inscrito no Martirológio Romano (22 de Maio). O culto de Santa Quitéria, promovido, particularmente, pelos jesuítas, encontra-se bem alicerçado na devoção popular que a invoca como advogada contra a raiva. $A$ arquidiocese de Braga celebra a sua memória no dia 8 de Junho. Felgueiras não só lhe erigiu um 
santuário no local onde, supostamente, foi sepultada, como tem Santa Quitéria como padroeira. A iconografia desta nobre donzela romana faz alusão a certos episódios da sua vida e revela o instrumento material do martírio, aspectos que nos propomos analisar bem como fazer referência ao culto e às dificuldades causadas pelas diversas lendas sobre a sua vida.

\section{O martírio de Inácio de Azevedo e dos seus trinta e nove companheiros (1570) na hagiografia da Companhia de Jesus entre os séculos XVI e XIX Maria Cristina Osswald}

No dia 15 de Julho de 1570 o recém-eleito Provincial do Brasil, Inácio de Azevedo, trinta e sete companheiros e um candidato à Companhia foram martirizados às mãos dum grupo de huguenotes no mar em frente à llha de Palma, Canárias. No dia seguinte foi martirizado o irmão Simão Costa. Estes quarenta mártires (32 portugueses e 8 castelhanos) são normalmente designados como os Mártires do Brasil, pois dirigiam-se à missão do Brasil. Uma bula de 21 de Setembro de 1742 por Bento XIV reconheceu o martírio dos quarenta religiosos, tendo Pio IX procedido à sua beatificação em 11 de Maio de 1854 .

Esta expedição comandada por Inácio de Azevedo foi simultaneamente a expedição missionária mais numerosa que partiu de Lisboa para as missões extra-europeias e o martírio colectivo mais numeroso de jesuítas em toda a Época Moderna. O mesmo episódio teve um importante significado hagiográfico, pois reunia simbolicamente a Europa dividida pelas lutas religiosas e as missões extra-europeias. A importância deste episódio deriva ademais do facto de estar ligado à difusão do culto da Madona di San Luca, um dos principais cultos jesuítas na Época Moderna.

\section{A iconografia dos Santos Mártires de Lisboa em quatro pinturas do século XVI - linguagem e significados \\ Manuel Batoréo}

Quatro painéis de muito boa pintura, representando aspectos da vida e martírios dos Santos Mártires de Lisboa, Veríssimo, Máxima e Júlia, estão patentes no Museu Carlos Machado, em Ponta Delgada, nos Açores.

Obras nunca estudadas antes de 2001, embora referenciadas documentalmente já no século XIX, permaneceram em colecções particulares até aos anos sessenta do século XX, quando foram doadas ao museu açoriano, onde se encontram em bom estado de conservação. Nunca dali saíram, a não ser um dos painéis para a XVII Exposição Europeia de Arte, Cultura e Ciência 
(núcleo da Casa dos Bicos) e outro painel, em 1992, para uma exposição em Génova. As obras, de relativamente pequenas dimensões, são muito ricas em aspectos iconográficos e de caracterização de ambientes. Datáveis da década de 30 do século XVI, têm sido atribuídas ao pintor Garcia Fernandes e, mais recentemente, a Cristóvão de Utreque, um dos mestres que foi referenciado como eventual colaborador dos chamados Mestres de Ferreirim: Cristóvão de Figueiredo, Gregório Lopes e Garcia Fernandes.

Muito interessante, no entanto, é a iconografia das paisagens urbanas de duas das pinturas, mas a vida e os martírios dos santos não acompanham o que se conhecia da literatura do tempo.

\section{Os santos mártires de Évora}

Artur Goulart de Melo Borges

A 27 de Outubro comemora a Igreja os santos Vicente, Sabina e Cristeta. Conhecidos como os Mártires de Évora, a eles foi erguida no século XV na cidade alentejana, no local onde se dizia terem nascido, uma ermida, ampliada no século seguinte já à conta do Município, que ainda hoje mantém a propriedade. Era-lhes também dedicada, na nave direita da Sé de Évora, uma das capelas laterais desaparecidas após a intervenção da Direcção-geral dos Monumentos Nacionais na década de 40 do século XX.

A naturalidade dos santos irmãos, embora assumida pelos eborenses, sobretudo após as argumentações de André de Resende, mantém-se de difícil comprovação, sendo por muitos autores atribuída não à cidade alentejana, mas a Talavera de la Reina (Toledo). Martirizados no século IV na cidade espanhola de Ávila, São Vicente e suas irmãs aí foram sepultados e em sua honra construída uma grande basílica, expressão do reconhecimento e devoção aos chamados Santos de Ávila.

Da descrição legendária das suas vidas e martírios decorre a respectiva iconografia. Tudo aconteceu em tempo do governador Daciano, enviado à Península Ibérica pelo imperador Diocleciano, que promoveu uma intensa perseguição aos cristãos. O jovem Vicente, que poderia servir de incentivo aos pagãos pelo seu comportamento cristão exemplar, foi chamado à presença de Daciano que o pretendeu convencer a sacrificar a Júpiter. Perante a recusa, mandou conduzi-lo a uma das praças da cidade e obrigá-lo a executar o sacrifício ou a ser morto. Colocado sobre o altar de pedra, esta tornou-se mole ficando impressas as suas pegadas, prodígio que deixou todos os presentes admirados e convencidos de que o Deus de Vicente era o verdadeiro. Tal facto levou Daciano a suspender temporariamente a condenação, tendo mandado o jovem para a prisão, onde foi visitado por suas irmãs Sabina e Cristeta. Convencido por elas a fugir, foram os três perseguidos e apanhados em Ávila, sendo sujeitos a vários suplícios e finalmente partidas as suas cabeças com paus e pedras. Os seus corpos foram deixados ao 
abandono para pasto dos animais; todavia apareceu uma enorme serpente que os protegia e que se enroscou à volta de um judeu rico da cidade que pretendia desprezar os santos despojos e que só se viu livre da serpente quando prometeu converter-se ao cristianismo. Os mártires acabaram por ser sepultados pelos cristãos, espalhando-se rapidamente a sua devoção.

O repertório iconográfico, muito reduzido no que concerne a arquidiocese de Évora, confina-se praticamente à igreja de São Vicente, onde se encontra a pedra na qual supostamente terá deixado as marcas dos seus pés; alguns painéis do retábulo-mor representam "São Vicente conduzido perante o altar de Júpiter," "São Vicente na prisão e a visita de suas irmãs", "o martírio de São Vicente", e "o judeu impedido pela serpente de ultrajar os corpos dos três santos". A representação escultórica segue muito de perto a de Ávila. Todos trazem a palma do martírio, São Vicente um livro aberto ou semicerrado. As irmãs Sabina e Cristeta apresentam uma iconografia pouco definida, sendo por vezes necessário, quando não estão inseridas no contexto duma cena conhecida, que o nome lhes seja sotoposto para fácil identificação.

\section{A invocação e o culto do Senhor Santo Cristo em Ponta Delgada - São Miguel Maria Fernanda Enes}

Pese embora o facto de se tratar de um culto cristológico, e nesse sentido fora do âmbito específico dos santos portugueses, a designação popular de "Santo Cristo dos Milagres", pela sua natureza taumatúrgica e cariz vivencial, representa uma forma específica de devoção, expressa num culto bem tipificado e localizado no espaço português, fixado e difundido por uma notável iconografia.

\section{Nossa Senhora de Brotas: Um exemplo de regionalismo na iconografia mariana Ana Paula Rebelo Correia}

Descrito por Frei Agostinho de Santa Maria no Santuário Mariano, o culto de Nossa Senhora das Brotas, padroeira dos animais doentes, tem como origem um suposto milagre ocorrido na localidade de Brotas no Alto Alentejo, no início do século XV. Culto rural, com base numa história simples entre um pastor e a sua vaca, a lenda de Nossa Senhora de Brotas é um curioso exemplo de regionalismo na iconografia mariana. 


\section{A iconografia da Senhora de Fátima: da criação ex nihilo às composições plásticas dos artistas}

Marco Daniel Duarte

O mais divulgado modelo iconográfico mariano da época contemporânea, presente em quase todos os templos católicos do mundo, nasceu em Portugal na sequência das Aparições de Fátima de 1917. Não teria o conhecido desenvolvimento sem que no processo cultual interviesse a disciplina escultórica que logo em 1920 faria cristalizar, através do escopro de um santeiro, a imagem de Nossa Senhora do Rosário de Fátima. O estudo do tipo, do arquétipo e dos subtipos da Virgem de Fátima, primeiramente produzidos em oficinais trabalhos de santeiros e, em fase posterior, interpretados por artistas, permite entender os contornos do nascimento de uma realidade imagética, isto é, de uma iconografia ex nihilo e o seu, necessariamente, tardio desenvolvimento estético. 



\section{Abstracts and keywords}

\section{Greater and lesser religious practices in 15th and 16th century Portuguese mural painting}

Luís Urbano Afonso

There are around 140 Portuguese monuments that still have preserved mural painting carried out between the late fifteenth century and the mid-sixteenth century. Due to various reasons, the distribution of these monuments throughout the country is very uneven, with a concentration in religious buildings located mainly in the rural area of Entre-Douro-e-Minho (c.30\%), in Tras-os-Montes ( c.25\%) and in the Beira Interior (c.20\%).

Iconographic analysis of these painting has enabled several conclusions to be drawn with regard to the main religious practices of the period. It appears that San Sebastian was the most represented saint, followed by St. Anthony (of Padua), Saint Catherine, Saint Peter, Saint Michael, Saint John of the Baptist and Saint James, while only the representation of the Annunciation and the Calvary was comparable to that of the saints mentioned. It is also possible to conclude that the preference for these saints was not dependent on the invocation of the religious buildings. It was also concluded that there was a clear distinction between the sacred images represented in the area of the churches looked after by the lay community, the nave, and the area belonging to the patron saint, the high altar.

This paper seeks to explain the reasons for the pre-eminence of the representation of certain figures from Christian hagiology during the period in question and the absence of other figures whose presence would be expected. It also seeks to explain the reasons for the difference in the iconography of the high altars and the iconography of the walls of the nave. The combined analysis of these data has enabled some light to be shed on the reasons for the principal religious practices of the Portuguese at the time, especially those living in rural environments. 


\section{Images of national religious practice in altarpieces of the Baixo Tâmega and the Vale do Sousa \\ José Carlos Meneses Rodrigues}

The painter has space in the Mannerist altarpieces, with this decreasing this in favour of the carver, in so far as the National Baroque programme implemented the art of carving. In Portugal, in the seventeenth and eighteenth centuries, workshops were defined in very broad strokes. Carver could mean sculptor, imaginary or assembler - just like the gilder is mentioned often as a painter and upholsterer, with a remarkable artistic versatility. It was the imaginary baroque grammar which appropriated intercolumnal spaces, among others, to fulfil the orders of the saints in accordance with the provisions of the Council of Trent.

The inventories, the Memórias Ressuscitadas de Entre Douro e Minho (Resurrected Memories of Entre Douro e Minho), (Craesbeeck Francisco, 1726), as Memórias Paroquiais de 1758 (the Parish Memories of 1758) (A.N.T.T.) and a photographic survey emphasise the sculpture of the patron saints and the invocations of the altarpieces in the churches of the Baixo Tâmega and the Vale do Sousa. The aim is to draw a matrix of the recurring specimens, thus marking the religious practices in the councils of Amarante, Marco de Canaveses, Felgueiras and Penafiel.

\section{Iconographic variations in Antonian representations}

D. Carlos A. Moreira Azevedo

This paper considers the history of Antonian attributes, starting with the figure and his apparel: Choirboy, Canon Regular of Saint Augustine and Francis. It analyses the evolution of Franciscan apparel and the single case with adornments befitting a learned man. The first Portuguese representations show Antony with the attribute of the cross, showing him to be a follower of the poor crucified Christ. The book appears open or closed characterising a depositary of evangelical doctrine. The Baby Jesus was the preferred attribute from the $15^{\text {th }}$ century onwards. He started by appearing on the chest and then was seen in various positions, often in relation to the book. The lily, documented since the $16^{\text {th }}$ century, became more usual from the $17^{\text {th }}$ century onwards. The attributes due to the confusion with Saint Anthony the great are also studied. New themes also linked the Saint to the souls of purgatory and the devotion of the bread of the poor, which was very widespread in the $19^{\text {th }}$ Century. 


\section{São Vasco Martins or Frei Vasco Martins? The iconography of the founder of the Portuguese Hieronymites in a painting by Valdés Leal}

Joaquim Oliveira Caetano

The Dresden Gemaldegalerie has on show a painting by Valdés Leal, which was painted between the years 1656 and 1658, one of the twelve commissioned for the Hieronymite Convent in Seville, which show the saints of the Order. The historical figure of Vasco Martins, from Leiria, "ermjtam de prove vida", and founder of the monastery at Penha Longa, is known for his more significant features, but less present today is his iconography and the worship which he received, aspects focused on in this study.

\section{Elizabeth of Aragon, queen and saint of Portugal: Her medieval tomb as an image extolling holiness Joana Ramôa}

Dona Isabel, infant of Aragon (daughter of Peter III) and queen of Portugal (wife of Dom Dinis), was born, according to tradition, in the year 1271 and was canonized by Pope Urban VIII on 25 May 1625. Throughout her life, she left material witness of a life devoted to good works, as the figure of a Poor Clare to whom she endowed her mausoleum, making it very clear that she was strongly determined to leave a memory of herself as a true devotee. She closely monitored the workmanship involved in making her last resting place (probably made about 1330, so still during the life of the queen, who passed away in 1336), and Dona Elizabeth of Aragon created an iconography of marked originality, both because of the modelling which was considered characteristic of Master Pêro, which inaugurated a new phase of Coimbra tumular sculpture, and because of the ostensibly religious character of its representation, even adopting iconographic characters which were quite innovative. As well as the most disseminated aspects from the Book of Hours, the angels and the baldachin (also providing a certain sense of the sacred), the tomb of Dona Isabel added the habit of St. Claire (a truly original idea, although repeated later on other tombs ), the beggar's pouch at the waist with the shell of Santiago and the staff of a pilgrim, identifiers of the Christian virtues of charity and peregrinatio - all these elements along with others transmitting a representation of fourteenth century feminine nobility (royalty only being symbolized through the use of the crown) to make the final image of Elizabeth of Aragon one fully conveying that of a queen of holiness. 


\section{The depiction of Queen and Saint Elizabeth: politics and devotion}

António Filipe Pimentel

The depiction of D. Elizabeth of Aragon cannot be dissociated from the surrounding political and devotional process, firstly as a memory and then the formalization of the cult of the royal emblem and the role given to depiction in the communication of ideas and forms in a society where their movement was necessarily limited. Indeed, if the rhythms of the canonical process and the proper dissemination of the cult closely follow the avatars of real power - in a process recognizable in many ways, from the dawn of the sixteenth century and the dusk of the eighteenth century - the production of imagery around the devotion to the Holy Queen, and within this, the depicted work (necessarily dependent on the progress of typographical resources) enables us to accompany, both in general and cyclical terms, that same affirmative rhythm of a devotion that would reveal its structural nature in the affirmation of its core values at the national level and the external projection of the sovereignty enabled by the actual regal status of the depicted. In this context, the depiction of devotion to the solicitous and bountiful Queen, honourable through her blood and by works, is undeniably an object of great interest not only in the field of the History of Art, but History itself.

\section{Style and iconography - The blessed of Portugal and romanesque painting} Nuno Saldanha

The seventeenth century proved to be very positive regarding the enrichment of Portuguese Hagiology, a trend that was kept active until the beginning of the eighteenth century. In addition to the canonization of Queen and Saint Elizabeth (1625), in 1671, Pope Clement X extended the devotion of Gonçalo de Amarante (beatified in 1561) to the Order of Preachers and the whole kingdom of Portugal, with his own liturgical Mass and Office.

This would be followed by other cases of Portuguese infantas (princesses), which were most prolific in terms of artistic creation and iconography, which took place at the turn of the eighteenth century. Firstly, blessed Joan of Portugal (1693) and some years later, the daughters of D. Sancho I - Theresa of Portugal, Sancha, Lady of Alenquer (1704) and Mafalda (the process was started in 1700, though she was only beatified in 1792).

These processes, independently of their success, prompted significant works with new forms of representation. The proximity of the papal power, and decision-making centres, such as the Sacred Congregation for Rites, consequently led to the choice of Romanesque creations with regard to new images. Although these commissions came about due to religious reasons, in order to increase devotion and extend worship, they not only contributed to the establishment 
of a new iconography, but also to the development of new stylistic concepts and taste. In fact, they ended up specifying the preponderant Italo-Roman trends, which would influence the predominant style of Portuguese art throughout the following century.

\section{A glimpse into the iconography of the Patroness of Aveiro: from 1470 (?) to 2008} Msgr. João Gonçalves Gaspar

Thanks to the singular prestige which Portugal enjoyed in fifteen century Europe, it was to be expected that the daughters and close relatives of our kings would be sought out to be spouses to "infantes" and foreign princes, and D. Joanna, the daughter of D. Afonso V and sister of D. João II was no exception. Her physiognomic traits are clearly evident on the painting housed in the National Museum of Aveiro, which possibly dates from 1471 or shortly before, by an anonymous painter, in the style of the school of the painter Nuno Gonçalves. In the 16th and 17th centuries several pictorial figures appeared which showed the Princess dressed in the Dominican habit. As was to be expected, in Aveiro after her beatification (1693) the idea appeared of sculpting an image of Blessed Joanna in wood for her public worship. Later, along with the many biographical publications, many representations of Blessed Joanna appeared, even abroad. I am particularly referring to two which are in the church of Saint Antony of the Portuguese in Rome.

To bring this rough outline towards its close, I will move to the last decades of the twentieth century. Particularly from 1938 onwards, it was possible to see dozens and dozens of images of Blessed Joanna the Infanta, made out of different materials and using different processes, mainly due to the design and art of the people of Aveiro, and found even in the "moliceiros boats" sailing the Aveiro lagoon and gracefully displaying her on their prows. Finally, I will mention one of the statues which stands within the perimeter of the city of Aveiro.This is the one to be found in the square in front of the Cathedral and the former Monastery of Jesus, inaugurated in 2002. Its sculptor, Helder Bandarra, conceived it with her determination, perseverance and decision to live and profess Jesus Christ.

\section{Iconography of Blessed Joan of Portugal - sources and models}

José António Rebocho Christo

António Rocha Madahil produced the first inventory of the representations of Blessed Joan, published between 1952-1957 in the "Archive of the District of Aveiro",covering painting, sculpture and printmaking. This work serves now, not only as a starting point for extending the number of these representations but, essentially, to attempt to systematize and understand them. 
First of all it is of interest to ascertain which sources led to the creation of the models which are known, starting from the information present in the convent manuscript "Chronicle of the Foundation of the Monastery of Jesus and Memorial of the Princess" "Crónica da Fundação do Mosteiro de Jesus e Memorial da Princesa" - MA, inv. 33/CD) which served as the basis for the first printed biography of the daughter of D. Afonso V, the work of Frei Nicolau Dias, "Life of the Most Serene Princess Joan" ("Vida da Sereníssima Princesa Dona loana", Lisbon, 1585).

As for the models, they can roughly be divided into three types: the portraits, which correspond to those of the Sixteenth Century table of the collections of the Museum of Aveiro (MA, inv. $1 / A$ ); the religious figure, depicted with her Dominican habit and with her attributes (crown of thorns, crucifix and the three crowns for the refused weddings); series and narratives.

\section{Quitéria, a Lusitanian saint from the lands between the Douro and the Minho Luís Alberto Casimiro}

This paper seeks to study the hagiography of Saint Quiteria, a young martyr of the $2^{\text {nd }}$ century, whose life involved legendary aspects which have still been hardly studied. The daughter of a noble pagan, she was probably born in the region of Braga, one of nine nonuplet sisters. The first miracles date from the $8^{\text {th }}$ century, when she began to be venerated as a martyr, a fate she shared with her sisters. The martyrdom is mentioned for the first time in the $12^{\text {th }}$ century, being reported in the Flos Sanctorum of Alonso de Villegas and Diogo do Rosario and registered in the Roman Martyrology (22 May). The cult of Santa Quiteria, promoted particularly by the Jesuits, is well grounded in popular devotion and her patronage is invoked against rabies. The Archdiocese of Braga celebrates her memory on 8 June. Felgueiras not only erected a shrine at the place where she was supposedly buried, but also has Santa Quiteria as its patron saint. The iconography of this noble Roman lady alludes to certain episodes of her life and reveals the material instruments of martyrdom, aspects which will be analysed and also through reference to the cult and the difficulties caused by the differing legends about her life.

\section{The $\mathbf{1 5 7 0}$ martyrdom of Blessed Ignatius de Azevedo and his thirty nine companions in the hagiography of the Society of Jesus between the $16^{\text {th }}$ and $19^{\text {th }}$ centuries Maria Cristina Osswald}

On 15 July 1570 the newly elected Governor-General of Brazil Ignacio de Azevedo, 37 companions, and an initiate of the Society were martyred at the hands of a group of Huguenots in the sea opposite the island of Palma, in the Canary Islands. The next day brother Simão Costa 
was martyred. These forty martyrs (32 Portuguese and 8 Castilian) are usually designated as the Martyrs of Brazil, since they were heading for the Jesuit missions in Brazil. A papal bull of 21 September 1742 by Benedict XIV recognized the martyrdom of the forty, and Pius IX beatified them on 11 May 1854.

This expedition led by Ignatius de Azevedo was both the largest missionary expedition that left Lisbon for missions outside Europe and the largest act of collective martyrdom of the Jesuits throughout the Modern Era. This event had an important hagiographical meaning, as it symbolically united a Europe divided by religious strife and missions outside Europe. The importance of this event was additionally due to the fact that it was linked to the spread of the cult of the Madonna di San Luca, one of the leading Jesuit cults in the Modern Age.

\section{The iconography of the Holy Martyrs of Lisbon in four 16th century paintings - language and meanings \\ Manuel Batoréo}

Four well painted panels, representing aspects of the lives and martyrdoms of the Holy Martyrs of Lisbon, Veríssimo, Máxima and Julia, are to be found in the Carlos Machado Museum in Ponta Delgada in the Azores.

These works were not studied until 2001, although they were documentally referenced in the $19^{\text {th }}$ century. They remained in private collections until the 1960s, when they were donated to the Azorean Museum, and are in a good state of conservation. Apart from one of the panels being exhibited in the $17^{\text {th }}$ Exhibition of European Art, Culture and Science (based at the Casa dos Bicos), and another in 1992 in an exhibition in Geneva, they have otherwise never been exhibited outside of this Museum.

The works are relatively small in size and very rich in terms of their iconography and their ambiental features. They have been dated to the 1630 s and have been attributed to the painter Garcia Fernandes and, more recently, to Crisóvão of Utrecht, one of the masters who was referenced as being a possible collaborator of the so-called Masters of Ferreirim: Cristóvão de Figueiredo, Gregório Lopes and Garcia Fernandes.

The iconography of the urban landscapes of two of the paintings is very interesting, but the life and martyrdoms of the saints is not in line with what was known from the literature of the time. 


\section{The holy martyrs of Évora}

Artur Goulart de Melo Borges

On 27 October the Church commemorates the saints Vincent, Sabina and Cristeta. Known as the Martyrs of Évora, a chapel was erected to them in the $15^{\text {th }}$ century in the Alentejan town, at the place where they are said to have been born, which was extended in the following century by the Municipality which still retains ownership of the building. They also had dedicated to them one of the side chapels along the right side of the nave in the Cathedral of Évora, which disappeared after works carried out by the Directorate-General of National Monuments in the 1940s.

The place of origin of the holy saints, though assumed by the people of Évora to be their town, especially following the arguments of André de Resende, remains difficult to prove, and many authors consider it not to be the Alentejan town, but Talavera de la Reina (Toledo). Martyred in the $4^{\text {th }}$ century in the Spanish city of Ávila, St. Vincent and his sisters were buried there and a great basilica was built in their honour, an expression of recognition and devotion to the socalled Ávila Saints.

Their respective iconography is derived from the legendary description of their lives and martyrdoms. Everything happened during the time of the governor Daciano, who was sent to Iberia by the Emperor Diocletian, who carried out an intense persecution of the Christians. The young Vincent, who could have served as an incentive to the heathen for his exemplary Christian behaviour, was called to the presence of Daciano which intended to convince him to make a sacrifice to Jupiter. Faced with his refusal he had him led to one of the squares of the city and forced him to perform the sacrifice or be killed. Placed on the altar of stone, it became soft and his footsteps were imprinted on it, an act which left all those present in wonder and convinced that Vincent's God was the real God. This led Daciano to temporarily suspend the sentence, ordering the youth to prison, where he was visited by his sisters Sabina and Cristeta. Convinced by them to flee, the three were chased and caught in Ávila and were subjected to various tortures and finally had their heads broken with sticks and stones. Their bodies were abandoned to grazing animals, but a huge snake appeared and protected them, coiling itself around a rich Jew from the city who wanted to despise the saints' mortal remains, and who was only able to free himself when he promised to convert to Christianity. They were eventually buried by the Christians, and their veneration quickly spread.

The iconographic repertoire, which is very small with regard to the Archdiocese of Évora, is confined practically to the church of St.Vincent, where the stone which is supposed to have left the marks of his feet is located, and where some panels of the altarpiece represent "St. Vincent brought before the altar of Jupiter","St. Vincent in prison visited by his sisters","the martyrdom of St. Vincent", and " the Jew prevented by the serpent from reviling the bodies of the three saints".The sculptural representation closely follows that of Ávila. They all have an open or half- 
closed book on the palm of the martyr St.Vincent. The sisters Sabina and Cristeta have a poorly defined iconography, and it is sometimes necessary to place their names underneath them for easy identification when they are not placed in the context of a well-known scene.

\section{The cult of the Holy Christ of Miracles in Ponta Delgada - São Miguel Maria Fernanda Enes}

Despite the fact that it is a Christological cult, and in that sense outside the specific scope of the Portuguese Saints, the popular name of "Santo Cristo dos Milagres" (Holy Christ of Miracles) through its thaumaturgical and experiential nature, represents a specific form of devotion, expressed in a clearly identified cult and situated within a specific Portuguese location, established and expressed through a remarkable iconography.

\section{Regionalisms in Marian iconography: Our Lady of Brotas}

Ana Paula Rebelo Correia

Described by Frei Agostinho de Santa Maria in the Santuário Mariano, the cult of Our Lady of Brotas, patron saint of sick animals, has its origin in an alleged miracle which occurred in the locality of Brotas in the Alto Alentejo at the start of the fifteenth century. A rural cult, based on a simple story of a pastor and his cow, the legend of Our Lady of Brotas is a curious example of regionalism in Marian iconography.

The iconography of Our Lady of Fatima: from ex nihilo to plastic compositions by artists Marco Daniel Duarte

The most widespread iconographic Marian model in modern times, present in almost every Catholic church around the world, was created in Portugal in the wake of the Apparitions at Fátima in 1917. This development would not have taken place without sculptural intervention in the process of worship that would soon crystallize in 1920, through the chiselling of the image-maker, into the image of Our Lady of the Rosary of Fátima. The study of the type, the archetype and the subtypes of the Virgin of Fátima, first produced in the workshops of the image-makers and, at a later stage, interpreted by artists, enables us to understand the contours of the birth of an imagetic reality, i.e., an iconography'ex nihilo' and its necessarily slow aesthetic development. 


\section{Cultura Revista de História e Teoria das ideias}

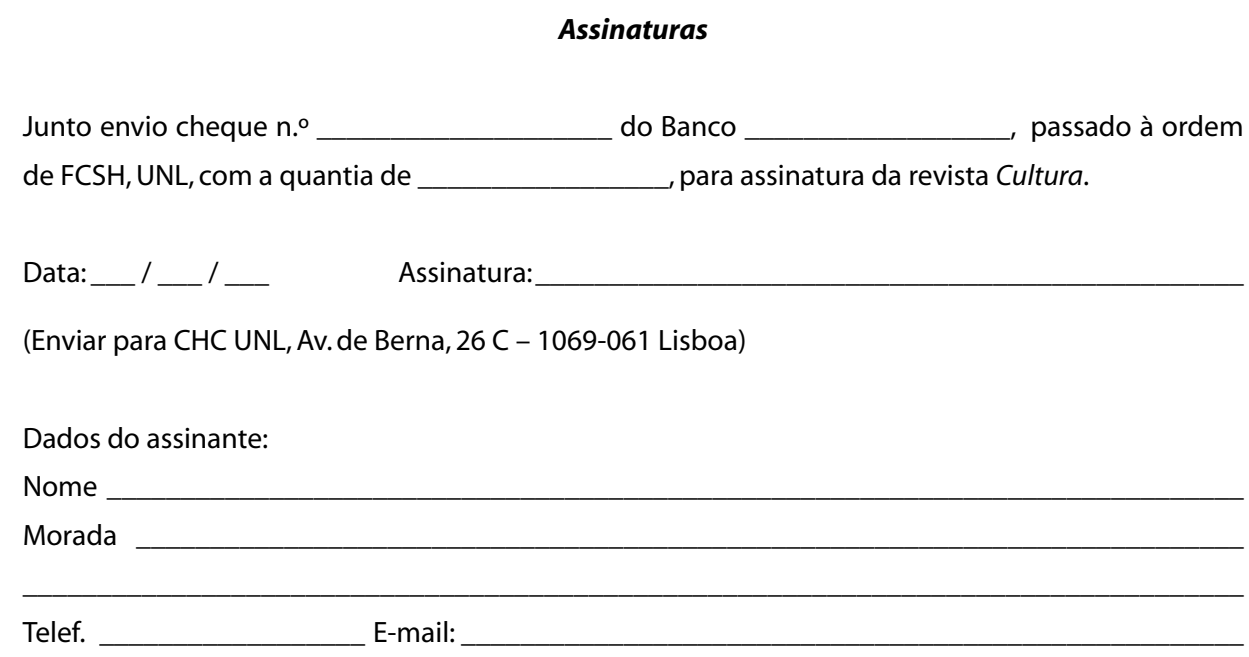

Assinatura para dois números:

$\begin{array}{ll}\text { Normal }-26 \text { euros } & \text { Estudante }-17 \text { euros } \\ \text { UE }-40 \text { euros } & \text { Resto do mundo }-50 \text { euros }\end{array}$




\section{Recomendações aos Autores}

\section{Envio}

- Pelo correio, um exemplar em papel acompanhado de uma disquete (formato Word) para:

Cultura. Revista de História e Teoria das Ideias

Centro de História da Cultura

Faculdade de Ciências Sociais e Humanas

Av. de Berna, n. ${ }^{\circ} 26-\mathrm{C}$

1069-061 Lisboa

- Por correio electrónico para:

chc@fcsh.uni.pt

\section{Forma e dimensão}

\section{Artigos}

- Preferencialmente, até cerca de 70000 caracteres, seja 20 páginas com 3450 caracteres por página, Times New Roman, 12 (formatação a um espaço e meio).

- Referências bibliográficas inseridas nas notas de rodapé de página (tendo bibliografia no final, não pode exceder uma página).

- Apresentação das referências segundo o modelo seguinte: apelido, nome, título da obra (itálico), local, editora, ano; ou, para artigos, apelido, nome, "título do artigo", revista (itálico), n. o de volume, data, páginas.

- Artigos longos deverão ter subtítulos.

- Ilustrações, gráficos e quadros: a preto e branco, com legenda, fonte e numeração.

\section{Recensões}

- Até cerca de 10000 caracteres, seja 3 páginas, Times New Roman, 10 (formatação a um espaço).

\section{Resumo e Biografia}

- Resumo de cerca de 750 caracteres, acompanhado de uma tradução em inglês de idêntica dimensão.

- Biografia do autor que refira o estatuto profissional, principais publicações, domínios de investigação e morada.

\section{Procedimento}

- Será acusada a recepção ao autor no dia de chegada do texto.

- Avaliação do artigo sob orientação da comissão científica.

- A decisão de publicação será comunicada nos 90 dias seguintes à data da recepção. 
Devoções maiores e devoções menores na pintura mural portuguesa dos séculos XV e XVI Luis Urbano Afonso

Imagens da devoção nacional em retábulos do Baixo Tâmega e do Vale do Sousa José Carlos Meneses Rodrigues

Variantes iconográficas nas representações antonianas

D. Carlos A. Moreira Azevedo

São Vasco Martins ou Frei Vasco Martins? A iconografia do fundador dos Jerónimos portugueses, a propósito de uma pintura de Valdés Leal Joaquim Oliveira Caetano

Isabel de Aragão, rainha e santa de Portugal:

o seu jacente medieval como imagem excelsa de santidade Joana Ramôa

A representação gravada da Rainha Santa Isabel: política e devoção António Filipe Pimentel

Estilo e iconografia - As beatas de Portugal e a pintura romana Nuno Saldanha

Relance sobre a iconografia da Padroeira de Aveiro: de 1470 (?) a 2008 Mons. João Gonçalves Gaspar

Quitéria, uma santa da Lusitânia nas terras de Entre-Douro-e-Minho Luís Alberto Casimiro

O martírio de Inácio de Azevedo e dos seus trinta e nove companheiros (1570) na hagiografia da Companhia de Jesus entre os séculos XVI e XIX

Maria Cristina Osswald

A iconografia dos santos mártires de Lisboa em quatro pinturas do século XVI: linguagem e significados

Manuel Batoréo

Os santos mártires de Évora

Artur Goulart de Melo Borges

A invocação e o culto do Senhor Santo Cristo em Ponta Delgada - São Miguel Maria Fernanda Enes

Nossa Senhora de Brotas: um exemplo de regionalismo na iconografia mariana Ana Paula Rebelo Correia

A iconografia da Senhora de Fátima:

da criação ex nihilo às composições plásticas dos artistas

Marco Daniel Duarte 